
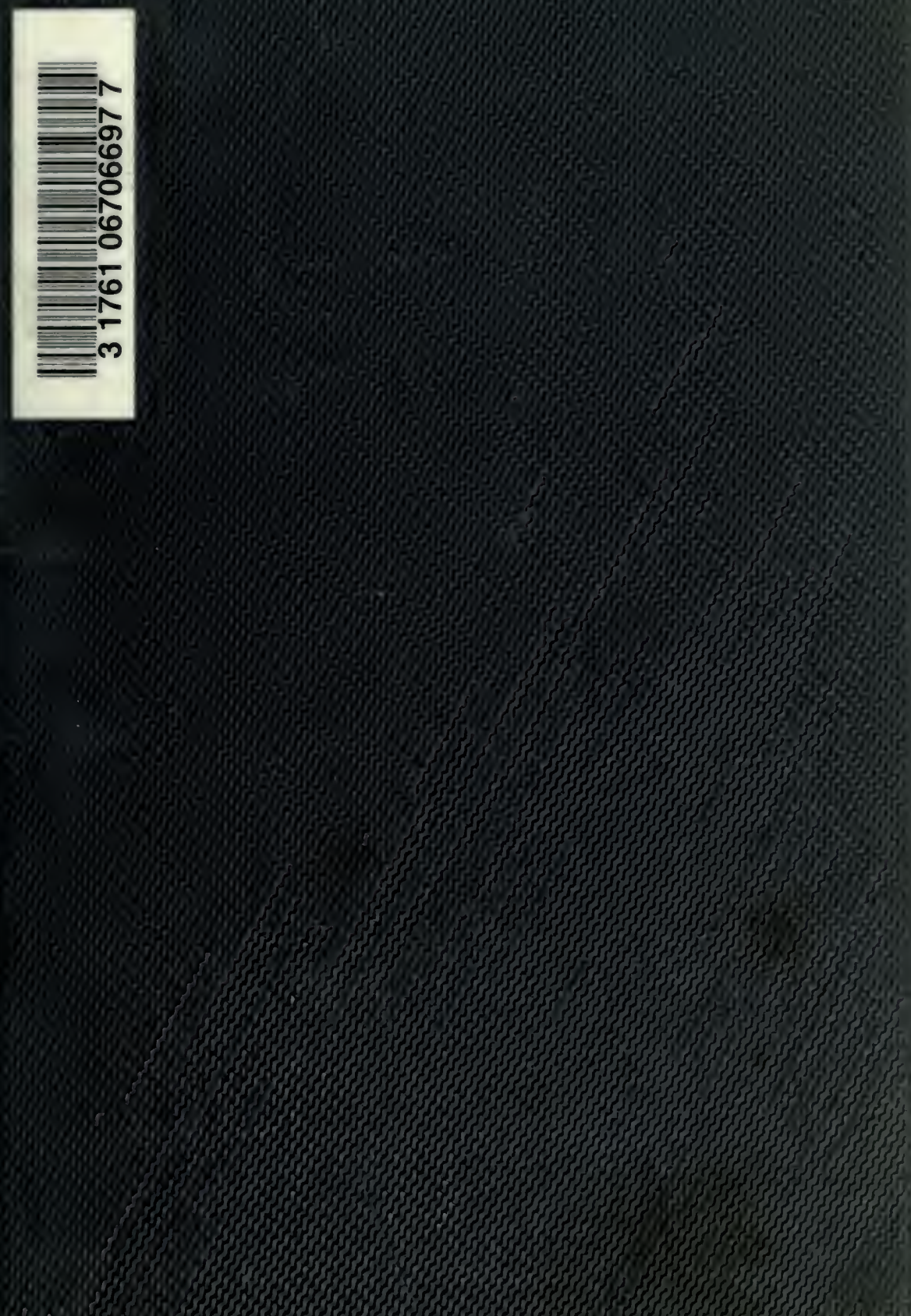

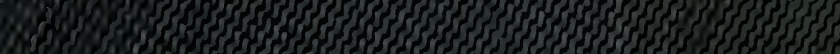

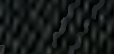



Digitized by the Internet Archive in 2007 with funding from Microsoft Corporation 

A

\section{H I S T O R Y}

OF TIIE

\section{BRITISH MARINE POLYZOA.}

$B Y$

THOMAS HINCKS, B.A., F.R.S.,

AUTHOR OF 'A MISTORY OF THE BRITISH HYDROID ZOOPIYTES,' ETC.

“. . naturî ipsî docente, et jucunditate suâ alliciente."

Otho Fabricies.

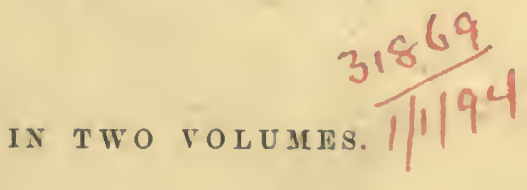

VOL. I.-TEXT.

L O N D O N :

JOHN VAN VOORST, PATERNOSTER ROW.

sipccclixxx. 
"Monograpuers, come from whenee they may, have, I think, fair pro. tence to elallenge some regard and approbation from the lovers of Natural History; for as no man can alone investigate all the works of Naturo, these partial writers may each in his department be more aceurate in their diswreries and freer from errors than more general writers, and so by degrees may pare the way to an unirersal, correct Natural History."

Chlabrt Wuite. 


\section{P R E F A C E.}

Two things I desire to do in this Prefacc-to indicate briefly the aim which I have liad bcfore me in the preparation of the present work, and to acknowledge the friendly cooperation and help which have contributed so largely to give it the measure of completeness which it may possess.

I must remind the reader that the work professes to be a 'History;' and as such I have cndcavoured to make it, so far as my opportunitics would permit, an exhaustive account of the organisms with which it deals. I have not aimed at the terse and almost epigrammatic diagnosis in which some of the early systcmatists excelled, believing that it no longer mects the requirements of science. I have substituted for it detailed and minute description, taking account, not mercly of a few salient characters, but of all the minor features and varictal modifications of ihe specific type. If in some cases it shonld secm that an undne space has been allotted 
to apparently trivial particulars, it must be remembered that it is precisely in these that we often meet with the most suggestive genealogieal hints, and discover the earliest stages of that process of minute progressive change which has resulted in such richly varied modification of organic form.

It is needless to say a word in these days on behalf of the careful study of varietics; it has been my cndeavour in the present work to exhibit them in their faint beginnings, as well as in their fuller development.

Our attempts at the Classification of the Polyzoa must still, I fear, be in large measure provisional; but it is ecrtainly time that the purely artificial methods of the past should give place to a system aiming, at least', to represent the natural relationships.

The arrangement which I have adopted has many points of agreement, so far as general principles are eonecrued, with that which we owe to the able Swedish zoologist, Professor Smitt; and I desire here to acknowledge my many obligations to his suggestive writings. Though its details may be open in some respeets to criticisu, it will, I trust, belp the student towards a truer coneeption of the relation of the different forms and the significance of their morphological eliarneters.

Whatever clianges of system may eome, I may be allowed to hope that the minute and careful study of the individual species, of which this 'History' is the record, may retain some permanent value, and may 
perliaps help the workers who suceed me to better results than I have attained.

It only remains to discharge the pleasant duty of acknowledging the various assistanee which has been so frecly rendered to me.

'I'o Mr. Busk I am under great obligations for the readiness with which, throngh many years, he las given me the benefit of lis extensive knowledge and large stores of material, and for his friendly sympathy amidst the difficulties incident to my work.

From the Rev. A. M. Norman I have received illvaluable assistance. His unsurpassed collections, comprising the rich inheritance bequeathed by the late Mr. Barlec, and the fruit of his own extensive dredgings, have been placed unreservedly at my service. Unique specimens of great value, and the types of the species deseribed by himself, have been frecly lent, in spite of all the risks of transit, and have becu left in my liands as long as wanted. Many of the figures in this work have been drawn from examples which his kindness has supplied. I also owe to him the opportunity of examining extensive series of specimens, such as only a collection like his could supply, thus making a more complete study of the species than would have been otherwise possible. And, in addition to this material help, most bountifully rendered, I have also to acknowledge much valuable information, especially respecting the distribution of the Polyzoa, which has been frecly placed at my dis. posal. 'I'le service which Mr. Norman has rendered me has been large in extent and peculiar in kind; 
and I can only hope that I may in some measure have repaid him for it by turning to aceount the material whieh he has so liberally supplied, in the interests of oul favourite scienee.

$\mathrm{My}$ old friend and ally Mr. Peaeh has kindly helped me, both with his rich eollections and his large expericnee as a praetical naturalist.

'I'o Dr. M'Intosh I an indebted for interesting speeimens, and, still more, for very valuable suggestions and for the communication of his views on some of the diffieult problems with which I have had to deal.

Professor Ray Lankester has most obligingly furnished me with information which I needed respecting those branches of my subject on which he is so high an authority.

Mr. Lcipner has freely supplied me with his beautiful mountings of the Polyzoa, in whieh they may be studied almost as when living-and has thus given me most important assistanee, especially in the investigation of the Ctcnostomatous forms.

To Mr. Alfred Bell I owe an extensive list of Polyzoa from the Upper and Post-Tertiary deposits, aceompanied by valuable notes on the charaeter and arrangement of the beds.

I have to thank Prineipal Dawson, of M'Gill University, Montreal, for a very interesting series of species from the St. Lawrence and from the Cantdian Post-Plioeene deposits, which he has so ably investigated.

'I'o Dr. J. Barrois, of Lille, I am under peculiar obligations for his eourtesy in pernitting me to re- 
produce some of the admirable figures from his great work on Polyzoan Embryology, and also communicating to me some of the latest results of lis researches -a service for which my warmest acknowledgments are due.

I certainly have reason for holding that good fellowship and an unselfish devotion to the interests of science are still the prevalent characteristics of the naturalist. May they be perpetual!

In the preparation of this work I have had the cordial cooperation of the Publisher, to whom British Natural History owes so much, and who is still true to the honourable traditions of his house.

The Plates bear witness to Mr. Hollick's admirable accuracy, and to his power of rendering the minutest detail with perfect fidelity. It is also right that Mr. Evans and Mr. Kirchner should have the credit of the Woodcuts, which do justice to their subjects.

In closing the pleasant labour of many years, I may take up the lament of that fine old student of nature, Otho Fabricius, "non sine dolore multa intacta relinquere coactus fui;" and (under a full sense of the imperfections of my work, beyond its mere incompleteness) I add, with him, "unico illo solatio fretus, QUOD ETAS SUPPLERET DEFICIENTIA."

T. H.

Budleigh-Salterton, Devon,

Norember 1879. 
"Naturalists now look upon the study of varieties as more important than that of well-fixed epecies. It is in the forner that we sce nature still at work, in the very act of proclucing those wonderful modifications of form, that endless rariety of colour, and that complete harmony of relations, which gratify every sense and gire occupation to every faculty of the true lover of nature."

A. R. Wathace. 


\section{TABLE OF CONTENTS.}

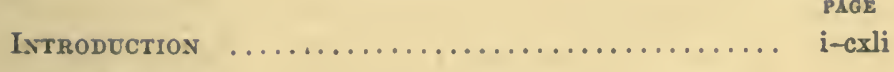

Termerologx $\ldots \ldots \ldots \ldots \ldots \ldots \ldots \ldots \ldots \ldots$ i

General Plan of Structure .............. iv

The Zoøcrom ........................ vi

Ecrocrst........................... vii

Comantcatron-plates $\ldots \ldots \ldots \ldots \ldots \ldots \ldots \ldots$ viii

ExDocrst $\ldots \ldots \ldots \ldots \ldots \ldots \ldots \ldots \ldots \ldots \ldots \ldots \ldots \ldots \ldots \ldots \ldots$

The Polypide $\ldots \ldots \ldots \ldots \ldots \ldots \ldots \ldots \ldots \ldots \ldots \ldots$ xiii

Tentacular Crown and Sheath ............ xiv

Alimentary Canal ..................... xviii

Nervots Srstey ..................... xxvii

Muscular Srgtey $\ldots \ldots \ldots \ldots \ldots \ldots \ldots \ldots \ldots \ldots$ zxix

The Perigastric Cavity ................ xxxiii

Tmr Exdosarc ....................... $\operatorname{xxxv}$

Fat.l and Rentewal of tue Polypide.-Tue "Brom BODY" $" \ldots \ldots \ldots \ldots \ldots \ldots \ldots \ldots \ldots \ldots \ldots$ lii

Modifications of the Zocecial trme.-Aricclariem Ixiv Vinraculum .......................... Ixxix

Polyprde of tur Estoprocta .............. Ixxxir 


\section{CONTEN'T'S.}

Orase

Organs of Srasse................... Irxxiv

Reprodection and Eymrology ............. Ixxxyi

Grasatron ........................... cii

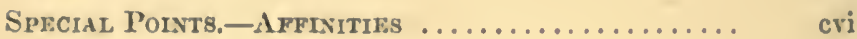

Distribution in Space and Time ............ cxii

Classification........................ cenviii

Name of the Class $\ldots \ldots \ldots \ldots \ldots \ldots \ldots \ldots \ldots \ldots$ cxxxi

Prosphonescence ..................... cxixx

Systematic Table ................... cxxxv

Subclass HoLodraxchia-Group Ectoprocta .......... 1

Order GrunoLienata ...................... 1

Suborder Cueilostomata ............... 1

Family Aeteid $\ldots \ldots \ldots \ldots \ldots \ldots \ldots \ldots \ldots$, 1-10

, Eucratudz............... 10-30

" Cellularid a ............ 30-63

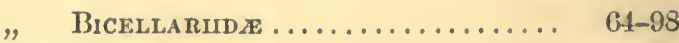

" Notamind ............... 98-103

" Cellaridde............... 103-113

" Flustrid . .............. 113-126

, Membraniporid $\ldots$.......... 126-172

" Microponid . . . . . . . . . . . . 172-182

" Cribrilinid . ............. 182-203

" Microponellid ............ 204-225

, Ponnid

" Mrniozoide. . . . . . . . . . . . . 236-295

", Eschanid . . . . . . . . . . . . . 295-397

" Cellepontd . . ............ 397-113

"PoriNide (species omitted previously) 413-415

Suborder Crclostomata................ 416

Frmily Crismind . . . . . . . . . . . . . 417-423 
CONTEN'TS.

PAGE

Family Tubuliporid. $\ldots . \ldots \ldots \ldots \ldots .424-460$

" Honverid ............. 467-471

, LICHENoportd . ........... 471-487

Suborder Ctenostomata.............. 489

Group HalcyonflLEa . . . . . . . . . . . . 490

Family Alcyontond. . . . . . . . . . 490-50t

" Flustrfllide ............ 501-508

$"$ Arachinidid E ........... 508-511

Group Stolonifera $\ldots \ldots \ldots \ldots \ldots \ldots \ldots, \quad 512$

Orthonemida .................. 512

Family Vesiculanidd . . . . . . . . . 512-530

$"$ Buskind... ............ 531-533

, CylindnazCHD. ............ 534-540

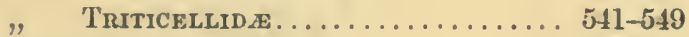

Campylonemida ................. 50

Family Valkerude . . . . . . . . . . 5 5 51-555

, Mimosellid . . . . . . . . . . 555-558

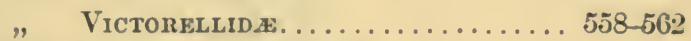

Subclass Holobraxchia -Group Entoprocta ......... 563

Order P'edicet.linea $\ldots \ldots \ldots \ldots \ldots \ldots \ldots \ldots \ldots$

Family Pedicellintd a . . . . . . . . 563-571

$"$ Loxosonide ............ 571-576

Subclass P'terobraxcuid ................ 577

Order Podostomata ................ 577

Family Rhaddopleuride.......... 577-582

List of Works and Papens on the Polyzoa....... 583-589

Explanation of Intrials................. $\quad 590$

INdex to Woodcuts . . . . . . . . . . . . . . 591-593

Gexeral Index ...................... 595-601 
Fig. xlvi.

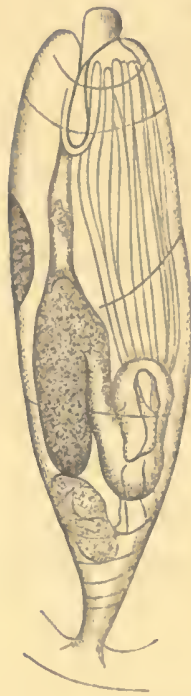

Farrelta.

Showing the mode in which the polypide is stowed away in its cell during retraction. 


\section{INTROD UCTION.}

Tиe Polyzoa are almost universally composite animals*, forming colonies, often of considerable extent, which are the produet of repeated, eontinuous gemmation. They are all inhabitants of water, and for the most part of the sea; but a eomparatively small though very interesting group las its home in fresh water-in river, stream, pond, or lake.

They present the greatest variety of form and labit, which eannot be generalized in any definite formula. Sometimes they grow in plant-like tufts, eomposed of series of eells variously linked together; sometimes they spread orer shell or stone, like the finest laeework or fairy chains; sometimes they rise into stony corals, or broad and flexile fronds. At times they bury the seaweed beneath their fleshy erusts, or invest it with silvery network. In many of the stony kinds the eells are riehly senlptured and exhibit an immense amount of mieroseopic ornament; in others the eolonies are built up of exquisite little frosted tubes, often graeefully

* The only known exceptions are the members of the genus Loxosoma, heferstein. 
curved and delicately tinted, which form the most varied and attractive combinations. But whatever the diversity of external aspeet, the interual strueture is conformed to one very definite type.

Before proceeding to sketeh the general plan of organization amongst the Polyzou, and the various zooidal forms, it will be necessary to define the prineipal deseriptive terms employed.

\section{TERMINOLOGY.}

Happily this is eomparatively simple, and presents no special difficulty in limine to the student. A few terms, which are most of them in general use, are suffieient for all the purposes of accurate scientifie deseription.

ZOARIUM (=polyzoarium auett.).-The eomposite strueture formed by repeated gemmation.

Zoøerum (=cell auett.; cystid, Nitsehe; Brutkapsel, Reichert).-The ehamber in which the polypide is lodged.

Polypide (=polype of older authors; bryozoid, Reichert).-The zooid, eonsisting of alimentary eanal, with tentacles, nervous ganglion, \&e., which is developed within the zoœeium.

Cencerum (=polypidom, Johnston; polypary auett.). - The eommon dermal system of a eolony.

Eетоеуsт (=ectoderm).-The outer layer of the conccium.

ENDoerst (=endoderm).-The inner layer of the cœencium.

Exdosarc (=" colonial nervous system," F. Müller; 
"Funicularplatte," Nitsehc; " das communale Bewegungsorgan," Reichert). $\mathrm{A}$ tissue, derived from the endocyst and composed for the most part of fusiform cells, which constitutes the eonnexion between the polypides in a eolony.

Funiculus. - A contractile cord, attached to the base of the stomach of the polypide and passing down to the bottom of the cell : a portion of the endosare.

Perigastrie cavity.-The space between the endocyst (or inner wall) of the zoceium and the polypide.

LOPHOPHORE. - The frame or stage surrounding the mouth, which supports the tentacles.

Communication-plate ("Rosettenplatte" of Reichert; communication-pore, Smitt).-A diaphragm, piereed by one or more minute orifices, occurring in the walls of the adjaecnt eells amongst the Cheilostomata, and between the internodes and at the base of the zoceia in the Ctenostomata; by means of which eommunication is maintained between all the eells in a colony and between all the eompartments of the stolon.

Oøerum (=ovicell auett.).-The special receptacle, attached to the zoøcium, in which the ova complete their development into the larva, in many of the Cheilostomata.

GoNocyst.-The inflation of the surface of the zoarium, in whieh the embryos are developed in certain sections of the Polyzoa.

Gonacium.-A modified zoøecium set apart for reproductive functions*.

- In the systematic portion of this work, the term oxcium is applied equally to the marsupium of the Cheilostomala, tho modificd, reproductive 
SroLos.-The ereeping tubular stem, by which the individual zoccia or eelliferous shoots composing a colony are held together, in certain members of the elass (e. $g$. the Clenostomata).

\section{Geseral plan of Structure.}

In every polyzoon we distinguish two fundamental elements, the zoceium and the polypide. These are the

Fig. i.

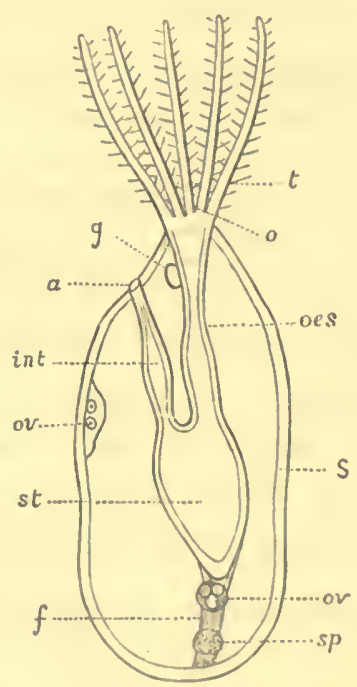

S. Membranous sac. t. Tentacular crown. o. Mouth. aes. CEsophagus. st. Stomach. int. Intestine. a. Anus. g. Nervous ganglion. $f$. Funiculus. ov. Ovary. sp. Spermary.

primary zooids in every eolony. When the larva fixes itself, after its brief term of free life, it is metamorphosed

cell of Crisia and other forms, and the superficial inflation of the zoarium in which the embryos are developed in many of the Cyclostomata. It is clearly desirable, however, that these very different structures should bo distinguished by separate names. 
into a single sac or eell $*$, inclosing a mass of formative material and ecrtain rudimentary elements, out of which a polypide is developed. These two constitute together the primary term of the eolony; and by repeated buddings, according to the pattern of the species, the composite zoarium is built up. The colony is formed by the indefinite repetition of the primitive zooids and their modifications.

The polypide consists essentially of a tube (alimentary canal) bent upon itself so that its two orifices approximate, one of them (the oral) (Woodeut, fig. i. o) being furnished with a number of eiliated tentacles (Woodcut, fig. i. $t$ ). In the tube or eanal distinct regions are rceognizable-an cesophagus, stomach, and intestine (fig. i. oes, st, int) : on the side of the œsophagus lying nearest to the second of the two orifices (the anal) is placed a nervous ganglion (fig. i. y). The alimentary canal, thus constituted, is inelosed in a sac filled with fluid (the zocecium) (fig. i. S), which possesses two openings, corresponding with the two extremities of the tube: through one of them the tentacles are expanded; through the other the rejectamenta are expelled (fig. i. a). In most of the members of the elass the upper or oral extremity of the sac is soft and flexible, and is eapable of being inverted (or invaginated) and drawn within the eavity when the polypide retreats into its ecll, the inverted portion forming a sheath round the tentacles $†$

* "La première zocicio, souche de la colonio nouvelle, n'est pas, comme on l'a dit, engendrée par la lario. C'est la larvo elle-ıuémo qui so métainorplıose comme la chenillo so uétamorphose en claryealide, c'est à diro en conserrant son individualité." - JoLst, Liryaz. d. cótes d. France, page 83.

+ This is not the enso amongst the Entoprocta (Pedicellina aud Loxosoma), nor in Phaldoplenera, the polypicle of which is quite mattnched to ita cell. 
(Woodeut, fig. ii. sh). All but universally * the alimentary canal is furnished with a system of museles, by means of which it can he partially exserted and retracted.

Fig. ii.

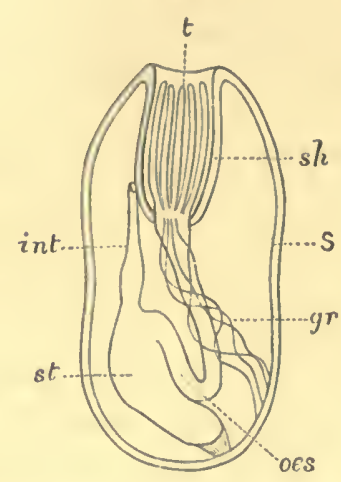

sh. Tentacular sheath (invaginated). $t$. Tentacles. gr. Great retractor muscles. st. Stomach. ces. Esophagus, doubled up alongside the stomach.

Within the eavity of the eell reproductive organs are developed, in various positions. Heart and vascular systẻm are wanting.

These are the general features of the polyzoan type of strueture.

\section{The Zocecium †.}

The zoceium or ecll, the home of the polypide, and one of the elements of which the ecnocium is composed, is the primary zooid of the eolony, and as such is entitled to our first consideration. In its normal condition it is a sae, of variable size and shape, which incloses and protects

* The exceptions here also are the Entoprocta, in which the polypide is not retractile and the tentacles are merely rolled up, and Rhabdopleura, in which the muscular system is suppressed and the polypide crawls out of its cell by means of a large foot-like organ.

+ Zw̄ov, mimal, ancl oixion, house. 
the alimentary zooid. But the struetural type which it represents appears under various modifieations, subservient to very different functions, as we shall see hercafter. At present we are to regard it, in its primitive form, as the house of the polypidc.

Its walls are madc up (with, perhaps, a single excepe tion*) of two mcmbrancs, which arc perfectly distinct in histological character and in function.

Естосуsт.-The outer (ectocyst) is essentially a simple chitinous membrane, witlout any apparent structure, and is a secretion from the inner layer of the cell-wall (endocyst). In a large proportion of cases the ectocyst is strengthened by the deposition of calcareous or siliceous particles, and forms a solid wall, the free surface of which is often curiously sculptured or embossed. In others it retains its primitive mcmbranous character, or is slightly coated with earthy matcrial; in others, again, it is soft and gelatinous. In many forms the calcification of the cetocyst is only partial; and important systematic distinctions are founded on the differences in degree which it exhibits, and the conscquent structural peculiarities of the cell.

The Polyzoan colony, as already remarked, consists of a larger or smaller number of zoœcia variously united together, which are produced by repeated gemmation. Buds are given off from the primary cclls, which are soon developed into secondary cells; and from these again others arisc. In the same way every sucessive zoœcium multiplies itself; and the cœnœcium continucs to cularge so

- Accorling to Allman, the fresluwater genus Cristtaella is destitute of an ectocyst. Hratt, however, regards it as possessing one, and describes it as "a transient gelatinous exeretion" (op. cif. page 14). 
long as the vital energies are unexhausted. But the eclls are not mere isolated ehambers placed side by side and connected one,with the other as portions of a continuous structure, like the bricks in a house, but are united in a much more intimatc and vital way. 'Their soft contents are in direct connexion 10 less than their external surfaces; and as the structure by means of which this connexion is maintained belongs to the system of the ectocyst, it may be noticed here.

In the outer wall of the cell (amongst the Cheilostomata) certain spaces are met with in various positions, which are composed of thinner material than the rest of the eetocyst, and are pierced by one or more very minute perforations (Woodeut, fig. iii. $c p$ ). These thin perforated

Fig. iii.
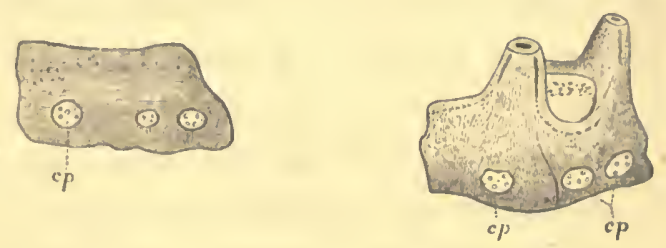

Memiranipora membranacea.-Wall of zoœcium.

cp. Communication-plates.

plates occurring in the cell-wall have been named by Reichert "Rosettenplatten"*; but as this term cannot be very aptly rendered into English, I shall distinguish them as communication-plates. Amongst the Ctenostomata we find their equivalent in the diaphragms elosing the eells at their base, and separating the internorles of

* "Vergleichende anatomische Untersucliungen ü. Zoohotryon pellucidus, Ehrenberg, von Karl B. Reichert," Ablundl. d. königl. Akad. d. Wissenschaften zu Berlin, 1869), p. 267: 
which both the crecping stolon and the ereet stems are composed. Througl the minute orifices in these plates thread-like prolongations of the endosarc pass, and establish a connexion between all the polypides in the colony. The communication-plates vary in number, position, and form; they are furnished cither with a single central foramen* or with scveral minute pores arranged in different ways (Woodeut, fig. iv.). According to Nitsche $\dagger$, in

Fig. iv.

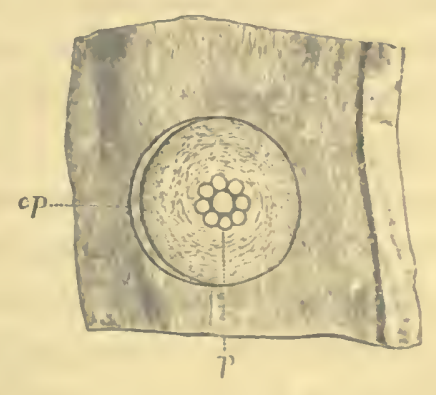

Zoobotryon.-Portion of stem.

cp. Communication-plate. p. Pores.

the common Membranipora membranacea each normal zoocium has generally twclve of these plates-two at each cxtremity, and four in each side-wall. Those belonging to each zoceium correspond with others in the adjacent walls, so that the connecting-threads can pass directly from cell to cell. Every zoœcium in this spccics has two openings into each of the six cells which abut upon it.

Mr. Waters lias drawn attention to the communication-plates as likely to afford good diagnostic characters,

- As in Bowerbankia imbricata, accorling to Joliet, 'Bryozoaires d. cootes de France, p. 31, note.

† 'Beitrïgo zur Kenntnisz der Bryozoen," ii. IIeft: "Ueber dio Inatomie 11. Entwicklungsgesch. von Flustra membranacea," Zeitsch. f. Wissensch. Zoul. xri. Band (1871), 4. Heft, p. 4:2. 
especially for the determination of fossil forms; and 110 doubt they may be available to some cxtent, ehicfly in cases in which the salicnt characteristics of the ecll have been more or less obliterated. Otherwise the difficulty of examining them must always himit their use in ordinary diagnosis.

Nitsche, in his intcresting monograph on Membranipora membranacea, has pointed out a modification in the structure of the ectocyst in this species by which it is adapted to its usual habitat. The cœnœcium is not a continuous stony framework, but in crery zoœcium certain scetions only of the wall are calcarcous, and between these are interposed uncalcificd and flexible plates. In this way the whole ecll is rendered flexible, and consequently the whole colony, composed of thousands of cclls; and instead of brcaking up as the great Laminarian fronds in which it delights sway backwards and forwards in tlic water, the living laccwork adapts itsclf to their undulations and cscapes destruction. So far as function is concerned, these flexible plates may be compared, as Nitsche has already remarked, with the corncous joints in the stems of many of the crect and branching Polyzoa.

The ectocyst, then, or external layer, is a mere structureless cxcretion from the endocyst, cliarged with a protective function, but with no special physiological significance.

We pass on to a mucl more important clement of the structure, the endocyst itself, or internal layer of the cellwall.

ENDocyst.-'This prescuts itsclf under somewhat different forms in the Gymnolamata aud Phylactolamata (or 
freshwater Polyzoa), amongst the Ectoprocta, and in the group of the Entoprocta. As this work does not include the Phylactolcemata, I shall confine myself at present to an aceount of the endocyst as it exists amongst the other sections of the class.

First, then, in the marine Ectoprocta the endoeyst appears in the adult cell as a delicate transparent membrane, without any cellular structure, a layer of simple protoplasm, lining the ectocyst throughout, and generally lying elose upon its inner surface*. But though it occurs in this condition in the older regions of the cœnœcium, it is essentially a cellular membrane; and its true nature may be readily determined by the study of the growing extremities of a branch or stolon amongst the Ctenostomata (for instance), which offer the greatest facilities for investigations of this kind. Here, according to Joliet, the cndocyst appears as a very thick layer, and cxlibits a distinctly cellular structure. He describes it as composed

* I may say here once for all that I do not propose to enter into minute bistologieal detail. The space at my command would not allow of my doing 80 ; and, apart from this, such detail would be out of place in a general sketch like the present.

On tlie structure of the endocyst the reader may consult:-Suitr, "Om Hafsbryozoernns Utveckling oeh Fettkroppar," Efr. Kongl. Vet.-Akad. Förh. 1865, no. 1, p. 16; Claparède, Zcitschr. f. wiss. Zool, xxi. p. 142; Nirscure, "Ueb. Flustra membranacea," Zeitschr. f. wiss. Zool. xxi. Heft 4, pp. 4t46; Reicierr, "Vergleich. anatomisehe Untersuehungen üb. Zoobotryon pellucidus (Ehrenb.)," Abhandl. königl. Ak. d. Wissenseh. zu Berlin, 1869, p. 270 ; Jolıt, 'Bryoz. d. còtes de Frnnce,' pp. 56-58, and p. 65; Euırs, "Hypophorella expansa, ein Beitrag zur Kenntniss der minirenden Bryozoen," Abhandl. königl. Gesellschaft d. Wissenschaften zu Güttingen, xxi. 1876, p. 27 (sep.). In the Entoprocta specially:-Nirscite, "Ueb. die Anatomie ron Pedicellina echinata," Zcitschr. f, wiss. Zool. xx. Heft 1. p. 18; Sal.exsky, "Etudes gur les Bryoz. Entoproctes," Ann. Sc. Nat. sér. 6, Zool. vol. v. art. no. 3; Jourt, op. cir. p. 61 . In the Phylactolemata:Alimax, 'Fresliwater Polyzoa,' p. 11 ; IYAtr, "Obsersations on Polyzon, suborcler Phylactolacinata," Proc. Fssex Inst. rols. ir. \& v. 186,6-68, p. 26; Jot.ter, up. cit. p. 50. 
of conical eclls placed closely together, their basal surfaces turned towards the ectocyst and forming an irregular mosaic work, whilst their opposite pole is dirceted towards the eentre. These eells possess a distinet nucleus, and are very refractive.

Amongst the Ectoprocta (Pedicellina, \&e.) the endoeyst eonsists of a layer of polygonal eells, with strongly refractive oval nuelei, which lies elose upon the inner surface of the ectocyst. In this division its cellnlar character is distinguishable at all points, though it is more elearly and strongly marked towards the upper extremity of the peduncle*.

As to the specific funetions of the endoeyst, it has been held that it gives origin directly to all buds formed within the conœeium, and to the generative produets of both kinds $\dagger$. Aceording to this view, it is the souree of the polypide, and of both the ovary and spermary. A different rôle, however, has been assigned to it by the able French biologist Joliet; and it will be neecssary to consider somewhat in detail the very important eonclusions to which his researehes have led him. It will be more eonvenient, howerer, to do this hereafter; and I shall merely state generally at present that he regards the endocyst as specially charged with the clllargement of the colony, and also as giving origin to a distinct tissue, which he names (provisionally) the enclosarc, to which are really assignable the functions hitherto eredited to the endoeyst, and others beside.

Connected with the endoeyst is an apparatus of

* Joliet, op. cit. p. 61.

† Nitsche, "Ueb. die Morplologie d. Bryozoen," Zeitsch. f. wis z. Zoul. xxi. IIeft $t$, p. 102. 
muscles, which plays an important part in the economy of the Polyzoon, and whiel may be notieed here. It eollsists of a number of sliort transverse fibres or bundles of fibres, which pass from point to point on the surface of the inner wall of the eell, and which by their eontraetions are instrumental in eompressing the membrane and so reducing the dimensions of the perivisceral eavity. In this way pressure is brought to bear on the eontained fluid, and a foree is generated which discharges, as we slıall see hereafter, a most essential function. These fasciculi are known as the parietal muscles.

We are to eoneeive, then, of the zoceium as a chamber inclosed by a more or less solid outer wall, and within lined by a soft tapestry of living membrane, a well-built and well-furnished dwelling, of which the polypide or alimentary zooid is the tenant.

\section{T'he Polypide.}

The general plan of the structure las been already sketehed. In examining the details it will be neeessary to take the two great divisions of the Polyzon (the Ectoprocta and Entoprocta) separately.

For a detailed aceount of the freshwater members of the former group (Phylactolemata), I may refer to the writings of Allman*, Van Beneden $\dagger$, Haneoek $\downarrow$, IIyatt $\$$,

* 'Monograph of the Freshwater Polyzon,' Ray Society, 1856.

+ "Recherehes sur les Bryozoaires fluviatiles de Belgique," Mfém. Ac. Roy. Belg. xxi. 1847; (Dumortier and Van Beneden), 'Hist. Nat. des Polypes composés d'eas douce, $2^{\star}$ partie : complément an tome xvi. d. Mlém. de l'Acad. Roy. Brux. 1848.

$\ddagger$ "On the Anutomy of the Freshwater Bryozoa," Ann. \& Mag. Nat. Hist. Mareh 1850.

\$ "Observations on Polyzon, suborcler Plıylactolxunata," Pra:. Essex Inst. $1866-198$. 
and Nitsche*; they lie without the limits of the present work.

The strueture of the polypide as it oeeurs in the ordinary marine forms may be eonsidered under the following headings:-i. the tentaeular erown and sheath; ii. the alimentary canal; iii. the nervous system; iv. the museular system.

Tentacular Crown and Sheath.-The tentaeles form a bell-shaped wreath, whieh is borne on a kind of eireular stage (the lophophore), oceupying the summit of the body, and perforated in the eentre by the mouth. They are ranged round the eireumferenee of the lophophore, which eonstitutes at onee the floor of the tentaeular bell and the roof of the perigastric eavity, lying immediately below it. The mouth is a simple round orifiee, opening into the œsophagus, and so plaeed as to form the foeus towards which the supplies of food drawn in by the eiliary vortex eonverge. The slender filiform tentaeles are tubular, elosed at the free extremity, and opening at the base into the perigastrie eavity $\dagger$, or spaee interposed between the wall of the eell and the body of the polypide, from which the nutritive fluid is freely admitted to them. They are furnished with vibratile eilia, which are ranged in a single line along the two opposite sides, and by their rapid and ineessant movement, when the polypide is expanded, create a very maelstrom in the water, which swceps the

* "Beitrïge z. Anat. u. Eutwicklungsgesch. d. phylactolæm. Süssw. Bryoz.," Archiv f. Anat. u. Physiol. 1868. Sep. Abdr. " Ueb. die Knospung der Polypide der phylactolæmen Süsswasserbryozoen," Zeitsch. f. wissenseh. Zool. xxv. Suppl. Bd. Heft 3, 1876.

+ There seeins to be littlo doubt that this is the case, though Roichert clescribes the cavity of the tentacles in Zoobotryon as being in communieation by means of minute orifices with that of the 'asophagus. 
passing animalcule or the floating food-partiele towards the eentral moutl. An examination of the strueture of the tentaele shows us on caeh side a layer of eells, furnislıed witl a large and brilliant nueleus; and from these the eilia originate as a simple Fig. v. extension of the eell-wall. (Woodeut, fig. v.)

Amongst the Gymnolamata the tentaeles are always disposed in a cirele; in the Phylactolcemata they range in a eontinuous series round a ereseentic lophophore. In the $E n$ toprocta the arrangement is somewhat obseurely bilateral; whilst in the aberrant group of the Pterubranchia they are borne in diseontinuous series on two lateral processes of the lophophore. 'They are very variable in number, ranging from eight (whiel seems to be the minimum) to eighty in some of the fresliwater forms. Their movements are rapid and energetic; they ean be bent hither. and thitlier; they strike with vigorous pereussive

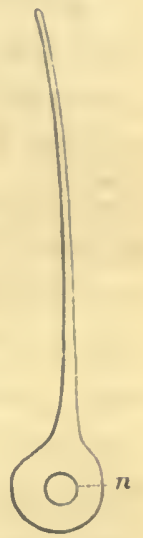

Ciliary cell of

Fredericella. $n$. Nucleus. aetion; they ean be instantaneously eoiled into a spiral, and as suddenly unrolled. They assist the eiliary currents, by their varied movements, in obtaining food, and help to keep off unsuitable or injurious matter.

But they are not only eoncerned with the direet nutrition of the polypide; they have also a distinet respiratory function. The ciliated tentaeles of the Polyzoa* are, no

* "Gill-filaments" (Ray Iaukester), identical with " the gills and labial tentacles of the Iamellibranchia and the spiral arms of the Brachiopods." See "Notes on Embryology and Classification," Quart. Journ. Micr. Soc. new ser. no. 68,1877, p. 423 . 
doubt, largely instrumental in promoting the aeration of the fluids whieh enter them freely from the perigastric cavity. They must also be regarded as taetile organs, and in many speeies arc furnished with spceial appendagres, by which their sensitiveness and power of detceting the presence of minute partieles are largely inereased. They are (as Hyatt has remarked*) "the only means possessed by the polypide of reeeiving impressions from without."

The encrgetie movements of whieh the tentaeles arc eapable would lead us to expeet an efficient service of museles in eonnexion with them. In Laguncula (Farrella) Van Beneden deseribes muscular fibres in each arm; he also detceted delicate bands in the freshwater group which he regards as of the same naturc. Hyatt has demonstrated two sets of "tentaeular bands," an outer and an inner, in each arm, which arc in eomncxion with museles ruming through the lophophore, and control the movements-the external bands inelining the tentacle outwards or sideways, the internal bending it towards the centre of the lophophore. This observation has been eonfirmed by Nitsehe, who finds in the tentacles a pair of faseieuli, each of which eonsists of two or three long fibres.

In the tentacles of Membranipora membranacea and of - Pedicellina the lattcr author has noticed obseure traces of muscular strueture; those of Loxosoma, aceording to Vogt, show no indieation of it.

* Op. cit. p. 47. The polypides (according to this author) aro not sensitive to light. "At ordinary temperatures even the darkness-luving Fredericella may be exposed for a time to tho direct rays of tho sun without any visiblo result, although but just removed from the perpetual shade in which it had previously lived." 
The tentacular sueatu is an important element of the structure, and a very characteristic feature of the ordinary Polyzoan type (Woodcut, fig. ii. $s h$ ). It is a membranous extension of the anterior part of the zoccium, which, when the polypide is retracted, is inverted and drawn in with it, eloscly surrounding the folded tentacles. According to some writers * it is wholly eomposed of the endocyst ; but Joliet refers it to the tissue which he has named the endosarc, of which an account will be given hercafter. The invagination of the sheath is duc to its attacliment at its upper extremity round the base of the erown of tentacles; as the latter deseends in obedicnce to the summons of the retractor muscles it is, of eourse, drawn down with it, and reversed as the finger of a glove miglit be under similar eircumstances, forming a protective ease around it, which somewhat exceeds it in length. By this arrangement the zoøcium is completely elosed; there is no real opening through which the polypide passcs. It is the upward movement of the tentacular corona (to bc explained hereafter) which carries with it and evcrts the flcxible sheath, and so permits the imprisoned zooid a certain amount of communication with the outer world; but the eavity of the cell itself is sealed. 'The movements of thic polypide in the acts of cxpansion and retraction arc limited to the evcrsion and inversion of the sheath ; and only the eorona is brought into immediate contact

* Allman and Nitsche. Ehlers, however (op. cit. p. 37), considers that both ecto- and endocyst enter into its composition, though the former is (in many species) less solid in this portion of the structure than in the rest of the outer wall of the cell. Joliet holds that the tentacular sheath is a derivative from the endosarc (see page $x \times x v$ ), and not an invaginable portion of the endocyst. He describes it as of the same nature as the funiculus, resembling it in its mode of development, in its coutractility, and in its histological elements (op. cit. pp. 51, 52). I an inclined to think that this may prove to be the true account of it. 
with the surrounding water. In the sheath museular fibres, both longitudinal and transverse, oceur; and the latter form a broad sphineter at a short distanee from the base of the tentaeles.

By "the orifice" of the zoceium is meant the opening through which the tentaeular sheath and the eorona are protruded. Of eourse it is not an opening in the sense of a passage giving aceess to the interior of the eell; it is the break in the more or less solid portion of the wall through which the evaginable part of the zoœeium is pushed forth; and by this and the tentacular eorona it is permanently elosed. The orifiee exhibits some remarkable struetural peeuliarities, eorrelated with other important eharacters; and these have becn happily employed by Mr. Busk in the definition of some of the leading systematie groups. They will be referred to more particularly in the section on Classifieation. (Sec Woodeut, fig. 35, p. 562.)

Alimentary Canal.-The plan of the digestive system amongst the Polyzoa, though very eonstant in its lcading featurcs, presents many variations in detail. I shall first describc its essential parts, and then refer to some of its more striking modifications.

Three well-marked regions are distinguishable in the alimentary eanal-the osophagus (ineluding the pharyngeal eavity, which is morc or less strongly defined in different speeies), the true stomach (or digestive sae), and the intestine.

The mouth, a simple orifiee, pierced in the floor of the tentacular erown, opens at onee into the upper part of the œsophagus, which is thickly elothed with vibratile eilia, by whose action the food drawn in by, the tentacular vortex 
is forced down into the tube, and brought well within the rangc of its peristaltic movements. The upper extremity of the csophagus is frequently organized as a distinet pharynx (Woodeut, fig. vi. $p h$ ), a wide, funncl-shaped

Fig. vi.

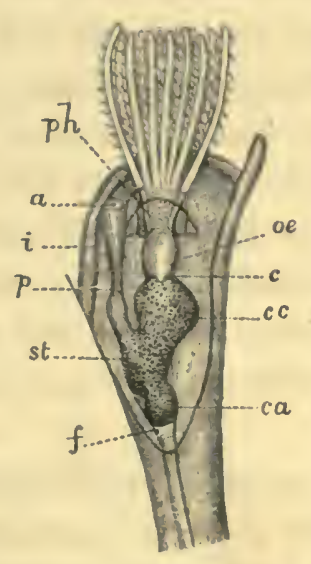

Polypide of Bugula plumosa.

ph. Pharynx. oe. CEsophagus. c. Cardia. cc. Cardiac eavity. st. Stomach. $c a$. Crecal appendage. i. Intestine. $p$. Pylorus. a. Anus. f. Funiculus.

chamber, with muscular walls, capablc of vigorous contractions, within which the particles of food collect, and from which they are hurled down the osophageal tube at intervals into the stomach.

The surface of the pharynx appears to be dotted over with minutc spots (Woodcut, fig. vi. $p h$ ) ; down onc side of it runs (in many cases, if not universally) a band, which is crossed by transverse strix, and which is very conspicuous from the contrast it presents to the rest of the strueturc. It also attracts attention from its vigorous movements, which arc eonnected with the expansion and contraction of the pharynx. There can be no doubt that 
we have here (as Dr. Farre has suggested) a special muscular apparatus, by which the action of this organ is regulated. The pharyngeal eavity, in such eases, must be regarded as playing an important subsidiary part in eonnexion with the nutritive system. Here the partieles of food gather in the first instance, and, it would seem, are submitted to some kind of selective process: when a suffieient amount of suitable material has collected, the constriction at the base of the canal is relaxed, and the food passes rapidly, impelled by the pharyngeal spasm, and subsequently by the peristaltic movements of the osophagus, to the stomach. In other eases, the pharynx is not so elearly defined, and the oral region of the cesophagus is ehiefly distinguished from the rest by its eiliated lining.

The œsophagus varies much in length in different species*: it is usually a straight and slender tube, which leads direetly into the digestive sac. In the course of this tube is placed a valve (the eardia), marking the entrance to the stomach, and eonsisting of a eonical perforated projection, with the free extremity direeted downwards, which opens for the passage of the food, but is otherwise closed, and forms a barrier preventing its return into the œsophagus (Woodeuts, figs. vi. \& ix.c).

The position of the eardia varies in different species; it is sometimes placed high up in the osopliagus, and sometimes much lower down and elose to the true stomach. In Beania mirabilis (Woodeut, fig. vii.) I can detect no separation between the stomach and the osophageal region but the eonstrietion which eloses the funnel-shaped

* Compare Woodcuts, figs. rii. and ri. In the former (Beania mirabils) it is of remarkable length; in the latter (Bugula plumosa) it is almost rudimentary. 
pharynx; and in this casc the dark-coloured hepatic cells range for some distance above the stomach on the walls of the tube, the lower part of Fig. vii. which may thercfore be regarded as in some sense an extension of the digestive sac (=the "cardiac cavity").

In the œsophagus transverse striæare distinguishable, which are muscular in character; and to their action in compressing the walls the peristaltic movements are duc*.

The stomach, in its simpler form, is a sac or bag, with rather thick walls (Woodcuts, figs. i. \& viii. st), often widc abovc, and morc or less pointed bclow; sometimes elongate and almost cylindrical in shape. It is coloured a rich yellowish brown, the colour being due

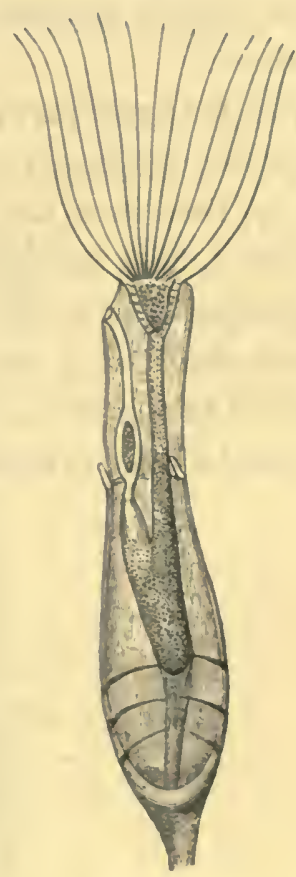

Beania mirabilis. to the presence of numcrous glands on its inner or lining membranc, which secrete a brown fluid, and probably discharge the functions of a liver; this fluid mingles frecly witl the contents of the stomach, and imparts its own colour to them $†$.

* Hyatt, op. cit. p. 48.

+ According to Vogt, these cells are not only biliary in function, but also act as absorbents. In polypides (of Loxosoma) that had been fod with car. mine, he has seen thein assume an orange or scarlet tint, showing that there had been an absorption of the colouring-matter, which had modified the ordinary amber-yellow of the cells.-. "Sur le Loxosome des Phascolosomes," Archiecs de Zoologic experimentale, 1877. 
The walls of the true digestive sac, like those of the œsophagus, are furnished with transverse museular fibres, by means of which the vigorous peristaltie movement, which plays so important a part in the digestive proeess, is seeured.

From the upper part of the stomach, and near the point where the cesophagus or the eardiac eavity (as the ease may be) rises from the main digestive sac, the intestine (Woodeut, fig. i. int) takes its origin, and passes upwards, terminating in an orifice which opens out through the tentacular sheath at a short distance (Woodeut, fig. vi. a) from the base of the eorona*.

Near the lower extremity of the intestinal tube is plaeed

Fig. viii.

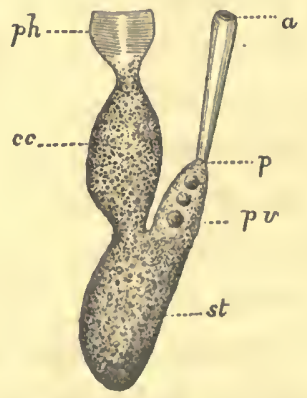

Alimentary canal of Cellepora.

ph. Pharynx. cc. Cardiac chamber. st. Stomach. pv. Pyloric vestibule. p. Pylorus. a. Anus.

the pyloric valve, whieh regulates the admission of the rejectamenta into it. Sometimes the valve is borme on

* The position varies: in some cases the anal opening is situated much lower down on the side of the zoceium; in Alcyonidium gelatinosum it is represented by Farre as occurring at the base of the setose operculumthat is, about halfway down the cell. 
the summit of a somewhat tubular extension of the stomach (Woodeut, fig. viii. $p v$ ), which forms a kind of vestibule to the intestine, and is richly clothed with cilia. Into this space, which may be distinguished as the $p y$ loric vestibule, the indigestible elements of the food are gradually gathered; and here they are formed by the action

Fig. ix.

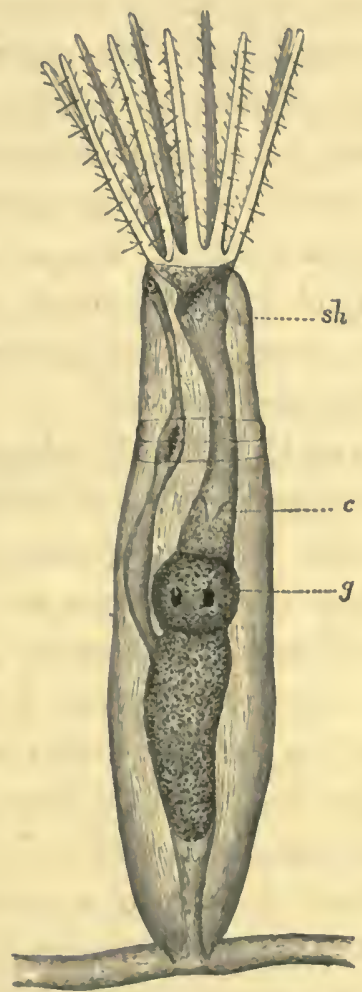

Bowerbankia.-g. Gizzard. c. Cardia.

of the cilia into pellets, which are kept in rapid rotation, and ultimately pass into the intestine. In other eases (as in Bowerbankia, Weodcut, fig. ix.) the intestine 
is continued to the digestive sac, and the pylorus is situated at the point of junction between the two. Amongst the marine Polyzoa the portion of the inner wall of the stomach which abuts upon the pylorus is always clotlied with cilia.

The intestine varies much in form : in some eases it is a long and slender tube (Woodeut, fig. vii.), with perhaps a slight dilatation at one point; in others it is short, wide below, and narrowing towards the upper extremity; in others, again, it expands into two distinct chambers-one placed a little above the point of origin, and the other (rectum) a little below the anus. The exercta are retained for some time in the intestine, and, as Allman has remarked, probably yield to the absorbent tissues their remaining nutritious elements; they are subsequently expelled through the terminal orifice.

Apart from the variations already referred to, there arc one or two important modifications of the digestive system which must be noticed. In some species a globular organ is interposed between the œsophagus and the stomach, which exhibits a highly specialized strueture, and discharges the functions of a gizzard (Woodeut, fig. ix. g). It is an enlargement of the eardiac portion of the stomach, the walls of which are here much thickened, and furnished with a powerful apparatus of muscles. The inner surface of the eavity is lined in part by a number of pointed processes (gastric tecth); and by means of these and the vigorous eontractions of the muscular wall the food is erushed, as in a grinding mill, and then delivered to the stomach to be treated with the biliary seeretion and exposed to the roll of its peristaltic movements. This organ in its fully developed form is only met with in 
one seetion of the Polyzoa, the Ctenostomata, of which the well-known Bowerbankia is a characteristic example (Woodeut, fig. ix.). We find its equivalent, however, in many of the Cheilostomata. This eonsists of a prolongation of the stomacl upwards in the line of the asophagus, extending to the eardia, which is placed high up in eases in whieh this appendage is largely developed. (Woodeuts, figs. vi. \& viii. $c c$.) In the former of these figures, representing the polypide of Bugula plumosa, this eardiae ehamber appears as a globular dilatation, oecupying the lower portion of what in other speeies would be the esophagus; in the latter (Cellepora) it is elongate-oval in form, and extends from the base of the intestine to the pharynx. In this ease the osophagus is redueed to the pharyngeal eavity, while the stomaeh is proportionately enlarged. The walls of the eardiae ehamber are thiekly eovered by the hepatie glands. We must, I think, reeognize in this strueture the homologue of the gizzard, whose place it fills.

In some speeics a. peeuliarity is Fig. x. notiecable in the lower portion of the digestive sae. 'The extremity of the crecum is separated from the rest of the stomaeh by a narrow passage or ehannel, and has the appearanee of a distinet ehamber suspended below it Lower part of stomach. (Woodeut, fig. x.). This cxeal appenca. Cacal appendage. dage is formed, aecording to Joliet, by a thickening of the walls of the stomaeh at a eertain point. It shares in the vigorous peristaltie movements of that organ; the food is earried into it from above, and then foreibly driven baek into the upper compartment. This appen- 
dage is very conspicuous in the common Bicellaria ciliata; I have also noticed it in Bugula. There is nothing in the structure to indicate that it differs physiologically from the rest of the sac. It may possibly have a merely mechanieal function in promoting and assisting the constant flux and reflux of the food within the digestive cavity.

Specialization reaches its height in the digestive system of such forms as Bowerbankia and Bugula, and its minimum probably in that of Eucratea and Valkeria (Woodeut, fig. 33, p. 550); and between the two extremes there lies a rather wide range of structural difference. In the latter we have a perfectly simple condition of the various parts, and the process of digestion is effeeted, so to speak, by a small number of agents.

The details of the digestive process may be studied to the greatest advantage in many of the Polyzoa, the walls of the eell being often so transparent as to permit the most thorough investigation of all that is passing within. In the pharyngeal chamber (where this is differentiated) the partieles of food gather and are sifted; when a ecrtain quantity has accumulated, it is foreibly ejeeted into the œsophagus, and hurried downwards by the contractions of the tube into the stomach. Lodged in the true digestive sac, it comes under the influcnee of the strong peristaltic aetion of its muscular walls, and is driven to and fro by its incessant swcep with a kind of rhythmical regularity throughout the length of the eavity. While this mechanical treatment is in progress, the biliary glands pour in their secretion and the food takes on its rich brown colour. At the same time the indigestible elements are gradually eliminated and gather near the pyloric orifice, where they are kept rotating for a whilc by the action of 
cilia, and gradually pass into the intestine. Where a gizzard is present, the food is crushed in its passage through it and delivered half prepared to the stomaeh*.

Nervous System.-This is present under a very simple and rudimentary form. It consists (amongst the marine forms) of a single roundish or oval ganglion, placed against the wall of the csophagus, towards its upper extremity, on the anal side (Woodeut, fig. i. $g$ ), from which sets of nerves are given off in different direetions. The latter it is exceedingly diffieult to follow; and in many eases they elude observation altogether. Allman, however, suceeded in deteeting, in some freshwater speeies, a nerve-trunk running through the lophophore, and sending off filaments towards the tentacles, and also a filament passing off from the nerve-eentre to the osophagus. The details of the nervous system amongst the Phylactolemata have becn more thoroughly worked out by Hyatt and Nitsehe, who have eonfirmed Dumorticr's observation of the union of two ganglionic eentres in the nerve-mass in this division. These are united by a eommissure, and each of them supplies the nerves to its own side of the body. Nitsehe has also demonstrated the existence of a narrow eollar eneireling the œsophagus. Hyatt deseribes, with some minuteness, the distribution of the nerve-trunks and branehes whieh supply the lophophore and probably the tentaeles (though no filaments are to be traeed into them), the tentaeular sheath, and the various portions of the alimentary eanal. The more delicate nervous filaments he was unable to define.

* I hare scen the food, after passing through the gizzard, driven back into this organ by the contractions of the stomach, and again submitted to its action. 
Generally there is extreme difficulty in making out the details of the system in the marine forms. In Membranipora membranacea Nitsche has only detected merc rudiments of nerve-trunks, on the surface of the ganglion. Ehlers has douc the same in Hypophorella. In Loxosoma Salensky has traced various filaments to the tactilc organs on the sides of the body*; whilst Nitsche has described thrce ncrve-trunks as given off on the opposite sides of the ganglion in Pedicellina, which soon divide and supply the tentacles (Woodcut, fig. xi.). Two of smaller size were also observed passing from the

Fig. xi.

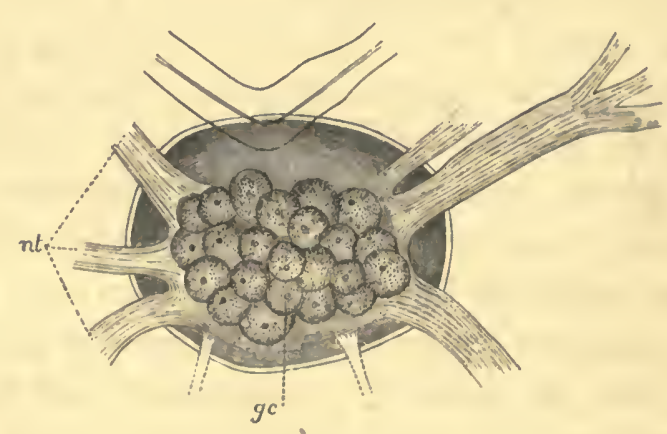

Ganglion or Nervous centre.

$n t$. Nerre-trunks. gc. Ganglionic cells.

anal surface towards the reproductive organs. The ganglion itself consists of a solid membranous envclope, inclosing a mass in the outer region of which no strueturc is distinguishablc, but which is madc up towards the ecntrc of large cells with granular contents and a nucleust.

* "Etudes sur les Bryozoaires Entoproctes," Aun. d. Sc. Nat. 6e sér. Zool. vol. v. (1877), Article no. 3, pls. xii.-xv.

+ Nitsche, "Ueber die Anatomio von Pedicellina cchinata," Sar's, Zeitsch. f. wissensch. Zool. xx. Heft 1, p. 28. 
Of the tissue described by Fritz Müller as a common or "colonial" nervous system; an aecount will be given hereafter.

Muscular System.-This is largely developed amongst the Polyzoa, and exhibits a high degree of eomplexity. Nor will any one be surprised at this who has observed the rapid and varied movements of the polypide and the curious mechanism of the cell. For the mere act of retraction a whole apparatus of muscles is required; and, in addition to this simple movement, the remarkable mobility and varied play of the corona as a whole, and of the individual tentacles, involve a special service. The opercular mechanism demands a distinet set of museles; another is needed to assist in the withdrawal and stowage of the alimentary eanal, another to steady it and hold it in its place when extended, and yet another to secure the contractility of the inner wall, on whicl the protrusion of the polypide is largely dependent. In addition to all these claims, the various regions of the digestive system must have their own supplies of contractile tissue to enable them to diseharge their respective functions efficiently. The power of rapid retreat is essential to the safety of the polypide; and laardly less essential is the perfect mobility of the tentacular wreath; and no one can have watehed a living colony without seeing how admirably these are provided for. At the slightest alarm the exquisite bells collapse and vanish on the instant. When the polypide is expanded and in quest of food the corona ean be swayed in every direction, and each of the tentacles composing it ean be brought into varied and vigorous action. 
Into the details of the muscular apparatus, upon which these and the other movements of the polypide depend, it is not my purpose to entcr hcre*; but onc or two of its lcading elcments may be noticed. The largest and most powcrful of the muscular bands in the cell of the Polyzoon are the great retractors (Woodeut, fig. xii. gr.). These consist of two broad fasciclcs, which are attaehed to the lowcr part of the eell-wall and extend upwards to the base of the tentaeles, where they arc insertcd into the sides of the œsophagus. When the polypide is expanded, they extend as two (apparently) solid bands throughout the greater part of the length of the eell; suddenly contracting, they drag down the corona with the speed of light, invcrting the tentacular sheath (doubling up the alimentary canal at the same time on itsclf), bringing all the parts into the shelter of the ccll, and disposing the wholc structure in orderly fashion within its eavity. In thesc largc bands we ean study to the greatest

Fig. rii.

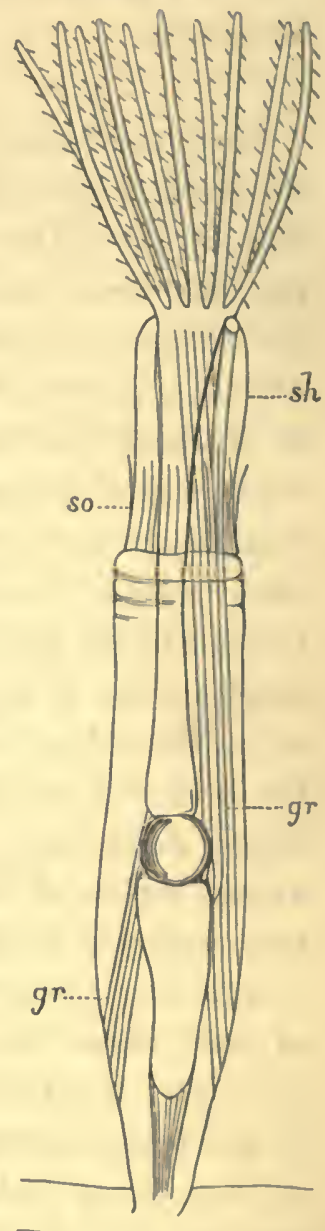

Bowerbankia. advantage the structure of the muscular tissuc.

* Full accounts of the different sets of muscles and of their respectire action may be found in the works of Farre (Phil. Trans.), Van Beneden (on Laguncula), Allman (Freshwater Polyzon), Hyatt (op. cit.), Nitsche (on Membranipora membranacea), \&c. 
The band which, when in a state of tension, seemed to be solid, is found, when relaxed, to be made up of a number of scparate fibres. Complex as the muscular system of the Polyzoa is, the individual muscle is universally of the simplest and most rudimentary kind-a bundle of distinet threads; it never presents the consolidated form which exists in the higher animals. In the large museles the fibres appear (under favourable circumstances) transversely striated (Woodeut, fig. xiii.). When the museular band is at rest, the threads which compose it separate and lie crumpled up within the cell.

Two sets of muscles (the parieto-vayinal) are concerned in regulating the action of the invaginated sheath, and pass from the cell-wall to various points on its surface. A powerful sphincter closes the sheath after the retraction of the polypide, and keeps all safe within.

The parietal muscles, which contract the inuer laycr of the cell-wall, as wcll as those which control the tentacles and the peristaltic movements of the alimentary canal, have been previously notiecd. For further detail I must refer to the writers already cited.

Fig. xiii.

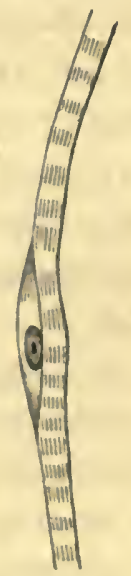

Striated muscular fibre.

The mode in which the retraction of the polypide is effected will be suffieiently evident from the foregoing liasty sketel of the muscular meehanism of the eell. But the act of protrusion requires a more detailed explanation. It will be borne in mind that the polypide is suspended from the lophophore, and langs free within the eavity of its eell, bathed on all sides by the periviseeral fluid. When the want of food or oxygen eompels it to issue from its 
dwelling, the parictal museles (see page xiii) are at onee brought into play, and contract the endocyst or lining membrane, thus redueing the perigastric space, and eompressing the fluid, which immediately begins to aet on the body of the polypide, and to force it upward in the direetion of the orifice*. As it rises, under the influence of this pressure, the sphineter which guards the entrance gives way, and the tentacular peneil passes outwards. Then the paricto-vaginal muscles relax their hold on the inverted sheath, and permit it to follow the eourse of the advaneing eorona. The wall-museles maintain their tension, and keep up a constant pressure from below; steadily and rapidly the ascent continues, the alimentary canal unfolding the while, until, the sheath being fully evaginated and the tentacles freed from restraint, the exquisite bell suddenly expands and the eilia start into play.

Although there ean be no doubt that the parietal museles are thus the great agents in effeeting the protrusion of the polypide from its cell, I am quite inclined so far to agree with Dr. Farre as to hold that a eertain subsidiary part is played in the proeess by the muscular walls of the alimentary canal itself; that it cooperates to some extent with the mechanieal action of the eompressed fluids.

* "These fibres [the parietal] were distinctly seen to contract whenever the protrusion of the animal took plaee, and to become relaxed again upon its retiring into its eell, the walls of the latter being so pellucid that the minutest alteration in the form of these muscles was readily seen."-Farkn.

The eontraction of the eavity of the eell, whieh takes place during the expansion of the polypide, is very apparent in sueh Ctenostornatous forms as have a yielding membranous area on one side of the zoceium. In Mimosella, for instence, when the polypide issues, this portion of the eell-wall is drawn inwards, and a distinet eleft is formed; on its return it. fills out. again, and its presenee is with diffieulty detecterl. 


\section{The Perigastric Cavity.}

The space intervening between the outer wall of the alimentary canal and the inner wall (or endocyst) of the eell is known as the perigastric cavity. It is filled with a colourless fluid, in which a large number of floating corpuseles of various size and shape arc always present, and which at ccrtain times swarms with active spcrmatozoa. Within this cavity the reproductive organs, both male and femalc, arc loeated; and here the ova pass through certain stages of their eourse, or, in many cases, complete their devclopment into the larva.

Grcat intercst attaches to the various questions relating to the precise nature and physiological import of the perigastric fluid, which bathes eontinually the body of the polypide and the tissues which line the cell. In the abscnee of any direct analysis, it may be presumed that it eonsists of water more or less charged with the products of digestion*, and that it is subservient to the funetions of respiration and nutrition. But it is equally difficult to determine preciscly how the watcr finds access to the closed sac, and how the ehyle eseapes into it from the stomach. As to the first point, no orifiees have becn detceted througl which the water might pass into the interior of the cell, if we execpt the one for the escapc of the ova in Farrella, described by Van Bencden, and the "intertentacular organ," investigated by Dr. Farre and myself, which occurs only in a limited number of species, and not constantly in these.

- Reichert bas made a rough analysis of the fluid contsined in the internodes of the stem of Zoobotryon, and finds it to bo a somewhat concentrated solution of cominon salt (like the water of the Adriatic, where the species was obtained), with traces of an albuminous substance (Abhandl. d. königl. Akad. d. Wissensch. zu Berlin, 1819, plysikalische Kilnsse, p. 268). 
Hyatt supposes that the entire endocyst may be piereed to a greater or less degree by aquiferous pores, but admits that he liad sought for them in vain. Allman suggests (as an alternative explanation) that the water may transude through the walls of the alimentary eanal into the cavity of the ecll*. It cannot be said that we have any real knowledge on the subject.

As to the second point, it appears all but eertain that the produets of digestion must mingle to some extent with the perigastric fluid, as therc seems to be no other way in which they can be utilized for the benefit of the whole organism. Aad this fluid bcing in immediatc contact with so large a portion of the tissues, is clearly indieated as the medium through which the nutritive material is supplied to them. But if we inquire how the transference from the stomaeh to the outcr sac is effeeted, wc ean get no further at present than the hypothesis that the aliment may transude through the walls of the digestive canal.

The perigastric fluid is admitted freely to the interior of the tentacular tubes, wherc, as in a system of gills, it is acrated by the water, which is constantly renewed by the eiliary eurrents. Amongst the freshwater Polyzoa the surface of the endocyst is lined by a ciliated epithelium, which keeps the fluid in constant movement and maintains a very regular cireulation. But in the marine forms this seems to be wanting, and its place is probably filled and its function diseharged by the general contractility of the inner wall of the ccll.

Joliet $\uparrow$ has investigated the corpuscles which are found

* How, then, shall we account for the presence of a similar fluid in the internodes of the stem of the Ctenostomata, which (though homologous with the zoceium) are destitute of a polypide?

+ 'Bryozoaires des côtes de France,' pp. 39=41. 
floating in the nutrient fluid, and finds that large numbers of them are derived direetly from the tissue whieh he has named endosarc-are indeed the eells of this tissue, somewhat modified in shape. He has seen the latter, on the endosareal cord which traverses the stem of the Ctenostomata, exhibiting the preeise form and strueture of the floating corpuseles, and on the point of detaching themselves from the eord. In some eases they are round or slightly oval, and eonsist of a delieate membrane and transparent contents, in which one or more very minute and refringent granules are present. In other eases the membranous envelope ineloses a eompart mass of granules, which are often set free by the rupture of the sac and swarm in the perigastrie fluid. These floating eells, emitted from the substance of the endosare, Joliet compares to the blood-corpuseles of the lower animals.

The Endosarc.

$$
\text { (=the " colonial nervous system" of Fritz Müller.) }
$$

We have not yet exhausted the eontents of the perigastrie eavity. Besides the muscular bands which pass from the eell-wall to the body of the polypide, we find a contractile eord eonuceting the base of the stomach with the lower part of the eell, which is known as the "funiculus" (Woodeut, fig. xix. $f$ )*.

This strueture is not only conneeted with the lower extremity of the digestive sac, but spreads for some distanee over one side of it, and not unfrequently gives off

- The funiculus probably assists in the retraction of the polypide, drawing the stomach down towards the bottom of the cell; it also serves to keep this organ in its proper position when the polypide is expanded. 
filamentary prolongations, which attach themselves at various points to the endocyst.

There is nothing constant cither in the number or direction of these offscts; but they are sometimes largely developed, and look like so many stays or supports to the alimentary eanal. The funicular cord (in such a form as Bowerbankia, Woodcut, fig. xiv.) attaches itsclf to the wall of the cell immediately over the perforated plate or scptum, which eloses it bclow, and at the point of attachment expands into a somewhat hemispherical granular mass. From this a thread-like prolonga-

Fig. xiv.

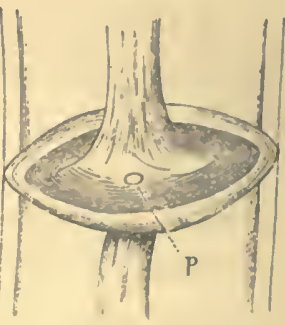

Septum in stem of Bowerbankia. p. Pore. tion passes off through the pore in the diaphragm, and forms a link of communication with the rest of the eompound organism. In all the Ctenostomatous Polyzoa the stem or stolon, along whieh the zoceia are distributed, is traversed by a cord (Woodcut, fig. xv. ec), resembling in essential strueture the funiculus; and with this the polypides are conneeted by means of the funieular threads just described *. But the stem (or stolon) is not a continuous tube; it is divided into numerous compartments, which are separated from one another by a septum or diaphragm, pcrforated in the centre like that of the ccll $(s$, Woodcuts, figs. xv. \& xviii.). On cach side of these septa the eord usually dilates into a hemispherical mass (endosarcal $k n o t)$; and the two hemispheres, divided only by the

* Ellis first noticed the funicular cord in the stems of Vesicularia. Farre sperks of it as a "direct medium of communication between the animnls." 
thin partition, present the appearance of a single subglobular collection of granules (Woodeut, fig. xv. ek). The cord traversing one eompartment is linked to that of

Fig. $x$.

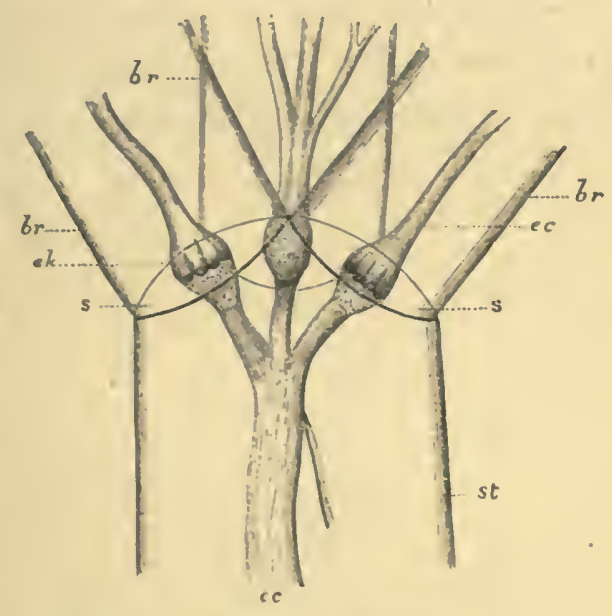

C'tenostomatous stem.

st. Stem. br. Branches. s. Septa, at the origin of the branches. ec. Endosarcal cord. $e k$. Endosarcal knot.

the next by a thread-like extension of its substance, which passes through the pore or pores in the septum. Not unfrequently the cord gives off from its surface a number of filamentary proecsses, which sometimes anastomose, and sometimes pass directly to various points on the wall of the tube, the whole forming a rude network of fibres, or plexus. This portion of the strueture is very irregular and variable, and, according to Joliet's obscrvations, is liable to frequent change and modification *.

* - Dans l'espace de peu de jours une portion du plexus s'est modifíé sensiblement sous mes yeux, puisque j'ai vu un de ses raneaux s'atrophier et dispa raitre totalement." The foregoing account of the funicular systen is based chiefly on the researches of Joliet ('Bryozoaires des cótes de Frunce') which I ean confirm in most points from uny own personal observation. 
The whole system of cords now described, with its globular enlargements at the junetion of the zoceia with the stem, and of one compartment of the stem with anotlier, and its filamentary offshouts, exhibits the same essential structure, and must be regarded as composed of one and the same tissue. Its histological character has been studied by Nitsehe, Reiehert, and Jolict, but most

Fig. xri.

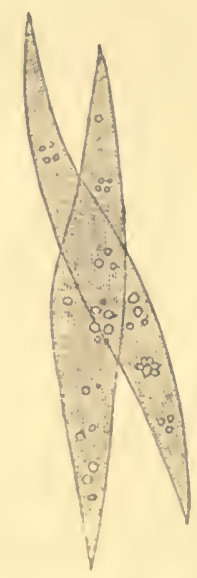

Cells of the Endosare.

exhaustively by the latter writer. It is eomposed in great measure of minutely granular fusiform cells, cither with or without a distinct nucleus, attenuated and pointed at the two extremities, and somewhat swollen in the centre, which are disposed longitudinally in the tissue. (Woodeut, fig. xvi.). In some cases the cord is laden with refringent granules, which are so erowded as almost to conceal it.

The plan of the endosare (to adopt Jolict's name for this tissue) varies somewhat in the different divisions of the elass. Amongst the Cheilustomata (for instance), 
where there is usually no stolon, and the cells rise immediately one from the other, the connective cord is of course not devcloped. But evell amongst these there are exceptions; in Bicellaria ciliata, in which the true zoccium is borne on a kind of peduncular support, the latter is traversed by a cord, which communicates at the basc of the cell with the funiculus.

In Membranipora membranacea, each cell of which is connected with scveral others, Nitsche deseribes two lateral strings or funieuli, extending down the sides of the zoceium, and in eontact with each of the communication-plates, which occur at intcrvals in its walls *.

But whatever may be the divcrsitics of plan, the endosare is essentially one in histological character. It remains to determine its function and physiological inıport.

Fritz Müller was the first to attempt the interpretation of this element of structure + ; and his views have been widely acecpted by subsequent writers on the Polyzoa. He regards the funicular system as a truc nerrous structure, but one which is related to the life of the colony rather than to that of the individual zooids composing it. To him it is a common or colonial nerrous system, which has to do with "thc associated morcments" of the Polyzoa, or sucl as do not seem " to depend upon the will of the individuals, but to be carried out by them in obedience, as it were, to a command from a higher quarter." Muiller's attention seems to have becn first drawn to the subject by the behaviour of the polypides in certain eases, which appeared to point to the existence of a

* Zeitsch. f. wissensch. Zool. xxi. Heft 4, p. 45.

+ Archir fur Naturgeschichte, 1860, p. 310, pl. xiii. ; translated in Quart. Journ. Micr. Sc. vol. i. (n. 8.) p. 300 ). 
system of nerves apart from the zoceia, by which the members of the eolony are to some extent controlled and brought into relation. He approached it on the physiological side, and perlıaps, as Joliet lias suggested, too much under the influence of an a priori conception. The colonial nervous system, as developed in each branch, consists, according to Müller (whose observations were made on a Ctenostomatous form), of ganglia placed at the origin of the branch, at the internodes, and at the base of the zoccia, of a nerve trunk running the entire length of the branch, and of a plexus of nerves resting on the trunk and connecting the ganglia. He also describes a nerve passing from the zoceial ganglion to the polypide. If we compare this scheme with the funicular system just described, we shall at once recognize the general correspondence between them. The ganglia are the granular enlargements, at the base of the zoceia and at the internodes; the trunk is the eonnective cord; the plexus is represented by the filamentary processes given off from the latter; the nerve between the polypide and its gallglion is the funiculus. The simple question is, will these parts bear the construction which has been put upon them?

Müller's views were adopted by Smitt* (who traced the supposed nervous system in the Cheilostomata), by Claparède + , and others; indeed for some time they secmed to command very general assent. It is only as the result of minuter histological research, and a more careful study of the general history of the tissue in question, that a change of opinion has set ill. I fully

* 'Om Hafsbryozoernas Utveckling och Fettkroppar,' 1865, p. 31-33.

† "Beiträge z. Anat. und Entwicklungsgesch. ron Seebryozoen," Zeitsch. f. wissenseh. Zorl. xxi. 
partieipate in this change; and the aeeount which follows will supply the grounds on whieh I have abandoned my former views oll this subject.

It must, I think, be admitted that the interpret:tion first suggested by Fitz Müller was founded rather on mere superficial resemblanees and the supposed fitness of things than on any thorough investigation of the strueture and functions of the so-ealled nervous system.

Nitsche, after a eareful examination of the tissue in question, decides against that interpretation*. Reiehert has given us an elaborate account of it, and has pointed out the important fact, that the supposed ganglia are eut in two by the septa, which separate the internodes from each other and close the zoœeia below. He holds that the tissue is not nervous in eharactert.

But by far the most important contribution to our knowledge of this element of polyzoan strueture has been made by Joliet. It is not in the slightest degree to detraet from the merits of this most able observer to say that further investigation is required before some of his conclusions can be finally aeepted. But so far as the general nature of the funicular system is eoneerned, his testimony seems to me to be eonclusive.

I am unable to enter here into the detail of his exhaustive researehes. I shall merely indieate briefly the characteristics of the tissue, which, in my judgment, are ineompatible with Müller's theory.

i. Its intimate strueture; the form and behaviour of the eells eomposing it are not those of a nerve-tissue.

The cells are normally fusiform (Woodent, fig. xvi.);

* Leb. Flustra membranacea, loc. cit. p. 56.

† Abhaudl. Ak. Berl. 1870, physikalische Klasae. 
but both shape and contents vary even in differeut portions of the same branch.

ii. The changeableness and indefiniteness, so to speak, of the system itself, as exhibited in the cord, and more especially in the so-called plexus, are evidenec to the same effect.

The cord or trunk presents the most varied appearances, bcing sometimes simply cylindrical (Woodeut, fig. xv. $e c$ ), sometimes composed of a number of anasto-

Fig. xvii.

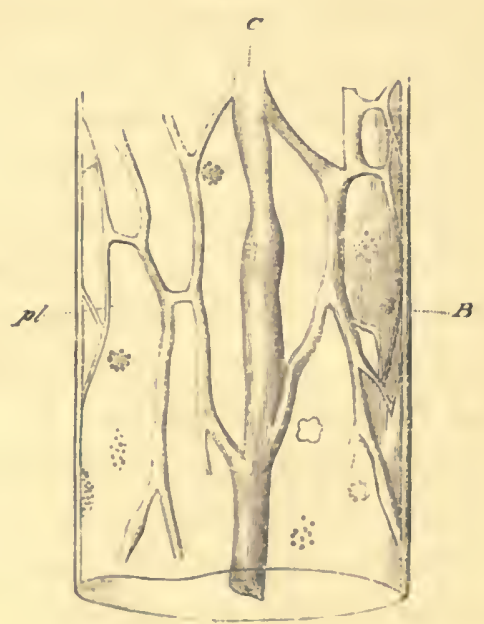

Portion of Branch, showing Cord and Plexus.

B. Portion of branch. C. Cord. pl. Plesus.

mosing strands, sometimes resolved into a wide, irregular, open-meshed network*. It also varies in histological character, and is frequently charged with granular matter, which completcly changes its aspect. But it is in the plexus (Woodeut, fig. xvii. $p l$ ), so essential an element of the supposed nerve-system, that the irregu-

* Reichert, op. cit. pl. iv. figs. 13 \& 15, and pl. v. fig. 18. 
larity and indefiniteness are most apparent and striking*. The so-called nerve-threads exhibit no constancy, either of number or direction; they do not seem to have any special aim. They reach the wall of the eell or stolon now here, now there, as if at haphazard. They are found direeting themselves to the most unlikely spots, and conducting the (supposed) nervous influence to points where it would seem to be least wanted. Their behaviour certainly is mueh more that of stray sareodic filaments than of the servants of a regularly organized and esseutial system. This indefuiteness in the strueture of the plexus had attracted $\mathrm{my}$ attention before I lad any misgivings as to the eorrectuess of Müller's views; and it now seems to me to supply one of the strongest arguments against them.

iii. In essential structure the funiculus agrees with the eord, with which it is directly commeeted at the base of the cell. It is contractile, as already mentioned, and in some measure plays the part of a musele. Its eontractility no doubt arises from the modifieation of some of the fusiform eells eomposing it, out of which, it would seem, in all cases the museular tissues are formed. It is a kind of cable, attaching the polypide to its cell, and so organized as to admit of the free movement of the former as it issues from its dwelling and again secks its shelter. Whether wc regard its strueture or its uses,

- The plexus described by Müller in the branch has its equivalent in the filnmentary offshoots from the funiculus in the zoceium; and any student of the Polyzon inust lave noticed their great irregularity and apparent aimlessness. Claparide has remarked, "On ne trouverait peut-itre pas deux loges ou le plexus soit semblable à lui-ınéme." Stwitt has also observed that the plexus varies greatly in the different cells of Memb. nembranncea, and that the same is the case with the (no-alled nervons filaments in Siru. pocellaria scruposa (op. cit. p. 3:). 
we can hardly, I think, identify it with any form of nerve*.

iv. The supposed ganglia arc not constructed as F. Müller imagined them to be. Hc overlooked (in common witl other obscrvers) the septa, by which the branch is divided into compartments, and by which the ganglion itself is divided into two scparate halves. As a matter of fact, the latter is made up of the enlargements of the cord, at the points wherc it touches the opposite faces of the scptum, and appears to liave no further significancc. The pore or porcs in the centrc of the septum (as already

Fig. xviii.

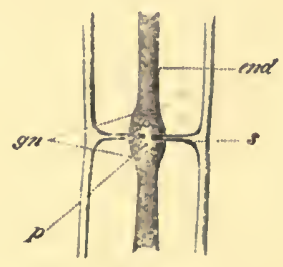

Portion of a Branch.

end. Endosarcal cord. s. Septum. p. Pore. gn. Supposed ganglion.

explained) allow of the passage of certain thrcads, which maintain a connexion betwecn the two sections of the cord; but the two granular masses never come into contact. With a true understanding of the structure, the ganglion disappears from the systcm.

Further evidence against Müller's vicw of the funicular tissue may be derived from the study of its general history and of the special functions which it is found to assumc. For our knowledgc of the latter we arc indebted to Joliet; and I shall give a bricf outlinc of his

* See Nitsche, "Ueb. F'lustra membranacea," loc. cit. p. "56. 
intcresting rescarches, which have added a new and most important chapter to the history of the Polyzoa. So far, however, as the "eolonial nervous system" is coneerned, we hardly scem to require other evidence than that which has becn already adduced. It is indeed, not impossible, as Nitsclic allows, that certain of its elements might scrve for the transmission of stimuli (a view which has been adopted by Reichert); but in the light of the later and more searehing investigation we must, it scems to me, admit that as a system it wants thic cssential characters of nervous tissue.

Origin and Functions of the Endosarc.-The tissue, commonly known as the "colonial nervous system," but to which I shall now assign Joliet's namc, is, according to this author, a derivative from the endocyst. It is formed by diffcrentiation of the eclls in the growing extremitics of this membranc; these become dctached, send out prolongations posteriorly (whieh ultimately anastomosc), and constitute the rudiments of the endosarc*. The lattcr maintains numerous relations with the cndoeyst, but is histologically distinct from it, being composed for the most part of fusiform cclls, usually (but not universally) destitutc of a clearly defincd nuclcus.

The cndosarcal system comprises the funiculus, the connective cord, and the network so often associated with them, both in the zoœcia and in the compartments of the stem, and also (according to Jolict) the parencliyma in the stem and stolon of Pedicellina, and the muscular layer connected with the cndocyst amongst the

* Joliet states that he has observed this process in inany species. It would be satisfactory to have a somewhat fuller account of it than he has given us. 
freshwater Polyzoa. Some of these determinations may be open to criticism, and certainly require the confirmation of further-research; but on the whole the French zoologist scems to me to have madc good the leading points of his case, and to have worked out with much ingenuity and skill the morphology of this tissue.

We pass now to the functions of the cudosare. If not a ncrvous system, what part does it play in the ceonomy of the polyzoon?

According to the observations of the writer just quoted, it equals in importance the principal constituent tissues, and descrves to be ranked as one of them. Its relation to the floating corpuscles in the pcrigastric fluid has alrcady. been noticed. It is also the sourec of the male reproductive elements, and in a large proportion of eases, if not universally, of the ova*. It has long been known that the spcrmary is devcloped on the funiculus $\dagger$. Mother cells, each containing one or more minute nuelcated vesicles, arc differcntiated from the substance of the cord, and cluster thickly roumd it, forming an irregular mass $\ddagger$. They finally detach themsclves, singly or in clusters; and from each of the contained vesicles a spermatozoon is liberated. 'The spermary is present on the funiculus at. a very carly stage in the development of the polypide (as I have observed in Farrella repens), and usually occupies

* In this section I shall report in brief the conclusious at which Joliet has arrived, with such critical and illustrative remarks as they may suggest.

+ Allman, indeed, describes the testicle in the freshwater Paludicella as attached to the inner surface of the endocyst; but it is placed at the point where the funiculus reaches the cell-wall, and no doubt has its origin in it.

$\ddagger$ Smitt has described the production of spermatozoa from the fluating corpuseles in the perigastric fluid in the absence of any definite spermary, these corpuscles being, as we hare seen, derived from the endosarc ('On Hafsbryozoernas Utreckling och Fettkroppar,' pp. 37, 35). 
the lower portion of it. But Joliet also contends that the ova are generally, if not always, a product of the endosare; and in taking this position he runs counter to the common opinion. IIuxley, indeed, has described both ova and spermatozoa as developed from the funiculus in Bugula avicularia; but the reccived vicw undoubtedly lias becn that the former arc devcloped normally from the cndocyst, at various points of the cell-wall, but usually towards the upper extremity of the zoœcium. They arc so figured by various autlıors; and in this position I have myself obscrved them. On the other hand, Joliet lias seen the ova produced in the funiculus (i.e. in the endosarcal tissuc) in a considerable number of specics, and has minutely described their position and the coursc of their development*. He also loolds that in many at least of tlic cases reported by authors, the ova which they describe as derived from the cndocyst, are really the product of the endosarc. For example, in Farrella repens the ovary was long since distinctly figured by Van Bencden $†$ on the upper part of the cell-wall, and described as a growth out of its inner layer. I have seen it in this position, presenting all the appearance of a pouch fastened to the lining membranc of the cell. On cxamining young zoceia of this species, in which the bud was in coursc of development, Jolict has found the mother cells even at this early stage surrounding the funiculus. As the growth of the polypide advanced, the cells on the upper portion of the funiculus had multiplicel to a great extent; and taken on a special

* He has positirely determined the production of ora in the funiculus of seven species.

† "Recherches sur l'organisation des Laguncula," Mém. Acad. Roy. Brux. vol. xviii. pl. i. fig. $1, A, B$. 
form-that of rudimentary ova; they eonstituted a considerable mass, whieh extended to the wall of the zoceium, and beeame adherent to it (Woodcut, fig. xix.) ; the rest

Fig.xix.

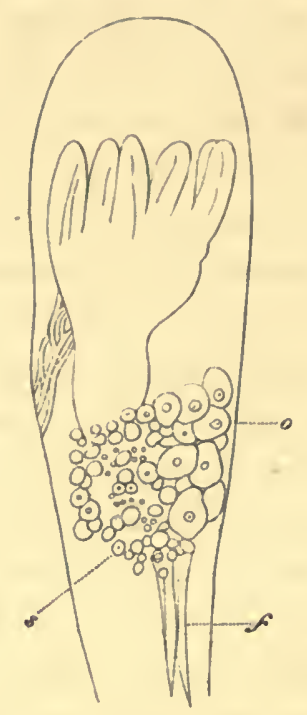

Young Zoxcium of Farrella.

f. Funiculus. o. Mass of ova, extending to the cell-wall. 8. Sperm-cells.

of the funieulus was eovered by the sperm-saes. As these gradually detaehed themselves, and the substanee of the testiele had beeome redueed in size, the adherent mass of ova was found to be separated from it, and was left on the faee of the eell-wall. In this position only it has been seen by those who deseribe it as developed on the endoeyst; but it is really, like the testiele, derived in the first instance from the endosare. Upon this I would merely remark that the explanation seems hardly to meet the faets of the ease, inasmuch as an adherent mass of 
ora cannot be regarded as the equivalent of the distinct ovary whieh Van Beneden figures, and which I have myself seen.

Nitsehe has seen ova produced on the cell-wall in Bicellaria ciliata, and Smitt in Scrupocellaria scruposa. These cases Joliet is unable thus far to harmonize with what lic regards as the general rule; but he suspects that here also the parictal ova may be in connexion with some offshoot of the endosare, perhaps witl the threads which pass througl the communieation-plates from cell to cell. Clearly this branch of the subjeet requires a much fuller investigation.

As variations upon what seems to be the more usual plan, Joliet has noted that in a Lepralia (L. Martyi) the ovary is placed at the very base of the funiculus, immediately above the eommunieation-plate; whilst in a Membranipora (membranacea) it occurs on the upper part of the cell-wall, also in immediate eonnexion with the same structure*.

On the whole, it nuy be regarded as established that the testicle is all but universally derived from the funiculus, invariably from some portion of the endosarethat the ova are in a considerable number of species also developed in the funienlus - that in one ease at least they originate from the endosare apart from this organ, but in eonnexion with a communication-plate-aud that in several cases they are plaeed on the eell-wall, but

* As in some measure confirmatory of this writer's view, I may draw attention to Allman's figure of the freshwater Paludicella (Freshwater Pol. pl. x. figs. 3,4 ), in which the ovary is represented on the cell-wall, but in direct communication with the "superior funiculus," a cord which proceds from the upper portion of the alimentary caual, while the testicle bears the same relation to the ordinary funiculus below. 
whether a product of the endocyst or endosare is still undetermined.

That the latter tissue is, to a large cxtent at least, concerned in the production of the generative clements can hardly be doubted; and this fact is properly accounted cvidence of its non-nervous nature.

According to Jolict the polypide is also produced by gemmation from the endosarc, at least in many cases (he is inclined to think, universally), and not from the endocyst, as gencrally supposed. We must have a much wider range of observation bearing on this point than we at present possess before we can come to any gencral conclusion about it. But in the case of Eucratea chelata therc seems to be no doubt that the polypide originates from the funiculus: we have the concurrent testimony of Jolict* and Barroist on this point. Further, in all the Cheilostomata which he has studied, the former of these obscrvers has seen reason to believe that the bud is really formed on some portion of the cndosarc, and not on the endocyst. In Hypophorella, Ehlers (allicd to the Vesiculariida), it is produced on the funiculus, in the centre of the ccll, as in Eucratea. In many cases it is developed at the very base of the zoœcium, immediately over the communicationplate or septum and the orifices through which the connective threads pass, and therefore probably in connexion with the endosare. I have observed it in this position in the young cell of Beania mirabilis (Woodeut, fig. xx. $b d$ ); and in this species Jolict has convinced himself that the polypide is actually derived from the cndosarcal cord. In the rudimentary zoœcium of Victorella (sce page 560) the

* Op. cit. p. 50, pl. xiii. fige. 1, 2.

| 'Rerue Scientifique' for Sept. 29, 1877. 
forming polypide scems to me to be enveloped in the endosareal plexus, and to be (in all probability) produeed by it. In Pedicellina the origin of the polypide is doubtful*. So the matter rests for the present. In a large number of cases undoubtedly the polypide owes its origin not to the endocyst proper, but to the tissue composed of fusiform elements, which has its most familiar representative in the funiculus. It may be, as Jolict suggests, that the authors who have referred it to the en- eium. bd. Polypidedocyst have not been sufficiently alive to bud.

Fig. xx.

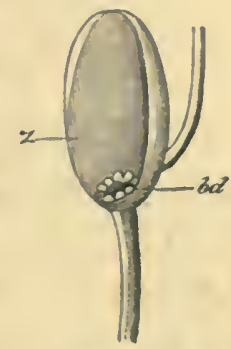

the distinetion between these two tissues; it may be that the function is to some extent shared by the endocyst. Further investigation, along the lines now indieated, must decirle the point.

'The question arises, whether this tissue, constituted as we have seen, and endowed with such physiological attributes, is to be regarded as a mere dependence of the endocyst, or whether it is more properly characterized as one of the principal elements of the Polyzoan strueturc.

Looking to the peculiarity of its histological cliaracter, to the undoubted importance of the part which it plays in the animal cconomy, and to its distinctness and definiteness, as a whole, Jolict is amply justified, in my judgment, in distinguishing it by a scparate name, and assigning it a special rank. He is also wise, at the present stage of inquiry, in sclecting a name for it which has no theoretic flavour, but simply indicates a fact.

\footnotetext{
"Snlensky, "Eintoproctes," Ann. Se. Nat. sér. 6, rol. v.
} 
The Fara and Renewal of tue Poldyide.

\section{The "Brown Body."}

Every student of the Polyzon must have noticed that the life of the individual polypides is eomparatively ephemeral. In most cases a large proportion of the zoccia have lost their original tenants, whilc at the same time the zoarium retains its vitality, and along the margin fresh additions are continually being made to it by the growth of new buds. Not uncommonly almost all the cells covering the lower or older portions of a tuft of Bugula or Bicellaria, for example, are thus cmptied of their polypides; but towards the upper cxtremities of the branches all are occupied by an active population, and along the outer edge zoœcia are to be seen in evcry stage of development. The disappearance of the polypide, however, is a comparatively unimportant incident in the life of the colony ; and amplc provision exists for securing new tenants for the deserted dwellings. The zoœcium which has lost its polypide is in turn filled by another, and may possibly be the home of a succession of occupants.

If we cxamine a specimen of one of the erect plant-like Polyzoa, we shall find, as I liave stated, along the upper edge of the branches, zoccia in eourse of formation, and exhibiting cvery degree of development; immediately below these will be zoœcia in which polypides are formed, but immature; below these again will cxtend a zone inhabited by adult polypides in full vigour and activity; further down still we shall probably eneounter dwellings for the most part destitute of tenants. Of course these 
divisions are not invariable, nor are they separated by any hard lines; but such is the general condition of the colony. In most of the tenantless zoœcia a dark, more or less spherical body occurs, which exlribits a definite and uniform appearance. It consists of a mass of brownish granular substance enclosed in a membranous cyst, the inner walls of which are covered with reddish-brown spots. It is generally placed about the middle of the zoceium, occupying, in fact, the same position as the lower portion of the digestive sac of the polypide, and, like it, is firmly attached to the funiculus and to the network of filaments which proceeds from it*. This is the well-known "brown body" of authors (Woodeut, fig. xxi.). Two or even more may occasionally occur in the same cell.

These bodies, which frequently give a dotted appearance to the zoarium, are much too conspicuous to escape the notice of observers; and accordingly we find them referred to by most writers on the Polyzon from Ellis downwards $\dagger$. We are now in the region of controversy. Around the "brown body" have gathered conflicting observations and rival theories. Its origin and its end have been alike in dispute. Many of the opinions that have been licld about it no longer claim our consideration; they have already been finally disposed of. I shall here confine myself chiefly to two opposite views of the nature of

" See a paper by the author, entitled "Contributions to the Ilistory of the Polyzoa," Quart. Journ. Mier. Se. xiii. (n. s.), p. 24.

+ For a historical account of the various opinions entertained about thein see:-Sinitt, "Bidrag till Kännedomen on Hafs Bryozoernas Utreckling," Ups. Lniv. Arsekrift, 1863; the paper by the author, just cited, pp. 17-23; and Juliet, op. cit. pp. 7-9. They have been regarded as the remains of the dead polypides, as ora, as oraria, as statoblaste, as a secretion from the endoeyst, as a storo of nutriment for the young polypide, as a reproductive body furmed out of the stomach of the decaying polypide. We may well eny. with Joliet, "Ces corps bruns ont bien intrigué les observateura"! 
this body-that which regards it as the merc lifeless débris of the defunct polypide, and that which recognizes in it a special structurc, derived indeed, from the substance of the histolyzed polypide, but cndowed with a reproductive function, and capable of originating a successor to it in the occupancy of the cell.

The lattcr opinion has been maintained by the able Scandinavian zoologist, Prof. F. A. Smitt, whose researches have added so largely to our knowledge of the Polyzoa; and he has supported it by a considerable body of carcful observation. My own studics had led me to adopt his view; and on various occasions I have recorded the grounds on which my conclusions were based. The oppositc opinion has had able exponents in Nitsche and Jolict. They find in the "brown body" nothing but the remains of the decayed polypide, a mass of inert material waiting to be ejected from the ccll. Another interpretation has been adopted by Repiachoff*. To him the "brown body" is not concerned directly in the production of a new polypide, but at a certain stagc it is cnvcloped by the forming bud in its substance, and scrves as pabulum for it during its further development.

It is quitc impossible for me to reproduce in detail the observations which have becn adduced in support of the conflicting views. I must refer the student to the works in which they are recorded. The theory of Smitt has been subjected to an claborate examination by Jolict, in the course of which lic has criticised at length and with much acumen my own contributions to the discussion. My object will be to point out how far and in what way the

" "Zur Naturgeschichte der chilostomen Bryozoen," Zeitscb. f. wissenscl. Zonl. rol. xxvi. (1876). 
evidenee relied upon by Prof. Smitt and myself is aflected by this eriticism and by later observations, and what the present state of the question secms to bc. This course will elearly be the most valuable to the student, as it will indicatc to him the directions in which further research may be profitably conducted. And as, of course, the only object to be aimed at in such work is the discovery of the actual fact, I shall cndeavour to approach the subject without any controversial animus.

i. As to the origin of the "brown body," if we except Claparède, who regarded it as a secretion from the endoeyst*, observers are generally agreed that it is derived from the substance of the polypide. As the latter, after a longer or shorter term of existence, gradually fades away, it gives origin to a "brown body," which remains attached to the funicular cord, and more or less enveloped by the plexus of threads arising from the latter. Joliet would eall it the mere wreek of the polypide; Smitt has named it the "germ-capsule" (groddkapsel) implying that it has in it the possibilitics of new life. In my papers on the subject, I have held that the "brown body" is formed out of the lower portion of the digestive sac, which in some species (c. g. Bicellaria ciliata) has the apparancee of being separated by a constrietion from the rest of the stomach, and constitutes, as it were, a separatc chamber of somewhat globular shape (Woodeut, fig. x.). This peculiarity of structure I have connected with the formation of the germ-eapsule; but I am now satisficd that this

" "Beitrïge zur Auatomie u. Entwicklungegesehiehte der Seebryozoen," Zeitsch. f. wissensch. Zool. December 1870 , p. 147. Claparide's view uust be considered a simple corollary frum his extraclinary theory of the "retrogressive metamorphosis" of the polypide, ruther than the result of any close and careful observation. 
is an error. 'This execal appendage (sce page $x x v$ ) is a permanent feature of the alimentary eanal in the speeics

Fig. xxi.

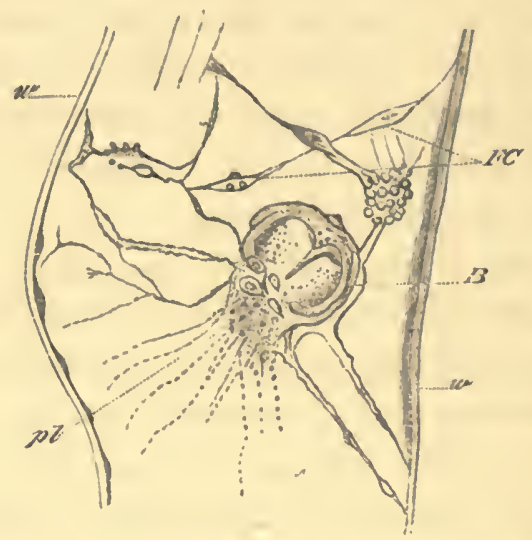

Cell of Hypophorella, with "Brown Body."

$B$. Brown body. pl. Plexus. FC. Fusiform cells. w. Wall of zocecium.

in which it oceurs, and has no special relation to the development of the "brown body." I now agree with Joliet in regarding it as due to a thickening of the outer wall of the stomach, and not, as I once supposed, to a real constriction of the part, indicating a gradual scparation of the lowest portion of the excum from the rest of the digestive canal. The question remains, whether the "brown body" is formed out of the whole of the polypide or merely out of the digestive sae. Jolict regards it as the débris of the whole structure; and his observations and figures seem very conelusive so far as the species which he examined are conecrned. Smitt, if I understand him rightly, holds that it originates from the stomach of the polypide; and such was certainly'my own impression. 
Ehlers reeords an observation which would seem to show that, in Alcyonidium at least, the tentacles are separated from the alimentary eanal during the progress of the histolysis*.

In any case the "brown body" is derived from the polypide, and is the result of its decline.

ii. As to its nature and destination, is it eapable of giving origin to a new polypide? The simple ground on which Prof. Smitt and myself have taken the affirmative side is direet obserration. In numerous eases the Swedish zoologist has traeed the formation of a bud on the "brown body," and, as it seemed to him, out of its very substaneet. My own observations have been to the same effect. Repeatedly I have seen gemmation taking Fig. $x x i i$. place in the elosest proximity to the surface of the "brown body;" and the bud, as I was fully persuaded at the time, was eontinuous with it and a growth out of it. One thing, at least, we may elaim to have established and brought prominently into view, the faet that there is so eommonly the elosest association between the polypide-bud and the "brown body" in the eell of the Polyzoon.

Another point my observations seemed to me to have established-that the polypides developed from the (soealled) germ-eapsule differ in appearance during their early stages from those which are found in the young marginal eells of the colony, and from other buds which oceur in the adult zoocia. The latter are destitute

* "Hypophorella cxpansa, ein Beitrng," \&c., Abhandl. königl. Gesellsch.

d. Wissensch, zu Göttingen, vol. xxi. (1876)p. 122.

+ Op. cit. pp. 23-20, pl. v. figs. 3, 17-19. See Woorlent, fig. xxii. 
of the reddish-brown colour imparted to the stomachwall at a later period by the biliary glands, whilst the

Fig. xxiii.

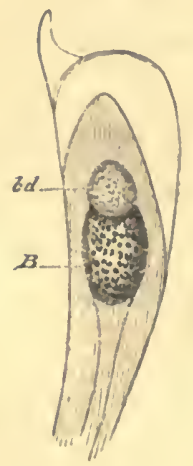

Fig. xxiv.

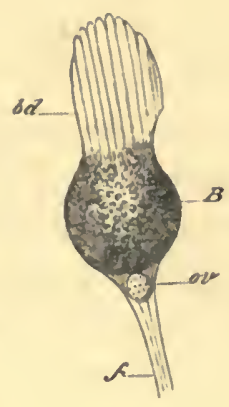

Fig. xx.

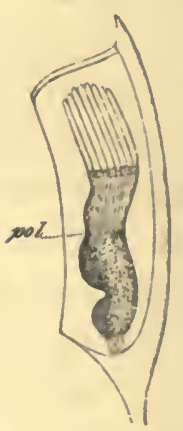

B. Brown body. bd. Bud. ov. Ovary. f. Funiculus. pol. Polypide supposed to be developed from the brown body *.

former, being (aceording to my view) a growth out of the brown body, possess it from the first.

Unfortunately I have been unable to repeat my observations to any extent with the help of the new lights which later researches have east on the subject; much less have I had the opportunity of doing so under the favourable conditions supplied by the modern Zoological Station $\dagger$. I shall confine myself now to stating very briefly how these observations are affected, in my judgment, by

* These three figures represent the supposed budding of the polypide from the brown body, and are copied from iny paper on the "gerin-capsule," los: cit.

+ Prof. Smitt has not made any addition to his early observations on this point; but in a letter recently received from him he says (after explaining that ho had not entered into the latest researches), "Still I retain my standing-point, because it seeme to ine impossible to interpret the observations in another way. I have followed the formation of the germcapsules out of the histolyzed digestive canal. I have prepared them out of their connexion with the funicular plexus; and after thus making loose the gern-capsules, I have seen the bud of the new digestive eanal either inclosed in them or protruding out of then." 
faets which have been brought to light sinee they were inade.

Two points bear direetly upon them :-i. Repiaehoff's very eurious observation, that the "brown body" is aetually taken into the substance of the young bud, supplemented by Joliet's, that it afterwards passes entire into the intestine and is ejeeted through the anus, or is dissolved in the stomach and the remains disposed of in the same way*; and ii. Joliet's interpretation of the funieular tissue (which, it must be remembered, more or less involves the "brown body"), and its relation to the development of the polypide (see page 1 ).

To take the latter first. Joliet holds that the buds

Fig. xxvi.

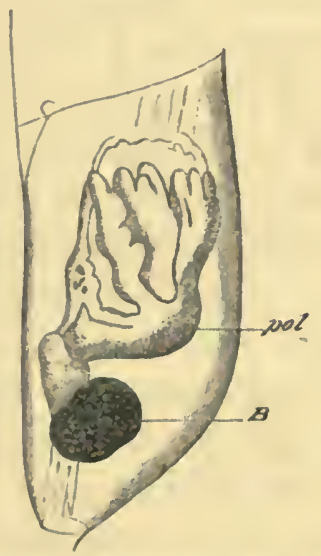

Polypide developed on the surface of a Broun Body.

B. Brown budy. pol. Polypide.

which Smitt and myself supposed to be formed out of the "brown body" are really developed out of the funieular plexus which overlies it, and whieh eseaped our notice.

- Up. cir. pp. 21-24. 
A delicate layer of protoplasm derived from this plexus surrounds the "brown body"*; and, indecd (according to Jolict), the euvclope whieh inmediately ineloses its graular contents is formed at the expense of this layer. It is from this protoplasmic eovering, and not from the substanee of the "brown body" itself, that the bud really originates; the case therefore enters into the usual order of development. In support of this view, Joliet asserts that the bud is always scparated from the "brown body" itself by the membranous envelope, and is not in connexion with its substanee (Woodeut, fig. xxvi.); but he adds, "Il n'est certainement pas toujours facile de décider si c'est aux dépens du corps brun lui-même ou aux dépens de cette couche-protoplasmique que se forme cette 'saillie de matière granuleuse' qui est l'origine du bourgeon." It ccrtainly must be very difficult to decide the point; and in the absence of any suspicion that a tissue adequate to the formation of the polypide was present in the neighbourhood, an observer would almost inevitably refer the bud to the so-ealled germ-capsule as its souree. Joliet's researches, showing that the endosare, by whieh the brown body is more or less surromuded, is such a tissue, materially alter the ease, and prove that the appcaranees upon whiel I relied may possibly be suseeptible of a different explanation. At the same time, I must add that the bud in the eases referred to always sccmed to me, after careful examination, to be direetly eontinuous with the "brown body," an uninterrupted growth out of it, as represented in my figures.

Secondly, what is the relation of Repiachoff's observa-

* Ehlers had previously described the "brown body" in Iypophorella as enreloped by a protoplasmic substance, op. cit. p. $11 \%$. 
tion to the theory of the germ-capsule? At a eertain stage the bud, whether developed at a greater or less distanee from the "brown body," approaehes it, extends its substance orer it, and finally lodges it in its stomach, the walls of which completely elose around it (Woodent, fig. xxvii.). 'Thus engulfed it scrves (he conjectures) as a store of nutriment for the growing structure.

Joliet, on the other hand, has witnessed in one species the same process of ingestion; but the "brown body" was subsequently driven through the intestinc and expelled unaltered through the anus. In

Fig. xxrii.

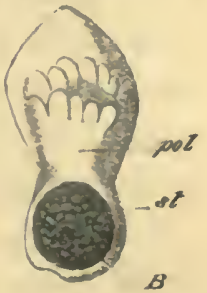

pol. Polypide (budding). st. Stomach. B. Brown body, inclosed in the latter. another species it was enveloped by the bud, and dissolved in its stomach; the eoloured granules eomposing it were retained for a short time only, and then rejeeted*. These observations are precise, and leave no doubt as to the facts. In the cases to which they refer, the relation between the "brown body" and the bud is, of course, totally different from that which is assumed in the theory of Smitt. The young polypide, instead of originating from the former, becomes the ehannel through which it is removed, as a useless encumbrance, from the cell. Again, in other eases the "brown body" has a different destiny : in these it seems to be (sometimes at least) separnted from the funieulus and east to one side of the cell, as so mueh lumber. 'These facts, unsuspected when my observations were madc, scem to me, I eoufess, to lave a most important bcaring on the point at issue, and to eall for a earcful reconsideration of the whole question.

"In such a case it is by no muans improbable that the "brown body" payss toll of nutritious matter to the pulypide as it passes outwart. 
Joliet imagines that the deeply eoloured buds, which I supposed to originate from the germ-eapsule, were really buds tinted by the granules of a "brown body" which had been thus dissolved in their interior. But this explanation seems to me inadequate, as the appearanee referred to was presented by buds which had reached a stage of development in which all traees of the substance of the brown body must have vanished from the stomach.

I will add a few further considerations that have been urged or may be urged against the theory of Smitt. i. If a branch of the polyzoon is treated with potash, all its soft portions (the polypides, the endoeyst, the endosare) are destroyed, but the "brown bodies" survive and are commonly intact (Joliet). ii. The remains of the food (Diatomacex, Foraminifera, \&e.) and the hard portions of the grizzard (in the species possessed of this organ) are sometimes reeognizable in the "brown body" (Nitsehe). iii. A very large number of brown bodies are often present in the eolony, which undergo little or no elange, and perish with the eell itself. These are usually found in the older regions of the zoarium, which are destitute of polypides; they show no signs of reproduetive power. iv. Admittedly a very large number of the buds, by means of which the polypide is renewed, are formed at a greater or less distance from the "brown body."* These buds have generally been regarded as the product of the endo-

* I may here record an observation made on a specimen of Bugula calathus which $I$ had dredged in full life and vigour. After keeping it for two or three days the polypides over the lower two thirds (about) of a branch had perished, and towards the base of each cell was a roundish dark reddish-brown body. A little in advance of it in almost every zoccium was a polypide-bud, arising (as it then seemed to me) from the endocyst-floor of the cell, consisting of the crown of tentacles and a small sac suspended from it. Sometimes the "brown body" was alınost close to the bud, sometimes a little way from it; but in all cases a separation between the two was here erident ennugh. 
eyst; but, according to Jolict's views, they originate in the endosarc-that is, in the very tissuc which supports and invests the brown body.

The following points may be taken as established:i. The brown body is universally derived from the substanee of the histolyzed polypide. ii. It is always attached (when oceupying its original position) to the funiculus, and more or lcss invested by the funicular plexus. iii. Burls for the production of a new polypide are very commonly developed in the elosest proximity to it and on its surfaee. iv. They also originate in various positions, and at greater or less distances from the brown body. v. In some speeies the latter is envcloped by the neighbouring bud, and passes into the digcstive canal, being ultimately expelled tlirougl the intestine, cither cntire or after having undergone dissolution in the stomach*. vi. There may be several brown bodies in a eell; and in somc cascs they lie loose in the periviseeral cavity near the bottom of it (Farre).

On the whole, and especially taking into considcration the later obscrvations to which I have more particularly referred, I must admit that the evidenec at present tallies better with the residuary thcory of Nitsehe and Joliet than with the reproductive theory of Smitt. At the same time I must also hold that no satisfactory explanation has yet becn offered by our erities of the very precise observations of Smitt and of my own. There scem, therefore, to bc grounds ( pro tanto) for desiring some further investigation of the subject.

- I must allow that it is improbable d priori that the same body would be in sone cases an important reprocluetive factor in the colony, and in others would be ejected as unere rubbisb by means of a special arrangernent. 


\section{Monifications of the Zodecral type.}

The Avicularium and Vibraculum.

The structural type of which the zoccium is the most familiar representative, cxhibits a number of modifications amongst the marine Polyzon; of thesc the most remarkable are the avicularium and the vibraculum. These curious appendages arc confined to a single suborder, the Cheilostomata, within the limits of which they oecur in great abundance and varicty. The vibraculum (probably a derivative from the avicularium) is rarely met with as compared with the latter, which is present in a large proportion of the Cheilostomatous genera*.

The avieularium is best known in its most highly specialized form as it occurs in the gencra Bugula and

Fig. xxviii.

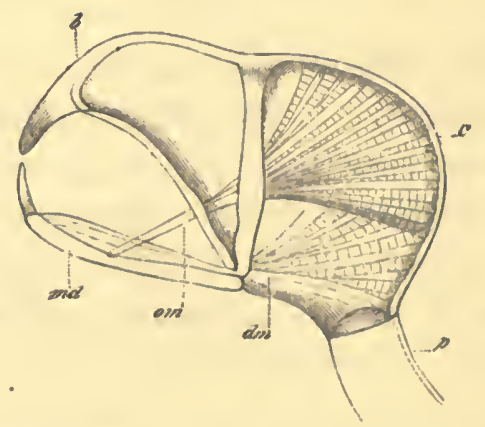

b. Beak. md. Mandible. C. Chamber. p. Peduncle. om. Occlusor muscles. . $d m$. Divaricator muscles.

* Out of forty-fire British genera of Cheilostomata, avicularia occur in thirty-one, vibracula only in four. In two genera both the sppendages are present together. 
Bicellaria. This is the true "bird's head," an articulated appendage attached to the zoccium, with a formidable hooked beak and a mandible worked by powcrful muscles, perpetually snapping its jaws with monotonous energy, and swaying to and fro with vigorous swing on its jointed base-grotesque both in form and movement.

But in a large proportion of cases the appendage exhibits a much simpler structure, and is totally destitute of the peculiar shape which has suggested its name. It is necessary to study its morphology in extenso to obtain a eluc to its history; the articulated "bird's head" bears no trace of resemblance to the associated structures, which are yet undoubtedly of its kin; it has assumed an alien form, and has parted with all the familiar features of its tribe; its aspect and its habits are those of a foreigner; and as we watch it, even with its genealogy in our hands, we ecase to wonder that it remained so long a mystery and a puzzle to the zoologist. When we come to consider the avieularium, not merely in its more complex and highly organized condition, but in its totality, as it is represented in a long series of gradational forms, we are left in no doubt as to its structural affinities. We ean trace the course of its development from the first rudimentary stages, which are bardly distinguishable from the ordinary zoœeium, through a multitude of phases, up to the highly claborated prehensile appendage in which no family likeness survives. And probably the best way of presenting its history will be to begin with the lowest forms in which it occurs, and to follow it through its chief modifications up to the highest.

It will be desirable, however, first to indicatc the essential elements of its structure; and in doing so, it will be 
neessary to avoid the deseriptive terms which might naturally be suggested by the organization and apparent function of the true "bird's liead." The latter would seem to be a grasping organ; but in a large proportion of the lower forms there is nothing that ean properly be ealled a "beak," whilst the equivalent of the mandible is utterly ineffieient for prehensile purposes.

Every avieularium eonsists of a chamber, of variable size and shape, in which is lodged an apparatus of museles, of a morable horny appendage which is worked backwards and forwards by the museles, and of a fixed frame opposed to it surrounding an aperture, upon which it falls when elosed. In many eases, if not in all, the ehamber also contains a cellular body, which is in all probability the lomologue of a polypide.

These elements may eompose a structure very elosely resembling the ordinary zoceium; or they may be so modified as to constitute an articulated and prehensile appendage, armed with eurred beak and powerful jaws, and provided with a delicate tactile organ such as we find in the genus Bugula. In all eases the avicularium is to be regarded morphologieally as a metamorphosed zoœcium*, though in its more eomplex forms there is little to betray its lineage.

Amongst our British Polyzoa we find this zooidal form

* In the zoccium of the Cheilostomata the following parts may be distinguished, which should be borne in mind in studying the history of the avicularium :-(i.) the chamber, in which the polypide is lodged (Woodcut, fig. xxx. c); (ii.) a movable corneous plate (the operculum) which closes the entrance to it (fig. xxx. o); (iii.) two sets of muscles, by which this ralve is opened and shut; (iv.) the aperture, an opening covered by membrane, which in many species occupics a considerable portion of the front surface of the cell (fig. xxx. a). In other cascs this is wanting, and is replaced by a solid calcareous wall. The mandible of the aviculnrium, under all its nodifications, is tho bomologue of the operctum. 
in its most rudinnentary condition in sucl gencra as Flustra and Cellaria. Here it is not a specialized structure attacled to the zoceia; it occupies the place of onc of them in the colony: It consists of a dwarfed ccll, on the upper surface of which is placed the usual oral valve, but which is destitute of a polypide; at the same time the valve is frequently of unusual and disproportionate sizc, and occupics a largc part of the arca of the ccll. Except in size, however, it has undergone but little change, though a ccrtain variability of form already indicates its plasticity. In one spccics (Cellaria sinuosa) it assumes a triangular

Fig. xxix.
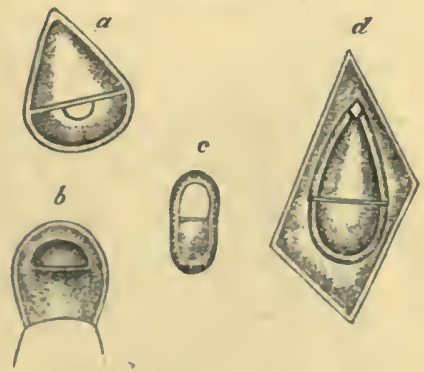

Primary Avicularia.

a. Celluria sinuosa. b. C. fistulosa. c. Membranipora cornigera.

d. M. arctica.

shape; in the common C. fistulosa it is almost undistinguishable from the ordinary operculum. The degree in which the avicularian chamber (or cell) is reduced in sizc varics greatly amongst these primitive and rudimentary forms. In Cellaria Jolinsoni it is a miniature copy of the normal zoœcium (sce Platc XIII. figs. 11, 12), alınost its only peculiarity bcing the elevation and somewhat increased size of the operculum. In other cases the atrophy of the cell is carricd to a great extent, and the operculum occupics almost the whole of the area. 
As specialization proceeds, the chamber is minimized, and the adaptive modification of the valve becomes more and more varied and claborate. In the mandible of the "bird's-head" appendages it reaches its climax, whilst in this form the zoceium itself has lost every trace of its original character and function, and merely lodges the machinery by which the curious prehensile instrument is worked.

Nowhere, perhaps, is the relation of the avicularium to the normal zoœcium more clearly traceable than in a Fig. $x \times x$.

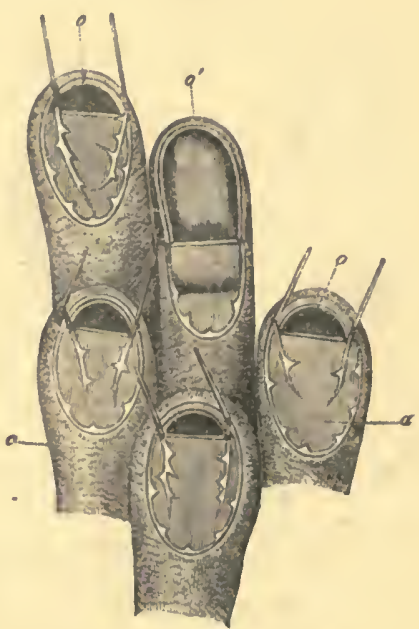

Membranipora longicornis, n. sp.

c. Chamber, in which the polypide is lodged. a. Aperture. o. Operculum or oral valve. $o^{\prime}$. Modified operculum.

foreign spccies of Membranipora (as yct, I believe, undescribed ${ }^{*}$ ), in which a very striking modification of the

* I propose to name it $M$. longicornis, from the remarkable serrated spines with which it is furnished. 
opereulum is combined with the slightest ehange in the cliaracter of the cell itself (Woodcut, fig. $\mathbf{x x x}$.). In this specics a number of zoccia are scattercd orcr the colony, which, whilst retaining in great measure the usual form, are distinguished by a remarkable elongation of the oral valve. This structure, which is normally semicircular in shape, is here much produeed and somewhat elevated above, and stands out conspicuously on the surface of the zoarium. It is fully four timcs the size of the ordinary opereulum, and of course increases very considerably the length of the whole zoccium, which in other respects departs very slightly from the normal condition. The aperture is somewhat redueed, and the spines are aborted; but in gencral appcaranec these abnormal cells very closely resemble the other mcmbers of the colony. The polypide in such cases is probably suppressed. We have here, it would scem, one of the earlicst and simplest departures from the normal type of the zoccium in the direction of the avicularium. In Flustra the change is much more marked, as the cell is merely rudimentary, and the movable operculum constitutes the essential feature.

These slightly spccialized forms, which fill the place of a zoccium in the eolony, may be distinguished as the primary avicularia. They oceur under various modifications : in Schizotheca fissa thc avicularium has all area of the same size and form as that of the zoceia, the beak and mandible oceupying much the same position as the oral opening (see Plate XLI. fig. 3). Nowhere is its morphological significance more apparent. A striking ease of the same kind is presented by Cellaria tenuirostris, Smitt (Woodeut, fig. xxxii.). In Schizoporella venusta, on the other hand, the area (which replaces a eell) is reduced 
to a rery diminutive size, and has a minute rounded mandible (Plate XXX. figs. $6 a, 7$ ) *.

The next marked stage in the developmental series is eharacterized by the contraction of the area combined with the assumption of a more or less peduncular eharaetel by the hollow portion of the strueture. The external resemblanee to the ordinary zoceia has disappeared; the eell is eommonly represented by a subeonical elevation, on the summit of which are placed the beak and mandible. At the same time the avicularium is now, for the most part, a secondary growth, and is developed, not on the original plane of the colony, but on the zooeia themselves. There has been a large reduction in the size of the ehamber, no longer required for the aceommodation of the polypide, and a growing speeialization of the mandible and its adjunets. To a great extent the avicularium has lost its apparent status as a distinet zooid in the eolony, and become an appendage of the zoceium. The bosses or mounds, so often forming part of it and supporting the mandibular apparatus, are to be regarded as the homologue of the ehamber in the normal zoceium. Such forms as I lave now deseribed, and others allied to them, may be classed as secondary or transitional avicularia. We must not suppose, however, that they constitute a elearly defined seetion; they are conneeted at all points by intermediate forms with the primary group. Nor are these divisions coineident with any particular genera or families; the various modifieations of the avieularium are distributed sporadically over the wlole Sub-

* In this spocies the aricularia alternate with the ordinary cells throughout the eolony. In the specimen represented in Plate XXX. fig. 7 there is a group of variously modifed cells which strikingly illustrates the relationship between the primary avieularium and the zocecium. 
order, with the exception of the highest, which occur only within very narrow and definitc limits.

The raised or pedunculate character commonly assumed by the hollow portion of the avicularium in this division

Fig. xxxi.
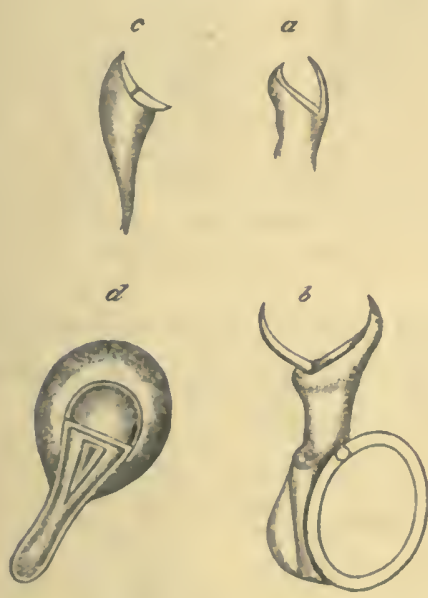

$a, b, c$. Fixed pedunculato avicularia. d. Mamillated avicularium.
Fig. Ixxii.

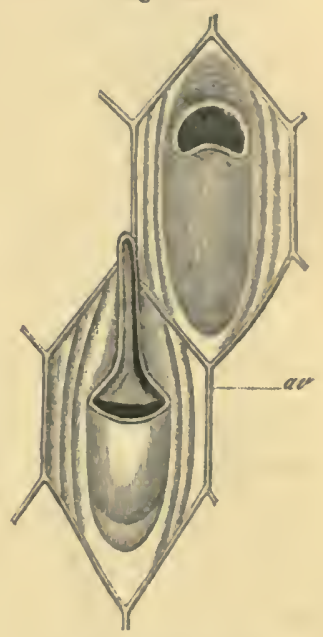

Cellaria tenuirostris. av. Avicularian cell.

beeomes very pronounced in ccrtain cases. The beak and mandible are elevated on a distinct stem, and (we may suppose) obtain in this way pcculiar advantages for the discliarge of thcir function, whatever it may bc. In such forms (Woodeut, fig. xxxi., $a, b$ ) we recognize an advance towards the peduncle of the true "bird's head." $\Lambda$ ncarer approacl to it is met with in the remarkable peduneulate avieularia which oceur in one or two species of Membranipora * (Woodcut, fig. xxxi., c). The want of

* Membranipora spinifera, Jolunston (see Pluto XIX. fig. 1, $a, b, c$ ) and M. cymbifurmix, Hircks. 


\section{Fig. xxxiii.}

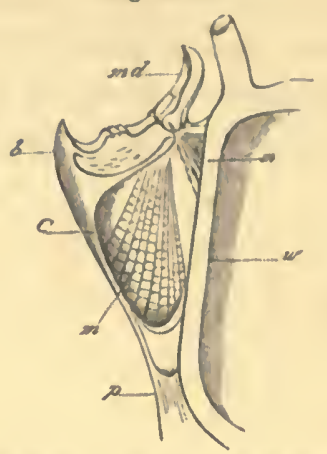

Avicularium of Scrupocellaria scruposa.

$w$. Wall of zoceciun. c. Chamber of avicularium. $m$. Muscles.

p. Peduncular portion. b. Beak. md. Mandible.

mobility is pcrhaps the most esscntial distinction between - this form and the avicularium of Bugula; the beak and mandible are less highly organized than in the latter; but the gencral eharacter is the same in both, and very slight ehanges would suffice to eonvert the one into the other.

In Scrupocellaria the avicularium is attached to the side of the zoœcium by its cntire length; but it is truly pedunculate (Woodcut, fig. xxxiii.), and if attached only by the basc, would bear a close general resemblance to the Bugulan form. The mandible is eurved in towards the extremity, and the beak is somewhat hooked; so that the appendage has considerable prchensile power. The ehamber is not morc than sufficient for the lodg- Pedunculate avieularium ment of the muscular fascieles.

Fig. xxxiv.

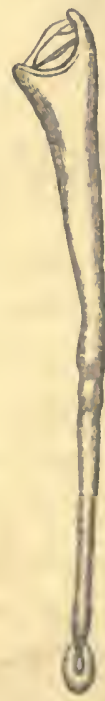

of

Bicellaria tuba. 
A still nearer approach to the higher avicularium oeeurs in the remarkable form described by Smitt under the name

Fig. xxry.

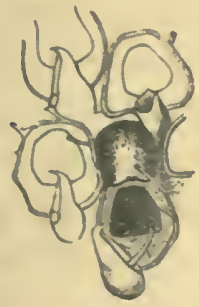

Membranipora princeps.
Fig. xxxri.

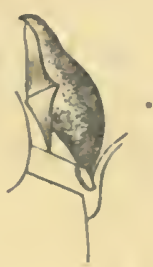

of Membranipora minax (Woodeut, fig. xxxv.)* Here we have the perfect form of the "bird's head" (a curious

Fig. xxrvii.

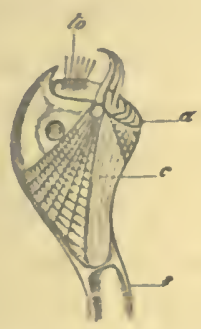

Aviculurium of Notamia.

to. Tactile organ. a. Aperture. c. Chamber. s. Stem.
Fig. xIxviii.

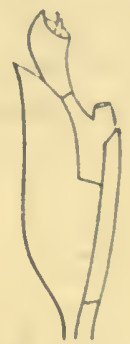

Cell of Notamia, urith avicularium.

antieipation of the organ as it exists in Bugula Murrayana) : but there is no basal joint, and the whole structure is calcareous. A eonnexion is very clearly established

- This is certainly distinct from M. minax, Busk; and I should propose for it the name of M. princeps. Compare the fired aricularium of this specie with the morable bird's head of Diachoris Magellanica (Woodcut, fig. xxxi.). 
between the simply mamillated avieularium and the artieulated through suel forms as we have in the true Membranipora minax (Woodeut, fig. xxxi., a), in Scrupocellaria ferox (Woodeut, fig. xxxi., $b$ ), and the present speeies.

In Notamia we have probably the fixed form which eomes, on the whole, nearest to the movable "bird's head," and eonstitutes the most direct link between the two elasses of avicularium (Woodcut, fig. xxxvii.). Here the hollow portion (or chamber) is borne on a slender stem of considerable length, from which it is separated by a partition; it expands from the base upwards; and on the upper surfaec is plaeed the eurved beak ("like that of a euttle-fish"), oeeupying about two thirds of its length, at the base of whieh the mandible takes its origin. The latter is mueh eurved, and terminates above in a sharp point. The upper edge of the eliamber below the mandible surrounds a semieireular space, elosed in by a membrane, whieh probably represents the aperture of the normal zoœcium. Two new features (both of them present in the "bird's head") make their appearance in this form. The beak and the portion of the wall of the ehamber from which it rises are of horny material; in the lower forms they are ealeareous. Between the mandible and beak, when the former is elevated, a tuft of minute setæ placed on a slight rising is visible, whieh eonstitutes a taetile organ, and conveys the cxternal stimuli whieh bring the museles into play. It is possible that this strueture may exist in speeies in whieh it has not yet been observed; but so far, I believe, it has only been notieed amongst the higher forms (which I shall call the articulated (avicularia) and in Notamia*. It may, I

* In all but its fixed condition Notamia ngrees with the articulated group. 
think, be concluded that it is the concomitant of the more highly specialized form.

I may add that the avicularia in Notamia have very much the shape and gencral appearance of zoccia reduced in sizc, and are placed, like the latter, in oppositc pairs.

We pass now to the articulated forms, in which the zoœcial type is completely masked, its elements being so modified as to constitute an claborate prehensile appendage, charged with a spccial scrvice in the interests of the eolony (Woodeut, fig. xxviii.).

In the articulated avicularium the " bird's head" is supported on a short peduncle with a basal joint, on which it sways to and fro. The head is composed of two portions, -a lowcr, which is more or lcss rounded above, and forms the chamber for the muscles (=the cavity of the zoceium), and an upper or anterior, which consists of a movable mandible and a curved beak opposed to it. This anterior portion is formed of horny matcrial, whilst the chamber itsclf is calcarcous. The walls of the projecting upper

Fig. xxxix.

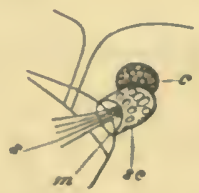

Rudimentary Polypide in Avicularium.

c. Cellular body. "sc. Setiferous cup. s. Sets. m. Membrane closing orifice.

jaw, which terminates in the hooked beak, inclose an aperture, over which stretches a delicate membranc, picreed by a small circular orifiec. 'This apcrturc represents the 
mouth of the zoœcium, the mandible taking the plaee of the opereulum. Within the ehamber oeeurs a small eircular body, composed of distinct eells, whieh is connected (in Bugula flabellata*) with a cup-shaped organ, opening out through the membrane of the aperture. From the bottom of the eup rise a number of setre, which projeet beyond the opening and constitute the tactile organ before referred to $\dagger$. The cellular body (Woodeut, fig. xxxix., c), in connexion with the setiferous eup, has been regarded as a nervous ganglion (Busk, Smitt); the two together eonstitute, according to Nitsehe, the homologue of the polypide, which is here reduced, in conformity with the altered significance of the whole structure, into a mere organ of toueh. There ean be little doubt, I think, that the latter is the true view; at the same time it must be regarded as probable that the rudimentary polypide is furnished with its nerve-eentre, by which the powerful muscular apparatus $\ddagger$ and the sensitive organ may be supplied. Whether the cellular body eonstitutes the ganglion, we are not at present in a position to decide. The artieulated avicularia are always attached to the wall of the eell, and usually at a short distance from the orifice; they are eonfined (apparently) to a comparatively small number of genera.

Some further evidence of the morphological nature of these eurious appendages may be briefly noticed. (i.) In

*According to Nitsche, "Ueb. die Morphologio der Bryozoen," Zeitsch. f. wissensch. Zool. xxi. 4 Heft, p. 111.

$\dagger$ According to Busk this organ is protruded by the mere throwing back of the mandible. When the avicularium is opened, it stands out prominently on the upper surface.

\$ The muscles are disposed in two sets-one for the opening and the other for the closure of the mandible; they are composed of transversely striated flbres. 
some cases I have met with ovicclls developed over the upper cxtremity of the avicularian beak and mandible, clcarly indicating their morphological relation to the orifice of the zoccium. On more than one occasion this lusus has occurred to me in Schizotheca fissa (Woodcut, fig. xl.)*.

(ii.) The rescmblances in minute detail between the avicularian cell and the ordinary zoccium of the species to which it belongs, which are not unfrequently met with, have a like significance. Thus, to take a single illustration, in one spccies a minute sinus occurs on the lower margin of the avicularian mouth, corresponding with a similar sinus in the orifice of the

Fig. xl.

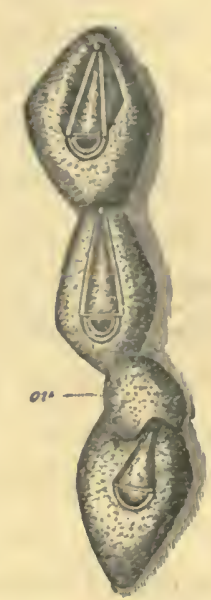

Avicularian cells. ov. Oricell. zoœcium. Instances of the samc kind might be multiplied.

The function of the avicularia is difficult to detcrmine ; nor, indecd, can the same function be assigned to all of them. The primary forms are many of them quite unfit for prehensilc work. The lid-like mandible, with plain rounded margin, has no power of grasping, and could not detain for a second the active worms which arc sometimes captured by the articulated kinds. Their scrvice for the colony must lic in some otlier dircetion. Even the fixed, transitional forms, in which the beak and curved mandiblc are present, must be incfficient for this work from their want of mobility, whilst in many of them the parts concerned in the act of prehension arc but slightly 
developed. The articulated avicularia, however, are 111 doubtedly grasping organs*; and the presenec of the tactile tuft between the jaws must be taken to indicate that eapture in some form or other is their function. They have been seen to arrest minute worms, and hold them for a considerable time with a tenacious grip, as if with some ulterior object; but what the object may be it is difficult to decide. Dr. Jolnnston suggested that they may assist in providing supplies of food, scizing "circumfluent animaleules," and retaining them until, "cnfeebled or killed by the grasp," the ciliary currents may bear them to the mouth. But the avicularium is not fitted to capture the extremely minute organisms on which the polypides feed; and even could they be captured and rendered helpless, there would be many clances, placed as the appendages usually are, against their coming within the attraction of the ciliary vortex. The worms, which seem to be the commonest victims, could only be utilized as food by being retained until, decomposition having set in, the particles of decayed matter might diffuse themselves through the surrounding water, and find their way, in greater or less degree, to the stomachs of the polypides. But the supplies of nutriment in the water of the occan must be ample and unfailing, and no better provision for appropriating them than the ciliary whirlpool can well be imagined. Unless we can suppose that a peculiar diet is necessary for the species furnished with the prehensile appendage, it is hardly probable that the ordinary arrangements would have to be supplemented by the service of such uncertain purveyors. And should they be feeders

* "When touched with a needle the beak generally seized the point so firmly that the who'e brnnch might bo shaken."-DARwin. 
on dead organisms only (as has been suggested), they would ecrtainly lead a preearious existence if dependent on the chance supplies of the avieularian eommissariat. The appendages, it must be remembered, have no freedom of morement; they do not go in quest of prey; they mercly oscillate without variation to and fro, snapping their jaws at haphazard, or when roused by some irritation of the tactile setr. Their eaptures must be fitful and uncertain; and if the food requires long kecping to be fit for use (and under the conditions this seems to be a necessary supposition), the colony must be in chronic danger of a faminc. If living animals be the required dict, then the eilia are adequate to the supply of them, and the avicularia are not.

On the whole (though the question is ecrtainly involved in much obscurity), I am inclined to regard the avicularia as charged with a defensive rather than an alimentary function. They may either arrest or seare away unwelcome visitors. Their vigorous movements and the snapping of their formidable jaws may have a wholesome dcterrent effect on loafing Annelids and other vagrants, whilst the occasional eapture of one of them may help still further to protect the colony from dangerous intrusion. On this view of them, they have a function analogous to that of the other appendage with which the Cheilostomata are furnished.

The Vibraculum, though morphologically related to the zoocium, like the avicularium, is more immediately conneeted with the latter; and we find a line of transition forms linking the two together. It eonsists, in its more perfect condition (Woodent, fig. xli.), of a chamber, in which the muscles are lodged, and a morable bristle, sus- 
pended in a kind of cleft at its upper cxtrcmity, in which it works backwards and forwards. The seta (or bristle)

Fig. sli.

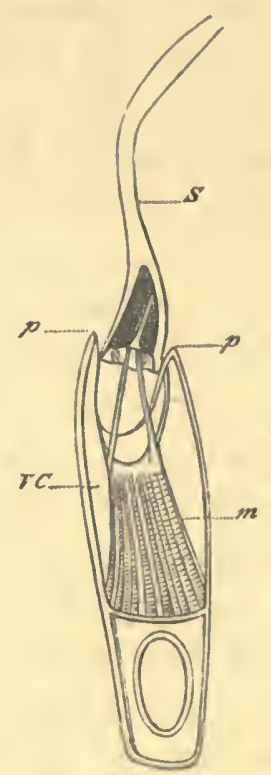

Vibraculum of Scrupocellaria scruposa.

IV. Vibracular chamber. $m$. Muscles. $p p$. Pointed extremities of the chamber, between which the seta is suspended. S. Seta.

is broad at the base, and above it slender, and often of considerable length. In some cases it attains an enormous devclopment, and forms either a whip-like appendage or an organ of sueh a size and strength as to be available for locomotive purposes. On the lower part of the wall of the ehamber thcre is always a small opening, marking the point from which a long tubular appendage (or radical fibre) originates (Plate VI. fig. 8, and Plate VII. fig. 2).

The vibraculum, as already mentioncd, is of compara- 
tively rare occurrence. In its most highly specialized forms, it is placed on the dorsal surface of the zoceium, and the movable seta (which when at rest is laid back upon the chamber) is swung round at intervals to the front of the cell, sweeping slowly over the surface as if to remove all noxious matter, and then returns to its original position. This movement goes on uninterruptedly during the life-time of the colony; and there can be no doubt that its object is to clear away dangerous intruders or accumulations of refuse from the neighbourhood of the orificc.

We have no difficulty in recognizing the equivalent of the avicularian mandible and the operculum of the cell in the seta. The mouth is here modified in the same sense as the rest of the structure : the raised "beak" is absent, being no longer useful; but the margin is carried out above into two prominent points, just within which the bristle is articulated, elear of all hindrances, and so as to possess the utmost frcedom of morement (Woodcut, fig. xli. $p p$ ).

The homology of the parts becomes more evident when we study the transitional forms. We meet with a developmental stage (corresponding to the primary avicularium), in which the vibraculum is developed on the original plane of the colony, and oecupies the position of an ordinary ecll; in some species the vibracular eells alternate regularly with the zoœcia. In sucl cases the movements of the seta are of necessity much restricted, and the appendage is rather a servant of the colony than of the individual polypide (Plate XXI. fig. 7).

The direct links between the vibraculum and avicularium are found in those forms of the latter in which the 
mandible is prolonged and attenuated, whilst the beak is almost rudimentary. Indeed it is diffieult to draw the line between them, unless we regard the total absence of a distinct beak as the cssential eharactcristic of the vibraculum. We have a ease of the slight cxtension and attenuation of the mandible in Schizoporella spinifera (Plate XXXV. fig. 7); in Membranipora ciliata the change is oeeasionally carried still further; but there is great variability, and the mandible is now of the ordinary form, and now prolonged into a vibracular process (Plate XXVIII. fig. 8). In Schizoporella vulgaris the mandible is metamorphosed into a scta, but the bcak survives, and the movement is probably nothing more than the rising and falling, as of a lid. In Mastigophora Hyndmanni (Plate XXXVII. fig. 5) the mouth is so modifier as to give much more play to the seta, whieh is thrown backwards and forwards with perfect freedom, and has much the appearance of a lash. In this species the vibraculum is borne on a distinct cell, resembling the zoœcium (on which it is developed) exccpt in size. In yet another ease the vibracular cells are still further reduced, and one is placed on cach side of the orifice of the zoœeium (Plate XXXVII. fig. 1). When we come to the higher forms we meet with cases in which the scta resumes the dimensions of the mandible, and loses its free and vigorous swing (Platc VI. fig. 8).

The most elaboratc form of this appendage is found in the genus Caberea. Therc the chambcr is large, and traversed on the upperside by a channel or groove, in which the seta lies when at rest*. The latter is of great length, and ser-

* This groove must be regarded as a modification of the aperture, $i . e$. of that portion of the front wall of the cell which, in Caberea and many other forms, is alled in by membrane. 
rated or toothed along the edge. In this genus the entire dorsal surface of the branch is covered by the vibracula, and the morcments of the seta are synchronous; they act together with perfect regularity-the whole company on a branch swinging to and fro at the same moment, and as if under a common impulsc (see page 58). We can hardly doubt that there must be some intercommunication between the nerve-centres of the individual vibracula, on which these combined movements depend; but so far the synchronism has attracted very little attention*, and we have no observations that throw any further light upon it.

The sctrattain their highest development in the family of the Selenariide, Busk : here they are of enormous size and of great strength, and assume, in some species at least, a locomotive function, acting probably as oars, and propelling the colony, which is frec in the adult state. In the history of these appendages we hare a curious illustration of the variety of function that may connect itsclf with the same morphological elcment $†$.

* It was first observed by Mr. Darwin in a species of Caberea ("Voyages of Adrenture and Beagle,' vol. iii. pp. 259-262; 'Origin of Species '(later editions). I have also studied it in Caberea Boryi.

In the passage referred to Mr. Darwin also states that the avicularia on one side of a branch were observed to move, "sometimes coinstantaneously, sometimes in regular order, one after the other."

t Salensky finds in the vibraculum a structure homologous with the polypide, corresponding exactly with that in the avicularium.

The aricularia were first noticed by Ellis; they have been in restigated by Nordmann ('Fauna Pontica'), Krohn, Van Beneden (" Recherches," Mrém. Ac. R. Belg. rol, xriii.), Reid (Ann. \& Mag. X. H. rol. xri. p. 385), Darwin (loc. cit.), Busk ("On Notamia," Trans. Micr. Soc. Oct. 27, 1847; "On Avicularia and Vibracula," vol. ii. p. 26), Smitt (Öfrers. Vet.-Ak. Förh. 1867,. p. 468), Nitsche (Zeitsch. xxi. Heft 4, p. 110). 


\section{Tue Polypide of the Extoprocta.}

In the group of the Entoprocta the polypide differs so widely and essentially in structure from that of the Ectoprocta that it is necessary to treat it separately. Its chicf peculiarities, however, are describcd elscwhere (pages 563, 564); and I necd only add that the importance of the characters on which the new division is founded has bcen generally rccognized $*$. For an account of the aberrant group of the Pterobranchia the reader is referred to the systematic portion of this work (pp. 577580).

\section{Organs of Sense.}

Special organs of sense are of rare occurrence amongst the Polyzoa; and such as exist are of the simplest kind. With a single exception they are all tactile in function, and very similar in structure.

The most elaborate occur in the genus Loxosoma, and consist of papilla, placed one on each side of the body of the polypide, bearing on the summit a number of rigid setæ. The papillæ are contractile, and can be almost wholly withdrawn + ; their cavity, according to Salensky, is occupied by a nerve-knot, which is connected by nervous filaments with the ecntral ganglion. The setre

* An extensire literature has sprung up devoted to the Entoprocta. See Nitsche, "Ueber Pedicellina echinata," Zeitsch. wissensch. Zool. Ix. (1870), Heft 1; "Ueb. den Ball, \&c. von Loxosoma Kefersteinii," ibid. xxv. p. 451 : Schmidt, O., "Die Gattung Loxosoma," Arch. f. mikr. Anatomie, sii.: O. Vogt, "Sur le Loxosome des Phascolosomes," Arch. de Zool. expérimen. tale, 1877 (transl. in Quart. Journ. Micr. Sc. (n. s.) vol. xvii. p. 353): Sulensky, "Etudes sur les Bryoz. Entoproctes," Ann. Sc. Nat. $6^{e}$ sér. Zool. v. (1877), article no. 3: Hatschek, "Ueb. Pedicellina," Zeitsch. xxix. p. 502.

+ Vogt describes the papillæe as containing "elongated, conical, converging cells, apparently in direct communication with the bristles." He failed to detect the nerres. 
are in contact with the knot*. These are clearly organs of toucl, similar to those which oceur in many other animals. Salensky compares their strueture to that of the antennæ of the Rotifers.

Closely allied to these sensitive papillx are the tactile tufts, which oecur in the articulated avicularia, and which have been already described. In the same eategory may be placed the bristles which form a line along the back of the tentacles in many speeies. These are probably analogous to the palpoeils of the Hydroida, and must largely inerease the sensitireness of the eorona, tlirough which the polypide communicates with the outer world.

An interesting provisional organ has been noticed by Salensky in the young of Loxosoma crassicauda. The arms of the budding polypide are furnished with a very long motionless bristle, placed on the external side, near the top, which disappears at a later stage. He regards it as a tactile organ, needful to the young after its detachment, when seeking a site for fixation, but useless to the adult.

In the larva of Loxosoma Vogt describes an organ composed of two circular hollows, surrounded by a thick border, which forms a kind of bridge between them. Within each depression are placed five or six conical papillæ, supporting long cilia, which ean be exserted or withdrawn into the hollow. He names it the "speetaeleorgan ;" and from its similarity of strueture we may infer that it has the same function as the preeding, tlough it is diffieult to determine its precise relation to the econony of the larva.

"Salensky, "Etudes sur les Bryozonires kintoproctes," Ann. Sc. Nat. 6e ér. Zool. rol. v. (187i), article uo. 3. 
We may probably also rank amongst the organs of sense, though of a very humble and rudimentary kind, the eoloured specks, frequently inclosing a refractive eorpusele, which oecur on many of the Polyzoan larve. They are sometimes numcrous (as in Bugula flabellata, Plate LXXXIII. fig. 6)*, and may perhaps be regarded as primitive eyes.

\section{Reproduction and Embryology.}

Two kinds of reproduction have a place in the lifehistory of the Polyzoa, a sexual and an asexual-(i) reproduction by means of ova and spermatozoa, and (ii) by gemmation $\dagger$.

In a large proportion of cases the species seem to be monœcious, both male and female organs being present in each cell. But the rule is not without its exceptions. Alcyonidium gelatinosum, according to Kölliker, is unisexual; and I believe the same to be the ease with $A$. mytili. In this species the ova are produeed in gonceia (that is, in cells destitute of a polypide and devoted to reproductive functions), whilst in some of the ordinary. zoœcia the spermatozoa oceur in enormous quantities: I have seen them darkened by the dense mass of wriggling filaments which filled the perivisceral cavity. Such eells were provided with the eiliated intertentacular organ (to be described hereafter); and through this the spermatozoa were finally discharged into the surrounding water. In this ease it would seem probable that the sexes arc distinet;

* Nitsche, "Ueb. die Entwicklungsgeschichto einiger chilostomen Bryozoen," Zeitsch. f. wissensch. Zool. xx. Heft 1, p. 7 (sep.).

+ Sexual elements hare not yet been obserred in the Cyclostomata. 
but I have not bcen able to determine the mode in whieh the fertilization of the ova is effected.

Joliet has observed the separation of the sexes in a Lepralia; and, aeeording to Vogt, Loxosoma phascolosomatum is unisexual; whilst in Tendra, aeeording to Repiaehoff*, some of the eells in a eolony are hermaphrodite, but the greater number of one sex only.

The origin of the reproduetive elements and their position in the perigastric eavity lave already been diseussed in the aecount of the endosarc (pp. xlvi-l).

The spermatozoa are formed out of the nueleus, whieh oeeurs in each of the vesieles ineluded in the sperm-eell; and eonsist of a thread-like body, which is oeeasionally vibrioid, but more eommonly somewhat enlarged at one extremity + . They have an undulatory movement; and in some eases I have notieed a violent shaking of the elavate head.

It is a question whether the ova are fertilized by spermatozoa developed in the same eell with themselves, or whether the offiee is diseharged by those whieh are liberated from other eells. Joliet has adopted the latter view, and supported it by a number of observations, which appear at least to show that in some eases the spermatozoa are entirely eleared out of the zoccium before the ora have reached the stage for fertilization. The very faet, too, that they are sometimes ejeeted in sueh immense numbers into the surrounding water (where they seem to live and thrive), may be taken to prove that they have a

* Zeitsch. f. wissensch. Zuol. xrv. p. 129.

+ Both Farre and Van Beneden describe them as baving in some cases a rounded or discoid head; and the former states that by this they occasionally fix themselves. 
function to discharge beyond tho preeinets of their birthplace. In some instances, too, Joliet lias been able to obtain direet evidenee of the fertilization of the ovum by extracellular spermatozoa. But though in eertain speeies this method may prevail, we have no reason for supposing that it is general. In Bugula avicularia I have observed the spermatozoa swarming round the ovary, which was situated on the funiculus immediately below the extremity of the excum; and it ean hardly be doubted that in this ease fertilization was effected either before or immediately after the eseape of the ova. In most of the cells eggs in various stages of development were present. In Farrella Van Beneden deseribes the ova as passing from the ruptured ovisae into the eavity of the eell, and being there surrounded on all sides by the spermatozoa. In Bicellaria ciliata Nitsehe has found the ovum fertilized whilst still within the body-eavity, and before its transference to the oceium; and in this ease there ean be no doubt that impregnation was due to the spermatozoa of the eell in which it occurred. We should draw the same inferenee from Smitt's aceount of the reproduetive elements in Scrupocellaria scruposa*. In Paludicella, aeeording to Allman, the spermatozoa liberated from the testicle at the bottom of the eell may be seen elustering round the ovary at the top of it. We must, I think, admit that both modes of fertilization exist. Of course, in the ease of unisexual species, the spermatic bodies must find their way from the male to the female zoøeia; and we ean only suppose that they take the road through

* He says "Sådana svärma de [the spermatozoa] upp till den plats, der ännu ägget ligger qrar uti djurhusets öfre del" ( Om Hafsbryozoernas Utreckling, p. 36). 
the surrounding water. We might be tempted to conjecture that the enormous production of spermatozoa which sometimes oceurs must be specially connected with the diceious character of the species, or at any rate that in such eases the fertilization of the ova must be effected from without. But obscrvations on this point are wanting.

Joliet states that in the ease of several species he has seen the spermatozoa pass from the eell "through the delicate tissue of the tentacular sheath:" and he supposes that their expulsion may be due to the pressure of the perigastric fluid at the moment of retraction. In other eases we know that there exists a special means of egress -the "intertentacular organ," which was first noticed by Dr. Farre*, though he failed to determine its place in the economy. He observed it in Alcyonidium gelatinosum and Membranipora pilosa; I have also met with it in Alcyonidium mytili and Membranipora membranacea. It consists of an oblong flask-shaped body, which is placed between two of the tentacles, and attached to the tentacular ring; its interior is oceupied by a eavity lined with eilia, "which vibrate downwards towards the outer and upwards towards the inner side;" and at the upper extremity there is a wide circular orifice surrounded by cilia. There is sometimes a constrietion a little below the top, so that the upper portion forms a eup-shaped compartment. The organ is elosely united to the sides of the tentacles, and is plaeed on the anal aspect of the body; below it opens into the perigastric eavity. It is not present on all the polypides in a colony, and is often

* Philosophical Transactions for 1837, pp. 40S and 412. See also "Nutes on British Zoophytes," by the author, Ann. \& Mag. Nat. Hist. for Nuvenber 1851 . 
absent altogether; in some cases it oecurs in great abundance*.

As I have already stated, this organ is the ehannel through which the immense numbers of spermatozoa, eongregated in certain cases and at certain seasons in some of the zoceia, find their way into the water. I have watched them streaming up incessantly from the lower part of the cavity for thrce or four minutes, the filaments as they reached the base of the organ being drawn into it and carried through it by the action of the cilia, and then ejected and borne away by the tentaeular currents. After a while a single filament madc its appcaranee oeeasionally; and at last none were to be seen. This swarming of the spermatozoa is really an extraordinary sight; and the numbers expelled in the course of it must bc immense.

At other times I have repeatedly seen a mass of exerementitious matter pass into the organ from bclow, which was gradually forced upwards by the cilia, and at last ejected, as a pellet, through the terminal orifice. This, I confess, surprised me not a little, as in some cases in which the organ was present the freal matter was seen to pass outward in the usual way through the anal opcning. I was at one time inclined to regard this curious appendage as denoting a differcncc of sex; but as I have met with it

* Ehlers suggests that this intertentacular organ may be nothing more or less than a parasite, as he had himself noticed a very similar structure on a Lepralia, which he had ascertained to be an infusorium! We may safely conclude that hecontented himself with referring to my paper, and dispensed with the reading of it, as it would be difficult to harmonize the very precise description which it contains of the passage of the spermatozoa through the cavity of the organ with any such hypothesis.

The curious structure which he has himself noticed as occurring on Hypophorella (op. cit. p. 56), and which has no doubt an excretory function, may very probably bear some anulogy to the organ which ho has too hastily dismissod as apocryphal. 
in a zoceium containing ova (in Menibranipora membranacea), I now eonsider it to be an exeretory organ, which serres at the swarming-season as the passage by which the spermatozoa escape from the cell into the surrounding water (= the nephridium, Ray-Lankester).

The ovary, as we have seen, varies in position; it also varies remarkably in size. In some species it contains a large number of ova (thirty in Hypophorella, and probably an equal number in Farrella), in others only one or two. Frequently two ova are produeed, which are either matured in succession, or one of them perfects its development at the expense of the other, which is atrophied. It appears that in some eases, after the first ovary (on the funiculus) has discharged its contents, it is followed by a second. In its early stage the funicular ovary is a minutcly granular body, of an oval form, and a pale golden colour (Woodeut, fig. xxiv. ov). In its interior the ova make their appearanee, and, when mature, consist of a granular yolk (vitellus), which is sometimes coloured, invested by a membrane, and presenting a conspicuous germinal vesicle, with a germinal spot. At a certain stage they eseape through the ruptured wall of the ovary into the perigastric eavity. After fertilization they exhibit the usual phenomena of segmentation, and are developed into free, ciliated larvæ.

An interesting question arises, as to the mode in which the embryo, imprisoned in the zoccium, makes its eseape into the outer world; and this eonneets itself with the history of the strueture known as the oxcium or ovieell. This is a small, somewhat globose or galeriform reeptacle, which in many species of Cheilostomata is developed during the breeding-scason, at the upper extremity of the 
cell. It is usually, but not always, terminal, and is produced by gemmation from the wall of the zoccium; its intcrior is in dircet communication with the perigastric cavity. In certain species (e. g. Bicellaria ciliata), the oœcium exhibits a somewliat complex structure. The opening is closed by a membranous capsule (attached by its base in front), which partially occupies the cavity. This capsule is furnished with muscles, by which it can be more or less withdrawn from before the orifice, so as to allow of the escape of the larva. The ovum, when transferred to the ovicell, lies between its outer wall and the capsule. By the action of the retractor muscles, the membranous wall of the capsule can be drawn down, so as to leave a larger space for the embryo as it increases in size, as well as secure a passage for it when mature *

At the time when the reproductive elements are present in the cells, ova are commonly found in the oœcia, where they occur in every stage, from the first segmentation to the perfect larval condition. Huxley was the first to suggest + that the ovicell must be regarded as a kind of marsupial chamber, into which the ova migrate from the zoœcium for the purpose of completing their development; and this view has met with general acceptance. I was at one time led, by observations which I had made on a number of species, to challenge it, and to contend that the ovum found in the ovicell was produced there, and was not a mere emigrant; but, as I have already $c x$ plained $\downarrow$, I am now convinced that the marsupial theory

* The structure and development of the ovicell have been admirably de: monstrated by Nitsehe (Zeitsch. \&c. xx. 1. Heft, pl. i. figs. 10, 11).

+ Quart. Journ. Micr. Sc. iv. (1856), p. 191.

+ "Contributions to the History of the Polyzon," Quart. Journ. Micr. Sc. (n. s.) xiii. p. 30 . 
is unaffected by those obscrvations. There can be no doubt that the ova gencrated in the zoœcium do pass into the ovicell and there ripen into the perfect larva, escaping at last through its orifice. The oœcium is thus both a brood-cliamber and the passage for the embryo from the cell to the surrounding water.

But whilst $I$ have no doubt that the ovicell acts as a kind of marsupium, there seem to me to be grounds for believing that in somc cases, and under conditions which I cannot explain, ova are also produced within it. Reid long ago described the oœcial ova as adhering in their earliest stage to the lining mcmbrane at the upper end of the capsule. I have repeatedly observed in the ovicell a minute and somewhat indefinitc mass of granular substance in contact with the membrane at the top of it, which had all the appearance of a nascent ovum; the first change seemed to consist in a slight concentration of the matter towards the centre of it. In other ovicells there was a small circular body; in others the ovum had increased in sizc, and exhibited the various stages of segmentation. Smitt has also recorded the formation of ova within the oœcium. In the case just referred to, the very small size and rudimentary condition of the ovum in its early stages seem to show that it must have been something differcnt from the ovum developed in the cell, which is perfectly formed and of considerable size when it passes into the marsupium. The subject must be lcft for future investigation.

The dircet passagc of the ova into the ocecium has not been witnessed; nor have wc, I bclievc, any obscrvations showing by what means it is effected. They are some- 
times met with, however, at a very short distanec from the entrance to the marsupium. In a specimen of Flustra papyracea, in whieh ova were present (in somc cases near the bottom of the zoceium, in others higher up in it, in others, again, elose to the opening into the oœeium), I observed one jerking itself spasmodically, as if it might be freeing itself from the investing envelope; and after repeatedly witnessing its vigorous movement, I could have no doubt that it might pass by means of the contraetion and extension of its substance from the eell to the ovicell.

In species which are not furnished with the marsupium, other means of egress must exist. In some eases the embryo is probably liberated after the disappearanee of the polypide, of whose destruetion it may pcrhaps be the eause. In Vesicularia spinosa I have found the mature rose-eoloured larva in the tenantless zoceium equipped with its eilia and ready for eseape.

In one or two forms a special opening has been deteeted, near the base of the tentacles, through which the ova pass. Van Beneden was the first to notice this in Farrella ${ }^{*}$; and recently Ehlers has detected a similar urifice, placed in much the same situation, in Hypophorella + . In the ease of Farrella the ova seem to eseape at a very early stage of development, and before the appearanee of eilia.

But the most remarkable provision for the liberation of the embryo remains to be notieed. For our knowledge of it we are indebted in the first instanee to the observa-

* Mém. Acad. Roy. Brux. xviii. "Rech. sur l'organisation d. Laguncula," p̀. 18 (sep.), pl. i.

+ Op. cit. p. 66. 
tions of Metselnikoff* and Nitsche $†$ on the Freshwater Polyzoa; whilst Jolict has recently detected the same or a strietly analogous arrangement in some of the marine species ‡. I shall give a brief account of it (after this writer), as it exists in the latter. In cells of Valkeria from which the polypide has disappeared (being replaced by a "brown body"), a mature ovum is met with at eertain seasons, not yet fertilized, and, as it seems, hopelessly imprisoned in the elosed eavity of the zoceium. But at the moment when eseape appears least likely, a bud makes its appearance at a certain point on the cellwall (in connexion witl some offshoot of the funiculus), which is rapidly developed into a young polypide. The latter passes to the top of the eell and develops new parieto-vaginal muscles and two great retractors, but otherwise remains in a perfectly rudimentary condition. It is to be imagined now as being in connexion with the tentacular sheath and, through the funiculus, with the orum.

The funieulus shortens, and the sheath is proportionately elongated; and the polypide is thus brought into contact with the egg: in a short time (but by what precise means is unknown) the latter makes its way within the tentacular sheath, and occupies a place above the polypide. The latter dwindles away and becomes a mere platform (movable by means of its attached museles), on which the ovum rests, inclosed by the walls of the sheath. It is now in free eommunication with the water; and at

* Bull. de l'Acad. de St. Petersbourg, xv. (1871), p. 507.

+ Zeitsch. f. wissensch. Zool. xxii.

$\$$ Op. cil. p. 70. This author seems to have been unaware of Motschnikoff's previous observations. Ilo has noticed the "auxiliary polypide" in three Ctenostomatous species,-Valkeria uva form cuscuta, Boucrbankiu imbricata, and Lagenella repens. 
this stage (aceording to Joliet) it is fertilized by passing spermatozoa, and immediately enters on its further development. At this time its beliaviour is in many respeets that of a polypide. Thanks to the museles which it has borrowed, it now rises to the entranee of the eell and now retreats to its recesses, until, having assumed its perfect larval form, it passes through the sheath into the water. The "auxiliary polypide" has diseharged the funetions of an oœeium, and has both supplied the ovum with a brood-chamber and a way of eseape. In its leading partieulars, this marvellous history rests on the authority of three able observers.

The true marsupium seems to be confined to the Cheilostomata, and even amongst them is by no means universal. In other seetions of the elass ova are frequently developed in speeial receptaeles, and not in the zoœeia : to these I have given the names gonøcium and gonocyst* Of the former we have a good example in the genus Crisia $\dagger$; it also oecurs amongst the Cheilostomata, and in one family at least (Alcyonidiida) of the Ctenostomata. The gonoeyst has only been noticed in eertain Cyelostomatous genera; it is probably only a modifieation of the gonœeium. Of the history of these struetures, howevel, we know little; they remain to stimulate and reward further researeh.

I do not propose to follow the ovum through the stages of its development; nor shall I enter minutely into the numerous modifieations of the larval form. To do so

* See Terminology, page iii.

+ Smitt has investigated the gonceium of Crisia, and considers the production of ova in it to bo asexual. 'On Hafsbryozoernas Utreckling,' \&c. (1865), p. 19. For a critical notice of Smitt's observations, see Barrois, 'Embryologio' (187\%), p. 59. 
with the neeessary thoroughness would require a mueh larger spaee than I have at my eommand. I must eontent myself with referring the student for detailed information on these branelies of the subjeet to the works of Allman, Smitt, Nitselıe, Metsehnikoff, Claparède, Hatschek, Vogt, Salensky, Repiachoff, Joliet, and (ehiefly) Barrois*, who lias specially devoted himself to this department, and has given us, in a splendid monograpl, a scries of admirable and exhaustive researehes.

The larræ, whieh are developed from the ova, and give rise to the first term of the polyzoan eolony, present many varieties of form and a somewhat eomplex strueture (see Plate LXXXIII.). The figures on this Plate will give some idea of the singularity of shape, the beauty of eolour, and the profusion of eiliary and flagellate appendages which they frequently exlibit. The forms represented in figures 9 and 10 are also furnished with a delieate bivalve shell. The larve are restless in their habits, and during their short term of free existenee are in almost eonstant morement, now whirling rapidly hitler and thitlier, now tumbling over and over in the water, now ereeping along, making use of their eilia as feet. Besides their eiliary appendages, they are often furnished with long setiform proeesses, which wave to and fro, and lash the water with mueh vehemence. After a while their energies fail, and they settle down and become attaelıed; the eilia begin to flag in their movements, and soon disappear; and the volatile and euriously organized being resolves itself into a fixed and (apparently) homogeneous mass, in which the first zoceium and polypide originate.

* The titles of the respective rorks will bo found in the Bibliographieal List at the close of this rolume. 
What, then, arc the extent and signifieanee of the ehange which takes place in the larva after its fixation? It has generally been held that in most cases the complex organization which eharacterizes it in its free condition suffers complete histolysis aftcr its attaclıment, and is replaced by a mass of struetureless material, inclosed by a membranous envelope. This was the view taken by Schneider in his aceount of the remarkable larva of Membranipora pilosa*, and adopted by Nitsche, Jolict, and others. According to the later observations of Barrois, however, this is by no means a correct representation of the actual fact. What really occurs is not an uttcr dissolution of the larval organism, but merely loss of a special larval organ, which disappears after fixation, as

Fig. slii.

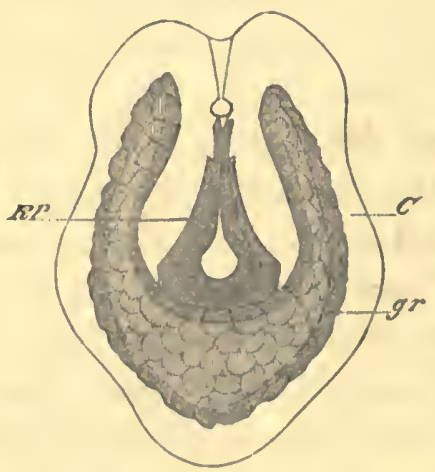

Cell of Sehizoporella shortly after fixation.

C. Cell. gr. Granular mass, result of histolysis of the corona. $R P$. Rudiments of polypide.

the tail of the Ascidian larva undergoes histolysis when it becomes attached. The organ which, according to Barrois, is the starting-point of the histolysis amongst

- Sitz.-Berieht. d. Gesellschaft nnturf. Freund. zu Berlin, 1868. 
the Polyzoa, is the eiliary wreath or coroua (Woodeut, fig. xlii.).

The other portions of the larval structure are destined to pass into the adult organism, the aboral face always constituting the zoceium, and the oral penetrating into the interior to form the rudiments of the principal internal organs *.

Claparède had previously criticised the views of Schueider and Nitsche respecting the complete dissolution of the larva, and had maintained that in the case of Bugula the retrogressive ehange limits itself to the loss of the cilia and the "whip," or tuft of setiform appendages $\dagger$.

If Barrois's view be correct (as we have every reason to believe), we get rid of the anomaly that would be involved in the reduction of the eomplex larval strueture to a mere homogeneous mass. We have to do with an ordinary ease of metamorphosis : certain elements of the larval form, it is true, are histolyzed, and give rise to a mass of granular matter; but this in nowise prevents the passage of the organs of the larva into those of the adult.

In the ease of the Entoprocta, the general opinion has been that the larva passes direetly into the perfeet animal ; the observations of Van Beneden $\neq$ and Uljanin $\S$ seemed to leave little room for doubt. In the larva of Pedicellina the internal organs are very fully developed, as they exist in the adult; even the rudiments of the reproductive organs and of the brood-chamber are said to be

- Comptes Rendus, 23 Sept. 1878.

+ Zeitsch. f. wissensch. Zool., Dec. 1870.

\$ 'Rocherches,' Sce, Mrém. Acad. Roy. Belg. xix. pp. 80-82.

"Zur Anatomic u. Entwicklungsgesch. d. Pedicellina," Bull. Soc. Imp. d. Naturalistes de Moscou, xlii. (1869) p. 435. Seo also Vogt on Laxosoma, 'Archives de Zool. experimentale,' 1877 ; translated by the author, Quart. Journ. Mier. Sc. (n. s.) xrii. p. 366, note. 
distinguishable. As Vogt has remarked, "it is difficult to imagine that all these organs tluus definitely constituted are to disappear that a new and similar set may be crolved." Van Beneden's observations are especially precise; and I had always regarded them as conclusive. Barrois, however, is of opinion that the eycle of derelopment is the same for Pedicellina as for the Cheilostomes; and he has recorded observations which, so far as they go, seem to sustain this view. Subject to further investigation, his conclusion is that histolysis takes place in Pedicellina as in the other Polyzoa, and that the passage from the larva to the adult is less direct and simple than has been usually supposed. We must await the results of a fuller study of the question.

Putting out of view the case of the Entoprocta, it seems probable that the larva of the Polyzoa after fixation always undergoes a partial histolysis, affecting especially the provisional structures belonging to its free life, and passes by gradual metamorphosis into the perfect animal*.

As the result of his extended rescarches into the embryology of the Polyzoa, Barrois reduces the various larval forms to a single primitive type, consisting of a gastrula with

* Joliet, indeed, has suggested a different riew. To him the larva may be considered as composed of a zoceium and a zooid (the homologue of the polypide), both of them modified with reference to the necessities of a free life-the zoceium more highly organized than in the adult, the polypide rudimentary. The histolysis of the larra he eompares to that of the polypide in the ordinary eell. When the former is on the point of fixing itself, the zooid which it contains dwindles away just as the latter does, and disappears. The larva of Pedicellina is strictly comparable to that of the other Polyzoa; it consists of a zoocium and a contained zooid; but as the ordinary polypide in this case does not undergo histolysis, neither does the larval zooid; it passes into the adult form, which it very closely resembles ('Bryozoaires d. cottes de Franee,' pp. 85, 86). Of course, if the observa. tions of Barrois are confirmed, they exelude this interpretation. For myself, so far as the Entoprocta are concerned, I awnit the results of further investigation. 
two opposite faces, separated by the eiliary corona-one (the aboral), which is much the most voluminous, at the opposite end from the month, the other (the oral) bearing the bneeal orifice at its eentre, and capable of being so corered as to constitute a vestibule (Woodeut, fig. xliii.).

From this primitive form all the other larval types are easily derivable, according to Barrois; "so far as the first portion of their development is concerned, there is a perfect uniformity throughout the entire group"\%. Provisionally he regards the three divisions of the Entoprocta, the Cyclostomata, and the Escharinat (of Smitt) as being three parallel modifications of an ideal primitive form (Woodeut, fig. xliii.). The Escharine larva (which

Fig. xliii.

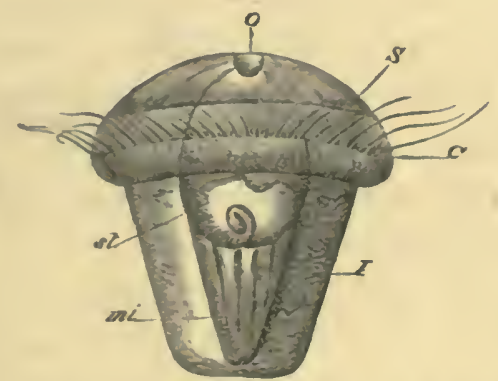

Ideal primitive form of the Polyzoan group.

o. Mouth of the gastrula. S. Oral face. I. Aboral face. C. Corona, st. Stomach. mi. Aboral mesoderm.

makes the nearest approach to this ideal primitive type) gives origin to two divergent and strongly marked modifications (with which it is connected by transition forms) that of the Cellularina (Smitt) and that of Cyphonautes,-

- Barrois, 'Embryologie,' \&c., p. 261.

$\uparrow$ The Escharina of Smitt include almost the whole of the Clreilostomatous forms in which the zoceium has a solid calcareous front wall. His Cellularina embrace all the Chcilostomatous families which rank, in the present work, before the Cellariide (p. 103). 
and also to two minor and intermediate modifications, the one represented by Alcyonidium, and the other by the Vesicularians. This seheme of the larval relationships of the Polyzoa must, however, be regarded as purely provisional. Notwithstanding the admirable investigations of Barrois and others, we ean only regard our knowledge of the embryology of the Class as being quite in its infaney; and though we may probably aeept as eonelusive the demonstration of the one primitive type, we must have a mueh larger aequaintanee with the varieties of the larval form before we ean safely proeed to traee the genealogy and map out the eourses of development*.

\section{Gemmation.}

The seeond mode in which reproduetion takes place amongst the Polyzon is by gemmation. Almost invariably the budding is eontinuous, resulting in the formation of a eomposite strueture; in the single ease of Loxosoma the gemmæ detaeh themselves from the parent, and are developed into solitary animals.

The formation of the bud is a subjeet of the highest interest; but it is one that ean only be treated satisfaetorily at length, and with the help of many illustrative figures. In this general sketeh of the elass, which is merely introduetory to the systematic portions of the work, it would be impossible to do justiee to it; and I must eontent myself with referring the reader to some of the best sourees of information $\dagger$.

* On the question of the histolysis of the larra after fixation, see Nitsche, Zeitsch. f. wissenseh. Zool. xxi. 4 HIeft, p. 59, note.

Mctschnikoff must be ranked as one of the first to dissent from Schncider's doctrine as to the complete dissolution of the Cyphonautes-larva (Nachr. d. Univ. Göttingen, 1869, no. 12).

+ Tan Beneden, 'Recherches,' \&c., Mém. Aead. R. Relg.: Allmun, 'Freslıwater Polyzon,' pp. 35-37 : Sinitt, QEf r. kongl. Vet.-Ak. Förh. 186i, nọ. 1 , 
Smitt has raised an interesting question as to the precise nature of the buds which are devcloped from the margin of the zoarium, and give rise to the new lines of cells. Round the growing edge of the eolony, in the incrusting forms, we find a membranous or subcaleareous expansion, which is divided by slightly raised lines into uumerous areas (sec Plate XXIX. fig. 3). On these partition-lines, as foundations, the side-walls of the new cells are ultimately built up. This expansion Smitt considers to be a colonial growth-a common bud ("samknopp"), which divides, and is devcloped into scparate cells*. But the interpretation seems to me both antecedcntly more probable and more in harmony witl the faets of the case, whiclı regards each of the marginal areas, ultimately developed into cells, as derived from an individual zoœcium $\dagger$. The inclosed area is often of considcrable length, and may divide transversely into several cells, or (sometimes) longitudinally into two; but in all eases it seems probable that it is in origin a growth out of one of the older clements of the eolony, not a mere segment of a common bud $\neq$.

The mode in which the ealeareous eetoeyst or outer wall of the zoceium is formed is a point which has received less attention than it deserves. In many species

pp. 5-16: Claparède, Zeitsch. Sc., xxi.: Nitsche, Zeitsch. xxi. 1871, IIeft 4, p. 58; "Ueb. die Ḱnospung, v. Loxosoma," Zeitsch. xxv. Suppl.-B. Heft 3, p. 146: Iratsehek, "Kuospung der Pedicellina echinata," Zeitsch. xxix. (1877) p. 517 : Metschnikoff, Bull. do l'A cad. de St. Pétersbourg, xv. (1871) p. 507 : Ehlers, 'Hypophorella,' p. 77 : Vogt, On Loxosoma, Arch. do Zool. expérimentale, 15i7: Salensky, "Etudes sur les IBryozoaires Entoproctos," Anu.

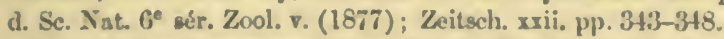

" "Om Irafsbryozoernas Utreckling," Cifv, kougl. Vet.-Aknd. Förh. 186.5, no. 1, p. 6.

+ See Nitsche, Zcitschrift, sce, xxi. 4 Heft, p. 66.

I At pago 223 a difterent mode of gemmeation is deseribed, which oceurs in some of the Chcilostomatous speeies. 
ealcification is earried to a great extent, and procecds with much rapidity; the eell is buried beneath a thick mass of stony matter, which in a short time obliterates its characteristie features, and completely elianges its aspeet. In such eases the original orifice of the cell is found to be placed at the bottom of a deep shaft, piereing the vitreous crust which has been piled on the surface. It is difficult to understand the mode in which this rapid accumulation of stony matter takes place, and the eonditions which favour it. When the ealeareous elcments are diseharged by immersion in acetic acid, the wall is represented by a thick stratum of animal matter. Physiologieally the subject is of high interest, whilst to the systematist the effect of the calcification in modifying the cliaracters of the species is a point of the first importance.

I shall add here an account of the development of the ccll in Mucronella coccinea, onc of the incrusting forms, so far as the external portions of the strueture are concerned.

First stage.-Membraniporidan condition: a rhomboidal eell, with its aperture covered over by a flat membranous roofing. Second stage.-A delicate, transparcnt, membrano-calearcous arehed eovering, in course of development over the aperture from the bottom of the eell upwards, marked witl transverse stria. Before this has spread over half the front surface, four spines are developed at its upper extremity (Woodcut, fig. xliv.). Third stage. - Front wall completed, arching over the whole aperturc, with the exeeption of a subeircular space at the top, which is left open; the membranc covering this free spaec takes on a decidedly corneous eharacter, and constitutes the 
oral opereulum. Rudiments of two more spines, placed far forward, now make their appearanee. Fourth stage.Spines lengthening, dentieles on the lower margin developed; mucro below orifice just beginning to rise. The avicularia marked out on cach side of the orifice, consisting of raised hollow processes, subcireular, and eovered in by membrane, resembling in general structure the early stage of the zoccium.

Fig. xliv.
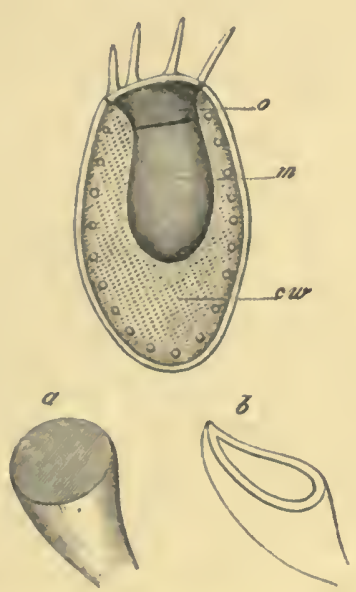

Young zoccium of Mucronella coccinea.

o. Orifice. $m$. Portion of primary (membranous) covering. cw. Culcereous wall. $a, b$. Early stages of avicularium.

These four stages were exhibited by four neighbouring eolls on the growing edge of a colony. The front wall in its earliest condition is of the most beautiful lyaline texture, and has a line of eireular foramina round the margin. Further change in it consists ehiefly of a gradual thickening, which culminates in a strongly granulose surface. (See Plate $\mathrm{XXXIV}^{\top}$.) 


\section{Special Points.-Afrinities.}

i. Relation of Zoxcium and Polypide.-As we have seen, each element of the Polyzoan colony eonsists of two parts, the cell and polypide. We have to consider briefly how these two arc related to each other. Are we to regard them as constituting together an individual? or must we eall them two zooids, associated, but individually distinet? According to the former view (which is the older), the polypide is an organ or collection of organs, the eell the enveloping sae, and their relation is the same in kind as that between any two ordinary portious of structurc. Allman was the first to hold the true zooidal nature of the two parts; to him both the zoceium and polypide are individuals, the latter produeed by budding from the former; and to this extent his doctrine has been generally aceepted. But he pushed it still further, and contended that the ovary and testis, also produced by internal gemmation, are equally individuals, thougl of a humbler type. Nitsche $*$ has pointed out the objeetions to this interpretation, and has insisted especially on the difficulty in the way of regarding the loose aggregation of spcrm-cells, which constitutes the testicle, as the homologue of a distinet individual + .

We have no diffieulty in recognizing the zooidal nature of the zoøcium, when we follow its history, and find it able to live apart from the polypide, and eren to survive several generations of polypides derived from its substance. Besides we meet with it under various forms, in some of which it is never assoeiated with a polypide or

* 'Morphologie d. Bryozoen,' Zeitsch. \&c. xxi. 4 Heft, p. 100.

+ Hatschel disputes the zooidal nature of the zocecium and polypide; Repiachoff also rejects the doctrine of the distinct individuality of the latter : Zeitsch. \&c. xxvi. 
any representative of one. The internodes of the stem amongst the Ctenostomata are elearly homologous with the zoceia; they are eells living as simple zooids. In the gonocium we have the same morphologieal element diseharging reproductive funetions, without any help from the polypide*. The latter, on the eontrary, seems to be always in connexion with a zoœcium; but the history of the eell shows elearly that we are not to regard the polypide as its organ, or in any sense an essential part of it. We ean only, therefore, view it as an associated zooid; its own strueture and habits foreibly suggest the same interpretation. An animal periodically losing all its internal organs and as regularly reproducing them would, indeed, be an anomaly. We are, then, to regard the zoœcium and the polypide as two individuals, one permanent, the other ephemeral, but eapable of renewal, which eompose together the primary element of the Polyzoan eolony (the "polypoeystid" of Nitsehe) $\dagger$.

ii. Excretory Organs.-It should be noted that very simple exeretory organs oecur in some of the Polyzoa, corresponding with those of worms, other Mollusea, \&e. These are the nephridia (primitive kidneys) of Ray Lankester; and consist of minute eiliated tubes, passing from the body-cavity to the exterior, and forming a medium of communication between the two; they open out in the neighbourhood of the anus. They were first deteeted by Hatsehek $f$, in both the larval and adult forms of Pedicellina, and subsequently by Joliet\$ in Loxosoma.

* The caso of the gonceium may be cited against the opinion maintained by Joliet, that the polypide and not the zoocium (ns commonly held) is the sexual zooid (op. cit. pp. 83, 84).

+ The aricularium and vibraculum nust also be accounted distinct zooids.

t Zeitechrift, de. xxix. (18i7), 4 IIeft, p. 51 li.

$\S$ Comptes Rendus, lxxxiii. (1879). 
Ehlers has notieed the nephridium in Hypophorella (op. cit. p. 66); and I should plaec in the same eategory the intertcntacular organ of Alcyonidium, \&e., previously deseribed, which, whatever its other funetions, serves, at eertain seasons, as a genital duet.

Salensky, in his aeeount of Loxosoma crassicauda*, deseribes a more eomplex glandular organ, placed in the parenehyma, on both sides of the intestine, and opening. out on the surface of the body, whieh, he eonjectures, may have an exeretory funetion.

iii. The Epistome.-This organ is only present in the freshwater Polyzoa; but its homologue may, I believe, be found in the so-ealled "bueeal shield" of Rhabdopleura (see p. 578); and in both of them may be reeognized, in my judgment, the equivalent of the mollusean foot $\dagger$. G. O. Sars has shown that in Rhabdopleura the "shield" oceupies the same position as the epistome of the Phylactolcmata. Both these organs bear the same general relation to the bueeal and anal orifiees and to the gillfilaments or tentaeles as the foot of the more typical mollusk. There seems to be no reason to doubt the homologieal identity of these struetures $\ddagger$.

iv. The Pedal Gland.-This organ oecurs only in the genus Loxosoma: in some speeies it is eonfined to the larva; in others it is permanent in the adult. It is situated at the base of the peduncle, and supplies the seeretion by whieh the animal is attaelied. It is interesting as being, in all probability, the homologue of the

* Ann. d. Sc. Nat. (fe sér. Zool. v. (1877), art. no. 3.

+ Allman has taken a different view of the homologies of these organs. See his 'Freshwater Polyzoa, p. 46, and paper "On the Relations of Rhabdopleura," Journ. Linn. Soc. Zool. vol. xiv. p. 581.

\$ See Ray Lankester, "Reınarks on the Aflinities of Rhabdopleura," Quart. Journ. Mier. Sc. xir. (n. в.) p. 77. 
"shell-gland," detected by Ray Lankester* in many of the Mollusea. The two organs exhibit a very similar structure, and occupy a corresponding position.

Affinities of the Polyzoa. - When we come to inquire into the exact position of the Polyzoa in the Animal Kingdom, we encounter a host of discordant opinions. They have been ranked among the Worms (Leuckart, Gegenbaur, Schneider, Ehlers-the two latter authors placing them near the Gephyrae); Barrois, though doubtful, inelines to eonneet them with the Rotifera; Reichert would approximate them to the Colenterates; Milne-Edwards, Agassiz, Allman, Huxley, Ray Lankester, and others either refer them to the Mollusea, or place them in a dependency of this subkingdom, the Molluscoida.

The subject must of necessity be treated briefly here; and I shall confine myself in great measure to a statement of the grounds on which I hold that the Polyzoa are essentially Mollusean. That they exhibit points of resemblanec to the Worms may be admitted at once; and whatever view may be taken of them, this ean hardly excite surprise. But the question really is, to which group are they united by a participation in its most distinctive characteristics. Now two of the most essential features of the Molluscan organization are ecrtainly the gills and the foot. To take the latter first, we have the equivalent of this important organ amongst the Polyzoa. In one seetion of the class (Phylactolamata) it occurs universally. I have already pointed out that the epistome, from its position in relation to other parts, may

* See his valuable paper on "the Development of the Pond Snail, and on the Farly Stages of other Mollusen," Quart. Journ. Micr. Sc. xiv. (u. 8.) p. 365. 
be regarded as the homologue of the foot (Woodeut, fig. xlv., 1, F). The organ, indecd, has changed its character and function in correspondence with the change in the conditions of life; but it maintains its original relations to the other elcments of structure, and is casily recognizable in its disguisc. In Rhabdopleura (which is a true Polyzoon) it scems to resume to somc extent its primitive office, in the absence of a muscular system, and at the same time exhibits a considcrable increase in sizc. We are not surprised at finding but slight traces of the organ in forms which have taken on a stationary habit of life, nor at its total disappcaranee in many of them. But the prescnce of this most distinctive Molluscan structurc within the Polyzoan group is a striking indication of its affinitics.

Secondly, as to the gills of the Mollusca, thcy correspond in all cssential partieulars with the tentacular corona of the polyzoon. If we compare the latter, as it appcars amongst the Phylactolemata or in Rhabdopleura (Woodeut, fig. xlv. 1, 2), with the cirrifcrous appendage of the Brachiopod, we find the closest rescmblance bctween them*, and not a mere resemblance, but such an identity of relation to otlier portions of strueture as clearly indieates their homology. The foot amongst the Brachiopoda is very slightly devcloped; but the disposition of this organ, of the arms, and of the oral and anal openings is the same in them as we find in Rhabdopleura. Turning to the other Acephala, the arrangement and mutual rclation of these parts (as Ray Lankester has insisted) are for the most part identical in the Lamellibranchs

* The roobility of the tentacular plumes of Rhabdopleura is a point in which they agreo with the arms of the Brachiopod. 
(Woodeut, fig. xlv., 3, compared with 1 and 2 ) and the foot-bearing Polyzoa. In the former the line of gills is interrupted behind the foot; and so it is in Rhabdopleura\%. The arm of the latter is also strietly comparable with the gill-plume of the Gasteropod.

The tentacles, then, of the Polyzoa are the homologue of the Mollusean gills; in some of their modifications

Fig. xlv.

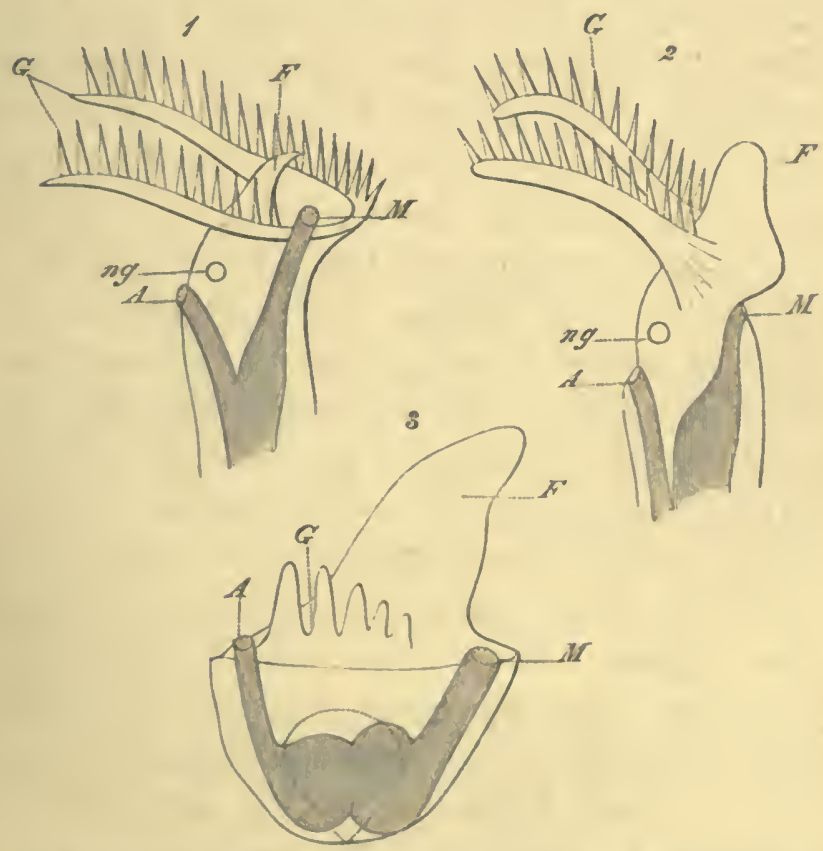

1. Phylactolematous Polyzoon. 2. Rhabdopleura. 3. Young Cyclas. M. Mouth. A. Anus. F. Foot. G. Gill-tentacles. ng. Nerre-ganglion.

"Sec Ray Lankester, "Notes on Embryology," Quart. Journ. Mlicr. Sc. xrii. (n. s.) p. 424; "Aflinities of Rhabdopleura," ibid. xiv. (n. s.) p. 7 " : Huxley; 'Classification of Animals,' Brachiopoda: Hancock, "Anatony of Freshwater Polyzos," Ann. N. H. 1850. 
they exhibit a close parallelism to the branchial organs of the other Acephala.

Reference has already becn made to the so-called "shell-gland" which occurs so extensively amongst the Mollusca. That the homologue of this characteristic organ may be found in the "foot-gland" or "fixationgland" of Loxosoma there can, I think, be no dloubt; and if so, we have here another of the essential features of the Molluscan organization amongst the Polyzoa.

If we take the evidence of embryology on this question, we find a remarkable agreement between the larva of the Brachiopoda and Polyzoa*, also between the primitive form of the latter (as demonstrated by Barrois) and that of the Molluscan group (trochosphere of Ray Lankester). The "general rescmblance" between the larvæe of the Entoprocta and the Rotifera, on the strengtl of which Barrois is inclined to believe in an intimate relationship between the Polyzoa and the latter, will hardly weigh against the positive evidence of their Molluscan affinities. The adult forms of the two classes are essentially distinct.

On the grounds thus briefly indicated, which may be summed up in the proposition that the most elaracteristic organs of the Mollusca have a place amongst the Polyzoa, these two groups, it scems to me, should remain in one and the same subkingdom. I quite agree with Prof. Lankester that the subgroup of the Molluscoida is superfluous. The Polyzoa, in spite of adaptive changes, are, like the Brachiopoda, to which they are most nearly related, of the true Mollusean race.

* "Les larres de Terebratule et Terebratuline présentent done réellement une ressemblance étonnante avee la forme primitive des Bryozonires." - Barrots. 


\section{Distribution in Space and Time.}

The number of species deseribed in the present work as occurring on the British coasts is 235. Of these, 69 have not so far been found elsewhere; but of eourse no inferenee as to their range can be drawn from this negative fact. For 28 species Shetland is the only British locality : of these, 8 have not been found (reent) beyond it ; and the remaining species are almost all Aretic forms, which appear to have here their southern limit. Two of the number, however, are exceptions, and range mueh further south-one (Cellaria Johnsoni) being a rather abundant Mediterranean form, and extending to Madeira. In this ease Shetland appears to be the northernmost limit in the range of an essentially southern form, the curious point being that so far it has not oceurred at any intermediate station between south and north *. Another of them (Porina borealis) is common to the deep water of the "Outer Haaf" and the Aretic seas, and to great depths off the coasts of Florida, Portugal, and the Azores. In this ease we have to do with one of the "abyssal" forms, which are remarkable for their extended distribution.

The Shetland sea, as Mr. Norman has remarked, seems to be "in an especial manner the meeting-place of northern and southern types." Aretic forms, as we have seen, deseend to it, and in many cases go no further south; southern forms have made their way up to it, and generally have not beeome naturalized in the eolder waters beyond it. Out of 68 species reeorded in the present

" Norman meutions other cases of a similar kind ("Shetland Drenging Report," Rep. Brit. Assoc. for 1867, p. 248). 
work as common to Brituin and the Meditcrranean, about 40 hare occurred in Shetland. Of these, some are species enjoying a very wide range, and a largc proportion arc generally distributed on the British coasts.

Aboint 24 of the British species are eommon to the Meditcrrancan and the Arctic seas: the greater portion of them are probably northern forms which lave migrated southwards; and more than half are also inhabitants of the North-American const.

It is interesting to trace the course of the northern forms in their migrations. Some have moved southward and found their terminus in the Shetland sea; others have extended their range down the north-eastern eoasts of Scotland and England*; others, again, have spread themselves to the Hebrides and west coast of Scotland, and to the opposite coast of Antrim, but apparently not further †; some are widely distributed on the English coasts; and a certain number have found their way far south $\ddagger$.

If we turn now to the southern forms, we find a nearly parallel scrics of facts. A number of Mcditcrrancan species reach our scas, which do not pass much beyond the south-western district, a few of them ranging for a greater or less distanec up the western side of England,

* Such as Collularia Pcachii, Mcnipea tornata, and Scrupocellaria scabra.

† Such as Lepralia polita, Schizoporella sinuosa, Mucronella laqucata, Escharoides rosacea, Stomatopora compacta, S. diastoporides (also at Wick), Homera lichenoides.

†Cribrilina annulata has migrated from the Aretic seas to our sonthwestern shores (Cornwall), and has also made its way down the northeastern side of Scotland (St. Andrews).

Jeffreys gires a list of 76 species of Mollusea, usually eonsidered northern, which are common to the North Sea and the Mediterranean. He adopts Forbes"s view, that at some former period "there was an open communication between the Atlantic and the Mediterranean, by which the fanna became diffused."-Shetland Dredging Repost, 1867. 
and a still smaller number in a south-easterly direction (Hastings). These give a peculiar interest and eharm to the marine famia of Devon and Cornwall and the Channel Islands. Amongst them may be named Mimosella gracilis, Lichenopora radiata, Diastopora Sarniensis, Entalophora clavata, Retepora Couchii, Lepralia adpressa, Lepralia foliacea*, Schizotheca fissa, Smittia cheilostoma, Schizoporella Cecilii, S. sanguinea, S. vulgaris, S. armata, S. venusta, Diporula verrucosa, Cribrilina Gattya, C. figularis, Microporella violacea, Caberea Boryi.

Other southern forms extend much further north; and a snall group occurs in the Shetland seas. A very limited number have found their way to the north-cast of Seotland and England; and in similar eases Mr. Norman has shown it to be probable that migration has taken place along the western and northern and domn the eastern eoasts $\dagger$.

The north-eastern district is eharacterized by the prevalenee of Aretic and boreal forms, and the absenee for the most part of distinetively southern species, even of such as have found their way as far north as Shetland.

Amongst the British Polyzoa we find a number of erratic speeies having a wide and somewhat anomalous range. For instance, Cellaria fistulosa has oecurred in the Mediterranean and at Madeira, in South Afriea, in Scandinavia and North Ameriea, in the Indian Occan, in Australia and New Zealand. Microporella ciliata, another eosmopolitan form, ranges to Florida, California, the Aretie seas, Seandinavia, Sonth Africa, the Arabian sea, Australia, and New Zealand. M. Malusii has been found in the Aretie seas, Scandinavia, the Black Sea, the

- L. folincea has occurred in the Hebrides.

+ Bugula turbinata is probably a southern form which has thus mado ita way to the Durham and Yorkshire coasts. 
Mediterrauean, Madcira, South Ameriea, Australia, New Zcaland. Caberea Boryi has a wider rangc. 'These are in no measure abyssal forms (which are grencrally very widely diffused), but flourish betwecn tide-marks and in shallow watcr, though also found at greatcr deptlis. There are many facts in the distributional history of the Polyzon of which it is difficult to find an adequate explanation. In addition to migration along the coast-lines and through the profound depths, which are subject to uniform elimatie conditions, there has been a more irrcgular and sporadic diffusion by the agency of currents, floating weed, timber, Sic., and by means of ships. Probably the lattcr may have played a not unimportant sceondary part in determining some of the morc abnormal phenomena of distribution. Many of the species exhibit great adaptability to differcnt climatic conditions, and if transported to distant regions might readily aecommodate themselves to their new home.

Glancing at the foreign rclations of our nativc speeies, we find a very closc resemblance between the Polyzoan fauna of the south-west coasts of France and of our own; of 53 species recorded by Fisehcr 45 or 46 are British. A small group is eommon to our shores and to those of South Africa: the specics composing it are in great measure very widcly distributed forms; and almost all of them are also Meditcrranean. Of the species (about 30) which are both Madciran and British, almost all are essentially southern forms: most of them have becu recorded as Mediterranean; and probably all will prove to be so. One or two northern intruders (Scrupocellaria scabra \&e.) oecur amongst them. Australia and New Zealand have each a few speeies that bclong to our fanna; and of 
these rather less than half are common to the two countrics.

About 100 British species occur on the more southerly coasts of Norway, and about 70 within thc Arctic region; no distinctivcly southern forms, I belicve, are met with amongst them. About 50 of our species range to the North-American coast, almost all of which have becn recorded from the Arctic seas *.

It is intcresting to compare the number of species found in three well-marked districts (each of which has been thoroughly investigated) - the south-west coast of England, Shetland, and portions of the north-east coast of England $†$.

\begin{tabular}{|c|c|c|c|}
\hline & Shetland. & South-west. & $\begin{array}{l}\text { Northumberland } \\
\text { and } \\
\text { Durham. }\end{array}$ \\
\hline Cheilostomata & . 102 & 103 & 59 \\
\hline Cyclostomata & . 21 & 17 & 12 \\
\hline Ctenostomata & . 11 & 17 & 16 \\
\hline Pediccllinca . & . 2 & 2 & 2 \\
\hline Podostomata & . 1 & 0 & 0 \\
\hline & 137 & 139 & 89 \\
\hline
\end{tabular}

Turning to the distribution of our British species in time, wc find that a considcrable number of them existed in the Tertiary period. Many are recorded by Busk; and about 40 are included in the list of the Upper T'ertiary

* We may expect a flood of light to be thrown on the subject of distribution by the results of tho 'Challenger' expedition, when published. In their absence it would hardly be safe to indulge in generalization.

$\dagger$ Alder, 'Catalogue of Zoophytes of Northumberland and Durham' and Supplement. Norman, "Sluetland Po!yzoa," Rep. Brit. Assoc. 1867. Hincks, "Catalogue of Zoophytes of South Deron and Cornwall." The Shetland and South-west lists have been revised; the North-east is as giren by Alder. 
Polyzoa for which I am indebted to Mr. A. Bell*. 'To these must be added species deteeted by Manzoni in the Italian Pliocene, by Waters in that of Sicily, and by Reuss in the Tertiaries of Austria and Hungary. Amongst the latter are a number belonging to the Miocene age. Altogether about 60 of our species have thus far been recorded from the Tertiary beds. Two or three forms seem to be identical with Cretaceous species.

The Polyzoa are of venerable antiquity; they oceur in the Palacozoic rocks, but are ehiefly represented there by the Cyclostomata + or kindred forms. There is evidenee, however (as I learn on the exeellent authority of Mr. R. Etheridge, Jun.), of the existence of a few Cheilostomatous genera at least within this epoch; and probably the group is represented in the Silurian division of it. The Polyzoa abound in the Jurassic strata, and seem to reach their maximum in the Chalk. In the latter the Cyclostomata exhibit a wonderful varicty and beauty; the Cheilostomata also have here reached their full development.

\section{Classification.}

It is quite unneecssary to enter into the various systems of elassification which have long since had their day, and which retain no permanent value.

Johnston $\ddagger$ recognized the Mollusean affinities of the Polyzoa; and his classifieation in its leading features

* In the nomenclature adopted by Mr. Bell the Middle Pliocene includes the Coralline Crag and part of the Red Crag, and the Upper Pliocene such portions of the latter as have a fauna closely assimilated to that of the boreal European Seas. The term Palcolithic is employed to designate post-glacial deposits.

+ Of recent genera, Stomatopora and Diaslopora appear to occur in the Silurian rocks.

f 'History of British Zouphytes,' 1847. ' 
agrees with the skilfully devised system which we owe to Mr. Busk, and which lias obtained so wide a eurreney*. As an artifieial arrangement, which alone it claims to be, the latter leaves little to be desired, and has rendered the most important service in promoting the aceurate knowledge of Polyzoan forms. But, from its very nature, however good of its kind, it could only lold a provisional place. Marshalling the known forms il eonvenient groups distinguished by easily recognizable characters, it is an admirable instrument in the hands of the student for the identifieation of speeics; but it gires him no elue to their natural relations. Its families are, for the most part, founded on eharacters of the slightest signifieance; and the forms ranked under them have often little to unite them but some trivial peculiarity. Thus the extensive group of the Escharida is based on the ramose condition of the zoarium (a structural feature of comparatively little moment), and includes a heterogeneous eollection of species, many of which have little in eommon but their branching stem, and are isolated from their nearest of kin; and the same eritieism applies to the genera.

D'Orbigny's claborate classification in his 'Paléontologie' + has one good feature at lcast: his family groups have a wider range, and embrace diversities in the morle of growtl. His genera, on the other hand, are often founded on utterly trivial features, and have been multiplied indefinitely to represent every insiguificant rariation of habit. As a systematist we owe him little

- Iritish-MLuseum Catalogue, 3 parts; 'Crag Polyzon,' Pảlsoutographical Society.

+ Pal. frauçaise, Terrains Crét. rol. v. 
(his nomenclature is uncouth and bewildering); but his knowledge of Polyzoan form is perhaps unsurpassed, and by his elear diagnosis and splendid plates he has given us a new revelation of the structural variety and beauty of the elass.

We owc to Prof. Smitt* the first serious attcmpt to substitute a natural systcm for the purcly artifieial arrangements hitherto in use; and it may at least be said that, if he has not overcome all the difficulties incident to the work and has left many problems unsolved, he has given us the most fruitful suggestions, and may perhaps have struck the track along which future advances must be made.

He has aimed at a gencalogieal classification, starting with the proposition that the variations of species follow the line of their development and may be in great measure explained by it. The Polyzoa, he remarks, as compound animals offer great facilitics for the study of the laws and eauses of variation. The differentiation of the colony gives us a series of variations, running from the carly and simple states to the fully developed form, which is the parallel of the serics of diffcrenees amongst spccics. Thus the British speeies of Crisia represent the evolutional stages of one and the same type, of which Smitt regards C. geniculata, Milue-Edwards, as the first and simplest. The forms of this genus he would arrange, according to the law of their cvolution, in a scries, the members of which, springing from a common origin, will hold cach its evolutional grade.

* "Bryozoa marina in regionibus arcticis et borealibus virentia," Efv. Kongl. Vet.-Akad. Förh. 1867 ; "Kritisk Forteckning," ibid. 1864 and following years; 'Floridan Bryozoa.' 
Of the Cheilostomatu he says:- "Hoc enim certum dicimus, ut ex origine simili progressa sint ha forma, quarum colonia et individua in uno vel altero stadio evolutionem sistere possint;" and he summarizes his doctrine thus:- "Si sermone theoretico uti licet, sicut individua, sic etiam species et ceterce divisiones, qua systema naturale conficiunt, legibus evolutionis subjecta sunt."

Certainly a most interesting ficld of inquiry is here opened before us; and though we may not be prepared at present to aceept Prof. Smitt's view (and as little are we prepared to rejeet it), there can be no doubt that it should gire for some time the direetion to investigation.

It scems to me, however, that the attempt at a genealogical arrangement in detail, if it should ever be feasible, is certainly premature, and that even in the hands of so able and conscicntious an observer as Prof. Smitt it yields any thing but a satisfactory result. He himself admits the serious difficulties attendant upon the work, some of which are never likely to disappear *.

It must, I think, be admitted that his reduetion of the older species is, to a considerable extent, excessive, whilst, at the same time, the grounds on which forms are associated in one and the same specific group are often questionable, and no small amount of confusion is caused by the blending of species of doubtful affinity under a single name.

Our knowledge of the morphology of the elass will be better promoted at the present stage by keeping separate,

- "Iterum et iterun memoranda est ignurantia nostra pracipue specierum extinctarum, qua limites harum divisionum incertos facit." $-a f v$. 1867, p. 486. 
and clearly diseriminating, the more eonstant and permanent forms, with due attention to their evolutional history and varietal tendencies, than by merging them in genealogical groups the composition of which must, in many eases, be largely speeulative.

One of the most important features of Prof. Smitt's system is the place which he assigns to the zoocium in the construction of families and genera. The mere mode of growth he treats as a perfeetly subordinate charaeter, and bases his divisions ehicfly on the essential element of the structure, the cell $*$. This revolutionary step involves the breaking-up of a large proportion of the older genera and the wide dispersion of forms hitherto most closely associated; but there can be no doubt that it is a necessary preliminary to the introduction of a natural system. The varieties of habit which have been made the eriteria of genera, may oceur within the limits of a speeies. It is not the mode in which the eells combine, but the cell itsclf, that is the true test of relationslip and the essential basis of a natural group. Prof. Smitt has remarked, "Semper videbimus, ubi forma zoccii eadem sit, ceteras dissimilitudines altero vel altero modo evanescere."

Retaining Mr. Busk's three prineipal divisions of the Gymnolemata, he arranges the Cheilostomata under four groups :-the Flustrina, with quadrate eells, the front surface of which is flat and equals the area of the primitive aperture; the Cellularina, with corncous or corneo-ealeareous infundibuliform eells, the inferior portion of which

* Of course, in practice, this principlo applies chiefly to tho Cheilostomata. Amougst the Cyclostomuta there is great uniformity of structure in the zoceium; and in the cuse of the Clenostomata other important chnracters are availablo. 
below the aperture is tubular or obconic; the Escharina, with calcarcous cells, the apcrture of which about cquals in size the operculum, no nembranous area being left; and the Celleporina, with calcarcous cclls more or less vertical to the plane of the colony, with a terminal aperturc, and irregularly heaped together. The familics and gencra are constructed in harmony with the principles which have been briefly indicated.

It is impossible to estimate too highly the thoroughness of rescarch on which Prof. Smitt's classification rests, and the important contribution which he has made towards a natural system, however much wc may be disposed to dissent from some of his results.

In his great work on the Embryology of the Polyzoa*, Barruis contends that in classifying these animals account should be taken of all the forms in the life-scries together, and sketches an arrangement suggested by the study of the larvæ (p. 250), for comparison with that of Smitt, from which it differs in some important respects. Our knowledgc of the larval forms, however, is as yet too fragmentary to allow of our building much upon it; Barrois's sketch is quite hypothetical, and, though interesting in itsclf, can only be accepted as a suggestion requiring the confirmation of further research.

In the present work the Polyzoa are ranged under the subclasses instituted by Ray Lankester, and based on the cliaracters of the lophophore. Most of them are Holobranchiate, and have the tentacles in a continuous series. A single genus only exhibits the Ptcrobranchiate strueture, in which the Molluscan character is more pronounced, and the lophophore is broken into two distinct

" 'Rech. sur l'embryologie des Bryozoaires,' 1877. 
arms, bearing a resemblanee to the branchial appendages of the Brachiopoda.

The Holobranchia form two eardinal groups-the Ectoprocta, in which the lophophore surrounds the mouth only; and the Entoprocta, in which it ineloses both the orifices of the alimentary canal *.

The former division embraces the great body of the Polyzoa; and its marine forms are comprised in a single order, the Gymnolemata, distinguished by two prineipal features, the complete abortion of the foot and the circular disposition of the tentacles.

The Gymnolemala I have ranged under the three wellknown suborders founded by Busk on certain structural peculiaritics of the eell.

i. Cheilostomata.-These are distinguished by the presence of a movable corneous valve, elosing the orifice through which the tentacular corona is protruded; the operculum is furnished with two sets of muscles, by means of which it is opened and shut. In this division we mect with some special structures which are wanting elsewhere: the ova are commonly matured in distinct marsupia; appendieular organs (avicularia and vibracula), which, as we have seen, are modifications of the Cheilostome cell, are present in great abundanee. The ealcareous test, in a large proportion of the forms, is highly developed; and there is also considerable variety, and, in

* Barrois has studied the development of the corona in Alcyonidium (op. cit. p. 257, pl. xvi.), and finds that at a certain stage the arrangement of the tentacles is temporarily the same as that which is permanent in the Entoprocta; this is followed by a division of the corona into two symmetrical halves, as amongst the Phylactolemata; and this gives place to the typical conformation of the Ectoprocta. The developmental history, therefore, gires us the comparative rank of these three divisions, and shows the Entoprocia to be the lowest in the seale. 
many cases, a good deal of specialization in the structurc of the polypide.

ii. Cyclostomata.-These, which are the earliest extant forms, are distinguished by the simple, inopcrculate orifice of the zoccium.

Simplicity, indecd, is in the highest degrec characteristic of the group: the cells arc unircrsally tubular; the polypide is without complexity of structure and has a small number of tentacles; all appendicular organs are wanting. There is also a remarkable uniformity in the embryology; and the larva of the leading families are identical. Barrois is right in describing it as "lc groupe le plus naturcl et le mieux circonscrit dc la classe entièrc des Bryozoaires."

iii. Ctenostomata.-The leading characteristic of this division is the curious opcrcular mechanism of the cell. The upper portion of the cell-wall is of slighter material than the rest, and tcrminatcs above in a number of delicatc setæ licld together by a thin transparent membranc. (Sec Woodcut, $35 e c^{\prime}$ and $o p$, p. 562.) When the polypide retrcats, the whole of this anterior portion is drawn in by mcans of a special apparatus of muscles, and the setæ, being brought closely together, form an opcrculum (or protective corering) abore the tentacles. This arrangement secures the freest play for the corona when exserted, and perfect security when the polypide withdraws. The Ctenostomata are also characterized by their horny, or membranous, or membrano-gelatinous tests; they are never calcareous. Marsupia and appendicular organs are wanting.

Ehlers has eriticised the constitution of this division : he considers that the sctose operculum is not suffici- 
ently diagnostic, as we find a similar strueture in some Cheilostomata (c. g. Aetea); he also objects to the union of the Halcyonellea and Stolonifera in a single group. As to the latter point, he seems to me to have exaggerated the amount of difference between these two seetions. The primitive forms of Stolonifera, such as Victorella, are very slightly removed from those Alcyonidia in which the cells are more or less detached and arranged in linear serics. In the former the crect, tubular portion of the adult cell is a direct continuation of the stolon; in the young state this crect portion is wanting, and the cell is wholly decumbent and in the line of the stolon. It is essentially the same as a cell of Alcyonidium disjunctum or of Arachnidium. If the fore part of the latter were to be prodneed into a tubular extension (and this takes place in some cases, as in Alcyonidium mamillatum and Arachnidium fibrosum), it would be almost identical with such forms as Victorella and Cylindrocium. In the higher Stolonifera (such as Bowerbankia) the stolon must be regarded as made up of cells in which the polypide is aborted, and the true zoceium is the equivalent of the tube of Victorella, which has gradually become contracted below and isolated from the stolon. The two groups, then, are elosely conneeted; and there seem to be no'sufficient grounds for separating them.

As to the sceond objection raised by Ehlers, I confess I eannot see that the existenec of eertain obscure vestiges of the setose opereulum in a few forms oceupying the borderland of the Cheilostomatous division should be accounted fatal to the present group. In the "frill" of the genus Aetea the structure has entirely lost its original eliaracter; and if this relic should indicate a not distant relationship 
betwcen the two sections, it would only be one morc proof that in our classifieations we may not look for sliarply dcfincd provinces, but must be eontent with the "vanishing lines" of naturc.

Our rcal perplexities eommence when we attempt to frame the families and genera; for in the easc of the Polyzoa it is extremely difficult to scize the signifieant charnetcrs. This remark applies especially to the Cheilostomata. Amongst the Cyclostome forms* therc is so much uniformity in the zoœcia, that wc arc compelled to base our divisions on the grouping or mode of combination. Throughout this suborder the cell has undergone the slightcst modifieation; but there is an almost endless variety in the zoarial form. In dealing with the Ctenostomata important characters arc supplied by the polypide and the structure of the zoœcium, and we have eomparativcly little difficulty in defining well-marked groups. But in the easc of the Cheilostomata, and cspecially of the Escharine forms (in the classification of Smitt), it is otherwise. Here the polypidc gircs us no material help, exlibiting few variations of any systematic importance. Amongst the Aeteide it is of a very simple type, and reminds us of that of the Crisiida; in this, as in other elements of structure, this group makes an approach to the Ctenostomata. In the genus Bugula it exlibits strongly marked fcatures; but such diffcreuees as gencrally occur are deroid of any spceial significance. The avicularia are for the most part much too inconstant to serve the purposes of the systematist; and thcir history shows us that as inclications of affinity they are scldom to be

- On the gemmation of the Cyclostomata, sec Barrois, 'Embryologie,' p. 7i. 
trusted. There remain the charaeters of the cell itsclf and the habit of growth. It ean hardly be deemed doubtful which of them should have preeedenec in a natural system; we may go very mueh further, indeed, and say that in such a system the latter must hold a very seeondary and subordinate plaee. The essential strueture of the ecll, as onc of the primary zooidal forms, must ccrtainly be aecounted the most important point, both in itself and as a clue to relationship. The merc habit is, so to speak, a superinduecd eondition, whieh may be different in the must nearly related and similar in the most divergent forms; and groups bascd on it, instead of fitting in with natural affinities, are found to traverse them at all points. Thus the vencrable family of the Escharide (auett.) is a mere jumble of ineongruous elements, and no morc represents the natural relationships of the forms which compose it than would a group of plants founded on the colour of their flowers. In the same way the genus Lepralia (auett.) is a misccllaneous eolleetion, made up, as it were, of numerous distinct nationalities, included within a purely artificial boundary-line. The older systems, indecd, for the most part, inverted the truc order, and gave the first plaee to secondary, but easily reeognizablc, characters, thus sacrificing nature to eonvenienee.

It is an important faet that within the compass of a single speeies the most diverse modes of growth may occur. Thus in Membranipora arctica (of which I have cxamined numerous speeimens obtained by the Dutch Aretic expedition) we meet with a crustaceous statc, in which it crecps as a nctwork over stones, a Hemeseharine, in which it rises into unilamcllate expansions, and an Eseharinc, in which it forms welk-compacted bilamellatc 
fronds. Many eases of the same kind oeeur. Smittia Landsborovii and Lepralia foliacea exhibit the same diversities of habit, the erustaceous predominating in the former and the foliaceous in the latter. A eonsiderable number of speeies are now known in which the same eell is associated with very various modes of growth. The genus Porella of the present work embraces species which exhibit the most striking differenees of habit; but they all possess zoceia which are both essentially identical in the adult state and pass through the very same course of development. So far as the eell is eoneerned, there are none but speeific distinetions between them; and we cannot doubt that it is more philosophieal to unite them in one genus on the strength of their struetural similarity, than to separate them for their diverse liabit.

I should lay it down, then, that in the formation of families and genera in this division, and especially in the Escharine group, the eharacters of the cell must be taken as the basis, and a seeondary place be assigned to mere zoarial habit.

What, then, are the most signifieant features of the zoceiuin for elassifieatory purposes? Form, superficial seulpture, the presenee or absenee of spines or other appendages, tliese are generally too variable and ineonstant to yield any sure eriteria. But we may find such in the structural peculiarities of the eell-as, for instanee, the modifieations of the aperture, the degree in which the primitive opening is preserved or obliterated, the ribbed condition of the front wall (as in Membraniporella and Cribrilina), the ehambered eondition of the eavity (as in Steganoporella), \&c. One of the most coustant features of the zoceium, too, is to be found (as notieed long aga 
by Hassall) in the orifice, which exhibits a series of wcllmarked modifications, and has in some cases a developmental listory, which affords the most valuable, becausc the most significant, characters.

In the Escharine* group it seems to me that the families and genera sloould be based almost wholly on the zoœcial character; but I am certainly not prepared to hold that other structural elements should never be taken into account. The Flustrida, which secm to constitute a most natural group, have a true Membraniporidan cell, and hold thcir separate placc by virtue of thcir corneous and foliaccous zoaria. It ccrtainly secms desirable that this marked zoarial modification should be distinguished by a separate name. Probably, howcver, it might be wcll to include this group and the Membraniporida in a single family, based on the unity of the cell. In such a tribc as the Polyzoa therc must undoubtcdly be somc flexibility in our system.

The principal systematic ehanges will be found in the Escharine division, where also the chicf difficultics have been encountercd. Many of the gencric groups (such as Membraniporella, Cribrilina, Porina, Smittia, Lepralia, Mucronella, \&c.) will, I think, commend themsclves at onec to the student. Some are less strongly marked, but not, I belicve, less natural. A few have more doubtful elaims, and may require revision in the light of fuller research $\dagger$. In all cases I have taken into account such foreign specics as werc available in studying our Britisl forms.

* I use this term as defined by Smitt, to include the old Lepralia, Eschara, and kindred genera.

t In a few cases I have not hnd a sufficiently large number of specimens to allow of the complete study of the form in its varions stages. 
Here and therc refractory species have becn cucountered, which it has becn difficult to range under any constituted group; they hare been associated (provisionally) with the forms with which they scem to have the largest amount of affinity.

A word in conclusion as to the nomcnclature. The student will note many changes, and will regret (as I do) the loss of old and familiar names. But the changes, such as they are, have been madc, not wantonly, but after careful examination, in obedience to a principle which I believe to bc, on the whole, emincntly conducive to the interests of seience. To the new generation, we must remember, they will bring no regrets, but only the gain of a more uniform and stablc system.

For the rest, I shall be well content if this revision of the older classification should be a step towards the realization of a natural system, and a help towards a yet further step in advance.

\section{Name of the Class.}

With reference to the namc of the Class, it scems almost vain to hope for uniformity of practice. The eontinental zoologists universally (I believe) employ Ehrenberg's designation, Bryozoa; the English generally, and some Amcricans at least, give the preferenee to J. V. Thompson's name. 'The point has often been diseussed, but with little result. The arguments on each side, however satisfactory to those who use them, do not diminish the amount of disagrecment. The eontrasted opinions have, indecd, their geographical range, and are subjeet to very stringent laws of distribution.

It secms necessary, howerer, to re-state the grounds on 
whieh those who eontinue to adopt 'Thompson's name rely, and to justify their departure from what is, it must be admitted, the prevalent usage. If the question were merely one of priority, it might be readily and conelusively settled, and in this ease the reeognized laws of seientifie nomenelature would eome in to restrain the license of individual systematists, and enforee a wholesome uniformity. But otler elements besides mere date are involved; and in these the real diffieulty lies.

So far as the mere question of time is coneerned, the faets are eonelusive in favour of Thompson's elaim, as long sinee shown by Busk (1852)* and Allman (1856)t. The term Bryozoa first made its appearanee in the 'Symbolx Physieæ' in 1831 $\ddagger$; but Thompson's 'Researehes,' in whieh he proposed the name Polyzoa for the type of strueture which he had demonstrated in the polypide of the Aseidian zoophytes $\S$, were published in 1830. We learı from himself that his discovery was made as early as 1820; so that he really anticipated Grant (1827) and MilneEdwards (1828), though the publication of his results was delayed. That his name was published before Ehrenberg's it is impossible to doubt. Carus, however, urges that it had been previously employed by Lesson (in the ' Voyage de la Coquille') for a genus of Tunieates, and that this faet alone must prevent its adoption $\|$. But the genus Polyzou of Lesson appears not to have made good its plaee in mollusean nomenelature; I caunot learn that it is found

" "On the priority of the term Polyzon for the Ascidinn polypes," Ann. N. H. ser 2 , x. p. 352 .

† 'A Monograph of the Freshwater Polyzoa,' pp. 5, 6.

† 'Symbolæ Physicæ; seu icones et deseriptiones animalium ' Sc., 18281831 .

\$ This I take to be what Thompson intended.

|| 'Haudbuch der Zoologie,' erster Band, ii. Hälfte, p. 790. 
ill any reeent systematic work. Whether it ever beeame current at all, I am not aware; but it seems to have lapsed; and it is therefore perfectly allowable to give the term another application.

The most plausible objection to the retention of Thompson's name is founded on his own mode of defining it. He uses Polyzoa in the singular number, and describes it as " a new animal discovered as an inhabitant of some zoophytes." It is argued that he evidently employed the name to denote the polypide merely, and that to make it a class-designation would be to give it a totally different sense from that which he intended $*$. This reasoning, it scems to me, proceeds on a eomplete misapprehension of his meaning. He used the term Polyzoa (in opposition to Iydra) to denote $a$ distinct type of structure, which he had demonstrated, and not as the mere name of the single zooid. This is evident from the following, amongst other passages :- "The Polyzoa will probably be found in many dissimilar genera of the zooplytes, and even mixed up witl Hydra in some; ... and henee this discovery must be the eause of extensive alterations and dismemberments in the class with which they have hitherto been associated. . . . I shall merely indieate here in a general way the whole of the Flustracec, in many of which I have clearly ascertainer the animals to be Polyzoa ;" which is equivalent to saying that they exlibited the new type of strueture, and were thus distinet from the Hydre. In a worl, Polyzoa, as he uses it, is essentially a class-designation, and not the name of a mere struetural element.

His Polyzoce were polypes cxhibiting a mollusean orga-

- See a paper by Mr. A. W. Water, P'roc. Manchester Lit. \& Plil. Soc, Microscop. \& Nat. Itist. Section, March 11, 1878; Ann. X. H. Jau. 1850. 
nization, as distinguished from the Hydre; that is, they were strictly a Chass *.

As to the form of the word, it seems to me to be a point of the rery smallest moment. No doubt Polyzore would be the proper reading, if we must of neeessity aecept Thompson's original error in the eonstruction of the word $\dagger$. But it is surely allowable to alter the ending, and so bring the term into harmony with our present usage. In doing so we retain all that is essential, and we leave the honour with him to whom it is justly due.

Bronn's eritieism that the term Polyzoa is not distinctive, and may properly be used of other groups besides the present, has a eertain weight; but if we were to employ the prineiple which it implies as a practical test of our nomenelature, it would involve not the mere displacement of a single name, but widespread change and eonfusion.

Thompson's name, then, secms to me to liave every claim to adoption; and as uniformity in seientific nomenelature is elearly desirable, I shall still venture to hope that eontinental zoologists may not be unwilling to reconsider the

* The following passages may be added, as showing clcarly the sense in which Thompson used the term Polyzoa:- "The other species of Sertularia in which the animals have been determined to be Polyzoce may, ... perhaps, be referred to one genus." "The present Memoir has for its object to demonstrate another form of animal not litherto known, and which, while it must be allowed to belong to a new type of Mollusea Acephala, resembles exteriorly in some manner the Hydra; this animal has been designated by the name of Polyzon." In this passage both Hydra and Polyzoa are used to denote types of structure, and not elements of the compound organism.

In the prospectus of the whole work, we find the following as the subject of the 10th Memoir:- "Animals of some Cellarie, Tubulipore, and Flustracea proved to be Polyzose" To substitute polypides for polyzoce in this sentence would be to render it perfectly unmeaning.

+ Thompson himself once uses Polyzoa as the plural form. M Mcm. 5 , p. 96. 
grounds on whiel they have hitherto given their adhesion to Ehrenberg.

\section{Note on the Phosphorescence of the PolyzoA.}

Phosphoreseenee has been observed in several speeies. In Membranipora membranacea Dr. Landsborough deseribes the light as being very beautiful; when a speeimen was shaken, it presented the appearance of a "sheet of fire." In Membranipora pilosa every eell showed a brilliant little star; the zoarium was like "an illuminated eity." Scrupocellaria reptans and Valkeria uva, form cuscuta, are also phosphoreseent speeies. We learn from M. Vélain * that a Bugula oeeurs in the island of St. Paul, in small submarine grottos, which is of a deep azure-blue colour and strikingly phosphoreseent. When the water eontaining it was agitated it showed the most brilliant eoloured lights, which ehanged with astonishing rapidity from red to green, or to azure-blue. When the water was left quiet the beautiful display eeased.

Srstematic 'Table.

\section{Subkingdom MOLLUSCA.}

Branch $A C E P H A L A$.

Class POLYZOA, J. V. Thompson.

Barozoa, Ehrenberg, \&c.

Cillobrachiata, Farre.

Textactibrascura, E. Raj Lankester.

Aeephala with well-dercloped, separate, eiliated gill-

* “ La Faune des Iles St. Paul et Ansterdam," Arch. Zool. expérimentale, 1877. 
filaments in the position of oral tentacles; mouth and anus approximate; foot rudimentary or aborted ; mantleskirt absent; inelosed in a elitinous or caleareous or gelatinous eell (=mantle shell); usually forming eolonies by continuous gemmation, rarely single.

Subclass HOLOBRANCHIA, E. Ray Lankester.

Lophophore either eircular or horseshoe-shaped, bearing an unbroken series of tentacles.

Group a. Есторкоста, Nitsehe.

Anal orifiee, without the lophophore.

\section{Order GYMNOLEMATA, Allman.}

Ixfuxpibulata, Gervaig.

Stelahtopoda, Van der Hoeven.

Polypide destitute of an epistome (foot); lophophore eireular.

Suborder I.-CHEILOSTOMATA, Busk.

Celleporiva, Ehrenberg.

Orifiee of the zoceium elosed by a movable opereular valve. Ora usually matured in external marsupia. Appendicular organs (avieularia and vibraeula) frequently present.

\section{Family I.-Aeteidæ.* \\ Aetea, Lamouroux.}

* The Aeteide with the genus Bcania are ranked by Carus as a suborder, the Stolonata, which is thus characterized-" The conical or tubular cells ranged singly on a tubular stolon." But Beania and Aetea nre not closely related; the peduncles by which the cells are united in the former are by no means homologous with the creeping stems of the latifer, whilst 
Family II.-Eucratiidø.

Eucratea, Lamouroux. Gemellaria, Savighy. Scruparia, Hineks.
Huxleya, Dyster. Bretria, Dyster.

\section{Family III.-Cellulariidæ.}

Cellularia, Pallas. Menipea, Lamouroux.
Scrupocellaria, Van Beneden. Caberea, Lamouroux.

\section{Family IV.-Bicellariidæ.}

Biceliaria, Blainville. Bugula, Oken.

Beania, Johnston.

Family V.-Notamiidæ*.

Notami, Fleming.

F'amily VI.-Cellariidæ.

Cellaria, Lamouroux (part).

Family VII.—Flustridæ.

Flustra, Linnæus.

Family VIII.-Membraniporidæ.

Membranipora, Blainville†.

Megapora, Hineks.

the cells themselves are of a very different type in the two genera. The Aeteide seem to be properly ranked as a family of the present suborder; their stoloniferous charactor is not suffieient to raise them to the rank of a higher group. Amongst the Eucratiide it is shared, by the genus Eucratea, but would certainly not warrant its separation from the forms with which in other respects it is most closely allied.

- Families 1 to 5 inclusive constitute the Cellularina of Smitt; fanilies 6-9, the Flustrina; fanilies 10-14, the Escharina; fanily 15, the Celleporina. The last group lie has now abandoned.

+ Membranipora pilosa. The systomatic position of this species must be cousidered doubtful. Its extraordinary larra (Plato LXXXIII. fig. 9) allies it to Flustrella and (in somo degree) to Eucratca. We are not in a position as yet to determine its affinities with precision. 
Family IX.-Microporidæ.

\begin{tabular}{l|l} 
Micropora, Gray. & Setosella, Hincks. \\
Steganoporella, Smitt. &
\end{tabular}

Family X.-Cribrilinidæ.

Cribrilina, Gray.

Membraniporella, Smitt (part).

Family XI.-Microporellidæ.

Microporella, Hincks. | Chorizopora, Hincks. Diporula, Hincks.

Family XII.-Porinidæ, D’Orbigny (part).

Porina, D’Orbigny.

Anartil ropora, Smitt (part).

LAGENIPORA, Hincks.

Celleporella, Gray.

Family XIII.-Myriozoidæ.

SchizoponelLa,

Hincks*.

Mastigophora, Hincks.
RHXNCHOPORA $\dagger$, Hincks. Scmizotheca, Hincks. Hippothos, Lamouroux.

Family XIV.-Escharidæ.

Lepralia, Johnston (part).

Umbonula, Hincks $\ddagger$.

Porella, Gray.

Escharoides, Smitt.
Smittia, Hincks. Pirylactella, Hincks. Mucronella, Hincks. Palmicellaria, Alder. RETEPORA, Imperato.

* Schizoporella hyalina. Barrois notes a peculiarity in the gemmation of this species. The buds originate laterally, instead of at the summit of a cell; and the zoceia may therefore be described as intercalary in their arrangement. (See Plate XLV. fig. 3.) There are also distinctive points in the larva. Microporella impressa, it seems, agrees with it in these respects ; and Barrois would unite these species in a distinct genus-a courso to which I cannot assent, as the differences between the adult forms seem to me much weightier and more significant than the alleged points of ngreement.

t This genus is wrongly placed amongst the Escharide in the body of the work (p. 385).

$¥$ In the descriptive portion of the text this genus stands as Umbonella (p. 316); but since it was in type I have ascertained that a group of 
Family XV.-Celleporidæ.

Cellepora, Fabricius (part).

Suborder II.-CYCLOSTOMATA, Busk.

Zoœcia tubular, with a plain inoperculatc orifice. Marsupia and appcndicular organs manting.

Group i.-RADICELLATA, D'Orbigny.

Family I.-Crisiidæ.

Crisia, Lamouroux (part).

Group ii.-InCrustata, D’Orbigny.

Family II.-Tubuliporidø.

Stomatopora, Bronn. Tubulipora, Lamarck. IDMONEA, Lamouroux.
Evtalophora, Lamouroux.

Diastopora, Lamx. (pt.).

Family III.-Horneridæ.

Hornera, Lamouroux.

Family IV.-Lichenoporidæ.

Lichenopora, Defrance. | Domopora, D’Orbiguy.

Suborder III.-CTENOSTOMATA, Busk.

Orifice of the zoœcium closed by an operculum of setæ. Zoarium never calcarcous. Marsupia wanting.

Group i.-HALCrovelLEA, Ehrenberg.

Family I.-Alcyonidiidæ.

Alcyonidium, Lamouroux.

Mollusca was so ealled by Arthur Adams in 1863, and Mr. Ridley (of the British Museum), to whose kind assistance I am much indebted, informs me that the name still holds its place in mollusean nomenclature. I have therefore adopted the form Umbonula. 
Family II.-Arachnidiidæ.

Aracinidium, Hincks.

Family III.-Flustrellidæ.

Flustrella, Gray.

Group ii.-STOLONIFERA, Ehlers.

a. Orthonemida, Hincks.

Family IV.-Vesiculariidæ.

Vesicularia, J. V.

Thompson.

Amathia, Lamouroux.
Bowerbankia, Farre. Avenella, Dalyell. FarRella, Ehremberg.

Family V.-Buskiidæ.

Buskia, Alder.

Family VI.-Cylindrœciidæ.

Cylindrecium, Hineks. | Anguinelu, Van Beneden.

Family VII.-Triticellidæ.

'Triticella, Dalyell. ～Hippuraria, Busk.

b. Campylonemida, Hincks.

Family VIII.—Valkeriidæ.

Valkeria, Fleming (part).

Family IX.-Mimosellidæ.

Mimosella, Hincks.

Family X.-Victorellidæ.

Victorella, W. Saville Kent. 
Subclass HOLOBRANCHIA,

Group 6.-Exт ориоста, Nitsche.

Both the orifices of the alimentary canal within the lophophorc.

\title{
Order PEDICELLINEA.
}

Only order.

\author{
Family I.-Pedicellinidæ. \\ Pedicellina, Sars. \\ Family II.-Loxosomidæ. \\ Loxosoma, Keferstcin.
}

Subclass PTEROBRANCHIA, Ray Jankester. AspidorHora, Allman.

Lophophore produced on each side into a process (plume), on which alone the tentacles arc devcloped, forming discontinuous scries.

Order PODOSTOMATA, Ray Lankester.

Foot large, ovcrhanging the mouth.

Family Rhabdopleuridæ.

Rhabdopleura, Allman. 



\section{B R I T I S H}

\section{MA RINE POLYZOA.}

Class POLYZOA, J. V. 'Thompson.

Subclass Holobrancina, E. Ray Lankester.

Group a. Eсторвоста, Nitsçhe.

Order GYMNOL EMATA, Allman.

Polyplaria infuxdibelata, Gervais, Ann, des Sc. Nat. 1837.

Polyzoa infuxdibulata, Busk, B. M. Cat.

Suborder I.-CHELOSTOMATA, Busk.

$$
\text { Family I.-Aeteidø. }
$$

Zoceris tubular, with a lateral membranous area; orifice terminal. Tentacular sheath terminating above in a circle of sctæ, which are everted during the expansion of the polypide.

THe Aeteide exhibit many points of affinity with the Ctenostomata. The morc or less crect, cylindrical cell, with the orifice at the top, and the frill-like termination of the tentacular sheath, which must be regarded as the homologuc of the setose opcreulum, are characters which, 
as Prof. Smitt las already remarked*, conneet these Cheilostomatous forms with the last-named division. To these, others may be added. The production of cells by gemmation from a stolon is eharacteristic of the largest section of the Ctenostomata as well as of the present family. Another link between it and eertain genera amongst the Ctenostomata is the membranous area occupying, in the more typical species, a eonsiderable portion of one side of the zoœeium, which has its equivalent in the genera Triticella (Dalyell) and (probably) Hippuraria (Busk) and (aceording to observations which $I$ have recorded in another part of this work) in Mimosella.

The Aeteide eonstitute a peculiar group; and I agree with Smitt in ranking them as amily, distinguished by the Ctenostomatous east of its structure.

On the other hand, it must be noted that they arc allied to Eucratea through the charaeter of the polypide, and in some other points.

The family contains a single genus.

Genus AETEA, Lamouroux†.

Aetea, Lamx. Bull. Soc. Philom. 1812: Busk: Smitt, \&ce.

Angursaria, Lamk. Extrait du Cours de Zool. 1812 (without character):

Johnston, \&c.

* 'Om- Hafsbryozoernes Uttreckl.' \&c., 1865, p. 11; “ Kritisk Fürteckning öfver Skandinav. Haf-Bryozoer," CEfrersigt af K. Vetensk-Akad. Förhandlingar, 1867, pp. 293-5.

+ Actea is clearly a mistake for Actea (or Actcea), one of the Nereids, according to Homer and Hesiod. Lamouroux himself tells us that his genus was named after one of the daughters of Nereus; but Actea is not of their number. Through a blunder of the author or printer this name has been substituted for Actea. It occurs in Lamouroux's paper in the Bull. Soc. Phil. (1812), in his 'Hist. Pol. Corall. Alex.', and in his 'Exposition Méthodique, and las passed into very general use. Nothing could be 
Falcaria $\beta$, Oken, Lehrb. Naturg. Zool., Abth. ii. 91, 1815.

Crrcaripora (for Aetea truncata \&c.), Fischer, Arch. Mus. Hist. Nat. ii. 292-313.

Generic Ciraracter. - Zoecia calcareous, tubular, erect, with a membranous area on one side; distributed along a more or less adherent, creeping fibre, dilated at intervals; orifice terminal. Oøcia none.

The polypide in this genus is of the simplest type. There is no gizzard; the long osophagus leads at once into the digestive sac, which is but slightly dilated, and tapers off below; the number of tentacles is small. During retraction the polypide is not folded upon itself, but strctches straight downwards within its cell.

The structurc recalls in many respects that of the simpler Ctenostomata, such as Valkeria.

Sercn species of Aetea have been described, of which three occur on our coasts. The genus has representatives in South America (Patagonia), West Indies*, Australia, and Africa, as well as in Europe, wherc it reaches far north. A. anguina ranges from Norway to Zanzibar, and is equally at home in Australia and in our own scas.

The spccific distinctions arc founded on differences in the size and shape of the cell, and especially in the shape of the oral extremity, in the comparative length of the membranous area, and in the characters of thc surface.

We may perhaps regard the straight forms (in which the

gained by the restoration of her lost honours to Actea to compensate for the confusion that would be caused by the displacement of a well-established term. I therefore retain the name as it stands in Lamouroux's works, and as it is known to science.

* D'Orbigny records the occurrence of a species in Cuba, which he names A. Americana; but his description is so meagre that it is impossible to decide whether it is really distinct. It is said to be nearly allied to A. anguina, but to have the cells rery much smaller, and narrower at the extremity. 
arca occupies a considerable proportion of the length of the cell) as the most primitive, and those in which the upper extremity is modified (as in $A$. anguina and the Australian $A$. dilatata) as the younger in the scries.

\section{Aetea anguina, Linnæus.}

Plate I. figs. 4, 5.

Ssake Coralline, Ellis, Corall. 43. no. 11, pl. xxii. figs. C, C, D.

Sertularia avguiva, Linn. Syst. (ed. 10) 816, (ed. 12) 1317.

Cellularia anguina, Pall. Elench. 78: Ellis, Phil. Trans. 17ii. 434, pl. xix. fig. 10 (in paper on Actinia sociata).

Celluaria anguina, Ell. \& Sol. Zooph. 26.

Akten anguina, Lamx. Bull. Soc. Phil. 1812; Pol. Corall. flex. 153, pl. iii. fig. 6: Busk, B.M. Cat. i. 31, pl. xr. fig. 1: Smitt, Kritisk Förteckn. iii., Effvers. Vetensk.-Akad. Förhandl. 1867, No. 5, 280 \& 296, p1. xvi. figs. 2-4.

Falcaria anguina, Oken, Lehrb. Naturg. Abth. ii. 91.

Sertularia mollis, D. Chiaje, An. s. Vert. Nap. iv. 147.

Angusaria anguina, Flem. B. A. 542: Lister, Phil. Trans. 1834, 385, pl. xii. fig. 4.

Anguinaria spatulata, Lamk. An. s. Vert. (ed. 2) ii. 196 : Johnston, B. Z. (ed. 2) 290, pl. i. figs. 7, 8: Busk, Trans. Micr. Soc. for 1849, 123, pl. xxvi. : Gosse, Dev. Coast, 141.

Zocecia white and glossy, more or less bent, spatulate at the upper extremity, ringed, with the exception of the clavatc portion at the top, which is minutcly punctate; area occupying from about a quarter to a third of the length of the cell ; crceping fibre sinuous, punctulate, swelling out at intervals; a cell originating from cach enlargement.

Range of Variation. The chief variation secms to be in the length of the spatulate extremity, and of the curved anterior portion of the cell. The enlarged spoon-like head is sometimes elongate, sometimes short and regularly oval in form. There are also differences in the degree in which the upper extremity of the cell is bent and the point at which the curvature eommenees. But I have not 
notieed any approael to the ereet mode of growth which eharacterizes the following species.

Habitat. On the smaller Algre chiefly, and especially the red kinds, occasionally on shells, stones, \&re, in tide-pools and in the Laminarian region *.

Localities. Very abundant in the south and west, less eommon apparently in the north of England, rare in Shetland. Coast of Ireland; Isle of Wight (W. T.) : Ayrshire (Landsborough) : south coast of Durham oceasionally (J. Hogg) : Shetland (C. W. P.) : Ramsay, Isle of Man; Filey, Yorkshire; Llandudno; Swanage; Ilfracombe; South Devon, most abundant; Guernsey (T. H.) : Cornwall (Couch) : \&c.

Geographical Distribution. Bahusia; Southern Norway (Smitt) : Atlantic Ocean; Antaretic Ocean; Tasmania (Busk) : Adriatic (Olivi) : Biarritz (W. T.) : Zanzibar; Natal (W. Oates) : Glenelg (T. H.).

Ellis's quaint account of this interesting form is worth reprodueing:- "From very small holes in the broadest part of this irregular winding tube [which he had just deseribed] there arise here and there small testaceous white hollow figures, exaetly resembling a snake without the lower jaw, in the place whereof is the entranee into the cell." His figure is admirable, and leaves little room for improvement to those who come after lim.

The area in this species oceupies the underside of the eurred portion of the eell; and at the top of it is the mouth; the opereular valve falls, like a little trap-door, when the polypide is about to issue from its cell, and is drawn up and tightly elosed after it when it retreats. The tube below

* "Invests those Alga chiefly whose stems are clothed with hair-like fibres, as Dasya coccinea, Griffithsia cquisetifolia, and Sphacellaria scoparia; but found occasionally on smooth-stennued eprecies, as Plocamium coccincum." - W. Tuovisos. 
the spatulate extremity is beautifully ringed. Mr. Busk has noticed the pouch "like the bag of the peliean's beak," which is formed by the membranous eovering of the aperture, and remarks that numbers of Navicula and Infusoria are often found in it. The polypide, which is small and delicate, has usually twelve tentacles of moderate length. When the oral valve opens, a membranous sheath is first pushed out, with a number of setiform processes round its frec extremity, which are thrown back and form a kind of frill; and then the polypide instantly darts forth : little more than the pharynx and tentacular crown is protruded.

The swellings on the ereeping base in this speeies are of moderate size, and generally oceur at short intervals; so that the cells are set pretty elosely together.

Aetea anguina is developed in extraordinary profusion; and bunches of weed are often so thickly eovered with it as to appear powdered over with white. Masses of Algæ from Australia are invested in a similar way by the kindred $A$. dilatata.

Aetea rects, Hincks.

Plate I. figs. $6,7$.

Hiprotios sics, Couch, Corn. Faun. 102, pl. xix. fig. 9 : Johnston, B. Z. ed. $2,292$.

Aetea recta, Hincks, Devon Cat., Ann. N. H. ser. 3, ix. 25, pl. vii. fig. 3.

Stomatopora Gallica, D'Orbigny, Pal. Franç. Terr. Crét. v. 836, pl. 759, figs. 1-3.

Aftea sica, Norman, Quart. Journ. Micr. Sc. п. 8. viii. 216.

Aeten anguisa $\beta$, forma recta, Smitt, OEfvers. K. Vet.-Akad. Förhandl. 1867, No. 5, $281 \& 297$, pl. xvi. figs. $5,6$.

Zoceia tall, nearly straight, very slightly dilated above, truncate at the extremity; surface eoarsely ringed below, the upper portion punctulate; area elongate, occupying more than a third of the length of the ecll; 
swellings on the creeping stem fusiform, finely wrinkled transversely, generally not distant.

Habitat. On shells, stones, \&e., from moderate depths to deep water (80 fathoms).

Localities. Torbay, abundant; Saleombe; off the Deadman, 60 fathoms; Isle of Man ; Lamlash, Arran (T. H.) : Guernsey ; Antrim; Shetland, 40-80 fathoms, frequent; the Mineh (A. M. N.) : Birterbuy Bay (G. S. Brady).

Geograpiucal Distribution. Baliusia; Southem Norway (Smitt).

In this speeies the delieate creeping fibre swells out at short intervals into elongate subfusiform bodies, which elosely resemble the eells of Hippothoa; a zoceium rises from each of them, placed at the larger end. Opposite branches are given off from the sides of these cell-like expansions. The zoceia are at onee distinguishable from those of Aetea anguina by their larger size and stouter habit, their ereet growth, the absenee of the spatulate head, and the greater length of the area in proportion to that of the eell. The ereeping fibre is also more delicate, and the swellings in its eourse larger and more regular in form, and finely striated transversely.

I have met with no varieties intermediate between these two very distinet forms.

The oral portion of the eells is very apt to be broken off; and when this is the ease the speeies resembles an Hippothoa with a produeed tubular orifice (Plate I. fig. 7) *.

* Though I have no doubt that Couch founded his Hippothoa sica on maimed and imperfect specimens of the present form, his name has, in my judgment, no claim to adoption. He had only seen the creeping base with portions of the cells attached to it; and his description, therefore, gires no ides whatever of the real character of the species. He knew nothing of its true cells, and so mistook it for an Hippothoa with a tubular mouth. As no student could identify Aetea recta by menns of the diagnosis which he has given us, us incleed its most essential feature is not included in that 
Aetea truncata, Landsborough.

Plate I. figs. 8-11; Plate II. fig. 3.

Axgeinaria troxcata, Landsb. Pop. Hist. Brit. Zooph. 288, pl. xvi. figs. $57,57 *$

? Salpingia Hassaldil, Coppin, Ann. N. H. ser. 2, ii. 273, pl. x. fig. 3.

Aetea truncata, Busk, B.M. Oat. i. 31: Hincks, Devon Cat., Ann. N. H. ser. 3, ix. 24: Smitt, "Om Hafsbryozocrnes Uttreckl.," WEfv. K. Vet.-Akad. Förhandl. 1865, 11, pl. ii. figs. 5-14, and pl. iii. figs, 1-8; id. Krit. Fört., EEfv. \&c. 1867, 279 \& 295 , pl. xvi. fig. 1 .

? Eteorsis elongata, Boeck, Förh. Vid. Sels. Christiania, 1861, 49.

Zoccia short, straight, narrowed below, upper extremity truncate; surface minutcly punctate; a tubular appendage frequently given off from the middle of the dorsal surfacc; swellings on the crecping fibre very slender, clavate, generally distant.

Sometimes the cclls, instead of being simplc, are linked together in a single serics, forming erect shoots, all the cclls in the series, except the primary one, being supported on long and slender pedicles.

Range of Variation. The zoccia differ much in size; and a dwarf variety occurs, in which they are only about half as large as the ordinary cell. The dorsal appendage, which is in fact a rudimentary ccll-pcdicle, is sometimes wanting. The habit is cither simple, or a number of zoœcia arc united in a single serics, as in Eucratea. The crecping stem is adnate or very loosely adherent.

diagnosis, the case, it seems to me, does not come within the scope of the "law of priority." There is no such species as Hippothoa sica; and the name simply lapses.

It is hardly necessary to add that sica would be a most inappropriate designation for the perfect Aetea recta, however well it may have fitted the portion of it for which it was originally intended.

D'Orbigny has repeated Couch's mistake, and founded his Stomatopora (=Alecto) Gallica on specimens of the present species from which the upper portion of the cells had entirely disappeared. 
HaBITAT. On Algae and shells, between tide-marks and in moderate depths.

Localities. Lamlash Bay, Arran, on Laminaria saccharina (Landsb.) : Isle of Man, on oyster-shells, common; Ilfracombe, on weed between tide-marks; Swanage; South Devon, not very eommon (T. H.) : Guernsey (Miss Renouf), \&e.

Geograpiical Distribution. Bahusia; Southern Norway (Smitt) : Madeira (J. Y. J.).

Aetea truncata presents very different appearances in different states or stages of growth. In its simplest condition, the zoarium consists of lines of sessile cells, distributed at intervals along a delicate thread-like fibre, as in the other species of this genus. It exhibits indeed one peculiarity : a large proportion of the cells are often furnished with a tubular tail-like appendage, given off from the back and usually direeted upwards; it varies in length, and originates about halfway down the eell. And in some eases this dorsal tube becomes much elongated, and supports a seeond cell. From this seeond eell a slender stem or pediele is giren off, which terminates in a third eell, and so on. The species has taken on the habit of Eucratea (Plate II. fig. 3).

This erect and eomposite form, however, secms to be comparatively rare; more eommonly, so far as I have seen, the simple habit prevails. The cclls are usually sessile, but oceasionally are bornc on a short tubular proecss given off from the ereeping stem. They are of a pure white colour, and very bright and glossy. The fibre is of extreme delicacy, and is very minutely but very beautifully dotted over; the enlargements from which the eells rise are slender and comparatively inconspicuous. From each side of them branches are given off nearly at right 
angles*; and not unfrequently these are not adherent, but project as slender tubular processes. The fibre generally is very loosely adherent, exeept on smooth flat surfaces, where it is more closcly adnate.

There is very commonly a constriction just below the aperture of the eell; and at this point it is often broken across.

Family II.—Eucratiidæ.

Zoacia uniserial, or in two series placed back to back, expanding from the base upwards, with a terminal or subterminal and usually oblique aperture. Avicularian and vibracular appendages wanting. ZOARIA forming slender, branching, phytoid tufts.

THIs family group includes a number of forms of very simple structure and habit. The plan of the zoarium exhibits no complexity and a very small amount of variability within its limits. The cells in a large proportion of cases are linked together in single series, each rising from the upper portion of the one below it. The ereet shoots thus formed give off branches; and the pattern of the ramifieation varies in the different genera. In the genus Gemellaria we have a slight deviation from the perfect simplicity of habit which is so eharacteristic of this family. The Eucratea-like eells are here disposed in a double series, and adhere to one another by the dorsal surface, so that the apertures of the two rows look in opposite dirce-

* I have seen a luxuriantly developed specimen on weed, in which these lateral branches were present in profusion, attaining a considerable length and bearing lines of cells. They were slender and of uniform thickness throughout, and showed no trace of the usual enlargements. 
tions. In Scruparia clavata, Hincks, we have an intermediatc form, which connects the uniscrial and biscrial genera, and illustrates the way in which the one plan of growth may have passed into the other.

Throughout this family, so far as its British rcpresentatives arc coneerned, the zoarium is continuous or not divided into segments by corneous joints.

In defining the genera I have relied chiefly upon the eharacters supplied by the differences in the aperture and the mode of branehing. If the number should seem to be large for so small a group, I can only urge that it is not more than sufficient to represcnt important modifications of the family type.

The family Eucratiide includes the whole of the Gemel: lariide of Busk, with the exception of the anomalous genus Notamia and Didymia (whieh last is distinguished by a very different type of eell). The Australian genus Dimetopia is allied to our own Gemellaria, and exhibits an intcresting modification of the back-to-back arrangement of the cells.

\section{Genus EUCRATEA, Lamouroux.}

Der. From Eucrate, one of the Nereids.

Evcratea, Iamx. Bull. Soc. Philom. 1812: Jobnston: Smitt.

Screparia, Oken, Lehrb. Naturg. Abth. ii. 90, 1813: Busk. .

Szrtcraria (part.), linnzus.

Cellularia (part.), Pallag.

Cerluaria (part.), Ellis and Solander.

Uxiceldaria (part.), De Blaint. Diet. Sc. Nat. 1830.

Catesaria (part.), D’Orbigny, Pal. Franc. 1850.

Generic Character.-Zonrium composed of a creeping adherent base and erect branching shoots. Zokcis sub. calcareous, rising immediately one from the other, so as to form a single series; aperture large, oblique, lateral or sub. 
terminal, the oral opening at the top of it; branches given off from the front of a cell below the aperture. O(EcIa terminal.

Avicularia and vibracela wanting.

Tentacular sheatu terminating above in a ring of setæe.

Thougu agrecing with Aetea in the character of the polypide and the general plan of growth, the present genus exhibits a very distinet type of ecll. The composite habit, which is rarely met with in the former (having only been noticed in $A$. truncata) is the rule in Eucratea, which also branches freely, and forms bushy plant-like tufts.

The structure of the primary eell presents some interesting peculiarities. Each colony of Eucratea commences with a small zoceium, which is free (not adherent) and borne on a sliort stalk, with a single joint in the middle of it (Plate II. figs. 5-8). This stalk, however, does not occupy the position of the usual peduncular portion of the cell, but springs from the front surface, a little below the aperture or area. It corresponds, in fact, with the pedicle of a branch. The primary zoceium terminates below in a sliort blunt process, which is perfectly free and unattached. The produced peduncular portion, extending in the normal eell from the aperture downwards, is not developed. 'The aperture occupies nearly the whole length of the cell; it narrows off to a point below, and expands slightly upwards, being open at the top. The upper extremity of the eell is subtruncate. From the base of the stalk supporting this primary eell, in the specimens which I have cxamined, another cell, decumbent and adnate, is given off, which exlibits the normal shape, and is attached to the parent zoœcium by its lower extremity (Plate II. fig. 7). It may be noticed in passing that there is a striking resemblanee between the primary eell of Eucratea and the cell of Beania in an carly stage of 
growth. The two arc esscntially identical in structurc.

The creeping basc exhibits somc eurious modifications in this genus. When it is developed on the stems of the more slender Algæe, it consists univcrsally, so far as I have seen, of lines of decumbent cells, from which the crect sloots risc, originating, like the ordinary branches, a little below the apcrturc. But in otlicr cases I have found it assuming the form of a dclicate tubular fibre, like that of Aetea, which at intervals swells out into small clavatc cnlargements, from which the cells arisc. I have never scen the passage of one of thesc conditions into the other; but it is difficult to avoid the conelusion that they arc morphologically equivalent, and that the clavate enlargements are merely aborted cclls. They arc frequently much attcnuated in Eucratea, sometimes almost obliterated; and in such eases wc havc an indication of the way in which the chain of adnate cclls passes into the perfectly simple tube. Under $E$. chelata I have described a curious variety, in which the deeumbent condition of the zoarium appears to be permanent.

Two specics of Eucratea, as now defined, have been described. One of them, E. ambigua, D'Orb., which closcly rescmbles the present form, is a native of South America. E. chelata has a widc distribution in Europc, whilc in Australia it is exccedingly abundant, attaining a size and beauty which are unknown in our scas.

Busk has described a Polyzoon from Madeira under the name of Scruparia (=Eucratea) diaphana*; but, from its modc of branching and the sizc of the aperture, it would scem to be morc properly referable to some other genus.

* Quart. Journ. Micr. Sc. (n. s.) riii., Zonphỵtol.281, pl. xxxi. figs. 1, la. 


\section{Eucratea chelata, Linnæus.}

Plate I. fig. 3; Plate II. figs. 4-8; Plate III. figs. 9-11.

Bolr's-horn Corallixe, Ellis, Corall. 42, no. 9, pl. xxii. fig. 6 , B.

Sertularia cielata, Linn. Syst. (ed. 10) 816.

Cellularia chelata, Pall. Elench. 77.

Sertularia loricata, Linn. Syst. (ed. 12) 1316.

Cellaria cirbata, Ellis \& Sol. Zooph. $25:$ Lamk. An. 8. Vert. (ed. 2) ii. 189. Eucratea cierata, Lamx. Expos. Méth. 8, pl. 1xv. fig. 10 : Johnston, B. Z. (ed. 2) 288-9, woodcut, fig. 64: Hincks, Ann. N. H. March 1853, pl. vi. fig. 3 ; id. Deron Cat., Ann. N. H. ser. 3, ix. 23 : Smitt, Kritisk Förteckn. iii., CEfvers. Vet.-Akad. Förhandl. 1867, 281 \& 301: Gosse, Dev. Coast, 132.

Scruparia cirelata, Oken, Lehrb. Naturg. Abth. ii. 90: Busk, B. M. Cat. i. 29, pl. xvii. fig. 2.

Eucratea loricata, Flem. B. A. 541.

Unicellaria cielata, Blainv. Actinol. 461, pl. Ixxii. fig. 2.

Eucratee corvée, M.-Edwards, Ann. Sc. N. sér. 2, ix. Zool. 20t, pl. viii. figs. $1,1 a$.

Catenaria chelata, D' Orbigny, Pal. Franç. Terr. Crét. v. 43.

Zoarium often mueh branched; zoccia in the form of a horn, narrowed below, enlarging gradually upwards to the basc of the aperture, which slants away to the top of the cell; aperture oval, surrounded by a thin raised unarmed margin; frequently a rudimentary cell below it in front. Ocecia mitriform, somewhat pointed above, with a keel down the eentre, borne below the aperture on an imperfectly devcloped cell. Primary zocecium small, destitute of the usual peduncular portion, and tcrminating below in a short eaudate process; aperture narrow, elongate, occupying the whole of the front; cell attached by a short, jointed stem, which originates a little below the aperture.

Var. u. repens. Zoœcia decumbent and adnate; aperture scarcely marginate; branches given off from the sides of the cells. (Plate I. fig. 3.)

Var, $\beta$. gracilis. Zoœcia very slender and elongatc, tubular below and enlarged above.

Range of Variation. In an early stage of growth this 
spceics is often deeumbent. A few cells are repent and adnate: and from these the ereet shoots arise, and the zoarium then assumes its normal eondition. But in the remarkable variety $a$ the deeumbent mode of growth seems to be permanent. I first met with it in the Isle of Man, where it is common, spreading in rather large dendritic patches over oyster and other shells. In this condition the speeies euriously imitates the habit of Hippothoa, Lamx., and sends off branehes from the sides of the eells.

Large, much-branched specimens frequently oeeur, which show no tendeney whatever towards an ereet growth, but seem to have taken on in permanenee the eharacters of the last-named genus. So eompletely are the habit and aspeet of the Polyzoon ehanged in this repent variety, that it is diffieult to reeognize it under its disguise. There are generally, however, a number of the tubular processes rising below the aperture which are so eharaeteristic of Eucratea chelata. In this variety the ecll is often much produeed below, and the aperture is less distinctly marginate than in the erect form.

Smitt has noticed that in Norwegian specimens of the normal habit this eharaeter is, as a rule, mueh less strongly marked than it is in English examples. In beautiful speeimens from Australia, wherc $E$. chelata is abundant, the raised border is highly developed; the eells are large, of most delicate texture, vitreous, transparent, and glossy; the whole aspect of the species has ehanged under the genial influeuees of its southern habitat.

The variety gracilis is of extremely delieate habit; and the portion of the ccll below the aperture is cylindrieal and very slender. The upper part, also, has much less breadth than in the normal form; and there is no longer the striking resemblance to a liorn. 
Habitat. On weed, shells, stones, erabs, \&e., between tide-marks more espeeially, and in the Laminarian region, and from moderate depths.

Localities. Common and widely distributed. Ayrshire (Landsb.): St. Andrews, on Ceramium rubrum and Sert. pumila \&e., between tide-marks (Dr. MeIntosh) : Searborough, very rare (Bean) : Brighton and Hastings, very rare (W. W. Saunders) : on all sides of Ireland (W. T.) : Northumberland, on small weeds and zoophytes, tidemarks and a little beyond (Alder) : south-west of Durham, rare (J. Hogg): Isle of Man; Filey, under stones; South Devon, very common; Saleombe, on Laminaria digitata, a favourite habitat, growing amongst the forests of Obelia geniculata; St. Ives, Cornwall, of great size and beauty, also on Laminaria; Ilfraeombe, off the Capstone, 8-10 fath. (T. H.) : Connemara, roek-pools (G. S. B.) : Shetland (C. W. P.) : \&e.

Var. $a$. On shells dredged off Maughold Head, Isle of Man (T. H.).

Var. $\beta$. North Devon (A. Leipner).

Geographical Distribution. Bahusia, 5-10 fathoms; Southern Norway (Smitt): Hougesund, on Delesseria, 5-20 faths. (Kirehenpauer) : south-west eoast of Franee (Fiseher) : Bay of Cadiz (Kirehenpauer) : Australia, abundant, normal and var. gracilis (T. H.).

In this very pretty species the eells are white, smooth and glossy, and are linked together in series, so as to form delieate, somewhat eurved, eonfervoid tufts. At times the shoots are elustered, but generally they are distributed irregularly on the trailing fibre. Ellis gives a good idea of the eell, in likening it to a bull's horn; Couch, on the other hand, sees in it a resemblanee to a shoe. The lowest eell in a shoot is generally mueh pro- 
duced below, and annulated towards the base. The form of the ovicells is peculiar and very picturesque; they are broad, rising to a point above, and carinate in front. They seem to be sparingly developed. The creeping stem is very much attenuated; it swells out at intervals, like that of Aetea, into somewhat oral expansions, from which the cells originate; but they are small and inconspicuous. Branches are giren off from the sides of these enlarged portions, as in the last-named genus. The polypide is very small and delieate, with 10 or 12 tentacles, and is remarkable amongst an active tribe for the vivacity of its movements *. It affords a good example of the simpler type of polyzoan strueture, and, from the nature of its cell, is readily examined.

\section{Genus GEMELLARIA, Savigny.}

Der. From gemellus, double.

Gearularta, Savigny, 1811: Van Beneden: Johnston, B. Z. : D'Orbigny : Busk, B.M. Cat. : Smitt.

Scruparia $\beta$, Oken, Lehrb. 1815.

Gemicellagia, Blainville, 1820.

Loricaria, Lamx. Expos. Méth. 7.

Orista (sp.), Lamx. : Lamk.

Notasia, Flem. Br. An. 1828.

Loricula, Cuvier, 1830.

Generic Character.-Zoarium erect, phytoid. Zorecia joined back to back; the cells composing the pairs rising one from the top of the other, all the pairs facing the same way. Aperture large, on the front of the cell, slightly oblique.

* I gire it this character after maly years acquaintance. It is a most. nimble creature; and there is alwnys a fresh interest in watching its pretty. wnys. 
Branches given off from the sides of the cells close to the upper extremity. No vibracula or avicularia. O๔CIA none.

GearelLarra is closely allied to Eucratea. The single eell presents the same general character in both; the differences lie in the mode in which the cells are united, the plan of the branching, the total absenee, as it scems, of oœcia, and the nature of the adherent base, which is not a crecping fibre, or line of adnate cells, as in Eucratea, but a mass of interlacing tubes, such as we meet with in the genus Bugula. An interesting intermediate form is found in the genus Scruparia, mihi.

\title{
Gemellaria loricata, Linnæus.
}

\author{
Plate III. figs. 1-4.
}

Cont-op-sair Coralline, Ellis, Corall. 40, no. 7, pl. xxi. fig. $b, \mathrm{~B}$.

Sertularia loricata, Linn. Syst. ed. 10, 815.

Cellugaria loriculata, Pall. Elench. 64: Dalyell, Rem. An. i. 233, pls. xliii. \& xliv.

Sertularia loriculata, Linn. Syst. ed. 12, 1314.

Cellaria loriculata, Ell. \& Sol. Zooph. 24: Lamk. An. 8. Vert. ed. 2, ii. 179.

Scruparia loricata, Oken, Lehrb. Naturg. 90.

Crisia loriculata, Lamx. Pol. Coral. flex. 140.

Loricaria europsa, Lamx. Expos. Méth. 7.

Notamia loriculata, Flem. B. A. 541: Farre, Phil. Trans. 1837, 413, pl. xxvii. figs. 6-9.

Loricula loricata, Cuvier, Règne Anim. ed. 2, iii. 303.

Gemicellaria loriculata, Blainv. Dict. Sc. Nat. lx. 425 : Actinol. 461, pl. Ixxriii. fig. 4.

Gemeluaria loriculata, Van Ben. Recherches (sep.), 1845, 33, pl. v. figs. 1-7: Johnston, B. Z. ed. 2, 293 \& 477, pl. xlvii. figs. 12, 13: Alder, North. \& Durh. Cat. (sep.) 47.

Gemeliaria roricata, Busk, B.M. Cat. i. 34, pl. xlv. figs. 5, 6: Smitt, CEfver8. K. Vet.-Akad. Förh. 1867, 286 \& 324, pl. xvii. fig. 54 :

Gemellaria Willisir, Dawson, Proc. \& Trans. Nova-Scot. Inst. Nat. Sc. i. pt. 3 (1864-65), Proceed. p. 3. 
Zoarium forming large densely bushy masses, several inches in width, of a brown colour, made up of numerous long, slender, tapering shoots *, irregularly branched; branches divided dichotomously. Zoccia elongate, more or less attenuated and produced bclow ; surface minutely pitted; aperture suboval, narrowed towards the bottom, slanting upwards, occupying about half the front, with a thin, raised, and unarmed margin.

Polypide with from 10 to 14 tentaclest.

Height several inches, oceasionally as many as 8 or 9 , according to Mr. Hassall; more usually 2-4.

Habitat. From the littoral region to deep water $(80$ fathoms).

Localitres. Isle of Sheppey, abundant (Ellis and Farre): Shetland, occasionally met with; the Minch (A. M. N.) : Kirkeudbrightshire (Landsb.) : very splendid on the west coast of Sutherland (C. W. P.): St. Andrews, abundant in deep watcr (Dr. MeIntosh): Bass Rock, 24 fms.; entrance to the Firth 'of Forth, 22 fms. (Kirchenpauer) : Northumberland, very abundant in the Coralline region (Alder): Dublin and Killiney Bays, common (Hassall) : north and cast coasts of Ireland, eommon and of large size (W. T.) : South Devon, not common; Lancashire coast, Lytham \&c., in the greatest plenty ; Ilfracombe, off the Capstone, 8-10 fms.; Llandudno, N. W.; Filey, Yorkshire; Oban, common (T. H.): Polperro, near the shore, rare (Couch) : Guernsey, after storms (R. S. Cooper).

Geographical Distribution. Seandinavia; Spitzbergen, 3-10 fms. (Smitt) : Grecnland (Lütken): Hammerfæst, rare, on Eudendrium ramosum; Harösund, frequently on

* "Growing much like a poplar tree."-Couch.

t Farre and $\operatorname{Van}$ Beneden gire 10 as the number, Dalyell 12-14, Sars 12. 
stones at extreme low-water mark (M. Sars) : Little Belt, near Fänoc, 10-26 fms. (Kirehenpauer): Sablc Island (G. Willisii) (Dawson): Labrador, $15 \mathrm{fms}$. (Wallich) : St. George's Banks, 50-85 fms. (Smith \& Harger) : White Sea (Mereschkowsky) : Ostend (Van Ben.).

The most striking characteristic, perhaps, of this species is the perfect simplieity of its strueture. There is no complexity in the arrangement of the parts; the general plan is plain and definite and singularly free from variability. There are no accessory appendages; even the radical fibres, which are generally very suseeptible of modifieation, are of the most rudimentary type.

The cells are at times more elongated below; and there are slight differenees of form, dependent on the degree in which the aperture slopes upward. From about the middle of the front surfaee, where the eell is thiekest, it narrows gradually towards the base; and from the same point the aperture slants more or less obliquely to the top. The pairs of eells rise immediately one from the other, each eell taking its origin at the back of the one below it, just behind the aperture, as in the genus Eucratea. The branches are given off from each side of the uppermost pair in a stem, elose to the top; and at times the stem aseends between them, and a triplet is formed in place of the more usual bifureation. The shoots rise from a trailing bundle of intertwining fibres of eonsiderable thickness, and are themselves composed towards the base of many tubular strands, some of which are carried up along the lower portion of the branches. There is a very grcat development of the radieiform fibres.

Alder mentions two varieties of this species-" the one rather more rigid, darker-eoloured, and with the branehes 
shorter and more numerous than in the other, which is very flaceid, pale, and with the terminal branches much attenuated."

G. Willisii, Dawson, from the coasts of Nova Seotia, which is said to differ from G. loricata " in its narrower and less-inflated cells and longer apcrtures, and in its more dense habit of growth," scems to me to present only the characters of a variety.

This species has suffered many things at the hands of systematists; and the formidable list of synonyms given above affords a striking illustration of the injury done to zoological scicnee by the unnecessary ereation of names.

Genus SCRUPARIA, Hincks.

Scruparta (part.), Hineks, Quart. Journ. Micr. Sc. v. (185T).

Generic Cinaracter.-Zoarium erect, branches given off from the back of a cell, and facing in the opposite direction. Zoccin subcalcareous, rising one from the other, so as to form a single series, or placed back to back. Aperture small, unarmed, slightly oblique, terminal. OvicelliGEROUS CELLS small and imperfectly developed, placed back to back with the ordinary cells. Oøcia terminal. No AVICULARIA Or VIBRACULA.

Tн1s genus is founded for Scruparia clavata, mihi. Further examination has convineed me that its peculiarities are such as to scparate it from the well-known Eucratea chelata, with which I had previously associated it.

I have adopted for the present genus Oken's name Scruparia, which would otherwise lapse altogether. No practical inconvenience, I believe, is likely to result from its retention with a new definition.

In 1858 Dyster established the genus Huxleya for a 
Polyzoon which he had obtained at Tenby, and named $H$. fragilis; and Norman has since identified this form with $S$. clavata, and has suppressed Dystcr's specific name in favour of minc *. Of course, if this decision werc well-founded, the present genus would be wholly superfluous.

I am quitc unable, however, to adopt the opinion of my friend Mr. Norman in this case. H. fragilis and S. clavata are, as I shall show, perfectly distinct forms, and, so far as our imperfect knowledge of the former will enable us to judge, are properly referred to different generic groups.

Dyster's description of his Huxleya fragilis would bc more satisfactory if it wcre morc minute; but the shape of the apcrture, which, we are told, is "rounded or semicircular above, and straight below," separates the species which he had in view conclusivcly from $S$. clavata. It is also noticeable that lis account of the mode in which the cells are connected could hardly have bcen suggested by the lattcr.

We have other important evidence to the same effect in the drawings of the two forms from Mr. Busk's accurate pencil, published in the 'Microscopical Journal.' It is only necessary to compare the figurcs of Scruparia clavata in the fifth volume of the Journal (plate xvii. figs. 5-8) with that of $H$. fragilis, taken from Mr. Dystcr's specimen, in the sixth volume (plate xxi. fig. 1), to be convinced that the originals wcre at least spccifically distinct. Not only the shape of the aperture, but its size and position arc shown by thesc figures to be different in the two forms, whilst there is also a striking dissimilarity in the charactcrs of the cell itself, and in the mode of branching. Wc have, then, two species to deal with.

As to the question of gcnus, if the principles which I 
have laid down for the definition of genera in this family be correet, we ean hardly hesitate to place the speeies under consideration in different groups.

The plan of the ramifieation in S. clavata, involving, as it does, the frequent oecurrenee of a biserial arrangement of the zoceia as in Gemellaria, and involving also the remarkable position of the ovicelligerous eell, is, in my judgment, a generie character. The differenee in the strueture of the aperture is also important. Scruparia is, I believe, as distinetive a form in its way as Gemellaria.

It may be regarded as intermediate in some respects between the last-named and Eucratea. In different states it presents the arrangement of the eells which is eharaeteristic of each of these genera: in some eases they are simply uniserial; in others two lines of cells are united back to back, and we have the general form of zoarium which belongs to Gemellaria. Perhaps the uniserial is the more common eondition; but intermingled with tall and well developed shoots of this elass there are generally others which hare assumed either wholly or in part the biserial eharacter. Frequently a shoot oceurs in which a few of the cells have others placed back to back with them, while the rest form a single series. A remarkable ehange also takes place in the eells which are united in pairs : they lose the elongated form which belongs to the uniserial elass, and beeome shorter and less slender in habit, so that the biserial shoots present a very striking eontrast in appearanee to the uniserial. The eells which earry the ovieells are, as in the genus Eucratea, partially developed; they are very short (about lialf the size of the ordinary eells), and have lost altogether the eharaeteristic form of the species. They are always placed back to back with another cell, exeept in the ease of biserial shoots, on which they are often, though 
not universally, developed at the side. Even on these, however, they are not unfrequently intercalated amongst the other eells.

The branelies are given off from the dorsal surface, rising from about the middle of it; and the cells composing them face in the opposite direction from those of the parent shoot. It is evident that the ovicelligerous eell is in most cases the first element of a branel, which is usually appressed to the shoot from which it rises, and united to it. Oecasionally, lowever, it remains free, and stands out obliquely from it, showing elearly its real signifieanee. It should be remarked that in Eucratea also the ovieelligcrous eell oeeupies the position of a braneh, and is in faet the first element of one, modified for the discharge of a speeial function.

To a ehange, then, in the plan of the ramifieation may be due the passage of the Eucratea-form into the Gemellaria-form. The braneh which in the former genus is given off in front originates in Scruparia at the back, and in many eases beeomes adnate to the shoot from whieh it rises; and we thus have as an oceasional eondition the form of zoarium* which is universal and permanent in Gemellaria.

The first eclls of the eolony are repent, as in Eucratea, forming a series of greater or less length, adnate to the surface on whieh the Polyzoon grows, from which the ereet shoots arise.

Scruparia clavata, Hineks.

Plate III. figs. 5-8.

Screparia clavata, Hincks, Quart. Journ. Micr. Se, v. 175, pl. xvii. figs. $5-8$.

\footnotetext{
* Essentially the same form, but with this differenco-that in Scruparia
} the cells are subalteruate, while in Gemellaria ther are exactly opposite. 
Zoarium sparingly branched. Zoccia sometimes uniserial, sometimcs in two scries placed back to back, clongatc, clavate, rounded at the top and attenuated downwards; each ccll attached to the dorsal surfacc of the onc below it, at some distance from the top, by a cordate expansion of the basc; aperture suborbicular, slightly produced and contracted below, not marginate. Oœcia globosc, with a few rathcr large punctures.

RANGE of Variation. I have noticed the principal variations to which this species is liable in the remarks on the genus, and shall mercly add the following detailed observations by way of illustration.

1. A line of eleven cclls ; from the third above the base, a branch giren off, and also from the sixth. Immediately below the higher branch a pair back to back, and immediately above it a pair, then an ovicelligerous cell. Also a pair immediately bclow the top cell.

2. A line of about seven cells; at the top two pairs back to back, and four ovicelligerous cells, two on each side, so that the shoot at this point exhibited four rows of cclls.

3. A normal ccll at the basc, then two pairs back to back, and an ovicclligcrous ccll at one side on the line of junction.

4. A long line of cells, the third being of the shorter form, and this alone having another cell back to back with it.

5. A line of seven cells; the fourth and fifth giving off cells at the back.

6. A normal scrics, with one or two ovicelligcrous cells at intervals on the dorsal surface.

Habitat. On other Polyzoa in shallow water.

Localities. Lamlash Bay, Arran; Filey Bay, off the Brigg, chiefly on Crisidia cormuta, abundant; on Cellularia 
Peachii either from Shetland or the Nortlumberland coast, probably the former (T. H.).

Scruparia clavata is a free grower : in Filcy Bay, where it is abundant, it spreads luxuriantly over the tufts of Crisidia, crecping along the stems, and sending off its linked eells at intervals as erect and slender shoots. It prescnts a curious diversity of appearance-now a single series of graceful elongate cells, now a double line in which the cells are shortened and the gencral aspeet is completely ehanged. The ovieclls are plentifully developed.

The aperturc is small, resembling that of a Lepralian cell; and the oral valve oecupics more than two thirds of its area.

\section{Genus HUXLEYA, Dyster.}

Der. Named in honour of Prof. Huxley.

Hưxleya, Dyster, Quart. Journ. Micr. Sc. vi. (1858), 260.

Generic Character.-Zoarium corneous or subcalcareous, dichotomously branched, the branches given off from the top or side of a cell, and facing in the same direction. Zoøcia uniserial; orifice small, subterminal, unarmed.

I HAVE somewhat altered Dyster's generic character. It represents the cells as biserial; but Mr. Busk's figure shows that this is not the ease in any true scnse. We have no direct information respecting the mode in which the zoarium is attached; but Mr. Busk represents tubular processes as given off from the sides of two of the eclls; and we may, I think, infer from their presence that Huxleya, like Gemellaria and Brettia, is attached by radiciform fibres and not by a crecping base. 
Huxleya fragilis, Dyster.

Plate II. fig. 1.

Hexuera pratarls, Dyster, Quart. Journ. Mier. Sc.vi. 260, pl. xxi. figs 1, 2.

Zoarium much branched, whitc and flexible, from half an inch to one inch high. Zoøecia pyriform, rounded above, narrowed but usually not much produced below, cach cell rising from the top of the one beneath it; orifice placed on the front of the cell, just below the top, very small, semicircular, with a straight lower lip; the margin unarmed and not thickened. Oxecia unknown.

Polypide with 10 tentacles.

Locality. Tenby (Dyster).

The differcnecs between this species and Scruparia clavala have already been pointed out. In this genus the oral valve is no longer placed at the top of a membranous area of greater or smaller size, but occupies the whole of the orificc and is immediately enclosed by the wall of the cell. The orifice is a simple semicircular opening, and scems not to be placed obliquely. The zoœcia in this species are not much attenuated and produced below, but arc somcwhat short and stout, and consequently present a much less elegant appearanee than those of Eucratea and Scruparia.

Genus BRETTIA, Dyster.

Der. Named after Mrs. Brett.

Bretria, Dyster, Quart. Journ. Micr. Sc. vi. (18j8).

Generic Charactrr.-Zoarium erect, corneous, branched, branches given off from the top of a cell a litlle to one side, and facing in the same direction as the cell. Zowcra uniserial, elongate, subtubular; aperture terminal or sub. 
terminal, large, with the oral valve at the upper extremity; margin armed with spines. OøCIA unknown.

From Scruparia this genus is distinguished by its mode of branehing and its eonstantly uniserial habit, by its subtubular eell, and large spinous aperture. From Huxleya it is separated by the shape and strueture of the aperture and by its elongate subeylindrieal eell.

\section{Bretria peluucida, Dyster.}

Plate IV. figs. 6, 7 .

Beettia Pellucida, Dyster, Quart. Journ. Micr. Sc. vi. (1858), 260, pl. xxi. figs. 3-5.

Zoarium perfeetly transparent, about half an ineh high. Zocecia mueh elongated, subeylindrieal, slightly expanded towards the aperture; aperture plaeed on the front of the eell, at its upper extremity, oval, rounded above, pointed below, with five to nine marginal spines, irregularly arranged. Oœcia unknown.

Polypide with 10 tentaeles.

Hавітат. On stone between tide-marks.

Locality. Tenby (Mrs. Brett: Dyster).

Nothing is known of this minute but eharaeteristie form beyond what we learn from Mr. Dyster's brief description and Mr. Busk's exeellent figure, whieh I-am permitted to eopy for this work.

\section{Brettia TUBAFORMIS.}

Plate II. fig. 2; Plate V. fig. 1.

Bretria Pellucida, Norman, Rep. Brit. Assoc. 1866, 196 \& 199.

Zourium minute, transparent, dichotomously branehed, surface smooth, attaelied by a number of tubular fibres. 
Zocecia elongate, somewhat trumpet-shaped, slender and tubular below, and expanding gradually upwards, with a distinet joint a little above the base; aperture terminal, slightly oblique, suborbicular, with about ten short spines round the margin. Oxcia unknown. Height about $\frac{1}{8}$ inch.

Localities. South-east eoast, on Fucus (R. S. Boswell): the Minch, Hebrides (A. M. N.).

Many years since, I reecived from Mr. R. S. Boswell a drawing of this form, which he had found on the English coast; but as it was unaecompanied by specimens, I was unwilling to publish it. In the mean time Mr. Norman dredged in the Minch a minute fragment of a species which he referred, in his Report on Hebridean Polyzoa \&e., to Brettia pellucida, Dyster. He was good enough to intrust it to me for examination; and it was with great pleasure that I recognized in it the species represented in Mr. Boswell's characteristic sketch (Plate V. fig. 1).

B. tubaformis is readily distinguishable from B. pellucida by the shape and proportions of the eell, and by the terminal position of the apcrture. The zoceium expands regularly from the slender base towards the top; and the upper portion is broader as eompared with the lower than in the last species. The cell of $B$. pellucida is almost cylindrical, that of $B$. tubaformis has the form, as its name denotes, of a trumpet. The position of the aperture at its summit, looking obliquely upwards, also produces a marked, change in the general appearance. In B. pellucida it is placed on the front surface immediately below the top. In one ease it is suborbicular in form, in the other obovate*.

The branehing is dichotomous and perfeetly simple.

- Mr. Boswell stntes (in litt.) that the oral spines are morable. 
The radical fibres are shown in Mr. Boswell's figure; and they are also present in Mr. Norman's fragment. They originate at various points on the surface of the lower cells.

\section{Family III.-Cellulariidæ.}

Cellularide, (part.), Johnston, Br. Zooph.

Cellulariade, Busk, B.M. Cat.

Cabereade, id. ibid.

Cellulariex (part.), Smitt, Krit. Förteckn., Gefvers. Skand. Hafs-Bryozoer.

Zoccis in two or more series, closely united and ranged in the same plane; avicularia and vibracula, or avicularia only, almost universally present, sessile. ZoARIUм erect, dichotomously branched.

IN this family the stems and branehes which compose the plant-like zoarium are formed of lines of cells plaeed side by side in the same plane, and intimately united. The strueture is compaet, and there is no tendency to the free and lax habit of growth which eharaeterizes the next group (Bicellariida). The eells are generally either suboval above, and more or less produeed and narrowed below, or subquadrangular. The aperture, which is usually armed with spines, and often protected by an opereular plate (modified spine), is placed on the upper portion of the front of the cell, and is for the most part direeted straight downwards. It is elliptieal or oval in form, and usually closed in entirely by a membrane; but in a few eases it is partially covered by a calcareous lamina.

As a rule the various appendicular organs are developed abundantly in this group. The marginal spines are often present in profusion, attaining a very large size, and assuming (as amongst the Menipea) very fantastic forms. 
The avicularia are of the sessile and fixed type, and exhibit, on the whole, a very constant and definitc arrangement. They are either disposed along the outer edge of the cells or on the front surface. The latcral avicularia are seldom absent, though where the median appendages are highly developed, they are more or less atroplied, and in some eases dwindle into complete insignificance. They are either attached to every cell, or each internode (in the jointed forms) carrics a certain number.

The vibracula are less universally present; but in certain sections of the family they attain a remarkable degree of development, and exhibit, perhaps with one exeeption, their most highly specialized form.

The radical fibres, by means of which the tufted zoaria are attached, exhibit many interesting modifications, corresponding strictly in some cases with the nature of the habitat, and assuming at times in the same species, under different circumstances, very different adaptive forms. I have referred to some of these curious modifications in the account of Scrupocellaria reptans*.

Though the family of the Cellulariida is properly described as rich in the secondary appendages, it possesses in the genus Cellularia a representative which is chiefly distinguished by the simplicity of its structure, and conneets it with the still simpler group of the Eucratiida.

In defining the limits of the present family, I have not ventured to cxelude the remarkable genus Caberea, although it presents some very striking peculiarities, and is distinguished from the rest of the tribe by the nonarticulated character of its zoarium. In other points of

- These interesting adaptations are not confined to this family. A remarkable instance of similar plasticity in the radical appendages is furnished by Bugula plumosa. 
structure there is the closest agreement between it and Scrupocellaria. The avicularia occupy the same positions in both, and though the vibracula are more highly developed in Caberea, they are essentially the same in strueture as those of the other genus. We have also a link between the two forms in the Canda arachnoides, Busk, an articulated species, in which the vibracular eclls are of large size, and stretch diagonally across two thirds of the length of the zoccium.

The non-articulated condition of the zoarium docs not appcar to be a point of so much signifieance as to warrant the separation of Caberea from forms with which it has such a close general affinity.

I retain the gencra Cellularia, Menipea, and Scrupocellaria as defined by Busk and Wyville Thomson, instead of uniting them, with Smitt, in a single division. The differences between them lie chiefly in the presence or absence and in the disposition of the appendicular organs (avieularia and vibracula). As there is undoubtedly much variability in these particulars, as the avicularia for instance are often present on some cells and absent on others within the limits of one and the same colony, and in some species are now present and now altogether wanting, it may be urged that these distinetions are purely arbitrary*. But it must be remembered that, with our present knowledge of the Polyzoa, a perfectly natural arrangement is unattainable, and that these groups are probably as good for their purposc as any that ean be substituted for them. They represent some of the principal modifications of the family type; and in point of fact each of them has, on the whole, a distinct and eharacteristic facies of its own.

"Vide "Floridan Bryozoa," by Prof. Smitt, part i. p. 16 (Kongl. Srenska Vetensk.-Akad. Handl. Band x. No.,11). 
Genus Cellularia, Pallas.

Der. From cellula, a diminutire of celia, a cell.

Celuularia, Pallas, Elench.: Busk: Smitt, part.

Buoula (part.), Gray.

Generic Ciraricter.-Zonrium jointed. Zocecia in two or three series, many in each internode, contiguous; dorsal surface perforated. Avicularia and vibracula usually wanting; occasionally an avicularium on a few of the cells in an internode.

There would seem to be no special reason for the appropriation of Pallas's name to this particular type; amongst the miscellaneous assemblage of forms which be has ranged under it, there is probably not one referable to Cellularia as here defined. But it is elearly most desirable to avoid any ehange of established nomenelature which is not imperatively ealled for; and as all the members of Pallas's genus seem to have a home elsewhere, there ean be no objection to the new application of his classieal name which we owe to Mr. Busk.

The only British member of this group is totally destitute of appendicular organs, and is remarkable for the neatness and simplieity of its strueture. The allied Australian species, C. cuspidata, elosely rescmbles it in general eharaeter; but in $C$. ornata, Busk, we meet with avieularia, which, however, are most sparingly developed and of a peculiar type. So far as my observation goes, they oceur only on three of the uppermost eells in each iuternode. They occupy a small triangular area, and are furnished with a semielliptical mandible.

I am inclined to think that we must regard both Cellularia and Menipea as descended from forms furnished 
with vibracula; they seem still to retain some obseure traees of these organs. In the latter the claspers or tendril-like fibres originate (in some cases at least) from a small swelling on the upper part of the zoccium, which oceupies the usual position of the vibracular eell, and is probably the remains of onc. In the present genus it is represented by a simple pore, from which the radical fibres proceed.

Celuularia Peachir, Busk.

Plate $\nabla$. figs. 2-5.

Cellularia Pracin, Busk, Ann. N. H. (2nd ser.) vii. 82, pl. viii. figs. $1-4$; B. M. Oat. i. 20 , pl. xxvii. figs. $3,4,5$ : Smitt, Kritisk Förteckn., CEfrers. af Kongl. Vetensk.-Akad. Förhandl. 1867 , no. 5, 285 \& 322 , pl. xvii. figs. 51-53.

Cellularia neritiva, var., Johnst. B. Z. 340 (teste Busk).

Bugula neritins, var. $b, c, d, e$, Gray, B. M. Cat. Radiata, 114.

Zoarium white and glossy, dichotomously. branched, forming slender phytoid tufts. Zoccia biserial, alternatc, elongate, attenuated downwards, with a small spine on the upper and outer angles, frequently wanting; aperture oval, sometimes much lengthened, and narrowed below, occupying about two thirds of the front of the cell; margin thickened slightly, and minutely granular; dorsal surface smooth, with 3-5 perforations; commonly a spine on the summit of the median eell at each bifureation. Oœcia subglobose, surface tessellated.

Range of Variation. The eells are more or less produced below; and the shape of the aperture varies from a pretty regular oval to an elongated form, narrowed towards the bottom. The granulated margin is not always present; and the marginal spine is very frequently wanting. 
Habitat. On stones, shells, zoophytes, \&c.; from deep water chiefly.

Localities. Peterhead; Wick, rare (C. W. P.): Buchanness; Tynemouth; Copinstra (Licut. Thomas) : Northumberland, from the five-men boats, not uncommon (Alder): Slietland, haddock-grounds and Outer Haaf, frequent (A. M. N.) : Searborough (Bean) : Aberdecushire (Dawson).

Grograpilical Distribution. Bahusia (Lovén); Spitzbergen, Henloopen, 30-60 fathoms; King's Bay, muddy bottom 200-250 fathoms (Torell and Swedish Expedition, 1861) : South Labrador, rare (Packard): Hamilton's Inlet, Labrador, 15 fathoms (Wallich) : Gulf of St. Lawrence (Dawson) : St. George's Banks, 150 fms. (Smith and Harger).

In this species the two rows of cells do not present a perfectly plane surface; each of them slopes slightly outwards, so that the eentral line of junction appears elevated, and the front of the shoot somewhat carinate. We may recognize in this, as in other points of structure, an approach to the genus Nellia, Busk, in which four series of cells are so united as to form a subeylindrical shoot. The present form has the closest affinity with the last-named genus, the eclls of the two being identical in character; and if we were to imagine two shoots of Cellularia placed back to back and united, we should lave a zoarium very like that of Nellia simplex, Busk.

Cellularia Peachii is furnished with a great number of very long tubular fibres, more or less anuulated, which are given off from the dorsal surface, ehiefly towards the lower part of the shoots. Many of them are perfectly simple; but others terminate in a number of fibrils or rootlets, by means of which they adhere. The sloots are 
divided into segments, which arc united by corncous joints. There are usually about 7-9 eclls in cach internode; but the number varies. Branehes are given off diehotomously; and at each bifurcation an additional eell is intcrposed, oceupying the spaee between them at their point of origin, which is surmounted by a short acuminate spine. Mr. Busk makes the presence of this cuspidatc proeess a distinetive mark of the Australian speeies C. cuspidata, but it belongs to $C$. Peachii as well.

\section{Genus MENIPEA, Lamouroux.}

Der. From Menipea, one of the Nereïds, according to Hesiod.

Cellaria (part.), Linnæus.

Menipea, Lamx. Bulletin Soc. Phil. 1812; Pol. Cor. flex.: Busk: Wyville Thomson, Dublin N.H. Rev. July 1858.

Crisia (part.), Lamouroux.

Tricellaria, Fleming, Br. An.

Cellularia (part.), Johnst. Br. Zooph: Smitt.

Cellarisa (part.), Van Beneden, Bull. Ac. Roy. Belg. 1849.

Eммa, Gray: Busk.

Generic Charaeter.-Zoceia oblong, widest above, attenuated and often elongated downwards; imperforate behind, with a sessile lateral avicularium (often wanting), and usually one or two avicularia on the front of the cell. No vibracula. Zoarium jointed.

The type of Lamouroux's genus Menipea is the $M$. cirrata*, a large species with six eells to the intemode. More eommonly they are disposed in triplets; and the division of the zoarium into short segments, each carrying a small eluster of eells, may be regarded as a charaeteristic of the group, though there are ccrtain exceptions.

* The eurled branches from which it takes its name are a striking feature of the genus. 
Menipea is distinguished from the Scrupocellaria by the total absenee of vibracula; but it also differs from them markedly in habit and what may be called its general expression.

The Menipere arc, for the most part, climbers; and the (so-callcd) radical fibres are modified, in most eases, so as to act as prehensile organs. This is the ease with our own $M$. ternata, and with all the smaller kinds. The branches too are incurved or eurled towards the extremities, and twine around zoophytes and algx like tendrils. The habit of the group is irregular and straggling; it exhibits much of the freedom of growth and wild luxuriance which characterize the tribe of ereepers amongst plants. In all this it eontrasts with the kindred group of the Scrupocellarice, which are much stiffer and more compact in habit, and generally ereet in their mode of growth, and which are never climbers.

Certain sections of the Menipece are also distinguished by the high degree of derelopment which the corneous joints, connecting the clusters of cells, attain amongst them. This is remarkably the ease in the very characteristic and beautiful group of species which occurs in the Australian seas. In these the tube which links together the internodes is often of very considerable length, and the glittering triplets or doublets of cells appcar as if strung on a slender thread. So transparent are thcy and sparkling, that they might be wrought in crystal; over the aperture there often bends a pretty antlcr-like opereulum, while the margin bristles with tall eurred spines, which seem to embower the little mansion. These spines are always attached to the edge of the aperture by horny joints.

Australian algae are abundantly wreathed and adurned by the various members of this attractive group. 
In the larger species the characteristics just referred to are mueh less strongly marked, and there is a tendeney towards a much stouter and more crect habit.

The Menipece are widely distributed. A small gronp oceurs in the Aretic Seas, of which two forms at least range to the North-American const (Gulf of St. Lawrence and Bay of Fundy). In these northern regions they grow vigorously, and seem to produce their ovicells much more freely than in more genial elimes. They have also occurred at the extreme point of the South-Ameriean eontinent (Ticrra del Fuego and Falkland Islands), in New Zealand and Australia, where they are well represcnted, and in South Africa. The Aretic spceies arc elosely related to $M$. ternata, and offor a decided contrast in scveral points to the Australian forms. The ovicells of one of the latter Sir Wyville Thomson deseribes as immersed; and if this eharacter should be general throughout the southern group, it may perhaps have a elaim to generic rank.

Menipea ternata, Ellis and Solander.

Plate VI. figs. 1-4.

Celilamia ternata, Ell. \& Sol. Zooph. 30.

Crisia ternata, Lamx. Pol. Cor. flex. 61.

Tutcellahia teknata, Flem. B. A. 540 : Gray, B. M. Cat. Radiata 113.

Celuvaria temxata, Johnst. B. Z. (ed. 2) i. 335, pl. lix. : Smitt, lírit. Förteckn. iii. 282 (1867).

Celuarisa gracius, Van Ben. Bull. Ac. Roy. Belg. xv. 7 (sep.), pl. x. figs. 1, 2.

Menipea tenxata, Busk, B. M. Cat. i. 21, pl. xx. fig8. 3-5.

Zoarium confervoid, forming delieate white bushy tufts, dichotomously branched, the branehes straggling; internodes consisting of a triplet of eells. Zovecia elon- 
gated, much attenuated downwards; aperture oval, occupying a small proportion of the length of the cell, with three spines, two at the top and one sone way below it on the outer margin; opereulum small, entire, variable in shape. Lateral avicularia large and prominent, gencrally present on the two lower eells in the internode; one anterior avicularium on each cell, immediatcly below the aperture, or, very eommonly, on the uppermost cell alone, minute, raised; mandible direeted downwards. Oxcia elongated, smooth.

Radical fibres simple, given off from the lower parts of thic shoots; many of the branelies furnished with long tendril-like elaspers, originating from the side of a eell immediately above the lateral avicularium, near the top of the internode, enlarged and curled above and open at the free extremity.

Primary cell short, cup-shaped, with a round terminal aperture surrounded by 10 or 11 spines.

RANGe of Variation. The cells are sometimes much more elongated than at others, or, I should rather say, the two lower eells in the internode, for the uppermost, which is plaeed at the bifureation, is always shorter than the rest, and does not appear to change much. The elongation of the cells of eourse gives a more slender and graceful habit to the shoots. The specific charaeter given above is founded on what seems to be the usual normal form. Occasionally an internode oceurs consisting of 4-7 eells, the rest being the usual triplets ; but sueh eases seem to be very rare. The variety gracilis, described by Smitt from the Aretic seas, has universally a large number of cells in each internode; the cells are shorter, straighter, and of more equal width throughout than in the present form; the lateral avicularia are very small, and both the spines and opereula seem to be sparingly developed. I belicre that this form, of which I 
have reecived abundant specimens, through Dr. Dawson, from the Gulf of St. Lawrence, is properly accounted a variety. It differs very slightly from $M$. arctica, Busk*.

The latcral avieularium is not devcloped on the uppermost eell, but is usually present on both the otlicrs, occasionally only on one of them. It varies mueh in size: sometimes on the same internode one of the avicularia is very much larger than the other, attaining comparatively gigantic dimensions. On the whole the size of the lateral appendages is remarkable in this spccies. The anterior avicularium I have generally found on the front of the terminal cell above, and nowhere else. But it is sometimes developed on every ecll, and is so figured by Busk. It is very minute, as we should expect, considering the large size of the lateral appendages. The changes in the form of the operculum are simply due to differenees in the stage of development. Regarded morphologically, it is a modified spine; and in its first stage it appears as a simple spinous process. It gradually expands into a broad protective shield or lamina; as it enlarges extension takes place ehiefly in the dircction of the bottom of the cell. When mature it is suboval or somewhat wedge-shaped. The spines vary in number. There are sometimes three or four, frequently only two. One of them is usually placed some way down on the outer margin, almost fronting the operculum; and it is often enormously developed, exceeding the intcrnode in height.

Habitat. On Algre in the littoral zone, and on various Hydroida (chiefly), shells, \&c. from shallow to decp water (100 fathoms).

* I have received from Mr. Peach two or three minute fragments of $\Omega$ Menipea from Shetland, in which the form of the cells is that of the gracilis variety. They also show a larger number in the internode than is characteristic of the normal $M$. ternata. But their condition is tou imperfect to allow me to determine whether they should be referred to this variety, or to one of the closely related forms $M$. arctica and $M$. Smittii. 
Localities. Aberdcen (Dr. Skene) : Scarborough, deep water, on a valve of Cytherea and on Hydroids, not rare (Bean) : Filey, very abundant on zoophytes (T. H.) : Stonehaven (Lady Keith Murray): Northumbcrland, from the deep-water boats, occasionally (Aldcr) : Cullereoats, rare (Alder and Coppin): St. Andrew's, from the deep water of the bay (Dr. M'Intosh): Peterhead and Wick (C. W. P.) : Shetland, on Tubularia indivisa, from 70 fathoms (A. M. N.).

Geographical Distribution. South Labrador (Packard) : Hamilton's Inlet, Labrador, 15 fathoms (Wallich) : Greenland (A. M. N., 'Valorous' dredg.) : off Frederiekshaab, 100 fathoms, not uncommon; Reykjavik Harbour, Ieeland, 15-20 fathoms (Wallich) : ? Grand Manan, 20 fathoms, shelly bottom (Stimpson) : Gulf of St. Lawrence (Dawson): St. George's Banks, 28-85 fathoms (Smith and Harger): Scandinavian coasts, ehiefly on Algæ in the littoral region (Smitt): Hammerfest; Lofoten (Sars) : White Sea (Mercschkowsky): West of Jütland, 10 fathoms (Kirchenpaucr): Bclgium (Van Beneden).

This attractive species is cssentially a climber. Its favourite habitat is on the larger Hydroida (Hydrallmania, Sertularia argentea, \&c.), to which it binds itself by its numcrous claspers, twining amongst their branelies and festooning thcm with its delicate pearly tufts. The tubular fibres, which on the lower portions of the shoot are simply adherent, are modified on the higher branches for the discharge of a different function. They are thickened and curled at the extremity, and eonverted into tendrils, which bear a close resemblance to the similar appendages on Diphasia fallax and other Hydroids. These claspers are distributed in considerable numbers over the branches.

They originate at the base of a swelling on the side of the zoocium, just above the lateral avicularium, which is 
probably the remains of the vibracular cell. It still retains the general form of the latter, but has lost its distinetive streuture. In Cellularia all trace of it has disappeared with the exeeption of the pores from whieh the radieiform fibres originate, and which are present on every eell.

M. ternata sometimes attains the height of an inch or more, but is gencrally of smaller size.

\section{Menipea Jefreeysit, Norman.}

Plate IX. figs. $1,2$.

Meniped Jefreersi, Norman, Quart. Journ, Micr. Sc. 1868, (n. 8.) viii. 213, pl. v. figs. $4-8$ *.

Zoarium dichotomously branehed; internodes short (4-7 eells). Zoccia biserial, alternate, elongated and narrowed below; aperture regularly oval, margin a little raised, with 3 (or 4) spines at the top; opcreulum entire. Lateral avicularia small and ineonspicuous, placed immediately below the spines; on the front of the eell below the aperture, a raised avicularium, with pointed mandible, direeted downwards. Occia subglobose, smooth.

Locality. Shetland (C. W. Peach). A few minute fragments only were obtained, among sand dredged in Shetland by Mr. Jeffreys and Mr. Norman.

We know nothing as yet of the size or general habit of this speeies. The diagnosis is founded on a mere fragment kindly lent me by Mr. Norman. There is nothing very marked in the minute eharaeters; the raised and prominent avieularium at the base of the aperture is perhaps the most striking feature.

I have found it diffieult to determine the exaet number of the spines, from the eondition of the speeimen; but it

* In fig. 8 the operculum is erronconsly represented us lobed. 
seems not to exeeed three, exeept in the ease of the terminal cell at the bifureation of the branches, whieh bears an additional one in the eentre of the upper margin. Two are generally present on the outer side of the eell at the top; and immediately beneath these is plaeed the very small lateral avieularium. A single spine is also developed, I believe, elose to the pediele of the opereulum. The opereulum originates very high up on the margin of the eell, and tends somewhat obliquely downwards; the lamina expands almost exelusively below, and fills in the inferior portion of the aperture. The surface of the zoarium is smooth and shining.

Menipea Smittii, Norman (=Cellularia ternata, forma duplex, Smitt), a Spitzbergen species, is nearly allied to the present form, but differs from it in not being furnished with either opereulum or spines.

\section{Genus SCRUPOCELLARIA, Van Beneden.}

Der. From serupus, a stone, and cella, a cell.

Screpocellaria, Van Beneden, "Recherches" \&c. 1814.

Bicellaria, sp., Blaiuville.

Cellucaria, sp., Pallas: Johnston: Smitt.

Cellaria, ep., Ell. \& Sol. : Lamk.

Scrtparia, sp., Oken.

CAsDA, sp., Busk.

Geseric Character.-Zoarium jointed. Zowcia mumerous in each internode, rhomboid; aperture with or without an operculum; a sessile avicularium placed laterally at the upper and outer angle, and a vibraculum in a hend or sinus on the lower part of the dorsal surface; fiequently an avicularium on the front of the cell.

Some of the differences between this and the preeding genus have already been pointed out. The leading cha- 
racter of Scrupocellaria, and that which gives it its distinguishing facies, is the association of a lateral avicularium and a dorsal vibraculum on each cell. The position of these appendages is very constant; and though one or the other may be occasionally absent, they are generally to bc met with on most of the cclls in a colony. They vary much, under differing circumstances, in the degree in which they are developed. The lateral avicularium, which is sometimes almost gigantic, is occasionally so much atrophicd as to be hardly distinguishable. The cause of the reduced condition in such cases may be found in the size and number of the avicularia on the front of the ccll, which have superseded it by discharging its functions. The vibracula also arc sometimes much below the normal size, but seem to be less liable to variation than the avicularia. In one species from the Gulf of St. Lawrence and also (I believe) from the Meditcrranean, the vibracular eell is unusually large, stretching completely across the back of the zoøcium to the median linc, and traversed throughout by the groove or fissure, in which the vibraeulum itself rests. This form makes an approach to Caberea.

The habit of the Scrupocellaria is erect, and their mode of growth regular and somewhat stiff. The internodes are long, and the corneous joints but slightly developed. They want the graccful curled extrcmitics of the Menipea; and the prehensile appendages of the latter are supplanted by modifications of the fibrils, which act chiefly as organs for fixing the zoarium in its place. Instcad of tendrils and claspers we have grapnels.

The Scrupocellaria form a rather large group, and are widely distributed. S. scruposa, which is so common in the seas of Europe, ranges from Norway to New Zealand. The genus is represented sparingly in the Arctic seas 
and on the Northern shores of Amcrica; but the number of species increascs in morc southern latitudes. About twenty are known. The genus has becn traced back in time as far as the Miocene deposits of Austria.

\section{a. Without an operculum .}

Scrupocellaria scruposa, Linnæus.

Plate VII. figs. 8-10.

Cresping Stony Coralline, Ellis, Corall. 38, no. 4, pl. xx. c. C.

Sertularia scruposa, Linn. Syst. 1315.

Celuularia scruposa, Pall. Elench. 72 : Flem. B. A. 539: Reid, Ann. N. H. Dec. 1845,388 , pl. xii. figs. 6, 7 : Johnston, B. Z. ed. 2, 336, p'. Iviii. figs. 5, 6: Smitt, Kritisk Förteckn. iii. 285 \& 320, pl. xvii. figs. 42-50.

Cellarta scruposa, Ellis \& Sol. Zooph. 23: Lamk. An. 8. Fert. ed. 2, ii. 192.

Scrtparia scruposa, Oken, Lehrb. Naturg. Zool., Abth. 2, 90.

Crisia scruposa, Lamx. Cor. 60.

Biczilaria scruposa, Blainville, Actinol. 459.

Scrupoceluaria scruposa, Van Ben. Recherches, 43 and 50, pl. $\nabla$. figs. 8-16 : Busk, B.M. Cat. i. 25, pl. xxii. figs. 3, 4: Gray, B.M. Cat. Radiata, 111.

Zoarium rather stout, dichotomously branched, internodes of moderate length (7-11 cells), forming large bushy tufts, of a white colour. Zocecia biserial, altcrnate, rather short, ovate, produced and slightly narrowed bclow; apcrturc regularly elliptical, occupying more than half of the front, with a thin margin, and two slender spines on each side above, often of considerable length. Lateral avicularia large and prominent, with a slightly hooked beak, which is toothed; no avicularia on the front of the cell. Vibracular cell crect, narrow, aperture perpendicular. Ooecia small, with a smooth surface, inclining inwards.

Radical fibres slender, smooth, giren of from the lower part of the zoarium, adherent by means of a terminal 
cnlargement (witliout fibrils); or furnished with hooks. Primary cell with a round aperture and eight marginal spines, four on the upper border and four in front.

Polypide with 12 to 16 long tentaeles, of a light orange colour.

Habitat. Between tide-marks, under stones \&e., and on Laminaria, Flustra, stones, shells, zoophytes, \&c. from shallow to deep water (40-80 fathoms, Shetland).

Localities. Generally distributed round our coasts.

Geograpuxcal Distribution. Ostend, on Flustra (Van Bcneden): French eoasts (Kirehenpauer): Nortlı Sea to Bahusia and Middle Norway, eommon (Smitt) : Heligoland; Iceland; North America (Kirehenpauer) : Adriatie, eommon (Grube and Heller) : Lyall's Bay, New Zcaland (F. W. Hutton).

RaNGe IN Trme. Corallinc erag (A. Bell): Scoteh Glacial deposits (Geikie).

This is one of our commonest Polyzoa. Its nearcst British ally is $S$. elliptica; but, as I have pointed out in the aeeount of that speeies, the two are distinguished from one another by a group of well-defined differenees. The lateral avieularia in the present speeies are very fully developed, compensating; we may suppose, by their size and prominenee for the total absenee of auxiliary organs on the front of the zoarium. They are smallest at the base of the internodes, and incrcase in size as they approach the top.

Scrupocellaria elliptica, Reuss.

Plate VI. figs, 5, 6.

Scrupocellaria elliptica, Reuss, Fossil. Bryoz. d. österreich.-ungar. Miocïns, 8, plate ii. figs. 1-9. 
Sceupoceliaria iseruis, Norman, Rep. Br. Assoc. 1866, 203 ; id. Quart. Journ. Micr. Sc. 1868, (n. 8.) viii. 215, pl. v. figs. 1-3.

Zoarium jather stout, ycllowish horn-colour, dichotomously branehed. Zoceia oblong; aperture elliptical, witl a broad flattened margin, destitute of spines and opereulum. Lateral avicularia not prominent; no avieularia on the front of the eclls. Vibracular cell subtriangular, scareely so broad as high, aperture stretehing diagonally downward and inward. Setce short. Oxcia smooth, imperforate, inelining inwards. Height about $\frac{1}{2}$ ineh.

Habitat. Moderately deep water.

Localities. 5-8 miles off Balta, in 40-50 fatloms, rare; the Minch, Hebrides (A. M. N.) : Shetland (C. W. P.) *.

Ravge in True. Austro-Hungarian Miocene (Reuss).

S. elliptica is not unlike $S$. scruposa in many respects, but is elearly distinguished from it by the broad and flattened margin of the apertures, the absenee of spines, the somewhat less prominent lateral avieularia, and, above all, the broad, triangular vibracular cells, with their slanting apertures. The last is ecrtainly the best distinetive eharacter.

There ean, I think, be little doubt that the prescnt speeies is identical with $S$ : elliptica of Reuss, a fossil form which is abundant in some of the Tertiary deposits of Austria. There is a minutc agreement between the two in most of the details of structure. The only points in which there may possibly be a slight differeuce are of sccondary importanec. Reuss states that there are occa-

* Kirchenpauer records this species from Greenland; but as he identifies it doubtfully with Smitt's Cellularia scalra, forma elongata, from which it is clearly distinet, I give this locality with reserve. 
sionally two or three small depressions on the upper margin of the eell, which, he thinks, may mark the positions of as many spines. Whaterer these depressions may be, they seem to be rarely present; and should they denote the oceasional development of spines in the living state, this fact could not outweigh the evidence of identity supplied by every leading feature, including the very distinetive form of the vibracular eell. As Reuss's name was published in 1847, it must, of course, supersede Norman's, which only dates from 1866. To the latter we are indebted. for the addition of the species to the recent Fauna.

\title{
b. With an operculum.
}

\section{Scrupocellaria scabra, Van Beneden.}

\author{
Plate VI. figs. 7-11.
}

Sertularia halecins, Fabr. Faun. Gronl. 443 (teste Smitt).

Flustra scruposa, Fabr. Nye Zool. Bidr. in Vid. Selsk. Phys. Skr. 1827-33 (teste Smitt).

Cellarisa scrabra, Van Ben. Bull. Acad. Roy. d. Belg. xv. No. 2, 73, figs. 3-6.

Celuularia scrupes, Alder, Trans. Tynes. Olub, iii. 148 (North. Cat. sep. 58).

Scrupocellaria scrupea, Busk, Quart. Journ. Micr. Sc. iii. 254.

Scrupocelearia DeliliI, Busk, Quart. Journ. Micr. Sc. vii. 65, pl. xxii. figs. 1-3: Alder, Quart. Journ. Micr. Sc. (n. s.) iv. pl. iii. figs. 4-8; North. \& Durham Nat.-Hist. Trans. i. 163, pl. viii. figs. 4-8.

Cellularụ scabra, Smitt, Kritisk Förteckn., Effers. af K. Vet.-Akad. Förbandl. 1867, 283 \& 314, pl. xvii. figs, 27-34.

Scrupocellaria scabra, Norman, Quart. Journ. Micr. Sc. (n. s.) viii. 214.

Zoarium slender, dichotomously branched, internodes moderately long (about 5-12 eells in each). Zocecia short, ereet, narrowed below; aperture oval, with a smooth border, occupying more than half the front, with one stout spine (or frequently two) on the outer margin above, and a smaller one on the inner. Oper- 
culum entire, suboval; a portion of the surface slightly hollowed out, forming a depressed area, with a lobate margin. Lateral avicularia moderately large, with a slightly hooked beak; a pedunculate avicularium on the lower part of each eell, below the aperture.

Vibracular cells wedge-shaped, stretching transversely across the back of the zoccium; vibracula short, not execeding the cell in length. Oxcia somewhat flattened in front, subglobose, with a smooth subtriangular space above the aperture, from which fine lines radiate towards the margin.

Radical fibres long and slender, and scattered over the whole of the zoarium.

Height about $\frac{1}{2}$ to $\frac{3}{4}$ inch.

Habirat. On stones, \&c., from shallow to deep water.

Localities. Northumberland coast, from the decpwater boats (Alder): Durham coast (Brady and Hodge): off the Firth of Forth, one specimen (C. W. P.).

Geograpiical Distribution. North Sea (Van Ben.) : Seandinavian and Aretic seas (Smitt): Spitzbergen, 6 fms., and more frequently 80-150 fms. (Swedish Exped.): Davis Straits, off Frederickshaab, 100 fms. (Wallich) : Greenland, Godhavn Harbour, Disco, 5-20 fms. ('Valorous' dredg.) : Reykjavik Harbour, 15-20 fms. (Wallich): Madeira (J. Y. Johnson).

$S$. scabra bears a strong general resemblance to $S$. scrupea, but differs from it in several important particulars. The opereulum presents commonly a three-sided figure, narrowing off towards the peduncle. It is depressed in the eentre, and is not unlike a saddle in shape. It is further distinguished by the hand-like pattern seulptured on its surface. The lateral avicularium is smaller than that of the allied species, and wants its strongly marked beak. On the other hand, the pedunculate avicularia are of larger size, and much more eonstantly present. 
But the most striking differcuce is found in the vibractlar appendage, which in S. scabra is of a very remarkable type, and totally unlike the form which prevails throughout this geuus. Instead of being crect, with a notch or cleft at the top in which the movable seta works, it lics across the back of the ecll, its shape and structurc reminding us of the fixed basc or beak of a sessile avicularium, while the setiform process is reduced in sizc and capability of movement, and rather performs the part of a mandible than of the vibraculum, with its free and vigorous swing. We cannot fail to rccognize in this modified structurc a transition form between the avicularium and vibraculum, which is of the highest morphological interest. In this species the vibracula are commonly wanting on many of the cells.

Amongst the minor characters may be mentioned the short spine which occurs at the top of the median cell at cach bifurcation of the branch. The internodes arc shorter than those of S. scrupea, but still of considerable length. Specimens from Greenland are much stoutcr and more massive that those from the Northumbcrland coast; and the speeies would seem to bc spccially a northcrn form, though ranging to Madcira.

Scrupocellaria scrupea, Busk.

Plate VII. figs. 11-14.

Scrupocellaria scrupea, Busk, Annals N. II. ser. 2, vii. 83, pl, ix. figs. 11, 12 ; B.M. Cat. i. 24, pl. xxi. figs. 1, 2: Heller, Bryoz. d. Adriat. M. 10 (sep.): Norman, Quart. Journ. Mier. Sc. (n. s.) viii. 214 (3 sep.).

Zoarium erect, the shoots dichotomously divided, internodes much clongated. Zoocia biscrial, alternatc; 
short, orate above, produeed and slightly narrowed below; aperture oval, oeeupying about half the front, with three spines on the outer margin above, and one, or oeensionally two, on the inner. Operculum somewliat reniform, entire, narrow and pointed above, cxpanded below and rounded, the upper extremity elevated. Lateral avicularia large and conspieuous, with a strongly hooked beak; small raised avicularia sometimes distributed along the median line, often wanting. Vibracular cell ercet, somewhat wedge-shaped. Oxcia rounded; surface smooth, shining and imperforate. Height $\frac{1}{2}$ to $\frac{3}{4}$ inch.

Habitat. On Algæ, stones, \&e. from shallow and deep water.

Localities. Off Dartmouth (E. Forbes): Cornwall, off St. Ives, on stones; off Berry Head, Torbay; Salcombe Bay, not uneommon; Guernsey (T. H.) : Northumberland, from the deep-water boats, a single speeimen (Alder) : the Minch (A. M. N.).

Geographical Distribution. Mediterranean (M'Andrew) : Adriatic (Grube and Heller) : Australia (MaeGillivray): Singapore (Liverpool Free Museum, teste T. H.).

This speeics lias an opereulum with a simple, unbranehed, and perfeetly smooth lamina, and in this respeet differs botll from S. reptans and S. scabra, the only other British opereulated forms.

The avieularia, which are disposed along the front surface of the zoarium, are very small; and I have only noticed them where the oceia are present; they arc eertainly very sparingly developed. They are plaeed immediately above the ovieclls, with the mandible directed alternately towards opposite sides, and probably rise from the front or side of the cell a little below the aperture. 
The internodes in this species are remarkable for their length, eonsisting frequently of as many as 20 cells. The habit is sometimes stout and massive, and the tufts short and compact; but I have a beautiful varicty from Guernscy, in which the shoots are more slender and rise to a height of $\frac{3}{4}$ inch.

On the lower segments an immense number of smooth and slender fibres are given off from the vibracular cells, which tend downwards and become adherent.

Scrupocellaria reptans, Linnæus.

Plate VII. figs. 1-7.

Creepina Coraluine, Ellis, Corall. 37, no. 3, pl. xx. fig. $b, \mathbf{B}$.

Sertularia reptays, Linn. Syst. (ed. 12), 1315.

Cellularia reptans, Pall. Eleneh. 73: Reid, Ann. N. II. Dee. 1845, 385, pl. xii. figs. 1-5 : Johnst. B. Z. ed. 2, i. 337, pl. Iviii. figs. 3, 4 : Dalyell, Rem. An. i. 235, pl. xlr.: Smitt, Kritisk Förteekn. iii. (1867), 284 \& 318, pl. xvii. figs. 37-41.

Sertularia repens, Berkenhout, Synops. i. 220 (1789).

Cellaria reptans, Ell. \& Sol.Zooph. 23 : Lamk. An. s. Vert. (ed. 2), ii. 191. Scruparia reptans, Oken, Lehrb. Naturg. Abth. ii.'90.

Crisia reptans, Lamx. Pol. corall. flex. 60.

Acamarcirs Georrroyi, Audouin, Expl. i. 241 : Savigny, Egypte, pl. xi. fig. 4.

Bicellaria reptans, Blainv. Aetinol. 459.

Scrupocellaria reptans, Gray, B.M. Cat. Rad. 112.

Caxda reptans, Busk, B.M. Cat. i. 26, pl. xxi. figs. 3, 4.

Zoarium crceping, branches divided dichotomously into numcrous segments, broadly expanded, flabelliform. Zoocia biscrial, alternate, ovate, produced and narrowed below; aperture oval, oceupying about two thirds of the front, with a somewhat thickened rim, three pointed spines on the outer side at the top and one opposite to them on the inner side; a branched pedunculate opereulum rising from the inner margin. Sessile avicularium on the outer edge, placed at the very top of the cell, minute, and set back behind the spines; at the 
base of many of the cclls a large pedunculate avicularium, with the mandible dirceted downwards. Vibracular cell somewhat curved, with a constriction about the middle. Oocia subglobosc, smooth, with a number of largc punctures. Radical fibres either simplc, and giving off at the cxtrcmity a number of anastomosing fibrils forming a netted disk, or toothed.

Polypide with 14-16 tentacles of a light orange colour.

Habitar. On Algæ, Flustra foliacea, rocks, \&c., from between tide-marks to deep watcr.

Locslities. Universally distributed. It may be found on the most barren coasts. It is morc especially a littoral form, spreading luxuriantly over various kinds of seaweed; but Mr. Pcach records its occurrence on coral taken in 100 fms., from the Outcr Haaf, Unst.

Geograpirical Distribution. Bahusia and Middlc Norway, pretty common in the littoral region (Smitt): Heligoland (Kirchenpauer) : Red Sea (?) (Savigny): Adriatic, common on Algr, zoophytes, Polyzoa, \&c. (Hcllcr) : north coast of France; coast of Spain (Kirchenpaucr).

Range in Tume. Scotch Glacial deposits (Geikic).

Mr. Busk has placed this wcll-known form in the genus Canda, Lamx., on the ground that it is destitute of the lateral avicularia, which constitute so striking and distinctive a feature of the allied genus Scrupocellaria, Van Ben. Smitt ranks it under his Cellularia, which cmbraces the last-named group, but agrecs with Busk in denying the existence of lateral avicularia*. In fact, however, the prescut species is furnished with these appendages, though they are minute and arc not developed on all the cells; and it therefore takes its place of right in the genus Scrupocellaria, with which, in all other respects, it entircly

" "Avicularia lateralia externa desunt " (Snitt). 
agrees. The smallness of the avicularia, and the faet that they are so plaeed as to be partially concealed by the spines, may explain their having eseaped the notice of sueh aecurate and experienced observers.

In S. reptans these lateral appendages are elearly dying out. They are only found on some of the eells, and, as I have said, are generally extremely small, mere pygmies as compared with the similar structures on such a form as S. scruposa. They are placed elose to the top of the eell, and just behind the triplet of spines. From their redueed size they do not extend down the side of the eell, and are therefore very inconspicuous and liable to be overlooked.

On the otlier hand, the peduneulate avicularia, plaeed at the bottom of a certain number of the eells in each internode, are most fully developed, and attain a comparatively gigantic size. We may no doubt trace a collnexion between their vigorous condition and the dwindling of the lateral appendages, which must be due to their comparative uselessness, and therefore disuse *.

These large avicularia are situated on the inferior portion of the eell, below the aperture; and though not connected with every cell, there is a certain definite and constant number on each internode + . Between the joints

* Sunitt has remarked that "on the whole the rule holds good for this genus" (Cellularia, including Scrupocellaria), "that the more the lateral avicularia are developed, the lcss are the anterior" (Kritisk Förteckn. part iii. p. 305, footnotc), a remark which I can fully confirm; and I believe that the converse is also truc. We have a remarkable illustration in S. ferox, Busk, a specics from Bass's Strait, which possesses a very large pedunculate avicularium, occupying almost the whole front of the cell below the aperture, with a long curved mandible, whilst its lateral avicuInria are rudinentary and quitc insignificant. 'The relative development of the two classes of aricularia is much the eame in S. diadema, Busk.

+ I3usk speaks of the front avicularia in this genus as "disposed in a special tract along the middle of the branch or internode." This is the case in his $C$. arachnoides, which also wants the lateral avicularia; nnd to this species the name Canda must be restricted; his remark does not apply to S. reptans. 
there are always, as far as I lave seen, seven or five eells; ou the larger internode there are three peduneulate avieularia, on the smaller two. The peduncle on which these appendages are mounted is much clevated; it is swollen at the base, and higher in front than behind, so that the avieularium is tilted up, its strongly curved beak being dirceted outwards.

The operculum, which in its earliest stage of growth is simple and entirc, becomes dichotomously branched, and spreads out like an antler over the entire apcrture, which it completcly protects.

The radical fibres are present under two forms, and cuable the species to adapt itself to very different habitats. In one they arc simple tubes, originating, as all similar appendages do in this group, at the base of the vibracular cell; and from the free extremity a number of fibrils are given off, which branch and anastomose and form circular reticulated disks, by which the polyzoon is firmly attached to the surface of the rock or the frond of the sca-weed. These disks may remind us of the rootlets by which the ivy elings to its support. The tubes are not mercly produced towards the base of the zoarium, but along the course of the branches, which, as they increase in length, are firmly attached at intervals; and in this way the polyzoon creeps, like a plant, over the surface on which it grows. But a modification of the merely adherent appendage is also met with; and it would seem that the particular form which the radical fibre assumes is very much determined by the nature of the base on which the polyzoon is dereloped. In its second form, the fibre is covered for about two thirds of its length witl sharp, recurved, hook-like processes, and is converted into an admirable prehensile organ. It is a veritable grapnel, which is plunged into the soft sar- 
eode of the sponge, or other yielding substanee, and holds the polyzoon, like an anehor, to its place*.

Dredging on one oceasion in Salcombe Bay, I took up a pieec of some cotton material which was overgrown by $S$ reptans. On the uneven fibrous surface the adhesive disks would have been almost useless; a few of them only were developed; but the toothed processes were present in profusion, and had worked their way in amongst the threads of the fabric, which had become entangled amongst the hooks, and so anchored the tufts securely. On a specimen beside me, growing on the flat surface of a Laminaria-frond, I eannot find a single grapnel; but the disks are fincly developed, and of large size.

$S$. reptans grows in somewhat eireular tufts, the branehes spreading out on all sides, and being more or less deeumbent.

This fine species is one of the most highly specialized

* This interesting piece of structure did not escape the "lyncean" Ellis. He says:- "Some of these little radieal tubes are discorered by the microscope to be full of hooks, the better to seeure the Coralline when it adheres to soft spongy substances" (Corall. p. 38). He also figures one of these modified fibres.

Couch has also briefly noticed the occurrenee of hooked fibres on the present species (Cornish Faun. pt. iii. p. 127). But we aro indebted to Mr. Peach for the most detailed obserrations on this interesting point. He describes very graphically the grapnels of $S$. scruposa, "the stout hooked spines" of which were buried in the sponge. These hooks "are shaped like the thorn of a rose-tree, and surround the 'root-fibres;' and when dragged out they hold in their grasp numbers of the sponge-spicules." He also met with similar appendages on $S$. reptans when growing upon sponge. A specimen developed on Flustra foliace was altogether destitute of the hooks, the fibres terminating in a number of short and simple "radiating processes," by which they adhered. Froin these processes "short disk-like pieces" are given off, which are inserted into the opening of the cell of the Flustra; and in this way a firmer grip is secured. There appenrs in this case to bo another slight adaptive modification determined by the habitat. On the smooth and solid surface of the Laminaria the terminal librils are unuch more branched, so as to give a larger adhesive surface to the disk. Mr. Peach's papers are published in the Limnean Society's Jourual, Zool. rol. xiii. p. 479, pl, xxiii., aud the Journal Roy. Inst. Cornw. 1877, No. 19. 
of the Cheilostomata and presents, as it were, an epitome of the structural characteristics of the tribe. As it is to be found everywhere, the student of the Polyzoa can select $n o$ better form to work upon, so far at least as exterual structure is concerned.

\section{Genus CABEREA, Lamouroux.}

Der. From Caberea, daughter of Protens.

C. beres, Lamx. (1816), Pol. corall. flex. : Busk : Smitt.

Cellaria (sp.), Lamarck.

Flustra (sp.), Flem.: Jolnnst.

Cellularia (sp.), id. : id.

Crisia (sp.), Audouin.

Selisi, Gray, Dieffenbach's New Zealand, ii.

Fuabelard, Gray, B.M. Rad. 106.

Caxda (sp.), D’Orb. Pal. Franç.

\section{Generic Character. - Zonrium not articulated.} Zoccia in two or more series, subquadrangular or ovate, with a very large aperture. Sessine avicularia on the side and front of the cells, the lateral avicularium minute. Vibracular cells very large, placed in two rows, stretching obliquely downwards across the back of the zoccia, which they almost cover, to the median line, notched above and traversed through a great portion of their length by a shallow groove. SETr usually toothed on one side.

Is Caberea the zoœcia have a tendency to assume a somewhat qualrate form, and the aperture occupics a very large proportion of the front surface. The arrangement of the avicularia is much the same as in Scrupocellaria; but the lateral avicularium is very inconspicuous, and may readily escape notice. The striking feature of the gemus is the enormous development of the vilsracula, which almost cover the back of the zoarium, and give it a rery marked and peculiar appearance. From the npper and outer angle 
of the ecll they streteh diagonally downwards, reaching to the median line, where the two opposite rows meet. The vibracular cell is of an clongate-oval figure above; and this portion of it bears some resemblance to a delicate bivalve shell resting on its dorsal surface, and slightly gaping. Below it is mucl produced and attenuated. At its upper cxtremity there is a cleft in which the movable seta works; and when at rest it lics in the groove, which passes from. the terminal notch downwards.

The sizc of the vibracula in the genus Caberea is not their only peculiarity. In C. Boryi (and probably in the other species) they differ from the same appendages in the kindred gencra physiologically as well as in form and size. Whilst the vibraeula of Scrupocellaria act independently of one another, those of $C$. Boryi move together with perfect regularity; they act not individually, but in companies, obedient to a common impulse. After a short interval of quictude all the vibracula on a shoot are scen to start into sudden aetivity, swinging themselves round simultaneously to the front of the eells, and then sweeping backwards again and resuming their former position. After another interval the same synchronous and perfeetly regular movement takes place, and so on continually. There is sometling positively startling, after the absolutc quict, in the sudden simultancous rush of the whole host of vibracula into cnergetic action *.

In this species, then, not only are the individual appendages highly developed, but the whole eompany of them attached to a colony are brought into combined and liarmonized action. It must be left to future observation to determine the precise struetural conditions on which these

* Sce a paper by the author, "On the Morements of the Vibracula in Cuberce Boryi" \&ce, in the Quart. Journ. Micr- Sci. fur Jan. 1878. 
remarkable movements depend; but they eertainly seem to imply the existenee of a nervous system distinet from that of the individual polypides, by which the vibracular zooids are controlled and brought into relation.

The Caberea constitute a small group, of which one (C. Boryi) is almost cosmopolitan; another (C. Ellisii) is an Aretic species, which ranges to the more northerly portions of our coasts, on the one hand, and to Labrador and Maine, on the otlier; and the remainder inhabit the Australasian seas.

Caberea Ellisit, Fleming.

- Plate VIII. figs. $6-8$.

Flustra Eluisi, Flem. Mem. Wern. Soc. ii. 25J, pl. xvii. figs. 1-3.

Flustra setaces, Flem. B. A. 536 : Johnston, B. Z. od. $2,346$.

Ceslltaaria Hookeri, Johnston, B. Z. (ed. 2), 338, pl. lx. figs. 1, 2.

Bicrllaria Hookera, Blainville, Dict. Sc. X. 1x. 424 .

Caberea Hookeri, Busk, B.M. Oat. i. 39, pl. xxrvii. fig. 2: Gosse, Mar. Zool. ii. 14, fig. 20.

Flabellaria sktacea, Gray, B.M. Cat. Rad. 106.

Caberes Eulisti, Hincks, Deron \& Cornw. Cat. 63: Smitt, CEfvers. K. Vet. Akad. Förhandl. 1867, $287 \& 327$, pl. xvii. figs. 55, 56 : Norman, Quart. Journ. Micr. Sc. (n. s.) viii. 217.

Zoarium fan-shaped, of a yellowish-brown colour, dichotomously branched, branches thick, widening upwards. Zoocia in 2-4 rows, short, subquadrangular; aperture elliptical, occupying nearly the whole of the front, with a broad, minutely granulated margin, sloping outwards; marginal eells with two stout spines above on the outer side and one on the inner; eentral eclls with one on each side. Lateral avicularia small and incouspicuous, placed a little below the top of the cell, with a rounded mandible; anterior avicularia raised, two below the aperture, placed one at each side, or sometimes only one; mandible rounded, direeted downwards. Vibracula very long, serrate. Oxcia flattened, frequently with a depressed, smooth, semi- 
circular space in front, from which finc stria radiate to the margin.

Height about 1 inel.

Habitat. Deep water.

Localities. Shetland, deep water (Flem.): Orkncys (Barlec): the Mineh; Shetland, 40-70 fms., abundant (A. M. N.) : off the coast of Antrim, 62-72 fms. (Mr. W. Swanston), the most southern reeorded locality on our coasts.

Geographical Distribution. Labrador and Mainc (Packard) : St. Georgc's Banks, 28 and 150 fms. (Smith and Harger): Greenland, 100 fms.; Reykjavik Harbour, 15-20 fms. (Wallich): Seandinavia and Finmark, 50-80 fms., not uncommon (Smitt) : Roseoff, rather rarc, in large tufts on fragments of Eschara (Joliet).

Range in Time. Scoteh Glacial deposits (Geikie): Palæolithie (A. Bell).

The cells in this remarkable form arc peculiarly shaped; they are short, somewhat four-eorncred, almost entirely open in front, and present, as Smitt has pointed out, a very Mcmbraniporidan appearanee. The branelies are convex, rising considerably towards the centre. They consist towards the lower part of two rows of eells; but this number increases to threc or even four rows, so that the branches widen upwards.

The lateral avicularia are very small, and may readily cseape detection. They are placed just at the base of the lowest of the spines on the outer margin, and extend for some distanee down the side of the cell, but projeet very slightly. We do not find the rounded mandible, which belongs to this species and to C. Boryi, in any of the allied genera.

The vibracular cell is of great sizc, somewhat fusiform, with a smooth and polished surface, and of very delieatc texture. The groove oeeupies about two thirds of its 
length, and opens below into a decp channelled space, inclosed at eacl side by a prolongation of the cell-walls, which tapers off downwards and is carried along the median line until it reaches the wall of the next vibracular cell. Owing to this arrangement of the vibracula, a very large proportion of the dorsal surface of the zoarium is covered by them.

A striking feature of the present species is the remarkable derelopment of the radical fibres, and the mode in which they are disposed. They take their origin on the side of the vibracular cells, and are given off from the upper as well as from the lower portion of the branches. Passing off from the vibracula on each side of the zoarium, the tubes tend downwards along the median line of the dorsal surface, one supcrimposed upon the other, and all closcly adherent, so as to form in the adult colony a prominent keel-like projection along the back of the branches. As growth proceeds and new cells are formed fresh strands are added to the fibrous bundle, whicl is, of course, smallest above. Below each bifurcation the bundles join and blend, while at the base of the zoarium the multitudinous threads become free and form so many scparate eables by which the polyzoon is anchored in its place.

All the fibres are earried down the centre of the dorsal surface, and neatly piled up along the median line; so that there is no interferenec with the action of the vibracula.

\section{Caberea Boryi, Audouin.}

Plato VII. figs. 2-11.

Caısı Bory, Audouin, Expl.: Savigny, Egypte, pl. xii. Ag. 4.

Cellularta Hookert, Fleming, B. A. 539.

Svlbia zblasica, Gray, Dieffenbeli's New Zeal. ii. 292.

Caberea zelaxica, Busk, Voy. 'Rattlesmake,' i. 378. 
Canda Boryt, D’ Orb. Pal. Franç. T'. Orét. v. 331.

Caberea Boryi, Busk, B.M. Cat. i. 38, pl. xvi. figs. 4, 5 (as C. zclanica), and pl. xxxriii. (as C.patagonica): Hincks, Ann. N. II. for Feb. 1855 (3 sep.): Heller, Bryoz. d. Adrint. Meeres, 13 : Norman, Quart. Journ. MLicr. Sc. (n. s.) riii. 217.

Zoarium forming small flabellate tufts; branehes stout, divided dichotomously into a few segments. Zoceia in two rows, or oecasionally three, short, ovate, very slightly produeed and narrowed below; aperture oval, with a flattened, rather broad border, expanded at the bottom; two or three spines on the outer side above, and one on the inner, springing from the peduncle of the operculum; operculum expanded downwards, and filling in the lower part of the aperture, oceasionally giving off a pointed process above; or more regularly developed and suboval. Lateral avicularia very small; mandible rounded. Anterior avicularia raised, placed between the cells down the median line, sometimes very large; mandible rounded. Vibracula broad and flat below, slender and tapcring above, serrate. Oæcia arcuate, smooth, inclined inwards.

Height about $\frac{1}{8}$ inch.

Range of Variation. On Australian specimens I have met with three spines on the outer side of the cells, instead of the two which characterize such British examples as I have examined. The Australian form, too, is distinguished by the very large size attained by the eentral avicularia. They are raised, swollen, well rounded above, and have the mandible on the front, perpendieular to the surfaee of the zoarium. They form a line down the ecntre of the branch. In British specimens they are much smaller. The lateral avicularia are extremely inconspicuous. The operculum exhibits some curious differenees in the mode of its development. Sometimes it expands altogether downwards, filling in the lower part of the aperture, and appearing as if soldered to the margin. Occasionally a short spur is given off above. In other 
eases it takes the regular course, and assumes the ordinary form, being pretty equally developed above and below. In the size of the tufts the.Australian and British forms agree.

Haвixat. On Eschara and other Polyzoa, Nullipores, Algæe, \&e., from between tide-marks to moderately deep water (Coralline ground).

Localities. Torquay (Hooker) : on Eschara foliacea and Scrupocellaria scruposa, off Budlcigh-Salterton (Miss Cutler and T. H.): Goran Haven, Cornwall (C. W. P.) : ? Ilfracombe (A. Leipner)*: Guernsey, eommon (R. S. Cooper and A. M. N.) : Herm, tidemarks, under stones (T. H.) : Jersey (A. M. N.) : Hastings, rare (Miss Jelly).

Geographical Distribution. Egypt (Savigny): Adriatie, on Nullipores (Heller) : New Zealand (Hooker and F. W. Hutton) : Glenelg, Australia (T. H.): Cumberland Island (Busk) : E. Falkland Islands; S. Patagonia, $49^{\circ}$ S.; Port St. Julian, Patagonia ; Strait of Magellan (Darwin): Algoa Bay (Busk): Singapore (Liverpool Free Museum, teste T. H.) : Roseoff, eommon (Joliet).

The vibracular eells of this speeies bear a elose resemblance to those of $C$. Ellisii. The radieal fibres originate only on the lower portion of the zoarium, hardly extending much beyond the base of the shoots; and the dorsal surface therefore wants the prominent subearinate appearanee which it exhibits in the latter species.

Both in this and the preceding species the older portions of the zoarium beeome eoarse and much thiekened; and in this eondition it is very diffieult to determine the minute strueture.

C. Boryi does not oceur in the extreme north, but otherwise is remarkable for the extent of its geographical range.

* Mr. Leipner has a fine specimen, which he has no doubt was obtained either at Ilfracombe or Tenby-he belieres, the forner. 
Family IV.-Bicellariidæ.

Bicellariade, Busk.

Biceliarie.e, Simitt.

Zoecis rather loosely united in two or more series, or disjunct; obconic, or boat-shaped, the aperture usually occupying a large proportion of the front. Avicularia, when present, capitate, pedunculate, and jointed. $\mathrm{Zos}-$ RIUM not articulated, erect, and phytoid, or composed. of a number of cells connected by tubular processes.

THe zoarium assumes two very different and strongly contrasted conditions within the limits of this family; and it is only after carefully examining the entire series of forms ineluded in it that we recognize the elose affinity of such divergent genera as Bicellaria and Beania.

The two are connected and linked together by the genus Bugula and the genus Diachoris, of which latter we have no representative on our coasts, but which occurs in the Mediterranean.

In Bicellaria the cells are widest above, and taper off very decidedly below. The inferior subtubular portion is generally much produeed, and occupies a much larger proportion of the whole than it does in the genus Bugula. The aperture is usually ample, though not so large as in the last named; it narrows downwards, and is slightly pointed below (woodeut, fig. 1). The eells are so placed that the lower extremity is directed inwards towards the median line; and this is also the casc, though to a less extent, in the genus Bugula.

Fig. 1.

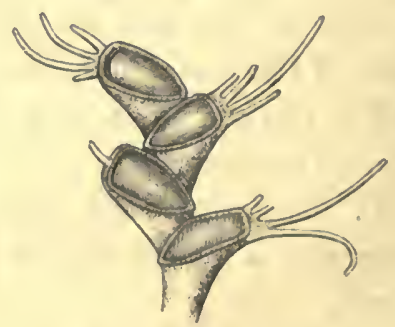

Bicellaria (Aust ralinn). 
In the latter the tubular portion of the eell towards the base is redueed in length, and the aperture oecupies fully two thirds of the front; oceasionally (as in B. umbella, Smitt) it extends to the bottom.

These two genera are united through the species of Bicellaria in which the aperture eneroaches most upon the tubular base of the eell, and the species of Bugula in which it is most contracted.

In such forms as B. Murrayana, with its elongatc, boatshaped cell, open in front through a great portion of its length, and margined with spines (woodeut, fig. 2), or B. umbella, with aperture actually extending to the base, we have a near approach to the form of Diachoris, which may be described popularly as a Bugula with its cells disjoined and held in eonnexion by a number of tubular processes, and assuming a Fig. 2. decumbent instead of an ereet habit of growth. These two genera also agree in having eapitate avicularia of much the same type, and occupying similar positions in the zoarium. It is only in this family that we meet with the eapitate and jointed avicularium-the true "bird's head," with its elaborate structure and eurious movements, the most highly specialized form which the organ assumes. In Beania we have a form elosely allied to both Bugula and Diachoris. The latter is distinguished from it by the more eomplex character of its zoarium, and by the presenee of avieularia. There is little differenee in the habit of growth; for in some Fig. 3. species of Diachoris the eells are semi-Diachoris spinigera. 
erect. The zoceia are essentially identical in eharacter; and such a species as D. spinigera, MacGillivray (woodeut, fig. 3), in a young state, when the cells are ranged in a single line, is hardly distinguishable from a Beania (woodeut, fig. 4).

Throughout this family the cells are loosely connected; in Bicellaria, though placed side by side, they are often really disjunct.

In some of the Bugula (e. g. B. Murrayana) the branches are composed of $a$ many rows of cells, and assume a somewhat Flustrine appearance; whilst such forms as Bicellaria Alderi remind us of Fig. 4.

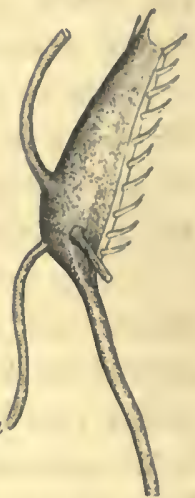

Beania miralilis. the Cellulariida.

\section{Genus BICELLARIA, Blainville.}

Der. From bis, twice, and cella, a cell.

Biceluaria, Blainville, Dict. Sc. Nat. 1830: Gray : Busk, \&c. Cellularia, Pallas (part.): Fleming: Johnston: D’Orbigny. Cerlaria (part.), Ell. \& Sol. : Lamk.

Crisia (part.), Lamouroux: Van Beneden.

Generic Character.-Zoarum erect, phytoid. Zoceia turbinate, or in the form of a cornucopia, loosely united, more or less free above; aperture looking more or less upward, directed obliquely inwards below; inferior portion of the cells subtubular, usually much produced. Avicularia, when present, jointed and capitate*. No vibracula.

Is Bicellaria the zoarium does not present the variety of structures which we have in Menipea or Scrupocellaria;

- An exception is presented by the Australian B.tuba, which possesses a fixed avicularium, borne at the top of a tall spinous process. 
but it is distinguished by graee, delicaey, and pieturesqueness, the latter being ehiefly due to the great development of spines, which is a feature of the genus, and to the peculiar turn of its cells in most of the species. The aperture varies in the proportion whiel it bears to the length of the eell, and the degree in which it is turned inwards. Oecasionally it is subterminal, and looks upwards much more deeidedly than is usual. In one or two Australian species it is elongated, and very much bent inwards towards the median line. In our own B. Alderi, while there is the same gencral form, the cells are much straighter, and the arrangement is more compaet and regular, reminding us, as I have already remarked, of the Cellulariida.

The spines are profusely developed in this group, and oceur not only on the margin of the aperture, but also on the dorsal surface. The avicularia, when present, are but sparingly developed; and in some species they are altogether wanting. In this respeet Bicellaria offers a eontrast to Bugula, which is remarkable for the profusion of these appendages as well as for their highly specialized form.

As in Caberea, there is in some of the species a wonderful development of the radieal fibres. In the exquisite Australian form, B. tuba, Busk, which grows in feathery tufts of considerable size, they extend along the back of the shoots for about two thirds of their height, forming a compaet mass of whitc, glistening tubes. Each tube originates on the back of a cell, and, so far as I liave observed, of those particular eells only which are placed between the diverging branches at a bifureation. From these points or stations the fibres tend downwards, uniting as they proeeed with the bundle already formed below them, which at the base resolves itself into a multitude of separate rootlets. 
All the known speeies of Bicellaria, with the cxeeption of the two that oecur in Britain, are natives of the Australian seas.

\section{Bicellaria ciliata, Linnæus.}

Plate VIII. Ags. 1-5.

Ciliated Coraluise, Ell. Corall. 38, no. 5, pl. 20, figs. $d$. D.

Sertularia ciliata, Linn. Syst. ed. 10, 815, ed. 12, 1316.

Cellularia ciliata, Pall. Elench. 74: Flem. B. A. 540: Johnst. B. Z. ed. 2, 335, pl. lvii. figs. 1, 2: Dalyell, Rem. An. Scotl. i. 239, pl. xlvii. : D’ Orbigny, Pal. Franç. Terr. Crét. จ. 49.

Cellaria ciliata, Ell. \& Sol. Zooph. 24: Lamk. An. s. Vert. ed. 2, ii. 186. Bugula ciliata, Oken, Lehrb. Naturg. 89.

Crisia ciliata, Lamx. Pol. cor. flex. 60: Van Ben. Recherches, 51, pl. vi. figs. 9-11.

Bicellaria ciliata, Blainv. Actinol. 459, pl. lxxviii. fig. 2: Busk, B.M. Cat. i. 41, pl. xxxiv. : Smitt, Gefvers. K. Vet. Akad. Förhandl. 1867, 288 \& 333, pl. xviii. figs. 1-3.

Zoarium of a pearly-white eolour, forming delicate feathery tufts; dichotomously branehed, branches curved inwards at the extremities. Zoccia alternate, turbinate, enlarged above, and narrowing off rather abruptly towards the bottom, the inferior portion eylindrieal, everted and free at the top; aperture elliptical, oblique ; $4-7$ very long, slender, ineurved spines on the upper margin, and one plaeed eentrally immediately below the aperture; one or two spines on the dorsal surface. Avicularia situated on the outer side of the eell, a little below the aperture, small, with a serrate beak. Oxcia peduneulate, helmetshaped, attached to the inner side of the eell.

Polypide with 12-16 tentaeles. Primary cell jointed at the base to a short proeess from the radieal fibre, widening upwards, elongate; aperture terminal, suboval, very slightly oblique, with about 11 spines (woodeut, fig. 5). Height eommonly about $\frac{1}{2}$ ineh. 
Habitat. On Alga and zoophytes (especially), and on stones, shells, \&c., from between tide-marks to moderately deep water.

Localities. Cornwall, on corallines and sponges; near the Eddystone, not common; Mount's Bay (Couch): South Devon, on Sertularian hydroids \&c., common; Ilfracombc, rock-pools and diedged in 8-10 fathoms; Filey, on zoophytes and under stones; Fleetwood, on a buoy; Menai Straits; Swanage Bay (T. H.): Tenby (F. Walker) : Hastings (Miss Jelly): Northumberland, rare (Alder): south coast of Durham (J. Hogg) : St. Andrews, frequent from the Coralline ground (Dr. M'Intosh) : Ayrshire, rare (Landsb.) : Peterhead and Wick, rare; Durness, Sutherlandshire (C. W. P.) : Shetland, 45 fathoms, haddockground, Out Skerries, very rare (A. M. N.) : coasts of Ireland, sparingly (W. Thompson).

Geograpuical Distribution. Ostend (Van Ben.) : La Rochelle, Gironde (Fischer): Roscoff (Jolict): Bay of Gullmaren, Bahusia (Lovén and Lilljeborg): Heligoland, 5-6 fathoms; N. America (Kirchenpauer): South Africa, var.* (T. H.).

The enormous development of the spines is the most striking feature of this attractive species. Those on the upper margin, which are of great length, curve inwards over the higher part of the ecll, while the solitary one $\dagger$ below is directed upwards, so that the polypide is completely cmbowered, and, no doubt, is largely benefited by

- In the South-African form the cells are much shorter than in the British; the portion below the joint is much less elongated, and the cells are thereforo moro closely packed together. The a vicularium is of larger size; and the inferior spine, so far as I havo seen, is always more or less lateral. The habit scems also to be stiffor. These slight differences have an interest as showing by what almost imperceptible degrees forms are modiffed and change their aspect.

$\uparrow$ There are occasionally two at the bottom of the aperture. 
the friendly shelter. There is usually one dorsal spine placed on the inner side, a little behind the margin; and sometimes a second is present. Just at the point where the narrow, eylindrical portion of the eell eommenees, there is a kind of joint. The oviecll does not rise from the margin, but from the side of the cell a little below it, and is distinetly pedunculate. Its opening is turned towards the aperture, which it overhangs*.

The avicularium presents no very marked feature, if we except the serrate beak. It is rounded behind, but not areled above, the upper surface being remarkably straight ; the beak is short, and searcely hooked at the point.

The shoots rise from a bundle of fibres which are earried up for a short distance upon the surface, involving the cells near the base.

No description or drawing, I may add, ean give an adequate idea of the beauty of this species, or do more than suggest the charm which lies in its exquisitcly soft feathery tufts, its transparent whiteness, and its graceful habit.

Bicellaria Alderi, Busk.

Plate IX. figs. 3-7.

Bicellakia Aldem, Busk, Rep. B. Assoc. 1859, Truns. Sect. 145; Quart. Journ. Micr. Sc. 1860, 143, pl. xxviii. figs. 1-3: Smitt, CEfvers. K. Vet. Akad. Förhandl. 1867, 289 and 335, pl. xviii. figs. 4-8: Norman, Quart. Journ. Micr. Sc. viii. 218.

Bicellaria unispinosa, Sars, N. Mag. f. Naturv. B. xii. 286; Geol. og Zool. Iagttagelser \&c. (1863) 34.

Zoarium white and transparent, dichotomously branched. Zocecia in two series, alternate, very loosely connected

* The structure of the occium has been admirably domonstrated by Nitsche in a paper "On the Developmental History of certain Cheilostomatous Bryozoa," Zeitschr. f. wissenschaft. Zool. Band xx. Heft 1, pp. 3, 4. 
laterally, often disjunct, turbinate, much produced and attenuated downwards; dorsal surface smooth and entire; aperture broad above, witl a somewhat straight upper margin, narrowed below, oecupying usually less than half the length of the eell, bearing a single, very long, curved spine on its outer anglc. Avicularia capitate, much swollen, placed on the side of the cells at the lower extremity, with the mandible direeted outwards. Oxcia superior, subglobosc; surface entire, polished, marked with fine radiating strix.

Polypide with 16 to 18 tcntacles. Primary cell small, very slender and cylindrical below, with an elliptical apcrture bearing on its margin six outspread spines.

Habitat. On hydroids (espccially), Gorgonia, small stones, and shells from deep water.

Localities. Shetland (Barlee) : 5 to 7 miles east of the island of Balta in 40-70 fathoms on soft ground; off Unst and Out Skerries, in 40-100 fathoms (A. M. N.).

Geographical Distribution. Eisterraat, Norway, attached to small stones and shells in 80-100 fathoms (M. Sars) : off the coast of Norway in 200 fathoms (Baron Uggla) : the Bömmel-Fjord, 106 fathoms (Kirchenpauer).

In this delicate and graceful specics the two lines of cells which compose the shoots are not welded together so as to form one solid pice, but rather run side by side united at certain points and morc or less separated through a great portion of their length. 'They are very looscly conneeted, and at the extremity of the shoots are usually altogether disjunct. The condition of the zoarium in this respect marks the transition from the simply uniserial forms to those in which the series of cells are more thoroughly connate, such as Cellularia, \&c. In the present speeies the shoots commenee with a few single eclls, which rise one from the other, each taking its origin above the angle which is 
opposite to the one bearing the spine. In this condition they bear a general resemblanee to Eucratea. This simple growth, however, soon eeases; after a while, from the uppermost in a series two eells are given off, the second taking its origin from the side a little below the angle. From these two eells two series are developed, which become more or less adnate, though never completely or very intimately united. The second line of eells may be compared to a branch, in sueh a form as Scruparia clavata, which (as sometimes happens in the latter) is closely appressed to the original shoot, and to a certain extent unites with it.

In $B$. Alderi the branching is simply dichotomous. At ecrtain intervals the terminal zoccia give off a pair of cells instead of one; and each pair becomes the first term of a new series. The branches, turned outwards by the two interposed cells*, diverge, forming at the point of divergenee an aeute angle. So loosely, however, are the lines of cells eonneeted, that above the fork they may sometimes be met with not even side by side, but perfectly free and independent.

Towards the base the shoots are involved in a bundle of tubular fibres, by which the colony is attached; the fibres pass upwards for some distanee along the dorsal surface of the eells, to which they are closcly adnate.

The spines on the projecting outer angle of the aperture are a striking feature in the present species. There is usually only one to a cell; but two are sometimes present, placed side by side. They are often of great length, two or three times as long as the cell; they are gracefully eurved, and taper slightly towards the extremity.

* The aperture of these cells is always elliptical, whereas that of the others is broad and somewhat truncate above, projecting considerably at the outer angle, and becomes narrow towards the bottom. 
The avieularia, judging from the deseriptions of the elder Sars (to whom we are indebted for a detailed and most admirable aceount of the speeies) and Smitt, must be plentifully developed in Seandinavian specimens; but they are not mentioned by Busk; and in none of the British examples which I have examined (a considerable number) have I found any trace of them, except in a single instance. They are shaped like a bird's head, short, and much swollen behind, and are destitute of the teeth on the rostrum which oceur in $B$. ciliata. The ovicells are semicircular in form, somewhat flattened, and prettily lineated in front, and, according to Norman's comparison, elosely resemble the flower of the Calceolaria.

\section{Genus BUGULA, Oken.}

Buctra, Oken, Lehrb. Nat. 1815: Busk: Smitt.

Acamarcirs, Lamx. 1816.

Crisia (sp.), Lamx.

Cellularia (sp.), Pallas: Johnston.

Cellaria (sp.), Lamarck.

Aviczlad (sp.), Van Beneden.

Avicularia (sp.), J. V. Thompson, MS. Brit. Mus. : Gray.

Begclixa (sp.), Gray, B.M. Radiata.

Crisularia (sp.), Gray, ibid.

Flabellaria (sp.), Gray, ibid.

Orvitnopora (for B. avicularia), D’Orbigny, Pal. Franç.

Orsituoporisa (sp.), D'Orbigny.

Generic Character.-Zoarium erect, phytoid. ZoaEIA boat-shaped, or subquadrangular, elongate, united in two or more series; aperture occupying a large proportion (occasionally the whole) of the front, not turned upwards or oblique. Avievialis in the form of a bird's head, pedunculate and jointed, usually one on each cell.

WE have a modification of the eell in the present genus 
by which it is distinctly separated from the preceding, and which marks it out as a rery natural group. The turbinate cell, with the more or less upturned and uplooking aperture, somewhat abruptly bent inwards below towards the median line, which is eharaeteristic of the more typical Bicellaria, gives place in Bugula to an elongate, boat-shaped eell, sliglitly attenuated towards the bottom, and often truncate at the top, the front of which is usually oceupied for three fourths of its length or more by the aperture. The latter stretehes vertically from the top of the cell downwards; it is not set obliquely, looking upwards; nor is it so decidedly bent in towards the median line at its lower extremity as in Bicellaria, although, from the peculiar turn of the eells, it is somewhat inelined in wards below. The spines have eeased to be so conspicuous a feature, though still present. The eclls are more closely united than in Bicellaria; but the strueture is far from solid or compact. The avicularia are developed in great abundance, and often attain a large size. In most eases every cell is provided with one, articulated to its outer side; and in the living specimen the surface of the zoarium exhibits a strange and animated scene as the multitude of grotesque heads sway themselves to and fro, and snap their tiny jaws, as it seems, with aimless energy.

In this genus the polypide exhibits a somewhat strongly marked struetural character. The tentacular corona is only just protruded beyond the orifice of the eell; the pharynx is wide and ample, while, on the other hand, the œsophagus is redueed in size and extremely short. At the bottom of it there is a distinet eardiac valve, and below this a subglobular chamber which opens into the true stomach. The walls of this ehamber, as well as of the stomach, are riehly eoloured by the hepatie glands, which are highly developed. A prolongation of the diges- 
tive sae above supports the pyloric valve; and beyond this the intestine dilates into a large oral cavity, extending to the point of exit at the base of the tentacles.

Altogether the alimentary canal presents a rather characteristic form; while the general appearance of the polypide is affeeted by the rudimentary condition of the osophagus.

The Bugula are not unfrequently brightly coloured. They are very widely distributed; and in B. neritina (the type of the genus as constituted by Oken) they have a cosmopolitan representative, which is to be met with in most seas*.

Bugula avicularia, Linnæus.

Plate X. figs. 1-4.

Brrd's-head Corallixe, Ellis, Corall. 36, No. 2. pl. xx. figs. a A.

Sertelaria avicclaria, Linn. Syst. ed. 10, 809.

Cellarta aricelaria, Ell. \& Sol. Zooph. 22 : Lamk. An. s. Vert. ed, 2, ii. 191.

Begi'la avicularia, Oken, Lehrb. Naturg. 90 : Busk, B.M. Cat. i. 45 , pl. liii.: Alder, North. Cat. 59 (sep.): forma 1, Smitt, Effers. K. Vet. Akad. Förhandl. 1867, 289 \& 339, pl. xriii. figs. 9, 10, 12-15.

Crisia avicularia, Lamx. Pol. corall. flex. 141.

Cellularia avicularia, Johnst. B. Z. ed. 2, 338, pl. Ixiii. figs. 7, 8: Landsb. Pop. Hist. 341, pl. xix. fig. 72.

Oeluelaria avicularis, Reid, Ann. N. H. ser. 1, xvi. 389 : Dalyell, Rem. An. Scotl. i. 241, pls. xlriii., xlir.

Orwituopora avicelaria, D'Orbigny, Pal. Franç. Terr. Crét. v. 322 †.

Zoarium bushy; branches flabellate, divided dichoto-

* "Acamarchis neritina, qui parait maintenant habiter lo monde entier, so fixo à la quille des navires et so fait transporter partout" (D'Orbigny, 'Voyage dans l'Amérique méridionale,' t. v. $4^{\text {me }}$ partie, Zoophytes, fig. 10).

+ I do not give Avicella avicularoides, Van Ben., as a synonym. He describes the aricularia of his species as having unandibles "courtes et ramasses," terms which are not applicable to those of the present forus. The 
mously into narrow linear segments, disposed spirally round the stem. Zoceia biserial, elongate, narrowed below, elevated towards the oral end; aperture oceupying more than three fourths of the front of the eell, obovate; margin thin, with two spines above on the outer side and one on the inner. Avicularia large, compressed laterally, with a much elongated and slightly bent beak, placed on the outer edge of the aperture about halfway down the eell. Oøcia subglobular, prominent, free, hyaline and smooth.

Polypide with 14 to 15 tentacles.

Habitat. On shells, zoophytes, Flustra foliacea (especially), \&c., between tide-marks, and from moderately deep water (20-50 fathoms).

Localities. The Minch, Hebrides; Shetland, not common (A. M. N.) : Peterhead and Wick, on Flustra foliacea, \&c., from deep water (C. W. P.): Coralline ground on Flustra foliacea (Dr. M'Intosh) : Northumberland, from deep water, occasionally (Alder) : Hastings (Mr. Tumanowicz) : South Devon, not common (T. H.) : Cornwall, on the Corwich Crab, Megavissey Bay and Mount's Bay, not common (Couch).

Geographical Distribution. Spitzbergen, Sörje Bay, 40-50 fathoms (mud bottom), rare; most northern part of Spitzbergen, on Cellularia and Flustra, 20-50 fathoms (Smitt): Adriatic (Heller): Hobson's Bay, Australia (MacGillivray).

This is a smaller and less striking species than the following, and apparently less common. It is of slender

aperture is also said to occupy half the length of the cell, whereas that of $B$. a vicularia extends to very near the bottom. Van Beneden himself points out differenees between his species and that of Ellis, though ho eeems to hare been half inclined to identify them. 
habit, of an orange-brown colour when reeent, but much paler when dried. The cells are somewhat elevated at the upper extremity; and each of them slightly overlaps the one above it. The number of spines is universally, so far as I have seen, three : two are placed on the outer side of the cell-one of them on the upper angle of the aperture, and the sceond behind it ; the third rises from the inner and upper angle. The avicularium is the striking feature of the species. It is of very large sizc, clongated, with a much produeed beak, which is slightly and gradually (not abruptly) curred; the head, as seen from above, has the appearance of being compressed laterally, and altogether wants the full rounded contour which we find in the avicularium of the next species. The ovicells are produced in immense numbers; they are very prominent, orving to the clcvation of the cell at the upper extremity, and, as seen in profile, have a very hood-like appearance. The apcrture is contracted. The branches are numerous, and set closely together, and wind round the stem in corkserew fashion. They divide dichotomously a little above the base into two principal segments; and these divide and subdivide, the whole assuming a flabellate character.

\section{Bugula turbinata, Alder.}

\section{Plate $\mathbf{X}$. figs. 5-8.}

Brro's-mrad Coralurxe, Ellis, Corall pl. xxxviii. Aggs, G, H.

Cellularia aviculazis, Pall. Elench. 63 ?: Gosse, Devonsh. Coast, 195, pl. $x$.

Bugela turbisata, Alder, Quart. Journ. Mficr. Sc. v. 174, pl. xrii. figs. 1-4: Hincks, Der. \& Cornw. Cat. 37 (sep.).

Zoarium orange-coloured when living, forming an as- 
cending spiral; branches broadly flabellate, dichotomously divided, arching outwards. Zocecia in two to six scrics, clongated, slightly raised towards the upper end; apcrturc reaching nearly to the bottom; a single spinc at each upper angle. Avicularia on the outer cells moderatcly large, the head much swollen and rounded bchind, with a short beak abruptly bent at the point, placed ncar the top of the cell ; avicularia on the inner cells small. Oxcia subglobose, prominent, the upper part opaque, with a hyaline border round the orifice, which rises into a pcak or into a blunt rounded process in front. Height of the shoots from 1 to 2 inches.

Polypide with about 13 tentacles.

Н and in shallow water.

Localities. Herm, under stoncs; Gucrnsey; Mcnai Straits (Alder) : Whitburn (Rev. G. C. Abbes) : Scaham Harbour, co. Durham (G. Hodge) : Tenby (Dystcr) : Filey, Yorkshire; Llandudno, drcdged off the Ormes Head; Islc of Man; Ilfracombe, very common; South Devon, vcry fine and abundant, near low-water mark; Swanage Bay, Dorset, on drift wood (T. H.) : Falmouth (Cocks); Malahide (Trin. Coll. Collect., Dublin).

This finc spccies is ncarly related to the prcceding, with which it had been confounded until detceted by the latc Mr. Alder's keen and discriminating cye.

It attains a much larger size than $B$. avicularia; the flabellate branches arc broader; and the wholc habit is stoutcr. It occasionally reaches a height of two inches, and forms large clustcred growths bencath the ledges of rocks, in the clcfts and gullies, and on the under surface of stones near low-water mark. As many as a dozen of its lovely spiral shoots will sometimes risc from the mass 
of intertwining tubular fibres by which it is attached. When living it is of a rich orange-colour, but fades to a pale straw-colour, or to a pearly whitc, when dricd.

Amongst the other points which distinguish $B$. turbinata from the last specics, are the following: the cells are arranged upon the branches in a greater number of longitudinal rows; in $B$. avicularia there are almost universally two; in the prescnt form the segments commence with two ncar the base, but the number rises in the upper portions to three, four, five, and occasionally six. B. turbinata has only a single spine on the outer and inner angles of the aperture. Its ovicell is smaller, and is readily distinguished by its hyaline border and the curious process (sometimes slightly pointed, but more usually rounded, at the top) which rises from it and occupics the centre of the front surface.

But the most important distinctive character is supplied by the avicularium, which, with its well rounded head, and short, sharply bent beak, contrasts strongly with the somewhat slender, compressed, long-billed appendage of $B$. avicularia. The avicularium is present on evcry cell; but those on the outer edge of the branch, which have morc spacc to work in, are very much larger than the rest. The number on a specimen of arerage size is very considerable; and when they arc all in active and cnergetic play, and the polypides are darting in and out, the surface of the zoarium presents a singularly animated scene.

As in the preceding specics, the ovicells are dereloped in amazing numbers, and the branches commonly appear as if studded over with innumcrable tiny pearls.

$B$. turbinata secms to be abundant and widely distributed, but has not yet been noticed in the further north. 


\section{Bugula flabellata, J. V. Thompson.}

Plato XI. figs. 1-3.

Brro's iread Corallixe, Ellis, Corall. pl. xxrviii. fig. 7.

Cellularia avicularia $\beta$, Pall. Flench. 68: Van Ben. Rech. Bryoz. 48, pl. vi. figs. 1-8.

Fuestra avicularis, J. Sowerby, Brit. Misc. ii. 21, pl. Ixxi. : Flem. B. A.

506 : Johnston, B. Z. ed. 2, 346, pl. lxiii. figs. 3, 4.

Flustra Angustiloba, Lamk. An. s. Vert. ed. 2, ii. 222.

?Crisia flustroides, Lamx. Pol. cor. flex. 141.

Flustra capitata, Hogg, Nat. H. Stockton, 36 .

Orvithoporina avicularia, $D^{\prime}$ Orb. Pal. Franç. Terr. Crét. v. 322.

Avicelda avicularia, Van Ben. Bull. Acad. Roy. Belg. xv. No. 2. 75; 9

(sep.).

Avicularia flabellata, J. V. Thompson, MS. Brit. Mus. 1817: Gray, B.M. Radiata, 106.

Bugula flabeliata, Busk, B.M. Cät. i. 44, pls. li., lii.

Bugula aticularia, forma 2, B. Flabellata, Smitt, GEfvers. . Vet. Akad. Förhandl. 1867, 290 \& 345; Flor. Bryoz. pt. i. 18.

Zoarium composed of a number of flabellatc shoots diehotomously divided into numerous truneate segments, somewhat cireularly disposed, often slightly eonvoluted, of an ashy eolour when dry. Zoocia multiserial (4-7 rows), oblong, of about equal width throughout, reetangular above, aperture cxtending to the bottom; two spines at each upper angle, plaeed one above the other, of which one is usually of eonsiderable length. Avicularia placed on the side of the cells, a little below the top, those on the outer edge moderately large, the inner much smaller; head not swollen at the sides, well arehed. above; beak of moderate length, the point abruptly bent. Oacia rather small, almost semieireular in form, hyaline and smooth, with a wide opening.

Polypide with 14 tentacles.

Habitat. On stones, shells, crabs, Flustra foliacea (very eommonly) and other Polyzoa, \&c.; from moderate depths to deep watcr; occasionally at cxtremc low-water mark. 
Localities. A very abundant and widely distributed speeies. Shetland, 15-50 fms. ; Dourie Voe and haddockground, Out-Skerries and Unst (C. W. P.): St. Andrew's, on Flustra, deep water, rather rare (Dr. M'Intosh): Northumberland, on Flustra, \&e., from the Coralline zone, not rare; Bamborough, roeks at extreme low-water mark (Alder) : Peterhead, on Flustra (C. W. P.) : Bootle (Tudor) : Filey; Isle of Man; Llandudno, N. W.; South Devon, eommon (T. H.): Guernsey (R. S. Cooper) : Cornwall, deep water, common (Couch), \&e.

Geographical Distribution. Heligoland (Kirehenpauer) : Ostend (Van Ben.) : Roseoff (Joliet) : Adriatic (Heller and Grube) : Florida, deep water (Pourtales) : Madeira; Cape of Good Hope (Kirehenpauer).

When dried this speeies may at onee be reeognized by its ashy colour. Its habit and mode of growth are also eharaeteristic. When living it is "of a very delieate flesh-colour."

The rows of eells in the strap-like segments which compose the branch vary in number; they are never, I believe, fewer than four, and range as high as seven. The eell is oblong and reetangular, and of equal width throughout, while the aperture extends to the very bottom of it. In these respeets it differs markedly from the previous species. Of the two spines placed at the top of the eell on each side, the higher are eomparatively stout and direeted upwards, while the lower pair are slender and bend inwards aeross the aperture. Two of the spines are generally mueh more fully developed than the others, sometimes the upper and sometimes the lower pair being the larger. Along the edge of the segments there are usually three spines near the outer angle of the eell, but never more than two elsewhere. The avicularium does not ex- 
hibit any very marked peculiarity. It is to some cxtent intermediate between that of B. avicularia and B. turbinata, not so broad and round at the back as the latter, nor provided with such an clongated beak as the former. The ovicclls arc cxtrcmely delicatc in texture, bright and hyaline, and without a trace of sculpturc.

B. flabellata attains a lieight of about one inch.

\section{Bugula calatirus, Norman.}

Plate XI. figs. 4-6.

Bugula Calatilus, Norman, Quart. Journ. Mier. Sc. (n. 8.) viii. 218, pl. vi. figs. 3-8.

Zoarium composed of a number of dichotomously divided branches, springing from a fibrous base, and spreading out regularly on all sides, so as to form a shallow cup; when dried of a ycllowish horn-colour. Zocecia multiserial (3-9 rows), oblong, equally wide throughout, with two spines at each angle above (commonly three at the outer angle on the edge of the segments). Avicularia on the outcr cells very large, on the inner small, placed about a third of the length of the cell from the top, sometimes about halfway down, elongate; the head much produced behind, not much arched above, marked with delicate stria, which pass off on each side from the median ridge; the beak short in proportion to the head, bent, but not very abruptly, at the point. Oæcia subglobular, rather large, with a smooth and polished surface, slightly thickened round the edge in front.

Height of a large specimen $\frac{3}{5}$ ineh, diameter $1 \frac{1}{4}$ ineh.

Habitat. Under stones betwcen tide-marks and in shallow water.

Localities. Herm, between tide-marks (A. M. N.) : off 
the South-Deron coast, on Eschara foliacea; off the Thatcher rock, Torbay, in about 9 fms. (T. H.).

The differenees between the present species and $B$. $f l a$ bellata are almost cntirely confined to habit and mode of growth. The zoarium of the former is shaped like a shallow cup, perfectly simple and without any trace of convolution ; the shoots or branches which compose it are shorter, and divided into a much smaller number of scgments, than those of the latter; the growth is more spreading than that of B. fabellata, the shoots of which are stout, erect, and much divided. The colour of the two, when dried, presents a striking contrast. When living, B. calathus is of a light straw-colour. If we examine the minutc structurc, we find a close agrcement in all essential points. The cells, ovicells, and avieularia are all on a larger seale than in the other species; and the latter seem to exhibit some slight differences in form and proportion of parts. They are more elongatc; the head is more produced behind, and not so much arched; and the beak is perhaps proportionally shorter, though therc is a good deal of variation in this respect. The strix are more elcarly defined; but they are present also on the avicularia of B. flabellata. On the other hand, the shape of the eells and ovicclls, the number of the spines, the position and general character of the avicularium are the same in both. Both are multiscrial; and in both the number of rows ranges very much within the same limits.

Mr. Norman describes the spines of the present speeics as "stout and blunt ;" but when fully devcloped they closely rescmble those of $B$. flabellata. The upper are stouter than the lower, but the latter usually (not universally) taller than the former. They oecupy the same relative positions as in the other form, and exhibit the same differ- 
ences of eharacter. As in B. flabellata, there are almost always three spines at the outer angle of the aperture, along the edge of the segments.

I confess that I rank this beautiful form as a distinet species with some liesitation. It may be a question whether, in the faee of its essential agreement with $B$. flabellata in all the leading structural points, the differenees which it undoubtedly exhibits should be regarded as more than varietal. In the absence, however, of intermediate forms it seems right to give it a separate name.

Viewed with reference to $B$. flabellata, $B$. calathus is a dwarf form of simple habit, in which the less luxuriant development of the zoarium is accompanied by an increase in the size of the individual elements of the structure (cell, avieularium, \&e.).

In the dried state the two are at once distinguishable by the differenee in colour.

\section{Bugula plumosa, Pallas.}

Plate XII. figs. 1-5.

Soft-peatiered Coralline, Ellis, Corall. 33, no. 1, pl. sviii. fig. a, A. ? Sertularia fastigiata, Linn. Syst. ed. 12, 1314.

Cellularia plumosa, Pallas, Elench. 66: Couch, Corn. Faun. iii. 128, pl. xxiii. fig. 4.

Cellaria plumosa, Ellis of Sol. Zooph. 21.

Crisia plumosa, Lamx. Bull. Soc. Phil. 1812, iii. 185; Pol. coral. flex. 62.

Cribia fastiglata, Templeton, Ann. N. H. ser. 1, ix. 468.

Bicellaria plumosa, Blainv. Actinol. 459.

Crisularia plumosa, Gray, B.M. Cat. Rad. 111.

Bugula plomosa, Busk, B.M. Cat. i. 45, pl. liv. figs. 1-5: Alder, Supp. North. Cat., Trans. Tynes. Nat. F. C. v. (20 sep.): Heller, Bryoz. d. Adriat. Meeres, 15.

Zoarium consisting of slender, feathery, confervoid tufts; branches flabellate, diehotomously divided into narrow linear segments, disposed spirally round the central 
stem; when living, of a bright buff colour. Zoceia biscrial, altcrnatc, elongated, much attenuated below; aperturc occupying three quarters of the front, as widc as the ccll abovc, below narrowed almost to a point, the outcr margin raised towards the top and somewhat bent inwards, running out above into a spine. Avicularia very small, placed at a short distance below the top of the cell. Oocia globular.

Habitat. On shells, \&c., from between tide-marks to deep watcr.

Localimies. On scallop and other shells, Salcombe Bay, not uneommon; Fleetwood, on a buoy (T. H.) : Polperro, rarc, on rocky ground, not far from shore (Couch): Falmouth (Miss Warren) : Northumbcrland, from the decp. water boats (Alder): Seaham Harbour, co. Durham, between tide-marks (G. Hodge).

Geographical Distribution. Adriatic (Grube) : Roscoff, pretty common (Jolict).

Ellis's name for this species, "the soft-feathered Coralline," is very appropriatc. It grows in tall slender tufts, tapering above into a fine spirc-like point, and is of very delicatc and graceful babit. Mr. Couch gives the height at four inches, or more commonly two and a half or threc. In Salcombe Bay it is found growing over the outcr surface of old scallop shells, but of much humbler size, not cxcceding an inch and a quarter.

The avicularium is remarkably small; and this is its chicf pcculiarity. The head is very much arched, the surface smootlı; the beak continues straight almost to the extreme point, where it is very slightly bent or hooked. The single spine on the outer angle of the cell is sometimes short and conical, but is very commonly produced into a sharp spikc-like process of considerable lengtl. 
The radieal fibres are thin and membranaeeous, and form a dense and tangled mass at the base of the shoots.

I have not been able to give many loealities for $B$. plumosa; for the speeies was commonly confounded with B. purpurotincta until Mr. Alder pointed out and defined the differenees between them, and it is difficult to decide in many eases which of the two is intended. I have reeorded none about which there eould be any doubt.

Bugula gracilis, Busk, var. uncinata, Hineks.

Plate XV. figs. 1-4; Pate XII. figs. 6, 7.

Bugula Gracilıs, Busk, Quart. Journ. Micr. Sc. vi. 125, pl. xix. fig. 1.

Zoarium eomposed of many slender shoots, about one ineh in height, united so as to form bushy tufts, of a pale horn-colour when dry; branches flabellate, somewhat spirally disposed, erowded, dichotomously divided into narrow segments, longest in the middle of the shoot and diminishing above and below. Zoceia biserial and alternate, elongate, narrowing slightly downwards, with two spines on the outer side above, one of them on the free angular extremity of the aperture, and one (the longer) behind it, and one on the inner and upper angle; aperture rather narrow, oceupying two thirds of the length of the eell or more, somewhat eontracted below, turned inwards towards the median line. Avicularia small, placed on the outer margin, a little below the top of the aperture. Uncinate prehensile appendages distributed in considerable numbers over the dorsal surface, and replaeing the ordinary radical tubes. Oxcia (?).

Habitat. Unknown.

Iocalities. I am unable to give any British loeality 
for this speeies; but I have a speeimen in my collection which was obtained on our coasts, and which I had wrougly referred to $B$. plumosa, until the examination of fine examples of the same form from the United States direeted my special attention to it.

Geograpiical Distribution. Madeira (J. Y. J.) : Lynn, Massachusetts (Rev. W. Hincks).

A referenee to Mr. Busk's description of this speeies in the 'Mieroscopieal Journal' will show that it differs in several important points from the one given above. I should hardly have felt justified in assuming the identity of $B$. gracilis and the present form (which I shall distinguish as B. gracilis, var. uncinata), had not Mr. Busk stated that his specimen of the former was a small one, so small indeed (it is implied) as to render it diffieult to determine the habit satisfaetorily.

The general eharaeter of the zoccium is undoubtedly the same in both; but B.gracilis, Busk, is represented as having only two spines, whilst its aperture is deseribed as not extending below the middle of the eell. At the same time there is no mention in Busk's diagnosis of the remarkable appendages which are present on every shoot of the var. uncinata, in both the British and NorthAmerican examples.

As to these differenees, it may be remarked that the spine or denticle on the outer angular extremity of the aperture is rather ineonspieuous, and might easily be overlooked, especially in dried speeimens, and that the aperture may not improbably vary in length. With respeet to the appendages, on a fragmentary specimen they might not be present; or it is possible that they may only be developed under certain loeal eonditions. Looking to the great general similarity of the two forms, 
it scems better to regard them as cssentially identical (at least provisionally) than to run the risk of introducing a falsc species. Should further acquaintance with them show them to be specifically distinct, the present form would rank as $B$. uncinata.

In some respects $B$. gracilis bcars a considerable rescmblance to B. plumosa, but is of smaller size and of dissimilar habit. It differs from it, too, in possessing three spincs instead of one, and in the character of the apcrture. The two free extremities of the margin above are more prominent than in $B$. plumosa, the inner one especially being carried forwards so as to be on a level with the outer, and each of them bcing crowned with a spine. The aperture is also much more decidedly turned in wards towards the middle of the branch than in the latter species. I have ncver met with the hooked appendage on $B$. plumosa.

In the number of the marginal spines $B$. gracilis agrees with $B$. avicularia; but they are very different in the two species. In the former the uppermost of the two on the outer side resembles the single spine of $B$. plumosa; that on the angular extremity of the aperture in front of it is a strong denticlc. The inner spine is not directed upwards like that of $B$. avicularia, but projects at right angles to the surface of the zoarium, and is placed exactly opposite to the denticle; the cclls and avicularia of the two specics are also dissimilar.

As I have mentioncd, this form is furnished with a very curious appendage, which must be regarded as a modification of the radical tube. It originates on the dorsal surface of the cell ncar its base, and stands out from it at right augles. It consists of a rather stout tubular process, which widens upwards from its point of origin, and at its free extremity bifurcates, each 
arm again dividing and subdividing, and the ultimate ramules forming a number of eurled, tendril-like elaspers (Plate XII. figs. 6, 7), by means of which we may suppose the slender tufts fix themselves or eling to some neighbouring support. These prehensile appendages are distributed in great numbers over the zoarium, ranging from its upper portions to its very base. The tuft commenees with one or two cells, disposed in single scries; and two of the appendages spring one on each side from the primary cell, close to its lower extremity.

We hare in this ease another adaptive modifieation of the simpler strueture, correlated, in all probability, with some peeuliarity of habitat. I have never met with any trace of the ordinary radieal tubes on $B$. uncinata; the appendages abound on the lowermost portion of the shoots; and in all eases it is more or less invested by some fibrous material, in which the base of the zoarium was probably plunged, and to which it was fast bound by its apparatus of hooks*.

\section{Bugdla purpurotixcta, Norman.}

Plate XII. figs. 8-12.

Cellclaria fastigiata, Dalyell, Rare and Rem. An. Scotl. i. 236, pl. xlvi. (not the Sertularia fastigiata of Fabricius).

Celuularia pluxosa, Johnst. B. Z. ed. 2, 341, pl. Ixi.: Sars, Reiso i Lofoten og Finm. 29.

Begula rastigiata, Alder, Cat. Zooph. North. and Durh. 59 : Sars, Geol. og Zoolog. Reise i sommeren 1862, 37.

Bugula avicularia, forma rastigiata (part.), Smitt, Krit. Fört., CEfr. Vetensk.-Akad. Förhandl. 1867, 291 and 346 , pl. xviii. figs. 16-18.

Beqce Perptrotiscta, Norman, Quart. Journ. Micr. Sc. (n. s.) viii. 219.

Zoarium stout, bushy, irregularly branched, of a purplish-

- In the footnote on page 30 , the name of the present species should be substituted for B. plumosa. 
red colour when dry. Zoccia biscrial, much elongated, attenuated below; aperture extcnding almost to the bottom of the eell, wide above, almost pointed below, with a stont eylindrieal spine, jointed at the base, on the upper and outer angle, and a dentiele in front of it. Avicularia plaeed about halfway down the eell. large, elongate, the head not mueh arehed, the beak curved for about a third of the length, with a very short hook at the extremity. Oœcia extremely shallow, hemispherieal, as viewed sideways, the aperturc occupying almost the whole of the front.

Habitat. In the Laminarian region, and on shells, \&e., from deep water.

Localities. Cullcreoats, common (Coppin): south coast of Durham, extremely abundant (J. Hogg) : Seotland (Dalyell) : Shetland, 5-7 miles east of Balta, 40-50 fms., searce (A. M. N.) : Seaham Harbour (G. Hodge) : Searborough (Bean): St. Andrews, Coralline ground, attaehed to shells, abundant (Dr. M'Intosh): Loch Ryan, oyster-shells (Landsb.) : Filey, Yorkshire; Mcnai Straits (T. H.) : Wiek, abundant; Peterhead, $\operatorname{rarc}$ (C. W. P.): Clontarf (Trin. Coll. eolleet.).

Geographical Distribution. Christiansund and Bejan, 40-60 fms. ; Lofoten (M. Sars) : Balıusia and Norway, eommon, 30-130 fms. (Smitt) : St. George's Banks, 110 and $150 \mathrm{fms}$. (Smith and Harger).

This specics had been eonfounded with $B$.plumosa until Mr. Alder pointed out, with his accustomed aecuraey and clearness, the eharaeters which separate them.

$B$. fastigiata is of stouter and stiffer habit, and mueh more bushy and irregular in its mode of growth than the "soft-feathered Coralline." The branehes are large and spreading, and divided into a multitude of narrow seg- 
ments. The older portions of the zoarium are brown, and coarse in appearance; but the newer tcrminal portions of the shoots are of the most dclicate whiteness and perfectly transparent. This in itsclf gives a very peeuliar and distinctive appearanee to the specics. The matcrial of which the eclls and ovicclls are composed is very thin and papyraccous. The cclls are much longer than those of $B$. plumosa, and with something of a cylindrieal charaeter; and the aperture oeeupics a larger proportion of the front. The stout, cylindrical, and jointed spine at the top of the cell differs widely from the sharp and rather slender spike of the other species, with which indeed, as Alder has remarked, it hardly corresponds. The true equivalent of the latter is clearly the small denticle, which usually rises in front of the larger spine from the free angular extremity of the margin. The avicularium of the present species is very largc, as long as the breadth of the ccll, and differs in shape from that of $B$. plumosa. Perhaps the most striking differenee is found in the shape of the oviccll, which in the lattcr is globular and of the usual type, while that of $B$. fastigiata is cxtrcmely shallow; as scen in profile (Pl. XII. fig. 12) it is hemispherical, the aperture oceupying nearly the whole of the front and looking straight outwards. So shallow is it that it only partially covers the embryo in its later stages.

When dry $B$. fastigiata takes on a ricl purplish-red colour, a peculiarity which has suggested the specifie name, and by which it may be at onee recognized.

The polypide has, according to Sars, 14 tentacles, while Dalycll gives the number at 16-18.

The present species rises from a dense mass of intertwining fibres to a heiglit of about 3 inclics. It is a northern form, not oceurring on our southern and western coasts. 


\title{
Bugula Murrayana, Johnston*.
}

\author{
Plate XIV. figs. 2-9.
}

Flustra Murrayaxa, Johnst. Br. Z. ed. 2, 347, pl. Ixiii. Ggg. 5, 6.

?? Sertularia spiralis, Olivi, Zool. Adriat. 291 \& 313, pl. vi. fig. 2 a, A.

Flabellaria spiralis, Gray, Cat. Brit. Rad. 106.

Avicella yultispisa, Van Ben. Bull. Acad. Roy. Belg. xp. no. 2 des Bulletins (1849), 76, pl. x. figs. 7, 8 (p. 10, sep.).

Bugula Murrayans, Busk, B.M. Cat. i. 46, pl. lix.: Smitt, forma 1 and forma 2, B. QUavridentata, l.c. 291 and 349 , pl. xviii. figs. 19-26 (?27).

Mexupea froticosa, Packard, List Labrador Mar. An. 9, pl. i. fig. 3.

Zoarium eonsisting of a number of shoots, mueh divided dichotomously into broad ribbon-like segments, truncate at the top, and forming entangled, spreading, bushy tufts. Zoocia multiserial (4-12 rows), alternate, oblong, truneate above, and slightly narrowed below (boat-shaped); aperture reaching nearly to the bottom; an ereet spinous proeess at each angle above, and a variable number of marginal spincs $(2-5$ on the outer edge and 1-3 on the inner) curving inwards $\dagger$. Avicularia on the front of the eells below the aperture, (those on the marginal eells about three times as large as the rest,) elongated, the head moderately arehed, well rounded bchind, surface smooth and polished; beak very short in proportion, with a mueh bent extremity; mandible long, sharply pointed. Oxcia large, subglobose, glistening, almost membranous, with radiating strix.

Radical fibres very long and stout, and wrinkled transversely, given off from the side of the marginal eells towards the lower part of the shoots.

Hcight about $1 \frac{1}{4}$ ineh. Of a light straw-colour when dry.

* The specific name originated with MIr. Bean, and was communicated by him in MS. to Dr. Johnston, by whom it was first published.

$t$ There is occasionally a spine at the bottom of the cell near the place usually occupied by the avicularium. 
VAR. a (fruticosa, Packard). Zoarium consisting of many shoots, divided dichotomously into very narrow linear segments, forming tufts of very delicate habit. Zocecia $2-4$ in a row, alternatc, an ereet spine at the two upper angles, and a single marginal spine on each side a little below the top. Large marginal avieularia wanting (?).

Habitat. On zoopliytes, Flustra foliacea, shells, stones, \&c., chiefly from the Coralline ground.

Localities. Searborough, deep water, very rare (Bean) : Northumberland (Miss Dale): ditto, from the fishingboats, Cullereoats, rather rare, more common from the deep-water (five-men) boats (Alder) : coast of Yorkshire; Orkney, common in deep water (Lieut. Thomas) : Shetland (E. Forbes) : The Minch (A. M. N.) : Lamlash Bay (T. H.) : Stonehaven (Lady Keith Murray) : Peterhead and Wick, plentiful (C. W. P.): Leith and Newhaven, on the fishermen's nets (D. Landsb. Jun.) : St. Andrews, plentiful from the Coralline ground (Dr. M'Intosh) : Dublin Bay, on Hydrallmania falcata, Flustra foliacea, and in bivalve shells ( $\mathrm{M}^{\prime} \mathrm{C}$ Calla).

Geographical Distribution. Skandinavian coasts; Grötsund, Finmark, 100 fathoms; Spitzbergen (Smitt): Greenland, Holsteinborg Harbour, 7-35 fathoms, both normal and var. $\alpha$; Godhavn Harbour, Diseo, 5-20 fathoms, var. $\alpha$ ('Valorous' Exped.) : South Labrador, var. $\alpha$, eommon (Packard): off Frederickshaab, Davis Straits, 100 fathoms, var. $\alpha$ (Wallich) : North Sea (Van Ben.) : Gulf of St. Lawrence (Dawson): New England (Kirehenpauer): St. George's Banks, 28-150 fathoms (Smith and Harger).

The remarkable variety, which was first deseribed by Paekard as a species under the name of Menipea fruti- 
$\cos a$, and whieh Lovén subsequently distinguished as $B$. quadridentata, presents a striking eontrast in general aspeet to the normal $B$. Murrayana. Its slender habit and mode of growth are very much those of a Scrupocellaria; while the typical form, with its broad truneate segments, reminds us of a Flustra.

After an examination of the minute characters, however, there can be no doubt that the two are referable to onc and the same speeies. The variety owes its very marked faeies simply to a reduetion in the number of the rows in which the eells are disposed. The other structural eharaeters are the same in both, with the single insignifieant exception that the marginal spines are less numerous in the form fruticosa. The case is an interesting one as showing how eompletely the external appearance of a speeies may be changed without the modification of a single essential eharaeter.

The shoots at their origin are uniserial, three or four cells being linked together, as in Eucratea.

On the dorsal surface the eells appear of a somewhat fusiform shape ("en forme de barillet," Van Beneden), separated by deep furrows, and marked here and there by transverse black and white bands. The surface is smooth and shining. On each of the marginal eells there is a pore plaeed on the back a little below the spinous process on the outer angle, which marks the point from which, in the lower part of the shoot ehiefly, the radical fibres originate. Above they are but rarely developed.

The long and remarkably stout radical fibres are developed in great profusion; they attach themselves by means of a number of fibrils given off from the free extremity, which adhere firmly to any neighbouring support. 
B. Murrayana seems to be in great mcasure a northcrn form, and to be cspceially at home in the extreme north. The var. fruticosa prevails in the Aretic seas. The identification of this specics with the Sertularia spiralis of Olivi is more than doubtful, and is so regarded by Heller, who has not himself obtained it in the Adriatic.

\section{Genus BEANIA, Johnston.}

Der. Named after William Bean, the well-known Scarborough naturalist.

Generic Character.-Zoarium subcorneous or calcareous, erect or decumbent. ZoccI sessile, erect, scattered, united one to the other by a slender tube, originating from the dorsal surface or from the side near the base; aperture occupying the entire front, the margin furnished with hollow spinous processes arching over the opening; mouth terminal. Ogecia and Avicula ria wanting.

TuE links which bind the present genus to the Bicellarian group have already been referred to. It has also affinities, though probably more remote, with Aetea. The tubular connexions between the cells may be regarded as of the nature of pedicels; and we may therefore compare such a form as $B$. mirabilis witle $A$. truncata (see Plate II. fig. 3), to which in scveral points it bears a curious resemblance.

The intereellular tubes are in no sense the cquivalent of a creeping fibre; nor are they in any way conccrned in attaching the zoarium to its place. This is effected by a special arrangement. From each ecll (in B. mirabilis) a mcmbranaccous tubular process is given off from a definitc point on the dorsal surface near the base (woodcut, fig. 4a), varying in length according to eircumstances, and tcrminating in a small disk, furnished witl a number 
of fibrils or rootlets, by means of which it adheres firmly to the shell or weed over which the polyzoon ereeps. After the disappearance of the radieal fibre itself, its point of origin is marked by a small tubular projection on the surface of the eell. In Diachoris, I find, attachment is effeeted in preeisely the same way.

The zoarium, then, in the genus Beania, is eomposed of a number of pedicellate cells, which spring one from the other in linear series, from which other lines are given off at right angles. The sceondary series originate at opposite points on the sides of the eell, near its base. The whole strueture is generally decumbent, and in this condition is attached by radical fibres emitted from the individual cells.

A Patagonian speeies, Beania australis, Busk, is said to form a conneeted frond at times, and in this state must approach very elosely to Diachoris.

Three speeies have been deseribed besides our. own $B$. mirabilis :-B. Swainsoni, Hutton, an ereet phytoid form from New Zealand (apparently taking on to some extent the habit of Bugula) ; B. admiranda, Packard, from Labrador; and the Patagonian form just referred to.

\section{Beania mirabilis, Johnston.}

Plate IV. figs. 8-10.

Bzamia Mirabilis, Johnst. Ann. N. H. ser. 1, v. 272 ; B. Z. ed. 2, 372, woodo. figs. 69, 70: Busk, B.M. Cat. i. 32, pl. xxiv. figs. 4, 5 : Hincks, Ann. N. H. ser. 2, xv. 129: Landsb. Pop. Hist. B. Z. 369, pl. xix. flg. 25: Smitt, QEfv. 1867, no. 5, 292 \& 357 : Heller, Bryoz. Ad. M. 13.

Zoarium adherent by means of radieal fibres given off from each cell. Zoœcia subealeareous, boat-shaped, contracted above and bulging below; two dentieles above 
the mouth; spincs 7-10, on cach side of the aperture; the connceting tube slender and smooth; opposite branches given off from the base of the cells. Polypide with 20 tentaeles.

Raxge of Variation. This scems to be very narrow. The only difference I have observed which is worth noting is in the number of the spinous proeesses on the margin of the apcrture. Johnston gives it at 5-7, but it often reaches 10 or even more ; 8 or 9 secm to be the usual quota in well-devcloped specimens. The uppermost pair are stouter than the rest and suberect.

Habitat. On weed (especially Laminaria), zoophytes, shclls, stones, \&c., between tide-marks; more rarely on shells from deep water.

Localities. Searborough, on shells and rock, and on Cellularia (Bugula) avicularia at or within low-water mark (Bean) : dredged off Seilly, on Pecten maximus (M'Andrew) : Petcrhead and Wick, very rare (C. W. P.) : off the coast of Antrim, on Pectunculus (Hyndman) : Filcy, on shell brought in by fishermen; Lamlash, Arran; Isle of Man, on weed; Swanagc, on Laminaria ; off Lulworth Covc, in shallow water; Ilfracombe, common, on stones in rock-pools; Exmouth, on Bugula turbinata, Laminaria, \&e. ; Torbay, stones between tide-marks; Herm, plentiful; Gucrnsey; Plemont, Jersey (T. H.) : Sidmouth (Mrs. Gatty) : Eastbourne (Roper): Hastings, rare (Miss Jelly): Shanklin, Isle of Wight (H. Lee) : off Falmouth, on a crab-float (Cocks). Not recorded from Shetland.

Geographical Distribution. Scandinavia (Lovén and Smitt) : Adriatic, at Lesina, on an Alga, one specimen (Heller): Roseoff, dredged, and at low-water mark (Jolict). 
This is a elarming species, and onc of the collcetor's treasures. Not that it is really rare, though from its minuteness it readily eseapes deteetion; but the beauty of its spinous eells and the singularity of their form make it a general favourite. It is perhaps most easily obtained by a careful search amongst the Laminaria-roots, at extreme low-water mark. Over these it often ereeps in great luxurianee, in eompany with Aetea anguina and other pygmy forms.

The polypide has about 20 tall and delicate tentacles, forming a singularly graeeful bell. It is of large size, and, when fully expanded, projeets very far beyond the orifice, the body at suel times only occupying about the upper third of the eell. A long, straight œesophagus leads from the pharynx to the stomach. The flexible portion of the eell, which unrolls as the animal issues, is of unusual length. Amongst the marine Polyzoa, I know of no polypide which exeels it in beauty, unless it be that of Flustrella hispida.

\section{Family V.-Notamiidæ.}

Gemellariade (part.), Busk.

Zocels in pairs, each pair arising by tubular prolongations from the pair next but one below it; at each bifurcation a new series of cells intercalated into the branches.

THe remarkable structure of the zoarium which distinguishes Notamia bursaria, entitles it to stand as the type of a separate family. It has eertainly no elose affinity with Gemellaria. Apart from-other differences, the 
charaeter of the zoceium is totally distinet in the two; while the point in which they agree-the disposition of the eells, opposite to one anotlier in pairs, is of very sceondary importanee.

The Australian genus Calwellia, Wyville Thomson, resembles Notamia to some extent in the structure of the zoarium, and should perhaps be included in the present family.

\section{Genus NOTAMIA, Fleming.}

Noтахіи (sp.), Flem. Br. An. 1828: Busk.

Epistovia, Flem. Br. An.

Serteraria (sp.), Linnxus.

Crluularia (sp.), Pallas.

Cemlaria (sp.), Ellis \& Solander: Lamk.

Drsajexa (sp.), Lamouroux.

Gruicellaria, Blainville, 1830.

Generic Character.-Zonrium consisting of a creeping tubular stem and erect shonts. Zoøcia united laterally in pairs ; above each pair two stemmed avicularia, originating, one on each side, from the inferior tubular prolongation of one of the cells immediately above. Orecis none.

Ir is no easy matter either to determine or to explain the complex structure of the zoarium in this genus. Without entering into details, it may be sufficient to state that the pairs of eells do not arise immediately one from the other, but that each pair is eonneeted with the next pair but one above it by tubular prolongations, which are given off from the upper and inner angles of the eells composing it. At each bifureation of the shoot, the two series of cells eomposing the internode immediately below it separate, and each of them forms half of one of the branches resulting from the division; and at this point two new series are introdueed to make eaeh branch complete. The several 
scrics of eclls which eompose the shoot are continuous from their point of origin to the termination of the branch to which they bclong; e.g. the serics which originate from the two primary cells pass uninterruptedly to the extremities of the branches of which they constitute the halves. And the same holds good of all the new serics intercalated at the bifurcations. It will be noted that above each bifurcation there is only a single cell instead of the usual pair. There are some irregularities in the composition of the first intcrnode; but the above is the general plan of the structure.

Those who desire to master all its minutiæ may refer to Mr. Busk's paper in the 'Transactions of the Microscopical Socicty,' in which he has given an exhaustivc account of the structural details*.

The zocecium of Notamia bears a general resemblance to that of Bicellaria.

Notamia bursaria, Linnæus.

Plate IV. figs. 1-5.

Shepuerd's-purse Coralune, Ellis, Corall. 41, pl. xxii. figs. a, A : Johnst. B. Z. ed. 2, i. 294, pl. li. figs. $1,2$.

Sertularia bursaria, Linn. Syst. 1314.

Cellularia bursaria, Pall. Elench. 65.

Cellaria bursaria, Ell. \& Sol. Zooph. 25 : Lamk. An. s. V. ed. 2, ii. 189.

Dramena bursaria, Lamx. Pol. cor. flex. 179.

Notamia burgaria, Flem. B. A. 541: Busk, Trans. Micr. Soc. ii. (1849), 110 , pl. xxv.; B.M. Cat. i. 36, pl. xlv. figs. 1-4.

Gemiceluaria bursaria, Blainv. Dict. Sc. N. Ix. 445 : Landsb. Pop. Hist. 297 , pl. xvi. fig. 59.

Sertularia BUrsa, Turt. Brit. Faun. 216.

Epistomia bursaria, Gray, B.M. Rad. 82.

* 'Transactions of the Microscopical Society of London' Tol. ii. (1819), pp. 110-121, pl. xxv. 
Zoarium pearly, mueh branched dichotomously, the branehes eurled at the extremities. Zocecia bracketlike, broad above, and produced at the outer angle into a sharp point, narrowed below ; the aperture oecupying almost the whole of the front; the oral valve semieircular, set somewhat obliquely near the inner angle above. Avicularia borne on short tubular stems and shaped like a tobaceo-pipe, the head tumid, widening from the base upwards, with a pointed mandible and a minute beak. Oœcia none.

Polypide with 10 tentaeles.

Habiтat. On Fuci, stones, shells, Crustacea, \&e., in shallow water.

Localities. Deron, on Hydrallmania falcato (Mrs. Griffiths) : Isle of Wight, abundant (C. W. P. and Busk) : Swanage Bay, Isle of Purbeek, extremely fine and plentiful, 3-10 fathoms (Busk and T. H.) : Cromer (Mr. Wigham): Hastings, on Rytiphloea pinastroides (M. 'Tumanowiez) : Brighton (Mr. Pike) : Weymouth (Bowerbank): off Essex; Southend and Ramsgate (teste Busk).

Notamia bursaria is no less remarkable for its beauty than for the singularity of its strueture. It grows in exquisitely soft and feathery tufts, of a pearly whiteness, formed of most delicate material, and gracefully eurled at the extremities. The ereet shoots rise at intervals from a rather stout creeping tube, whieh is filled with a yellowish granular substance. The stem is slightly attenuated towards the point of origin, and for some distanee above it is destitute of eells. The two primary zoceia are quite rudimentary, and originate in a slight dilatation of the stem, which is divided by a central wall or partition into two chambers. From thesc a sccond pair proeeed, which approach more nearly to the normal condition; they 
differ from it, however, in size, and to some extent in shape; and one of them bears on its outer side a small and peculiarly formed avicularium. From this second pair two series of zoceia are developed aceording to the plan which has been already described.

Seattcred here and there over the zoarium gigantic cclls frequently occur, resembling in form the ordinary zoœcium, but twice as large. They are rendered opaquc by their contents, and are very conspicuous objects. I have not been able to make a minute examination of their internal structure; but it is not improbable that they may have a reproductive function.

Two avicularia are interposed above each pair of cells, execpt immediately bclow a bifurcation, where one of them is suppressed. These appendages are given off laterally from a ecntral tube which traverses the posterior surface of the zoarium, and bear a very close resemblance in form to a tobaceo-pipe. Some of them are very much larger than the rest, more than double the size, very tumid, and almost of equal width throughout (Plate IV. fig. 5).

"This most beautiful pearl-coloured Coralline," as Ellis calls it, has generally bcen accounted extremely rare. It is ecrtainly local; but in the south it is not at all uncommon*, and at ecrtain points it oceurs in extraordinary profusion. Mr. Busk has told us how common he found it to be in Swanage Bay. In the same loeality I have dredged it in large quantities, almost every haul bringing it up (gencrally in company with the extraordinary Hydroid

* Dr. Landsborough remarks that "Rytiphloea pinastroides seems its favourite weed;" and he adds, "from the number of little bittocks which I have detected on various weeds from the South of England, it is evident that it is not rare."-Pop. Hist. Brit. Zooph. p. 298. 
Ophiodes mirabilis, mihi). Wonderful specimens were obtained, consisting of multitudes of the feathery tufts elustering thickly about the bunches of wced. It is also common off the neighbouring coasts of the Isle of Wight. On the Devon coast it must, I should think, be extremely rare, as after a prolonged and carcful examination of this region, extending over many years, I have never met with a specimen.

\section{Family VI.-Cellariidæ.}

Escilarid.e (part.), Johnston.

Salicorvariade, Busk.

? Vixculariad.e, id.

Celohariere, Smitt.

Salicoradidida (part.), Reuss.

Zoøers usually rhomboidal or hexangular, disposed in series round an imaginary axis, so as to form cylindrical shoots. Zoanium erect, calcareous, dichotomously branched.

I нAVE not included the jointed condition of the zoarium in the above diagnosis, as it must be accounted more than doubtful whether this character is of sufficient importance to warrant the relegation of such closely allied forms as Cellaria and Vincularia, Defrance, to different family groups. All the British members of the family, however, possess an articulated zoarium.

The Cellariida are comected through the genus Nellia, Busk, with the Cellulariida, whilst in the character of their avicularia and the immersed condition of the ovicells they agree with the Flustrida. 


\section{Genus CELLARIA, Lamouroux (part.).}

Der. from cella, a cell.

Celuaria (part.), Solander: Lamouroux, Bull. Soc. Philom. 1812: D'Orbigny: Smitt.

Salicorvaria, Curier, Règne An. 1817 : Johnst.: Busk, \&o.

Farciara, Fleming, Brit. An. 1828.

Salicoria, Schweigger, 1819.

Genertc Character.-Zoarium jointed at intervals, the internodes connected by flexible horny tubes. Zowcia depressed in front, and surrounded by a raised border, disposed in quincunx. Avicularia immersed, irregularly distributed, situated above a cell or occupying the place of one. Oecra immersed.

I will give as briefly as I ean my reasons for reverting to Solander's name Cellaria, as applied by Lamouroux, and displacing Cuvier's Salicornaria, which has obtained so much eurrency through the elassical works of Johnston and Busk. A glanee at the synonymy of Cellaria fistulosa must convince any one of the importance of maintaining with rigor the law of priority in seientifie nomenclature. The earliest name, accompanied by a sufficient diagnosis, has an indefeasible claim to adoption; and to set it aside for any secondary reasons scems to me to be a serious offenee against scientific order.

The facts in the present ease are as follows:-Cellaria was introdueed by Solander, in his edition of Ellis's posthumous work (1786), as the designation of a miscellancous assemblage of forms, a purely artificial group, which only existed to be dismembered.

In 1812, Lamouroux adopted it as the name of a genus, of which he expressly constituted Cellaria salicornia ( $=C$. fistulosa) the type. He says, "J'ai conservé le nom de Cellaire au groupe dont les polypiers avaient 
pour type le Cellaria salicornia, un des plus remarquables et des plus aneiennement connus"*. It is true that he has ineluded in the genus one or two forms which are not referable to this type; but he has himself supplied us with the test by which we at onee recognize and reject them as aliens. His genus Cellaria, according to his own showing, embraces those species only which exhibit the same structural features as Cellaria fistulosa.

Instead of rejecting Lamouroux's genus altogether because he has wrongly referred species to it which do not belong to it, the proper course surely is to retain it for the type which he has himself selected for it, and to allow the forcign elements to find their place elsewhere. I eannot share Mr. Busk's apprehension that it may be "confounded with the more extensive Cellaria of Dr. Solander" and others, as the latter has long since been resolved into its elcments, and ceased to exist but as a name. Were there, however, any ground for such apprehension, I should hesitate on this account to set aside a genus which has such undoubted priority $\dagger_{\text {. Cuvier's Salicornaria was }}$ published in 1817.

Lamouroux's name has been adopted by Smitt in his 'Critical Catalogue' of the Skandinavian Polyzoa; and he has stated very clearly the grounds on which he bases his decision $\ddagger$.

In this well-marked form the surface of the cylindrical internodes which compose the zoarium is divided into regular, (usually) rhomboidal, or hexagonal, or oval areas by the walls which elose in the front of the eclls. The

* Hist. d. Pol. cor. Alex. p. 125.

+ Mr. Busk afterwards adopted the name Cellaria (Quart. Journ. Mier. Sci. (n. s). rii. p. B5), and promised his reasons for doing so; but he has sinco reverted, probably through mere inadrertence, to Salicornaria (ibid. viii. p. 280).

† 'CEfrersigt af Kongl. Veteuskapg-Akademiens Förlandlingar,' 1867, pp. 383,384 . 
latter is always mueh depressed, and eonsists of a ealeareous lamina, pierced by a more or less semicireular orifice. The avieularia are of a very simple type, and exhibit a eomparatively slight modification of the ordinary zoceium. The ovicells are completely concealed, as in Flustra; and the opening is placed at the upper extremity of the area, a little above the oral aperture.

The Cellaria are widely distributed, members of the group oceurring in New Zealand, Tasmania and the Australian eontinent, and Cumberland Island (on its east eoast), the Falkland Islands, South Ameriea, South Afriea, Madeira, the Mediterranean, Great Britain, Nortl Sea, Greenland, and Spitzbergen, south coast of North America, Indian Ocean. The genus possesses a very eosmopolitan representative in our own C. fistulosa.

The Cellaria reach back as far as the Cretaceous epoch at least, during which they formed a very small group, while at the same period a large number of the allied Vincularia flourished.

The present genus ranges from shallow to very deep water. We learn from Sir Wyville Thomson that forms referable to the family were obtained during the 'Challenger' voyage, at depths between 2000 and 3000 fathoms, a sterile region, where other animal life was scaree*.

Cellakia fistulosa, Linnæus.

Plate XIII. figs. 1-4.

Bugle Coralline. Ellis, Corall. 46, no. 1, pl. miii. figs. a, A, B, C, D.

Escitara fistulosa, Linn. Syst. ed. 10 (1758), 804.

Cellularia salicornia, Pall. Elench. 61.

Tumularia fistulosa, Linn. Syst. ed. 12 (1766-8), 1302 ,

Fuestra fistulosa, Linn. Faun. Suec. ii. 2234.

* 'The Atlantic,' by Sir C. Wyville Thomson, F.R.S., vol. i. p. 3H8. 
Cellaria salicorsia, Lamx. Pol. cor. flex. 55; Exposit. Méth. 5 : Lamk. Anim. 8. V. ed. 2, ii. 176: Blainv. Actinol. 455, pl. Ixxrii.

fig. 1: D'Orbigny, Pal. Franç. Terr. Crét. v. 28.

Crluaria farcisinoides, Ellis of Sol. Zooph. 26.

Salicorsaria salicoria, Cuvier, R. Anim. ed. 1, iv. 75.

Farcisia pistulosa, Flem. Br. An. 533.

Salicorsaria diciotosia, Schweigger, Handb. 428.

Salicornaria fistulos., Templeton, Mag. N. Hist. ix. 469.

Crelaria fistulosa, S. V. Wood, Ann. N. H. xiii. 17 : Smitt, hrit. Fört.,

CEfr. h. Vetensk.-Ak. Förh. 1867, 362 and 3s6, pl. xx. figs. 18-20.

Farcinia salicorsia, Johnst. Br. Zooph. ed. i. 295, pl. xxrvii. figs. 6, 7 :

Couch, Oorn. Faun. part 3, 129, pl. xx. fig. 3.

Salicorsarta rarcimivoides, Johnst. B. Z. ed. 2,355 , pl. lxvi. figs. 6, 7 : Busk, B.MI. Cat. i. 16, pl. lxiv. figs. 1-3, pl. lxv. fig. 5 : Reuss, Foss. Bryoz. d. öst.-ung. Miocäns, 3, pl. xii. figs. $3-13$.

Glacconome yarginata *, v. Münster in Goldfuss's Petref. Germ. i. 100, pl. xxтri. fig. 5 .

Cerlaria yargivata, Reuss, Wien. Tertiärbeck. 59, pl. vii. figs. 28, 29.

Viscularia submargisata, $D^{\circ}$ Orb. Pal. Fr. T. Crét. v. 60.

Viscelaria Reussi, D’Orb. l.c. 60.

Salicoria sargixata, Stoliczka, Foss. Bryoz. aus d. tert. Grïnsandst. der Otakci-Bai, Auckland, 146.

Viscularia margivata, Rümer, Pol. d. Norddeutsch. Tertiärgeb. 105.

Guaccosose Ritombifera, v. Münster in Goldfuss's Petref. Germ. i. 100, pl. iii. fig. 6 .

Salicorsaria ruombifera, Reuss, Zur Fauna d. deutsch. Oberoligocïn, ii. 15 , pl. xiv. figs. 7-10.

Vixcclaria rhombifera, Römer, l. c. 6.

Cellaria aftisis, Reuss, Sitzungsber d. k. Ak. d. Wiss. 1S55, xviii. 259, pl. xi. fig. 106.

Zoarium dichotomously branched, internodes of moderate length, slender, cylindrical, slightly attenuated below. Zocecia contiguous in the same line, lozenge-shaped or hexangular, or rounded above and truncate $\dagger$ below; area minutely pitted; orifice arched above, lower lip slightly eurved inward, usually subecutral, sometimes placed about $\frac{1}{3}$ the length of the area from the top. Avicularia at the top of a ccll, on a small transversely

- The remaining synonyms ure given fide Reuss, who had a large acquaintance with fossil forms.

$\uparrow$ "The shape of the cells is not always of a lozenge-figure: sometimes we fird them arched at top, and sometimes of the shape of a coflin."-Euls. 
oblong area; mandible sliallow, rounded, direeted upwards. Ovarian opening suborbicular. Polypide with about 14 long tentacles.

Ha Bitat. On roeks, sliells, Corallines, \&e., from shallow to deep water.

Localities. Very generally distributed. From the Eddystone to the Lizard and Land's End, eommon (Coueh): South Dcron (Torbay, Saleombe, Brixham trawlers, \&e.), abundant; Ilfraeombe (T. H.): Hastings (Tumanowiez): Dublin and Belfast Bays (W. T.) : eoast of Antrim, 62 and 72 fathoms (Mr. W. Swanston): Northumberland, frequent in deep water (Alder): Lamlash (Landsborough): St. Andrews, deep water (Dr. M'Intosh): Hebrides; Shetland, 40-70 fathoms (A.M.N.) : 5 miles south-west of Mull of Galloway, 110-140 fathoms (Beeehey), \&e.

Geographical Distribution. Mediterranean (Pallas) : Adriatic, attached to Nullipores, mussel-shells, and stones by delieate fibres, eommon (Heller) : Cigale, 30 fathoms (Grube): on the Falmouth and Lisbon eable, between N. lat. $47^{\circ} 58^{\prime}$ and $47^{\circ} 35^{\prime}$, and in W. long. $7^{\circ} 6^{\prime}$, at depths from 89-205 fathoms (Sir James Anderson): Algiers (J. Y. J.) : Madeira (fide Kirehenpauer); Algoa Bay (Busk): New Zealand (Hutton): Australia (MacGillivray): Indian Oeean (Lamouroux): Norway (Sars): Bahusia, forma fragilis (Lovén): "ad insulas Waderöarne" (Goës) : St. George's Banks, 28 and 60 fathoms (Smith and Harger).

Range in Time. Austro-Hungarian Miocene (Reuss).

Cellaria fistulosa exhibits the same variations in the shape of the cell as occur in the following speeies. It is slender in habit; and its internodes are generally mueh shorter than those of $C$. sinuosa. The normal position of 
the aperture seems to be central or subcentral ; but eases occur in which it is placed much nearer the top of the area. It wants the raised and prominent lower lip of the latter species. The avicularium, with its very shallow arcuate mandible, directed upwards, is alone sufficient to distinguish it from the other British forms.

I have restored Linnacus's specific name, on the simple ground of its priority. Dr. Johnston summarily displaces it for its "impropricty," and because the retention of it would only tend "to the perpetuation of error." Of course, we are well aware now that the branches are not tubular; but if we were to proceed to abolish all the names which represent an error in theory or observation, we should have our hands full, and should certainly inflict an injury upon science, for which a more strictly correct nomenclature would be poor compensation.

I have noticed two interesting monstrosities or irregularities of development in this species :-a doubling of the avieularium, two of smaller size occupying the place which is usually filled by one ; and ankylosis of the joint. The latter has been observed by Busk in C. malvinensis, and more frequently in the fossil species.

Cellaria sinuosa, Hassall.

Plate XIII. figs. 5-8.

Farctria siscosa, Hassall, Ann. N. H. vi. 172, pl. ri. figs. 1, 2.

Farcimia spatrulosa, Hassall, ibid. xi. 112.

Saltcorsaria sixuosa, Johnst. B. Z. (2 ed.) i. 356, pl. Ixvi. fig. 8: Busk, Orag Pol 23: Alder, North. \& Durh. Cat, Trans. Tynes. F. Club, iii. 152 (62 sep.).

Salicorsaria rarcimixoidra, rar., Busk, B.Mf. Cat. pt. i. 17: ? Manzoni, Bry. Foss. Ital. pt. iv. 4, pl. i. Ifgs. 1, 2 *.

* I have littledoubt that Manzoni's fgures should be reforred to this species, and not to $C$. fistulosa. The position of the aperture in the upper part of 
Zoarium dichotomously branched, internodes long and stout, eylindrieal, slightly thiekened towards the top, the extremities rounded. Zocecia lozenge-shaped or hexagonal, or arehed above and tapering off below; area finely dotted, walls minutely granular; orifiee arched above, placed almost at the top of the area, with a much-raised lower lip, which forms a broad and prominent plate in front. Avicularia at the top of a eell, often set obliquely, with a triangular mandible pointing downwards. Ovarian opening at the very top of the area, elongated transversely, with a broad tooth on the lower margin.

Habitat. Attached to stones, \&e., from deep water and the Coralline ground to shallow water.

Localities. Belfast and Dublin Bays (W.T.): South Devon; abundant on the Brixham trawling-grounds ; Salcombe Bay, \&e.; Cornwall (T. H.) : Northumberland, off Whitburn, in about 20 fathoms (Alder): Shetland, 40-70 fathoms (A. M. N.).

Range in Trme. Crag (Busk): Italian Plioeene; Quaternary, Livorno (Manzoni): near Mt. Gambicr, South Australia, in Tertiary strata corresponding to the English Crag (Rev. J. E. Woods).

The eharacters which distinguish this speeies from the preeeding are the mueh stouter habit and larger size, the shape of the avieularium, the position of the aperture in the upper part of the area and its raised and prominent lower lip, and the form of the ovarian opening.

the area, and its produced lower lip, and the shape of the ovarian and avicularian openings are all distinctive features of the present form. The author seems to have formed an imperfect conception of the group of characters by which $C$. sinuosa is distinguished from the last named species; for he speaks of it as a very trifling variety (" ma ben leggera var. di $S$. farciminoides"). In point of fact they differ in almost every important element of structure, as well $n$ in habit. 
The mere shape of the eclls is of little moment, as they exhibit marked yaricties of pattern on the same specimell, being sometimes rhomboidal, and sometimes arched above, and sometimes almost quadrangular. There are also great differences in the number of the rows of eells composing the cylinder.

The avicularia are commonly placed obliquely; but in some cases the broad triangular mandible points straight downwards; they occur in larger numbers than on $C$. fistulosa. The ovarian opening is picreed, as. it were, in the wall, at the upper extremity of the eell, just above the orifice. On its lower margin there is sometimes to be seen a broad denticle; but it is either often absent or is difficult to detect. Busk represents it as bicuspid; it may be so at times; but as I have met with it it has a perfectly plain straight top.

The shoots are attached by a mass of tubular fibres, cach of which originates within the area of a cell, towards the base of it; they frequently eover the lowest internode. The tubes are simple, often of considerable length, and give off short processes at the extremity, which form a rude kind of adherent disk.

This handsome species grows in large tufts, from 3 to 4 inches in height, or even more.

The distinction between $C$. sinuosa and $C$. fistulosa has been so imperfectly appreciated that localities for the present form must be aecpted with caution. I have only given those which seem to be beyond question. It has no doubt a more gencral distribution than these would indicate. 
Cellaria Johnsoni, Busk.

Plate XIII. figs. 9-12.

Neluia Joussonı, Busk, Quart. Journ. Micr. Sc. vi. (1858), 125, pl. xix. fig. 2 [described from imperfect specimens].

Cellaria Jonnsont, Busk, ibid. vii. 65, pl. xxiii. figs. 4, 5; pl. xxviii. figs. 4, 5 (nat. size and a vicularium).

Salicormaria Jonssoxi, Busk, ibid. viii. (1860), 280.

Zoarium slender, diehotomously branched, forming small white tufts, about 1 to $1 \frac{1}{2}$ ineh in height. Zoocia elliptieal, distant, the spaee between them traversed by a ridge, which divides above into two lateral branehes, passing off one on each side to the top of the adjaeent eells; area smooth, walls very finely erenulated along the edge : orifice placed above the middle of the eell, arehed above, lower margin slightly eurved inwards. Avicularium situated in the line of the eells, and oeeupying the plaee of a eell; mandible semieircular, direeted upwards. Ovarian opening orbieular.

Habitat. Deep water.

Localrty. Shetland, Middle Haaf (A. M. N.).

Geographical Distribution. Madeira; Algiers (J. Y.J.).

The habit of this speeies is decidedly slender; but in this respeet some varieties of $C$. fistulosa make a near approach to it. The prineipal distinetive charaeters are the elliptieal or subelliptieal form of the front of the eells, the interspaee by which they are separated from one another, with its eentral bifurcating ridge, and the avieularium, which replaees an ordinary zoceium. The mandible oceupies the position of the oral valve, on an area resembling that of the eell, but smaller in size. It is large, semieireular, and of a dark horn-colour. 
This simple type of avicularium is common amongst the members of this genus*.

The aperture is placed above the middle of the ecll, and therefore rather higher up than in C. fistulosa. The cells in the same series are scparated by a very considerable space. In the older portions of the zoarium the ridge which traverses it is often inconspicuous or ncarly obliterated; but it may always be traced in the younger parts of the colony, towards the extremity of the cylindrical internodes.

\section{Family VII.-Flustridæ.}

Fscriarid.z (part.), Johnst. B. Z. : D'Orbigny, Pal. Franç.

Flustrad.e (part.), Busk.

Futstride, Smitt.

ZoARIOM corneous and flexible + , expanded, foliaceous, erect. Zocera contiguous, multiserial. Avicularia usually of a very simple type.

Closely allied to the Membraniporida, the Flustrida arc distinguished by their crect, flexible, and frond-like zoaria. The two families are certainly not very sharply defined. In its primary stage, Flustra sometimes takes on the Membraniporidan mode of growth; whilst, on the other hand, Membranipora in some cases (c. g. $M$. flustroides and $M$. cornigera) exhibits the type of avicu-

* In this less highly specialized form of avicularium all the parts of the cell aro distinctly represented. The area with its inclosing walls is present, though reduced in size; the mandible is simply the oral operenlum, enlarged, and raised by the hoor-like eleration of the beak behind it.

+ A certain amount of calcareons matter is combined with the horny substance of the zonrium. 
larium which is usual (though not universal) amongst the Flustrida*. Still the general features of the group are suffieiently salient and striking, and its boundary lines probably not more evaneseent than those of most of our systematic divisions.

\section{Genus FLUSTRA, Linncus.}

Der. Flustrian (Saxon), to weave.

Esciara (part.), Pallas : Linn. Syst. ed. 10.

Fuustra, sp., Linnæus : Lamk. : Johnst. (part.): Busk : Smitt (part.), \&c. Cinatella, Gray (for $F$. papyracea, \&c.).

Carbasea, Gray: Busk (? part.).

Semiflustra, s]., D’Orbigny.

Generic Character.-Zoarium erect, frondose. ZoEcIA disposed in a single layer, or in two layers united by the dorsal surfaces, more or less quadrangular or linguiform, with a raised margin, the aperture occupying the whole or a considerable portion of the front of the cell, and closed in by a membranous covering. Oøcia immersed.

Turs genus, as now defined, includes species with two layers of eells, and others with only a single layer. The latter have been detached by some writers, and ranged under the genus Carbasea, Gray; but, so long as the type of the zoccium is the same, it seems to me quite unneecssary to separate the bilamellate and unilamellate forms. It may be a question, perhaps, whether those members of the genus Carbasea, Busk, in which the aperture is redueed to a small opening at the upper extremity of the eell, and the ovicells are external, sliould

* The South-African form Carbasea armata, Busk, is furnished with lateral aricularia resembling those of Scrupocellaria. 
not be referred to a distinct group-a point which can only be settled after a carcful study of these forms. But all the British Flustride may be included in the present genus.

The polypide of Flustra exhibits no structural peculiaritics.

The avicularia occur in most cases under a very rudimentary form. They are usually developed in the linc of the eclls, from which, indecd, they differ but slightly. Nowhere is the morphologieal signifieance of thesc curious appendages more easily reeognizable.

This genus ranges to the Arctic regions and the northern eoasts of Amcrica (Gulf of St. Lawrence), and is represented in the Meditcrranean, in South Africa, in New Zcaland and Australia; and in China and the Society Islands by $F$. foliacea. Of the Arctic species three ( $F$. serrulata, Busk, $F$. membranaceo-truncata, Smitt, and $F$. securifrons, Pallas) occur in the Gulf of St. Lawrence; and two ( $F$. carbasea and $F$. securifrons) arc also British, but confined to our morc northcrly coasts. The genus has its principal scat in Europe, and is most abundant and most richly represented in northern latitudes.

\section{a. Zoxcia in two layers.}

Flustra foliacea, Linnacus.

Plate XVI. figs. 1, $1 a, 1 b$; and Plate XIV. fig. 10.

Pores cervixus, Jussieu, Mém. de l'Acad. Roy. d. Sc. 1742, 290, figs. 3, A, $\mathrm{B}, c c$.

Broad-leaved Horswrack, Ellis, Corall. 70, no. 2, pl. xix. fig. a, A.

Escitura poliacra, Linn. Syst. ed. 10, 804: Pallas, Elenchus, 52: Moll, Eschara, de. 44, pl. ii. fig. 7.

Fr.uotra Folicea, Linn. Syst. ed. 12, 1300: Ell. of Sol. Zooph. 12. pl. ii. fig. 8: I"an Ben. Recherehes, 56, pl. vii. figs, 11, 17 : Lamk. 
An. s. Vert. ed. 2, ii. 219: Grant, Ed. New Phil. Journ. iii. 111,337: Flem. Brit. An. 535 : Couch, Corn. Faun. iii. 121, pl. xxi. fig. 1 : Johnst. Brit. Zooph. ed. 2, 342, pl. Ixii. figs. 1, 2: Busk, B.M. Cat, pt. i. 47, pl. 1v. figs. 4, 5, pl. lvi. fig. 5: Smitt, Kritisk Förtockn., Wfvers. K. Vet.-Akad. Förh. 1867, 360 and 381, pl. xx. figs. 12-16.

Zoarium of a brown eolour*, deeply divided into numerous multifid segments, which are narrowed towards the base, and expand upwards, generally bifid at the extremities, and slightly rounded. Zocecia in semialternating rows, arehed and expanded above, with two spines on each side, and frequently one in the eentre of the upper margin; below eontraeted and truncate; avicularia seattered, with semieireular mandible. Oocia extremely shallow, the opening forming an areh over the upper extremity of the eell.

Polypide with 13 or 14 remarkably long and slender tentacles.

Height of fine speeimens about 6 inehes.

Habitat. On stones, shells, \&e., generally in moderate depths, but also in much deeper water (62-70 fathoms).

Localities. Universally distributed on our coasts.

Grographical Distribution. Belgium, exeedingly eommon (Van. Ben.) : eoast of Normandy (Jussieu) : Lissa, Adriatic (Heller) : Charente-inférieure, "eommon at great depths" (Beltrémieux) : south-west eoast of Franee, very rare (Fiseher) : Soeiety Islands (E. Forbes) : Algoa Bay, a form only distinguished from the European by the eomparative smallness of the eells; Amoy, China (Kirehenpauer): Norway (Smitt) $t$ : the Belt and Kattegat (Kirehenpauer).

The frond-like shoots of $F$. foliacea rise from an in-

" "Yellowish grey," Grant; " of a lively flesh colour," Couch.

+ It seems not to be an Arctic species; it has not been found, according to Smitt, in Finmark or Spitzbergen. There ean be no doubt that the $F$. foliacen of Fabricius is a totally different form. 
erusting network of cells, often of considerable extent, which bears a close resemblance to a Membranipora. On this crustaceous base they are crowded togetlier, so as to form large elustered growths. The nascent shoots are wedge-shaped. The species is liable to many varieties of habit. In some cases the fronds are broadly palmate, and the segments into which they divide are much elongated, and expand regularly upwards from the slender base, terminating above in a broad, somewhat truncate extremity. In the more usual form the fronds are comparatively slender, the segments shorter and often bifid at the top. Occasionally specimens oceur in which the frond is semielliptical, witl the margin almost entire or slightly sinuated*, and with a distinct border, formed by a line traversing it from side to side, at a short distance from the edge and rumning parallel to it. (Plate XIV. fig. 10). When examined with the microseope the margin of the zoceia is seen to be very minutely beaded. The polypides of this species are of very large size as compared with their cells; and the body is therefore very much bent and folded upon itself during retraction.

Much has been written of the scent of $F$. foliacea. When freshly taken from the water it has a decided perfume, not unlike that of the violet $†$; but it would seem to affect different persons very variously. Dr. Landsborough found its seent like bergamot, or, rather, like that of Verbena triphylla. It reminded Pallas of the eitron $\ddagger$; others have compared it to "the mixed

* "Broadening out towards the extremities, so as to present the outline of Padina paronia."-Wx. THoxrsos.

+ +A strong and pleasant odour of violets."-Grast. "An odour resembling that of violets after a shower."-Covcr.

† "Recens e mari extracta amcuun, eitri fere æunulum, cum pelagico mixtum odorem spargit; quem et sicenta aliquamdiu servat."-Elenchus Zomphyt. p. 54. 
odour of roses and geraniums ;" whilst Ellis bluntly ealls it "fisliy."

The flat frond of $\boldsymbol{F}$. foliacea $*$ offers an execllent site for the colonies of the smaller Polyzoa and Hydroida; and many species are commonly found associated with itamongst the rest, Scrupocellaria reptans and S. scruposa, Crisia eburnea, Bugula fabellata, Sertularella rugosa, \&c.

The rare and interesting Hydroid Hydranthea margarica, Hincks, would seem to have no other habitat; and in the only known locality for it, the shallow water off the Capstone at Ilfracombe, almost every tuft of the Flustra which comes up in the dredge is eovered with its delicate network and flower-like polypites.

Sir John Dalyell has studicd the embryos, and states that he has known ten thousand to be liberated from a specimen in the course of three hours!

This species is one of the commonest of sea-side objects, and may generally be met with on any sandy beach.

Flustra papyracea, Ellis and Solander.

Plate XVI. figs. 2, $2 a$.

Flustra PaPyracea, Ell. $\oint$ Sol. Zooph. 13: Fleming, Brit. An. 535: Busk B.M. Cat. i. 48, pl. 1v. figs. 6, 7 : Hincks, Dev. \& Corn. Cat $37+$.

Flustra cirartacea, Turt. Gmel. iv. 663: Couch, Corn. Frun. iii. 121 : Johnst. Brit. Zooph. ed. 2, 343, pl. lx. figs, 5, 6.

Cuartella Papyracea, Gray, Cat. Rad. B. M. 104.

Zoarium forming small bushy tufts of a light straw-colour, much divided dichotomously, the segments short and

* .. " telam sericeam texturd smulans."-PuUкeneт.

+ Flustra papyracea of Hutton's Catalogue of New Zealand Polyzon must be a totally different form. He describes it as haring fusiform avicularia "situated on the right or left marginal spine." 
rather narrow, expanded at the summit, truncatc or slightly rounded. Zoxecia oblong, with a single short spine at cael sidc aborc. Oæcia small, galcriform, somewhat produccd. Avicularia none (?).

Height of tufts about $1 \frac{1}{2}$ inch.

Habitat. On stones, shclls, \&c., generally in very modcrate depths.

Loealities. South Devon, not uncommon; Salcombc Bay; Plymouth; Torbay; Ilfracombe, 8-10 fathoms (T. H.): Cornwall, very rare, on shell from deep water 8 leagues south of the Deadman (Couch) : Tenby ( $F$. Walker): Hastings (Ellis) : Brighton (Lister) : cast and south of Ireland (W. T. \& Allman).

Geographical Distribution. Roscoff, very rare (Joliet): Charente-Inférieure, pretty common (Beltrémieux): west eoast of Francc (Fiseher)*.

This pretty species is distinguished by its small size, its bushy habit of growth, and the delieacy of its texture. The zoarium has a varnished and glistcning appearanee; the scgments into which the fronds divide are short and subtruneate. Avicularia scem to be altogether wanting. It is limited in its rangc, and has probably not occurred in the north.

The oœeium is placed very far back, and projects into the cell above it, being eompletely roofed over by its front wall. The arch across the orifice is slightly raised; but the rest of the oviecll is completely immersed, and

* Kirchenpauer records this form from Hougesund, and Lüthen from Greenland; but these localities are extremely doubtful. Kirchenpauer's species is probably not identical with our $F$. papyracea; for he remarks that it had not its thin papyraceous character. And ns wo have no other record of the occurrence of the present species in the north, and especially as it does not appear amongst the 'Valorous' dredgings, or those of the North. German Polar Expedition, I renture to think that Litken must bo in error in assigning it to Greenland. 
the mere outline is traceable through the membranous covering. The aperture of the ovicell is closed in by a delicate membrane; and at the top of it there is frequently an opening of definite form, which probably gives egress to the mature embryo.

Flustra securiprons, Pallas.

Plate XVI. figs. 3, $3 a$.

"Narrow-Leaved Hornwrack," Ellis, Corall. 69, no. 1, pl. xxviii. fig. 1, a, A, B.

Esciara foliacea $\beta$, Limn. Syst. ed. 10, 804.

Esciiara securifrons, Pallas, Elench. (1766), 56.

Flustra truncata, Linn. Syst. ed. 12, 1300: Lamk. An. 8. Vert. ed. 2, ii. 219: Flem. B. An. 535: Johnst. Br. Zooph. ed. 2, 344, pl. lxii. figs. 3, 4: Busk, B.M. Cat. i. 48, pl. lviii. figs. 1, 2, and pl. lvi. figs. 1, 2.

Flustra papyracea, Dalyell, Rem. An. ii. 19, pls. v., vi., and vii. (var.). Ohartella securifrons, Gray, Cat. Rad. B. M. 104.

Flustra securifrons, Smitt, Krit. Förteckn., QEfv. K. Vet. Ak. Förh. 1867, 358 and 378 , pl. xx. figs. $6-8$.

Zoarium bright straw-coloured, divided and subdivided into narrow segments, which are linear or slightly dilated above, and truncate, rooted by many tubular fibres. Zoccia linear, oblong, with unarmed margins. Avicularia seattered, elliptical, with a rounded mandible. Oxcia globose, with a slightly thickened rim in front, the lower part of the aperture elosed in by two rib-like processes.

Height 4 or 5 inches.

Habitat. On shells, \&c. from the Laminarian region and the Coralline ground.

Localities. Chiefly a northern form. Shetland ( $\Lambda$. M. N.) : Scotland, common (Johnst.) : Peterhead, abundant (C. W. P.): St. Andrews, Laminarian and Coralline zones, common (Dr. M'Intosh): Leitl ; Dirleton, opposite 
the Bass Rock (Landsb.): Oban (T. H.): Firth of Forth, 30 fathoms (Kirehenpauer): Northumberland and Durham, abuudant (Alder) : two miles east of Sana Island, in 40 fathoms (Hyndman): 8 miles S.S.W. Mull of Galloway (Capt. Beeehcy) : Filey, plentiful (T. H.): Dublin Bay (Templeton) : Belfast Bay (W. T.): coast of Antrim, 20 fathoms (Mr. W. Swanston).

Var. (papyracea, Dalyell) "with the ends expanded into undulating foliations, from the fusion of several of the terminal branchlets into one." Scotland (Dalyell) : Northumberland (Alder).

Geographical Distribution. Mediterranean (Pallas): Adriatie (Heller) : Lofoten; near Tromsö and Havösund, in 40-50 fathoms, rare (MI. Sars) : Spitzbergen; western coast of Skandinavia, 10-50 fathoms (Smitt) : ibid. 150300 fms. (Koren): South Labrador, frequent (Packard).

This species forms very large bunehes, of a light strawcolour when fresh.

In many speeimens "wedge-shaped leaflets" are developed along the edges of the segments eomposing the zoarium.

The ovicell, as in all the speeies of this genus, is inclosed within the walls of the eell above it, and overlaid with its membranous eovering, so as to be quite inconspieuous. Indeed, the ovieell itself is all but invisible; the arch in front of it and the aperture are the only signs of its existenee which strike the eye. The latter is filled in by a membrane, and is also proteeted by two rib-like appendages, which are given oft one on each side of it, and mect in the centre. The oceium of this speeies is larger and more fully developed than that of Fhestra foliacea (woodeut, fig. 6).

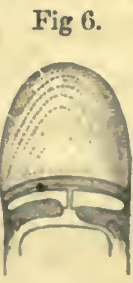

Orreium. 
I have followed Gray and Smitt in substituting Pallas's name for that of Linnæus. The publication of the 12th edition of the 'Systema,' in which the present form first reecived the name truncata, commeneed in 1766 , the date of the appearanee of the 'Elenchus;' but the work was not eompleted till 1768, and it is in the volume bearing date 1767 that the name occurs. Pallas, therefore, has undoubted preeedence; and it becomes a pleasant duty to associate this fine species with the name of onc of the most sagacious and accuratc of observers.

Flustra Barleei, Busk.

Plate V. figs. 6-8.

Flustra Barleei, Busk, Quart. Journ. Mier. Sc. viii. (1860), 123, pl. xxv. fig. 4.

Zoarium foliaceous, thin and brittle, light-coloured, divided, the segments above terminating in short rounded lobes. Zocecia oblong, very large, with a simple margin. Avicularia scattered, plaeed obliquely, with a semieircular mandible. Oxcia globose and rather shallow. Height of fine specimens about 2 inches.

Habitat. In moderately deep water.

Localities. Shetland (Barlee) : "very loeal, between Whalsey and Balta, and off Unst, in about 50 fathoms" (A. M. N.).

Geographical Distribution. Entrance to the BömmelFjord, in 106 fathoms (Kirehenpauer).

This species is distinguished by its very large, reetangular cells, with an unarmed margin, by the oblique position of the avicularia, and by its habit of growtl. It 
eonsists of foliaceous fronds, which divide near the base into segments; these again subdivide, and at the top are eut into shallow blunt lobes. The habit is neat and compaet. When dry the zoarium has a varnished appearanee. There is nothing very distinetive in the eharaeter of the oœeium; it is globose in form, moderately shallow, with a large aperture, completely filled in by a membranous eovering, the arel of which alone rises above the surface of the zoarium. The immediate cause of the immersion of the ovicell is at onec apparent in the ease of eells from which the front wall has disappeared. It is then evident that the top wall of the zoccium, to which the ovicell is attached, is eonsiderably lower than the side walls, which support the roofing. The eonsequenee is, that when fully developed the ovieell is still below the surface, inelosed by the sides of the eell above it, and concealed by its membranous covering.

This is one of the many forms which we owe to Mr. Barlee's assiduous labours as a dredger.

\section{b. Zoœcia in a single layer.}

Fuustra carbasea, Ellis and Solander.

Plate XVI. figs. 4, $4 a$, and Plate XIV. fig. 1.

Flustra carbasea (Lawn Sea-mat), Ell. \& Sol. Zooph. xiv. pl. iii. figs. 6, 7 : Lamk. An. s. Vert. ed. 2, ii. 221 : Flem. B. A. 535 : Grant, Ed. N. P. Journ. iii. 111: Dalyell, Rem. An. Scotl. ii. 3, pls. i. \& ii. : Johnst. B. Z. ed. 2, 345, pl. lxiii. figs, 1, 2: Kirchenpauer, Bericht. ü. d. Untersuchungs-Fahrt d. 'Pom. merania,' 177, 178.

Oarbasea paptracea, Gray, Cat. Rad. B. Af. 103.

Carbasea papyra, Busk, B.M. Cat. i. 50, pl. xlix. figs. 1, 2, 3: Alder, North. \& Durh. Cat。 61. 
Semirlubtra carbasea, D'Orb. Pal. Franç. Terr. Orét. v. 326.

Flustra papyred, Smitt, Krit. Fört., CEfv. \&c. 1867, 359 and 380, pl. xx. figs. 9-11 (not Eschara papyrea, Pallas)*.

Zoarium frondose, attached by a small disk, narrowed bclow, with a thickened margin towards the basc, expanding upwards, decply divided into segments, which again subdivide, and tcrminate in somewhat broad and rounded lobes; of a yellowish brown colour, and thin, delicate, papyraccous texturc. Zoccia on one side only, large, oftcn much clongated, arched above, contracted below, and truncate at the bottom (linguiform). Avicularia none. Oxcia nonc.

Polypide with about 22 tentacles.

Height 2-4 inches.

Habitat. On stone and shell from rather deep water.

Localities. Shetland, fishing-boats, Middlc Haaf (A. M. N.) : Peterhead, rare (C. W. P.) : Abcrdecn (Skenc) : St. Andrews, after storms and from the fishingnets, not abundant (Dr. M'Intosh): Leith (Dr. Coldstream) : oystcr-beds, Firth of Forth (Grant): Bcrwick (Johnst.) : Newhaven, fishcrmen's nets (Dr. Landsb.) :

* Kirchenpauer, in his Report on the North-Sea Polyzoa obtained during the royage of the 'Pommerania' (1875), proposes to separate the Eschara papyrea, Pallas (Flustra papyracea, Linn.), from the Flustra carbasea of Ellis and Solander, on the ground (chiefly) that the cells of the former are described as "rhomlic" whilst those of the latter are "linguiform." He regards Pallas's species as a Mediterranean form, distinct from our British species, which is undoubtedly the Flustra carbasea of Solander. I am inclined to belicre that this view is correct. "Pallas is singularly accurate in his descriptions, and would have been little likely to characterize the strongly marked cells of $F$. carbasea as rhombic, a term which is in no sense applicable to them. They are, as Linnaus describes them, "supra ovate, medio angustate, infra truncate." Pallas also makes no mention in his description, as Kirchenpauer has remarked, of the thickened margin of the zonrium towards the base, which is so peculiar and striking a feature of the latter form, an omission which we should not have expected from the author of the 'Elenchus.'

It must be admitted, at the same timc, that in most respects his description agrees with the present species. Linnacus recognized the two forms as 
Northumberland, deep water, frequent (Alder): Filey, abundant (T. H.) : Bootle, rare (Tudor): Dublin Bay, rare (M'Calla): North of Ireland (Templeton).

Grographical Distribution. Hammerfast, 40 fathoms, on a stony bottom; Ramfjord, near Tromsö (Sars): Bohuslän (Lovén) : Spitzbergen, 40-60 fathoms (Torell) : Greenland (Lütken) : Gulf of St. Lawrenee (Dawson).

This species is not attached by means of radical fibres; nor does it rise from an expanded erust. The zoarium narrows towards the base into a kind of stem, terminating below in a small disk, by which it adheres to stone or shell. The lower portion or trunk has a thickened, opaque, and channelled margin. The tcrminal segments of the frond are broad and wedge-shaped, and generally more or less lobate; and the width of the whole zoarium is great as compared with its height. A varicty oceurs in which the shoots are composed of broadly palmate expansions, sometimes almost entire, sometimes with numerous marginal lobes. The texture is remarkably delieate (like that of lawn, aecording to Ellis); and the

distinct. On the whole I think we are fairly entitled to say that we should not be justified in setting aside the diagnosis of so careful an observer as Pallas, and implying that he had failed to appreciate an important character. It may bo added that he gives no British locality for his Eschara papyrea.

Kirchenpauer also considers Smitt's Flustra papyrea a distinct species, on the ground that this author has not stated that it has only a single layer of cells, and that it must therefore be regarded as bilnminate. But though he has not expressly referred to this character in the text, he has flgured the posterior surface of the frond, showing the back of the cells (Krit. Förteckn. pt. iii. pl. xx. fig. 10.), while at the same time he has placed amongst his eynonyms Carbasea papyrea, Busk, and other names, which he must bave known were appropriated to a unilnmellate form. His figure 9 is an accurate repsesentation of the cells of Flustra papyrea; and in his descriptive text he has notired several of its distinctire peculiarities. There is no ground whatever for separating his species from the present. 
surface glistens when dried. The eclls are arranged with extreme regularity, and form a pretty and distinct lacework pattern on the frond. The strueture is eminently simple; spines, avicularia, and probably occia, are all wanting. Grant deseribes the development of the ovum, which is of a light-yellow colour, and its eseape from the ecil itself into the water.

\section{Family VIII.-Membraniporidæ.}

Celleporid s (part.), Johnston, Brit. Zooph.

Membraniporide (part.), Busk, B.M. Cat.

Flustrellaride (part.), D'Orbigny, Pal. Franç. T. Crét.

Escharide (part.), id. ibid.

Escharellinide (part.), id. ibid.

Flustrellide (part.), id. ibid.

Flustrinide (part.), id. ibid.

Electrivide (part.), id. ibid.

Membraniporide, Smitt, Krit. Förteckn.

ZOARIUM calcareous or membrano-calcareous, incrusting (so far as British species are concerned) *. Zoccia forming an irregular continuous expansion, or in linear series, with raised margins, and more or less membranaceous in front.

THis family represents an earlier stage of zoccial development, as compared with the two following. The calcification of the cell is always more or less imperfect; and in a large proportion of eases the whole of the front is merely closed in by a membranc, a condition which we meet with in the immature eclls of the old Lepralian group.

* There are fossil and other forms with an erect habit of growth, which from the structure of their zocecia, should probably be included in this fainily. 
The avicularia in this family almost always exhibit a more highly specialized form than in the preceding. They are usually secondary formations, borne upon the zoœeia instead of being developed in the same plane with them.

In a great proportion of eases the colonies in the present family, and indeed very eommonly amongst the Cheilostomata at large, originate in a peculiarly shaped eell, which differs widely from the mature zoœcium. And these primary eells exhibit, with minor differences, a general similarity of strueture. They are for the most part somewhat rounded, with a large terminal aperture, closed in by a membrane, and usually surrounded by a number of spines. Such a form was long since deseribed by Van Beneden as a distinet genus, under the name of Tata $^{*}$; and the original cell of the Cheilostomatous colony is often distinguished as the Tata-form. Of course this genus, bcing founded on an carly and immature condition, which is common to a large scetion of the Polyzoa, has not been maintained. I have designated the first element of the Cheilostomatous colony the primary cell; and if a separate name is needed for the form which it generally assumes, it may be styled the Tata-stage.

\section{Genus MEMBRANIPORA, Blainville.}

Der. From membrana, a thin skin, and porus, an opening.

Escitara (part), Pallas.

Fecstra (part.), Linn. : Lamurck: Fleming: Lamouroux: Audouin.

Mesbravipora, Blainville, Man. d'Actinol. Johnston: Busk: Switt : \&e. Discopora (part.), Laink. An. s. F.

* "Recherches sur les Pol. Bryozoaires de la mer du Nord," Bull. Ac. Roy. Belg. xri. no. 12 (1819), p. 6 (sep.). 
Oellepora (part.), Hagenow : Rouss: D'Orbigny * (for species with a calcareous lamina).

Anvelipora (sp.), Gray, B.M. Rad. Append.

Coxopeva (sp.), Gray, id. ibid.

Callotora (sp.), Gray, id. ibid.

Ampurbegtrum (sp.), Gray, id. ibid.

Margixaria (part.), Romer: Hagenow.

Derantorora (part.), Hagenow.

Generic Character.-Zoarium incrusting. Zogecia quincuncial, or irregularly disposed, occasionally in linear series; margins raised ; front depressed, wholly or in part membranaceous.

TuE essential characters of this division are the raised margin, and the depressed front wall of the zoceium, which is always more or less membranaceous. The orifice is merely an opening in the membranous portion of the covering, closed in by an opereular valve, and is never surrounded and isolated by a calcareous border. In the most typical forms, such as $\boldsymbol{M}$. membranacea and $\boldsymbol{M}$. Lacroixii, the entire arca of the zoccium is covered uniformly by a thin membrane, which lies a little below the lcvel of the margin. In others this membrane is calcificd to a greater or less extent, and a solid lamina is thus formed, which protects a certain portion of the cell. But eren in spccies in which this process of calcification is earried furthest, and almost the whole front is hardened into a solid wall, its position within and below the marginal rim at once indicates the mode of growth, and reveals the true Membraniporidan strueture. The passage to the old Lepralian type is not through such forms, or through the genus Micropora, but through Membraniporella, in which the ealcareous covering is an outgrowth

* I havo not thought it necessary to swell this list of synonyms by referring to all D'Orbigny's genera, which include species of Membranipora as now defined. The groups to which they belong are given in the family eynonymy. 
from the margin of the cell, ovcrarching, as it wcrc, the original membranous covering.

The present genus may be divided into two principal groups-the first including those species in which the area is wholly roofed in by a chitinous membranc, and the sccond those in which the covering is converted, to a greater or less cxtent, into a solid platc.

It has been proposed to refer to a distinct genus certain forms with a trifoliatc or subtrifoliatc apcrturc, taking M. Flemingii as the type. But this character is rather a shadowy one, and the group thus constituted would not be sufficiently differentiated from other Membranipore with a calcarcous lamina.

The terminology employed in describing the members of this genus requires a word of explanation. The area is the portion of the cell surrounded by the raised margin. The aperture is that part of it which is not closed in by a calcarcous wall ; and on this is placed the true orificea scmicircular opening, with a valvular operculum. In the species which have the front wall wholly membranous, the arca and the aperture of course coincide.

The genus Membranipora, as now limited, has a wide range both in spacc and time, and includes a rich varicty of forms. It reaches back as far as the Cretaccous pcriod at least, in which it was represented by a large number of species. It is found in almost all parts of the world.

\section{a. With a membranous front wall.}

Mrmbranipora Lacroixit, Audouin.

Plate XVII. Ags. 5-8.

Flustra Lacroixu, Sarigmy, Egypto, pl. x. fig. 9.

Futegtra distass, Hassall, Ann. N. H. vii. (1841), 369.

Flustia Peacuir, Couch, 9th Rep. Oornw. Polytechn. Soc. 81. 
Mresbraxtrora Peacuit, Couch, Corn. Faun. iii. 120, pl. xxii. fig. 13. ?Membranipora mesibranacea, Johnst. 13. Z. 2 ed. pl. lvi. figs. 11, 12. Cosopeum reticcues, Gray, B.M. Rad. 108.

Mexbrasirora Lacroixit, Busk, B.M. Cat. ii. 60, pl. Ixix., pl. civ. fig. 1: Hincks, Der. Cat., An. N. H. ser. 3, ix. 28 (38 sep.).

Membrantrora reticulux, Reuss, Foss. Polyp. d. Wioner Tertiärbeck. 98, pl. xi. fig. 25 .

Bifustua Lacroixir, Smitt, Flor. Bryoz. pt. ii. 18, pl. iv. figs. 85-88.

Zoxcia oval, sometimes much elongated, area oceupying (usually) the wholc of the front of the cell, with a membranous covering; or oceasionally a calcarcous expansion round the inner edge; margin slightly thickened, rounded, granulated, rising, so as sometimes to form a prominent ridge; often armed with two ereet spines, one on each side abovc, more rarely bearing a considcrable number (about cleven), very delicate and sharply pointed ; frequently a triangular hollow on each side, immediately above the aperture: Oocia none.

Colonies forming a thin gauzc-like crust over shells and stones, often of great extent.

RANGe of Variation. The front of the ecll is either a very regular oval or much elongated and narrowed. It is generally occupied cntircly by the aperture; but oceasionally the zoœcium is slightly produced below. The cells lic very closely together in most cases; and specimens are rarely met with in which they are more or less disjunct. The spines vary in number from two to about a dozen. Usually they are represented by the couple at the top of the cell; but in sheltered situations the margin bristles with slcnder spinules, and in most colonies cells may be met with on which a few at least survive. The hollow triangular spaces above the aperture are often wanting. They are not true avicularia, but consist of a three-cornered area inclosed by calcareous walls, and covered in by a transparent membrane. This membranc is frequently destroyed; and they then appear as hollow 
triangular struetures, which bear a general resemblance to the pointed form of avicularium.

Habitat. On stones and shells from tide-marks to deep water.

Localities. Cornwall, in Falmouth and Fowey rivers, on mussel- and oyster-shells; off the Deadman (Couch) : South Devon, between tide-marks and from moderate depths, common; Ramsay, Isle of Man, on stones in tide-pools (T. H.) : on stones east of Kingstown Harbour (Hassall) : St. Andrews, on a valve of Cyprina Islandica from deep water (Dr. M'Intosh) : Tynemouth, a single specimen (Alder) : Hastings, eommon (Miss Jelly).

Geographical Distribution. Mediterranean (Savigny) : coast of Florida, 13-60 fathoms (Pourtales) : St. Lawrenee (Whiteaves)*.

Range in Time. Coralline and Red Crag (part.) (Middle Plioeene); Palæolithic (A. Bell): Austro-Hungarian Mioeene and Plioeene deposits; Vienna Basin (Reuss) : Italian Plioeene beds at Volterra (Manzoni) : Postpliocene (Dawson).

Membranipora monostachys, Busk.

Plate XVII. figs. 3, 4 ; Plate XVIII. figs. 1-4.

Mexbraxipora yonostaciys, Busk, B.M. Cat. ii. 61, pl. lax.; Crag Pol. 31, pl. ii. fig. 2: Hincks, Devon. Cat. 38 (sep.), Ann. N. II. ser. 3 , ix. 28.

Fucetra distass, Landsb. Pop. Hist. B. Z. 354 (not F. distans, Massall). Menbranipora rilosa, 4, forma yoNostacius, Smitt, Gefvers. K. Vet.-Ak. Förh. 1867, 370 and 416.

?Flcbtrellaria pustllosa, $D \prime$ Orb. Pal. Franç. Terr. Crét. v. 526, pl. docxxr. figs. 22-25.

?Mzybraxipora sobius, Reuss, Foss. Polyp. W. Tertiärb. 98, pl. xi. fig. 26.

* The M. Lacroirii of Packard's List of Labrador Invertebrata is referable, according to Smitt (who had seen a specimen forwarded by the above naturalist), to his $M$. Americana. 
Zoccia suborate, produced and attenuated below; area oval, more or less elongate, oceupying about two thirds of the front of the eell, with a membranous eovering; margins thin and plain, bearing a single acuminate spine below the aperture, bending inwards, and oeeasionally a tall and very slender ereet spine on each side near the top, or armed with numerous delieate spines (about 18), the eentral one below being larger and stouter than the rest, and the two uppermost standing ereet. Zoarium usually assuming a dendritic growth, giving off branches eonsisting of lines of eells two or three abreast, or in single series, which anastomose freely.

Var. a (fossaria). Zoccia elongate-oval; area oecupying the whole of the front of the cell; a single stout eonieal spine at the bottom. Zoarium spreading over the stems of plants in braekish water, and forming friable, irregularly shaped, sponge-like masses.

Range of Variation. M. monostachys affords a striking illustration of the remarkable diversities in habit and general appearanee that may rank under one and the same speeifie type. In its early eondition it forms a continuous expansion, the eells being disposed in somewhat radiate fashion. But the zoarium does not long maintain this simple eharaeter; it is soon resolved, as it were, into lines of eells, in which two or three are ranged abreast; and these again give off single series, from which in time other eompound series may originate; and so the ramifieation proeeeds, until a large and eomplex and very beautiful dendritie growth is the result.

The differences in the number of the spines with which the margin of the eell is armed are also great, and they affeet very materially the appearanee of the speeies. The aeuminate spine at the bottom of the area is tolerably eonstant; it is always present on some of the eells in a 
eolony. The two erect spines at the top of the eell are frequently associated with it, though very commonly absent. The lateral spines seem to be rarely developed. In a beautiful variety from Roach River, the branehes are mostly uniserial, and the margin of the eells is elothed with about sixteen delieate spines, which bend inwards over the aperture. I have a similar variety from Torquay. Specimens of this form bear a eurious general resemblanee to Hippothoa dentata, Busk, a Crag speeies.

In the variety (fossaria), which oeeurs in brackish waters, the aperture is much elongated and oceupies the whole, or nearly the whole, of the front of the eell. The produeed pedunculate portion at the base has disappeared, and with it most of the eharacteristic facies of the species. There is a single stout eonieal spine at the lower extremity of the aperture. The eells seem to be eomposed of lesssolid material than in the normal form; and, from the nature of the base over which it spreads, the zoarium assumes a peculiar habit.

Habitat. On rocks between tide-marks; on shells and stones, chiefly at the mouths of rivers; and on the stems of water plants in brackish ditehes.

Localities. Mouth of the river Deben, on the Suffolk coast, abundant (Busk) : Roach River (J.G. Jeffreys) : Torquay, on stone between tide-marks; Ilfracombe, on the Capstone roeks (T. H.) : Hastings (Miss Jelly).

Var. a. Yarmouth, in ditehes of brackish water, about a mile from the sea, on stems of aquatic plants (Mr. Wigham).

Geographical Distribution. "I have a specimen very like this speeies, from St. Vineent, one of the Cape de Verde Islands" (Busk): "minus expressam hane formam ad Bahusiam vidi" (Smitt).

Ravge ix Trme. Red Crag, on shells (Mactra, Mya, 
and Purpura) (Busk): Tertiary beds, Vienua Basin (Reuss)?

Mr. Busk assigns avicularia to $M$. monostachys; but as $I$ liave never met with them on any of the speeimens from very various localities which I have examined, I have omitted the eharacter. There are structures, however, scattered over the zoarium, which in some measure remind us of avicularia. These are dwarfed and imperfectly developed eells, which are interspersed in considerable numbers amongst the normal zoccia. They are of small size, roundish, or miniature copies in shape of the ordinary cells, with a subcircular or oval aperture, which is covered in by a delicate membrane.

Membranipora catenularia, Jameson.

Plate XVII. figs. $1,1 a, 2$.

Tubipora catexularia, Jameson, Wern. Mem. i. 561.

Tubipora catenulata, Stewart, Elem. ii. 425.

Hippothos catenularia, Flem. B. A. 534: Johnston, Brit. Zooph. (ed. 2), i. 291, pl. 1. figs. 9, $10:$ Busk, B.M. Cat. i. 29, pl. xviii. figs. $1,2$.

Hippothon Elliota, Gray, Zool. Misc. 34.

Pyripora ramosa, D'Orb. Pal. Franç. Terr. Crét. v. 539.

? Hippotioa rugosa, Stimpson, Invert. Grand Manan, 18.

Membranipora pilosa, forma catenularia (M. catenularia), part., Smitt, Kritisk Förteckn. iii., Gefvers. K. Vetensk.-Akad. Förhandl. 1867,370 and 415 , pl. xx. fig. 45.

Zocecia contiguous, ovate above, more or less produced and narrowed below, linked together in linear series, from which branches are given off irregularly, frequently anastomosing, or massed together and coalescent; walls solid, smooth, or transversely wrinkled; 
arca, occupying the whole of the upper part of the ecll, oblique, oval, slightly expanded below and contracted above, with a plain, rather wide and flat border. Occia nonc.

Hавітат. On shells, stones, Algie (rarcly), \&c. from deep water.

Localities. Gencrally distributed. Pinna, off thic Deadman and west to the Lizard (Coueh) : South Devon, . very common (T. H.): Isle of Wight (W. T.): St. Andrews, less common than Hippothoa divaricata (Dr. M'Intosh) : Pinne, I. of Coll (Landsb.) : Shetland, on stoncs, 40-170 fathoms; The Minch (A. M. N.) : Pinnce, coasit of Cork; co. Galway, on Buccinum Zetlandicum; off the Gobbins, co. Antrim, 40 fathoms (W. T.) : off Mull of Cantire, 40 fathoms (Hyndman) : \&c., \&c.

Geographical Distribution. On mussels, Algæ, \&e. Adriatic (Heller): Naples (A. W. Waters): Ile de Ré, France (D'Orbigny) : North Sea, "extra Norvegiam," on Gorgonia, 200-300 fathoms (Barou Uggla): Gulf of St. Lawrenec (Dawsou) : Labrador (Packard) : ? Grand Manan (Stimpson).

Range in Trme. Palroolithic; Red Crag (part.); Cor. Crag (A. Bcll) : Seotch Glacial deposits (Geikic) : Postpliocene deposits, Canada (Dawson): Italian Pliocene, Calabria (Manzoui): Plioeenc of Bruccoli, Sicily (A. W. Waters).

M. catenularia has been ranked by most authors in the genus Hippothoa; but its large aperture, oceupying a great proportion of the front of the eell and closed in by a membranous covering, at the top of which the oral valve is placed, is a cliaracter which separates it from the other 
members of that genus and allies it to the present. There is no essential distinction between $\boldsymbol{M}$. catemularia and such a form as $M$. monostachys, which also takes on not unfrequently the charactcristic habit of Hippothoa. There is, indecd, a difference in the mode of branching; but in a variety of $\boldsymbol{M}$. pilosa figured by Smitt*, branches are given off from the sides of the cells and at right angles to them, in the most typical Hippothoan fashion; and - therefore we cannot use this character as a diagnostic. In the present form the cell is more or less produced below, but there is no approach to the thrcad-like prolongation which distinguishes the true Hippothoce. I have no doubt that its proper place is amongst the Membranipore.

There is a great tendency in this species to the massing together of the cells, which often form a continuous expansion of considerable cxtent. In such cases the branch lines of cells, which are very numcrous, take an upward direction, and are brought into closc union, so as to constitutc what scems to be a solid crust of somewhat fan-shaped figurc. In other cases a different habit prevails, and the zoarium covers the shell, which it incrusts, with a very pretty dendritic pattern.

In many of the zoœcia the area is completcly closed in by a solid calcareous covering. I have never met with the spine below the aperture, as figured by Smitt $\dagger$, on any specimen which I could refer to this specics.

* Krit. Förteckn. iii. pl. xx. fig. 49.

† Loc. cit. pl. xx. fig. 46. 


\title{
Membranipora pilosa, Linnæus.
}

\author{
Plato XXIII. figs. 1-4.
}

Irregluar Sposgy Foliaceous Coralline, Ellis, Corall. 73, no. 4, pl. xxxi. and pl. xxix. fig. D.

Flustra rilosa, Linn. Syst. ed. 12, 1301 : Ellis \& Sol. Zooph. 13: Lamk. An. 8. Vert. ed. 2, ii. 224: Grant, Edinb. N. Phil. Journ. iii. 111: Flem. B. A. 537 : Lister, Phil. Trans. 1834, 334, pl. rii. fig. 2.

Escinara Pilosa, Pallas, Elench. 50: Moll, Esch. 37, pl. ii.

Flustra dentata, Ell. \& Sol. Zooph. 15 : Müll. Zool. Dan. iui. 24, pl. xcv. figs. 1, 2: Lamk. An. 8. Vert. ed. 2, ii. 224.

Flestra liveata, Esper, Pflanz. Flust. pl. vi.

Men вhanipora pilosa, Farte, Phil. Trans. 1837, 412, pl. xxrii. figs. 1-5: Johnst. B. Z. ed. 2, 327, pl. Iri. fig. 6: Van Ben. Recherch. 53, pl. vii. figs. 1-10; Mém. Acad. Roy. Belg. xviii. 29, pl. iv. figs. 1-10: Hincks, Ann. N. H. ser. 2, viii. (1851) 355: Busk, B.M. Cat. ii. 56, pl. laxi.: Smitt (1, forma pilosa), Efvers. K. Vet.-Ak. Förh. 1867, 368 and 415, pl. xx. fig. 49 (var.).

Membranipora stelilata, Thomps. Ann. N. H. ser. 1, v. 101.

Assteipora pilosa, Gray, B.M. Rad. 107.

Avvelifora devtata, Gray, ibid.

Rertelectrisa pilosa, D’ Orbigny, Pal. Franç. Terr. Crét. v. 33 .

RETTELECTRINA DENTATA, id. l.c.

Zoceia ovate, more or less prolonged, and narrowed below*, the walls thiekly covered with minute oval disks, and often with a silvery sheen; area oval or suborbicular, sometimes mueh elongated, surrounded by a smooth thiekened border; marginal spines 4-12; below the area a single corneous spine, often of great length, sometimes aborted. Oœcia none.

Var. a (dentata). With numerous, slender, acuminate spines which bend inwards over the area; the horny spine wanting; zoarium assuming a stellate mode of growth, the cells running out in lines two, three, or four abreast.

Var. $\beta$ (laxa, Smitt). Zoarium consisting in great part 
of lines of cells arranged in single series, which somctimes anastomose so as to form a rude network.

Var. $\gamma$. Zoarium rising into frond-like expansions, and frequently much branched [Pallas].

Polypides with 11-14 rather thick tentacles, each of which is furnished with a number of very delieate setiform appendages (taetile hairs), ranged along the back.

RaNGe of Variation. The appearance of this species is much affected by the presence of a greater or smaller number of spines, and the degree in which the eorneous vibraculoid appendage is developed. One variety, which usually spreads over stone and shell, forms a delieate silvery crust; while another, investing the fronds of Algæ, has the appearance of a coarse brown eoating, which bristles with the tall setæ. In the former the aperture is almost completely surrounded by slender, acuminatc, ineurved spines, of which one, placed in the eentre of the lower margin, exeeeds the rest in sizc. In other eases the marginal spines are much fewer in number, and often short, subeonieal, and ereet. In one variety (Plate XXIII. fig. 3) they seldom exeed three, of which two are situated at the upper part of the eell, and one below the aperture. The horny appendage rises from a kind of soeket, and frequently attains an enormous size. In many eases it is aborted; in others it is present in abnormal profusion. Sometimes there are two, sometimes three together; and I have seen a eell round which no less than six were developed, the small marginal spines being also present. Oceasionally one or two of the tall horny spines are interealated amongst the latter.

There are also differenees in the size of the aperture and the proportion which it bears to the inferior portion of the eell. In one marked variety it is much elongated, 
and occupies almost the whole of the front of the eell; more eommonly it is plaeed at the upper part of it, oecupying about half its length or less. In the former case an approach is made to the form which we have in $M$. membranacea, in which the prolongation of the eell below the aperture is almost entirely wanting.

Besides these variations in the struetural details there are others in the habit of growth (Vars. $\beta$ and $\gamma$ ).

Habitat. On stones and shells (var. dentata) from the Coralline ground and from deep water, and on Laminaria and other Algæe (masses of which are often eompletely eoated by it), Sertularians, \&e., between tide-marks and. in shallow water.

Locality. Universally distributed on our coasts, and extremely abundant.

Geographical Distribution. Roseoff, everywhere abundant on Fucus serratus, and especially on Rhodymenia palmata (Joliet): Belgium (Van. Ben.): Mediterranean (Risso): Adriatic, common (Heller) : Aden; Arabian Sea, on weed taken up between Bombay and Aden, lat. about $15^{\circ} \mathrm{N}$, long. about $65^{\circ} \mathrm{E}$. (W. Oates) : Melbourne; New Zealand (T. H.): Norway, var. laxa (Sars): Hougesund; Heligoland, about 100 fms. (Kirehenpauer): Finmarek (Goës and Malmgren): Grcenland (Lütken) : Gulf of St. Lawrence; Nova Seotia (Dr. Dawson) : South Labrador, eommon on Desmarestia, just below low-water mark (Packard): var. stellata, New Jersey and Rhode Island, on Lam. saccharina, \&e., eommon (Leidy): Baltic, Eastern basin, abundant (K. Möbius).

In its more delicate forms, as developed in the hollow of a shell, or spreading, as I have seen it, over the surfaec of one of the red Algæ, this is a beautiful speeies. Its little eells have a metallie lustre, and almost look as if 
they were wrought in silver and richly chased. In its ordinary condition it has a coarse spongy appearance. It is probably the commonest and most abundant of the Britislı Polyzoa.

The polypides are furnished with the eurious intertentacular organ, which I have deseribed elsewhere*. The tentacles are liable to many irregularities, and are often of very different sizes on the same polypide. Very commonly those on one side are inferior in height to those on the other, and the tentacular bell is obliquely truneate above. The same peculiarity has been notieed by Dr. Farre in Alcyonidium gelatinosum.

The palpocils on the back of the tentacles are of considerable length.

\section{Membranipora membranacea, Linnæus.}

Plate XVIII. figs. 5, 6.

Frustra membranacea, Linn. Syst. ed. 12, 1301: Müller, Zool. Dan. Prod. 253: Ellis \& Sol. Zooph. 18: Fleming, B. An. 536 : Lamx. Pol. corall. flex. 107 : Couch, Corn. Faun. iii. 123, pl. xxi. fig. 2: Johnston, B. Z. ed. 2, 348, pl. 1xvi. figs. 1, 2, 3.

Flustra telaces, Lamk. An. 8. Vert. ed. 2, ii. 223.

Membranipora membranacea, Busk, B.M. Cat. ii. 56, pl. Ixviii. fig. 2 : Blainv. Actinol. 447 (not the M. pilosa, forma membranacca of Smitt).

Rertorlustra telacea, D' Orbigny, Pal. Franç. Terr. Crét. v. 328.

Zoccia oblong, disposed in lines, alternate, with a stout hollow spine at each angle above; area oceupying the whole of the front of the cell, with a membranous covering; margin smooth. Avicularia none. Closed tubular processes frequently developed from the front wall of the cell.

Polypide with about 20 very long tentaeles.

* V'ide the Introduction to the present work. 
Colonies forming a delicate network, often extending to a length of several feet on the fronds of the larger Fuci.

Ravge of Variation. Distinguished for great regularity of growth and constaney of character.

Habrtat. The fronds of Laminaria digitata and other Fuci.

Localities. Universally distributed on our coasts, and very abundant.

Geograpuical Distribution. Hvidingsoe; Hougesund (Kirehenpauer): Roseoff, on Saccorhiza bulbosa (Joliet) : Adriatie, on sea-weeds (Heller) : Lyall's Bay, New Zealand, on Fucus (F. W. Hutton): Australia (MaeGillivray).

Range in Trme. Coralline Crag; Palæolithic (A. Bell).

This species is one of the eommonest of our British Polyzoa, as it is undoubtedly one of the most beautiful. Wherever Laminaria digitata is present its exquisite lacework is almost sure to be found, lighting up the sombre fronds, and itself appearing all the more delieate in contrast with the dark surface over which it spreads.

It possesses a power of free and rapid development corresponding with the size of the marine plants in which it prineipally delights; and the huge fronds of the Laminaria are often swathed in its silvery net. Dr Landsborough mentions a specimen 5 feet in length by 8 inehes in breadth; and probably most tangle-beds of any size would yield a similar growth.

I lave noticed in some eases a remarkable thickening of the membranous front wall of the eells in this species. This is sometines carried to such an extent that the whole of the free surface of the zoarium seems to be eovered by it, except the extremities of the spines. 
The curious tubular processes*, which have been supposed to be ovicells, are often developed in enormous numbers. They are irregularly distributed over the zoarium, and frequently occur in groups. Mr. Couch speaks of them as appearing in December, January, and February; but I have met with them in June and Oetober, and it seems probable that they are not eonfined to any partieular season.

The polypides have about 20 tall tentaeles, which form a very graceful bell. They are sometimes furnished with the eiliated intertentaeular organ which oeeurs on $M$. pilosa and other specics. A colony in full health and vigour affords a rare display of delieate strueture, vivaeious movement, and graeeful form.

* Ellis was the first to notice these bodies. "There are dispersed," he says, "here and there, at regular distances orer the surface, little transparent, short, erect tubes; but to what use I shall not pretend to determine, unless they are the ovaries."-Ellis \& Solander, Zooph. p. 18. Couch describes them as "of a yellow colour, semitransparent, and filled with minute yellow granules, which appear to be ova" (Corn. Faun. pt. iii. p. 93).

These processes are cylindrical, and consist of a perfectly transparent ehitinous tube, which is lined throughout by a brownish membranous sac. The sac is frequently inverted towards the top of the tube. They are closed above, and open into the cavity of the cell at the base (Plate XVIII. fig. 6). They appear at first as a swelling on the front wall of the cell, sometimes placed at one cnd of it, sometimes subcentrally. The zoceia on which they are developed are frequently abnormal in shape, being roundish and much larger than is usual. The processes attain a very considerable length. So far as I have observed, there is no trace of a polypide in the cells to which they are attaelied; I have never seen any thing within them except a small quantity of granular matter, and have been unable to obtain any clue to their history.

These bodies have becn investigated by Nitsche, who describes the zocecia on which they occur under the name of "tower-cells" ("Thurmzoöcicn'). $\mathrm{He}_{\mathrm{e}}$ is inclined to regard the latter as zoceia, originally normal, which, having lost thcir polypides, instead of developing others, have undergone this curious transformation ("Ueb. d. Anatom. u. Entwickl., von Flustra membranacea," Zeitsch. f. Wissensch. Zool. xxi. Bd. 4. Heft, pp. 64, 65). According to this riew they are mercly abnormal growths. 
Membranipora hexagona, Busk.

Plate XVIII. fig. 7.

Mexbranipora nexagoina, Busk, Quart. Journ. Micr. Sc., Zoophytology, iv. 308 , pl. xii. fig. 4.

Fuustra coriaces, Johnst. B. Z. ed. 2, 318 (the diagnosis by Forbes), pl. lvi. fig. 8.

Zoceia hexagonal or subelliptical; surface smooth ; margin smooth and even; mouth semilunar.

Habitat. On shells and stones.

Localities. Isle of Man, on Pecten opercularis (E. Forbes) : coast of Devon (Miss Cutler).

Mr. Busk is probably correct in identifying E. Forbes's Flustra coriacea with the present species.

I know nothing of $M$. hexagona but what may be gathered from the brief description and figure in the ' Zoophytology.'

Judging from the figure, the covering of the area is wholly membranous, and the zoarium appears to form a thin flat crust.

Membranipora lineata, Linnaus.

Plate XIX. 01gs. 3-6.

Flustra lineata, Linn. Syst. ed. 12, 1301 : Fabr. Faun. Groenl. 437 : Johnst. B. Z. ed. 2, 349, ? pl. Ixvi. fig. 4*.

* There is much difficulty in determining the synonymy of this and the allied spiniferous forms, as the descriptions of anthors are often extremely rague, and bare probably in many case been based on specimens of more than one species.

Johuston's figure of his $F$. lineata is useless as a menus of identificntion. 
PTata regosa (part.), Van Ben. Bull. Ac. Roy. Belg. xvi. no. 12, 648, pl. ii. fig. 12.

Callopora liseata, Gray, B.MI. Rad. 109.

Remelectrisa lineata, D'Orb. Pal. Franç. Terr. Orét. 334.

Membrasipora liseata, Busk, B.M. Cat. ii. 58, pl. Ixi. fig. 1 : Alder, North. Cat., Trans. Tynes. Fiold Club, iii. 143, pl. viii. fig. 1 : Smitt, forma 2, CEfvers. K. Vet.-Ak. Förh. 1867, 364 and 390 , pl. xx. fig. 23: Florid. Bryoz. pt. ii. 7, pl. ii. fig. 62 : Manzoni, Bryoz. foss. Ital. Contrib. iv. 10, pl. ii. fig. 13 [not pl. iii. fig. 14].

Zoceia oval, slightly expanded below, separate; the margin with 6-12 spines, of which two are placed at the top of the eell and direeted somewliat upwards, the seeond pair stand ereet; and the rest, which are slender, and not flattened, bend inwards; a rather large, raised avicularium at the bottom of the cell, with triangular mandible direeted downwards. Occia large, globose, slining, with an arehed rib towards the top, an avieularium usually on one side of it above, with the mandible pointing upwards.

Colonies forming subcireular patehes.

Ravge of Variation. The spines vary in number, but are always less numerous than in the two following species, twelve being about the maximum, and eight or ten the more usual number. They are sometimes almost ereet, but more eommonly they bend slightly inwards.

A variety occurs $(a)$ in which the margin is armed with six spines only, two at the top and two on each side. The eells are larger than usual, and the border rather broad and erenate. The avieularia are very large and much elevated.

The cells also vary somewhat in shape and size. Normally they are pretty regularly oval, widening a little below; but occasionally they are mueh shortened and almost orbicular in form. Sometimes they lie rather widcly apart. 
Haвiтst. On weed, stone, shell, \&e., from between tidemarks to deep water. It is more especially a littoral form, and is developed in extraordinary luxurianee on some of the Fuci.

Loealities. Common, and widely distributed. Shetland, on Fuci and Laminaria; Hebrides (A. M. N.) : Wick (C. W. P.) : Northumberland and Durliam, from tide-marks to deep water, frequent on Patella lavis (Alder) : Isle of Man; Ilfracombc, on Laminaria ; South Devon, between tide-marks; Mount's Bay, under stones (T. H.) : Hastings, normal and var. $\boldsymbol{a}$ (Miss Jelly) : \&e.

Geograpincal Distribution. Roscoff, on Laminaria saccharina, eommon (Joliet) : coasts of Skandinavia, in shallow water, common (Smitt): Baltic (Lenz): Spitzbergen (Lovén): Davis Strait, 100 fms. ; Reykjavik Harbour, Iceland, 15-20 fms. (Wallieh): Nova Zembla, 3-50 fms.; Kara Sea (Nordenskiöld, fide Smitt): South Labrador (Packard): Adriatic (Heller): Florida, on coral, $42 \mathrm{fms}$. (Pourtales) : New Zealand (F. W. Hutton).

RANGe in Time. Italian Pliocene and Miocenc deposits (Manzoni).

$M$. lineata is readily distinguishable from the allied British species, and on the whole is vcry eonstant in eharactcr. Smitt unites it with $M$. craticula, M. unicornis, and scveral others under one specific designation. But there are no intcrmcdiate varicties, so far as I know, eonnecting together the prescnt specics and $M$. craticula: they are well-defined forms, each with a marked facies, separated from onc another by a group of constant characters, and exhibiting, aeeording to my experience, a very moderate amount of variability. It may be remarked, too, that amongst Smitt's figures referred to his $\boldsymbol{M}$. lineata there is certainly nothing that makes any approach to $\boldsymbol{M}$. craticula. 
It is of course easy to understand how they may have been derived from a common and not very remote ancestor through a process of gradual modification; but in their actual condition they seem to be sufficiently distinet and stable forms*.

$M$. lineata differs from $\boldsymbol{M}$. craticula in the larger size and much less regular arrangement of its eclls, and in the character of the spines, which are rounded, and not flattened, fewer in number, and much less recumbent than in the other form. The disposition of the spines in $M$. craticula is very distinetive, and gives a decided individuality to the species. There are also differenees in the ovicells. The avicularium of the present species is large and much raised, and projects very prominently at the base of the cell.

Towards the margin of the colony the cells are sometimes slightly produeed below the aperture, so as to assume to a ecrtain degree the form which we have in the normal $\boldsymbol{M}$. monostachys. Round the lower part of the zoceia there are several rather large oval orifices (intercellular communications), one placed at the top and bottom, and two on cach side. On the inner edge of these foramina there are generally a few minute denticles.

* The truth seems to be that the difference between Prof. Smitt and myself lies chiefly in the conception we have respectively adopted of a specics. By a "form" he intends to denoto what I should name in a largo proportion of cases a species. His "species" is a block of "forms," the various elements of which are supposer to be so related and interconneeted as to constitute an erolutional serios which is properly regarded as a whole. But to sustain this view an amount of variability is assumed of whicl I can find no sufficient proof; I have certainly had no experience of the "innumerable transition-forms" ("otalika mellanformer"), which, according to Prof. Smitt, bind together $M$. craticula and $M$. lineata. That they are not distantly related I have no disposition to deny ; but whatever their history may have been in the past (and the same may probably be said of the other five specics which Prof. Smitt refers to his lineata-stoek), they nre now distinct and well-established forms, and should be treated as such in our s5stems. We unust have much more evidence of variability than wo yet possess to justify us in merging then in one specifie.group. 


\section{Membranipora craticura, Alder.}

Plate XIX. fig. 7.

Fuustra liveata, Couch, Corn. Faun. pt. iii. 124, pl. xxii. fig. $15 ?$

Membrasipona craticula, Alder, North. Cat.o, Trans. Tyneside Field Club, iii. 144 , pl, viii. fig. 3 .

M[zmbrayirora lineata, 1, forma craticula, Smitt, Eefrers. K. Vet.-Ak. Förl. 1867, 363.

Zoceia small, in very regular, radiating, linear scries, oval, somewhat narrowed above; the margin with about thirteen spines, of which the two uppermost pairs are creet and often of very great length; the rest flattish, glistening, elosely set, bent inwards, and meeting across the ecll, especially crowded together at the bottom of it : an avicularium, witl acute mandible directed down wards, at the base of the eclls. Ocecia rather small, smooth, cylindrico-globose, with a rib across the middle; an avicularium at the top or at one side, with the mandible pointing upwards.

Primary cell subeircular; aperture terminal, with about nine marginal spines.

Colonies forming small flabellate or subeircular patehes, with a soft spongy look, from the great number of closely-set spines.

RANGE of Variation. I have observed very little variation in this species. There are slight differenees in the number of the spines; but the clief features are very constant and uniform.

Habitat. On shclls, \&e., from shallow to deep water, and on littoral sca-weeds.

Localities. Northumberland and Durham, on Modiole from deep water (Alder) : Isle of Man, very abundant on shells dredged off Manghold Head; Oban (T. H.) : St. Andrews, occasioually in decp water (Dr. M'Intosh): 
Shetland, shallow water, Hillswick; on Laminaria, Bressay Sound (A. M. N.): Wick and Petcrhead; Cornwall (C. W. P.).

Geograpinical Distribution. Davis Strait, $100 \mathrm{fms.}$ (Wallich): Gulf of St. Lawrence (Dawson): Bahusia, 7-10 fms. (Smitt): Spitzbergen, on Cellularia, hydroids, \&c., 20-45 fms. (Swedish Expcd.) : Nova Zcmbla, 4$60 \mathrm{fms}$.; Kara Sea (Nordenskiöld).

Range in Time. Scotch Glacial deposits (Grikie).

This is an exccedingly pretty species, recognizable at a glance by its general aspect, even without a minutc examination of the characters. The cage-likc appearance of the little cells, with their closely-set glittering bars, their small size, and the extreme regularity of the linear series in which they are disposed, are points which at once arrest attention.

The spincs are crowded together at the lower part of the cell, over which they bend, and converge to a central point. The two immediately below those which stand erect arc larger than their companioss; and their free extremitics curve upwards. It should be noted that there is an essential difference between the crect spines and those which bend inwards and protect the arca of the ccll. The latter only exhibit the flattish glistening appearance so characteristic of the specics; the others are rounded and of the usual type.

M. craticula, so far as our present knowledgc goes, must be accounted a rare spceies. 
MeMBRANipola SPINIFERA, Johinston.

Plate XIX. figs. $1, a, b, c$.

l'Lustra spinipera, Johnst. Newe. N.IX.S. Trans, ii. 266, pl. ix. fig. 6.

? Flustra lixeata (part.), Johnst. B. Z. ed. 2, 349.

Membranipora spiviera, Alder, North. Cat., Trans. Tynes. Field Club, iii. 143, pl. viii. fig. 2 : Hincks, Der. Cat., Ann. N. H. ser. 3, ix. 29 [not M. spinifera of Smitt, EEfrers. K. Vet.-Ak. Förh. 1867, 366 \& 411 , pl. xx. fig. $32 *$ ].

Zocecia elongate-oval, contiguous, arranged in lines; the margin with about 14-16 tall and stout spines, two of them at the very top of the eell, the seeond pair ereet and very large, the rest bending inwards. Avicularia pedieellate, borne on a short and slender stem, which tapers downwards, developed on the eells, outside the row of spines; mandible acute and directed upwards. Occia shallow, smooth, with a rib aeross the front.

Colonies forming rather large, eircular, brownish patches.

RaNGe of VARiation. I have only notieed slight differences in the size of the eells and the number of the spines. The avieularia are sometimes very sparingly produced, or at least are present in very small numbers. It is very probable that their absence in such eases may often be due to accidental eauses; for the pediele by which they are eonnected with the eell is much attenuated below, and they must be easily detached from their plaee. On some specimens almost every ecll is furnished with one of these eurious appendages.

Habitat. Chiefly on stones, between tide-marks; also on Laminaria and on shells, \&e., from moderate depths.

Localities. Northumberland and Durham, "on the

- This is the M. cymbeformis, mihi, an Arctic and North-American form. l'ide a paper by the author in the Annala \& Mag. N. II. for Jan. 1ETi, p. 110. 
underside of stones, between tide-marks, frequent; more rarely in shallow water" (Alder): Shetlaurl, on stones, between tide-marks (A. M. N.) : Birterbuy Bay (G. S. B.) : Isle of Man, between tidc-marks; Salcombe, Devon; Cornwall (T. H.) : St. Andrews, abundant between tidemarks (Dr. M'Tutosh).

Geograpincal Distribution. France, south - west (Fischer).

From $M$. lineata the present species is readily distinguished by its elongate closely-set cells, its numerous stout spines, and its remarkable avieularium. In the latter we lave a very interesting transition-form, standing between the highly specialized movable appendage which we meet with in the genus Bugula, and the ordinary avicularium of the Membraniporidce. A short and very slender pedicle supports the avicularian cell, which widens gradually upwards above it, so that the whole structure presents a somewhat elavate figure. Above, it is obliquely truneate, and terminates in a pointed beak-like apex. On this truncate portion the acute mandible is placed, directed upwards towards the beak. The whole appendage bears a very close general resemblance to a cell of the common Eucratea chelata.

'The pedicle near its point of junction 'with the base of the cell is extremely slender, and composed of very delicate material; and it is quite possible that the appendage may possess a certain amount of mobility, even though not cudowed witl any special motor apparatus. On this point, however, I cannot speak with certainty, as I liave never had the opportunity of examining the species in a living state." Alder describes the avicularia as "dereloped sparingly on any part of the margin of the cell;" but, according to my obscrvations, they are rery constant in 
position, and oeeur on the side of the eell (not on the margin) in the neighbourhood of the first pair of spines below the orifiee. It is perhaps hardly necessary to add that they bear 110 morphologieal relation whatever to the spines.

Membranipora flustroides, Hineks.

Plate XIX, fig. 2.

Membranipora Flugtroides, Hincks, Ann. N. II. Sept. 187t, ser. 4, xx. $213,214$.

Zocecia large, in regular lines, set elosely together, oval; margin with 12-14 massive, flattish, sometimes subclavate, sometimes bifid spines, which bend inwards, and almost meet aeross the area, with the exeeption of the two uppermost, which stand ereet; an oval aviculurium on a somewhat quadrate area at the top of many of the eells, slanting upwards, with a semicireular mandible. Ocecia very small and ineonspicuous, smooth, elevated in front, forming a hood-like eovering over tlie extreme end of the ecll.

Colonies forming large subeireular patehes with a somewhat lobate edge.

Range of Variation. Very limited. The eells are oeeasionally smaller than usual; and there are very slight differences in the number of spines. At times two avieularia oceur side by side; and rarely one is met with abnormally large. When developed above an ovicell, the avicularium is eommonly plaeed transversely. With the exception of sueh slight differenees, there is a remarkable constancy of eharacter in this well marked and very interesting form.

Habitat. Stones, shells, Se., from moderate depths and from deep water. 
Localities. Antrim (Hyndman) : off Donaghadee, 32 fathoms (Mr. W. Swanston); Guernsey ; off the Deadman, Cornwall, 60 fathouns; South Devon (T. H.): Birterbuy Bay (A. M. N.).

The massive, often subelavate, spines and the avieularium, which is of the Flustrine type, distinguish this fine species from the other Membranipore. The avicularium is always placed, as amongst the Flustra, immediately above the zoceium, an a distinct area, which is in a line with the cells. We have a similar form in $M$. cornigera. Through the present species and such a form as Flustra denticulata, Busk, a very close relationship is established between the families of the Flustrida and Membraniporida.

Membranipora discreta, Hincks. Plate XIX. figs. 8, 9.

Mesibraxipora discreta, Hincks, Devon \& Cornw. Cat., Ann. N. H. ser. 3, ix. 200, pl. xii. fig. 1 (page 40, sep.).

Zoccia ovate, separate, varying in size, and irregularly disposed; the margin cut into about twenty lobes, supporting as many delicate, sharply pointed spines, which bend slightly inwards. Oxcia very small, globose, frosted.

In the only two specimens I have seen, the colonies eonsist of very minute and inconspicuous groups of cells.

Habitat. Shells from moderately deep water.

Localıties. South Devon; Guernsey (T. H.).

I do not identify the present species with Smitt's $M$. lineata, forma discreta, which, so far as I can judge from 
his description and figure, seems to be a distinet form. He represents a large, muel elongated avieularium in the spaces between the eells; but $\boldsymbol{M}$. discreta is destitute of avieularia. In other respects the two appear to differ.

In the present species the cells are rery irregularly grouped, and vary eonsiderably in size, and the colony has a somewhat confused and disjointed appearanec. The entire margin is divided into distinet lobes, ranged elosely together, which may be traced down the exterior wall of the cell; and each of them bears a spine. They number about twenty or upwards. The spines, with the exception of one or tro near the top, are very delicate and bend inwards. The oœcium is small and rounded, and minutely granular.

From $M$. lineata this species is distinguished by the characters just enumerated, to which the former, I believe, makes no approach in any stage of its development.

Membranipora curvirostris, Hincks.

Plate XX. figs. 5,6 .

Membrasipora curvirostus, Hincks, Devon \& Comw. Cat., Ann. N. H. ser. 3 , ix. 29 , pl. vii. fig. 4 (p. 39 , sep.).

Zoccia elongate-oval, margin granular and somewhat thiekened, the inner edge minutely serrulate; a short stout spine on each side near the top, which projeets in front of the oviecll, and at the bottom a single subconical spine; no ealcarcous lamina; large subereet avicularia distributed amongst the eells on distinet areas, with eurved and pointed mandible, direeted upwards. Ocecia prominent, subglobose, rather shallow, strongly frosted.

Colonies forming a delieate pearly-white lacework. 
Range of Variation. There are slight differences in the shape of the eell (the prevailing form being a very regular oval); and the spine at the bottom is sometimes wanting.

Habitat. Stones from deep water.

Locality. Ten or twelve miles south of Polperro, in 10 fathoms (T. H.).

The avieularium is the striking feature of this speeies. It is of very large size, subereet, and furnislied with a triangular mandible, which is much eurved towards the tip. A very interesting peculiarity is the distinetness of the area on which it is placed. It resembles very elosely that of the ordinary eells, being only slightly smaller and having a similar granulated margin. The avieularium rises out of the lower part of this inclosed cell-like area, which it fills, the space above it being unoeeupied and destitute of membranous eovering. The relation between the appendage and the ordinary zoceium is very elearly indieated in this species.

I have a elosely allied form from Singapore, which is prineipally distinguished by the charaeter of the avieulariumn.

Membranipora Unicornis, Fleming.

Plate XX. Ag. 4.

Flustra unicornis, Flem. Br. An. 536.

Membranipora memibanaces, Johnst. B. Z. ed. 2, 328 (part.)?

?Lepralia squama, Dalyell, Rem. An. Scotl. ii. 79, pl. xxv. figs. 14, 15 *.

Mesibranipolia uniconnis, Alder, North. Cat., Trans. Tynes. F. O. iii. 146, pl. viii. fig. 6.

Mrmbranipora lineata, 5 , forma unicornis, $\beta \beta$, stadium longius adultum, Smitl, CEfvers. K. Vet.-Ak. Fürl. 1867, 365 and 399 , pl. xx. fig. 30 . 
Zoceia large, oval, quincuncial, the margin granulated; two spines on each side, near the top of the cell, the lower pair showing in front of the ovicell. Oøcia subcylindrical, smooth, with a strong rib just above the margin, and bearing on their summit a large conical avicularium. In the absence of the ovicell the avicu. larium oecupies the spaee at the bottom of the ecll, placed somewhat obliquely, and with the mandible directed downwards.

Colonies forming a rather coarse network, spreading in subcircular patches.

Range of Variation. There are occasionally two avicularia at the base of the ecll, which are placed one towards each side. The zoceia are very uniform in size and shape.

Habitat. On shells, stones, Ascidians, \&e., from shallow to deep water; oceasionally between tide-marks.

Localities. Northumberland and Durham, old shells, Se., frequent (Alder) : Balta Sound, between tide-marks (C. W. P.) : St. Andrews, decp water (Dr. M'Intosh) : Dogger Bank (T. H.).

Geographical Distribution. Boluuslän, at greatdeptlıs; north of Spitzbergen, 6-50 fathoms (Smitt) : Greenland ('Valorous' dredgings): Nova Zembla, 10-60 fms. (Nordenskiöld).

Range in Trme. Seoteh Glacial deposits (Geikic).

The avicularium in this species is large and massive, and very decidedly suberect. The zoceia are of much stouter build than in the following. The points of difference between the two species are given in detail under M. Dumerilii. 


\title{
Membranipora Dumerilit, Audouin.
}

\author{
Plate XX. fig. 3 .
}

Furstra Dumerilu, Aud. Expl. Savigny Egypte, Polypes, pl. x. fig. 12.

Membranipora membranacea (part.), Johnst. B. Z. ed. 2, 328, pl. lvi. fig. 7.

Membrasipora Fuemingi, Busk, B.M. Cat. pl. cir. fig. 2.

Membranipora Pourleetn, Alder, North. Cat., Trans. Tynes. F. C. iii. 146, pl. viii. fig. 5; Quart. Journ. Micr. Sc. v. 248: Busk, Crag Pol. 32 , pl. iii. figs. 4 \& 6 .

Membranipora Dumerili, Norman, Rep. Brit. Assoc. for 1866, 305: M'Intosh, Mar. Invert. of St. Andrews, 45.

Membranipora lineata, 5, forma unicornis, $\alpha \alpha$, stadium juvenile, Smitt, CEfvers. K. Vet.-Ak. Förh. 1867,365 \& 397, pl. xx. fig. 29.

Zoøcia small, ovate, broad below, vcry rcgularly quineuneial; margin granulated, with a thin cdgc ; spines four (rarely six), plaecd two on each side, ncar the top of the cell, the lower pair showing below the ovieell, one of them sometimes enormously developcd. Oxcia large, globose, or elongated, strongly frosted; a small pointed avicularium on each side above, or on one side only; mandible directed upwards and slightly outwards. In the absence of the ovieell, an avieularium usually at the base of the cell, placed transversely, with the mandible direeted downwards.

Colonics forming a neat, pcarly laeework.

Range of Variation. There are slight diversities in the shape of the cell; but in its prevalent and charneteristie state it is contraeted at the top and broad below. The oviecll is often mueh produeed; but it also assumes a more rounded form.

Habitat. Chiefly on shclls, stones, \&c., from shallow to dcep water; occasionally on Laminaria.

Localities. Shctland, oceasionally on Cellepora cervicornis and shells; Hcbrides (A. M. N.) : St. Andrcws, on bivalves from deep water (Dr. M'Intosh) : Northumberland and Durham, on shells and zoophytes, especially on 
Flustra foliacea (Alder): Arran; Dogger Bank; Isle of Man ; South Devon, abundant on shells, \&c. ; Ilfracombe, on Laminaria ; Cornwall, off the Deadman, in 60 fathoms, on stone (T. H.) : Hastings (Miss Jelly) : Antrim (Hyndman): \&c.

Geographical Distribution. Scandinavian Seas (Smitt) : ? Mediterrancan (Savigny) : France, south-west (Fischer).

Ravae in Trae. Coralline Crag, on shell (S. Wood).

This speeies is distinguished from the last by several well-marked characters, though the two forms are nearly related. The cells are much smaller than those of $\boldsymbol{M}$. unicornis, and not so regularly oval. There is, indeed, some amount of variation in form; but the eell in $\boldsymbol{M}$. Dumerilii is usually narrowed towards the top and expands below; while that of the kindred speeies is of a pretty uniform elongate-oval shape. The chief difference lies in the ovieell, which is globosc, or (very often) eonsiderably clongated, and strongly granulated; that of $\boldsymbol{M}$. unicornis, on the other hand, is smooth, with a rib across the front of it, just above the margin, and a prominent avicularium on the summit, "giving the whole," as Alder has remarked, "the appearance of a Phrygian bonnet." The general aspect of the two speeies is very different. The lacework of $M$. unicornis is much coarser than that of its ally, and wants its remarkably delicatc and pearly texture.

The cnormous derclopment of one of the spines in front of the oricell, which is so common in the present species, I have nerer noticed in $\boldsymbol{M}$. unicornis.

Smitt remarks tliat the form which he refers to $M$. Dumerilii differs from that which Alder figures (l.c. pl. viii. fig. 5) in having the mandible of the avicularium directed towards the ecutrc of the colony. His figure, how- 
ever, is taken from a specimen without ovicells; and in such eases the avicularium is almost universally so placed. Alder's, on the contrary, represents a fertile group; and whenever the ovicell is present, the direction of the avicularium is always reversed and it points upwards. This remark applies equally to other species.

Membranipora solidula, Alder and Hincks.

Plate XX. figs. 7, 8.

Membranipora solidula, Hincks, Proc. Dublin Univ. Zool. \& Botan. Assoc. ii. pt. $1(1860), 75$.

Zoccia oval, with a crenulate margin, the membranous covering opaque and of a dull waxy appearance, lying very much on a level with the margin, so that the zoarium presents a very flat surface; four spines at the upper end of the eell immediately above the semicireular orifice; frequently onc or two prominent smooth nodules below the base of the ecll. Oxcia globose, subimmersed, shallow, smooth, witll a strong thickened ridge across the upper part. Avicularia none.

Range of Variation. Slight differences in the shape of the cells, which are occasionally somewhat narrowed towards the top and expand below.

Haвiтat. On shells, stones, \&c., from moderate depths to deep water.

Localities. Off the coast of Antrim (Hyndman): Guernsey (T. H.) : Hastings (Miss Jelly).

Some of the peculiarities of this species were pointed out to me by the late Mr. Alder; and I have therefore associated his name with it as well as my own.

The cells are small and regular in form, with a prettily 
bearled margin. The flatness and dull opaque look of the surface of the zoarium are very charactcristic. The nodules are sometimes a conspicuous feature.

\section{Membranipora aurita, Hincks.}

Plato XXI. figs. 5, 6.

Mismbrasipora aurita, Hincks, Ann. N. II. ser. 4, xx. 213 (Sept. 1877).

Zoœcia ovate, somewhat cxpanded bclow, disposed witl great rcgularity' in quincunx; area with a membranous covering; no calcarcous lamina ; margin plain, in young cells armed with four spincs, of which one is usually present in the adult, placed about halfway down the side; immediatcly above each ecll, or the ovicell when present, two raised avicularia, onc on each sidc, with a pointed mandible usually dirceted upwards and slightly outwards. Oøcia subglobosc, partially immersed, with a strong rib on the front, rising to a point above and inelosing a triangular spacc.

Colonics forming large subcircular patches, rescmbling the most regular lacework.

Навітат. On stoncs and shells.

Localities. Cornwall and Devon (T. H.) : Antrim (Hyndman): Northumbcrland (Alder).

From $M$. Flemingii this species is distinguished by the more regularly ovate form of its ecll, the entirc absence of a calcarcous lamina, the triangular figure on the front of the ovicell, and the perfectly regular quincuneial arrangement of the cells. The latter character is a very marked one; and in well developed specimens the specics may be at once recognized by it.

Of the four spines which occur on young marginal cclls 
one only is usually permanent, but oceasionally a second survives. When the ovicell is absent there is some amount of irregularity in the number and position of the avicularia; sometimes the mandibles are turned downwards, as is frequently the case amongst the Membranipore under such circumstances; sometimes only a single avicularium is developed, which is placed crossways, or in the centre, with its mandible pointing straiglit downwards. This very distinct form has probably been confounded with $M$. Flemingii, which, as I have pointed out clsewhere, has had a character for ineonstancy which it by no means deserves.

Membranipora imbellis, Hincks.

Plate XX. figs. $1,2$.

Mrmbranipora mbelis, Hincks, Quart. Journ. Micr. Sc. riii. (1860), 275, pl. xxx. fig. 1 ; Devon \& Cornw. Cat., Ann. N. H. ser. 3 , ix. 28 (38 sep.) : Norman, Shetland Polyzoa, Rep. Brit. Ass. 1868,305 .

Zoceia large, pyriform, contracted above and much expanded below; covering of the area wholly membranous; margin crenatc or coarsely granulated, thickened, especially at the bottom of the cell, where it is usually somewhat produced and pointed. Oocia very prominent, frosted, with a depressed somewhat quadrate area in front. No spines or avicularia.

Range of Variation. There is very great constancy in the leading characters. The eclls differ to some extent in shape and sizc, and occasionally assume a subtriangular form.

Habitat. On shclls, stones, \&c., from deep water.

Localities. Coast of Antrim (Hyndiman): Scotland, 
west eoast; Brixham, from the trawl-boats; off the Deadman, 60 fathoms (T. H.): The Minch; Shetland, rare, $40-50$ fathoms, $5-7$ miles east of Balta (A. M. N.).

This species, whieh seems to be essentially a deep-water form, is distinguished from $M$. Flemingii by the much larger size of its eells, and the total absence of a ealeareous lamina and of all spines and avieularian appendages. Mr. Busk regards it as " an unarmed variety" of the last named; but it is not the mere absenec of the eharacteristic armature of $\boldsymbol{M}$. Flemingii that differentiates the present form. The ealeareous lamina, eovering in the lower portion of the area, which is so important a charaeter of the normal $M$. Flemingii, is universally wanting in $M$. imbellis. In the latter the area is wholly roofed in by a membranous eovering as in $M$. lineata and $M$. Lacroixii. At the same time it should be remarked that the spines and avieularia (which eonstitute its armature) are most eharacteristie features of $\boldsymbol{M}$. Flemingii. The former may be wanting at times in old and worn speeimens; but there is generally a hole or stump to show where they have been. The avieularia, I believe, are always developed in greater or less number on the form with ealeareous lamina, to which I restrict the name Flemingii; but in $\boldsymbol{M}$. imbellis not a trace of such appendages is to be met with in any stage of growth. Mr. Busk, I venture to think, has eredited the former speeies with a larger amount of variability than really belongs to it. Certain it is that, of the figures which he refers to it in his admirable 'Catalogue,' one or two at least of those whieh diverge most widely from the normal type (e.g. plate eiv. figs. 2 and 4 , and probably 3 ) are representations of totally distinct spceics.

Apart from the important differences to whieh I hare 
just referred, the scale and general eharacter of the zoœcia are very dissimilar in the two forms.

I am not aequainted with any other speeics with which the present ean be eonfounded. $M$. irregularis, D'Orb., with which Busk eompares it, exhibits a totally different type of eell.

b. With a calcareous lamina.

Membranipora Flemingir, Busk.

Plate XXI. figs. 1-3.

Flustra mesibranacea, Miiller, Zool. Dan. iii. 63, pl. cxvii. figs. 1, 2.

Membranipora membranacea (part.), Johnst. Br. Zooph. ed. 2, 328 (not pl. lvi. fig. 7).

Flustra tuberculata, Johnst. B. Z. ed. 1, 289.

Ampinblestrum membranaceum, Gray, B.M. Rad. 110.

Membranipora Flesingir, Busk, B.M. Cat. ii. 58, pl. lxxriv. figs. 3, 4, 5 (not pl. cir. figs. 2, 3, 4): Alder, Hincks, Heller, \&co.

Membranipora Flemingir, forma trifolivm (part.), Smitt, l. c., Krit. Fört. iii. 367 and 405 , pl. xx. figs. 37 \& 40.

Zoccia ovate, more or less produeed below; area eontraeted above, mueh expanded and elevated below, filled in for about a third of its length by a ealeareous granular lamina; aperture trifoliate; margin mueh raised, erenated; oral spines six (in young eells usually eight) - two, very tall and slender, plaeed at the top, and two, muels stouter, on each side below them, the foremost of those on one side often enormously developed, and forming a long, flattened, scimitar-like appendage, which is artieulated to a short tubular process on the margin. Avicularia one on each side below the arca, raised, with acute mandible dirceted upwards and outwards when the ovieell is present, but usually downwards when it is absent ; sometimes a single central avieularium, plaeed trans- 
versely. Ocecia globose, commonly with a raised line or rib forming an arch across the front of it, and inclosing a minutcly granulated arca.

primary cell small, circular, with a membranous covering, and eight or nine ercet spincs round the margin.

RaNge of Variation. I belicve, as I have said elsewhere, that this spceics has becn credited with a much larger amount of variability than it really exhibits. Many of the forms referred to it which dircrge most widcly from the normal type are in fact distinct speeies. Its most rcmarkable variations are due to age, and the consequent loss of characteristic structures.

Haвiтat. On shells, stones, Algæ (more rarely), \&c., from between tide-marks to deep water.

Localities. Very common and widely distributed.

Geographical Distribution. East Greenland (Kirehenpauer, N. Germ. Pol. Exped.) : Gullmarcn (Smitt) : Adriatic, on mussels, Algæ, and corals (Heller) : Roseoff, common on Eschara foliacea (Joliet).

Range in Trme. Scotch Glacial deposits (Geikie): Palæolithic; clays of Western Scotland, \&c. (A. Bell).

In fully developed spccimens, in which the cells are erowded together, their real shape is scareely apparent. The arca scems to occupy the whole of the front; but, in fact, the cell is produced to a greatcr or lcss extent below it; and it is on this produced portion that the avicularia arc situated (Plate XXI. fig. 2). The zoœcia are contracted above, swcll out in the middlc, and then narrow off towards the lower extremity. The area follows the shape of the upper portion of the ccll, and is narrow at the top and rery broad below. It is also much elevated towards the bottom, so that the margin surrounding this portion of it stands out very prominently. 'The spincs 
are usually a very conspicuous featurc. Of the four at the top, which are found in young marginal cells, one or two scem to be deciduous and soon disappear. Six usually remain, of which the two uppermost are tall and slight and sharply pointed, and the rest tubular and comparatively stout. One of them is separated from its eompauions by differences in sizc and structure, which show themselves at its first appearance. It consists of a short, tubular basc, open at the top, to which a long spinous process is articulated, which often attains a truly gigantic size. It also takes on very commonly a pcculiar form, being broad and flattened, and bearing no slight resemblance to the blade of a scimitar. This, however, is not universally the case, since, though always of remarkable size, it seems sometimes to retain the eylindrieal shape. When fully developed, this sword-like appendage, bending across the cell as if to guard the entranee, has a very peculiar cffect.

Two of the spines, or sometimes four, are visible in front of the ovicell.

There ean seldom be mueh diffieulty in recognizing this species. The characters of the area are amply sufficicnt for identification, apart from the less stable and permanent portions of the structure.

When furnished with its full armature, $M$. Flemingii is eminently picturesque and characteristic.

Membranipora cornigera, Busk.

Plate XXI. fig. 4, and Plate XXII. fig. 3.

Menbranipora cornigera, Busk, Rep. Brit. Assoc. 1859, Trans. Sect. 45 ;

Quart. Journ. Micr. Sc. viii. (1860), 124, pl. xxr. fig. 2.

Mesbrasiposa Flemingi, 1, forma cornigera, Smitt, Cifrers. K. Vet.-Akad.

Förh. 1867, 367 and 403, pl. xxiv, fig. 1 . 
Zoøecia pyriform, or somewhat lozenge-shaped; lamina minutely granular, filling in more than half the area; margin not beaded, armed with six spines, of which two arc placed at the top of the cell and the rest on the sides, the lowest pair forked. Large oblong avicularia, with a rounded mandible, distributed amongst the cells. Occia rounded, finely granular.

Habitat. On stoncs, coral, \&c., from decp water.

Locality. Shetland (Barlce) : "a very interesting and very rare species ;" 100 fathoms, Outer Haaf (A. M. N.).

Geographical Distribution. On Oculina from 200300 fathoms, off the coast of Norway (Baron Uggla).

This species is readily distinguished by the two forked spincs bending inwards over the lower part of the apcrturc, and by the character of its avicularia, which are of the Flustrine type, and have a semicircular mandible, a form which occurs on only one other British spccies, M. flustroides. They are numerous, and are distributed amongst the cells, and on the same plane with them, instead of being dereloped upon them as secondary formations.

In old and worn specimens, from which all the membranous portions have been removed, a curious appearance is presented by the upper part of the aperture, which is marked off by a calcareous rib, and divided into two compartments (Plate XXII. fig. 3). This peculiarity is usually concealed by the oral valve; but when visible, it changes materially the aspect of the species. 
Membranipora Rosselit, Audouin.

Plate XXII. fig. 4.

Flustra Rosseril, Aud. Expl. 240: Savigny, Egypte, pl. x. fig. 11.

Mesrbranipora Rosseli, Busk, B.M. Oat. ii. 59, pl. c. fig. 2: Hincks, Devon Cat. 38 (вер.): Heller, Bryoz. Ad. Meer. 20: ?Manzoni, 1. c., Contr. 4, 11, pl. iii. fig. 15.

Zocecia oval, or elongate, wide and arched above, contracted below, and either truneate or pointed at the lower extremity, very regularly quineuneial ; a minutely granulated lamina filling in more than half the area; aperture longer than broad, arehed above, widest below, and contraeted towards the top, lower margin straight or slightly eurved inwards; margin of the eell mueh raised, especially above the aperture, finely beaded. Oxcia flattened in front. Avicularia none.

Colonies forming very flat, elosely appressed, neat-looking brownish erusts, often of large size.

Range of Variation. There are considerable differences in the shape of the zoœeium, which is sometimes pretty regularly oval; but more commonly it exhibits a rudely lozenge-shaped figure, elongate, and rather narrow in proportion to its length, arehed above, where it is widest, contracting from about the middle downwards, and terminating below in a truncate or pointed extremity. The margin is generally more elevated above the aperture than elsewhere, and sometimes forms a very thiek and prominent wall at this point. The aperture usually oeeupies decidedly less than half the area, but in some eases a rather larger proportion.

Haвitat. On shells (ehiefly) and stones, from shallow to deep water.

Localities. Orkney (Busk): Shetland, on stones, Outer Haaf, 80-140 fathoms (A. M. N.) : Isle of Man, off Maughold Head; Torbay, forming large patehes on 
shell; Guernsey (T. H.) : Antrim (Hyndman): Peterhead and Wick (C. W. P.).

Geographical Distribution. Algiers (J. Y. J.) : Bay of Gibraltar ( $\mathrm{M}^{\prime}$ Andrew and Landsborough) : Adriatic, on Tellina depressa (Heller).

\section{Membranipora trifolium, S. Wood.}

Plate XXII. figs. 5, 6.

Flustra trifoluy, Searles Wood, Ann. N. H. ser. 1, xiii. 20.

Mexbrayipora trifolicy, Busk, Crag Pol. 32, pl. iii. figs. 1, 2, 3, and 9 (part.).

Mfembranipora solida, Packard, Labrador Anim. (1860), 8, fig. 2.

Mestbranipora sacculata, Norman, Ann. N. H. ser. 3, xiii. (1864), 88 (8 sep.), pl. xi. fig. 3 .

Membranipora Flemingi, forma tripolicm, Smitt, CEfv. K. Vetensk.Akad. Förh. 1867, no. 5; Krit. Förteckn. pt. iii. 367 and 405 , pl. xx. fig. 42 .

Zocecia lozenge-shaped, or ovate, or elongate, arehed and wide above and narrowed downwards; the lower part of the area eovered in by a thin, minutely granular lamina; aperture ample, trifoliate; margin elevated, erenated. Avicularia sparingly developed, raised, plaeed between the eells; mandible aeute, direeted upwards or downwards. Occia semielliptical, smooth, but having on the front a triangular space, bordered by a raised line, whieh is minutely granular.

Colonies of a pale olivaeeous-green colour.

Var. $a$ (quadrata). Margin of the eells very prominent and strongly erenated, rarely two spines at the top, one on each side. Oeeasionally a prominent avicularium on the lamina, near the bottom of the eell, plaeed obliquely; mandible pointing downwards and outwards. Oaciu globose, bordered in front by a raised line, inelosing a somewhat quadrangular spaee, whieh is minutely granulated.

Colonies forming subeircular, reddish-brown erusts. 
Range of Variation. There are very considerable differences in the form and proportions of the cells, corresponding generally with those which I have already described in M.Rosselii. The lozenge-shape predominates; but the elongate form, wide and arched aborc, and narrowing off from an angle on each side about the middle of the cell, is far from uncommon.

The varicty $\alpha$ differs from the typical form as described by Norman chiefly in the character of the ovicell. The avicularium, too, is situated on the lamina instead of between the cells; and the margin is more strongly developed and coarsely beaded.

Habitat. Incrusting shclls and stones in shallow and deep water.

Localinies. Shetland, common, 40-170 fathoms (A. M. N.) : Wick, var. $a$ (C. W. P.).

Geograpiical Distribution. South Labrador (Packard) : St. Lawrence (Dawson) : Bahusia, common, 10-100 fathoms (Smitt): Spitzbergen, Röde-Bay, 40 fathoms (Goës) : Greenland, Holsteinborg Harbour, 7-35 fathoms ('Valorous' dredgings) : Bergen (A. M. N.).

Range in Time. Coralline Crag, very abundant on Terebratula grandis and other shells (S. W.) : Red Crag (A. Bell).

The present species is closely allied to $M$. Rosselii. In the abscnce of the ovicells and of the avicularia, which are very sparingly developed, there may be some difficulty in distinguishing the two. In the latter the surface of the zoarium is flatter, and neater in appearance than in $M$. trifolium, the zoœcia are smaller and narrower, the aperture generally occupics a smaller proportion of the arca, the margin is more elevated round the top of the ccll, the lamina is thicker and more depressed. In M. tri- 
folium the lamina is tumid, thin, and glistening; the cells are commonly rhomboidal or lozenge-shaped, but, as I hare mentioned, there are many variations, and there secms to me to be less differenee in this respect between the two forms than Mr. Norman supposes. There is usually no trace whatever of spines; but on a small colony from Wick, two are present at the top of the cell, placed one at each side.

There can, I think, be no doubt as to the identity of $M$. sacculata, Norman, with the Crag species M.trifolium. In the figures of the latter in Busk's Monograph, the same differences in the position of the avicularia are represented as we find in the recent form (compare figs. 1 and 3 on plate iii.).

\section{Membranipora minax, Busk.}

Plate XXII. figs. 2, $2 a, 2 b, 2 c$.

Membraxipora yisax (rhyncota in the description of the plate), Busk, Zooph., Quart. Journ. Micr. Sc. viii. (1S60), 125, pl. xxv. figs. 1, $1 a, 1 b$ (not $M$. rhyncota, Crag Polyzoa).

Membranipora Flemingir, forma minax, Smitt, Efv. Köngl. Vet.-Akad. Förhandl. 1867, no. 5, 367 and 409, pl, xx. fig. 43.

Zocecia pyriform, narrowed bclow; area occupying about half the front of the eell, oval, inclosed by a much raised, wall-like margin with a thin edge, two long spines on each side near the top; lamina smooth; aperture obscurely trifoliate, oceupying about two thirds of the area; a large, raised, central avicularium placed transversely on the margin at the bottom of the area, or immediately below it, with a long and slender mandible, tapering to a very fine point. Occia small, subimmersed, globular, minutely granular.

Primary cell Tata-like, with eleven or twelve, or sometimes with only five or six ereet spines round the margin of the circular or elliptical arca (Smilt). 
Habitat. On stones and shells in deep water.

Locality. Shetland (Barlec) : ibid., in 40-170 fathoms, common; "the most abundant spceies in deep water, it encireles the dead shells of Dentalium and Ditrupa with its polyzoary" (A. M. N.).

Geographical Distribution. Finmark (Lovén) : East Greenland (North Germ. Polar Exped.) : Bergen (A.M.N.).

In the original aceount of this speeies the name rhyncota found its way through some oversight into the deseription of the figures. Of eourse, the name in the text would naturally have preeedenee; and Mr. Busk has sinee given the other to a very different speeies, in his 'Monograph of the Crag Polyzoa.'

Smitt seems to have confounded two very distinct forms under his $M$. Flemingii forma minax. The one represented in his plate $\mathrm{xx}$. fig. 44, with the remarkable avieularium reealling that of Bugula Murrayana, ean hardly be referred to Busk's speeies.

Membranipora nodulosa, Hincks.

Plate XX. fig. 9.

Membrasipora yodolosa, Hincks, Ann. N. H. ser. 4, xx. 213 (Sept. 1877).

Zoccia small, oval, scparate; margin continuous, slightly raised, granular, unarmed; more than half the area eovered in by a minutely granular ealeareous lamina; aperture oceupying rather more than a third of the area, arehed and somewhat eontracted above, lower margin almost straight; at the base of each eell a very large, prominent, smooth nodule, usually subtriangular in shape.

Oxcia very small and shallow, rounded, smooth.

Colonies forming small and rery ineouspicuous erusts. 
Rave of Variation. Only two or three specimens have been examined; and they exhibit very little variation, exeept in the size of the nodules, which constitute so striking a feature of the speeies.

Habitat. Shells from about 30 fathoms and from decper water.

Localities. Off the coast of Antrim (Hyndman) : South Deron, off Brixham (T. H.).

This species is at once distinguished from $M$. Rosselii, perhaps its nearest ally, by the much smaller size and oval form of the cell, the continuous and very slightly granular margin, and the large and conspicuous interccllular bosses or nodules.

\section{Genus MEGAPORA, Hincks.}

Der. From $\mu \dot{\epsilon} \gamma a s$, large, and $\pi \delta \rho o s$, an opening.

Lepralia (part.), Busk.

Megapora, Hincks, Ann. N. H. 1877.

Generic Character.-Zoarium incrusting. Zoceia with a depressed area in front, surrounded by a raised margin, and partially closed in by a calcareous lamina; aperture trifoliate, the lower portion filled in by a horny plate, on which the opercular valve works.

THis genus is instituted for the remarkable form described by Busk as Lepralia ringens. It exhibits many points of resemblanec to some of the Membranipore (c. g. $M$. Flemingii), and should ccrtainly, I think, be included in the present family.

It holds its separate place and name by virtuc of the peculiar structure of the aperture. 
Megapora ringens, Busk.

Plate XXII. fg. 1.

Leprazia risaens, Busk, Quart. Journ. Micr. Sc. iv. (1856), Zoophytol. 308, pl. ix. figs. 3-5: Norman, Shetland Pol., Rep. Brit. Assoo. $1868,307$.

Megapora ringens, Hincks, Ann. N. H. ser. 4, vol, zx. 529.

Zoøcia ovate, with an inclosed area, which occupies the upper portion of the front surface; surface minutely pitted; orifiee trifoliate, arched abovc, much contracted below the middlc, and expanded at the bottom into a transverse fissure-like eompartment, which is filled in by a fixed loorny plate, distinct from the movable oral valve; marginal spincs $4-6$; on the front or side of the cell a tall corneous vibraculoid spine. Oøcia small, globose, smootl, with a raised central rib passing from the front margin backwards.

Colonies growing in small inconspieuous patehes of irregular shape.

Habitat. On stones from deep water.

Localıties. Shetland (Barlee) : ibid., 80-170 fathoms (A. M. N.).

Geographical Distribotion. Bergen (A. M. N.).

Family IX.-Microporidæ.

Microponide, Smitt, Floridan Bryozoa.

Membraniporide (part.), Busk.

Zowcis with the front wall wholly calcareous; margins elevated.

Tus family is distinguished by the total disappearance of 
the membrauous area on the front of the eell, a character in which it agrees with the forms grouped under the old genus Lepralia; while, on the other hand, the elevated margin of the zoccium indicates its affinity with the Membranipora.

\section{Genus MICROPORA, Gray.}

Der. From $\mu$ xрòs, small, and $\pi$ ópos, an opening.

Flustra (part.), Johnston.

Discopora (part.), Lamarck.

Micropora, Gray, B.M. Rad. 115: Smitt.

Membrasipora (part.), Busk, \&e.

Lepralia, sp., Nomnan: Reuss.

Reptescilareluisa (part.), D'Orbigny.

Generic Character.-Zoarium incrusting. Zoceia with prominent raised margins; front depressed, wholly calcareous; orifice semicircular or suborbicular, inclosed by a calcareous border.

In this genus the zoœeia agree with those of Membranipora in the possession of a raised margin and depressed front; but there is no trace left of the membranous covering, while the orifiec, which is placed at the very top of the eell, is bounded above and at the sides by the margin of the wall, and below by a calcarcous rib or border. Avicularia are present in some speeies, and wanting in others.

Besides the three species described in this work, a considerable number of Membranipora, both fossil and reeent, must be referred to this group.

Several Miocene forms bave been recorded; and the generic type is as old as the Chalk at least. 


\section{Micropora coriacea, Esper.}

Plate XXIII. figs. 5-7.

Flustra coriacea, Esper, Pflanz. Flustr. pl. vii. fig. 2.

Discopora coriaces, Lamk. An. s. Vert. ed. 2, ii. 251.

Micropora coriacza, Gray, B.M. Rad. 115: Smitt, Flor. Bryoz. pt. ii. 13, pl. iii. fig. 74.

Membranipora corlacea, Busk, B.M. Cat. ii. 57, pl. lxxiii. figs. 4, 5.

Zoccia broadly elliptical or rhomboidal; margin slightly roughened, tcrminating above on each side in a smooth elaviform knob; area minutely granular and punctate, frequently with a foramen on each side a little bclow the moutl ; orifice broader than long, arched above, lower margin straight, pouting. Occasionally an avicularium immediatcly above the orifice, placed somewhat obliquely, mandible directed upwards. Oxcia large, subimmersed, minutely granular, with a projection or rib in front.

$R_{\text {ange of }}$ Variation. The foramina in the front wall are frequently wanting; but in some colonies they arc present on almost cvery cell, and give a very marked character to the specimen. Oecasionally the tuberosities, which form so striking a featurc of the species, attain an enormous growth. The avicularia secm to be rarcly devcloped. There is always a projection or callosity on the front of the ovicell ; but it varics considerably in charactcr, being in some cases a massive umbo, in others forming a smooth, thickened area, arched, or rising to a blunt point abovc, and with a rib-like border, and in others, again, assuming the shape which is represented in Plate XXIII. fig. 7.

Навітат. On shclls, stones, \&c., from tide-marks to very deep water.

Localities, Shetland, under stones betwcen tide-marks ; 
the Mineh (A. M. N.) : Antrim; off Sana Island (Hyudman) : Cornwall, deep water; Guernsey (T. H.) : Hastings (Miss Jelly) : Caithness; Aberdecnshire (C. W. P.).

Grograpuical Distribution. Florida, 36-135 fathoms (Pourtales).

\section{Micropora complanata, Norman.}

Plate XXIII. figs. 8, 9.

Lepralia complasata, Norman, Ann. N. H. January 1864, 84, pl. x. fig. 4.

Menbraxipora Suitti, Manzoni, Bryoz. foss. Ital. Contr. 4, 11, pl. iii. fig. 16 (Sitzb. K. Akad. d. Wissensch. Bd. Lxi. 1. Abth. März-Heft, 1870).

Zocecia lozenge-shaped, flattened, quincuncially arranged; marginal lines smooth; surface thickly covered with pather large punctures; mouth semieircular, well arched above, slightly contracted on each side below, the upper margin usually thiekened and produced into a point, unarmed, lower lip nearly straight, pouting. Ocecia depressed, in the form of a quarter-moon, smooth.

Colony forming a white, glossy crust.

Habitat. On shells and stone.

Locality. Unknown. Mr. Norman's speeimens were found without label amongst Mr. Barlee's extensive eollection. They occurred on shell, and "in the little hollows of a rounded and much water-worn piece of coarse-grained granite.".

Raxae in Time. Italian Pliocene deposits (Manzoni).

Membranipora Smittii of Manzoni is clearly identical with the present specics. But in the fossil there is always a small callosity on each side near the lower corners of the mouth, which is rarely developed in the recent form; it 
does oceur, however, oeeasionally, though never sueh a striking feature as it is represented in Manzoni's figure.

The mouth has an obseurely trifoliate appearanee, whieh is due to a slight marginal projeetion on each side, almost immediately above the lower lip. This eonstitutes an important difference between the present speeies and $M$. coriacea. Another is found in the thickened border, more or less pointed above, surrounding the upper margin of the orifice. The area is also mueh more thickly punetured than in $M$. coriacea; and the punctures are of larger size.

\section{Genus STEGANOPORELLA, Smitt.}

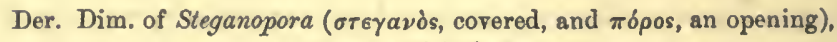
a genus of Polyzoa.

Membranipora (part.), auctt.

Reptescharelliva (part.), D’Orbigny.

Steginoporella, Smitt, Flor. Bryoz.

Generic Character.-Zoarium incrusting or (occasionally) rising into foliaceous expansions*. Zoccia with the external characters of Mieropora, but having an inner chamber occupying the whole of the cavity below, and above narrowed into a tubular passage, which either communicates directly with the orifice or opens into a second chamber immediately beneath it.

THE speeies in which the eharacters of this group are most strikingly exhibited is the Membranipora magnilabris, Busk. In some respects, however, it is peculiar; and we have a better average representative of the genus in our British speeies.

- According to Smitt, S. magnilabris, Busk, sometimes assumes this condition (Flor. Bryoz. pt. ii. pl. iv. fig. 100). 
In exterual appearance the cell of Steganoporella resembles very elosely that of Micropora; but in many eases the large foramina in the front wall allow the neck-like termination of the lower ehamber to be seen, and so reveal the struetural differenee between them.

At a short distance from the upper extremity of the zoccium a diaphragm shuts off the lower portion of the eavity, and forms a chamber in which the polypide is lodged. From the eentre of this diaphragm a tubular prolongation passes upwards to the opening of the eell (in S. Smittii), and is there elosed by the opereular valve. In $S$. magnilabris this tubular passage (through which the polypide issues from its dwelling) opens into a large elamber oceupying the upper portion of the ecll, and probably occial in eharacter, which is closed in by an opereulum of unusual size and strueture.

The peculiarities of the last-named speeies eonnect themselres with the remarkable modification of the ovicell, which has no existenee in other members of the group. In S. Smittii, for instanee, the oœcium is of the ordinary kind; the upper chamber is wanting, and the tubular passage from the lower chamber extends to the orifice of the eell (woodeut, fig. 7).

The name seleeted for this generie Fig. 7.
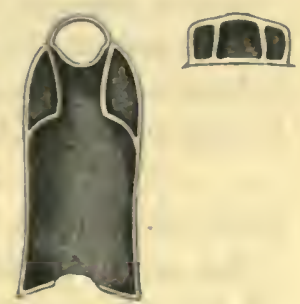

Sections of the zoocium. group is intended to eonneet it with the Steganopora of D'Orbigny, but there seems to be no real analogy of strueture between the two. 


\section{Steganoporella Smititi.}

Plate XXIV. figs. 5, 6.

Membranifora Annegavensis, Busk, Crag Pol. 35, pl. 1i. figs. 5 \& 9 (probably not Eschara Andegavensis of Michelin).

Zoocia large, elongate, subquadrangular, slightly arched above; margins granular, the front wall punctate, rising somewhat abruptly towards the orifice, an oval foramen in a reecss on cach side a littlc below the mouth; orifiec suborbicular, contraeted below by a small projection on each side, with the lower lip slightly curved outwards; the upper margin thickened, the lower thin. Avicularia distributed amongst the zoœcia, placed on an area nearly as large as the cell, which is arched above and pointed below; mandible of a dark lorn-eolour, oceupying nearly two thirds of the area, flat, eontracted towards the point of attachment, expanded and rounded above, strengthened by a narrow central plate. Oxcia ample, rounded, very broad (much broader than high), flattencd at the top, smooth, carinate in front, with a large arehed opening closed by a horny movable lid.

Colony forming a thin whitish crust.

Habitat. On the tube of an Annelid from deep water.

Locality. Off the Cornish coast; incrusting a Serpula (C. W. P.).

Range in True. Coralline Crag, on shell (Searles Wood).

For this finc addition to our fauna we are indebted to Mr. Peach, who has obtained it on two oceasions from the Cornish coast.

- There can be no doubt as to the identity of the British specimen which I have examined with the Crag fossil; but I can hardly agrec with Mr. Busk in referring the 
latter to Michelin's Eschara Andegavensis. His figure exhibits none of the peeuliarities of the present species, and is more probably, I think, a representation of the eommon Mediterranean form (also found in Tertiary deposits), which has been deseribed under various names, but was first eharaeterized by Moll as E. impressa.

The zoceia are subquadrate, the opposite walls being almost parallel. The front wall is somewhat depressed below, but rises rather abruptly towards the inferior margin of the orifiee. On eaeh side of its elevated portion, which marks the eourse of the tubular entranee to the inner ehamber, are placed the foramina. They are sometimes met with overspread with a delicate membrane, and are not unfrequently obliterated by age and the progress of ealeification. They open into the spaee lying between the outer walls and the tubular ncek of the ehamber.

On the Comish specimen the very eurious avicularia are present in great numbers, and, from their size and the dark eolour of the mandible, are very eonspicuous objeets. The area on which they are plaeed is large, almost equalling in size that of the eells. It narrows off to a point below; and about the middle the aperture is eontracted by a projection of the margin on each side, which bends over it, forming with the arched top of the area a kind of frame round the mandible. The latter is flat, and is traversed for about two thirds of its length by a narrow band or rib, which is formed of stronger material than the rest. In Mr. Busk's type speeimen from the Crag the avicularia are also numerous; and in two eases the mandible has been prescrved, showing very clearly the eharaeteristic strueture which $\mathrm{I}$ have just deseribed.

The oviccll is of unusual size, and exhibits a eurious peeuliarity in the horny lid which eloses the large arched 
aperture. This lid falls like a trap-door, and when down covers a cousiderable portion of the front of the cell. In the ovicelligerous cells the orifice is larger than in the ordinary zoceia, and of different form. There is a close resemblance between the occia of the present species and those of S. Rozieri, Audouin.

\section{Genus SETOSELLA, Hincks.}

Der. A dim. formed from setosa, bristly.

Memranipora (part.), Busk.

Cupularia (part.), Smitt, Floridan Bryoz. ii. 14.

Setosell., Hincks, Anu. \& Mag. N. H. Sept. 1877.

Generic Character.-Zoariug incrusting. Zogech with raised margins; front depressed and wholly calcareous; aperture semicircular. VIBRACULAR CELLs alternating with the zoccia throughout the colony. Vibraculua slender and setiform.

IN this genus cach of the zoccia has a vibracular eell immediately above it; the vibraculum is of the more highly specialized type, and exhibits no traec of the fixed beak-like structure which is found in connexion with the more rudimentary transitional forms. The zoœeia agree in general character with those of Micropora.

There is also a resemblance between Setosella and Cupularia, Busk, in the mode in wlich the vibracular eclls are distributed over the colony; and Smitt would unite the two forms in one generic group. - As I cannot subscribe to lis fundamental principle, that the plan on which the eells are associated in the zoarium is of no account as a generic 
eharacter, I am unable to assent to this view. The remarkable strueture of the zoarium in Cupularia, and its free eondition when adult, are points of muel systematic value; and to these must be added the great development of the vibracula, and their (probable) assumption of a loeomotive function *.

\section{Setosella vulierita, Busk.}

Plate XII. fig. 7.

Menbrastpora vulverata, Busk, Quart. Journ. Micr. Se. viii. (1860), 124, pl. xxr. fig. 3: Norman, Shetl. Dredging Rep., Brit. Assuc. Rep. 1867, 305.

Setosella velnerata, Hincks, Ann. \& Mag. N. H. for Dec. 187 .

Zoccia somewhat pyriform or oval ; margin slightly raised, smooth, unarmed; orifice small, arehed above, the lower lip a little eurved outwards ; lamina minutely granular, rising rather abruptly towards the mouth, usually with a narrow, slit-like fissure, slightly eurved, on each side, a little below the orifice. Long and slender vibracula distributed over the eolony on distinet intercellular areas, one immediately above each ecll. Oxcia?

Colonies forming very small, white, subeircular patehes.

Ravge of Variation. There are sometimes eonsiderable differenees in the size of the eells within the limits of the same colony. The shape varies from suboval to pyriform; the eells are generally mueh narrowed towards the orifiee, and expand to a moderate degree below. The lateral fissures in the lamina are occasionally wanting.

- Mr. Busk informs me (in litt.) that his conjecture respecting the locosuotive function of the vibracula amongst tho family of Selenariude (to which ('upularia belongs) has been confirued by actual obsernation. 
Habıтат. Very small stones in deep water. Mr. Norman says :- "This very distinet little species has a very peeuliar habit; it is never found on any but the smallest stones. I do not remember to have ever seen it on a pebble larger than the little-finger nail; more generally it seleets those that are not more than a fourth of that size."

Locality. Shetland (Barlee) : ibid., in 80-110 fathoms (A. M. N.).

Geographical Distribution. Bergen (A. M. N.).

In this species the vibracula seem to be always present, alternating regularly with the zoccia throughout the colony. They reveal very elearly their homologieal nature, as modifieations of the ordinary cell. The vibracular eell is in many respects a eopy in miniature of the zoceium, presenting the raised margin, the lamina, and the equivalent of the orifiec, the setiform appendage taking the plaec of the oral valve.

\section{Family X.-Cribrilinidæ.}

Esciaride (part.), Jolinston.

Membranipolido. (part.), Busk.

Esciariporide (part.), Suitt.

Escuarellide (part.), D’Orbigny.

Zомкічм adnate, forming an indefinite crust, or erect. Zocecis having the front wall more or less fissured, or traversed by radiating furrows.

Tнє Cribrilinide form a section of the large and miscellaneous assemblage of forms included in the genus 
Lepralia of Johnston. That the latter is a very heterogeneous group, and eannot be maintained in its integrity, will probably be admitted by most. There will be less agreement as to the prineiples on which it slould be subdivided, and the eonstitution of the new genera that are to replace it. Our knowledge of the Polyzoa is not yet sufficient to admit of a strictly natural elassification, and our arrangement of them must still be, to a large extent, more or less artificial; and to some it may appear hardly desirable to interfere with the existing order of things for the sake of a change which, after all, may be merely provisional. But it must be borne in mind that, as a matter of convenienee, and to facilitate the work of the student, it is essential that the unwieldy colleetion of forms bearing the name Lepralia should be broken up into groups of some kind or other; and it seems better to aim at a natural subdivision, even though the attempt slould be only partially suecessful, than to perpetuate the purely arbitrary method hitherto in use.

Of the numerous species ranked under the genus Lepralia, many have little in eommon but general habit; and to mass them together indiseriminately ean only be accounted a very rude and provisional kind of elassifieation.

I am very sensible of the diffieulties-some of them, I fear, insurmountable for the present-which are attendant upon the work of reorganization in this department, even after the valuable labours of Prof. Smitt*. My aim has been to form groups which shall represent the more important variations in the arehiteeture and struetural eomposition of the zoceium. The other prineipal zooidal

- Sco his paper entilled "Bryozon marima in regionibus urctivis et borealibus virentia recensuit IS. A. Sunilt," CEfv. Kongl. Vetensknps.Akndenicu's Pörlandlingar, 1867, no. 13, p. 413 . 
element in the Polyzoan colony-the polypide-does not exhibit any differenees amongst the Lepralice that ean be employed as diagnostic characters in the construction of genera. The avieularian appendages constitute in the present section a very unstable and variable clement, and are of very sccondary value for systematic purposes. In the plan of the gemmation and the colonial habit there is on the whole much uniformity; but the important and difficult question arises, whether forms of kindred zocecial character, but exhibiting an erect mode of growth, should be combined in one genus with those which are crustaceous. This and other systematic points are discussed in the section of the Introduction devoted to the subject of Classification.

The present family is a very natural and well-defined group.

\section{Genus CRIBRILINA, Gray.}

Der. From crilrum, a sieve.

Cellepora (part), Fubricius.

Esciura (part.), Moll.

Lepralis (part.), Johnston: Busk.

Crimilina, Gray, B.M. Rad. 147 : Smitt, Floridan Bryoz. pt. ii.

Repteschanelu, D’Orbigny, Pal. Franç. Terr. Crét.

Eecuaripora, Smitt, QEfv. Kongl. Vet.-Ak. Förhandl. 1867, Bihang.

Genemic Character.-Zonkium incrusting. Zocecia contiguous, having the front more or less occupied by transverse or radiating punctured furrous; orifice stmicircular or suborbicular.

THE peculiar condition of the front of the zoccium, which distinguishes this genus, has a special significance. It is not a mere varicty of superficial sculpture, but 
depends on the primary composition of the cell-wall, and indieates the course of its development. The ridges radiating towards the centre represent the rib-like processes given off from the margin of the young eell, as in the genus Membraniporella, which ultimately meet and form a protective covering. These ridges are united laterally by outgrowths of stony matter occurring at intervals; and the spaces between the conneeting links are represented by the interstitial punetures of the adult organism. So that the genus is founded not on any trivial peculiarities, but on the essential structure of the eell itself.

Cribrilina marks a transitional stage in advance of that represented by Membraniporella.

A considerable number of fossil species are known, some of which reach back to the Cretaccous deposits.

\section{Cribrilina radiata, Moll.}

Plate XXV. figs. 1-9.

Escusas madista, Moll, Seerinde, 63, pl. ir. fig. 17.

Lepralia innomixata, Couch, Corn. Faun. iii. 114, pl. xxii. fig. 4 (worthless): Johnston, Br. Z. ed. 2, 319, pl. Iv. fig. 12: Busk, B.M. Cat. ii. 79, pl. lxruvi. figs. 2, 3: id. Crag Pol. 40, pl. iv. fig. 2: Hincks, Deron and Corn. Cat., Ann. N. HI. ser. 3, ir. 203 (p. 43 sep.): Manzoni, Suppl. Bryoz. Medit. prima Contr. 4, pl. i. fig. 5 (Sitzb. k. $\Lambda$ kad. d. Wissensch. 13d. Lxiii, 1. Abth. Feb.-Heft, 1871); Bryoz. Pliocen. Ital. prima Contr. 8, pl. ii. fig. 13 (Crag form).

? Flestra Poulletu, Audouin, Savigny, Egypte, pl. ix. fig. 12.

? Lemralia yultiraniata, Reuss, Oberburg, 31, pl. x. fig. 5; Paliontol. Studien, ii. 43.

Lerialia scurta, Reuss, Sitzungsb. k. Akad. d. Wissensch. Bd. 1. 28, pl. xv. fig. 3; Bryoz. d. deutsch. Septarienth. 1866, 58 ; (Cellepora), Polyp. d. Wiener Beckeus, 82, pl. ix. fig. 23: Mansoni, Suppl. \&c. 5, pl. i. Iig. 6.

Lezrala raztosa, Reuss, Bryoz. d. deutsch. Septarienth. 59, pl. viii. fig. 4 .

Letollata calonomin, lieuss, l. c. $62, \mathrm{pl}$. xi. fig. 10. 
Lerralia raricostata, Reuss, Foss. Bryoz. üsterrcich-ungarisch. Miociins, 26 , pl. i. fig. 8.

? Lepralia Endeicueri, Reuss, 1. c. 31 , pl. i. fig. 9.

Reptescilakela proares, D'Orb. Pal. Franç. Terr. Crét. r. 468, pl. 716. figs. 7,8 .

? Reftescharella radiata, D'Orb. op. cit. v. 468, pl. 716. figs. $4-6$.

Cribrilina raplata, Smitt, Floridan Bryoz. pt. ii. 22, pl. v. figs. $107,108$. Cribrilisa innominata, Smitt, l. c. 22, pl, v. figs. 109, 110.

Lepralia anvulata, Heller, Bryoz. Adriat. M. 33 : Manzoni, Suppl. Faun. Bryoz. Medit. prina Contr. 4, pl. i. fig. 4.

? Lepralia cribrilliva, Manz. Brioz. di Castrocaro, 27, pl. iii. fig. 40.

Zoccia oval, sometimes subglobose, distinct, quincuncially arranged, with six to ninc ridges on each side, radiating from a central line, the furrows between them occupied by a row of minute punctures, often a more or less prominent keel down the centre, terminating in an umbo above; orifice semicircular, the lower margin straight, on each side of it a very delicate setiform appendage, often wanting; immediately below it a projecting triangular arca, bounded by raised walls and inclosing a subtriangular pore (form i.), or all umbo and a few large punctures only (form ii.) ; marginal spines 5-6. Avicularia elongate, with pointed mandible, scattered amongst the zoœcia. Oœcia globose, with a keel down the front.

Colonies forming large irregular crusts, sometimes white or silvery.

Var. . Cells very small, radiating ridges five, two on each side and one at the bottom, very prominent, the two uppermost forming a wall across the face of the cell; median pore present; two slender vibraculoid setce. Oxcium with many nodulous projections on the front.

Var. $\beta$. Cells very minute, distinet, oval, with deep sutures between them, of a delicate pearly whiteness; the front flattish, traversed by ten radiating ridges, which are surrounded by a narrow border of smooth cell-wall; ridges not promineut, interstitial punctures distinct; no central pore or umbo; immediately below the mouth a number of punctures of various shapes and sizcs. (Plate XXV. fig. 4.) 
Var. $\gamma$ (tenuirostris). With the avicularium developed on a distinct eell; mandible short, broad at the base, much attenuated above.

Raxge of Variation. After careful consideration I liave united the Eschara radiata, Moll, and the Lepralia innominata, Johnston, as one species. The elief difference between them is that one of them has the large pore below the orifiec, and the other wants it; but this is far from being a coustant distinction between these two forms, and cannot be used in this ease as a specific eritcrion. It nust be remembered that specimens which exlibit most strikingly the differenees between the radiata and innominata types are connected at all points by very numcrous intermediate and transitional forms, in which the elements of the two are variously mingled and combined. In a specimen before me, presenting the general characteristies of radiat $a$, the triangular area below the orifice is present, but not perforated. The Lepralia pretiosa, Reuss, which is referable to the same type, is furnished with the median pore. In Lepralia raricostata, Reuss, a very well-marked example of the innominata type, the pore is wanting. In the Lepralia Endlicheri, Reuss, which I am inclined to refer to the same series, the pore is present on some cells and absent on others. The form from Madcira, which Busk figures (Quart. Journ. Micr. Sc. vi. pp. 128 \& 263, pl. xx. fig. 4) as L. radiata, and which undoubtedly exhibits many of the characteristies of Moll's speeies, has the median pore well developed! 'The L. innominata of Manzoni from the Mediterranean seems to be somewhat intermediate between the two varietics; it wants the median pore. In other respeets the two forms pass insensibly one into the other. 'The differenees, too, which lie chicfly in texture, the more or less 
pronounced condition of eertain parts (e. $y$. the radiating ribs, the eentral line, the umbo), are of slight importanee, while the leading features are eommon to both and constant*.

C. radiata, as now defined, exhibits a wide range of variation in what may be called its secondary eharacters. The eells are sometimes much rounded and widened below, sometimes regularly oroid; frequently they are produced below into a point; they also vary much in size. The inclosed triangular space below the mouth is more or less marked; at times it is altogether absent; but there is always a smooth space between the iuferior margin and the ribs. The median pore is sometimes wanting; when absent there are usually two or three large punetures just below the mouth. In eertain fossil varieties there is a blunt tuberele on each side of the eentral pore.

The zoarium also varies much in its general appearanee. In some cases (radiata form) it is of extremely delicate texture, silvery and shining; in others (innominata form) it is of much eoarser make, and of a brownish colour. The area traversed by the radiating furrows is larger or smaller, ovate or subeireular, at times surrounded by a very considerable tract of smooth cell-wall. The umbo, below the orifiee, is in some eases largely developed, in others abortive. The same is the ease with the ecntral keel. In some forms it all but disappears, and the furrows seem almost to pass continuously from side to side. The ridges or ribs are often very inconspicuous, while in other eases they are strongly defined, radiating from a distinet keel, and standing out prominently round the edge of the area.

* "I have some doubts whether these two (L. innominata, Johnst., nud L. radiata, Moll.) may not, strange as it may seem, prove to be varieties of each other, in which case Moll's name will, of course, have precedence."Busk, Zoophytology, Quart. Journ. Mier. Sc. viii. p. 283. 
They rise up oceasionally into ereet spinous processes. The interstitial pores are either very distinet (radiata form), or almost obliterated (innominata form). The small vibraculoid appendages are often wanting. In the avicularium there is a considerable amount of variability. In some eases it is much more elongate than in others, and much more clevated. In a specimen from the Red Sea (?) it is of unusual length, rather blunt at the extremity, and almost pedunculate. In British examples it is usually shorter and broader. A more remarkable modification oceurs in a specimen of the radiata type from Madeira, in which the avieularium is dereloped on the upper part of a distinet cell, of much smaller size than the ordinary zoœcia, but still well marked; the beak is very short, projecting slightly beyond the top of the ecll; the mandible is broad at the base, but becomes suddenly attenuated, and tapers off to the extremity.

This form may be regarded as less completely differentiated than that which is commonly met with, in which the avicularian eell is all but aborted, and little is to be seen but the beak and mandible. These differenees are elearly of no specific value; but they are interesting as showing us what an unstable element of strueture the avicularium is.

It may be mentioned here, that in this species there are a number of large oval foramina round the base of the eclls, which are very conspicuous in those that are placed on the edge of the colony.

Haвiтat. At low-water mark, and on stones, sliclls, zoophytes, \&c. from moderate depths to deep water (175 fathoms).

Localiries. Abundant on the soutl and soutli-west eoasts of England, ranging to the Isle of Man, west coast of Scotland, Helbrides (the Minch), and Shetland, where, 
however, it is scarce; almost absent on the north-castern coasts. Birterbuy Bay, Commemara (G. S. Brady) : IIastiugs (Miss Jelly): Cornwall, 60 fathoms (rudiata and innominata forms); Gnernscy (T. H.) : Shetland, scarec, down to 170 fathoms (A. M. N.) : Wick, rare (C.W.P.): \&c. Var. $\alpha$. Antrim, deep water (Hyndman).

Geographical Distribution. Mediterranean (Moll, Manzoni): Naples, from 6 fathoms to considerable depths (A. W. Waters) : Madeira (Busk) : ibid. (var. tenuirostris) ('T. H.) : Adriatic, pretty common (Heller): Gulf of Florida, 29-175 futhoms (Pourtales): on the Falmouth-Lisbon cable, between N. lat. $47^{\circ} 58^{\prime}$ and $47^{\circ} 35^{\prime}$ and in W. long. $7^{\circ} 6^{\prime}$, from 89-205 fathoms (Sir James Anderson): Roscoff (Joliet) : France, S. W. (Fischer).

Range in Time. French Cretaceous deposits (D'Orbigny): Austro-Hungarian Miocene, abundant; Oberoligocän and Mittcloligocän (at Söllingen), rare (Reuss): Coralline Crag (S. Wood): Middle and Upper Pliocene (Coralline and Red Crag) (A. Bell) : Italian Pliocene beds (the Crag form) (Manzoni) : Boulder Clay, Wick (C. W. P.) : Quaternary, Reggio (A. W. Watcrs).

Cribrilina punctata, Hassall.

Plate XXVI. figs. 1-4; and Plate XXIV. fig. 3.

Leprala levetata, Hass. Ann. N. H. vii. 368 , pl. ix. fig. 7 , and ix. 407 : Johnston, B. Z. ed. 2, 312, pl. Iv. fig. 1: Busk, B.M. Cat. ii. 79, pl. xc. figs. 5, 6, pl. xcii. fig. 4, pl. xcri. fig. 3 ; Crag Polyz. 40, pl. iv. fig. 1; Quart. Journ. Micr. Sc. ir. 310, pl. xi. figs. 4,5 .

Cuibrilina punctata, Gray, B.M. Rad. 117.

? Lepralia cribrosa, Bocck, Förh. Vid. Selsk. Christiania, 1861, 50.

Escilaripora punctata, Smitt, GẼfr. K. Vet.-Ak. Förh. 1867, Bihang, Kirit. Förteckn. iv. 4 \& 51, pl. xxiv. figs. 4-7.

Zocecia subcylindrical; more or less distinct, sometimes 
eonfluent, disposed in lines, the whole front perforated with punetures of varying size and shape, in rows, or sometimes irregularly distributed; orifiee transversely oblong, lower margin muel thiekened, projeeting into a prominent muero; marginal spines four or five, the two foremost eurved in fertile eells, meeting aeross the mouth in front of the oceium; an avicularium on each side of the orifiee (sometimes on one side only), with pointed mandible, direeted obliquely upwards. Oœcia rounded, smooth, and vitreous, sometimes witl a strong rib in front, inclosing a triangular spaee, from whieh a keel passes off to the base ; frequently a raised proeess immediately behind it supporting a small avieularium; sometimes destitute of the rib and keel, and thiekly punetured.

Polypide tall and very delieate, with about 13 tentaeles.

Primary cell small, with a large, terminal, orbieular orifice, surrounded by twelve spines.

Colonies forming silvery shining patehes when young, mueh thickened and coarser when old, with a tendeney to a subeireular growth. A central group of diminutive eells marks the origin of the colony.

Var. $\alpha$. With a central umbo, from which ribs pass off to eacl side, rising into ereet proeesses round the front of the eell, usually a single large pore in each furrow; muero and marginal spines strongly developed; lateral avieularia in a line with the lower margin of the orifiee, the mandible direeted straight outwards. Oxcium covered with spinous projeetions, and eommonly with a raised avieularium on the hinder part of it.

Range of Variation. This is a speeies of very variable aspect. The elianges in its appearance are eliefly due to the greater or less development of various nodulous and other proeesses on the surface of the eell and ovieell. Perlıps the most remarkable form which it assumes is 
that which I have eharacterized as var. $\alpha$; but it appears in a multitude of guises, and in some of them is very unlike its proper self. The cells are usually somewhat clongate, but oceasionally short and almost orbicular. The normal arrangement of the punetures is in tranșverse rows; but the rows are often very inconspicuous, and in many eases the pores are seattered thickly over the surface. Down each side of the eell sevcral ereet nodulous processes are not unfrequently ranged, whilst one of larger size is placed eentrally at the base. In one very marked varicty the punetures are arranged in rows cx. tending from near the margin to an clevated median kecl or erest, and oceupy an oval space on the front of the cell, which is inclosed by a line of minute raised pores. The lower margin of the orifice is always thickened and more or less mucronate; but in some cases it becomes very massive and bears a broad, projecting expansion in front. At times on the inner margin there is a bifid proeess. Probably the oøcium is more variablc in appearance than any other portion of the structurc; it is sometimes smooth and silvery, with a raised thickened rib across it in front, rising in the centre into a knob. In some cases it is covered with raised punctures and numerous nodules, and bears a small elevated avieularium at the top; in others, again, it is smooth, and so much immersed as to be hardly visible, the thick and often subtriangular rib alone standing out promincutly above the orifice. Oceasionally it is elongated and punctured.

The species, it will be seen, is liable to great diversities in what may be called its surface-decoration. In fresh specimens the eells are silvery and bright; but there is more than the usual tendeney to thickening and opacity in the older states. 
Haвitat. Between tide-marks, on Algæe, stoncs, \&e., and in moderatc depths.

Localities. Very widcly distributed on the British coasts. Shetland, tidc-marks; the Minch (A. M. N.) : Soutlı Devon; Ilfracombe; Guernsey; Isle of Man (T. H.): Hastings (Miss Jclly) : Birterbuy Bay (G. S. Brady) : \&c.

Geograpuical Distribution. North Sea (littoral region, on Algæ) to Bahusia (Smitt): Southern Norway (Boeek) : Kara Sea (Nordenskiöld) : France, south-west (Fischer).

Range in Time. Coralline Crag, on shells, abundant (S. Wood) : Middle Pliocene beds (Lower and Middle Coralline Crag) (A. Bell).

Cribrilina anvulata, Fabricius.

Plate XXV. figs. 11, 12.

Oezlepora assulata, Fabr. Faun. Gronl. 436.

Lepralia axxclata, Johnst. B. Z. ed. 2, 312, pl. 1v. figs. 2, 3 : Busk, B.M. Cat. ii. 76, pl. Ixxrii. fig. 1. (Not the L. annulata, Heller, Bryoz. d. Adriat. Meeres, 33, which is probably Cribrilina radiata.)

?Reptescharella Heermaxnit, Gabb \& Horn, Monogr. Polyz., Journ. Acad. Nat. Sc. Philadelphia, v. pt. ii. 137, fig. 20.

Escharipora asvolata, Smitt, CEfv. K. Vet.-Ak. Förh. 1867, Bihang, Krit. Fört. ir. 4 and 53, pl. xxir. figs. 8-10.

Zocecia regularly ovate, very distinct, convex, produced into a point below, semialternate, obscurely carinate in front, with about six punctured furrows on each side; orifice suborbicular, slightly compressed transversely, with a thickened peristome, projecting in front into a mucro; marginal spincs three or (occasionally) four. Oøcia globose; very small and inconspicuous, set far back, glabrous, punctured; two spines showing in front of it, which are commonly united so as to form an arch-like rib. 
Colonics forming small (often) cireular crusts of a reddish colour. The primary eell appears to be normal, but inferior in size to the rest.

Ravge of Variation. C. annulata seems to be less variable than any other British species of its genus. The zoceia exhibit slight differcnees of shape, being sometimes short, ovate, and well rounded off below, and sometimes elongate and produced into a point. The ridges and central keel are more or less pronouneed; and the punetures vary in size; usually they are rather large and transversely oval in form. There are commonly three spines, two lateral and one in the centre of the upper margin; but not unfrequently the latter is replaced by two of smaller size.

Habitat. On the fronds of Laminaria and other weeds, on the under surface of stones between tidemarks, and on stones and shells from shallow and deep water.

Localities. Shetland, on Laminaria and stones, shallow water (A. M. N.) : Wick (C. W. P.) : coast of Ayrshire ; Arran; Cumbracs (Landsborough) : Lamlasb, abundant on Laminaria \&e; Oban (T: H.) : St. Andrews (Dr. M'Intosh) : off Sana Island; Antrim (Hyndman): Isle of Man, rarc; Cornwall (T. H.).

Geographical Distribution. Eminently a northern form. Greenland (Fabr.) *: Nova Zembla, 4-50 fms.; Kara Sea (Nordenskiöld) : Hammerfäst, 40-60 fathoms (Lovén): Spitzbergen, 3-30 fathoms (Smitt): Bergen, common on Laminaria (M. Sars): Labrador (A. S. Packard): Grand Manan, Bay of Fundy, deep water, incrusting shells \&c. (Stimpson): Gulf of St. Lawrence (Dawson).

Range in Time. Scotch Glacial deposits (Gcikic).

* "Habitat in fucis et ulvis minoribus, lepadibus et lapidibus marinis haud infrequens."--FABr., Fauna Gronlondica. 
The mode in which the zoœcium is developed in this species is interesting as throwing light on all similar structures, and on the affinitics of the genus to which it belongs. In its earlicst stage it cxhibits the simple Membraniporidan form-the area occupying the cntire front, and being closed by a membranous covering. The ribs, which compose the front wall in the adult, arc given off ou cach side as tubular processes from the edgc of the nasecnt cell, and, gradually lengthoning, meet in the centre and unite, the line of junction giving the subcarinatc appearance to the zoøcium. Thesc tubular girders, which are probably the equivalent of the marginal spines on many of the Membraniporce, are connected at intervals by lateral outgrowths of calcarcous matter; and in this way the porous structure of the furrows is produced. This mode of formation may be well studied in the thickened antcrior margin of the orifice, which is composed of two tubular pieces, the pointed cxtremities of which in meeting often bend outwards, and give rise to a central mucro. Sometimes they are not closely welded together, but overlap onc another, or remain partially separate so as to girc a bifid appearance to the mucro. Occasionally they do not unite at all, but continue permanently free and detached.

The cells of C. annulata are not so intimately united as those of most other species. "Aggregatæ (nec tamen connatæ)" Fabricius says of them. They lie side by side, but do not blend onc with the other. Fabricius describes them as occurring in a solitary condition in Greenland. The walls are formed of very solid substance; and when fresh they are smooth and lustrous.

The marginal spines are of two kinds : the lateral pair are tall, and jointed to a short tubular process; the hinder one is not jointed, but is a stout subeonieal outgrowth of 
the margin itself. The rib, which arches across the front of the ovicell, is composed of the two lateral spines.

This is a very attractive spccics. Fabricius, in his enthusiasm, could say of it, "Pulcherrima et perfectissima hæc omnium visarum." There arc certainly few that surpass it in beauty.

L. puncturata, S. Wood, of the Red Crag, is a nearly allied speeies, liaving much closer affinity with $C$. annulata than with $C$. punctata, with which Busk compares it.

Cribrilina figularis, Johnston.

Plate XXVI. figs. 5-7.

Lepralia figularis, Jolnnt. B. Z. ed. 2, 314, pl. 1vi. fig. 2 : Gray, B.M. Rad. 119 : Busk, B.M. Cat. ii. 80, pl. Ixxiii. figs. 1-3: Hincks, Deron \& Cornw. Cat. 44 (sep.).

Escharipora figularis (forma typica auctt.), Smitt, GEfv. K. Vet. Ak. Förh. 1867, Bihang, Krit. Fört. iv. 4. (Not Cribrilina figu laris, Smitt, Floridun Bryoz. pt. ii. 23, pl. v. figs. 111, 112.)

Zoccia ovate, large, sometimes pointed below, the upper portion of the front surface occupied by a raised oval area crossed by five or six ridgcs, which terminate at each sidc of the area in prominent papilla, usually perforated at the apex, the furrows betwcen the ridges minutcly punetured; walls of the cell bcyond the area smooth and shining; orifice subquadrangular, margin straight above, slightly curved and projecting below, unarmed. Avicularia of large size, elongate, with the mandible enlarged and rounded at the upper extremity, distributed over the colony amongst the zoøcia. Oocia globose, smooth, closcly united to the cell above, with a keel down the front, terminating above in a knob, and a pyriform fossa on each side.

Var. $\alpha$ (fissa). The furrows punctured towards the centre of the area, and towards the edgc of it traversed by a fissurc ; area small, not lobed round the margin.

Colonies forming large, irregulaily spreading erusts; the 
cells distinet to the oaked eyc. The young, marginal zoceia vitreous and glistening.

Ravge of Variation. A very beautiful clongate variety oceurs, in which the ridges number as many as cighteen. In some cases they are half obliterated, and the area presents a very flat appearanec. The avicularia are often absent. Thougl really a very striking feature of the species, they have not, I belicve, bcen noticed by any author, with the single execption of Heller.

I have met with a curious monstrosity, in which tlic area was so much reduced in size as only to occupy lcss than half the length of the cell.

The var. $a$ is from Singapore. The fissured surface of the arca gives it a very different appearance from the ordinary form; but it cxhibits no peculiarity that would warrant its ereetion into a species.

Habitat. Oceasionally at low-water mark, and on shells and stones from moderate depths to deep watcr (60 fathoms).

Localities. Cornwall, 30-60 fathoms; Gnernsey, abundant (T. H.) : Hastings (Miss Jelly) : coast of Antrim, deep water, rare (Hyndman) : Birterbuy Bay, Connemara (G. S. Brady).

Geograpilcal Distribution. Roscoff (Joliet) : Adriatic, not rare, on mussel-shells and Nullipores (Heller).

Range in Time. Lower Coralline Crag (A. Bell). The Escharella Arge, D'Orbigny, of the French Cretaceous deposits, is most nearly related to the present species, so far as the characters of the cell are eonecrned, but has an crect and apparently foliaccous mode of growth. The species described by Reuss under the name Lepralia Ungeri scems to be a connecting form between $C$. figularis and C. radiata. It is from the Austro-Hungarian Miocene deposits. L. Haneri from the same is most closely allicd to the present species, but has a sinus on the lower margin. 


\section{Cribrilina Gattrye, Busk.}

Plato XXV. fig. 10.

Lepealia Gattye, Busk, B.M. Cat, ii. 73, pl. 1xxxiii. fig. 6: Landsborough, Pop. Hist. B. Z. 326, pl. xviii. fig. 71.

Lepralia Steindacuneri, Heller, Bryoz. d. Adriat. Meer, 33, pl. ii. fig. 5.

Zocecia ovate, distinct, divided by deep sutures, produced and pointed below, very minute, quincuncial; in the centre a raised subcircular area, umbonate, with radiating lines, scalloped round the margin, a circle of punetures within the edge of the area, and another surrounding the umbo; rest of the eell smooth and glassy, sometimes with radiating striæ ; orifice semicircular, inferior margin straight, immediately under it three minute punctures, of which the eentral one is the largest; a vibraculum on each side a little:below it; marginal spines five, black or brown at the base.' Avicularia none. Ocecia globose, smooth and shining, minutely punctured; two spines showing in front of it.

Colonies originating in a small oval or subcireular cell, with membranous covering and about ten marginal spines, and forming small, silvery-white patches.

Var. a. Zoccia covered with radiating ridges; a sercenlike elevation placed transversely a little below the inferior margin. Occia ridged. The spines in this beautiful variety are dark-coloured both at the top and at the base.

Habitat. On Phyllophora rubens and other Alga, and on shells, from moderately deep water.

Localities. Sidmouth (Mrs. Gatty) : Jersey, on weed (Alder): Guernsey, on shell dredged off Fermain Bay (T. H.) : Hastings, normal, and var. $a$ (Miss Jelly).

Geographical Distribution. Adriatic (Heller).

This is the smallest of its tribe; and its minute size and delicate whiteness are eharacters that at onee attract the eye. It has a special liking for ${ }^{\circ}$ Phyllophora rubens, the 
bright smooth fronds of which are sometimes dotted over with its compact little pearly patehes, in company with the ubiquitous Microporella ciliata. In deeper water it is found on shells.

There is a graphic deseription of this species by its accomplished discoverer, the late Mrs. Gatty, in Dr. Landsborough's ' Popular History of British Zoophytes.'

\section{Genus MEMBRANIPORELLA (part.), Smilt.}

Der. Dim. of Membranipora, a genus of Polyzoa.

Berevices (part.), Fleming.

Lepralia (part.), Johnston and Gray: Busk : \&c.

MeMbrasipora (part.), Smitt.

Mrmbrantporelua (part.), Smitt, Floridan Bryoz. pt. ii. 10.

Gexeric Character.-Zohrium incrusting, or rising into free, foliaceous expansions, with a single layer of cells. Zowcis closed in front by a number of flattened calcareous ribs more or less consolidated.

Turs genus has been constituted for a group of forms (well represented by Lepralia nitida of authors) which may be regarded as intermediate between Membranipora and the Lepralia of Johuston. The passage of the one type into the other may be clearly traced in the history of the species just named. In its earlier condition Membraniporella nitida closely resembles one of the spiniferous Membraniporce. The front is completely elosed by a membranous roof; and the ribs of the adult state are represented by subereet spines set round the margin. As growth proceeds the spines bend inwards and inerease in size, and gradually take on the flattened, rib-like appearauce. After a time the opposite rows meet in the centre of the eell-area, and the extremities, which are often enlarged, are soldered together, so as to form a well-marked median line. In some instances the ribs also unite laterally 
to a great extent, and the front becomes almost a solid wall. In others they continue quite separate. The pair of ribs immediately below the aperture is often much thickened, so as to form a distinet margin. A similar course of development is met with in some of those forms in which the front wall of the cell is much more thoroughly consolidated. Under Cribrilina annulata I have described an analogous mode of growth. In this ease, the porous radiating furrows on the surface of the cell are the equivalents of the spaces between the ribs in such forms as M. nitida.

As representing a marked developmental stage, the present group appears well entitled to gencric rank.

Membraniporella is strictly a transitional form; but as its spines, in the adult condition, are so modificd as to form a front wall which rises above the margin and roofs in the area, its place would seem to be amongst the Cribrilinida. It will include, besides our British species, Lepralia sceletos, Busk, from Madeira, and Flustra Aragoi, Audouin.

\section{Membraniporella Nitida, Johnston,}

\section{Plate XXVII. figs. 1-8.}

Escharoides nitida, Milne-Edw. in Lamk. An. s. Vert. (ed. 2), ii. 259.

Berenicea sitida, Flem. Br. An. 533.

Le'ralia intrida, Johnst. Br. Zooph. ed. 2, 319, pl. Iv. fig. 11: Couch, Corn. Faun. iii. 114, pl. xxii. fig. 3: Busk, B.M. Cat. ii. 76, pl. Ixxvi. fig. 1: Hincks, Dev. Cat. 43 (sep.); Ann. N. H. ser. 3, ix. 203: Smitt, CEfvers. Vet. Akad. Förh. 1865, 32, pl. vi. fig. 1.

Mèmbisipora Nitida, Smitt, Krit. Fört., CEfv. \&c., 1867, no. 5, 366 and 401, pl. xx. figs. 50,51 .

Mrmbraxiporella Nitida, Smitt, Flor. Bryoz. pt. ii. 10.

Zoocia ovate, arched in front, disposed in lines, silvery and lustrous; front wall composed of a variable number of flattened ribs separated by larger or smaller inter- 
spaces, on each side (three to eleven or twelve, or even morc); mouth semicircular, frequently a mueronate proeess, immediately below it, at the top of the median line; oral spines 4-6: a raised avicularium at the base of many of the cells, or sometimes two; mandible acute, directed obliquely downwards. Oøcia subglobose, smooth or minutely granular, often of a pearly-white colour; an avicularium above it on each side, pointing upwards and outwards.

Primary zoccium broad, ovate; area closed in by a membrane; four tall erect spines at the top, and ten round the margin, slender, and bent inwards (Plate XXVII. fig. 6).

Polypides very delieate, bluish-white, with 14-16 tentacles. Colonies forming subcircular, shining patehes.

Range of Variation. The proportions of the cell and the number of the rib-like processes composing the front wall are liable to much variation. An elongated oval form from Deronshire has sometimes as many as twelve or thirteen of the latter on each side, placed closely together. This is the maximum; and in the same colony the number ranges from seven to thirteen on each side. Varieties, however, oecur in which it is reduced to four or even three; and in these cases the ribs are much broader and more widely separated than in the ordinary form.

In the Devonshire specimens* just referred to the cell is unusually long, and very regular and graceful in shape; the surface is also remarkably bright and silvery. In some cases a broader and flatter type is met with; and in others, again, the eell is contraeted above and expanded and well rounded off below. There are also differences in the degree in which the ribs are united and consolidated, and in the breadth of the central band or sternum.

* Dr. Landsborough speaks of rery beautiful specimens which he had obtained from Budleigh Salterton, "the whole fabric of which had a metallic appearance; the tiny ribe seemed made of stecl."-Pop. Hist. p. 318. 
The oral spincs are generally four in number; but five or six occur; the forcmost pair are often very tall and stout. When old the zoarium loses its metallic shcen, becomes of a dull whitc colour, and assumes a very skcleton-like appcarancc.

Habitat. On stones, shells, sponges, Algæ, Ascidians, \&c., betwcen tidc-marks and in shallow water chicfly; more rarely in deep water.

Localities. South Devon, common, on stones, sponge, \&c., between tidc-marks; on Eschara foliacea, from moderate depths (T. H.) : Tenby (F. Walker) : Cornwall (C. W. P.) : Guernsey (Dr. M'Intosh) : Isle of Man (E. Forbes) : Ayrshire (Landsb.) : the Minch; Shetland, tide-marks and shallow water (A. M. N.) : Berwick (Dr. Johnston): St. Andrews, abundant between tide-marks and in dcep water (Dr. M'Intosh) : Scarborough (Bean) : Wick and Peterhead, tide-marks and deep water (C. W. P.): entrance of Strangford Lough, deep water; Belfast Bay (W. T.).

Geographical Distribution. Roscoff, very common on stones and on Ascidia sanguinolenta, from shallow to deep water (Joliet) : Douarnenez, Finisterre (Fischcr) : Bohuslän, Algæ and Ascidians, in shallow water, 7-10 fathoms (Smitt)*: New Zealand (F. W. Hutton).

Membraniporella melolontin, Busk.

Plate XXVII. figs. 9, 10.

Lepra lia Melolontiu, Busk, B.M. Cat. ii. 78, pl. Irxxv. fig. 3: Landsb. Pop. Hist. B. Z. 319, pl. xviii. fig. 70.

Lepralia Nitida, rar., "branched in a fine dendritic manner like Alecto dilatans," Johnst. Br. Zooph. ed. 2, 319.

* Not found as yet in Finmark or Spitzbergen (Smitt). 
Zocecia ovate, produced below, distant, separated by a deep and wide groovc, disposed in linear scries; the central portion of the front wall composed of about eight flat ribs, closely contiguous, on each side, forming an oval figure, which is surrounded by a border of smooth cell-wall; mouth semicircular, a stout tubular process on each side, projecting like a tusk, and two slender spines above (often wanting); at the lower end of the cell, immediately under the ribbed portion, a conical process, inclined upwards. Avicularia none. Occia unknown.

Primary cell small, suborbicular, raised; surface smooth, solid; area occupying the whole upper part of the cell, with membranous covering; no spines. Two normal cells originate from the primary zocecium; and as growth proceeds the successive scries widen, so as to produce a somewhat fan-shaped figure.

Colonies spreading in dendritic fashion, with a tendency to rise into delicate free expansions.

Ravge of Variation. There is very little variability in this spccics as compared with the last. The number of ribs is pretty constant (six to eight). When young and fresh, the cells are hyaline and glistening; they become dense and opaque with age.

Habitat. On shells, especially on the oyster, at the mouths of rivers.

Localities. Estuary of the Thames (Lieut. Thomas): near the mouth of the Orwell, coast of Suffolk (Busk): East coast (Mrs. Gatty) : Roach River (Mr. Jeffreys)*.

- If Mrs. Gatty was right in identifying Dr. Johnston's dendritic variety of Lepralia nitida with the present species (and it is probable that she was), Kirkwall Bay must be added to the list of localitieg, on the authority of Lieut. Thomas. 


\section{Family XI.-Microporellidø.}

Celleporidx (part.), Johnston.

Membraniporide (part.), Busk.

Poniside (part.), 1'Orbigny.

Escirariporide (part.), Smitt.

Zocers adnate and incrusting, or forming erect and foliated or dendroill zoaria; orifice more or less semicircular, with the lower margin entire; a semilunate or circular pore on the front wall.

Tне Porinida of D'Orbigny inelude two types of form, which seem to be properly referable to separate groups. One is well represented by Lepralia ciliata auett., and the other by Porina borealis, Busk (= Quadricellaria gracilis, Sars). I have retained D'Orbigny's name for the latter.

\section{Genus MICROPORELLA, Hincks.}

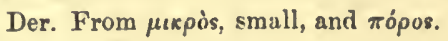

Esciura (part.), Pallas.

Cellepora (part.), Linn. : Audouin.

Flustra (part,), Audouin.

Berevicea (part.), Fleming.

Lepradia (part), Johnston, \&c.

Escinarisa (part.), M. Edwards: Gray.

Herentia (sp.), Gray.

Reptoporivi (part.), D’Orbigny, Pal. Franç. Terres Crét. v. 441.

Porisa, Smitt, Kritisk Förteckn.

Porelliva, Smitt (not D'Orbigny), Floridan Bryoz.

Microporells, Hincks, Ann. N. H. for Dec. 1877, 526.

ZOARIUM incrusting. ZOECIA with a semicircular aperture, the lower margin entire, and a semilunate or circular pore below it.

WE do not know the physiological import of the defi- 
nitely shaped opening in the front wall of the cell, which belongs to this genus. But the character, which is constant, may fairly be accounted of considerable importance, and, taken in combination with the form of the aperture, is a good diagnostic mark.

Milne-Edwards lias suggested that the pores may be connected with the function of respiration. In his account of Eschara gracilis, Lamk.* (a species probably referable to the next family), he cxpresscs his belicf that the surrounding water may find access through thesc openings to the perivisccral cavity, and so promote the oxygenization of the fluids. Whatever may be thought of this view, it is in the highest degree probable that these structures bear some not unimportant relation to the vital economy, and are fairly entitled to consideration in a natural system. In the large and vcry beautiful pore of M. Malusii (woodcut, fig. 8) the aperture is guarded by numcrous delicate tceth, which are set round its inner edge; through these the water in all probability finds its way to the interior of the cell. In this case the dentatc opening must act as a sieve or strainer, and prevent the cntrance of bodies that, from their size or otherwise, might be Fig. 8. a source of injury or inconvenience to the Median pore. polypidc.

D'Orbigny's Reptoporina includes the present group; but it also embraces a somewhat miscellancous assemblage of forms; and I lave thcrefore thought it bettcr (though most desirous to aroid additions to the nomenclaturc) to designate it by a new name. Lepralia bicristata, Busk (Capc Horn), and L. Californica, id., belong to this genus. The lattcr has an avicularium on cach

- 'Recherches anatomiques, physiologiques et zoologiques sur les Polypes' (1838): "Sur les Fechares," p. 30. 
side of the cell, but in general ehararter makes a near approach to $M$. ciliata.

The eommon but very beautiful Australian species, Lepralia diadema, MaeGillivray, is also a member of the present genus.

\section{a. With a semilunate pore.}

\section{Microporella ciliata, Pallas.}

Plate XXVIII. figs. 1-8.

Escilara ciliata, var. $\beta$, Pall. Elench. 38.

Celifepora ciliata, Linn. Syst. ed. 12, 1286.

Eschara vulgaris, var. $\beta$, Moll, Seerinde, 62 , pl. iii. f. 11.

?Berenicea utriculata, Flem. Br. An. 533.

Lepratia ciliata, Johnst. Br. Zooph. ed. 2, 323, pl. 1vii. figs. 4, 5 : Busk,

B.M. Cat. ii. 73, pl. lxxiv. figs. 1, 2, and pl. Ixxvii. figs. 3,

4, 5 ; Crag Pol. 42 , pl. vii. fig. 6.

Lepralia ingignis, Hass. Ann. N: H. vii. 368, pl. ix. fig. 5.

Flustra Gexisir, Aud. Expl. 239: Savigny, Egypte, pl. ix. fig. 5.

Escharina vulgaris (part.), Milne-Edw., Lamk. An. 8. Vert. (ed. 2), 231.

Reptoporellina subvulgaris, D'Orb. Pal. Franç. Terr. Crét. v. 477.

Lepralia personata, Busk, B.M. Cat. ii. 74, pl. xc. figs. 2, 3, 4 .

Lepralia lunata, Macgillivray, Trans. Phil. Inst. Victoria, iv. (1860), 159, pl. ii. fig. 6.

Celuepora crenilabris, Reuss, Foss. Polypar. Wien. Tertiärb. 88, pl. $x$. fig. 22.

Cellepora plevropora, Reuss, ibid. 86, pl. x. fig. 21 .

Porixa ciliata, Smitt, CEfv. K. Vet. Akad. Förh. 1867, Bihang 6 and 58, pl. xxiv. fig. 18.

Porellima cilicta, id. Floridan Bryoz. pt. ii. 26, pl. vi. figs. 126-129.

Lepralia vtriculus, Manzoni, Bryoz. Pliocen. Italian., Sitz. k. Akad. d. Wissensch. Bd. lix. 1. Abth. Jän.-Heft, 1869, 7, pl. ii. fig. 12*.

? Lepralia glabra, Reuss (smooth var.), Foss. Bryoz. österr.-ungarisch. Mioc. 17, pl. iv. fig. 3.

* Manzoni's fig. 1, plate ii. ('Supplement') is not referable to this species, but probably to the $F$. coronata, Audouin ( $=F$. umbracula, id.), which may be identical with Heller's $L$. appendiculata, and perhaps even with Busk's $L$. marsupiata, a Madeiran species. All thesc forms are certainly most closely allied. 
Zocecia ovatc, obscurcly six-sided, conrcx, separated by well-marked sutures, silvcry, and more or less distinctly punctatc, or whitc and granular, quincuncial, or disposed in radiating lines; orifice arehed above, with a slight rim, the lower margin straight, the upper with from five to seven long spines; median porc lunate, a little below the orifice, frequently borne on a prominent mucro, or sometimes almost hidden bchind it ; on onc side or the other a large avicularium, with acute mandible, directed obliquely upwards, which is often prolonged into a slender vibraculoid spine. Occia globosc, occasionally arcolated round the base, minutely punctate or granular; two spincs visible in front of it.

Var. personata. Oocium extended in front, so as to form a wall-like inclosure round the orifice (hooded).

The colonies originate in a small oval cell, with an aperture occupying the entire front, which is covered in by a membrane, and surrounded by numerous slender spines.

Range of Variation. This species shows a tendency to rariability in almost all portions of its structure, except the orifice of the cell, but may always be easily recognized by the semicircular mouth, the median pore, and the lateral avicularium. The texture and seulpture vary with habitat and age. The delicate form, with sheeny frosted surface, occurs principally on weed, betwecn tide-marks, or in shallow water. In deep-water specimens the cells are usually granulous, of denser substance, and a dull white colour. When old, they arc less convex, much thickened, and coarse in appcaranee.

Shape of cells : this is commonly pretty regularly ovate; but sometimes the figure is broad and six-sided. Arrangement: usually in quineunx, rarcly in radiating lincs. Size: cxtremely variable: speeimens oecur(PI. XXVIII. fig.4) in which they are fully a third smaller than in the ordinary 
form. Spines: variable in number, and often wanting altogether, especially in deep-water specimeus. In a remarkable Australian form thcy are dark-eoloured at the base, as in Cribrilina Gattya. Median pore: sometimes nearer to the lower margin of the orifiec, sometimes more remote; often elevated on a mucro or knob; in the hooded variety inelosed by the wall-like extension of the oøcium. Avicularium developed indifferently on either side of the cell, and rarely on both sides : mandible in many eases extended into a vibraeuloid process. Occium: simply globose or hooded, areolated or plain; sometimes with a prominent umbo on the front of it.

Habitat. On the red weeds (the delieate variety), stems of Laminaria, shells of limpet in rock-pools, stones and dead shells \&e., from between tide-marks to 300 fathoms.

Localities. Generally distributed round our coasts. Shetland, tide-marks to $90 \mathrm{fms}$. (A. M. N.) : off the Deadman, Cornwall, 60 fms. (T. H.) : Beaufort Dyke, 110-145 fms. (Capt. Beechey) : Belfast Bay (W. T.) : Dublin Bay (A. H. H.). Var. personata : Hastings (Miss Jelly) : Cornwall; Isle of Man (T. H.): Birterbuy Bay (Norman) : \&e.

Grographical Distribution. Cosmopolitan. Spitzbergen, 6-30 fms. (Lovén): Greenland (Lütken): Nova Zembla, 15 fms. (Nordenskiöld) : Bahusia, in deep water (Smitt): coast of Norway, $300 \mathrm{fms}$. (Sars): coast of Florida, 7-60 fms., hooded variety as well as the normal form (Pourtales): Roseoff, eommon, espeeially on Chondrus (Joliet): Naples, eommon, down to $40 \mathrm{fms}$. (A. W. Waters) : Adriatie (Heller) : Algiers (J. Y. J.) : East Falkland Islands, 4-10 fms., var. personata, Busk (Darwin) : Geelong; New Zealand, in Pectunculus (T. H.): Zanzibar; Aden; Arabian Sea, on weed, taken up in lat. about $15^{\circ} \mathrm{N}$, long. about $65^{\circ} \mathrm{E}$. (W. Oates) : attached to the Falmouth and Lisbon cable, between N. lat. $47^{\circ} 58^{\prime}$ 
and $47^{\circ} 35^{\prime}$, and in W. long. $7^{\circ} 6^{\prime}$, from 89-205 fms. (Sir James Andcrson) : France, S.W. (Fischer) : California (Miss Jclly)*: \&c.

Raxge in Trme. English Coralline Crag, on shcll (S. Wood): Middle Pliocenc beds (A. Bcll): Vicnna basin (Reuss) : Italian Pliocenc beds (Manzoni) : Sicilian Pliocenc, Bruccoli (A. W. Waters) : \&c.

This protean specics presents itsclf in many disguises, but is casily recognized amidst them all. Perhaps the characteristic features arc most completely rciled in the varicty with the hooded ovicell, in which the form of the mouth is not apparcnt, and the pore is sometimes concealed behind the wall which incloses the aperturc in front; but ercn in this case the lateral avicularium is a good diagnostic. The wall is often incomplete towards the centre (in some colonics it is always so), and a subcircular opcning is left, through which the pore may be detectcd.

Busk's Lepralia personata, from the Falkland Islands, is cvidently only a form of $M$. ciliata, the equivalent of our hooded varicty, although it has the pore outside instead of within the wall-likc extension of the ovicell.

The diversitics in size arc very striking. On the same shell, specimens may be met with in which the cells arc on a totally diffcrent scalc, ranging from cxtreme minuteness to the full normal dimensions.

In a varicty, which occurs in Australia as well as in

* In the Californian specimen, which I have seen, all the structural features are very pronounced. The wall of the cell is much calcified and thickly punctured; the pore is of unusual size, and the besutiful sieve-like structure very apparent. The oocium is large and with a prominent umbo in front; while the aricularia, which are much elevated, are developed in a great proportion of the cells on both sides. This may be the Lepralia Californica of Busk; but if so, it seems to me that this species must rank as a variety of the present form. In one or two instances I hare met with two a ricularia on a British specimen. 
our own seas, the vibraculoid mandible of the avieularium is exceclingly slender and delicate, and the oocium umbonate. In the Australian form, the base of the oral spines is black, a peculiarity which I lave not noted in British specimens. Another marked variety has the surface thickly covered with wcll-defincd granules, the avicularium very large, a prominent mucro bclow the mouth, concealing the median pore, and a prettily areolated ovicell. In an Algerian specimen, which incrusts a stem, frce expansions are given off, composed of two layers of cells placed back to back, and resembling a foliaceous Eschara of authors.

The form from the English Coralline Crag and the Italian Pliocene beds corresponds completely with the recent decp-water variety, distinguished by the thick granular wall of the cells.

But the most interesting variation to which this species is liable, is that which takes place in the avicularium. In some cascs, and especially in the thick-walled granular form, this organ exhibits the usual structure; in others, and chiefly in the more delicate varicties, the mandible is lengthened and attenuated, so as to take on a distinctly vibraculoid appearanec. - No alteration, however, takes place in the fixed, beak-like portion of the strueture; and the mandible is therefore incapable of any true vibracular function. The two conditions of the avicularium are sometimes met with in one and the same colony. We have here an indication of the way in which the avieularium may pass by gradual modification into the vibraculum.

The pore beneath the orificc is either dentate or filled in by a finc calcareous network (a beautiful strueture), which must effectually guard the cntrance to the intcrior of the ecll (woodcut, fig. 9).

Fig. 9.

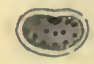

Pore (Californian var.). 


\section{Mieroporella Malusit, Audouin.}

Plate XXVIII. figs. 9-11; and Plate XXIX. fig. 12.

Cellepora Mlalusir, Aud. Expl. i. 239 : Savigny, Egypte, pl. viii. fig. 8.

Cellepora Macri, W. Thompson, Ann. N. H. x. 20.

Lepralia biforis, Johnst. B. Z. ed. 2, 314, pl. Iri. fig. 2.

Herestia biforis, Gray, B.M. Rad. 123.

Escilarisa corsuta, I’ Orb. Voyage dans l'Amér. mérid. (1839), 13, pl. v. Iigs. 13-16: id. (Reptoporina), Pal. Franç. T. O. v. 443.

Reptoporisa Malesir, id. Pal. Franç. Terr. Crét. v. 443.

Reptoporina hexagona, id. ibid. 444 (fide Fischer).

Lepralia Malusi, Busk, B.M. Cat. ii. 83, pl. ciii. figs. 1-4; Quart. Journ. Micr. Sc. viii. 125, pl. xxiv. fig. 1 ; Crag Pol. 53, pl. viii. fig. 3 : Heller, Bryoz. Adriat. Meer. 34 (not pl. ii. fig. 3): Manzoni, Suppl. Bryoz. Medit. 5, pl. ii. fig. 2 (Sitzb. k. Akad. d. Wissensch. Bd. Ixiii. 1ste Abth. Februar-Heft, 1871) (the stellate pores absent).

Lepralia tuyreoplora, Busk, Quart. Journ. Micr. Se. v. 172, pl. xr. figs. 4, 5. Porisa Mlalesir, Smitt, l. c. 5 \& 56, pl. xxir. figs. 11, 12.

Zocecia ovate or rhombic, often truneate at each extremity, convex, well-defined, disposed in radiating lines; surface smooth and silvery, more or less thickly eovered with stellate pores, especially round the sides and immediately below the orifice, the central space usually entire : orifice arched above, straight below, with three or four spines on the upper margin, the lowest of which on each side is oceasionally forked: median pore lunate, toothed, placed about halfway down the cell, often surrounded in great part by a raised border. Oœcia globular, smooth, or with indistinct radiating lines, sometimes poreellaneous, areolated round the base.

Primary cell* oval, the aperture occupying a large proportion of the front, with membranous covering and about ten short spines round the margin (woodcut, fig. 10); from this the normal zoceia radiate in all directions, spreading in somewhat cireular patehes (woodeut, fig. 11).

- Round the lower part of the cell there are four elongate-oral foramina, of which two are placed at the extremities and one on each side, a little below the top: they correspond with the gemme to which the zocecium gires origin. 
Var. a (thyreophora). Upper half of the zoœcia in frout occupied by a seutiform area, in the eentre of which is

Fig. 10.

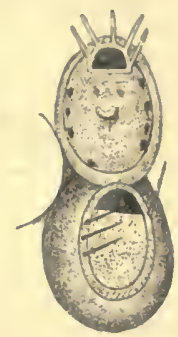

Primary cell.
Fig. 11.

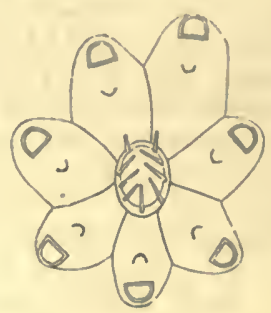

Centre of colony.

the lunate pore, and on either side a single row of punctures, which also extends across the front of the eell immediately below the mouth. (Busk.) (Pl. XLV. fig. 1.) Var. $\beta$ (vitrea). Zoccia glassy and transparent, and entircly destitute of the stellate pores. In this varicty the cells are unusually small, and the two anterior spines are forked.

Range of Variation. This is a much less variable species than the last. The stellate pores are oecasionally wanting altogether, and the walls of the eell are smooth and glassy. In some eases they form a single line along the sides, and a small group above the central pore; in others, again, they are more diffused, and the smooth, central spaec is proportionately redueed. In old specimens the walls are thickened, the surface is retieulated, and the median pore surrounded by an elevated border.

Oecasionally the two anterior spines are forked, a eharacter which is eonstant in some species. According to Busk, in all South-American specimens the eells are much larger than in the European form-a difference which is no doubt due to climatal influences. 
Lepralia thyreophora, Busk, is a very unimportant variation upon the normal M. Malusii. The inclosed "scutiform area," which is its prineipal feature, is due to a very slight eliange in the ordinary eonstitution of the cell. The raised line which bounds its anterior surface, and which is generally so far down as to be all but invisible, in the New-Zealand form is plaeed higher up on the front of the cell, where it is distinetly seen, inelosing a smooth area, and edged along its inner margin by a line of the stellate pores. The size of the area, however, varies greatly; and there is a marked tendeney to a return to the normal condition. I have noticed that in this variety the cells are much less elosely compacted together than in our British form; and to this in great measure, I think, is due the peculiarity just referred to. Apart from these points, the New-Zealand spceies agrees entircly with our own.

Habitar. On weed, shells, stones, \&e, from inshore to deep water (60 fathoms).

Localities. Widely distributed and abundant. Guernsey; South Deron; Cornwall, 60 fathoms; Isle of Man (T. H.) : Sidmouth, a transparent varicty on weed (Mrs. Gatty): Killinehy, co. Down; Roundstone (W. T.) : coast of Antrim, deep water (Hyndman): Northumberland, occasionally (Alder) : St. Andrews (Dr. M'Intosh) : Wick (C. W. P.) : Ayrshire (Landsborough) : the Minch; Shetland, tide-marks to 50 fathoms (A. M. N.) : Birterbuy Bay (G. S. Brady) : \&e.

Geographical Distribution. Gullmaren, Bahusia, 10-20 fathoms (Smitt) : Bergen (A. M. N.) : Finmark, rare (Lovén): Greenland (Lütken) : Mediterranean (Manzoni): Adriatie (Heller): France, south-west (Fiseher): Black Sea (Ulianin) : South Patagonia, 48 fathoms; Terra del Fuego; Falkland Islands (Darwin): Valparaiso, on shells of Venus thaca, very common (D'Orbigny) : New Zcaland 
(Dr. Lyall). Var. thyreophora:-Australia; New Zealand ('T. H.) : Mediterranean (A. W. Waters).

Raxge in 'l'me. Coralline Crag, on Terebratula (Bowerbank): Older Plioeene, Castroearo (Manzoni).

b. With a circular pore.

Microporella inpressa; Audouin.

Plate XXVI. figs. 9-11; and Plate XXIX. figs. 10, 11.

Flugrra impressa, Aud. Expl. (1826) i. 240: Savigny, Egypte, pl. x. fig. 7. ? Escilara bimucronata, Moll, Eschara \&c. 65, pl. ir. fig. 18 (=var. a).

Lepralia graxıfera, Johnst. Br. Z. ed. 2, 309, pl. liv. fig. 7 : Busk, B.M. Cat. ii. 83, pl. lxxrii. fig. 2, pl. xer. figs. $6,7$.

Lepralia pyriformis, $B u s k$, Crag. Pol. 51 , pl. v. fig. 3 (=var. $\gamma$ ).

Zoccia elongated, often lozenge-shaped, narrowed off to a point below, quineuncial, walls vitreous and glistening, thiekly eovered with raised punctures, or with a line of them round the margin; orifice arched above, straight below, with a narrow rim, unarmcd; median pore minutc, eireular, slightly dentate, placed a little below the orifice, sometimes a blunt umbo immediately behind it. Oæcia globose, punetured.

Polypides small, with about 15 tentacles.

Var. a (?bimucronata, Moll: var. cornuta, Busk). An ercet, conieal process on each side of the orifiee; sometimes an umbo on the upper part of the oceium in front.

Var. $\beta$ (glabra). Zoocia white and poreellaneous, flattish, transvcrsely rugose, punctures round the margin only, in a single line; rest of the surface smooth; an umbo below the median pore. Ocecia with a very prominent keel down the centre, terminating above in a large umbo, with a line of punctures round the base and a few scattered over the surface.

Var. $\gamma$ (pyriformis, Busk). Zoncia destitute of the median pore. 
Ravae of Varition. The eclls vary slightly in form, being sometimes rather irregularly ovate, and at others of a very neat and definite diamond- or lozenge-shape. The punctures are diffused over the surface, or merely ranged in a single line round the edge of the eell. The umbo is occasionally wanting, and at times is of great size and fantastic form. The oœcium is either simply globose and punctured, or kecled down the front and umbonate.

Habitat. On weed, stones, and sliells, from tide-marks to deep water (30-40 fathoms). Chiefly a littoral form.

Localities. South Devon; Ilfracombe, under ledges on the Capstone ; off the Deadman, Cornwall ; Isle of Man (T. H.) : Bamborough, tide-marks (Alder) : Holy Island and Berwick (Johnston): St. Andrews, near low-water mark (Dr. M'Intosh) : Ayrshire (Landsborough): Shetland, tide-marks (Norman) : island of Stroma (C. W. P.) : Ireland (Mrs. Gatty). Var. cornuta:-Lambay Island (W. T.) : Salcombe Bay; Guernsey, on red weed (T. H.).

Geographical Distribution. Algiers (J.Y.J.) : France, S.W. (Fischer): Roscoff (Jolict) : Bergen (A. M. N.). Var. $\boldsymbol{~ u . ~ N a p l e s ~ ( W a t e r s ) . ~}$

There can be no doubt of the identity of $L$. granifera, Johnston, with the Flustra impressa* of Audouin; and the more familiar name must gire place to the earlier. The figure in Savigny's work represents our var. $\beta$ (glabra) with great fidelity.

The Crag form, Lepralia pyriformis, Busk, agrees exactly with the present in every point but the absence of the median pore; it ought, I think, to rank as a varicty. The diffusion of the punctures over the entire surface of the cell is not, as Mr. Busk supposes, uneommon in our M. impressa.

This is a very brilliant species-in its young and fresh

- The Eschara impressa of Moll is a Steganoporella. 
condition, the vitrcous and hyaline eells literally glittering on the red weed, which it speeially loves. "It is so glassy in its texture," writes Mrs. Gatty, "that the colour of the red Phyllophora ean be distinguished through the eell." The punetures, which are surrounded by a white ring, slow very prettily on the elear and glistening surfaee. When the polypides are living, their delieate bells have the appearanee of a bluish mist over the hyaline and speckled erust.

Microporella violacea, Johnston.

Plate XXX. figs. 1-4.

Lepralia violacea, Johnst. Br. Zooph. ed. 2, 325, pl. Ivii. fig. 9: Busk, B.M. Cat. ii. 69, pl. Ixxxvii. figs. 1, 2; Crag Pol. 43, pl. iv. fig. 3 : Manzoni, Bryoz. Plioc. Ital., 1st Contrib. 5, pl. i. fig. 9 (Sitzb. k. Akad. d. Wissensch. Bd. lix. 1. Abth. Jän.Heft, 1869).

Escrarelua violacea, Gray, Brit. Rad. 125.

Lepralia plagiopora, Busk, Crag Pol. 44, pl. iv. fig. 5.

Lepralia diversipora, Reuss, Foram. Anthozoa u. Bryoz. d. Deutsch. Septar. 60, pl. viii. fig. 3 .

Porina viouacea, Smitt, Floridan Bryoz. pt. ii. 30.

Porina plagiopora, $i d$. ibid.

Zocecia ovate or lozenge-shaped, surface roughened, frequently punctured or areolated round the border, and sometimes surrounded by a raised line; a rather deep depression in the eentre, within which there is a single cireular pore; orifice slightly arehed above, elongated transversely, the lower margin nearly straight; peristome somewhat thiekened and raised above; immediately below the inferior margin an avicularium, with an aeute mandible pointing upwards. Oxcia none.

Var. a. Zoccia flat below, much raised towards the orifice; the peristome much elevated behind the mouth, and projeeting like a pent-house; two pores in the eentral depression. Avicularium very long and slender; raised 
tubular pores scattered over the zoarium, gencrally one or two above the orificc.

Var. $\beta$ (plagiopora). The central avicularium very large, and turned obliquely to one side.

Colonies forming large, rather thick crusts, bright and glossy wlicn fresh, spreading irregularly, and of a dark purplish or cream colour.

Var. $a$ secms to be always of a light colour.

Ravge of Variation. The cells vary slightly in shape, being sometimes orate or subpyriform, and sometimes hexagonal or lozenge-shaped. They vary morc remarkably in size; and within the limits of one and the same eolony cells of the most different dimensions are found assoeiated (Plate XXX. fig. 4). They are frequently punctured round the margin, and the punctures are sometimes channelled. In young eells a number of narrow loop-like fissures or areolæe extend from the margin to the middle. These disappear with the progress of the caleification, which materially changes the appcarance, and destroys much of the beauty of the speeies. In some cases the punctures extend over a large portion of the surface. In certain states the walls are much thiekcned, and covered with large perforations, and prescnt a coarsely reticulate appearanee. In old specimens the cells are almost confluent, the zoarium is of a dcad white colour, flattish, of granular texture, and sometimes thiekly perforated. The avicularium is only represented by a foramen a little below the orifice.

In the eurious varicty $a$, the clevation of the cell towards the oral extremity is a very marked peculiarity; the avicularium is much more elongate than in the normal form, with a very slender mandible; the one eentral pore is replaced by a pair; and a new fcature makes its appearance in the raised tubules (? ariculiferous) which are dis- 
tributed over the zoarium. In this varicty too the surface is either smooth or minutcly granulated, like shagreen.

L. plagiopora, Busk, from the Crag, should probably be ranked as a varicty of the present specics. It differs from it in the sizc and oblique dircetion of the avicularium-points which taken by themsclves are of very small moment.

Smitt has suggested that if from any cause the avicularium wcre morc fully developed than usual, as not unfrequently happens in other specics, it might probably takc an oblique direction to obtain sufficient space.

In a beautiful specimen from the Crag (Plate XXX. fig. 4) each ccll is bounded by an inciscd line, within which is a low of numerous small punctures, which are occasionally channclled.

M. violacea is commonly of a dark purplish colour; but cream-coloured specimens not unfrequently occur. Heller remarks that the light-coloured form is pretty common in the Adriatic, but that he had only observed the dark violet varicty once.

Habirat. On shells, stones, Nullipores, \&c., gencrally in moderate depths.

Localities. Isle of Man (E. Forbes) : Cornwall (Pcach): Brixham, from the trawlers; Torbay; off the Dcadman; Gucrnscy (T. H.) : Birterbuy Bay (G. S. Brady).

Var. a. Guernsey, abundant (T. H.) : Hastings (Miss Jelly).

Geograpihical Distribution. Roscoff, extreme lowwater mark (Joliet): Algiers (J. Y. J.) : Adriatic, the light-coloured variety pretty common, the dark violet once on Nullipore (Heller): Gibraltar Bay (Landsborough): Mazatlan, on Murex and Byssoarca pacifica; Adclaide, a much thickened variety (T. H.) : west off Tortugas, in 35 fathoms (Pourtales): Charente-Inféricurc (Fischer). 
Var. $\beta$ (plagiopora). West off Tortugas, in 60 fathoms (Pourtales) : France, S.W. (Fischer).

Raxge in Trme. Italian Plioeene deposits, very abundant, forming very large eolonies of a dark-grey eolour (Manzoni) : Tertiary beds at Söllingen (Reuss) : Coralline Crag (S. Wood) : Middle Plioeene (=Coralline Crag and Red Crag, part) (A. Bell).

In the oldest and most worn eondition this species may be recognized by the eentral depression and pore, and the foramen which marks the position of the avieularium.

The Tertiary $L$. diversipor $a$ of Reuss is, I think, referable to $M$. violacea, the only point in which it seems to differ from the recent form being the shape of the eentral pore, which is described as ereseentic. In fossil speeimens the double pore of the var. $a$ might probably be represented by sueh a figure; but in any ease so slight a difference could hardly of itself be aceounted distinetive.

A eurious point in the history of $M$. violacea remains to be noticed. Seattered over the eolony, usually in small groups, eells of abnormal size are often to be met with, which are furnished with a narrow slit-like mouth, much extended transversely, and filled in by a corneous opereulum. These gigantic eells are about twice the size of the ordinary zoceia. They are ovate in form, and want the central depression; the pore, however, oceupies its usual position; and the avieularium is present, though re. dueed in size and separated by a space from the orifice. They are probably eells modified for the discharge of reproductive funetions. M. violacea is one of the species on which ovicells have not been notieed.

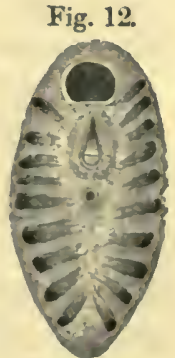

Young cell. 
Genus DIPORULA, Hincks.

Der. From dis, double, and $\pi \delta$ ós, an opening.

Esciara, part, auct.

Diponula, Hincks, Ann. N. II. Feb. 1879, 156.

Generic Character.-Zowein with the orifice arched and expanded above, contracted below, and slightly constricted by two lateral projections (horseshoe-shaped), lower margin straight; a semilunate pore on the front wall. Avicularia.

Distinguisined from Microporella by the structure of the orifice, which exhibits much the same type of form as we have in the genus Lepralia; and, so far as the British species is concerned, by its dendroid zoarium with cylindrical branches.

\section{Diporula verrucosa, Peach.}

\section{Plate XXXI. figs. 1, 2.}

Eschara verrucosa, Peach, Journ. Roy. Inst. Cornwall, iii. (1868-70), 116; figured in vol. iv. (1871-73), 88.

Escinara luxaris, Waters, 'Bryozoa from the Pliocene of Bruccoli (Sicily),' 11, fig. 9 .

Zoarium of a light brownish colour, dichotomously branched, the branches eylindrical, rather thick, of about equal size to the extremities. Zoæcia disposed in about seven longitudinal rows, quineuncial, ovate, slightly eonvex; the surface smooth in the young eells, and more or less pitted, a row of large punetures round the margin ; in the older portions of the zoarium the walls are much thickened, rugose, and eovered with wart-like prominenees, and the boundaries of the cells are obliterated; orifice somewhat raised, longer than broad, arehed above, slightly eonstrieted below the middle, the sides inclined inward, lower margin straight; the 
peristome thickened, especially round the upper part, and bearing usually five spines, of which the lowest on each side is larger than the rest; a minute pore a little below the inferior margin, and on one side a raised avicularium, with a produced vibraculoid mandible direeted outwards. Oxcia globose, fincly punetured.

Locality. Lantivet Bay, Cornwall (C. W. P.).

Geographical Distribution. Naples, 40 fms. (Waters). Range in Trme. Sicilian Plioecne (Waters).

Nothing is known of the size which this species attains, or of its mode of growth; but the fragment obtained by Mr. Peach shows it to be of a stout habit.

The characters of the cells ean best be recognized in those which are placed at the tips of the branches. There they are distinet, though only moderately convex, broadly ovate, almost smooth, and bordered by a row of rather large foramina. The surface is also usually more or less covered witl smaller punctures or "pit-like depressions." The pore is placed centrally at a very short distance below the inferior margin. The avicularium is developed indifferently on either side; it occupies the inner aspect of a large conical elevation, which rises a little below the aperture. The mandible is triangular below, and runs out above into a long spinous process, similar to that which occurs on Microporella ciliata.

There is a little variation in the shape of the orifice; the sides are sometimes rather straighter than is usual, and the constriction below is not quite so strongly marked. In such eases there is less disproportion between the breadth above and below. In the typieal form the orifiee expands above, and is decidedly contracted by two latcral projections a little above the lower margin, where the wilth is only about lialf as great as at the top. 
A remarkable change is produced in the appearance of the zoarium by the progress of the calcification. At a very short distance from the top of the branches the boundaries of the eclls and many of their charactcristic features are sometimes obliterated by the enormous overgrowth of calcarcous matter; the whole surface, with the execption of a small space below the orifice, is overlaid with a thick crust, which rises into numerous wart-like promincnees, and is traversed by irregular grooves, and presents, even to the naked eyc, a strikingly rugose appearance. In the older portions little but the orifice is visible of the original cell; even the avicularium is almost buricd beneath the stony envelope. In this condition the species well deserves the name which Mr. Peach has given it.

\section{Genus CHORIZOPORA.}

Der. From $\chi \omega{ }^{\prime} i{ }_{\omega}$, to separate, and $\pi$ ópos, a passage or opening.

Flostra (sp.), Audouin.

Lepralia (sp.), Johnston: Busk: \&c.

Mollia (part.), D’Orbigny.

Generic Character.-Zoecia more or less distant, connected by a tubular network; the orifice semicircular, with the inferior margin entire; the special pore wanting.

Tuis genus agrees with Microporella in having a semicireular orifice with the lower lip straight and entirc, but differs from it and the rest of the family in being destitute of the special pore on the front wall. In other respects it is peculiar. The cells are separated from onc another, but arc connceted at intervals by tubular extensions of the wall (Plate XXXII. fig. 4). In our British form the tubes sometimes pass imme- 
diately from eell to eell; and the zoccia have then the appearanee of being surrounded by a single line of punetures; in other eases a number of tubereles are interposed between the eells, which are conneeted with one another and with the neighbouring zoceia by tubular bands; and in this way a reticulated erust is formed, which is often of eonsiderable extent. The tubereles, which are really modified cells, are sometimes merely perforated at the top; but they frequently bear avicularia : one of them is always plaeed (in C. Brongniartii) at the upper extremity of the zoceium, or on the summit of the ovicell, when present.

The only speeies, I believe, which is referable to this genus is the Flustra Brongniartii of Audouin. Its affinities are somewhat obseure; but the simple semieireular orifiee allies it to the present family, while the absenee of the speeial pore and the peeuliar eondition of the zoarium seem to entitle it to a separate place.

The mode in whieh the cells are developed in C. Brongniartii, though by no means unique, differs from that which is prevalent in this seetion of the Polyzoa. In the inerusting forms, massed together under the old genus Lepralia, we usually find that the nascent eells on the edge of the colony are sketehed out to begin with; they are outlined in full; the foundations of the whole strueture are first laid, and on these the walls are gradually built up. But in C. Brongniartii (and some other forms) the eell grows upwards from the base, each seetion of it is eompleted at onee; there is no ground-plan of the whole. Inerease takes place along the free upper extremity; and the suceessive inerements are marked by transverse strix on the surface.

The same mode of growth occurs in Schizoporella hyalina. 
Cirorizopora Brongniarti, Audouin.

Plate XXXII. figs. 1-4.

Fuustra Broxgriarti, Audouin, Expl. i. 240: Savigny, Egypte, Pol. pl. x. fig. 6.

Lepralia tesurs, Hassall, Ann. X. II. ix. (1842), 412 : Johnst. B. Z. ed. 2, 303, pl. liv. fig. 2.

Lepralia Assimitis, Johnst. B. Z. ed. 2, 304.

Lepralia Jacotixi, Gray, B.M. Rad. 117.

Leprahia Brongniartir, Busk, B.M. Cat. ii. 65, pl. lxxxi. figg. 1-5; Crag Pol. 46, pl. vi. fig. 1 : Heller, Bryoz. d. Adriat. Meer. 25 : Manzoni, Bryoz. foss. Ital. 2nd Contr. 7, pl. ii. fig. 9 (Sitzb. k. Akad. d. Wissensch. Bd. lix. 1. Abth. April-Heft, 1869). Moldia tuberculata, $D^{\prime}$ Orb. Pal. Franç. Terr. Crét. v. 388.

Mollia Brovgniartir, $i d$. 1. c.

? REPTESCIARINELLA RHOMBOIDALIS, id. 1. c. 429.

Lepraira Capitata, Reuss, Bryoz. d. österr.-ungar. Miocäns, 21, pl.iv. fig. 7.

Zoceia ovate-elongate, somewhat pyriform, distinet, separated by retieulated spaees or by a single row of interstitial punetures; surface smooth and silvery, or transversely furrowed; orifiee semieireular, with a thin, very slightly raised peristome, frequently a prominent muero a little below it; at the top of each eell a small avicularium with pointed mandible, direeted upwards. Ocecia prominent, smooth, subpyramidal, often with a kecl in front; a small avicularium on the summit.

Colonies forming large, often silvery erusts, with a lobed margin; frequently assuming a very definite figure.

Range of Variation. The degree in which the retieulated crust between the eells is developed varies greatly; and the general appearanee of the speeies is affeeted aeeordingly. In many eases the eells seem to lie elose together; but the conneeting tubes may be deteeted towards the margin of the eolony. Sometimes they are bordered by a single line of punetures; sometimes a rather wide interspaee separates them, filled in by a tubular network and a number of tubereles frequently bearing avieularia. The 
cells are usually elongate and pointed below ; but a shorter form oecurs, which is rounded off at the base. The texture of the eell-wall is generally very delicate and translueent, and the surface smooth and shining. In one variety, however, the cells are strongly furrowed transversely; they are also frequently traversed by delicate longitudinal strix. The mucro (which is sometimes wanting altogether) is often placed immediately below the inferior margin, rising above it, and projecting over the mouth. When thus plaeed it is expanded at the base, and tapers off to a sharp point above. It also oceurs lower down on the eell-wall, and is not unfrequently eentral. The keel on the front of the ovicell is often wanting.

Habitat. On shells, stones, Fucus, \&e., from shallow to deep water.

Localities. South Devon, very abundant; Ilfraeombe, on Laminaria; off the Deadman, 60 fathoms; Isle of Man (T. H.) : Tenby (F. Walker) : Hastings (Miss Jelly): Northumberland, rare; on a stone from deep water, Cullercoats (Alder): St. Andrews, on Laminaria-roots thrown ashore after storms, rather plentiful (Dr. M'Intosh): Ayrshire (Landsborough): off Sana Island (Hyndman): Shetland, 40-100 fathoms, frequent (A. M. N.) : Dublin Bay (Hassall): Birterbuy Bay (G. S. Brady) : \&e.

Geographical Distribution. Mediterranean (Busk) : Algiers (J. Y. J.) : Adriatic, on shells, not rare (Heller) : on the Falmonth-Lisbon cable, between N. lat. $47^{\circ} 58^{\prime}$ and $47^{\circ} 35^{\prime}$ and in W. long. $7^{\circ} 6^{\prime}$, from 89-205 fathoms (Sir J. Anderson): Roseoff (Joliet) : France, S.W. (Fiseher).

Raxge in 'Trme. Coralline Crag (Searles Wood): Pliocene deposits at Volterra and Castrocaro (Manzoni) : Austro-Hungarian Miocene (Reuss). 


\section{Family XII.-Porinidæ (part.), D'Orbigny.}

Membraxiporide (part.), Busk.

Eschariporida (part.), Smitt.

ZOARIUM incrusting, or erect and ramified. Zo๕CIA with a raised tubular or subtubular orifice, and frequently a special pore on the front wall.

Ir is difficult to determinc how far division and subdivision should be carricd in classification. The present family has many points of affinity with the preceding; and it may fairly be a question whether it is better to separatc the two on the ground of their differences, or to blend them for the sake of their agreement.

On the whole (though not without doubt) I am inclined to kecp them apart, taking the tubular prolongation of the cell above, with its terminal and usually orbicular orifice, as the chief characteristic of the present group; in the more typical forms we have also the spccial pore on the front wall*. Amongst the Microporellide the mouth of the cell is either semicircular or exhibits a modification of this form, the lower margin being always straight or nearly so. It is never elevated on a free tubular extension of the ccll-wall. In the prescnt family there is a certain indcfiniteness in the degrec in which the oral extremity of the zoccia is devcloped; but the adult cell is always more or less lageniform.

The special porcs amongst the Porinida scem to be of simple structure, and destitute of the protective contrivances which occur so commonly in those of the preceding family.

* In the aberrant genus Iajenipora it is wanting; but the zocecia are 80 essentially Porinidan that it naturally finds a place in this family. 
The genus Tubucellaria, D'Orbigny, must rank in the present group, with which it agrees entirely in the eharacter of the zoceium, though distinguished from the other members by its articulated zoarium.

\section{Genus PORINA, D’Orbigny.}

\section{Der. From жópos, an opening.}

Fiscuara (part.), auctt.

Bidistopora (part.), D’Orbigny.

Pustulipora (part.), M. Sars.

Lerkalia (part.), Busk.

Porisa, D'Orbigny, Pal. Franç. 1851 (not Smitt).

Oxculopora (part.), Busk.

Quadricellaria, Sars (not D’Orbigny).

Axarthropora (part.), Smitt.

Tessaradoma (sp.), Norman.

Crlisproporelua (sp.), Hincks.

Geseric Character.-Zooscia tubular or subtubular above, with a terminal circular orifice; a median pore on the front wall. Zosrium (in the British species) incrusting, or erect and ramose.

As employed by D'Orbigny, the name Porina is restrieted to species with ereet and branehed zoaria, such as our $P$. borealis; but if the difference in habit between it and $P$. tubulosa is not regarded as generie, we may very properly give it a wider applieation, and make it eover the larger group. This is the more allowable, as there is no other available name which would be appropriate under the eircumstances.

Porina borealis was originally deseribed by Sars as a Pustulipora. Subsequently (1863) lie trausferred it to the Cheilostomata, to which it properly belongs, and founded for its reeption a new genus, Quadricellaria. 
This name, lowever, had been previously (1850) appropriated by D'Orbigny, and could not stand. In the meanwhile Busk, having only a fragment to deal witl, had made it an Onchopora. It then found a home in the Anarthropora of Smitt, from which, however, it was subsequently dislodged by Norman as an alien, and lie proposed for it the genus Tessaradoma. I most. reluetantly disturb it onee more; but, as I ean find no essential distinetion between the Tessaradoma of Norman and the Porina of D'Orbigny, founded as early as 1851, I have no eloiee but to refer it to the latter. Now that incrusting species are admitted to the genus, Norman's name would, in any ease, be elearly inapplicable.

The British form, indeed, has fewer rows of cells than the species deseribed in the 'Paléontologie;' but their' mere number is a matter of no systematic importance; the differenee between four and six or eight eannot reasonably be made one of the eriteria of a genus. The point has no struetural significance. In all essential particulars Tessaradoma and Porina are identical.

Unfortunately the change in the generie designation involves the displaeement of Sars's speeifie name for the British form, as the Eschara gracilis, Lamk., is a Porina. It becomes necessary, therefore, to adopt in its stead Busk's name borealis, though it seems hardly right that the diseoverer of the species and the first to deseribe it should have no direet part in it. I should gladly eonneet his name with it did the laws of scientific nomenelature permit.

As to the union of $P$. tubulosa and $P$. borealis in one genus, the cells of the two agree in all essential points; and, as I liave already urged, there seems to be no suffieient reason for ereating genera merely to represent such differences of habit as they exhibit. 


\section{a. Zoarium erect, ramose.}

\section{Porina borealis, Busk.} Plate XXXI. figs. $4-6$.

Pustultpora gracilis, Sars, Reise i Lofot. og Finm. (1850), 26.

Oschopora Boreals, Busk, Quart. Journ. Micr. Sc. viii. (1860), 213, pl. xxviii. figs. 6, 7 .

Quadricellaria gracilis, Sars, Beskr. Norske Polyz. (1863), 15 : Alder, Quart. Journ. Mficr. Sc. (n. 8.) iv. (1864), 101, pl. ii. figs. 9-12.

Anartiropora borealis, Smitt, Gefvers. K. Vet.-Ak. Förh. 1867, Bihang, 8 and 67, pl. xrir. figs. 25-29.

Trssaradoma gracile, Norman, Shetland Polyz., Rep. B. A. 1868, 309. Tessaradova burzale, Smitt, Flor. Bryoz. pt. ii. 32 , pl. vi. figs. 1, 3,4,5.

Zoarium white, slender, much branched dichotomously; branches cylindrical, tapcring somewhat towards the extremity. Zocecia disposed in four longitudinal series, ovate, slightly convex, separated by indistinct lines, with a row of channelled porcs round the margin, and traversed longitudinally by delicate undulating furrows; orificc orbicular, somctimes bilabiate, subtubular; median pore placed some way (usually about one third thic length of the cell) below the aperture. Avicularia small, circular, somewhat raised, usually one on each side, a little below the apcrture, and occasionally others in the line of the punctures. Oxcia terminal, slightly raised, transversely elliptical, with a striated surface.

Polypide with 18-20 tentacles.

Height of specimens about 1 inch, occasionally nearly 2 inches.

Habitat. On stems of Tubularia indivisa and Sertularia, Sic., from decp water.

Locality. Shetland (Barlee); ibid., rather local, but not rare on the Outer Haaf (A. M. N.)

Geograpuical Distribution. Near Bergen, 30-40 fathoms, on rocky ground; Christiansund; Bejau, mouth of the Trondhjems fjord; Lofoten; Finmark (M. Sars) : 
Bahusia, at great depths, rare (Lovén) : between Norway and Spitzbergen, $77^{\circ} 5^{\prime}$ N. lat., $10^{\circ} 5^{\prime}$ E. long., in 600 fathoms, muddy ground (Dr. Chydenius, Swed. Exped.) : Bohuslän, 120-130 fathoms (Olsson) : Florida, 82-450 fathoms, abundant; off Portugal; Azores (Smitt).

This speeies varies in the habit of growth, the branches being in some eases (as Sars has remarked) ereet and eompaet, whilst in others they spread out horizontally and on all sides. The eells are ranged in four longitudinal rows, alternating regularly with eaeh other, so that the opposite eells are on the same level. The avieularia are somewhat irregular both in number and position; besides those which have been mentioned, there is oceasionally one of larger size and mueh raised on the front wall. Exeept in the younger portions of the eolony, the zoceia are not usually well defined; as ealeifieation proeeeds, their boundaries are almost obliterated, and the zoarium presents a uniform surfaee, traversed eontinuously by the undulating furrows, which wind round and inelose the pores and avieularia.

\section{b. Zoarium incrusting.}

\section{Porina tubulosa, Norman.}

Plate XXXII. figs. 6-9.

Lepralia tubulosa, Norman, Shetland Pol., Rep. B. A. 1868, 308: Hincks, on Arctic Polyzoa, Ann. N. H. January 1877, 101, pl. xi. fig. 8 (see also Ann. N. H. July 1877).

Axarturopora moxodox, forma minuscula, Smitt, Eff. af Köngl. Vet.Akad. Förh. 1867, Bihang, Krit. Förteckn. iv. 7 \& 65, pl. xxiv. figs. 20-22.

Cylindroporella tubulosa, Hincks, Ann. N. H. Dec. 1877, 528.

Zoccia separated by very shallow sutures and disposed in regular linear series, ovate and somewhat depressed 
below, smooth, punetured with small stellate pores; above, produeed into a long, tubular neek, which stands erect, surface entirc, with a circular orifiee and thin peristome, which is armed in the young state with two or four spines; on the lower part of the neck a large projecting tubular pore. Oœcia arcuate, shallow, set very far back behind the tubular peristome, smooth, with a few perforations.

Range of Variation. The cylindrieal prolongation of the cell varies considerably in length. This is partly dependent upon age; and in marginal eclls the erect portion and the pore, which is placed upon it, are wanting altogether. Apart from this, however, colonies differ very much in the degree in which the neek is developed. In speeimens from Greenland and the Gulf of St. Lawrence it is a much less striking feature than in British examples.

Habitat. On stones, shells, Algæ, \&e., from the littoral region to deep water.

Localities. Shetland; " on a stone dredged in a few fathoms water at Hillswick" (A. M. N.) : Wick, between tide-marks (C. W. P.).

Geographical Distribution. Spitzbergen, not com. mon, on Algæ, Ascidians, shells, from the littoral region to 30-50 fathoms (Smitt) : off Frederickshaab, Davis Straits, 100 fathoms (Wallich): off Bear Island (Duteh Arctic Exped.) : Gulf of St. Lawrenee (Dr. Dawson).

Range in Trme. Scoteh Glacial deposits (Geikie): Palæolithic (A. Bell).

In this well-marked form the oral spines are eommonly wanting, and are only to be met with on the edge of the colony. The ovieell is placed very far back; and the cylindrical portion of the cell rises in front of it. The pore is situated at the base of the neek, close to the june- 
tion between it and the depressed body of the eell. Avicularia are wholly wanting*.

\section{Genus ANARTHROPORA (part.), Smitt.}

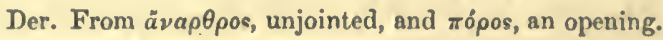

Ijepralia (part.), Busk.

Generic Character.-Zocecia with the oral extremity slightly produced and free, subtubular; orifice terminal, semicircular; an avicularian pore on the elevated portion of the cell in front; special pore wanting. ZOARIUM (in the British species) adnate.

Surte has united $A$. monodon with the two species of Porina in one genus. But the more I have examined the former, the less I have been inclined to adopt this eourse. It scems to exhibit points of divergence from the lattcr forms, which make it eonvenient to mark it off by a separate generie designation. We are not, of course, to understand by genera hardly-defined isolated provinees : such, indeed, it would be diffieult to find. They mercly represent pliases or modifications, more or less marked, of the family type, and are set apart to indieate in a striking way its ehief morphological variations. In framing them we do not look for hard-and-fast lines: they just as often suggest affinities as mark differenees; they are simply landmarks in the morphologieal history of a tribe. The present form seems to me to have quite cnough individuality to separate it from Porina.

The orifice in $A$. monodon is semieireular, instead of orbicular as in the latter. The shape indeed is affected

* Smitt, incleed, has figured a specimen with a vicularia, obtained by Pourtales of the coaste of Floricla (Flor. Bryoz. pt. ii. pl. vi. fig. 141), which he refers to this forn; but I have little doubt that it is really a young colony of Anarthropora monodon. 
by the thickening of the peristome, and is somewhat irregular in adult cells; but in its primary condition it is arehed above and straight below. The special pore is absent; the opening which usually cxists on the front of the elevated portion of the cell is merely avicularian, and is in no sense the equivalent of the raised tubular pore of the Porine.

Anartiropora MoNodoi, Busk.

Plate XXXIII. figs. 10, 11.

LfePral14 yoNodoN, Busk, Quart. Journ. Alicr. Sc. vii. 213, pl. xxix, figs. 3, 4: Norman, Shetland Pol., Rep. B. A. 1868, 308.

Asarturopora yosodos, forma yajuscula, Smitt, Gefrers. \&c, 1867, Bihang, 7 and 64, pl. xxiv. figs. 23, 24 (not figs. 20-22): Hincks (A. monodon), Ann. N. H. Dec. 1877, 528.

Asarturopora suxesclu (part.), Smitt, Flor. Bryoz. pt. ii. pl. ri. fig. 141.

Zoccia ovate below, somewhat depressed, aborc suberect, produced into a short neck; surface (in the adult state) reticulato-punctate, covered with stellate perforations; occasionally radiating ridges round the border; orifice (primarily) arched above, with the lower margin almost straight, often much contracted in the older cells; peristome much thickened, without spines; a circular hole in front, immediately below the inferior margin, placed centrally or at one side, which is frequently covered by an avicularium, with an acutc mandible, directed obliquely upwards; on the upper margin also an avicularium, or, in its absence, a small circular pore. Occia unknown.

Colonies with a somewhat branching or dendritic habit of growth.

RANGE OP VARIATION. In young cells the surface is smooth and polished, and wants the rather coarse reticulated covering which characterizes the adult. In this condition the punetures are rery distinct, and show their beauti- 
fully stcllate character. Calcification is carried to a great extent in this species; and the walls bccome very thick and solid, and rather coarse in appearance, as we might expect in a decp-water form. It is often difficult to determine the nature of the pore on the front of the neek-like prolongation of the cell. In the older zoceia it is usually a simple eireular opening of rather large size; but in the younger it shows its true character, and is covered by a pointed avieularium. The smaller pore on the upper margin, which is sometimes very conspicuous, is also avicularian; but the appendage itself is very generally wanting; when present, its mandible is directed downwards.

There is considerable variability in the shape of the orifice, which secms to be chiefly due to the thickening of the peristome with age.

Habitat. On stones, shells, Gorgonia, \&c., from deep water.

Locality. Shetland, on shell (Barlee) : ibid., common in 80-170 fathoms (A. M. N.).

Geographical Distribution. North Sea, off Norway, on Gorgonice and stones from 200-300 fathoms (Baron Uggla): W. off Tortugas (Pourtales).

In $A$. monodon the zoœeia are distinet, but separated by shallow sutures, and very slightly convex, so that the zoarium has a flattish appearance. The stellate character of the punctures with which they are thickly covered, is hardly apparent except in young specimens. The oral cxtremity is slightly turned uprards; and the mouth is girt about with a massive peristome : the pore in the centre of the upper margin is the "tooth" which suggested the specific name.

At the base of the cells there is a row of circular openings. 
Genus LAGENIPORA, Hincks.

Der. From lagena, a fask.

Generic Character.-Colonies consisting of a number of cells immersed in a common calcareous crust. Zoccia decumbent, contiguous, lageniform; oral extremity free, tubular, with a terminal orbicular orifice.

Tre leading characteristic of this genus is the common calcareous crust, in which the cells composing the colony are more or less immersed. The zoarium is not a mere congeries of eells, laid side by side in a certain order, but consists of a calcareous matrix, in which a number of zoœcia are imbedded, and by which they are united into one commonwealth. The cells themselves bear a close resemblance to those of Porina tubulosa, but are destitute of the large tubular pore on the front wall, which is so striking a character of the latter form.

Lagenipora socialis, Hineks.

Plate XXXIV. figs. 7, 8.

Lacesipora social1s, Hincks, Ann. N. H. for September 1877, 215.

Crust whitish, granulated, of irregular figure. Zoocia flask-shaped, the lower part immersed, the upper part (in adult eells) produced into an erect tubular neek; orifice eireular, terminal, frequently with a number of spinous processes on the upper margin; surface granular, exeept on the ereet portion, where it is smooth. Oxcia small, rounded, smooth, set far back behind the tubular neek of the eell.

Colonies forming small, rather thick white crusts. 
Habitat. On shells of Pecten maximus.

Localıty. Hastings (Miss Jelly).

The eells are irrcgularly disposed; but there is a tendeney to a radiate arrangement around the eentral part of the eolony. The crust varies much in form. In one speeimen which eame under my observation the eolony consisted of threc or four parallel rows of immersed eells, whieh are eonnected at intervals by erust and cclls, so as to form an anastomosing strueture. Probably as growth proceeded this would have been filled in and become a eontinuous expansion, whieh is the usual condition of the erust. In young eells the erect tubular portion is wanting, and the peristome is very slightly raised. In the adult the marginal spines arc eommonly absent, and when they occur seem to be irregularly developed. Sometimes therc are two small spines in the eentre of the upper margin, and on each side a spinous proeess (projeetion of the peristome). The peristome is somewhat everted. Round the base of the cell there are sometimes a number of indistinet punctures. The ovieell is plaeed at the baek of the tubular neck below the aperture, and is very inconspicuous.

This interesting species has only been found, so far, on shells of the eommon scallop obtained from the Hastings fishermen.

Family XIII.-Myriozoidæ (part.), Smitt.

Celleporides (part.), Johnston.

Porisibe (part.), D’Orbigny.

Mímbraniporide (part.), Busk.

Mrriozoide (part.), Smitt, Kritisk Förteckn.

ZOARIUM incrusting, or rising into foliaceous expansions, 
or dendroid. Zowcia calcareous, destitute of a membranous area and raised margins; orifice with a sinus on the lower lip.

TuE oral sinus, as Smitt has remarked, is the representative of the median pore in the preeding family.

\section{Genus SCHIZOPORELLA, Hincks.}

Der. From $\sigma \chi i \zeta \omega, I$ divide, and mópos, an opening.

Lepralia (part.), Johnston : Busk : \&c.

Escharisa (part.), D’Orbigny.

Reptoporisa (part.), id.

Escharella, subgenus Herextia (part.), Smitt, Kritisk Förteckn.

Mollis, Smitt, ibid.

Hiprotnoa (part.), id. Floridan Bryozoa.

Generic Cimaracter.-Zoecia with a semicircular or suborbicular orifice, the inferior margin with a central simus. Avicularia usually lateral, sometimes median, with an acute, or rounded, or spatulate mandible; occasionally wanting. ZOARIUM (in the British species) incrusting, or (occasionally) forming foliaceous expansions.

I Regret that I eannot adopt Prof. Smitt's name for this group, which he was the first to define. But the Hippothoa of authors is not, in my judgment, superseded or merged in other genera; and the name must therefore be retained with its original applieation. I am not aware that there is any other existing designation which has any speeial elaim to the vaeant place, or, indeed, which eould be employed without the risk of ereating confusion. 
a. Avicularia with a pointed mundible, generally lateral.

\title{
Schizoporella Unicornis, Johnston.
}

\author{
Plate XXXV. figs. 1-5.
}

Berzacicea coccinea, Johnst. Trans. Newc. Soe. ii. 267, pl. xii. fig. 5.

Lepralia coccinea, Johnst. Br. Z. ed. 1, 278, pl. xxxiv, figs. 1-3.

Lepralia unicorsis, Johnst. Br. Z. ed. 2, 320, pl. lvii. fig. 1 : Busk, Quart. Journ. Mier. Sc. iv. 309, pl. x. figs. 3, 4; Crag Pol. 45, pl. v. fig. 4: Alder, North. Cat. 49: Hincks, Devon \& Cornw. Cat. 41 (sep.).

Lepralia spinifera (part.), Busk, B.M. Cat. 69, pl. lxxx. figs. 5-7, pl. xei. figs. 1, 2 : Heller, Bryoz. d. Adriat. Meer. 28 (vars. unicornis and serialis): Manzoni, var. unicornis, Bryoz. Plioe. Ital. prim. Contr. 7, pl. ii. fig. 11.

Lepralia ansata, Johnst. B. Z. ed. 2, 307, pl. liv. fig. 12: Busk, Crag Pol. 45, pl. vii. fig. 2: Hincks, Dev. \& Cornw. Cat., Ann. N. H. ser. 3, ix. 70: Reuss, Bryoz. österr.-ungar. Mioeäns, pt. i. 18, pl. vi. fig. 12 : Heller, Bryoz. Adr. Meer. 29 : Manzoni, Bryoz. foss. Ital. Contr. iii. 9, pl. ii. fig. 11.

? Escharisa Isabelleavi, D’Orb. 'Toyage' \&e., v. pt. 4, 12, pl. iv. figs. 13-16 (atlas in rol. ix.).

Lepralia tetragoxa, Reuss, Foss. Polyp. d. Wiener T. B. 78, pl. ix. fig. 19 (form unicornis): Manzoni, Bryoz. foss. Ital. Cuntr. iii. 8, pl. ii. fig. 10.

Lepralia ansata, var. tetragona, Reuss, Bryoz. d. österr,-ungar. Miocäns, pt. i. 19, pl. vii. figs. 1, 2; var. porosa, l. c. 18, pl. vi. fig. 13.

Reptoporina tetragona, D'Orb. Pal. Fr. Ter. Cr. v. 442.

Escinariva variabilis, Leidy, "Mar. Invert. Rhode Isl. \& New Jersey," Journ. Ae. N. Sc. Philadelph. ser. 2, iii. (1855-8), 142, pl. xi. fig. 37.

?Moldia vulgaris, forma assata, part., Smitt, 1. c. Krit. Fört. pt. iv. 15 \& 104, pl. xxr. fig. 80 .

Zoceia ovate or reetangular, distinet, separated by deep sutures, surface thickly punctured, often silvery, disposed in linear series; orifice semicircular, lower margin straight, with a well-marked central sinus, peristome not raised; a pointed muero of varying lengtl, a little below the orifice, and on each side of it (or on one) an avicularium, sometimes nearly on a level with the lower margin, the aeute mandible directed obliquely outwards, 
somctimes placed near the top of the ccll, and pointing straight upwards. Oøcia globosc, prominent, rather smooth in front, with groores radiating from the centre towards the base.

Polypides large, with a remarkably long œsophagus of a grecnish-yellow colour; tentacles 18, forming a very tall and graecful bell.

Form axsata. Zoopcia short, broad, and squarish, usually granular, and with a raised line round the border; mucro oftcn rudimentary. Oocia small, very elosely united to the cell above, indistinctly grooved.

Colonies forming large spreading crusts, often (in the littoral varicty) of a beautiful silvery whiteness.

RaNGE of VARiation. The forms which Johnston named Lepralia unicornis and $L$. ansata must be referred to onc spccies; there arc no characters of any importance separating the one from the other. L. ansata, as commonly understood, represents a deep-water condition of the species, distinguished by its short, broad zoœcia with dense and usually granulous walls and a somewhat flat surface, and by its small oviccll, on which, owing to the thickened and incrusted state of the zoarium, the peculiar sculpture is inconspicuous. All the essential characters are identical in the two forms. The shape of the zoœcium has been taken as the distinctive feature of $L$. ansata; but this is a most variablc character; and although there is no doubt a variety specially distinguished by its short, broad cells, yet this type of cell is commonly found along with the more elongated form on the same specimen.

In breadth and length, and in the proportion of breadth to leugth, the zoceia vary endlessly. They are found very broad and almost square, at times broader than long; reetangular, but elongate, sometimes much produced and very narrow; orate, and occasionally subglobose. No 
speeifie distinction can be founded on so unstable an element. As to sculpture, the puncta are generally absent on the deep-water form, being obliterated by the dense crust whieh involves the surfaee; but traees of them may almost always be met with on the young marginal eells.

The avieularia are sometimes present on both sides of the eell, frequently on one side only; and in many eases they are wanting altogether. They also vary slightly in position, as $I$ have pointed out in the diagnosis of the species. Besides the oral avicularia, there are oceasionally others, irregularly plaeed. Sometimes one is developed at the bottom of the eell, with the mandible pointing downwards or sideways; and I have seen one on each side of the muero, a little below the aperture. The species secms to be very liable to "sports." Oecasionally the surface, of the cell presents a very singular appearanee, being studded with umbonate processes of various shapes and sizes (Plate XXXI. fig. 4). The usual muero is now largely developed, so as to form a prominent spike, and now, espeeially in the deep-water variety, almost abortive.

I have also met with anotlıcr very remarkable lusus. On a speeimen from deep water, a eell has the ovieell developed below the mouth and reversed, so that the aperture faees towards the lower margin. In several instances, too, on the same speeimen, a second oviecll oceurs on the eell, at one side, so plaeed as to cover, or partially cover, one of the lateral avicularia. This monstrosity is of peeuliar interest, inasmuch as the growth of an ovieell immediately ahove and overarehing the avieularium is an indieation of the morplıological significanee of this strueture, as a modified zoœcium.

Ha ziтst. On rock and under stones and on Laminaria 
in the littoral region, and on stones, shells, \&e., from decp water.

IJOcalities. Very widely distributed.

Form unicornis. Guernsey; South Devon (one of the eommonest littoral species); Ilfracombe; Filey (T. H.) : Northumberland and Durham (Alder): St. Andrews (Dr. M'Intosh): Ayrshire (Landsb.): the Minch (A. M. N.): \&e.

Form ansata. Shetland, 40-170 fathoms, extremely abundant; the Minch (A. M. N.) : Antrim (Hyndman) : Hastings (Miss Jelly): Cornwall, 30-40 fms. (T. H.) : \&c.

Geograpincal Distribution. Form unicornis:-Adriatic (Heller): Naples (A. W. Waters): Gibraltar Bay (Landsb.): France, S.W. (Fiseher): North Ameriea (Leidy) : Durban, South Africa* (W. Oates). Form ansata:-Greenland ('Valorous' dredgings). Bergen, botll forms (A. M. N.).

Range in Time. Form unicornis:-Coralline Crag (S. Wood): Vienna Basin; Austro-Hungarian Mioeene (Reuss): Italian Pliocene (Manzoni): Seoteh Glacial deposits (Geikic) : Palæolithic (A. Bell). Form ansata :Coralline Crag (S. Wood) : Vienna Basin (Reuss): Ital. Pliocene (Manzoni) : Palæolithic (A. Bell).

Schizoporella spinifera, Jolinston.

Plate XXXV. figs. 6-8.

Leprala cilata, Hass. Ann. N. H. vi. 171, \& vii. 367, pl. ix. fig. 2 : Couch, Corn. Faun. iii. 118, pl. xrii. fig. 10.

* The South-African specimens are extremely beautiful. The surface of the zoarium is silvery and lustrous, and of the most remarkably delioate texture; the wall of the cells is reticulated, the punctures appearing as very deep perforations in a thick ritroous crust. The oricell is more or less punctured in addition to the usual sculpture, and the cells are very regular in form and arrangement. The specimens show rery plainly the influences of climate. 
Lepralia amiseza, Johnst. B. Z. ed. 2, 324, pl. Ivii. fig. 6: Busk (in part), B.M. Cat. 69, pl. Ixxri. figs. 2, 3: Hincks, Devon \& Cornw. Cat., Ann. N. H. ser. 3, ix. 201 (41 sep.).

Mollia vulgari8, forma spisirera, Smitt, OEfv. K. Vetensk.-Akad. Förh. 1867, Bihang, Krit. Fört. iv. 15 \& 103, pl, xxr. fig. 78.

Lepralia gpinipera, var. actleata, Heller, Bryoz. Adriat. Meer. 28.

Zocecia rhomboid, eonvex, smooth or slightly roughened, silvery, often indistinetly punetured; orifice ample, arehed above, lower margin straight, with a large rounded sinus in the eentre; peristome thin and not raised ; 5-7 large and stout oral spines; a little below the orifiee a eentral mamilla, to which a horn-eoloured spine is artieulated, and on one side of it a large, raised avicularium, pointing outwards, mandible mueh produced and very slender towards the extremity, projeeting beyond the beak. Oxcia prominent, subglobose, smooth and somewhat flattened in front, with ribs radiating towards the base.

Primary cell short, raised, the top oeeupied by a large oval aperture, with a membranous eovering, and about ten stout marginal spines (woodeut, fig. 13).

Fig. 13.

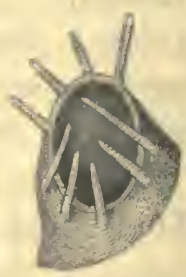

Primary cell.

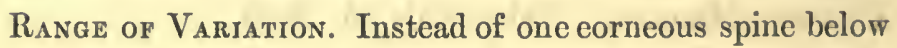
the aperture, there are sometimes two, elose to one another, and oecasionally as many as three or four ranged in a line aeross the eell.

The avieularium is always single, I bclieve, and is plaeed indifferently on either side. It is often absent.

There seems to be little variation in the form or size of the cells or in the general eharaeter of the zoarium, as we might naturally expeet, remembering the very limited bathymetrical range of the speeies.

Habitat. On stems and roots of Laminaria and otler weeds ehiefly, more rarely on stones, \&e., between tidemarks and in shallow water; oeeasionally from deep water. 
Localities. Shetland (A. M. N.) : St. Andrews, very common (Dr. M'Intosh) : Wick and Peterhead, on stones from deep water and between tide-marks (C. W. P.) : Lamlash; Llandudno; Isle of Man; South Deron; Ilfracombc (T. H.): Hastings (Miss Jelly): Dublin Bay (Hassall).

Geographical Distribution. Bahusia, on sea-weeds, not common, 10-12 fatloms (Smitt): Adriatic, rare, on stones (Heller).

Schizoporelia Alderi, Busk.

Plate XXXVI. figs. 9, $9 a, 10$.

Alysidota Aldent, Busk, Quart. Journ. Micr. Sc. ir. (1856), 311, pl. ix. figs. 6, 7 : Aorman, Shetland Pol., Rep. B. A. 1868, 306.

Lepralia Barlezi, Busk, Quart. Journ. Micr. Sc. vii. (1860), 143, pl. xiri. figs. 1, 2.

Mollia vulgaris, forma ansata, Hippothooid var., Smitt, $l$. $c$, Krit. Fört. iv. $15 \& 104$, pl. $x \times$ v. fig. 81 , (?) 79 .

Zocecia broad-orate, distinct, subgranular, sometimes punctured, glossy, irregularly massed together, or disposed in a single branching series; orifice arclied above, inferior margin straight, with a central notch; immcdiately bclow the mouth an umbo; occasionally a small avicularium with acute mandible, pointing obliqucly downwards, on one side a little below the mouth, rarely on both sides. Oøecia globose, promincut, smooth, usually with a central umbo.

Range or Variation. This species assumes two very distinct modes of growtl. The eclls are either massed together, so as to form a continuous crust, or they run out into chain-like linear scries, which send off branches in a dendritic fashion.

There is a striking contrast in habit between the two 
varietics; but the cell is identical in both*. The branches originate in pairs from the top of a ccll, diverging gradually as they lengthen.

The avicularium of this species has becn generally overlooked, but is figured by Smitt. It is very sparingly developed. When it occurs, it is usually single; but occasionally there is onc on each side of the cell. Beyond the superficial differences, dependent principally on age, there is no further variation in S. Alderi that requires any special notice.

There is a row of large punctures round the base of the zoœcium.

Habitat. On stones, shclls, \&c., from deep water.

Locality. Shetland, common, 50-170 fms. (A. M. N.).

Geographical Distribution. Hammerfest, 40-60 fathoms (Lovén) : Bergen (A. M. N.) : Southcrn Norway, on Astarte (Dr. Boeck).

Schizoporella vUlgaris, Moll.

Plate XXXVII. fig. 7, and Plate XV. figs. 5, 6.

Eschara vuraakis, Moll, Seerinde, 55, pl. iii. fig. 10.

Escharixa vulgaris, Lamk. An. s. V. ed. 2, ii. 231 (excl. syn. E. Dutertrei). Cellepora vulaaris, Lamx. Pol. Cor. flex. 94.

Lepralia velgaris, Busk, Quart. Journ. Micr. Sc. vi. 127, pl. xviii. fig. 3 : Hincks, Devon \& Cornw. Cat. 43 (sep.); Ann. Nat. Hist. ser. 3, ix. 203.

Lepralia Alba, Hincks, Quart. Journ. Micr. Sc. niii. 275, pl. xxx. figs. $2,2 a$. Cellepora otophora, Reuss, Polyp. d. Wiener Tertiürbeckens, 90, pl. xi. fig. 1.

Leprali оторнова, id. Sitz. d. kais. Ak. d. Wissensch. Bd. L. 25, pl. xт. fig. 1 ; Bryoz. d. deutsch. Septar. 62 (sep.), pl. vii. fig. 4. ? Lepralis cograts, Reuss, Bryoz. d. deutsch. Septar. 62, pl. rii. fig. 5.

* We hare similar varieties in Phylactella labrosa, Busk, and Membranipora monostachys, id. 
Lapratia interwedia, Reuss, Bryoz. d. österr.-ungar. Miocäns, 20, pl. riii. fig. 11 (granular var.).

Mollia vulaaris, forma trpica, Smitt, l. c. 14.

Zoceia oval or rhomboid, convex, distinct, smooth or subgranular; orifice well arched above, the inferior margin straight, with a notch in the middle, occasionally a ccntral mucro a little bclow it ; oral spincs four or five; an avicularium on each sidc, about lialfway down the cell, or, in somc eases, nearer to the top, witl a long and slcnder vibraeuloid mandiblc. Oœcia small, subglobosc, smooth, united to the cell above, sometimes umbonatc.

RANGe of Variation. I have noticed the smallest amount of variability in British examples of this species. The cells are more or less granular, a differencc of no significance whatever, and disposed sometimes irregularly, sometimes in lines.

In a beautiful Meditcrrancan spccimen, for which I am indebted to Mr. Waters, there is a muero on the front of the cclls, whiel sometimes attains a considerablc length, and a prominent umbo on the oœcium (Plate XV. figs. 5, 6).

On the whole, there arc few species more eonstant in cliaracter.

Habitat. On stones, shells, weeds, \&e., from moderate depths to decp water.

Localities. South-west of Polperro, 30 fathoms (T. H.): coast of Antrim, decp water (Hyndmail) : Hastings (Miss Jelly) : Birtcrbuy Bay (A. M. N.).

Geographical Distribution. Mediterrancan (Moll) : Naplcs, on Sargassum (A. W. Waters): Madcira (J. Y. J.).

Range in Trme. Vienna basin (Reuss): Austro-Hungarian Mioecne deposits, granular var. (Reuss): Pliocene deposits, Bruccoli, Sieily (A. W. Waters).

The appendages in this specics rescmble in eharacter 
those of Microporella ciliata; they are placed on small, somewhat oval risings on the cell-wall. The mandible is much elongated and attenuated above, and bears a decidedly vibraculoid appenrance; but it is expanded and flattened towards the base, and the fixed beak is present, though in a rudimentary condition. They are properly ranked as avicularia, but exhibit a transitional form.

Schizoporella simplex, Johnston.

Plate XXXV. figs. 9, 10.

Leprahu simplex, Johnst. B. Z. ed. 2, 305, pl. liv. fig. 4: Gray, B.M. Rad. 118: Busk, B.M. Cat. ii. 82, pl. lxxxiv. figs. 1, 2: Hincks, Dev. and Cornw. Cat. 44 (sep.); Ann. N. H. ser. 3, ix. 204.

Zoccia ovate, ventricose, very distinet, scparated by deep sutures; walls smooth, dense, greyish white; orifice suberect, arched above, lower margin straight, with a large eentral sinus; peristome clevated and thickened, forming a wall round the entire aperture; below the mouth an umbo; sometimes a small avicularium on one side, about halfway down the eell, placed transversely, mandible acute, directed outwards. Oœcia globose, ample, smooth, usually with two or threc umbonate processes in front; peristome in the fertile eells much developed, forming a prominent, everted, semicireular border.

Range of Variation. This is quite one of the least variable of its tribe. The eharacters are strongly marked and very constant. The avicularium, which has hitherto been overlooked, is often absent, and seems never to be developed on more than a few cells in each colony.

Habitat. On stones, shells, \&e., from moderate depths.

Localities. Off Sana Island, 40 fathoms; coast of Antrim, very abundant (Hyndman) : Belfast Bay, 20-35 
fathoms (W. T.) : South Devon, rare; Guernsey (T. H.) : Hastings (Miss Jelly): Hebrides (A. M. N.) : Unst, Shetland, 45 fathoms; Peterhead and Wiek (C. W. P.).

Distribution in Trme. Seoteh Glacial deposits (Geikie).

The elevated, subtubular peristome, half eoneealing the orifiee, gives a very remarkable appearanee to this speeies, and somewhat interferes with the recognition of its real affinities. But the form of the mouth and the lateral avieularium are characters which elearly eonneet it with the present group. It seems to be loeal in its distribution, and has only been found abundantly at one or two points.

Schizoporella liNearis, Hassall.

Plate XXXVIII. figs. 5-10, and Plate XXIV. fig. I.

Lfipralia lisearis, Hass. Ann. N. H. vii. 368 , pl. ix. fig. 8 : Johnst. B. Z. ed. 2, 308, pl. liv. fig. 11 : Busk, B.M. Cat. ii. 71, pl. lxxxix. figs. 1-3: Manzoni, Bryoz. fossil. Ital., Contrib. iii. 5 (sep.) pl. i. fig. 4 ; Sitzb. k. Akad. d. Wissensch. Bd. 1x. 1. Abth. Dec.-IIeft, 1869: Norman, Shetland Polyz., Rep. Brit. Assoc. 1868, 306: var. hastata, Hincks, Dev. Cat., Ann. N. H. ser. $3, \mathbf{x}, 362$.

Herentia Lisearis, Gray, B.M. Rad. 123.

Lepralia inastata, Hincks, Dev. and Corn. Cat., Ann. N. H. ser. 3, ix. 206 (46 sep.), pl. xii. figs. $4,4 a$.

Escirarelda livearis, forma 1, Smitt, CEfvers. K. Vet.-Ak. Förh., Bihang, 1867, Krit. Fört. iv. 13 and 95, pl. xxiv. figs. 68, 69.

Lepralia tenelaA, Reuss, Foss. Bryoz. d. österreich.-ungarisch. Miocäns, 23, pl. vi. figs. 3-5.

Zocecia rhomboidal, depressed, disposed in regular linear series, and separated by raised lines, sometimes eollfluent and forming a uniform erust; the surface flat, nodulous or eovered with anastomosing ridges, and punetured, or enveloped in a granular erust; orifice orbieular, slightly rimmed, with a pointed sinus below; marginal spines 2-4; oeeasionally a central muero a 
little below the mouth; a small raised aviculurium on each side of the orifiee, almost in a line with the lower margin; mandiblc acute, directed obliqucly downwards or straight across, sometimes replaced by a large central avicularium, pointing upwards. Oœcium globose, prominent, somewhat flattcned in front, and thickly punctured; frequently a large avicularium at the back of it, placed transversely.

Colonies forming largc rosc-coloured crusts.

Var. a (hastata, Hincks). Orifice with a broad, shallow sinus on the inferior margin; immcdiately below it a tall, sharply pointed nucro, expanded at the base, tapering towards the apcx, bearing on one side or the other at the bottom a largc avicularium, with a pointed mandible directed upwards; surface thickly covered witl ratlier large punctures and intersected by ridges, which are sometimes arranged in radiating fashion. (Plate XXXIII. figs. 10, 10 a.)

Var. $\beta$ (mamillata). Zoccia tumid, irrcgularly disposed; a single avicularium immediately bclow the oral sinus, borne on a mamillary cnlargement of the front wall; mandible directed straight outwards.

Var. $\gamma$ (nitida). Zoccia much more elevated than usual, bright and lustrous, the front wall ascending towards the large and massive mucro, from which ridges radiatc towards the sides, anastomosing, and rising into many nodulous proccsses; an avicularium on each side of the mouth, pointing obliqucly outwards.

Var. $\delta$ (crucifera, Norman). "With a ecntral, suboral process rising from the cell in the form of a very long, gradually tapering, rugosc, perpcndicular spine, which is more than cqual to the length of the cntire cell, and in its most perfect state gives off a branch at nearly right angles at rather more than half its lengtl, so that the whole process is in the form of a cross or trident." Sometimes a branch is devcloped near the base of the mucro, and a second towards the upper extremity. 
Ravge or Variation. Apart from the usual superfieial differenees dependent upon the degree in which the ealcareous crust is developed, the chief variation in this wellmarked species takes place in the position, size, and direction of the avicularia. Normally there are two, which usually occupy corresponding positions on cach side of the eell, though in some eases there is a great deal of irregularity. Frequently, however, these are replaced, on one and the same colony, by a single central aricularium, which is often very prominent and of large size. In some eases the avicularium is borne on the side of a short rostrum, placed a little below the oral sinus. Occasionally a large raised avicularium is met with near the bottom of the cell, placed transversely; and the occium is sometimes attended by one or two, in addition to the oral pair.

In an Algerian specimen the latter are placed almost close together, facing one another, below the inferior margin of the mouth, and are larger and much more elevated in front (almost vertical) than in the usual form. In another very marked varicty (mamillata), which is also from Algiers, the avicularium is single, placed immcdiately below the oral sinus, and borne on a mamillary enlargement of the front wall of the cell, the mandible pointing straight outwards. The position is constant and invariable; the cells are granular, tumid, and irregularly disposed; and there is (in the specimen which I have examined) a total absence of the rudimentary ovicelligerous cells that are so characteristic of S. linearis. This las somewhat the appearance of a distinct species; but, on the whole, and especially considering the great variability in the position of the avicularium, which distinguishes the present form, I believe that it is more properly ranked as a variety. 
The direction in which the mandible of the avicularium points is also very variable in this species : most commonly it is placed transversely; but very often it is turned straight upwards, or obliquely downwards or outwards.

The mueronate proecss, which is often present below the mouth, is likewise subject to many diversities in the degree of its development. In some eases it is absent altogether; in others it is small and inconspieuous; in others again (as in the var. crucifera) it rises into a tall and slender spine, which gives off one or more branches: In this form it is oceasionally double; the ovicell is sometimes developed round onc of the two spines, the extremity of which appcars as a spike-like process on the front of it. In the Mediterranean variety (nitida) the mucro is large and massive, and traversed by radiating ridges.

The variety hastata presents some very striking features; and $I$ at one time regarded it as a distinet species. The tall mueronate proeesses, each with a rather large lateral avicularium at the base, are profusely devcloped; the orifice has a broad sinus on its inferior margin; the zoarium is usually white and silvery; and the surface is covered with large punetures, which often assume a radiated arrangement. The oœeium has not unfrequently a muero at the top.

Haвitat. Under stoncs, near low-water mark, and on shells, stones, \&e., and more rarely on Alga, from shallow to very deep water.

Localities. Very abundant and generally distributed. Shetland, common down to 170 fathoms. Var. crucifera:On a shell dredged in 40-50 fathoms off Unst (A. M. N.): Orkney (Barlec) : Ireland, north and west (W. T.) : Birterbuy Bay (G. S. Brady): Beaufort Dyke, 110-147 fathoms (Capt. Beechcy) : Filey, Yorkshire, betwcen tide- 
marks; South Devon; Ilfracombe, 8-10 fathoms; Cornwall, down to 60 fathoms (T. H.) : \&e. Var. hastata:South Devon; Guernsey (T. H.): Budleigh-Salterton, very fine (Miss Jelly).

Geographical Distribution. Roseoff (Joliet): France, S.W. (Fischer) : Mediterranean (M'Andrew) : Adriatic (Heller): Algiers, normal and var. mamillata (J. Y. J.): Scandinavia, on Aseidians and Algx, 10-20 fathoms (Smitt) : Norway, from 200-300 fathoms, on Oculina (Baron Uggla) : Bohuslän (Lovén) : South Labrador, rare (Packard).

Range in Trme. Austro-Hungarian Mioecne deposits (Rcuss) : Pliocene beds, Calabria (Manzoni).

I have alrcady referred incidentally to the eurious rudimentary cells bearing oœcia, which arc devcloped abundantly on this species. They occur on the front surface of the ordinary zoœcium, which they almost eompletely eover. The upper portion presents the usual appearance of the oviccll; it is closely united to the wall of the cell, ample, well rounded above, but contracted slightly towards the arehed opening in front, which is elosed by a horneoloured opereulum. Below the opening there is a semicircular calcareous wall, continuous with the sides of the ovicell; and between the top of this wall and the opereulum there is a space, which is usually filled in by a transparent membranc. The area inclosed by the semicireular wall is evidently an aborted eell. The whole strueture consists of an oœeium attached to the merc rudiment of a eell.

These singular bodies are in most cases distributed thickly over the surface of the zoarium, and oeeur indifferently on cells which are furnished with the ordinary ovicell and on those which are destitute of it. Oecasionally they are plaecd transversely. 
'They may be compared-with the ovieclligerous eells of S. hyalina or of Eucratea, which are more or less imperfeetly developed. In the former the fertile zoceia are produced upon the primary layer of eclls, and are always atrophied and small in size, elosely resembling in eharaeter and position the struetures in question. The peeuliarity in the present speeies scems to be that the two eonditions of the fertile cell eoexist. Eschara Brongniartiana, D’Orb.*, from Chili, is furnished with a large number of similar struetures distributed over the surfaee of the eells.

Another peeuliarity of this speeies should be notieedthe tendeney to the development of single eells and groups of eells over the surface of the zoarium, forming in fact a seeond layer. These seeondary eells are more tumid than the primaries, and very irregularly disposed. They never exhibit the preeise linear arrangement which eharaeterizes the latter, but are strewn, as it were, over the primitive layer.

\section{Schizoporelda sanguinea, Norman.}

Plate XXXIX. figs. 6, 7.

Hemeschara sangitei, Norman, Quart. Journ. Micr. Sc. (n. 8.) viii. 22:, pl. vii. figs. 9-11.

Excharella saxguixes, Smitt, Flor. Bryoz. pt. ii. 54, pl. viii. figs. $164,165$.

Zocecia subquadrangular, arranged with great regularity in linear series, quineuneial, flattened, bordered by raised lines, thiekly eovered with large, eireular perforations, the perforations sometimes separated by nodulous retieulated ridges; orifice arehed above, a eentral sinus on the lower margin, and on each side of it a very small noteh-like indentation. Sometimes a small avicularium,

* Voyage daus l'Amér. méricl., rol. r. part 4, page 14, pl. vi. fig. 12. 
with subacute mandible, on eael side of the aperture at the very top of the eell, and others distributed over the zoarium. Oxcia subglobose, tumid, punetured, and nodulous.

Colonies incrusting, or "rising in frill-formed, frec expansions, consisting of a single series of cells" [Norman]; or "in tubiform convolutions" [Smitt]; shining, and of a deep red colour.

RaNGe of VARIatiox. S. sanguinea is often strongly ealeified, and it changes muel in appearanee according to the degree in which the stony erust is developed. The habit of growth is also variable to some extent; and though it commonly takes the form of a spreading erust, it also rises at times into free expansions, consisting of a single layer of cells. The detaehment and upward growth of the cellular lamina, unaccompanied by any ehange in the plan of budding and the struetural composition of the zoarium, is a very trivial variation; and the genus Hemeschara, which is based on this character, has eertainly no elaim to stand.

The avicularia in this speeies, according to Prof. Smitt, are variable in position, number, and size; in their most normal arrangement, he says, they are placed one on each side of the orifice. They are often either wanting altogether, or are overgrown and concealed by the ealcareous erust.

I have a Mediterranean form which agrees closely with the present, but has three small avieularia, placed in a line below the orifice, with a rounded mandible.

Ha вiтat. On shells and stones, \&e., in rather deep water.

LoenLities. Off Fermain Bay, Guernsey, on shells and Eschara (A. M. N.) : on stones, Cornwall, deep water ('T. H.).

Geograpinical Distribution. Florida, south-west of 'Tortugas, in 60 fathoms (Pourtales): Naples (A. W. Waters). 
Schizoporella chistata, Hineks.

Plate XL. figs. 6, $6 a$.

Scuizororflla cristata ", Hincks, "On the Classifiention of British Polyzon," Ann. N. 11., February $1879,157$.

Zoccia small, short-ovate, or rhomboidal, distinet, eonvex, divided by rather deep sutures; surfaee silvery, smooth, or slightly furrowed, with a few punetures; orifiee suborbieular, with a eentral sinus below, and five marginal spines; immediately under the lower margin a prominent muero, from whiel the elevated peristome passes off on eaeh side, forming with it a wall round a large proportion of the orifiee; on the inner side of the muero a very small and delieate avicularium, with pointed mandible direeted straight upwards. Oœcia (proportionally) large, subglobose, punetured, with an ereet, erest-like ridge running aeross them at the top.

Primary cell very small, suborbieular, sides sloping steeply upwards, the summit oeeupied by an oval area, at the upper part of which is placed the semieireular orifiee, sinuated below; six spines round the orifiee, and three on the lower border of the area.

Habitat. On the shell of the seallop.

Locality. Hastings (Miss Jelly).

I have only seen a single eolony of this very beautiful speeies, eonsisting of the primary and about sixteen other eells, which, from their freshness, have a remarkably bright, glossy, subhyaline appearanee. I have no doubt that with age it undergoes very eonsiderable ehange in superfieial eharaeter.

* This species was first labelled (in MS.) nitidula, and appears under this name, without description, in the List of Polyzoa published by the NaturalHistory Society of Hastings and St. Leonards (1878). I hare ehanged it, that the specifie designation may be founded on a permanent character, and not on one which is probably fugitive. 
The cells are decidedly convex and very distinet, the wall sloping up rather abruptly from the base towards the ccntrc. The mucro forms the middle point of the wall, which incloses the orifice in front and at the sides, and rises above it like a pillar. The avicularium on its inner aspect is minute, and not easily detected. The ovicell is large, and covers the whole of the front of the cell above it; the surface is silvery, and thickly perforated below the prominent crest which crowns it.

b. With rounded or spatulate avicularia, lateral or median.

Schizoporella biaperta, Michelin.

Plate XL. figs. 7-9.

Escuara biaperta, Michelin, Icon. Zooph. 330, pl. lrxix. fig. 3.

Lerralia biaperta, Busk, Orag Pol. 47, pl. vii. fig. 5: Manzoni, Bryoz. d. Pliocene Antico di Castrocaro, 21, pl. ii. fig. 28*.

Reptoporina biaperta, D'Orb. Pal. franç. Terr. Crét. 442.

Escharella lisearis, forma biaperta, Smitt, GEfv. K. Vetensk-Ak. Förh. 1867, Bihang, 14 \& 98, pl. xxiv. figs. 70, 73.

Hiprotion biaperta, Smitt, Flor. Bryozoa, pt. ii. 46, pl. viii. figs. 173-176. Huppotnos Divergess, id. Flor. Bryoz. pt. ii. 47, pl. ix. figs. 177, 179.

Zocecia ovate, slightly convex, quincuncial; surface smooth and shining, the front wall perforated in the young state; orifice suborbicular, with a sinus, more or less open, bclow ; peristome not raised, except in the fertile eclls, in which it forms a wall round the front of the cell; on each side of the mouth a small, round,

* Manzoni describes the species from the Castrocaro beds as having a ribraculum on eacb side of the orifice, and an avicularium on the lower part of the cell. But the real nature of the lateral appendages would not be apparent in foseil specimens; and the openings left by the small, rounded aricularia which occur on $S$. biaperta might easily be mistaken for "ribracular pores." The aricularium on the front of the cell in Manzoni's description corresponds with the large elerated aricularium, with a pointed mandible, which is found on the recent species. 
elevated avicularium; mamillx scattered here and there over the zoarium, bearing large avicularia, with a slender, pointed mandible. Oxcia rounded, broader than long, somewhat flattened in front, the base enveloped by a thiek layer, which ineloses a semieireular space, traversed by radiating lines.

Colonies forming rather large, irregular erusts; the eells sometimes disposed in detached series (forma laxa, Smitt).

Form eschariformis (A. W. Waters). Zoarium ereet and foliaeeous.

Range of Variation. Smitt has deseribed as a new speeies, under the name of Hippothoa divergens, a Floridan form whieh, I eonfess, seems to me to be identieal with S. biaperta. The only distinetion between them, so far as his descriptions enable me to judge, of any importanee, is a slight differenee in the form of the mouth. In Miehelin's speeies (= Hippothoa biaperta, Smitt) the sinus appears to be smaller, and to partake more of the eharacter of a noteh in the eentre of the lower margin. In the divergens form, to which all the British speeimens which I have seen are referable, the suborbicular orifiee is produced below into an open, wedge-shaped sinus, the peristome usually slants gradually away to the bottom of it, and there is only a slight eonstriction of the aperture on each side. But there are many intermediate variations; and remembering the diversities in this partieular that are met with in such a species as $S$. auriculata, it is diffieult to regard this difference as possessing any great importanee. The shape and general eharaeter of the eell, and the structure and position of the lateral avieularia, are, I believe, the same in both forms. In both, the mamilla, supporting large avieularia with a pointed mandible, are present, and often in eonsiderable numbers. 
The ovieells of Hippothoa divergens are not deseribed by Smitt; but on Algerian specimens in my possession, which cxlibit the characters of this varicty, they are developed abundantly, and they are identical with those figured by Smitt for the biaperta form. On the whole, I can see no reason for making two species, and I therefore unite the varieties under Michelin's origiual name.

Besides the differenees in the contour of the mouth, to which I have just referred, there are others in the superficial characters.

In British specimens the walls are solid and eompact, perfectly smooth, of a glossy whitc colour, and imperforatc. In the Algerian examples the walls are thinner, and the texture much more delicate. The Crag form, figured by Busk, has a perfectly smooth surface, and has an avicularium on one side of the mouth only. In recent specimens there are more usually two, one on each side; but in some cases a single oral avicularium occurs.

Smitt assigns to $S$. biaperta a row of punctures round the margin, which I have not observed in British specimens. Their absence may be due to a different degree of calcification.

The number of the large, mamillated avicularia varies in a remarkable manner. Sometimes they are searcely to be met with; sometimes they occur in wonderful profusion, as on the Algerian specimens, in which almost every cell, in certain portions of the colony, bears a large mound, covering the greater part of the front surface. The avicularia are placed on the side of these mound-like prominences, the extremity of the "beak" just reaching to the summit. The mandible is broad at the base, and tapers off rapidly to a point.

In this and the allied species, S. armata, we have a striking illustration of the variability of the avicularium; 
in one case the rounded and the spatulate, in the other the rounded and the pointed forms, are assoeiated.

The Lepralia plana, Dawson, from the Gulf of St. Lawrenee and the Canadian Postpliocene deposits, is an allied but distinet speeies.

Habitat. On stones and shells, from shallow to deep water.

Localities. Var. divergens:-Guernsey (A. M. N.) : Hastings, on seallop-shells (Miss Jelly).

Geograpinical Distribution. Var. divergens:-off the coast of Florida, 135 fathoms (Pourtales): Algiers (J. Y. J.). Var. biaperta:-Spitzbergen and Greenland, not frequent (Smitt): Kara Sea (Stuxberg and Théel) : Floridan Sea, very common (Pourtales).

Range in Trme. English Crag (Busk): Older Plioeene, Castrocaro (Manzoni): Miocene, Doué, Franee (fide Waters). Forma eschariformis, Sieilian Pliocene, Bruecoli (A. W. Waters).

Schizoporella armata, Hincks:

Plate XUI. figs. 7, 8.

Lepralia armata, Hincks, Devon and Cornw. Cat., Ann. N. H. ser. 3, ix. 207 (47 sep.), pl. xii. fig. 5 .

Zoccia rather broad, ovate, distinet, quincuneial; surface granular, sometimes punetured round the margin; orifiee orbicular, with a deep, loop-like sinus below; peristome raised and thiekened in front and at the sides; oral spines four or five, very tall and stout, two or three plaeed on the upper margin, and two lateral, the latter projeeting in front of the ovicell; on each side of the orifiec, near the top, a raised process bearing a small avicularium, with a semieireular mandible 
dirceted outwards, often replaced by a large spatulate avicularium. Oxcia scmicircular, rather shallow, flattened in front; surface smooth, with obscure radiating ridges.

Colonics forming large brownish or grey patches.

Haвitat. On stones, \&c., from deep water.

Locality. South-west of Polpcrro, in 30 fathoms (T. H.).

Geograpincal Distribution. Algiers, on shell (J. Y. J.).

The cclls in this strongly marked species arc moderately convex, well defined, arranged very regularly in quincunx, and coarsely granulated. The orifice is rather large, and appears to be deeply depressed from the elcvation of the cell-wall around it; it is filled in by a light horn-coloured operculum, which bears a very close resemblance in form to a balloon. In fresh specimens the spines are a very conspicuous feature; they are stout, and of remarkable length. The two foremost are articulated to a short, tubular process; and when the oviccll is present, they stand erect in front of it, and rise high above it. There is somctimes an avicularium on each side of the orifice, sometimes on onc side only. The semicircular mandible is turned outwards; it is interesting to notc that on the lower margin of the avicularian aperture there is a minute sinus corresponding to the larger one on the mouth of the cell. The small avicularia are placed at the upper extremity of an ascending process; occasionally they are situated rather below the inferior margin; but their morc usual position is near the top of the cell. Not unfrequently their place is occupied by a very different structurc. Instead of the small rounded form, there often occurs an clongate avicularium of large sizc, with a spatulate mandible, usually, but not unirersally, pointing 
upwards, and elevated above the surface of the cell. These large avicularia are also seattered irregularly over the zoarium.

Schizoporella auriculata, Hassall.

Plate XXIX. figg. 3-9.

Lepralia auriculata, Hass. Ann. N. H. ix. 412: Johnston, B. Z. ed. 2, 310, pl. liv. fig. 8: Busk, B.M. Cat. ii. 67, pl. Ixxrix. figs. 4-6.

Escharella auriculata, Smitt, Gefv. K. Vet.-Ak. Förh. 1867, Bihang, Krit. Förteckn. iv. $12 \& 90$, pl. xxiv. figs. $58,59$.

Lepralia ochracea, Hincks, Dev. and Cornw. Cat., Ann. N. H. ser. 3, ix. 206, pl. xii. fig. 3 .

Zoocia rhomboid, oecasionally subovate, short, depressed, disposed in linear scries, radiating from a central point, separated by raised lines, punctured or granular, sometimcs covcred with a thick reticulated crust; orifice suborbicular, with a sinus below; marginal spincs 2-4; a small avicularium, with rounded mandible, immediately below the centre of the lower lip, usually on a mamillary eminence, which is sometimes prolonged into a mucro, frequently replaced by a larger avicularium, with spatulate mandible. Oxcia subglobose, depressed, elosely united to the eell above, sometimes completely immersed, punctured, often partially enveloped in a granular crust; oceasionally mucronate.

Colonies spreading in subcireular patches of a bright red colour; when young surrounded by a distinet border of partially developed zoœcia.

Var. a. ochracea (=Lepralia auriculata, var. Leontiniensis, Waters). Surface of the zoarium flat, thickly covered with minute papillæ; orifice of the zoceia suborbicular, produced below into a pointed sinus; a little below it a small oval avieularium, immersed, sometimes plaecd obliquely, mandible pointing downwards; often replaced by a very large, elongate avicularium, covering a great portion of the front of the cell; mandible of almost 
equal width throughout, very slightly, if at all, cxpanded at the extremity.

Colony a large, irregular crust, of a dull-ycllow colour when dead.

Var. $\beta$ (cuspidata). With a conspicuous spike-like proeess on the frout of the ovicell; avicularium very prominent. (Plate XXIX. fig. 8.)

RaNGe of Variation. S. auriculata is liable to many variatious, some of which involve a remarkable change in the appearance of the species. Many of these variations are due to the different degrces of ealcification which mark the different stages of growth, and which are also probably to some extent dependent on diversities in habitat. In their youngest state the cells have the walls thin and perfectly smooth, and more or less punctured. They are soon, however, enveloped in a crust composed of anastomosing ridges, amongst which the punctures are visible. This is their normal adult condition. But in some cascs the thickening of this secondary enrelope is earried to an extraordinary extent. The cells are buried so deeply beneath a mass of coarse reticulated crust, that the mouth and avicularium, instead of bcing on the surface, are placed at the bottom of a kind of eircular shaft. 'The charactcr of the ovicell is also much affected by the development of the calcarcous covering. It is sometimes so much enveloped by it, that it appears as a very slight swelling on the surface of the zoarium. At other times it is partially inclosed by the erust, a somewhat semicireular spacc being left frec in front. In some cases the zoarium is overspread by a white granular crust. Besides these differences, which are duc to ealeification in its various degrees, there are others in the form and position of the avieularium which have a special interest. In its normal condition this appendage is small and almost circular, 
and is situated on the top of a mamillary swelling immediately below the inferior margin of the mouth. In other states, however, some of the mamilla, espeeially towards the edge of the eolony, are found of much larger sizc, bearing an clongated avicularium of somewhat oval shape. In others the inercasc in size has been earricd muel further, aeeompanicd by a striking modifieation in the form of the avicularium, whieh is now distinetly spatulate. A specimen of $S$. auriculata, in which a eonsiderable number of the eclls have passed into this eondition, presents a very remarkable appearanee-the avieularia, with their largc rounded extremitics, projeeting beyond the mamillary eminenees on whiel they are mounted. In the interior of the eolony eells may be found which bear the usual eharacter.

In the var. marked a (ochracea) there is eonsiderable divergenee from the normal type. In most of the eells the avieularia, instead of being elevated and plaeed immediately bclow the mouth, are situated at some distanee from it, on the front surfaee, and are eompletely immersed. They arc small, and oval or subeireular in shape. Many of the eclls, however, bear avicularia that may truly be called gigantie. They extcnd from a little bclow the orifice to the bottom of the eell, and are so ample as almost to eover the front surface. They have not the truly spatulatc figure which distinguishes the large avicularia just mentioned, and are best deseribed as linearoblong. The sides are not hollowed out, nor is the extremity enlarged.

So striking are the peeuliarities of this form that I at first regarded it as a distinet species, and described it under the name of Lepralia ochracea. I am now eonvineed, however, that these variations in the avieularium are not eharaeters of speeific value. On a speeimen of 
undoubted S. auriculata I have met with large avicularia exhibiting the same type of form as those just described. The short oval avicularia correspond with an carly developmental stage in the normal form. The total absence of the umbo and the immersed condition of the avicularium secm to be the only really distinctivc points; and these are of comparatively small importance.

Thesc varictal modifications of the avicularium, of which we have many instances, have a high morphological interest. They illustrate the instability of this element of the structure, to which I have elsewhere referred, and should teach us caution in employing it as a diagnostic cliaracter.

Haвiтat. On shells, stonc, Coralline, and occasionally weed (Ptilota plumosa, Finmark), from very shallow to dcep water.

Localities. Widely distributed, and common. 'The Minclı; Shetland, to 100 fathoms (A. M. N.) : Orkney (Lieut. Thomas) : Northumberland, rarc (Alder) : Norfolk (Hassall) : Suffolk; Isle of Wight (Busk) : Islc of Man; Devon; Cornwall, 60 fathoms (T. H.) : Scilly (M'Andrew) : Bclfast (W.T.) : Dublin (Hassall) : \&c. Var. a. coast of Cornwall, 30 fatlioms; var. $\beta$. Guemsey (T. H.).

Geographical Distribution. Grecnland (Torell) : Finmark (Lovén): Spitzbergen, on Nulliporcs and stones, 3-30 fathoms (Smitt) : Bergen (A. M. N:) : Gulf of St. Lawrence (Dawson) : Algicrs (J. Y.J.) : Figean Sea, var. (E. Forbes) : ? E. Falkland Islands, 4-70 fathoms (Darwin) : Glenelg (T. H.). Var. $\beta$. ? Red Sca or Meditcrrancan.

Range in Trme. Normal and var. a., Sicilian Plioccuc, Bruccoli (A. W. Waters). 
Schizoporella Umbonata, Busk.

Plate XXIV. fig. 2.

Lepralia umbonata, Busk, Quart. Journ. Mier. Sc. viii. 143, pl. xxrii. - fig. 1 .

Zoceia oblong, serial, separated by a narrow raised line, areolated round the margin, and sometimes punetured in front, with a eentral umbo; orifiec suborbicular or sometimes eontraeted below, peristome simple, armed with four spines above; immediately below the orifice a prominent avicularium, with a semieircular mandible. Uocia large, rounded, umbonate, with a small vitta or dcpressed area plaeed obliquely on each side below.

Habitat. On stone.

Locality. Shetland (Barlee).

Mr. Busk compares this form with Lepralia verrucosa. Of its affinities I ean only speak doubtfully, as it is one of the few species which I have not had the opportunity of examining; but in general character it eertainly approaehes very nearly to $S$. auriculata; and as it is stated that the orifice is somctimes eontracted below, we may, I think, infer that its elosest relationship is with the present group. The umbo in the eentre of the eell, and the vittre on the oœeium are the most elaracteristie features. In most other respeets, in the shape and disposition of the eells, in the general form of the orifiee, in the number of the spines and the position of the avieularia, it agrees with the preeeding speeies.

The umbo on the ovieell, as Mr. Busk has remarked, "is merely that belonging to the eell in front of whieh the ovicell rises." 
Schizoporella discoidea, Busk.

Plate XXX. figs. 8, 9.

Lepralia DiscordeA, Busk, Quart. Journ. Micr. Sc., Zoophytul. vii. (1859), 66, pl. xxii. figs. 7, 8; ibid. viii. 144, pl. Ixvii. figs. 4, 5; ibid. viii. 283 : Hincks, Quart. Journ. Micr. Sc., Zoophytol. viii. 276 , pl. $x \times x$. figs. $4,4 a$.

Alysidota conferta, Busk, Rep. Brit. Assoc.

Zoccia ovate, punctured or granular, surrounded by a raised line, disposed in linear scries, which radiate regularly from a central depression; orifice slightly raiscd, arched above, lower margin straight, with a notch in the centre; peristome, in fertile cclls, much elevated in front; oral spines 6-7; on one side (or on both sides), a little below the mouth, a small raised, oval avicularium, mandible directcd downwards ; frequently replaced in the marginal cells by a long linear avicularium slanting outwards. Oxcia globose, recumbent, punctured, looded.

Colonies small, forming subcircular patches, slightly depressed in the centre.

Range of Variation. The surface of the cclls, which is smooth and punctured in an early condition, becomes more calcificd with age, and the punctures arc surrounded by roughened ridges of stony matter; in a more advanced stage the walls are much thickened and granular. The chief variations occur in the number, shape, and distribution of the avicularia. The elongated form is almost confined to the young or marginal cells, and is by no means always prescut upon them. It usually occurs in pairs, one on cach side of the mouth. Occasionally, but very rarcly, it is met with on onc of the inner cells. In most cases it is replaecd by a small raised avicularium, situated a little below the mouth, sometimes on both sides, 
sometimes on onc side only, and frequently in the eentre. Specimens seem to oeeur in whieh these appendages are wanting altogether.

Habitat. On shells from moderate depths.

Localrties. Shetland (Barlee): eoast of Antrim (Hyndman): Hastings (Miss Jclly): Guernsey (T. H.): Birterbuy Bay (A. M. N.).

Geographical Distribution. Madeira; Algiers (J. Y. J.).

This eminently eharacteristie species is readily distinguished from all other British forms. It grows in somcwhat eircular patehes, slightly depressed at the centre, where the eells are mueh smaller than elsewhere. From this point well-marked rows of eells radiate with perfect regularity towards the margin. A very peculiar appearanec is given to the colony by the hooded ovieclls, which are produeed in great profusion. The peristome rises to a eonsiderable hcight in the fertile cell, projeeting in front, and united at the sides to the ovicell, so as to form a wall round the mouth, whieh conceals the real opening. In some eases it is extended as an areh across the front of thc oviecll itself. In fresh spceimens the cells are distinctly defined by a raised marginal line. The long, dependent avicularia are frequently wanting.

\section{e. Usually without avicularia.}

Schizoporella sinuosa, Busk.

Plate XLII. figs. 1-6.

Lepralia siscosa, Busk, Quart. Journ. Micr. Sc. viii. (1860), 125, pl, xxiv. figs. 2,3 .

Escharfila linearis, forma secundaria, Smitt, Efr. K. Vetensk.-Ak. Förh. 1867, Bihang, 14 and 99, pl. xxr. figs. 74-77. 
Zocecia subrhomboidal or irregularly ovate, flattened in front, slightly elevated towards the orifiee, bounded by a prominent sinuous line; surface granular, large foramina round the base of the cell, and frequently seattered over the entire surface; orifice, in its earliest stage, arched above, lower margin straight, with a rounded sinus in the eentre, peristome thin, unarmed; at a more advaneed stage suborbicular, produeed below, peristome raised. Ooecia rounded, depressed, subimmersed, granular, frequently with a single large pore on the front.

Colonies forming subeireular, flat, glossy erusts, of a rieh red eolour.

Var. a (armata). With a small avicularium within the mouth on the lower margin; mandible rounded (Plate XIII. fig. 2).

Range of Variation. This speeies exhibits some very remarkable variations, dependent ehiefly on the extent to which ealeifieation has proeeded. The mouth completely ehanges its eharaeter at different stages of growth, the primitive shape being more or less eoncealed by a sccondary formation, which surrounds and partially overhangs the original aperture. As it appears in young eolonies or in marginal eells, the mouth is almost semicireular, with a straight lower margin, whieh is hollowed in the eentre into a rather broad rounded sinus. The seeondary aperture, which is found in the older portions of the colony, and which eloses in the original opening, is suborbieular, more or less produeed and pointed below. The latter charaeter varies considerably; and, especially towards the edge of the erust, the lower secondary margin is often without the sinus.

The surface is usually granular, eovered with minute wart-like prominences. The large foramina are sometimes eonfined to the border of the eell, but very frequently they are seattered orer the surface. They are filled in by a 
membrane, and appear as glittering spots of a pale golden colour. With age the walls thieken and the foramina are sometimes obliterated, the surface being uniformly granular. In a variety from Shetland the front wall of the cells is almost smootl and glossy, and covered by a network formed by a delieatc beaded line (Platc XLII. fig. 4). When old and worn the red tint is lost, the walls are much thickened, and of a dirty whitish eolour, and coarsely punctured. Postplioeene examples from Canada present exactly this appearance, and hardly differ, except in the larger size of the cells, from old spceimens dredged in Seotland.

Smitt has remarked that a small avicularium is sometimes present on the lower margin, betwecn the primary and secondary apcrtures. On British specimens I have never seen any traee of such a structure; but on a form from the Gulf of St. Lawrcnee, which in all other respeets (exeept, perhaps, the size of the eells) agrees with $S$. sinuosa, an avicularium with a rounded mandible oceurs, oeeupying mueh the same position as in Porella concinna. I have deseribed this form as var. \& (armata).

The ecntral pore on the front of the ovieell frequently shares the fate of the foramina in the ccll-wall, and is obliterated by the ealcarcous overgrowth.

Habitat. On shells and stones from shallow to deep water (150 fathoms).

Localities. Shetland (Barlee) : ibid., on stone and shell, Outer Haaf (A.M.N.) : west eoast of Seotland (T. H.).

Geograpincal. Distribution. Spitzbergen, 30-50 fathoms ; Finmark, frequent (Smitt): Grecnland (NorthGerm. Pol. Exped.): lat. $72^{\circ} 55^{\prime}$ N., long. $37^{\circ} 57^{\prime} 68^{\prime \prime}$ E., 150 fathoms (Dutel Arctie Exped. 1878): Gulf of St. Lawrence, normal and var. $a$ (Dawson).

Range in Time. Canadian Postpliocene deposits (Dawson). 
Schizoporela Cecilit, Audouin.

Plato XLIII. fig. 6.

Fuvstra Crcili, Aud. Expl. i. 239 : Savigny, Egypte, pl. viii. fig. 3 *.

Lepralia Cecili, Busk, Quart. Journ. Micr. Sc., Zoophyt. v. 173, pl. xт. figs. 6, 7 : Hincks, Deron and Cornw. Cat., Ann. N. H. ser. 3 , ix. 205 (45 sep.).

?Lerralia Pervgiana, Heller, Bryoz. Ad. M. 26, pl. ii. fig. 10.

Zoceia ovate, distinct, separated by moderately deep sutures, lined round, quincuncial, thickly punetured over the surface, with a smooth eentral umbo; orifice arehed above, lower margin straight, with a loop-like sinus in the middle; peristome slightly thiekened. Oœcia globose, prominent, minutely granular, of a delieate pearl-whitcness. Avicularia none.

Colonies spreading irregularly, vitreous and glistening when fresh.

RANGe of Variation. There is very little variability in this handsome speeies; but it seems to be very liable to monstrositics. The ovicells are eommonly distorted and bent out of their natural position. Abnormal eells also frequently oecur, of great width and irregular shape, formed evidently by the union of two cells.

Habitat. On stone, shell, \&e. from rather deep water.

Localities. Jersey (Mrs. Buckland) : coast of Cornwall, on stone, \&c., from deep water; Guernscy (T. H.).

Geograpinical Distribution. Algiers (J.Y. J.) : ?Adriatic (Heller): Naples (A. W. Waters): Australia (Miss Jelly).

* Sarigny's figure is admirable in most respects; but the artist has represented a granular instead of a punctured surface. 
Schizoporella cruenta, Norman.

Plate XXX. fig. 5.

I.epralia violacea, var. cruenta, Busk, B.M. Oat. ii. 69, pl. cx. fig. 1. Lepralia cruesta, Noman, Ann. N. I. for Jan. 1864, 7.

DiscoporA cruesta, Smitt, CEfr. Kong. Vetensk.-Akad. Förh. 1878, No. 3, 23.

Zoocia ovate, often irregular in outline; walls massive, the surface. undulated, eoarsely granular, perforated in front by a number of large foramina, and also more or less punetured round the edge; orifiee suborbieular, elosed in by a thiek rounded border, which is slightly - channelled in front. Oocia unknown.

Colonies in small, roundish or irregular patehes of a deepred eolour.

Haвitat. Usually on large stones from deep water; more rarely on shells.

Localities. Shetland, rare, 80-100 fathoms (A. M. N.) : Peterhead, rare (C. W. P.): Orkney (Dr. Greville) : Channel Islands (Busk).

Grographical Distribution. Nova Zembla, Beluseha Bay, 30-50 fathoms (Stuxberg and Théel, fide Smitt); Greenland ('Valorous' dredgings).

Range in Time. Seoteh Glaeial deposits (Geikie).

Distinguished by its massive habit, its rugged surface piereed by numerous large punctures, and its rieh red eolour. The typical form of the eell is ovate; but there are many irregularities. The surface of the zoarium is eovered with inequalities, piereed by many holes, and roughened throughout by a multitude of granules. Round the mouth the thiek walls swell out into a broad massive border and close it in. There is no armature whatever, but the greatest struetural simplicity. The 
rich colour, which is tolerably preserved in dead specimens, is a good specific mark.

The orifice in young eclls is slightly sinuated in front; and this character allies the species to the present group; but it is singularly destitute of striking struetural features.

Schizoporella hyalina, Linnæus.

Plate XVIII. figs. 8-10.

Cellepora itralisa, Linn. Syst. ed. 12, 1286: Fabr. Faun. Groenl. 435.

Oellepora sitida, Fabr. Faun. Grœnl. 435.

Cellepora persorata, D. Chiaje, Ann. S. Vert., Mem. iii. 39, pl. xuxir. figs. 17,18 (oricell).

Escharisa persomata, M.-Edwards, in Lamk. An. s. F. ed. 2, ii. 236, no. 24 .

Begenicea myluna, Hass. Ann. N. H. vii. 367.

Lepralia crlisdrica, Hass. Ann. N. H. vii. 368, pl. ir. fig. 6 (opaque var.).

Lepralita uyalixa, W. Thompson, Ann. N. H. v. 253: Johnston, B. Z. ed. 2, 301, pl. liv. fig. 1: Busk, B.M. Cat. ii. 84, pl. Lxpxii. figs. 1-3, pl. scr. figs. 3-5, pl. ci. figs. 1, 2.

? Crllepora orordea, Lamx. Pol. Corall. Alex. 89, pl. i. fig .1 ; Exp. Méth. 2 , pl. Ixiv. figs. $4,5$.

Celleporella iralisa, Gray, B.M. Rad. 128.

Mollia uralisa, forma uralisa auctt., Smitt, loc. cit., Krit. Fört. iv. 16 and 109, pl. xxv. figs. 84,85 .

Zocecia elongate-ovate or subcylindrical, horizontal, distinct, oceasionally subearinate, disposed somewhat irrcgularly in radiating rows often separated by punetured spaces; walls very thin and hyaline; surface smooth and shining, or slightly furrowed transversely; orifice terminal, orbicular, frequently with a deep sinus in front; peristome thin, the upper margin raised. Oxcia globose, prominent, punetured, often rising into a boss in front; fertile eells small and partially aborted, produced chiefly in the ecntral portions of the eolony, and developed upon the primitive layer of cells.

Polypide with 12 tentacles. 
Colonics forming whitc circular patches, often with a silvery lustre.

Var. $a$ (cornuta). With a stout tubular process on cach side of the mouth.

Var. $\beta$ (incrassata). Walls thickened and opaque.

Var. $\gamma$ (tuberculata). With a number of tubercles on the front of the cell, and often a strongly developed umbo bclow the orifice*.

RANGe of Variation. In what may be regarded as its normal condition, the cells of S. hyalina are glassy and transparent, of thin substance, and most delicate texture.

A variety, howcver, is of common occurrence in which the walls are much thicker, opaque, and of a dirty white colour. The cells, except those which carry the ovicclls, are usually subcylindrical, elongated, and very slightly bulging at the sides, but occasionally of a shorter and broader make. In some cases the cell-wall slopes rather steeply up on each side towards a central keel; which passes from the orifice, where it rises into a prominent point, to the base of the ccll. A ridgc-like umbo is also frequently developed immediately below the inferior margin. The orificc presents itself in two very different conditions : in onc it is ample and simply orbicular; in the other there is a marked sinus on the lower margin, which is sometimes broad and open and sometimes very

* Busk, in a paper on new Species of Polyzoa from Kerguelen's Island (Ann. N. H. for Feb. 1876, p. 116), describes a variety conferta, distinguished by "the crowded and confused growth of cells and ovicells in the central portion of the patch," giving it the appearance of a Cellepora, and by the wide, patulous mouth. But the first of these cbaracters has certainly no claim to be regarded as varietal. It belongs to the ordinary form of the species, and is one of its most striking features. It is associated with the wide, patulous, orbicular mouth, and also with the smaller sinuated aperture. 
deep and narrow. The extreme forms (the simply orbicular and that with a subtubular sinus) are connected by intermediate varicties. In many cases the two projections or denticles, placed one on each side of the aperture a little above the inferior margin, which mark the position of the hinge of the oral valve, are quite ineonspicuous, and the mouth appears almost perfectly circular. In other eases they are more strongly developed, and stand out so prominently as to produce a decided narrowing of the aperture, while, at the same time, they define a broad and shallow sinus below. In this condition there is only a slight departure from the orbicular type; but a further change in the same direction brings with it the contraction and deepening of the sinus, and affects materially the contour of the mouth.

A common variety (cornuta) (Plate XLV. fig. 2) has two erect processes, rising one on each side of the orifice. But perhaps the most remarkable deviation from the ordinary type is met with in an Australian form, which, in spite of its peculiarities, must be referred to this species. On cach side of the orifice, which is furnished with a decp and narrow sinus, is a process such as we find in the variety cornuta. Immediately below the inferior margin rises a very tall mucro, broad at the base, and tapering upwards, which usually bends inward over the mouth. A line of prominent tubercles runs down each side of the cell on the front wall; and frequeutly one is also present in the centre. The ovicell is developed on the ordinary zoceia, is flattened in front, with a number of tubereles round the edge, and an umbo in the middle. Notwithstanding the extraordinary development of tubercular processes in this form, it agrees so fully in essential eharacters with $S$. hyalina, that it is properly ranked as a varicty. 
Not unfrequently the interstitial spaces between the lines of cclls are punetured, the perforations being narrow and elongatc. Small tubules are also sometimes present in the same situation, which I believe to be the rudimentary stage of the dwarf cells that bear the oœeia, and of the other secondary cells associated with them.

In a variety from Santa Cruz the eclls are much produeed and attenuated below, with massive transverse ridges, one of which projcets immediately beneath the mouth; the intcrstices are strongly punctured. (Plate XLV. fig. 3.)

Habitat. On shells, stoncs, Laminaria saccharina and other Algæ, stems of Sertulariidæ, \&e., from between tide-marks to deep water (between 62 and 72 fathoms, eoast of Antrim; 100 fathoms, Greenland).

Localities. Universally distributed on the eoasts of Great Britain and Ireland.

Geographical Distribution. Cosmopolitan. Australia (vars. cornuta and tuberculata); New Zealand (T. H.) : East Falkland Islands, 4-10 fathoms (Darwin) : Cape of Good Hope (Harvey): Kcrguelen's Island, threc vars. (Busk): Natal, var. cornuta (W. Oatcs): California, normal and var. cornuta (Dr. Sinelair): Anticosti and Mingan Islands (Packard) : Bahusia to Spitzbergen and Greenland, 3-30 fathoms (Smitt) : Davis Strait, off Frederickshaab, 100 fathoms (Wallich) : Nova Zembla, 2-20 fathoms (Stuxbcrg and Théel) : off Bear Island (Duteh Arctie Exped.): Roscoff, on red Algæ and Chondrus (Joliet) : Franee, S.W. (Fiseher) : Santa Cruz, var. (Miss Jclly).

Range in Trme. Cor. Crag, Sutton, on shell (S. W.) : Red Crag (A. Bcll): Scotch Glaeial deposits (Geikie) : Postpliocene deposits, Canada (Dawson). 
The most intercsting point in the history of this eommon and widely spread species is the mode in which the ovicelligerous eells are developed. Univcrsally, it would seem, in the common form, the ovicells are produced, not on the primary perfect zoceia, but on special rudimentary cells, which originate on the upper surfacc of the former, and are intercalated betwecn them, at the oral extremity.

These ovieclligerous cells arc wedge-shaped, and of very small size, and fit into the space that separates the zoœcia at their upper end. They are aggregated in the central portion of the colony, where they occur in great numbers, and give the crowded and "hcaped" appearance so charactcristic of the specics in its adult condition. Amongst the ovicelligcrous cells there are usually many cells of normal form, but small sizc, frequently extremely diminutivc, developed, like the former, upon the primitive layer, and constituting an upper stratum. As I have said, the mass of ovicelligcrous and other secondary cclls is collfined to the centre of the eolony; and surrounding it there is generally a broad tract occupied by the subcylindrical cells, lying horizontally and regularly disposed, and forming a glittering belt round the opaque central nucleus*.

The ovicclligerous cclls of $S$. hyalina derive an additional intercst from the close resemblanec which they bear to the curious structures that frequently oceur on the front of the zoccia in S. linearis. The chief difference between them lies in the more rudimentary condition of the ccll in the latter.

" "Limbum quani radiatum faciunt." -OTno Fanricies. 
d. Avicularia on a distinct area above the cell.

\author{
Schizoporella venusta, Norman.
}

Plate XXX. figs. 6, 7.

Lepralia vexusta, Norman, Ann. N. H. January 1864, 84, pl. x. figs. 2, 3. Gemelitora glabra, forma striatula, Smitt, Flor. Bryoz. pt. ii. 37, pl. xi. fig. 207.

Zoceia lozenge-shaped, oeeasionally ovate, moderately eonvex, irregularly disposed, with a prominent umbo below the mouth; surface smooth and hyaline, punctured; orifice orbieular above, produeed below into a wide, shallow sinus, immediately above which are two small lateral sinuses, placed one on cach side; above each eell a small reetangular area, with a minute avieularium near the top of it, mandible rounded. Occia rounded, somewhat depressed, punetured, surmounted by a very small avieularium.

Habitat. On shells, in shallow water; on Nullipore, from a greater depth.

Locality. Off Guernsey, in about 10 fathoms (A. M. N.).

Geographical Distribution. Florida, 68 fathoms (Pourtales).

This is a very elegant species. The eells in their young and fresh eondition are smooth, hyaline, and glittering, prettily speekled with a multitude of minute puneta. In some eases, however, they soon losc this beauty, and are eovered by a dull whitish erust, which partially coneeals thc perforations, and gives the zoarium a coarse appearance. I have seen the whole of the central portion of a eolony in this eondition, but surrounded by a bright zonc of semitransparent cells. 
The zoceia are eomparatively short in the older portions of the eolony, and more elongated towards the margin. The shape of the orifiee is very peeuliar and distinctive: the portion above the hinge of the oral valve is round; but at this point there is a slight eonstrietion, caused by two small lateral projections; immediately below them the margin recedes, and two minute indentations are formed, and the aperture then narrows away into a shallow and somewhat pointed sinus. The whole orifice has an elongated appearanee, and tapers off downwards, the regularity of its outline being broken by the lateral sinuses.

The eentral umbo is of large size, and seems to be generally present. Above the eells there is a small reetangular space, marked off like the ordinary zoœcia, and, like them, with a punctured surface, but having a minute avicularium near the top of it in the place that would be oceupied in a normal eell by the oral aperture. When the ovicell is present, it eovers a large portion of this avieularian eell, but the avicularium itself projects beyond it and is visible on the summit.

I have met with a considerable group of these modified cells, of various sizes and shapes, in the midst of a eolony, and on one or two of them the umbo was present in the usual position (Plate XXX. fig. 7). They afford one more striking illustration of the morphologieal relation between the avicularium and the zoœeium.

The remarkable strueture of the orifiec of the cell in the present form seems at first sight to separate it in a very decisire way from the allied speeies. But it must be remembered that we have the same peeuliarity, though in a much less marked degree, in $S$. sanguinea, a speeies which in general charaeter agrees very elosely with $S$. linearis. In what seems to be a variety of the latter, I have noticed an approach to the same condition; whilst in 
Mastiyophora Hyndmanni the lateral sinuses are in some states very apparcnt, and in others almost disappear. In all eases this peculiarity in the form of the orifice is due to the degree in which it is eonstricted near the hinge of the opereulum, and is a mere matter of detail, and not a change of type. In S. venusta the variation seems more striking, from the orbicular form of the orifice above and the great width of the sinus. I do not think that wc can isolate this species from the present genus.

Lepralia obvia, deseribed by Manzoni from the Pliocene of Castrocaro, agrecs with S. venusta in the form of the mouth.

\section{Genus MASTIGOPHORA, Hincks.}

Der. From $\mu a ́ \sigma \tau \iota \xi$, a whip, and $\phi \dot{\rho} \rho \omega$, to bear.

Fuostra (part.), Audouin.

Lepralia (part.), auctt.

Herentia (part.), Gray.

Hгртотно (part.), Smitt.

Generic Character.-Zocecia with a semicircular orifice, the inferior margin straight, with a central sinus; furnished with lateral vibracula. ZoARIUM (in British species) incrusting.

THE presence of fully developed vibracula in place of the more usual avicularian appendages distinguishes the present genus from the preceding. The charactcr seems to be one of considerable importance, both morphologically and physiologically, and may fairly be used, I think, to mark off a separate group. 


\title{
Mastigophora Dutertrei, Auduuin.
}

\author{
Plate XXXVII. figs. 1, 2.
}

Flustra Dutertrex, Audouin, Expl.; Savigny, Egypte, pl. ix. fig. 2.

Lepralia Woodiasa, Busk, Crag Pol. 42, pl. vii. figs. 1 \& 3; Quart. Jouri.

Micr. Sc., Zooph. viii. 284 : Hincks, Quart. Journ. Micr. Sc. viii. 276.

Leprala aUrita, Reuss, Bryoz. d. deutsch. Septarienth. 62, pl. vii. fig. 13. Lepralia otophora, Manzoni, Bryoz. di Castrocaro, 23, pl. iii. figs. 30 (not L. otophora, Reuss).

Zoxcia ovate or rhomboid, distinct, usually punctured round the margin; surface granulated, the granules frequently in radiating lines; orifice arched above, inferior margin straight, with a slit in the middle, occasionally an umbo below it; peristome sometimes raised and thickened in the fertile cells, and forming a wall round the mouth; marginal spines fivc or six; on each side of the orifice, near the top of the cell, a slender vibraculum of moderate length. Oxcia globose, closely adnate to the cell above, often subimmersed, sometimes with one or two spines in front of them on each side.

Colonies forming rather large crusts, with a tendency to a lobate mode of growth.

RANGE of Variation. There are two very marked forms included under this species. In one (a), which is common in Shetland, the cells are of a greyish colour and somewhat silvery, and the granules covering the surface are disposed pretty regularly in lines which radiate from the centre towards the margin. The row of large pores round the base is wanting ; and the peristome in the fertile cells is not raised and thickened in frout; occasionally there is a slight promincnce beneath the lower margin. The vibracula are rather small. This varicty is much more delicatc than the following. In the other $(\beta)$ the surfacc is uniformly granular, and there is usually no 
endency to radiation, the marginal punctures are a eonspicuous fcaturc, and the peristome is greatly developed, especially in the fertile cclls, in which it forms a wall round the orifice. There is no trace, however, of the broad and prominent umbo with a eup-like cavity above it, which, aecording to Busk, distinguishes the Crag representatives of the specics. This second form has occurred on the eoasts of Antrim and Cornwall*.

The first of these varieties scems to agrce very elosely with the Flustra Dutertrei of Audouin. The Crag form agrees generally with the Antrim and Cornish specimens; and with thesc may be ranked the Tertiary Lepralia aurita of Reuss.

I see no sufficient reason for separating these varietics specifieally, though they eertainly present a very different appearanee; and I have therefore restored Audouin's name. A Madeiran form, mentioned by Busk, seems to combine some of the peculiarities of each + ; and I have a speeimen from Antrim in which there is a eurious blending of the characters of the two varictics. It has the clevated peristome in the fertile eclls and the flat surface which distinguish the form $\beta$; but therc is a decided tendeney towards the radiatc arrangement of the granules, whilst in one half of the colony the marginal punctures are a eonspieuous featurc, and in the other are altogether wanting.

The Hippothoa pes-anseris of Smitt, from the Gulf of Florida, seems to differ from the present species in a single eharacter only-the remarkable shape of the vibraculum, which euriously imitates the webbed foot of a bird.

Hавітат. On shells and stone, from deep water.

* The specimens from these localities stand alone in having the peristome elevated into a wall round the mouth in front of the oceium. The cells are also somewhat more depressed than in the Shetland variety.

+ Quart. Journ. Microsc. Sc. riii. p. 284. 
Localities. Form $a$ :-Coast of Antrim (Hyndman) : off the Deadman, eoast of Cornwall, 60 fathoms (T. H.). Form $\beta$ :-Shetland, very abundant, 80-170 fathoms (A. M. N.) : Guernsey (T. H.).

Geographical Distributron. Red Sca (Savigny) : Madeira (J. Y. J.).

Distribution in Trme. Coralline Crag, on Tellina (Searles Wood) : Mitteloligocän Tertiary beds, at Söllingen (Reuss): Older Plioeene, Castrocaro (Manzoni).

Mastigopiora Hyndani, Johnston.

Plate XXXVII. figs. 3-6.

Leprali Hyxdyasi, Johnst. B. Z. ed. 2, 306, pl. liv. fig. 6 : Busk, B.M. Cat. ii. 74, pl. lxxrrii. figs. 5-8.

Herextia Hrsdususi, Gray, B.M. Rad. 122.

Hippotnoa porosa, Smitt, Floridan Bryozoa, pt. ii. 41, pl. vii. 6g. 158.

Zoceia ovate or rhomboid, broad, flat, smooth, and often with a row of punetures round the edge, or coarsely punetate over the entire surface, bordered by a raised line; orifice arehed above, straight below, slightly notehed at each side above the inferior margin, and with a eentral sinus; peristome forming a broad, thiekened border round the upper part of the orifiee; a long vibraculum, springing from a distinet vibracular cell, on one side, a little below the mouth. Oxcia small, arcuate, flattened in front.

Colonies forming small, flat, ineonspieuous patehes.

Range of Variation. $M$. Hyndmanni exhibits a very interesting series of varieties, embraeing forms whieh, in the hands of some systematists, would probably obtain specific rank. Indeed Smitt has separated one of them, 
and by no means the most marked, under the name of Hippothoa porosa.

The cclls in our British specimens usually present a very flat surface, and arc rhomboid in figure; the walls arc of dense texture; and the border is perforated by a single row of porcs. In some cases, however, the shape varies to ovatc, the surface is convex, and the marginal pcrforations are wanting. The vibraculum also varics much in length. In a form from the Red Sea (?) the species wears a vcry different aspect. The cells are nearly half as large again as in British specimens, ovate and vcry convex, and a good deal narrowed above; the thickened peristome surrounds the whole orifice, instead of bcing confined to the upper part of it; the entire surface is covered with coarse punctures; and the vibracula, which are slender and whip-like, attain an enormous development. The vibracular cell is also placed much nearer to the orificc than is usual. This is probably the porosa of Smitt (Plate XXXVII. fig. 5). In a yet more rcmarkable form from South Africa the shape of the orifice has undergone modification, and the central sinus has disappeared; the ovate cells, which do not exceed in size thosc of our British form, are covered with puncta; and a little below the inferior margin of the mouth therc is a small circular pore. Perhaps the most remarkable change has taken place in the vibracula, which, instead of being slender and thread-like, prescnt a rigid appearance, are of moderate length, broad below, and tapering gradually to a point, and bear no slight resemblance to a miniature sword or scimitar. This very marked form is worthy of being recorded as $M$. Hyndmanni, var. ensiformis, if it is not entitled to specific rank (Plate XXXVII. fig. 6).

Habitat. On stones, shells, \&c., from deep watcr.

Locality. Sana Island, off the south-cast of the Mull 
of Cantire, 40 fathoms; off the coast of Antrim, abundant (Hyndman) : Belfast Bay (W. T.) : Beaufort Dyke, west coast of Scotland, 110-145 fathoms (Capt. Becehey): Shetland, 80-110 fathoms; Hebrides (A. M. N.) : Peterhead, a single specimen (C. W. P.). This species has a very limited range in our seas, being almost confined to the western coasts and Shetland so far as our present knowledge goes.

Geographical Distribution. Madeira (J. Y. J.) : South Africa, var. ensiformis (Miss Jelly) : off the coast of Florida, var. porosa (Pourtales) : ?Red Sea (R. S. Newall).

\section{Genus SCHIZOTHECA, Hincks.}

Der. From $\sigma \chi i \zeta_{\omega}$, to divide, and $\theta \dot{\eta} \kappa \eta$, a receptacle.

Lepralia (part.), auctt.

SchizotuecA, Hincks, Ann. N. H. Dec. 1877.

Generic Cinaracter.-Zocecia with a suborbicular primary orifice, the lower margin sinuated; the secondary orifice raised, tubular, notched in front. Oøcrum terminal, with a fissure in the front wall. ZOARIUM (in British species) adnate.

Turs genus agrees with the rest of the Myriozoidæ in having a sinus on the lower lip of the primary opening; but in the adult cell this character is eompletely concealed by the growth of an elevated, tubular, secondary orifice, which in the British spceies is more or less notehed in front, and earries a number of very tall marginal spines. There is a total absence of the punetures in the cell-wall, which are so general amongst the Schizoporelle; and the ovicell exhibits a peculiarity in its fissured front surface which is only met with elsewhere amongst the Releporc. 


\section{Schizotheca Fissa, Busk.}

Plate XLI. figs. 1-3.

Lepratia Pissa, Busk, Quart. Journ. Mier. So., Zoophytol. iv. 308, 303, pl. ix. figs. $8,9,10$.

Zoocia lozenge-shaped, smootl and glassy, disposed in regular linear series, divided by deep furrows, and radiating from a common eentre; orifice orbicular, much raised, tubular, with a deep noteh on the lower margin; oral spines six, long and slender; aviculariu large, with a pointed mandible, generally direeted outwards, placed at the upper end of a distinet area, distributed irregularly over the colony. Oxcia globose, prominent, smooth or slightly roughened, with a large, wedge-shaped fissure in front; two spines visible in front on each side.

Colonies forming small silvery-white patehes.

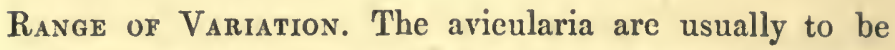
met with near the margin of the colony, where they often alternate with the ordinary cells. Sometimes they are ranged in a line, with perfect regularity, amongst the latter; not unfrequently there is a large collection of them at a ecrtain point, whilst few are found in other parts of the colony. In some eases they are seattered irregularly in the interstitial spaees. They are of large size, with a long, pointed mandible, which falls upon a well-developed "beak," and are placed at the upper end of a distinet, lozenge-shaped area, which in size and general appearanee eorresponds with the normal cell. Apart from these differenees in the number and position of the avieularia, this is a very constant species.

In the earlier stages of growth, the eell is destitute of its tubular peristome, and is slightly sinuated on the lower margin. When old there is a remarkable ehange in the appearance of the zoarium, the walls becoming thick, 
coarse and grauulous, and losing altogetler their vitreous charaeter and their lustre, whilst the very elaraeteristie spines are usually wanting. At first sight the speeies is hardly reeognizable in this eondition.

Habita'. On shells, stones, \&e., from moderate depths.

Localities. Coast of Devon (Miss Cutler): Exmouth (Barlee) : off the Deadman, Cornwall, 30-40 fathoms; Birterbuy Bay (T. H.) : Guernsey, where it is abundant (Alder) : eoast of Antrim (Hyndman).

Geograpiical Distribution. Naples (A. W. Waters).

Mr. Busk deseribes "two or three unequal teeth" as oecurring on either side of the mouth; but I believe that these are nothing more than the stumps of some of the spines which are set very far forward, so as to projeet in front of the ovieell. The whole number of the spines is six.

\section{Schizotheca divisa, Norman.}

Plate XLI. figs, 4-6.

Lepralia ntrisa, Norman, Ann. N. H. Jan. 1864, 86, pl. x. fig. 6.

Zoccia small, erowded, slightly eonvex, smooth, disposed in regular lines; orifice orbieular, raised, tubular, with six very long and slender spines above, a slight noteh and two or three minute dentieles on the lower margin, which is much swollen, and sometimes produeed into a large spatulate proeess or flattened umbo. Ocecia semielliptieal, mueh elevated, smooth, flattened in front, and with a narrow, slit-like fissure, which is not open below.

Colonies of a glossy white colour when fresh.

Ha bitat. On dead shells, in moderate depths and in deeper water. 
Localities. Between Guernsey and Herm (A. M. N.) : eoast of Antrim, on shell (Hyndman).

There is always a swelling below the orifice; and not unfrequently this is developed into a massive spatulate process, which gives a very grotesque appearanee to the cell. There seem to be generally two or three raised points within the front margin, and, I think, a minute eentral noteh. The fissure on the ovieell is narrow and linear, extending to within a short distance of the lower margin. The mouth of the ecll is armed with six very tall and slender spines, of which two are visible below the ovicell. A marked eharaeteristie of this speeies, as of the allied $S$. fissa, is the very regular disposition of the cells in linear series. Between the two forms there are many points of resemblance and affinity; but the lastnamed is at onee distinguished by the more elongate eell, the deeply-eut sinus on the lower (seeondary) margin, and the wedge-shaped fissure in the ovicell.

\section{Genus HIPPOTHOA, Lamouroux.}

Der. From ' $\mathrm{I} \pi \pi \circ \theta 0 \dot{\eta}$, one of the Nereids.

Catenicelia (part.), Blainville.

? Terebripora, D'Orbigny*.

Tubulipora (sp.), Jameson.

Molus (part.), Smitt.

Generic Character.-Zowcia distant, caudate, connected with one another by a slender prolongation of the lower extremity, so as to form linear series; branches given off from the sides of the cells; orifice subterminal, sub-

* The members of this genus burrow in the shells of certain Mollusks; but structurally they seem to agree with the present group. Our common $H$. divaricata erodes to some extent the surface to which it is attached; and the position of its cells, after their remoral, is often marked by a rery distinct depression. 
orbicular, with the lower margin sinuated or produced. Zомкіи adherent.

Surt disallows the genus Hippothoa, and ranks its members with speeies whieh are supposed to possess similar zoceia, irrespective of the habit of growth. Thus $H$. divaricata is regarded as a hippothoiform variation upon Schizoporella hyalina. In eertain varieties of the latter speeies the eell is attenuated and produeed below, and no doubt in this eondition bears a considerable resemblance to a somewhat gigantic Hippothoa. On the other hand, the eonneeting fibre is sometimes much abbreviated in the latter genus, and oceasionally is quite rudimentary. In such eases we may find indications of the way in which one type has passed into the other. But as I should not place S. hyalina on the strength of this oceasional variation amongst the Hippothoce, so I should not merge the latter in Schizoporella because at times the eaudate prolongation of the eell is almost wanting.

In screral of the massive speeies we meet with varieties or states in which the eells run out into single linear series; but this deviation from the normal eondition does not eonvert them into Hippothoce. In such eases the cells do not usually beeome caudate, mueh less are they furnished with the thread-like appendage which is the eommon and typieal eharacteristie of the latter group. These linear varieties eaunot bc correetly designated hippothooid.

Universally, I believe, amongst the Hippothore the eell is narrowed bclow into a kind of tubular pedunele, more or less extended ; prevailingly it is distinetly eaudate, and produeed into a filiform appendagc, while the remarkable plan of the gemmation is eonstant. I think we have here the eharacters of a natural group, sufficiently (though of course not absolutely) isolated, and worthy of a scparate 
plaee and name. I have therefore decided, with the greatest respeet for Profesor Smitt's opinion, to retain the genus Hippothoa, which has not only a strongly marked faeies but also an ancient pedigree. In the Cretaceous beds it is well represented by charaeteristie speeies; and it is widely distributed in the waters of our own epoch.

\section{Hippothoa divaricata, Lamouroux.}

Plate XLIV. figs. 1-4; and Plate I. fig. 2.

Hippothoa divaricata, Lamx. Expos. Méth. 82, pl. luxx. figs. 15, 16 : Johnst. B. Z. ed. 2, 291, pl. li. figs. 3, 4: Busk, B.M. Cat. i. 30 , pl, xviii, figs, $3,4^{*}$.

Catenicella divaricata, Blainv. Actinol. 462.

? Hippothoa laxceolata, Gray, Zool. Misc. 35: Hassall, Ann. N. H. vii. 366, pl, viii. figs. 5, 6: Couch, Corn. Faun. iii. 102, pl. xriii. fig. 6.

Hippothoa Patagonica, Busk, B.M. Oat. pt. i. 30 , pl. xvii. fig. 1 ; id. Crag. Pol. 24, pl. i. fig. 5.

Mollia hyalina, forma divaricata, Smitt, CEfv. K. Vetensk.-Akad. Förhandl. 1867, Bihang, 17 and 112, pl. xxт. figs. $86,87$.

Hippothoa lomaicauda, Frscher (=H. Patagonica, Busk, Orag Pol.), Bryozoaires d. côtes du sud-ouest de la France, Actes Soc. Liun. d. Bordeaux, axvii. 1870 (p. 21, sep.).

Zoccia more or less remote, ovate or pyriform, smooth or finely striated transversely, glossy, of a pearly whiteness, carinated in front; orifice arehed above, with a noteh in the lower margin. Ocecia small, globose, with a boss in front, borne on eells which are somewhat inferior in size to the ordinary zoœcia.

Var. a (conferta). Zoccia erowded, ovate or pyriform, rather short, strongly striated transversely, the conneeting fibre rudimentary; orifice arehed above, with a noteh on the lower margin; a prominent umbo immediately below it. Occia rather large, rounded, broader

* I do not include Audouin's $H$. divaricata amongst the sJnonsnas, as it possesses a very differently shaped mouth from that of the present species. It is the H. Savignyana of D'Orbigny. 
than high, with a boss in front, borne on eells of the normal size.

Var. $\beta$ (carinata, Norman). Zoocia and connceting fibre traversed by a prominent ridge-like keel.

Var. $\gamma$ (Patagonica, Busk). Zoceia oval, more or less attenuated downwards, irregularly annulated, thick.

Haвitat. On shells (chiefly), stones, \&c., from between tide-marks to deep water.

Localities. Gencrally distributed. Special localitics must be accepted with eaution, as this form has been hitherto confounded with $H$. flagellum. Var. $\beta$. Antrim (Hyndman) : Birterbuy Bay (A. M. N.). Var. a. Sidmouth, on red weed (T. H.). Var. $\gamma$. ?Britain (Busk).

Geographical Distribution. Mediterranean (Lamx.) : Roscoff, rare (Joliet): France, S.W. (Fischer): Bergen (A. M. N.) : Aretic seas to Spitzbergen, on Ascidians, Astarte, Saxicava, in great depths (Smitt): Godhavn Harbour, Disco, 5-20 fathoms ('Valorous' Exped.) : Gulf of St. Lawrence (Dawson) : Mazatlan, on Murex; Hobson's Bay, Australia ('T. H.). Var. Patagonica:-Patagonia and Falkland Islands, on Fucus (Darwin): Tasmania (Busk).

Range in Trme. Pliocene, Castrocaro, very rare (Manzoni) : Scotch Glacial deposits (Geikie): Palæolithic (A. Bell). Var. Patagonica:-Coralline Crag (S. W.) : Hippurite limestone, St. Grégoire, near Rennes (Michelin). .

Of the varieties of this common species with which I am acquainted, the most remarkable is the one described as var. $\alpha$ (conferta). In this form the zoœcia are gencrally massed together and laid side by side, and do not assume the ordinary dendritic mode of growth. Oecasionally lines of eells arranged in single series are given off from the mass. The connecting fibre is very slightly developed; 
generally the eells are somewhat produeed below, so as to be pyriform, and are attaehed to one another by the base of the sliort peduneular extremity; sometimes three, sometimes two, originate from the top of another eell. The lateral branches do not usually stand out at a right angle, but take an ascending direction. The habit and mode of growth seem to resemble very elosely those of the Crag species $H$. abstersa, Busk.

The cells, when erowded together, are rather short and ovate; they are umbonate, and traversed by very distinet transverse striæ. The orifice agrees in all respects with that of the normal $H$. divaricata. The ovieelligerous eells are not smaller than the rest. Notwithstanding the striking peculiarities of this form, I believe that it is properly referred to $H$. divaricata, which exhibits many variations in the length of the tubular fibre, and not unfrequently has the eells more or less massed together*.

The var. $\beta$ is characterized by an exaggerated condition of the keel on the front of the ecll. When seen in profile it stands out as a prominent ridge, but is abruptly truneated immediately below the orifice.

H. Patagonica, Busk, appears to be nothing more than a thick-walled and rudely annulated variety of the present speeies. As represented in the British-Museum Catalogue, it has some affinity with our var. conferta; but the figure in the 'Crag Polyzoa' makes a near approach to the ordinary $H$. divaricata.

In charaeteristic and well-developed specimens of the latter, branching takes place with much regularity at right angles or nearly so to the main lines of eells, and colonies exhibit a very definite dendritie habit.

* Dr. Jolnston mentions a variety "in which the cells are contiguous." and which occurs on sea-weeds only. 
Hippothoa expansa, Dawson.

\author{
Plate I. fig. 1.
}

Hrppothos Expassa, Dawson, "Cat. Anim. and Plants observed on the Southeast side of the St. Lawrence, from Quebec to Gaspé," \&ce. By Robert Bell. Polyzoa by Dr. Dawson. Geol. Survey of Canada, Report of Progress for 1858 (published 1859), 255: Nirman, Quart. Journ. Micr. Sc. 1868 (n. 8.), viii. 216, pl. vi. figs. 1,2

Zoceia large, ovate, elongate, ribbed transversely, and traversed by delieate longitudinal strix, tapering bclow into a tubular stem; aperture arehed above, with a sinus on the lower margin; peristome slightly raised; the cells and fibrc bordered by a ealeareous expansion of greater or less extent. Occia large, broader than high, umbonate, bornc on an imperfectly developed eell.

Habitat. On small pebbles and stones, from moderate depths to deep watcr (30-100 fathoms).

Locality. Off Unst, Shetland, on Pecten Islandicus, 100 fathoms (Jeffreys and Peach).

Geographical Distribution. Gulf of St. Lawrenee, eommon; Marsouin, north coast of Gaspé, in about 30 fathoms (Dawson): Labrador; Maine (Paekard) : lat. $66^{\circ}$ $59^{\prime}$ N., long. $55^{\circ} 27^{\prime} \mathrm{W}$, in 57 fathoms ('Valorous' Expedition).

Raxae in Trme. Postplioeene deposits, Beauport and Rivière-du-Loup*, Canada (Dawson).

From $I I$. divaricata this speeies is distinguished by its larger size (the eells are about half as large again as those

* "The assemblage of shells at Rivièro-du-Loup is in almost erery particular that of the modern Gulf of St. Lawrence, more especially on its worthern coast."-Dr. Dawsox, Notes on the Postpliocene Geology of Canada, p. 52. 
of the last-named) and much stouter habit, by the very regular transverse ribbing of the zoceia, and by the ealeareous expansion which in greater or less degree borders the latter and the eonneeting tubular stem.

I have met with $H$. expansa in two very different conditions. In one the zoceia are massed together, and the lateral expansion is much developed, and forms a connecting crust, which fills up the spaces between the cells and unites them together. In this form the branches originate, as Mr. Norman has remarked, from the side of a cell at a very slight angle. From the masses thus produeed linear series of eclls are given off, which sometimes anastomose and form an irregular wide-meshed network.

In the other eondition $H$. expansa exhibits a very regular growth, having much the same habit as Alecto granulata. The zoœeia range in single lines and bifureate frequently, two cells in each case arising from the top of the terminal eell of the series. In this form the ealearcous edging is almost if not entirely wanting; there scems to be great variability in this eharacter. When fresh the cells are beautifully hyaline and glossy, and very finely lineated longitudinally. The ovicelligerous cells, which are exceedingly small, are generally attached by a short stem to the side of another eell, as is usual in this genus. In all eases the tubular prolongation of the zoccium seems to be of very moderate length in this species; and very commonly it is quite rudimentary.

Dr. Dawson was the first to notice and describe this form; but the list of Polyzoa in which he published it, included under a more general title and imbedded in a volume of the Canadian Survey Reports, eseaped observation, and it was subsequently redescribed by Norman, who gave it the same name as its original discoverer. It is much more characteristically American than British, 
and is fittingly associated with the name of onc who has done so much to illustrate both the recent and fossil fauna of his adopted country.

H. expansa is a northern specics, and is said to be much more abundant in the Aretic seas than the kindred $H$. divaricata.

Hippothoa flagellum, Manzoni.

Plate XLIV. figs. 5-7.

Iirpotuoa ruagclux, Manzoni, Bryoz. foss. Ital. 4th Contrib. 6, pl. i. fig. 4 (Sitzb. d. k. Akad. d. Wissensch. Bd. Ixi. 1. Abth. März-Heft, 1870); id. Suppl. alla Faun. d. Bryoz. Medit. 1st Contrib. 3, pl. i. fig. 5 (l.c. Bd. lxiii. 1. Abth. Feb.Heft, 1871): Hincks, Ann. N. H. Sept. 1877, 218.

Zocecia ovate, smooth, not carinated, slightly elevated towards the oral cxtremity, not much produced below, connected by a very slender thread, usually much longer than the cell; orifice subovate, clongatc, broader above than below, with a slightly thickened peristome. Oocia small, globosc, smooth, bornc on a partially devcloped ccll, which is generally attached to the side of a normal zoœcium by a very short fibre.

Habitat. On shells chiefly.

Localities. $H$. flagellum scems to be common and widely distributed; probably it is as common as $H$. divaricata, with which it has hitherto becn confounded. I am only able to give the localities which have come under my own noticc. Gucrnscy; Cornwall, on stones from decp water; South Devon; Hastings; Islc of Man; coast of Antrim (amongst Mr. Hyndman's dredgings) : ibid., 47 fathoms, and 62-72 fatloms, off the Maiden Lighthouses (amongst Mr. Swanston's dredgings): Birterbuy Bay; Shetland, on Dilrupa, bearing Retepora Beaniana ('I. H.). 
Grographical Distribution. Mediterranean (Manzoni) : Singapore, on Tubipora musica (T. H.).

Range in Trme. Plioeene deposits (newer), Calabria; Castroearo ("Pliocene antico") (Manzoni).

This is a smaller and more delicate speeies than $H$. divaricata, and may be at once distinguished from it by the shape of the orifiec. The cells are rather less produeed below than those of the last-named; they are smooth or slightly wrinkled transversely, and want the keel which, in a more or less pronouneed form, is always present in H. divaricata.

The eell rises a little towards the upper extremity; and the elongate obovate aperture is therefore prominent and conspicuous. In this respeet the species differs markedly from $H$. divaricata, in which the middle of the cell is elevated, and the wall slopes away from the centre towards the upper extremity, so that the mouth is placed slantwise and is less apparent when the cell is viewed in front. The ovicelligerous eells are very small, much smaller as compared with the normal eell than those of $H$. divaricata; the oviecll is regularly globose, smooth and shining, and destitute, I believe, of the kind of boss on the front which oceurs in the latter species.

The fibre is extremely slender, and, though variable, generally much exceeds the cell in length.

I have met with a very pretty variety (vitrea), in which the eells are exeeedingly small, perfeetly vitreous and transparent, and very widely separated, the eonneeting fibre being three or four times the length of the zoceia.

\section{[Hippothoa cassiterides, Couch.}

Hiprothoa cassiterides, Couch, Johnst. Br. Zooph. i. Suppl. 476, woodcut, fig. 87.

I only know this species by the deseription in Johnston's 
'History;' I suspeet it may have been founded on the repent condition of Eucratea chelata (see Plate I. fig. 3).

The following is the diagnosis:-

Zocecia ovoid (more pear-shaped than those of $H$. divaricata), connected by a short, stout thread, about one third the length of the cell; orifice longitudinally oval, rather large, with thickened rim; a short distance from the lower lip a small pearly tuberele, larger in one cell than another.]

Family XIV,-Escharidæ (part.), Smitt.

Celleporid.e (part.), Johnston.

Esciarid.e (part.), id.: Busk.

Miembrayirorid.s, (part.), Busk.

ZOARIU⿴囗十 calcareous, incrusting, or erect and lamellate, or ramose. Zoøcia without a membranous area or raised margins: (a) with a simple primary aperture, horseshoe-shaped, or semielliptical, or suborbicular; or (b) with an elevated secondary orifice inclosing an avicularium; or (c) with a primary orifice having a dentate lower margin and a secondary orifice channelled in front or entire; or (d) with the lower margin elevated into a mucro: in all cases destitute of a true sinus and special pores.

Turs may at first sight appear a somewhat miscellaneous assemblage of forms; and no doubt it is largely distinguished by negative eliaracters. But on eloser examination it will be found that there is a thread of affinity running through the whole and linking together the different genera, and that the group is marked by common features and tendencies of much significance. It embraces the residue of forms belonging to this section. which do not rank under any of the preeeding families, and amongst which there does not seem to be any such 
striking difference of type as to eall for the creation of a distinct group. The primary orifice ranges in the different genera from semicireular (which seems to be the simplest and most primitive form), through semielliptical and suborbicular, to subquadrangular and horseshoe-shaped.

A striking characteristic of the family is the development of a secondary orifice under various modifications, or the elcvation of the peristome into a mueronate process in front. The dentate lower margin is also found only in this group, and oceurs in more than half the genera composing it. In no case is there a sinus on the inferior margin of the primary orifice, nor is there any trace of the special pores which oceur amongst the Microporellida and Porinide.

The crect habit of growth is common in this family. It contains no less than eight British species which would rank under the genus Eschara (auctt.).

It may be divided into three prineipal sections:- $\mathrm{i}$. Species with a simple primary orifice only: Gencra Lepralia and Umbonella. ii. Spceies with a secondary orifice differing in form from the primary: Genera Porella, Escharoides, Smittia, Phylactella. iii. Species with a mucronate clevation of the peristome: Genera Mucronella, Palmicellaria, Rhynchopora.

The difference between the genus Smittia in the second of these sections and Mucronella in the third lics really, as I have noticed elsewhere, in the extent to which the secondary development of the peristome is carried. In Umbonella verrucosa, amongst the simpler forms, the rising which supports the avicularium is, I believe, the equivalent of the secondary ehamber below the primary orifiee in Porella*. In Lepralia Pallasiana and canthariformis,

* We may also trace a connexion between the latter and such a form as Smittia Landsborovii. 
belonging to the same section, we see the tendeney to the secondary development of the peristome which is so strongly marked in this family.

i. With a simple primary orifice only.

Genus LEPRALIA, Johnston (part.).

Der. From $\lambda \lambda^{\prime} \pi \rho a$ scurf, and å`ıs marine.

Escusara (part.), auctt.

LePralia (part.), auett.

Leprali, Smitt.

Generic Character.-Zocecia usually ovate, with the orifice more or less horseshoe-shaped, arched above, contracted at the sides, and with the lower margin entire and generally slightly curved outwards. Zoariom (in the British species) incrusting, or rising into foliated expansions composed of one or two layers of cells.

\section{Lepralia Pallasiana, Moll.}

Plate XXXIII. figs. $1-3$; and Plate XXIV. fig. 4.

Escilara Paluasiana, Moll, Seerinde, 64, pl. iii. fig. 13.

Cellepora Pallasiana, Lamx. Pol. flex. 95, no. 190.

Flustra Hibernica, Hass. Ann. N. H. vi. 172, pl. vii. fig. 1 ; ibid. vii. 370.

Lepralia Pedilostosia, Hass. Ann. N. H. vii. 368, pl. ix. fig. 4 (not the $L$. pedilostoma of Couch).

Leprala pediostoya, Johnst. B. Z. ed. 2, 315, pl. Iv. fig. 7.

Lepralia Pallasiasa, Busk, Mar. Pol. ii. 81, pl. laxxiii. figs. 1, 2; Orag Pol. 54, pl. ix. fig. 7 ; (var. armata) Quart. Journ. Micr. Sc. Zoophytol, iv. 309, pl. xi. figs. 1, 2: Hincks, Deron Cat., Ann. N. H. ser. 3, ix. 204 : Smitt, CEfv. K. Vet.-K. Förh. 1867, Krit. Fört. iv. 19 and 123, pl. xrvi. Ag. 93.

Zoæcia large, broad-ovate, distinet, eoarsely punctured over the entire surface, disposed in lines; orifice ample, longer than broad, arched above, contracted on each side below the middle, lower margin slightly curved 
outwards; peristome clevated, thickened, unarmed, forming a conspicuous border round the mouth, sometimcs mucl raised, so as to be almost infundibulate, and often rising on each side into a pointed proeess; eommonly an umbo below the mouth. Frequently an avicularium immediately under the inferior margin, with semieireular mandible directed downwards. Oœcia none (?).

Colonies forming large subcireular erusts.

Primary cell small, the orifice oceupying a large portion of the front surface; in other respeets normal.

Polypide with 16 slender tentaeles, forming a rather deep bell.

Range of Variation. The eharacters are on the whole very eonstant. When old the erust is thiekened and eoarsely retieulated; oecasionally the surfaee is traversed longitudinally by raised anastomosing ridges. The umbo below the mouth is often absent; while at times it is developed into a tall spike-like proeess. A variety oeeurs in which the peristome is mueh produeed; and in this eondition the speeies makes an approaeh to $L$. canthariformis, Busk (Plate XXIV. fig. 4). The avieularia are often wanting.

Habitat. On shells and stones (chiefly) between tidemarks, and in very shallow water; rarely in deeper water.

Localities. Cornwall (C. W. P.) : South Devon, abundant, the predominant littoral speeies on the southwestern eoasts; Guernsey; Lulworth, under stones, on a remarkably rough and barren shore; Llandudno; Isle of Man, common (T. H.) : Jersey (Alder) : Tenby (Busk) : Berwiek Bay, very rare (Johnston): Bamborough and Cullereoats, Northumberland (Alder): Thurso; Wiek (C. W. P.) : Ayrshire (Landsborough) : Dublin Bay (Hassall): off the Copelands, Belfast Bay, deep water (W. 
Thompson): the Minch; Shetland, eommon, between tide-marks (A. M. N.) ; Orkney (C. W. P.).

Grograpincal Distribution. Rhode Island.and New Jersey (Leidy): Bahusia and Southern Norway, the most eommon littoral speeies (Smitt): France, S.W., 6-10 fathoms (Fiseher) : Roseoff (Joliet) : Adriatic, on shells, stones, and Algæ, pretty common (Heller) : 7-10 fathoms, island of Lussin, Adriatic (Grube): Mediterranean (Lamx.).

Range in Time. Coralline Crag (S. Wood).

This handsome speeies is for the most part a littoral form, and is extremely abundant between tide-marks on many parts of our coast. The smaller pebbles are often eompletely inerusted by it.

In young eells the front wall is thin and silvery, and covered with simple eircular punetures; but with age a thick-glassy crust forms over the primitive lamina. In this state the ridges between the foramina frequently rise into prominent nodules.

According to Smitt, L. Pallasiana oceasionally assumes the Hemescharine habit, and forms free and ereet expansions.

Lepralia canthariformis, Busk.

Plate XXXIII. fig. 4.

Lerralia caxtmaryoness, Busk, Quart. Journ. Micr. Sc. viii. (1860), 143, pl. xxri. figs, 3,4 .

Lepralia Pallasiaxa, var., Norman, Shetland Pol., Rep. Brit. Assoc. for $1868,307,308$.

"Zoccia broadly ovoid, surface granular, punetate, shining; orifiec large, suborbieular, oblong or irregular; peri- 
stome mueh produeed, often infundibuliform, entire." (Busk).

Habitat. On shell, probably from deep water.

Locality. Shetland (Barlee).

This speeics is evidently allied to L. Pallasiana, and especially to the variety with a much clevated peristome. At the same timc, in the abscnee of specimens, I do not venture to pronounee them identical. Judging from the deseription and figure, there are scveral points of difference between them. The eells are broader in $L$. canthariformis, and very distinetly granulated, a condition which I have not observed in L. Pallasiana. The mouth, whieh is definitely horseshoe-shaped in the latter, seems to be very irregular in form in the present speeies, while the peristome is mueh more highly developed in $L$. canthariformis than I have ever seen it in L. Pallasiana (eompare Plate XXXIII. figs. 3 and 4). Provisionally at least the two must be aceounted distinet.

Lepralia foliacea, Ellis and Solander.

Plate XLVII. figs. 1-4.

Esciura retifordis, Ray, Syn. i. 31 : D'Orb. Pal. franç. Terr. crét. v. 101.

Stony foliaceous Coralline, Ellis, Corall. 71 , no. 3, pl. xxx. figs. $a, A$, $\mathrm{B}, \mathrm{C}$.

Porus ceryixus, Ellis, Corall. 72, pl. xxx. fig. b (=var. $\alpha$, fascialis).

Millepora tanialis, Ell. \& Sol. Zooph. 133 (= var. a.).

Eschara fascialis (vars. lasiellosa and fascialis), Pall. Elench. 43: Moll, Seerinde, 31, pl. i. figs. 1, 2: M.-Edwards, Recherches sur les Eschares, 39, pl. iv. fig. 1.

Millyara foliacea, Elis \& Sol. Zooph. 133.

Cellepora la mellosa, Esper, Pflanz. Cellep. 146, pl. vi. figs. 1-5.

Escuara bujentata, M.-Edwards, (=var. $\beta$ ), Recherches sur les Eschares, 38 , pl. iii. fig. 2. 
Fiscinara foliace., Lamk. An. 8. Vert. ed. 2, ii. 266: Milne-Edro. Ann. d. Sc. Nat. ri. 36, pl. iii. fig. 1: Couch, Corn. Faun. pt. iii. 131 : Johnst. B. Z. ed. 2, 350, pl. Ixvii. : Busk, B.M. Cat. ii. 89, pl. cri. flgs. 4-7; Heller, Bryoz. d. Adriat. Meer. 38 : Manzoni, Bryoz. foss. Ital., Contr. iv. 18, pl. i. fig. 4, and pl. iv. fig. 24, \&c.

Zoarium foliaeeous, membrano-ealcareous, rising from a spreading erust, eomposed of thin expanded plates, sinuous and rariously eontorted, with an entire margin, whieh frequently anastomose and form eavities of different shapes and sizes; when living, of a delieate flesh-eolour. Zoceia disposed in two layers plaeed back to back, or oeeasionally in one layer only, ovate-elongate, or rhomboid, quineuneially arranged, scparated by lines, very moderately eonvex; surface punetured and often nodulous, the punetures frequently surrounded by thick retieulated ridges, sometimes areolated round the margin; orifice arehed above, eontraeted a little below the middle, where there is a small dentiele on each side, the lower margin almost straight, or very slightly elevated in the eentre; immediately below it a prominent eentral avicularium, with a rounded mandible pointing downwards, sometimes replaeed by a spatulate avieularium. Oxcia large, often subimmersed, a little flattened in front, smooth and shining; in fertile eells the peristome is raised at the sides, and earried up on the front of the ovicell.

Colonies forming large foliated and ehambered masses, of very brittle texture and of a brownish colour, when dead.

Var. a (fascialis). Divided into narrow, ligulate segments, frequently anastomosing.

Var. $\beta$ (bidentata, M.-Edwards). A pointed projeetion eneroaching on the orifice at each side, and giving it a trifoliate appearanec (Plate XLVII. fig. 4).

RaNGE of VARiation. In the young cells the walls are 
thin and delicate in texture, and only slightly roughened. The punctures show as merc eircular depressions elosed in by membrane. Calcification, however, proeeeds rapidly; and already in the seeond or third row from the margin of the eolony, ridges are growing up amongst the pores; these anastomose as they rise, and the original surface is very soon coneealed by a thick vitreous erust, piereed by as many deep cireular shafts as there were punetures on the primitive wall. In the early state the peristome is elevated; but as the crust thiekens, the orifice is on a level with the surface of the cell.

The zoccia are liable to some variation in form, and are often much elongated and subquadrangular.

The avieularium is generally small, with a rounded mandible, and placed immediately under (and outside) the lower margin; but oceasionally it assumes a lengthened spatulate form.

The var. $\beta$, which Milne-Edwards has deseribed as Eschara bidentata (Plate L. fig. 4), is distinguished by having a dentate proeess on eaeh side of the orifice, and overhanging it, which gives it a deeidedly trifoliate appearanee. In all other respects it seems to agree with the normal form. These dentate processes are, I believe, quite superfieial. In eertain states a thin membranous envelope invests the eells, eoneealing the punetured erust, and eovering the zoarium with a smooth and somewhat glossy epidermis. The lateral proeesses originate from this superficial layer, and have no eonnexion with the underlying calcareous erust.

Oeeasionally the zoarium of $L$. foliacea assumes a Hemeseharine mode of growth; but usually it is bilaminate, and its broad foliated expansions, variously eontorted and anastomosing freely, form large eavernous masses, often of enormous size. Striking, however, as its habit is 
and its luxuriant growth, it differs in no respect either in the plan of its gemmation or the charactcr of its cell from the simply incrusting forms with which it is associated.

For the occurrenee of the remarkable variety fascialis, which is common in the Mediterrancan, on our coasts, we have only the authority of Pallas, who says that he had scen a specimen from the Islc of Wight. MilncEdwards considered it to be a distinct specics; but Pallas tells us that he had seen many transitional forms between it and the common lamellate rariety, and had no doubt of their specific identity.

Joliet has obscrved two varietics of this species at Roscoff-one red, which is the commoner, and the other white; in the latter both the living portions of the colony and the bells of the polypides are of a very pale colour*.

Habitat. On shells and stoncs (chicfly) from deep water.

Localities. Isle of Wight, on oysters (Ellis) : South Devon, common, off Budleigh, Exmouth, \&c.; Ilfracombe, off the Capstone; Guernsey (T. H.) : Sussex, frequent (Dillwyn) : about 2 miles N.N.W. from the Eddystone, very common; off the Deadman, occasionally (Couch) : Falmouth Bay (Miss Vigors) : off Cape Clear (W. Todhunter): Isle of Man (Dr. G. D. Brown): the Minch, Hebrides (A. M.N.). This is the most northern locality yet recorded. Var. $a$. South Deron (T. H.).

Geographical Distribution. Mediterranean (M'Andrew) : Adriatic, on stones, not common (Heller): ibid. Lussin, 24 fathoms (Grube): Algiers (J. Y. J.): La Charente Inféricure and La Gironde, sometimes in cnormous masses (Fischer): Roscoff, very common (Joliet) :

* 'Bryozosires des cótes de Franee,' 1877, p. 99. 
Naplcs, Hemescharine as well as the usual form; also var. a. (A. W. Waters) : Cape of Good Hope; Indian Occan (Pallas).

Raxge in Trme. Italian Pliocenc (Manzoni) : Sicilian Pliocene, Bruccoli (A. W. Waters).

This species not unfrequently occurs as a simple crust*, and in this statc bears a very strong rescmblance to Lepralia Pallasiana. In its erect and foliated condition it often attains a luxuriant growth, and forms largc corallike masses. The usual height of specimens is from 3 to 4 inches; but Couch mentions that he had seen one hooked up by a fishcrman off the Eddystone, which measured 7 fect 4 inches in circumference and 1 foot in depth. Off the South-Devon coast it occurs abundantly, and often attains a large sizc; but I have seen nothing approaching this Cornish giant. Bcing thin and cxtremely brittle, it is very liable to be broken up by the dredge; and usually only fragments reach the surface. In its sheltercd cavities many creatures find a homc, whilc the incrusting Polyzoa spread in grcat luxuriancc over its even surface †.

L. foliacea is cssentially a southern form: on the warmer western side of Scotland it has been taken in the Minch; and this is so far its most northerly locality.

* "The first appearance of its rising into a lamellated form is the production of detached ridges and papillary eminences; as these become more elevated they assume the form described above."-Covcr, Cornish Fauna, iii. p. 132.

+ Membranipora Flemingii and Membraniporella nitida are rery commonly found upon it. 
Lepralia pertusa, Esper.

Plate XLIII. figs. 4, 5.

Ceflepora pertusa, Esper, Pflanz. Cellep. 149, pl. x. fig. 2.

Escharixa Pertusa, Milne-Edwards, Lamk. An. s. Vert. ed. 2, ii. 232.

Escharta pertacea, id. ibid. ii. 234.

Cellepora perlacea, W. Thompson, Ann. N. H. x. 20.

Lrpratia Pertusa, Johnston, B. Zooph. ed. 2, 311, pl. liv. fig. 10: Busk, B.M. Cat. ii. 80, pl. Ixxviii. fig. 3 (? figs. 1, 2), pl. Ixxix. figs. 1, 2: Heller, Bryoz. d. Adr. Meeres, 35, \&c.

Escirareith Pertusa, Smitt, Flor. Bryoz. pt. ii. 55.

Zocecia large, regularly ovate, tumid, distinct, separated by raised lines; surface covered with punctures; orifice suborbicular, contracted below by two lateral denticles, the lower margin slightly curved outwards; usually a tubercle below the mouth, which sometimes rises into a well developed mucro; peristome slightly thickened, unarmed; rarely an avicularium on one side, a little below the orifice, with semicircular mandible directed obliquely upwards. Oøcia globose, somewhat depressed in front, thickly covered with punctures of different sizes, and with a smooth border round the base.

Colonies forming circular patches, the cells radiating from a common centre, of a fine orange colour; very bright and silvery when fresh.

RaNge of Variation. Busk credits this fine species with a large amount of variability; but I confess I should give it a very different character. As I have found it, it is remarkably constant in all its leading features, and at once recognizable by its large, ovate, and very tumid cell, and its almost circular mouth *. I have never met with any variety of it at all rescmbling the form represented

* The orifice is slightly elongated transversely. 
in plate lxxviii. fig. 2, of the 'Catalogue,' whieh has a depressed subquadrangular eell, and a sinus on the lower lip. Norman eonjeetures that this figure, as well as fig. 1 on the same plate, may have been drawn from speeimens of his Hemeschara sanguinea. This is not improbable; but at any rate they eannot, I think, be referred to $L$. pertusa.

The tuberele below the mouth is oecasionally replaeed by a well-developed muero. The avieularium seems to be very sparingly developed, and has hitherto escaped notice. When old and strongly ealeified, the eells are covered with a thiek network of stone.

Habitat. On shells, stones, \&e. from shallow to deep water.

Localities. Isle of Man (E. Forbes) : Cornwall (C. W. P.): South Devon, very eommon; off the Deadman, 40 fathoms; Guernsey (T. H.) : Tenby (F. Walker) : eoast of Antrim, deep water; off Sana Island (Hyndman) : Orkney (Lieut. Thomas) : Shetland, "on shells, espeeially Ditrupæ, and stones, 40-100 fathoms" (A. M. N.).

Geographical Distribution. Adriatie, eommon on stones, mussels, and Algæ (Heller) : Lussin Island, 9-10 fathoms (Grube): Australia (Maegillivray): New Zealand, on shells and eoral (F. W. Hutton): Fiji and Samoa Islands (fide Kirchenpauer) : Antieosti and Mingan Islands; South Labrador (Packard): Florida, 60 fathoms (Pourtales): Mazatlan, on Murex bicolor (T. H.): Greenland (North German Polar Exped.) *.

* I give some of these localities with a certain measure of doubt. There seems to have been some difficulty in identifying $L$. pertusa. The form from the Italian Pliocene deposits and from the Mediterranean, figured by Manzoni under this name, is certainly not the present species, but is referable to Schizoporella sanguinea. 
Range in Thme. Scotch Glacial deposits (Geikic): Palæolithic (A. Bell).

In $L$. pertusa the shape of the orifice varies somcwhat from the generic typc, but the structure is cssentially the same as in the other specics with which it is associated. Smitt ranks it amongst the Myriozoide; but it wants the distinguishing character of this family. Its peculiarity is that the two lateral projections by which the orifice is constricted are placed rery close to the inferior margin, which curves slightly outwards inmediately below them; but there is no approach to a sinus.

LEPRALIA ADPRESSA, Busk.

Plate XXXIII. figs. 5-7.

Lepralia ADPRegsa, Busk, B.M. Cat. ii. 82, pl. cii. figs. 3, 4; Quart. Joum. Micr. Sc. iซ. 178, pl. viii. fig. 6 (Zoophytol.): Hincks, Devon \& Cornw. Cat., Ann. N. H. ser. 3, ix. 205.

Lepralia lata, Busk, Quart. Journ. Micr. Sc. iv. 309, pl. x. figs. 1, 2 : Manzoni, Bryoz. Plioc. Ital., Contr. prima, 4, pl. i. fig. 6 : Supplem. Contr. prima, 8, pl. iii. fig. 2.

Zocecia lozenge-shaped or irregularly ovate, depressed, quincuncial, surface punctate in young cells, minutely granular at a later stagc, sometimes obscurely reticulated; orifice narrow, much longer than broad, arched abovc, contracted a littlc below the middle, inferior margin straight; peristome slightly thickened, frequently a knob on each side on a line with the lower margin. Ocecia rounded, granular, closely united to the ccll above, occasionally umbonate.

Colonies forming flat, compact, and inconspicuous crusts.

Var. $\alpha$. Surface marked with grooves radiating from the lower border of the mouth. 
Range of Variation. The South-Ameriean speeimens on which Mr. Busk's deseription of Lepralia adpressa was founded are eharaeterized by a strongly grooved surfaee, which I have never met with in British or Mediterranean examples. The latter agree more eompletely with his $L$. lata; but there really seems to be no important difference between these two forms. There is no marked seulpture of any kind on the speeies as it oeeurs in our seas. In young eells the surface is thiekly punetured, and bright and glossy; but the punetures are soon surrounded by retieulated ridges, and then almost obliterated, so that the surfaee is merely pitted; at a later stage they disappear altogether, and it becomes dense and almost smooth. The knobs on each side of the orifice are sometimes present on almost every eell, while in other eases they are rarely met with. Oeeasionally they attain a large size, and eonstitute a very striking feature; the ovicell is also sometimes erowned by a prominent umbo.

Habitat. On shells, ehiefly small univalves, from moderate depths to deep water.

Localities. Torbay (T. H.) : Guernsey (A. M. N.) : Hastings (Miss Jelly).

Geographical Distribution. Chiloe, 96 fathoms (Darwin): Mazatlan, abundant, on Columbella and Pisania (P. P. Carpenter): Bay of Gibraltar (Landsborough) : Algiers (J. Y. J.) : Naples (A. W. Waters).

Range in Time. Italian Pliocene (Manzoni). 
LEPRALIA HIPPOPUS, Smitt.

Plate XXXIII. figs. 8, 9.

Lepralia hippopvs, Smitt, Gefv. af Kongl. Vet.-Ak. Förb. 1867, Bihang, Krit. Fört. iv. 20 and 127, pl. xxvi. figs. 99-105.

Zocecia ovate, moderately convex, not deeply divided, arranged quincuncially, occasionally bordered by a raised line; surface almost smooth, with a hyaline lustre (in the young state), or obscurely granulated or roughened by anastomosing ridges, with a number of large punctures round the edge, and usually a central mucro; orifice longer than broad, wcll rounded and expanded above, constricted on each side a little above the lower margin, which is slightly curved outwards; oral spines $2-4$; an avicularium, with a rounded mandible pointing upwards, on one side, often a little below the mouth, placed obliqely. Oœcia globose, subimmersed, smooth or pitted, with a prominent mucro on the front.

RANGe of Variation. In young marginal cells the form is distinctly marked, the front moderately convex, rising towards the central umbo; the surface almost smooth, or slightly roughened, or reticulated, glossy, and of a bluish grcy tint. In the central portions of the colony the walls arc much thickened and roughened, and, as a consequence, the divisions between the cells are almost obliterated, the surface is of a morc uniform level, and the mouth more or less depressed. The avicularia vary in position : sometimes they are placed about the iniddlc of the side of the orifice, sometimes a little below it; and occasionally there arc two, one on cach side. Rarely an elcvated avicularium of an abnormally large sizc is met 
with; and I have seen a space, formed by an aborted cell, occupied by a group of four or five. In some cascs the cells are bordcred by a raised line; but it is more com. monly wanting. I have never met with more than two spines, and in a large proportion of cases thcre are none. Smitt, however, states that therc are usually four in the younger colonies.

Habitat. On shells, stones, Ascidians, the tubes of Annelids, \&c. from moderate depths.

Locality. Coast of Northumberland (Alder).

Geograpuical Distribution. Finmark, on Rhynchonella (Lovén): Spitzbergen (Swedish Exped.) : Greenland (Lütken): Gulf of St. Lawrence (Dr. Dawson).

Range in Time. Postpliocene, Canada (Dawson).

There is a closc relationship between this species and $L$. adpressa; but I have no doubt that they are properly accounted distinct. L. hippopus is much the larger of the two, and assumes in the adult state a much more massive character and a coarser habit. The mouth is vcry similar in both; yet there are differences which, if slight in themselves, are not without significance in the aggregate. In $L$. adpressa it is narrower and taller in proportion to its brcadth than in the other form, the constriction takes place higher up, and the projections or denticles on the side are less strongly marked. On the other hand, in $L$. hippopus the upper part of the mouth expands considerably, the lateral projcctions are prominent, and are placed immediatcly above the lower margin, and the length is less in proportion to the breadth. In the former specics avicularia and, I believe, spincs are always wanting; in the lattcr there is no trace of the knobs, which are almost always present in grcatcr or less quantity on $L$. adpressa, and which arc often so striking 
a feature. The central mucro and the marginal punetures, which are pretty constant characters of $L$. hippopus, are absent in the kindred species. I may add that the two differ remarkably in general appearance, and that the one is (so far as we know) a northern and the other a southern form.

The only British example of $L$. hippopus which I have heard of, is from the Northumberland coast, and agrees in all respects with specimens from the Gulf of St. Lawrence, which I owe to the kindness of Prineipal Dawson of M'Gill University.

Lepralia Edax, Busk.

Plato XXIV. figs. 7, 7 a.

Cellepora edax, Busk, Crag Pol. 59, pl. ix. fig. 6, pl. xxii. fig. 3 ; Quart. Journ. Micr. Sc. n. ser. i. 154, Zoophytol. pl. xxrir. figs. 3, $3 a$ : Hincks, Devon Cat., Ann. N. H. ser. 3, ix. 304 (48 sep.).

Letralia edax, forma typica and forma calcakea, Smitt, Flor. Bryozoa, pt. ii. 63, pl, xi. figs. 220-223.

Zoarium rather massive, usually moulded on a small univalve shell, oceasionally forming erect, pumicose stems. Zoceia ovate rhomboid or hexagonal, very irregularly disposed, surrounded by a marginal line, and punctured round the edge; the cell-wall rising more or less towards a prominent umbo, placed below the mouth, which is often prolonged into a tall mucronate process; surface roughened, often striated by radiating furrows; orifice rounded and expanded above, contracted a little below the middle, where there is a small denticle on each side, lower margin slightly eurved outwards; peristome not elevated, unarmed; small oval avicularia irregularly distributed, often wanting; large avicularia, with a pointed mandible, placed on a distinct area 
bounded by a raised line, are occasionally present in considerablc numbers, but are sometimes altogcther absent. Oocia rounded, sometimcs almost immersed, sometimes suberect; a dcpressed area on the front, less strongly calcificd than the rest of the surfacc, inclosed by a raised linc, which takes the form of an 'arch; at the top of this arca a transversely clliptical orifice closed in by a membrane.

Colour, when fresh, bright red.

Range of Variation. There are very considerable differences in the elevation and convexity of the cells; in some cases they are much raised and have a mamillated appearance. According to Smitt the umbo is sometimes wanting; but generally it is a very prominent feature, rising at times into a spiked process. The punctures seem to be commonly confined to the base of the cell, where they form a single line; but I have secn them spreading ovcr the entire surface. This seems, however, to be of very rare occurrence. The surface is sometimes smooth, but more generally roughened, and is very commonly striated by furrows passing upwards from the margin.

The oval avicularia are extremely irregular in their occurrence, and when present are only developed here and there over the colony. They are not noticed by Busk in his account of the Crag specimens, nor can I find them on that from the Devon coast; but on the Guernsey and Floridan specimens they are prescnt.

The large pointed avicularia, each placed on a definite area as large as that of the zoccia, are extremely rare on the British examples which I have seen. I believe I have detected one or two of them by diligent search; but on the Floridan form figured by Smitt they are numerous, 
interspersed amongst the ordinary cells, and constitute a marked characteristic *.

Habrtat. Usually on small univalve shells (Natica, Thurritella, Trochus, \&c.) from moderately deep water.

Localities. Plymouth Sound; off Fermain Bay, Guernsey, in about 30 fathoms (T. H.) : in onc confined area off Guernscy, in 15-20 fathoms, incrusting Trochus Montagui, Wood, Nassa incrassata, Ström, Trophon muricatus, Montagu, \&c. (A. M. N.): off the Dcadman (C. W. P.).

Geographical Distribution. Florida, in 49 and 79 fathoms (Pourtalcs).

Raxge in Time. Coralline Crag (S. Wood) : Middle Pliocene (Coralline and Red Crag) (A. Bell).

L. edax is found almost universally investing certain univalve shells, or rather occupying the place of the shell of certain Gasteropod mollusks. For it is a remarkable fact that in all cases the shell which served as the original site of the colony, has disappeared, and its place is filled and its form perpetuated by the crust of the Polyzoon. This is true of fossil as well as of recent specimens. The Lepralia possesses the power of eating away and removing the shcll; and its own zoarium supplies a good and solid substitute for the house which it has supplanted. Busk has noticed (in Crag specimens), "that other shells, either entire or in fragments, together with minute pebbles, are occasionally found imbedded in the parasitic mass" + .

Smitt describes a form from the coast of Florida, which

- "The greater avicularia ... bare an inversely spatulate or a flaskshaped form of their aperture, with its linear produced tip pointing obliquely upwards." - Flor. Bryoz. pt. ii. page 65.

+ Crag Polyzos, p. 60. 
seems to be identical with the present, as "growing in raised stems of a pumicosc consistence," and mentions that in one case a Serpula had "fixed itself upon such a colony, wherc at last it was enveloped by the overgrowing Bryozoon, and its calcareous shell, in the well-known manner, was eaten away"*. The peculiarity in the mode of growth exhibited by this Floridan form has not been noticed either in Crag specimens or in those which have becn obtained on our own coasts.

A species of Actinozoon presents us with a similar habit to that of L.edax. This is a Zoanthus described by Düben and Koren under the name of Mamillifera incristata, which is commonly parasitic on shells tenantcd by a species of Pagurus. In all cascs the shell is destroyed after a while by some process of erosion or absorption, the diffused basal crust of the zoophyte forming a perfect cast of it, and affording shelter to the crab $†$.

An interesting peculiarity of the present species is the special aperture with which the oœcium is furnished, and which is placed at the upper end of the depressed área, on its front surface.

Another characteristic point is the extremely irregular disposition of the zoccia. They lie in all directions, without the least uniformity of plan-now turned this way, now that, forming a confused medley, which contrasts strongly with the usually definite and methodical grouping of the cclls amongst this family.

The first recent example of $L$. edax was obtained on the coast of Devonshire; and I have since dredged it off Guernsey, where it has also been taken by Mr. Norman.

* Floridan Bryozoa, pt. ii. p. 64.

† Hincks, Catalogue of Deron and Cornwall Zoophytes, Ann. N. H. ser. 3, rol. ix. p. 304. 
It is probably not uncommon, but may easily have becn passed by from its general and superficial resemblance to Cellepora pumicosa.

\section{Lepralia polita, Norman.}

Plate XXXII. fig. 5 .

Lepralia Poltta, Norman, Ann. N. H. ser. 3, xiii. (1864), 87, pl. xi. fig. 1.

Zoceia large, ovatc, suberect, ventrieose, deeply divided, irregularly arranged, the surface smooth and polished; orifice longer than broad, arched above, the lower margin straight or slightly curved outwards; 4-5 short oral spines, rarely present; peristomc usually raised on each side into a knob-like process, which, in fertile cells, projects in front of the ovicell. Oæcia globose, reeumbent, closely united to the cell above, smooth or minutely pitted.

Colonies forming small patehes of a pinkish colour when living.

Habitat. On shells and stones from deep water.

Localities. Shctland, 70-100 fathoms; the Minch, Hebrides (A. M. N.).

The cells are remarkable for their size and distinctncss and for their smooth and highly polished surfacc. When dead the zoarium loses its pinkish tint, and is of a silvery greyish-whitc. The cells are very slightly raised towards the oral cxtremity, and often obscurely punctured round the base. The mouth is ncarly semiclliptical, the height excecding the width considcrably; the oral spincs arc seldom met with, but traces of them may generally be detceted on some of the cells in a colony. There scems to be much diversity in the degrec in which the peristome 
is elevated and thickened. The nodulous processes on the sides are generally well developed in the fertile eells, and stand out prominently in front of the ovieell ; in other eases they are sometimes inconspieuous, and sometimes wanting altogether. Very commonly the whole peristome is slightly raised and thickened, with the exception of the inferior margin, which is always simple.

It is not easy to determine the affinities of this speeies; but, in the absenee of all striking features, the tall, arehed orifice, with the lower margin almost straight and entire, seems to eonneet it with the present rather than with any other group.

\section{Genus UMBONELLA.}

Der. From $u m b o_{2}$ a rounded elevation.

Lepratia (part.), Johnston, \&c.

Discopora (part.), Gray.

Eschara (part.), Smitt.

Generic Character.-Zocecia with the primary orifice suborbicular or subquadrangular, lower margin slightly curved inwards, peristome not elevated, no secondary orifice; a prominent umbo (?avicularian cell) inmediately below the mouth, supporting an avicularium. Zoarium (in the British species) incrusting.

In this genus the primary orifiee remains unchanged, as it usually does in Lepralia, but it exhibits a very different form from that whieh is eharaeteristie of the latter. It is wide, well-arched above, with the sides slightly rounded, or somewhat compressed, and the lower margin a little curved inward. It is now suborbieular and now deeidedly subquadrangular, but it never makes any 
approach to the scmielliptical and laterally constricted form which characterizes Lepralia. The hollow umbonate rising below the mouth, on which the avicularium is bornc, is also, I believc, properly accounted a character of considcrable (secondary) importance. It is as wide as the infcrior margin, and extends for some distance over the front wall of the cell. The avicularium is placed in the centre of its inner aspect, resting on the lower lip of the orifice. This umbo may be regarded as a partially aborted cell, and is probably the equivalent, as I have elsewhere stated, of the chamber below the primary orifice in the genus Porella.

The Arctic form which Smitt describes as Eschara verrucosa, can hardly, I think, be the same as Lepralia verrucosa of Johnston and Busk. He speaks of the elevatcd sides of its peristome, and describes them as uniting with the margin of the ovicell, which, as he expressly states, is imperforate. These characters do not belong to our British form, which also exceeds the Arctic very considerably in size. In his latest paper, Smitt ranks his Eschara verrucosa as a "form" of Porella compressa, which seems to show pretty clearly that it must be quite distinct from the British species.

\section{Umbonella verrucosa, Esper.}

Plate XXXIX. figs. 1, 2.

? Cellepora verrecosa, Esper, Cellep. pl. ii. 6g8. 1, 2.

Lepralia verrecosa, W. Thompson, $\Delta$ nn. N. H. xiii. 441 : Johnst. B. Z. ed. 2, 316, pl. Ivi. og. 3: Busk, B.M. Cat. ii. 68, pl. Ixxxrii. figs. 3, 4, and pl. xciv. Ag. 6: Heller, Bryoz. d. Adriat. $\mathbf{3}$. 27.

Lefrala reticulata, Couch, Corn. Faun. iii. 117, pl. xxii. fig. 9. 
Discopora verrucosa, Gray, B.M. Rad. 126.

?? Eschara verrucosa, $\beta \beta$, formse costatæ, Smitt, Gfv. K. Vet.Akad. Förb. 1867, Bihang, 22 and 142, pl. xxvi. flg. 135.

Zoocia largc, broad-ovate, or occasionally rhombie, bordered by raised lines, depresscd below, elevated above, the front wall rising into a broad and prominent umbo a little below the orifiee, whieh is often produeed into a kind of rostrum; surfaee smooth or subgranular, strongly areolated round the margin, and traversed by radiating ridges; orifice ample, suborbieular, or often subquadrangular, arehed above, the lower margin almost straight, slightly eurved inward in the middle; usually an avicularium, with a semieireular mandible, on the inner side of the umbo. Occia semicireular, punetured in front, and surrounded by a thickened spinous border or erest.

Polypide red, with 20 to 30 tentaeles.

Colonies forming large erusts, of a fine rose-red eolour, spreading irregularly.

Range of Vartation. This species, under different eonditions, exhibits a great variety of aspeet. In the littoral form the walls of the eells are very slightly ealeified; they are generally thin and smooth, or merely subgranular, and round the edge of the eolony are often almost membranous. In some cases they appear as if eovered with a thin, rather glossy, papyraceous material; the areolations round the margin are obseure; and there is a total absence of the radiating ridges. In the littoral variety the latter are always eomparatively slender, and frequently extend for a short distance only from the margin. In young speeimens the cells are hyaline and shining, the surface is perfectly smooth and of a bluish-grey tint, a white line runs round the eell a little above the base, inelosing the marginal areolæ, while the eentral portion is traversed by delicate longitudinal ridges and frequently 
by conecntric strix. Specimens in this condition are extremely beautiful. With age the walls become dense and opaque white. The umbo is a very conspicuous feature; it is blunt and smooth, and very prominent. The avicularium is often almost hidden behind it; in some eases it is wanting, and I have met with a large colony on which scarecly one was to be found. While the avicularium is, in some cases, half-eonecaled and difficult to recognize, in others it stands out prominently and projeets to some extent over the aperture.

When developed in deep water, $U$. verrucosa takes on a very different character. The walls are dense and solid, the ridges, which are continuations of the septa between the areolar spaces, bccome much thicker, and often rise into nodules and spinous projections; and the umbo is massive and roughened. The strongly marked ridges radiate from the margin to the umbo; and the space between them is occupied by a rather deep, loop-shaped depression. The oviecll, which I have never observed on the littoral variety, partakes of the same character: it is thickly perforated in front; and the punctured space is surrounded by a calcareous border, which rises into a number of spinous processes, forming a very handsome crest (Plate XXXIX. fig. 2).

Decp-water specimens are highly calcified, and the appearance of the species undergoes a corresponding change, but the leading features are unaffected.

The orifice, which does not change with age, is arched abore, and the lower margin is almost straight or slightly sinuous. On each side of it the front wall is earried up for some distance, terminating above in a blunt extremity.

Habitat. On the surface of rocks, stones, shells, Laminaria-roots, \&e. between tide-marks, and in shallow water, and on shells \&e. from decper water (40 fathoms). 
Localities. South Devon, rare; Polperro, betwcen tide-marks; Cornwall, 40 fathoms; Ilfracombe, in clefts on the Capstone; Guernsey, about 30 fathoms (T. H.) : Scarborough (Bcan) : Northumberland, frequent betwcen tide-marks (Alder) : St. Andrews, on roots of Laminaria digitata and stones near low-water mark, rather abundant (Dr. M'Intosh) : Wick and Peterhead, plentiful (C. W. P.) : Scotland, west (Dr. Landsb.) : Shetland, tide-marks and shallow water (A. M. N.) : Dublin coast (Miss Ball).

Geograpinical Distribution. Roscoff (Joliet) : Adriatic, on mussel-shells, rare (Heller) : Greenland (Lütken).

Range in Trme. Scotch Glacial deposits (Geikie) : Palæolithic (A. Bell).

ii. With a raised secondary orifice.

Genus PORELLA *, Gray.

Der. From $\pi \delta \rho o s$, an opening.

Cellepora (part.), Fleming.

Eschara (part.), Sars: Busk: Alder: Smitt: \&c.

Hemeschara (part.), Norman, \&c.

Lepralia (part.), Busk, \&c.

Porelza, Smitt.

Generic Character. Zoceia with the primary orifice semicircular; secondary (or adult) orifice elongate, inversely subtriangular or horseshoe-shaped, inclosing an avicularium, usually with a rounded mandible. ZOARIUM

* Gray introduced this name, with a very insufficient diagnosis, for a genus of which he made Esch. cervicornis, Johnst., the type; and it will be convenient to retain it for the group to which the latter species belongs. Smitt, in his 'Oritical Oatalogue,' adopts it for a genus in which he places $P$. concinna and $P$. lavis; but $P$. compressa he relegates to his genus Eschara. 
incrusting, or erect; foliaceous with a single layer of cells, or ramose.

'Throughour this very natural group there is a striking uniformity, not only in the characters of the adult ccll, but also in the course of its development; and the study of it has done more than most things to convinec me that in this section of the Polyzoa we cannot safely regard the merc ereet and branehing habit as a generic critcrion. If we cxamine a colony of the common $P$. concinna, we find in the margiual cells a plain scmicircular opcning, without any trace of the peculiar structure which is characteristic of the adult. In those which arc somewhat older, the cell-wall begins to risc round the primitive aperture, and the outlinc of a secondary orifice is traceable, which extends for some distance below the former, narrowing off downwards, and so taking on the very distinctive shape which belongs to this spccies. As development proceeds the wall of this sccondary orifice rises higher and higher, until it completely closes in the original opening and forms bclow it a chamber in which the avicularium is ultimately lodged. The primary scmicircular apcrture is covered by the operculum, and continues to be the real entrance to the interior of the cell; the secondary formation is an outwork, as it were, which to some extent protects the entrance, and affords a sitc for the avicularia.

We have precisely the same course of development in all the species which are grouped under this genus.

This arrangement could not stand, as theso forms are most nearly allierl, and cannot be separated in a natural system. In his later paper, on Pulyzoa from Nora Zembla, he transfers $P$. levis to Eschara, assoriating it with $P$. compressa and one or two other species. Porclla, however, which is not encumbered with inconvenient associations, and which wns lirst adopted by Stuitt himself for part of the group, seems to we to be in all respects n preferable name. 
In $P$. compressa, for instance, the phases of the cellgrowth are, in all respects, similar to those which occur in $P$. concinna; and to separate these two forms would be

Fig. 14.

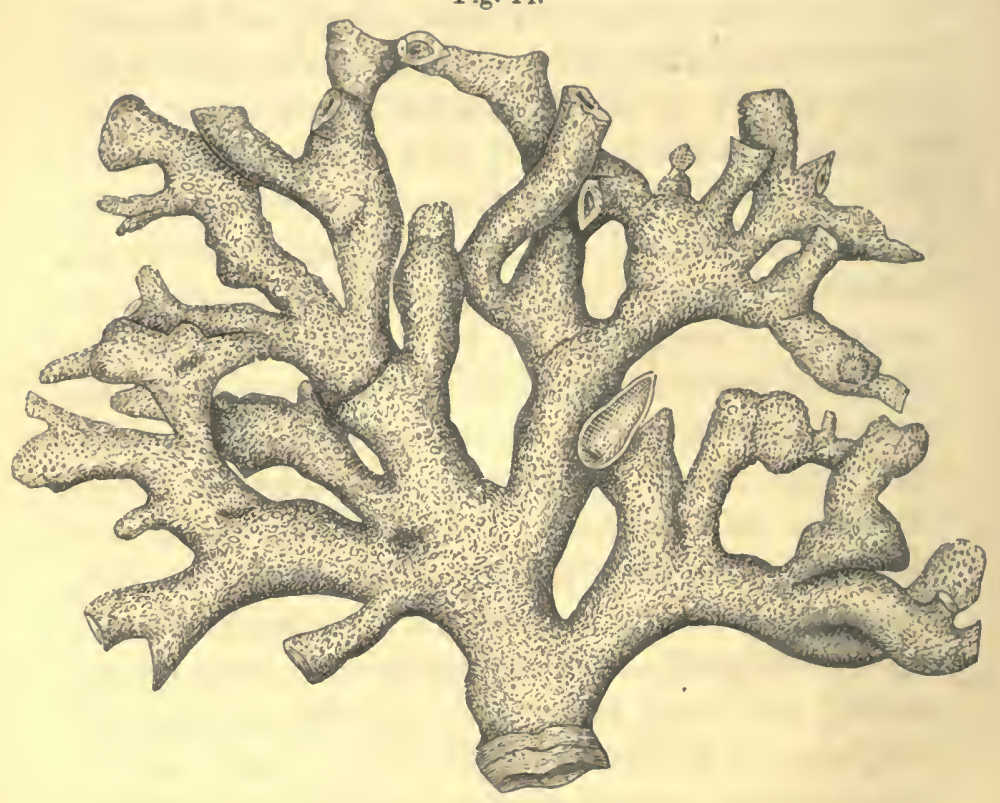

Porella compressa.

to make morc of the ercet habit than of the essential elcments of the structurc. If this course werc adopted, there would be an indefinite multiplication of genera; for the same type of ccll is found associated with very diverse modes of growth. Unless we are prepared to hold to the old method and allow the most external and superficial characters to rulc, to the exclusion of those which are the real indications of affinity, wc must, I think, found our genera in this division on the structure of the zoœcium, and treat the ordinary variations of habit as mcrely subscctional. 
Our only alternative would be, whilst grouping in the same family all the forms with kindred zoœcia, to found genera for the morc striking variations of growth, as well as for the morc important modifications of the cell. But as our object in classification is merely to indicate, as far as possible, natural affinities, wc shall attain our end cqually, and with more convenience, it seems to me, by the course which is here adopted.

\section{a. Zoarium incrusting.}

Porella concinna, Busk.

Plate XLVI.

Lepralta concinsa, Busk, B.M. Cat. ii. 67, pl. xcix.: Hincks, Deron and Cornw. Cat., Ann. N. H. ser. 3, ix. 201 (41 sep.).

Lepralia APErta, Boeck, Förh. Vid. Selsk. Christiania, 1861, 50.

Porella Levis, Lepraliæ auctt. forma, Smitt, CEfr. K. Vet.Ak. Förh. $1 S 67$ (Bihang), 21 and 134, pl. xxri. figs. 112-119.

Lepralia Belli, Dawoson, Rep. Geol. Surv. Canada, 1858, 256.

Zoœcia ovate or rhomboid, slightly convex, granular, often punctured round the margin, disposed in lines; orifice (adult) arched above, contracted below, longer than broad, lower margin straight, the cell-wall frequently raised and thickened round the mouth, a broad denticle set rather decply within it; oral spines two; a small avicularium, with rounded mandible, on the lower lip, the front of the cell immediatcly below it often morc or less mamillated. Oxecia globose, prominent, minutely granular, sometimes a single, central puncture in front; fertile zoceia much raised and swollen towards the orifice *.

* They are so much elevated and enlarged torrards the oral region that they appear as little hillocks studding the flat surface of the zoarium. 
Colonies forming large, eircular, reddish patches, very compact and neat in appearanee.

Var. a (Belli, Dawson). Zocecia flattish, granular, separated by a deep sinuous and punetured furrow; the front wall earried up on each side of the orifice into a digitiform process (Plate XLVI. fig. 6).

Var. $\beta$ (gracilis). Zoocia elongate, punctured over the entire surface (Plate XLVI. fig. 9).

Range of Variation. This species changes its appearanee considerably with age and the attendant thickening of the ealcarcous crust. It also assumes many varietal forms; but the differenees which it exhibits are mainly superficial, and, with the exeeption of the avicularium, no important element of structure is much affected. When old it becomes coarsely granulous, and of a deadwhite colour, the mouth is surrounded by a thick eollarlike extension of the crust, the walls are massive, the perforations often very distinet and numerous, and the avieularium is sometimes obliterated, probably by the calcarcous overgrowth.

The form of the mouth is very constant; and that of the cell itself is subject to but slight variation. But the differenees in superficial character are numerous and striking. The surface is more or less granular; the marginal punctures are sometimes a marked character, but often they are altogether wanting *; frequently the mouth is surrounded by an elevated collar; in some eases this is replaced by a prominent umbo, immediately below the avicularium, and in others the whole central portion of the ecll is mamillated. In other eases, again, the

* The marginal punctures may, I think, be regarded as an essential character, though they are often obliterated by the thickening of the cellwalls. 
surfaec is even and uniform. But the avicularia exhibit the most remarkable variations. They are sometimes plaeed rather deeply within the moutl, and sometimes on the outer edge of the inferior margin, erowning the umbo immediately below it. Oecasionally they are developed in large numbers, and distributed irregularly over the zoarium, each avicularium supported on a small moundlike prominenee (Plate XLVI. fig. 12). At times they are modified in slıpe, as in Schizoporella auriculata, $S$. armata, and probably in many other speeies. The small cireular avicularia are replaeed, at least in a eonsiderable number of the eells, by oval or spatulate avieularia of much larger size, which often cover a great part of the front surface (Plate XLVI. figs. 5 \& 10).

Oecasionally a large avicularium is prescnt on a eell which bears one of the ordinary form and in the normal position. I lave seen one mounted on a mamillary eminence whieh oeeupied the whole of the eentre of the eell, with its mandible direeted upwards, and almost in contaet with the normal avieularium on the lower lip (Plate XLVI. fig. 10). Generally, however, the larger form replaees the latter, of which it is evidently a modifieation. These remarkable ehanges illustrate still further the instability of this structural element, to which refercnee has so often been made.

In the variety ( $\alpha$ ) deseribed by Dr. Dawson as a speeics, in lis valuable paper on the Invertebrata of the Gulf of St. Lawrence, the zoceia have a somewhat sinuous outline, which ehanges very materially the general appearanee, but lias no signifieanee as a specific eharacter. The wall of the eell is carried up on cach side of the moutl into a stout digitiform process-a condition which is met witl in otlier varieties.

Very commonly in the fertile eells these portious of the 
wall overlap the ovicell, and form two rib-like prominenees in front (Plate XLVI. fig. 3). On the whole $P$. concinna must be accounted a variable species; but it is readily distinguishable under all its disguises by the peculiar character of the adult orifice.

Habitat. On shells, \&c., from shallow to deep water.

Localities. The species is common, and widely distributed. Belfast Bay, 20-25 fathoms; ibid., deep water off the Copclands (W. T.) : Isle of Man; Torbay; Guernsey, very abundant; off the Dcadman, 60 fathoms (T. H.): Northumberland, decp-water boats, rare (Alder): St. Andrews (Dr. M'Intosh): Antrim, deep water (Hyndman) : Shetland, 40-170 fathoms ; the Minch (A. M. N.) : Hastings (Miss Jelly): \&c. With fine spatulate avicularia, Guernsey (T. H.). Var. $a$, Shetland (A. M. N.).

Geographical Distribution. Adriatic, on Serpula, rare (Heller): Bahusia; Finmark (Lovén): Norway (Sars): Spitzbergen, 20-30 fathoms (Swed. Exped.) : Godhavn, Grecnland (Torell) : Gulf of St. Lawrence (Dawson). Var. $a$ (Belli), Gulf of St. Lawrence (Dawson).

Range in Trme. Scotch Glacial deposits (Geikie) : Palæolithic (A. Bell): Postpliocene beds, Canada (Dawson).

Porella minuta, Norman.

Plate XXIX. figs. 1, 2; Plate XXXVI. figs, 6, 8.

Lepralia minuta, Norman, Shetland Pol., Rep. Br. Assoc. 1868, 308.

? Lepralia chilopora, Manzoni, Bryoz. di Castrocaro, 32, pl, iv. fig. 51.

Zoccia minute, distinct, divided by deep sutures, disposed in regular ${ }^{\Downarrow}$ radiating lines, somewhat wedge-shaped, smooth or granular, strongly areolated round the 
margin; primary orifice semicircular; sceondary orifice arched above, slightly contracted below, the sides straight, somewhat inclined inwards, on the lower lip a rounded proninence (often with a crenated rim) supporting an avicularium, with semicircular mandible; the cell-wall sometimes much raised and thickened round the orifice, sometimes rising into a mucro in front. Orecia subimmersed, rounded, smooth, or granular.

Colonies foiming "very small roundish patches."

Range of Variation. In the few specimens I have had the opportunity of examining the characters are on the whole very constant. The littoral form, however, of which I have received specimens from $\mathrm{Mr}$. Peach, differs in some points from the deep-water form. It has the cell and ovicell smooth and of a delicate whiteness, while in the latter they are granular and comparatively coarse; the peristome is not thickened; the circular prominence which supports the avicularium is not so apparent, being partially conecaled by the orerhanging preoral muero, which is strongly developed, and it has a plain rim, whereas in the decp-water variety the border is very prettily crenated. In the littoral specimens also the arched top of the orifice is carried across the front of the oviccll (Plate XXXVI. fig. 6).

In some cases the mucro is well developed; in others it is absent, and there is merely a swelling below the mouth.

The primary orifice, as seen in the marginal eclls, is semicircular, without any elevation of the peristome.

Habitat. Between tide-marks, on stones, shells, \&ec, and from deep water.

Localities. Shetland, very rare; Guernsey (A. M. N.): Wiek, between tide-marks (C. W. P.) : Antrim (Hynd- 
n1an): Hastings (Miss Jelly). No foreign locality has been recorded.

Range in 'Trme. Older Pliocene, Castrocaro (Manzoni): (if I am right in identifying Lepralia chilopora, figured by this author in his Monograph on the Polyzoa of Castrocaro, with the present species).

'This species eomes very near to $P$. concinna. The points of difference between the two may be briefly summed up. $P$. minuta is very inferior in size to $\boldsymbol{P}$. concinna; its eclls are more distinct, and divided by deeper sutures, and they are more pointed off below ; they are also arranged morc regularly and markedly in radiating lines. At times the rows of cells are rather widely separated, and the intervening space is crossed by connecting ridges, which pass at intervals from side to side.

The occium of the present species is less prominent than that of $P$. concinna. It may be added that in the latter the front of the cell is never mucronate, while within the lower lip there is a broad denticle, of which no trace cxists in $P$. minuta.

The very close affinity between these two species is not apparent from Norman's description, as he has overlooked the presenec of an avicularium. But there is no doubt that they are most intimately allicd.

On one or two marginal zocecia I have detected traces of a pair of spines. 
b. Zoarium incrusting, or erect and unilamellate.

Porella struma, Norman.

Plate XXXIX. figs. 3-5.

Hemescuara strema, Norman, Quart. Journ. Mlicr. Sc. (n. 8.) riii. 221, pl. vii. figs. (i-8.

Zoceia obovate, slightly convex, quincuncially arranged, the ecll-wall mucli swollen immediately below the mouth, surface smooth or roughened by anastomosing ridges, a line of wedge-shaped arcolæ round the margin, which become much more distinct with age; orifice (adult) broader than long, upper margin arched, the sides straight and slanting inwards, lower margin somewhat curved outwards ; peristome unarmed ; a rounded avicularium within the lower lip. Oøecia rounded, not much raisel, smooth and silvery, or slightly roughened; closely united to the cell above.

Colonies forming a yellowish, glistening crust, which rises here and there into frec frill-like expansions, not excceding half an inch in height, and consisting of a single scries of cells.

Ravge of Variation. 'The description is founded upon comparatively young spccimens. With age the species takes on a very different aspect. The front of the eells is covered with a thick glassy crust, which completcly conecals the characteristic goitre-like cnlargement below the mouth, obliterates the sutures between the eclls, and forms a perfectly flat surface. On this the marginal arcola appear as deep fissures, while the eentral portion is filled up with anastomosing ridges, separated by cavities of various size and shape. To add to the disguise, the cells are now inclosed by thick raised lines, which mark them out with great distinetuess. In this condition 
of course the mouth is sunk below the surface. In few eases is the appearanee of a species so completely elianged by age and the progress of calcification (Plate XXXIX. fig. 5).

Habitat. On stones, and Porella compressa, from deep water.

Locality. "About 25 miles north of the island of Unst, the most northern of the Shetland group," very rare (A. M. N.).

Geographical Distribution. Bergen (A. M. N.) : lat. $73^{\circ} 41^{\prime} 6^{\prime \prime}$, long. $22^{\circ} 58^{\prime} 30^{\prime \prime}$, in 220 fathoms (Dutch Aretic Exped.).

I have no hesitation in referring this species to the genus Porella. It is closely allied to $P$. concinna; it presents the very marked shape of the mouth, slightly modified in its proportions, which is characteristic of that species, while at the same time there is a complete parallelism between the two forms in the mode in which the orifice is developed.

\section{c. Zoarium erect; branches compressed.}

Porella compressa, Sowerby.

Plate XLV. figs. 4-7; woodcut, fig. 14.

Porus cervinus, Borlase, N. Hist. Cornwall, 240, pl. xxiv. fig. 7.

Millepora compressa, Sowerby, Brit. Miscel. i. (1806), 83, pl. xli.

Cellepora cervicorsis, Flem. Br. An. 532: Johnston, B. Z. ed. 2, 298, pl. liii. ( fide Alder, who had examined the type specimen in the British Museum): Couch, Corn. Faun. pt. iii. 111, pl. xx. fig. 1: Busk, Ann. N. H. ser. 2, xviii. 32, pl. i. fig. 1: Sars, Reise Lof. Finm., N. Mag. f. Naturv. vi. 147 (27 sep.): Alder, Quart. Journ. Micr. Sc. n. s. iv. (1864), 98.

Escuara cervicorsis, Busk, B.M. Oat. ii. 92, pl. cix. 6ig. 7, exix. fig. I : D’ Orbigny, Pal. Franç. l. c. 344: Hincks, Deron Cat., Ann. 
X. H. ser. 3 , ix. 308 (50 sep.): Smitt, Escharse (nuctt.) forma, l. c. 1867, Bihang, 23 and 149, pl. xxvi. figs. 138, 139 ; Bryoz. from Nora Zembla, l. c. 1878, no. 3, 11 (not Millepora certicornis of Pallas, nor Eschara cervicornis of Milne-Edwards).

Porella cervicoris, Gray, B.Mr. Rad. pt. i. 127.

? Celceporaria surcularts, Packard, Invertebr. Labrador, Mem. Boston Soc. N. H. i. (1867), pt. ii.

Eschara stellata, Peach, Journ. Linn. Soc. Zool. xiii. 481, pl. xxiii. fig. 5.

Zoarium erect, of a delicate flesh-colour when living, surface roughened by numcrous prominent cells ; much and irrcgularly branched; branches gencrally morc or less compressed, occasionally roundish, truncate or bluntly pointed. Zooecia on both sides of the zoarium, very irregularly disposed (except oll the growing extremities of the branches, where thcy arc regular and the surfacc smooth), ovatc, ventricosc, rising towards the mouth; surface dense, minutcly roughened and punctured with rather large perforations round the margin; the younger cells often with ribs radiating from the side towards the centre; orifice (in the adult statc) arched and cxpanded above, contracted below, sides slanting inwards, a slight constriction a little above the lower margin, forming a sinus in which there is an avicularium, witl rounded mandible. Oxcia rounded, more or less immersed, surface smooth and entirc.

Height of finc specimens about 3 inches.

RaNGE of Variation. In mode of growth there arc many variations; but the minute characters are sufficiently stablc. There is, in the first place, a marked difference in habit between southern and northern specimens. The former are much more massive than the latter; they have usually very broad and thick compressed branches, rendered irregular by many nodulous protubcrances, which frequently anastomose and occasionally terminatc above in somewhat palmate expansions. Shetland cxamples, 
on the contrary, are usually much more delicatc, their branches are comparatively slender, and the whole zoarium has a lightness and elcgance which arc wanting in the ordinary Cornish form. The branclics in this species are, as a rule, deeidedly compressed, and the ramification is, for the most part, irregular and intricate. In a Shetland variety, however, which I owe to Mr. Norman, the zoarium is very sparingly ramified, and the branches are clongate, nearly simple and roundish. In southern specincns thic stem is often of great thickness towards the base, mcasuring as mucl as half an inch in diameter.

The cell of $P$. compressa scems to be liable to very littlc variation, except such as is connected with age and the sevcral stages of growtl. Within the limits of one and the same colony indeed it presents very different appearances according to its position: Towards the growing extremity of the branches the zoœcia are regularly disposed, immersed, and often punctured over the surface. These portions of the zoarium, in the smoothness of their surface and the regularity and neatuess of their appearance, differ widely from the rest. At a short distanec below the top the branehes are, as it were, strewn over with numbers of eells, forming a supcrficial layer, and giving them a rough and warty appcarance. Thesc cells are distributed without any regularity over the surface; they are raised, prominent, ventricose, with thickened walls, and a singlc row of marginal punctures. They extend from a little below the extremities; over the whole of the lower portions of the zoarium.

The young cells have a plain semicircular mouth; and the formation of the raised secondary orifice, which bears the avicularium on its lower margin, may be traced in almost any colony. A smooth space may be noticed 
extendiug for a sliort distance below the primary opening; and around this and the original mouth the eell-wall is gradually elevated, forming the elongate and somewhat horseshoe-shaped orifiee of the adult eell.

In some eases the zoceia towards the upper portion of the branches are deeply immersed, and eovered with a considerable thickness of stony crust, the original mouth and avicularium are sunk below the surface, and the actual orifice is orbicular, contracted below into a narrow, pointed sinus (Plate XLV. fig. 6). Such eells are flat, strongly punetured round the edge and sometimes orer the whole of the front surface. Peach's Eschara stellata was probably founded on a specimen in this condition.

Habitat. On stones and rocks in deep water.

Localities. Cornwall, common (Borlase, Couch) : Devonshire (Dr. Coldstream) : Embleton Bay, deep water (R. Embleton) : Fifeshire coast, rare (Goodsir): Shetland (Jameson): ibid., 40-170 fathoms; the Minch (A. M. N.) : Nymph Bank, abundant (R. Ball) : Roundstone Bay; off the Gobbins, co. Antrim (M'Calla) : Belfast Bay (W. T.) : Youghal (Miss Ball).

Geograpilcal Distribution. West coast of Norway; Finmark, 30-50 fathoms (Sars) : Bahusia (Lovén) : Spitzbergen (Swed. Exped.): Greenland (Möller and Torell) : Nova Zembla (West), 30-60 fathoms; Kara Sea (Stuxberg and Théel) : Roscoff, common (Jolict).

The synonymy of this species has been hopelessly confused by our systematic writers; and it bears a name in their works to which it has no legitimate claim*. $\mathrm{Mr}$.

* An exception must be nuado in Dr. Johnston's farour, who clearly distinguished it from MI.-Edwards's Eschara cervicornis (which is totally distinct and a Mediterranean form), and who had an excuse for giving it the same specific name as the latter, innsmuch as he referred it to another genus (Cellepora). 
Alder, indeed, did good service by pointing out the distinetion between our British form and that which Pallas and Milne-Edwards had described as Millepora (or Eschara) cervicornis; but he retained Pallas's name for the former, and it still holds its place. Sowerby's name compressa, though it lias never eome into use, seems to have the best claim to supersede it, and is sufficiently expressive; and I have therefore adopted it.

\section{d. Zoarium erect, branches cylindrical.}

Portela lavis, Fleming.

Plate XLVII. figs. 10, 11.

Cellepora levis, Fleming, B. A. 532 : Johnst. B. Z. ed. 2 , 299.

Fischara teres, Busk, Ann. N. H. ser. 2, xviii. 33, pl. i. fig. 2.

Eschara lavis, Sars, Beskr. over Norske Polyz., Förh. Vid.-Selsk. Christiania, 1862, 150 (12 sep.): Alder, Quart. Journ. Micr. Sc. (n. s.) iv. 102, pl. iii. figs. 8-11 (8 sep. ) : Smitt, CEfv. Kongl. Vet.-Ak. Förh. 1878, 23.

Ponelua lavis, Escharæ (auctt.) forma, Smitt, Eff. K. Vet.-Ak. Förh. 1867, Bihang, 21 and 134, pl. xxri. figs. 120-123.

Zoarium yellowish, much branched dichotomously; stem short, cylindrical, rising from an incrusting base; branches elongated, cylindrical, spreading, subdivided dichotomously into numerous short segments with a blunt extremity; the lower portions of the zoarium smooth and polished. Zoøcia immersed, flattish, ovate, with a line of large punetures round the edge, surface very minutely granulated; orifiee somewhat longer than broad, arehed above, slightly contracted a little above the lower margin, which is straight and bears an avicularium with semicircular mandible. Oxcium large, prominent, globose, the peristome slightly clevated in front of it. 
Height of a very fine specimen from Shetland $1 \frac{1}{4}$ inch, breadth $1 \frac{1}{2}$ inch.

Habitat. On corals \&ce, ehicfly in very deep water.

Localities. Shetland (Fleming and Barlee) : 20-25 miles N. and N.N.E. of Unst, in 100-170 fathoms (A. M. N.).

Geograpuical Distribution. West and north eoasts of Norway, tolerably abundant, 30-150 fathoms, often on Oculina prolifera (Sars): "extra Norvegiam Oculine affixam ex abysso," 200-300 fathoms (Baron Uggla) : Greenland, a specimen in the Copenhagen Muscum (teste Smitt) : Nova Zembla, Matotschkin-scharr, in Beluscha Bay, 30-70 fathoms; Kara Sea (Stuxberg and Théel).

When finely dercloped, $P$. lavis has a rather broad shrubby growth, the principal shoots, which are much clongated, dividing into very numerous dichotomous branchlets. One of its most striking characteristics is the smootl and polished surface, which extends over the whole of the lower part of the zoarium. The eell-apertures are only met witl in any number on the upper portion of the branches; below they seem to be almost obliterated by a varnish-like coating. The walls over the whole zoarium are thick and dense, and the apertures are generally decply sunk, while in the lower part of it the ealcification seems to have proceeded so far as to remove all traces of the ecll. The zoceia are immersed, exeept towards the extremities of the branches, where they are somewhat prominent; the marginal punctures are hardly distinguishable in the older cells. In young cells a line of punetures is sometimes present, running across the front, a little below the mouth. 'The orifice is rather large, well arehed above, and eontracted a little below the middle, where 
there is a slight projection on each side, so that it is, as Sars has remarked, somewhat lyre-shaped. The ovicells are large and very prominent, elosely united to the wall of the eell above, and in front to the peristome, which forms a thin raised border round the orifice.

On the British coasts C. lavis las only oceurred in Shetland, and ranges thenee to the Aretic seas.

It was first noticed and briefly characterized by Fleming (1828), and was then almost lost sight of until it was redescribed by Sars (1862) and subsequently by Alder.

\section{Genus ESCHAROIDES *, Smitt.}

Der. Formed from Eschara, a genus of Polyzon.

Escinara (part.), auctt.

Generic Ciraracter.-Zocecia with the primary orifice suborbicular; peristome much elevated and forming a secondary orifice, arched above and with a sinus below, within which an avicularium is inclosed. ZOARIUM (in British species) erect, ramose.

\section{Escuaroides rosacea, Busk.}

Plate XLVII. figs. 5-9.

Escilara rosacea, Busk, Ann. N. H. ser. 2, xviii. 33, pl. i. fig. 4 : Norman, Quart. Journ. Micr. Sc. (n. s.) viii. 9, pl. vi. figs. 10-12.

Escunardes rosıcen, Smitt, OEfv. K. Vet.-Ak. Förh. 1867, Biliang, 25 and 161, pl. xxvi. figs. 155-159.

Zoarium composed of a short stem and a number of compressed foliaceous branches, divided into shallow dilated

- The namo originated with Milne-Edwards. 
lobes, and more or less curved or contorted; white or of a delicate rose-colour. Zocecia ovatc, slightly convex, walls thick and dense, surface granulated; primary orifice simple, semielliptical, on a level with the surface of thc zoarium; secondary aperture arched above, with a rather deep and narrow sinus on the lower margin, immersed; an avicularium on one side of the sinus, with a scmicircular mandible. Oøcia hemispherical, granulated.

Height from $\frac{1}{2}$ to $\frac{3}{4}$ incll.

Habitat. On stones and shells \&c., from moderate depths to deep water.

Localities. Loch Fyne, on Pecten opercularis (A. M. N.) : Orkney (Busk) : off Shetland, 80-100 fathoms (J. Gwyn Jeffreys, fide Peach).

Geographical Distribution. Finmark, on Balanus, Rhynchonella, Ptilota plumosa (Lovén) : Spitzbergen, 20 fathoms (Malmgren) : Norway (M'Andrew) : St. George's Bank, lat. $42^{\circ} 56^{\prime} \cdot 5 \mathrm{~N}$, long. $64^{\circ} 51^{\prime} \cdot 3 \mathrm{~W}$. (Smith and Harger).

E. rosacea is generally of small size, not much cxceeding half an inch in height, and possesses a rery characteristic habit. A short stem rises from a small incrusting mass of cells; and this divides irregularly into a number of foliaceous, flattened, rather thick branches, variously curved and twistcd, and terminating above in short lobes, which cxpand towards their cxtrcmity. Young specimens consist of a simple cxpansion cleft above into two lobes, and arc very delicately tinted. Possibly the colour may be dependent on age. Smitt describes his Norwegian specimens as glossy white.

The cells are very slightly convex; and the boundaries between them are almost obliterated in the older portions of the colony by the grcat overgrowth of calcareous 
matter. At the extremity of the branches they are somewhat prominent, regularly oval and distinctly separated. In this portion of the zoarium we find the primary orifice, which is perfectly simple, without any trace of sinus and on a level with the surface, instead of being, as it is in later stages of growth, decply immersed. The characteristic aperture of the species, with the marginal sinus, is altogether a secondary formation, which is developed as calcification proceeds. The avicularium is connected with the secondary orifice, and in the first instance is placed on the surface, outside it and slightly overhanging it, close to the sinus*. But ultimately it is inclosed by the accretion of stony matter on the front of the cell, and lies completely within the wall which has grown up around the mouth. The various stages in this curious history may be traced amongst the cells occupying the tips or growing portions of the branches $\dagger$.

A striking feature of the species is the degree in which the walls of the zoœcia are thickencd by the accretion of calcareous matter, and the (apparent) rapidity with which the process goes on. As a consequence the build of the adult zoarium is solid and massive.

In some cases numerous circular avicularia are distributed irregularly over the cells, at times slightly elevated, at times subimmersed. In the latter condition they are no doubt being enveloped by the calcareous crust, and would probably have disappeared altogether after a time. I believe that in other instances the non-occurrence of these organs, where they are usually present, may be due to a similar cause.

* It is so represented in Alder's figures of the cells accompanying Norman's description of the species (Quart. Journ. Micr. Sc. l.c. pl. vi. figs. I1, 12). These figures are taken from cells in which the secondary orifice has been recently developed.

+ They have been accurately described by Smitt (l. c.). 


\title{
Escharoides quincuncialis, Norman.
}

\author{
Plate XV. fig. 7.
}

Eschara quiscuscialis, Norman, Hebridean Polyz., Rep. Brit. Assoc. for 1866 (1867), 204; Quart. Journ. Micr. Sc. (n. B.) viii. 10, pl. vii. figs. 1-3.

Zoarium cylindrical, smooth, polished. Zooecia in linear series, disposed quincuncially round an imaginary axis, almost confluent, flat or slightly depressed below, the oral region mammæform; orifice (adult) rounded above, usually with a sinus, placed towards one side on its lower margin, and a small and inconspicuous avicularium close to it; the peristome raised and thickened. Oxcia rounded, subimmersed, with an arched space in front, filled in by less highly calcified material, and sometimes perforated, closely united to the raised peristome, and forming with it elongated mamillary risings on the upper portion of the cell.

Locality. Dredged in deep water in the Minch (A. M. N.).

The specific character is founded on the fragment, "not more than a quarter of an inch long," which was obtained in the Hebrides by Messrs. Jeffrcys and Norman. So minute a specimen does not afford the means of studying the various stages in the development of the zoøcium; and the diagnosis must be accepted subject to any corrections which a more thorough study of the species may supply. An examination of the few marginal cells available for the purpose shows that, in the earlier stages of growth, the minute avicularium is borne on a short rostriform elevation, placed a little towards one side of the primary aperture. At this point the raised and thickened peristome, which is so marked a characteristic of the adult, is not formed; when developed it seems to 
inclose the rostrum, which is now within the (secondary) aperture. The cells are disposed in longitudinal lines; and each series alternates with the next; so that the plan of arrangement over the surface of the zoarium is quincuncial. They are divided by a very slight depression, and have almost the appearance of being confluent. The surface is flattish; and the raised and somewhat swollen and massive peristome, with the ovicell to which it is united, forms a rather large ovoid mamillary rising at the top of each cell. This is the most striking feature of the species. The ovicell is small and subimmersed; and there is always on the front of it a depressed area, which is arched above, and filled in by some slighter and probably membrano-calcareous material. The surface of the zoarium is perfectly smooth, entire, and glossy.

\section{Genus SMITTIA, Hincks.}

Der. Named in honour of Prof. F. A. Smitt.

Eschara (part.), auctt.

Berexicea (part.), Johnston.

Lepralia (part.), Johnston: Busk : \&c.

Escharella, Smitt (as limited in his paper on Bryozoa from Nova Zembla, CEfv. K. Vet.-Ak. Förh. 1878: not Escharella of Gray or D'Orbigny).

Sxiтria, Hincks, Ann. N. H. February 1879.

Generic Character.-Zoocia with the primary orifice suborbicular, the lower margin entire and dentate; peristome elevated and forming a secondary orifice, which is channelled in front; generally an avicularium below the sinus. ZOARIUM (in British species) either incrusting, or erect and foliaceous, the cells in a single or double layer.

For this very natural and well-defined group Smitt has 
adopted the name Escharella, first introduced by Gray, and aftcrwards employed in a totally different sense by D'Orbigny, for a form which he made the type of a family, the Escharellida. Smitt himself has not been very constant in his mode of applying the namc, having first given it to a somewhat heterogeneous collection of species and afterwards to a mere section of it.

It seems undesirable that terms which have been thus bandied about until they have becn emptied of all fixed meaning should be retained; and I have great pleasure in substituting for this questionable name another which commemorates one of the most able workers in this department of zoology.

The cardinal character of this genus is the elevated secondary orifice, produced and channelled in front. The dentate lower margin is common to it and the following genera. They also agree in having a raised peristome, though in the present group it forms a perfect secondary mouth; whilst in Phylactella it only incloses the primary opening in front and at the sides, and in Mucronella takes the form of a mucronate process on the lower lip.

Smittia Landsorovir, Johnston.

Plate XLVIII. figs. 6-9.

Lepralia Laxdsborovin, Johnst. B. Z. ed. 2, 310, pl. liv. fig. 9: Busk, B.M. Cat. ii. 66, pl. Imxvi. fig. 1, and pl. cii. fig. 1 (referred to $L$. reticulata): Hincks, Quart. Journ. Micr. Sc. viii. 277 ; Deron Cat., Ann. N. H. sor. 3. ix. 200 (40 sep.).

Escuara Lasdeborovi, Alder, Quart. Journ. Mict. So. n. s. iv. 105, pl. iv. figs. 1-3.

Escinara rolucea, var., Alder, North. Cat., Trans. Tymes. F. O. iii. 151.

Leprali a crystallixa, Aorman, Rep. Brit. Assoc. 1866, 204.

Egcharela Laxdserovil (part.), Smitt, CEfr. K. Vot.-Ak. Förh. 1867, 
Bihang, 12 and 92, pl. xxiv. fig. 63; Floridan Bryoz. pt. ii. 60 , pl. x. figs. 201, 202*.

? Escharella porifera, Smitt, forma mususcula and forma majuscula, L. c. Krit. Förteckn. 9, 73, and 74, pl. xxiv. figs. 33-35 and 36-38. Escuarella pektesa, Smitt (=E. porifera), Gefv. K. Vetensk.-Ak. Förh. 1878 , no. 3,21 .

Zocecia ovate or rhombic, or elongate and somewhat rectangular, in linear series, alternate, separated by raised lines; walls thin and glassy, punctured round the margin or over the entire surface; primary orifice suborbicular, or slightly subquadrangular, a prominent tooth within the lower margin, and a minute denticle on each side of it; peristome raised, especially in the fertile cells, thin, cleft in front into a narrow, spoutlike sinus, partially inclosing a small rounded avicularium; below it usually a mamillary rising. Occia globose or ovate, prominent, punctured, frequently a large, raised, spatulate avicularium placed transversely on each side or on one only.

Colonies spreading in large subcircular patches, silvery when fresh, and often of a reddish colour; or rising into thin foliaceous expansions, "anastomosing irregularly, and undulated on the margin."

The erect form attains a height of 2 inches.

Form a (crystallina, Norman) (Plate XXXVI. fig. 2). Zoceia small, lozenge-shaped, rather convex, not very regularly arranged, surrounded by inconspicuous lines, white and silvery, surface covered throughout with round punctures; orifice (secondary) triangular, peristome much raised at the sides, in front deeply cleft into a channelled sinus, and immediately below it a small avicularium, with rounded mandible, pointing downwards; oral spines five (rarely present); a central tooth on the lower (primary) margin and two lateral denticles. Oxcia globose, prominent, punctured.

Colonies forming small silvery-white patches.

* Of Smitt's figures of Escharella Landsborovii in bis 'Catalogue,' only one (fig. 63) seems to me referable to the present species. 
Form $\beta$ (?porifera, Smitt). Zocecia short-ovate or rhombic, flattish, very thiekly punetured over the entire surfaee; orifice (seeondary) suborbicular, with two minute lateral dentieles; central tooth wanting; peristome very slightly elevated; suboral avicularium subcircular or oval. Occia rounded, not hooded, obseurely punctured; spatulate avicularia none (?). (Plate. XXXVI. fig. 1.)

Fig. 15.

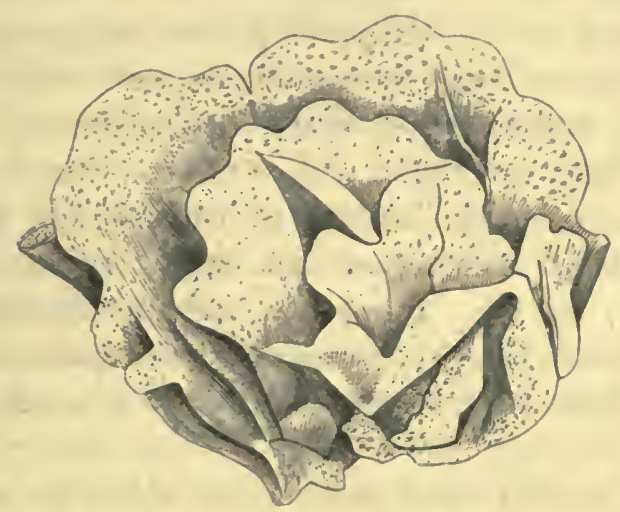

Smittia Landsborovii.

RANGE of Variation. The cell in the typical form is usually elongate, often somewhat reetangular, with a flattish surfaee and thin walls; but it is also not unfrequently, within the limits of one and the same colony, short and ovate, or rhomboid. The peristome is more or less developed: sometimes it forms an elevated wall round the mouth, which is cleft in front into a very deep fissure or sinus; in other eases it is very slightly raised. These differenees affeet the form of the seeondary orifice.

The primary aperture is to some extent subquadrangular ("rotundato-quadrangularis"); the secondary orifice, 
formed by the clevation of the peristome, is more or less triangular, or (occasionally) almost orbicular. The ccllwall is either punctured round the margin only, the central portion remaining entire, or is thickly covered over the whole extent with circular pores. The median avicularium scems to bc constant; but the largc spatulate form is in most cases rarcly developed, and always in connexion with the ovicell.

The differences in the mode of growth are similar to those which wc find in Lepralia foliacea and other spccies. The crustaceous habit seems to be the prevalent one. On the south-western coasts, where S. Landsborovii is abundant, I have never met with it in the erect foliaceous state; but in certain localities it rises into free lamellate fronds, which anastomose and form coral-like masses (woodcut, fig. 15). It assumes both the Escharinc and Hemescharine habit; and under the older system of classification three genera would have about an equal right to claim it.

These are the chief variations to which the species is liable, apart from the superficial changes dependent on age and locality.

Lepratia crystallina, Norman, is a small and very delicate variety of the present species, distinguished by its highly developed peristome and produced triangular secondary orifice, and by its bright and hyaline appearance. It is a deep-water form.

The variety porifera, Smitt, is characterized by its short ovatc ccll with a thickly punctured surface, its slightly developed peristome, and suborbicular secondary orifice, and by the total absence of the central tooth. The ovicell also seems to be smaller than that of the normal S. Landsborovii; and the spatulate avicularia are, I believe, always wanting. Smitt, in his latest paper 
(on Polyzoa from Nova Zembla), identifies his Escharella porifera with Lepralia pertusa, Busk; but the latter, which seems to be littlc known in the North, is certainly referable to another group.

I have had much difficulty in unravelling the synonymy of this species, and suspect that the Scandinavian naturalists have associated with it some northern varicties which are not known on our coasts. I should refer all the forms assigned by Smitt to his $E$. porifera to S. Landsborovii, with the exception of those represcnted in his plate xxiv. figs. 40,41, whieh I cannot identify, and the one which he names forma edentata. This seems to be a distinct species; and I have elsewhere characterized it as Lepralia reticulato-punctata.

Habitat. On shells, stones, \&c., from moderate depths to deep water.

Localities. South Devon; Cornwall, 30 fathoms, on Sertularia abietina; off the Great Orme's Head (the erect form) ; Guernsey (T. H.) : Hastings (Miss Jelly) : Scarborough (Bean) : north coast of Northumberland, erect (Embleton) : Ayrshire (D. L.): Peterhead, rare (C.W. P.): Shetland, very rare; the Lepralian state on a stone from 170 fathoms (A. M. N.) : Antrim (Hyndman) : Birterbuy Bay (G. S. B.). Var. porifera. South Devon (T. H.). Var. crystallina. The Minch; Shetland, 80-140 fathoms (A. M. N.) : off the coast of Antrim (Hyndman).

Geographical Distribution. Durban, Natal, on oyster shclls (W. Oates): Australia (T. H.)*: Florida, 176 fathoms (Pourtales): Grcenland (North-German Pol. Exped.) : Arctic Seas (Smitt). Var. porifera. Davis Strait, off Frederickshaab, 100 fathoms (Wallich). Var.

- In the Australian spociunon, which I have examined, the cells are orate. lined round, thickls punctured orer the entire surface, and with three or four marginal spines. 
crystallina. Greenland, lat. $66^{\circ} 59^{\prime}$ N., long. $55^{\circ} 27^{\prime}$ W., 57 fathoms ('Valorous' dredgings): Bergen (A. M. N).

Range in Time. Var. crystallina, Scotch Glacial deposits (Geikie).

Smittia reticulata, J. Macgillivray.

Plate XLVIII. figs. 1-5.

Lepralia Reticulata, Macgill. Ann. N. H. ix. 467 : Johnst. Br. Z. ed. 2, 317, pl. Iv. fig. 10: Busk, B.M. Cat. ii. 66, pl. xc. fig. 1, and rcii. figs. 1, 2 (not pl. cii. fig. 1).

Escharina rimulata, D'Orb. Voy. d. l'Amér. mér. Polypiers, 15, pl. vii. figs. 1-4 (fide Smitt).

Reptescharella rimulata, id. Pal. franç. terr. crét. v. 465.

Escharelda Legentiliı * forma typica, Smitt, CEfvers. K. Vet.-Akad. Förb. 1867, Bihang, 10 and 81, pl. xxiv. figs. 50-52.

Zoccia ovate-elongate, in linear series, separated by raised lines, punctured or strongly areolated round the margin, smooth or slightly roughened, and somewhat raised in the centre; orifice orbicular, with a thin raised margin and a deeply channelled sinus in the lower lip, three denticles within, the central one the largest; immediately below the sinus a large avicularium, with acute mandible pointing downwards, sometimes projecting and sometimes immersed; marginal spines three. Oœcia semicircular or globose, prominent, punctured, the elevated peristome in front giving them a hooded appearance.

Colonies spreading irregularly, and often of considerable size, silvery and bright when fresh.

The primary cell seems only to differ from the rest in size.

Range of Variation. S. reticulata exhibits many diffe-

* I do not follow Smitt in adopting Audouin's name, because it seems to me impossible to say with any certainty that Savigny's figure represents the present species, and there is no description to appeal to. 
rences of appearance, dependent upon age, locality, \&cc.; but there is very little variability in important characters. Sometimes the zoœcia are margined by a row of circular pores; sometimes they are very prettily areolated round the edge*

Commonly the avicularia are elevated, and project in front of the lower lip; but in one of the best-marked varieties they are immersed and of smaller size than usual, the cells are flat, punctured round the sides, and of dense texture; the margin of the orifice is but slightly raised; and the occium is closely united to the cell above, and not so prominent as in the common form (Plate XLVIII. fig. 2).

A curious monstrosity has occurred to me, in which two cells have but a single ovicell between them, which is of grcat breadth, and overarches the two openings. The cells are somewhat narrowed; and the avicularia are turned a little to one side (Plate XLVIII. fig. 3).

Habitat. On shells, stones, corals, \&c., chiefly from deep water.

Localiries. Guernsey; South Devon; Cornwall, especially on Pinna, from 40-60 fathoms (T. H.) †: Norfolk (Lieut. Thomas): Northumberland, on shells from deep water, not rare (Alder): Aberdeen (Macgillivray): St. Andrews, not uncommon in the siphons and inside the mouth of Fusus antiquus, and on Cardium, from deep water (Dr. M'Intosh) : Loch Fyne (Lady Emma Campbell): Wick and Peterhead (C. W. P.) : Shetland, rare, 80 fathoms (A.M.N.) : Belfast Bay, decp water (W. T.) :

- This difference is probably dependent upon age. The youngest cells are perfectly smootb, the walls extremely thin, and perforated round the edge by a number of circular pores.

+ One of the most abundant species on the Cornish Pinne, from 60 fathoms, forming exquisite patches on the interior surface of the shell. 
coast of Antrim, 47 fathoms (Swanston): Birterbuy Bay (A. M. N.) : \&c.

Geographical Distribution. Roscoff (Joliet): Charente-Inférieure (Fischer) : Ægean Sea (E. Forbes): Adriatic (Hcller) : Bergen (A. M. N.) : Bahusia and Southern Norway, chiefly in great depths, 200-300 fathoms; in moderate depths rather rarc (Smitt): Falkland Islands (D’Orbigny): New Zealand (F. W. Hutton).

Smittia Afrinis, Hincks.

Plate XLIX. figs. 10, 11.

Lepralia arfinis, Hincks, Devon and Cornw. Cat., Ann. N. H. ser. 3, ix. 206, pl. sii. fig. 2 (46 sep.).

Zocecia broad-ovate, distinct, moderately convex, separated by lines; surface smooth (in the young cells), minutely punctured; orifice orbicular, with a thin, raised peristome, channelled in front, three denticles within, the central one the largest; immediately below the inferior margin, to which it is attached, an avicularium, placed more or less transverscly, with pointed mandible. Oœcia unknown.

Colony forming a circular patch.

Habitat. On shell.

Locality. Start Bay, South Devon (T. H.).

As only a single specimen has occurred, it is impossible to decide how far this is a permanent, well-established form. Its nearest ally is $S$. reticulata, from which it is distinguished chiefly by the position of the avicularium, which, instead of projecting longitudinally bclow the orifice, and pointing straight downwards, is placed trans- 
versely, or somewhat obliquely across, in front of the lower margin, to which it is attached. It is so placed as to fill up the sinus in the peristome ; in front it is tilted up, and the mandible is pointed obliquely towards the side.

$S$. affinis also differs from $S$. reticulata in having a broader and shorter and less convex cell, and in having the whole surfacc rather thickly punctured. It may possibly be an abnormal condition of the last-named species; but looking to the marked difference in the general character of the zoccia, and the very peculiar position of the avicularium, which is constant over the whole colony in the only specimen that has come under my notice, I am inclined to give it provisionally specific rank.

In support of this view it may be remarked that the position of the avicularium in S. reticulata is not liable to variation as it is in some species. On the contrary, it is remarkably constant, and I do not remember to have seen any approach to the peculiarity which distinguishes the present species.

\section{Smittia cheilostoma, Manzoni.}

\section{Plate XLII. figa. 7, 8.}

Lepralia cueilostoma, Manzoni, Bryoz. foss. Ital., Contrib. 3, 13, pl. iv. fig. 22 (Sitzb, k. Akad. d. Wissensch. 1. Abth. Dec-Heft, 1869).

Zocecia ovate or rhombic, very slightly convex, usually separated by raised lines, quincuncially disposed, the series radiating from a common centre; surface covered with punctures; orifice (primary) suborbicular, with a hammer-shaped denticlc on the lower margin, surrounded by a much raised peristomc, with a decp cleft or sinus in front; avicularia none. Oœcia de- 
pressed, closely united to the cell above, rounded, slightly elongated transversely (almost scmicircular), punctured, with a subgranular border round the base. Colonies forming subcircular patches of a decp red colour.

Habitat. On shells, stones, \&c., from shallow to deep water (60 fathoms).

Localities. Guernsey, abundant; South Devon; Cornwall, deep water (T. H.) : Hastings (Miss Jelly) : west coast of Ireland (A. M. N.).

Range in Trme. Italian Pliocene (Manzoni).

In this species the peristome is much elevatcd, and the secondary orifice is suborbicular above, slightly compressed or flattened at the top, and below is produced into a deep notch or sinus. The surface is uniformly and thickly punctured. The ovicell is generally much depressed, and is inclosed round the edge by a narrow belt of granular crust. The peristome is carried across the front of it.

When young the cells are semitransparent and glossy; but with age the zoarium becomes coarse in appearance, and of a dull whitish colour.

A variety occurs of delicate texture, and with very minute puncta; but otherwise the species is very constant in character.

Smittia marmorea, Hincks.

Plate XXXVI. figs. 3-5.

Lepralu marmorea, Hincks, Ann. N. H. Sept. 1877, 214.

Zocecia ovate, short and rather broad, somewhat elevated towards the mouth, disposed in lines, with a row of 
rather large punctures round the border; surface coarsely granular; orifice suborbicular, with a looplike sinus on the lower margin; peristome raised, not thickened, a very broad plate or denticle set deeply within the mouth; a little below the orifice an elongate avicularium, usually immersed, with a pointed mandible directed downwards. Oœcia globose, punctured, immersed in the older cells, with a narrow raised border. round the base.

Habitat. On stone and shells.

Localities. Cornwall, probably (T. H.) : Guernsey (A. M. N.)

The walls of the cells are thick; and the surface, which is covered with large granules, has a somewhat polished and marble-like appearance. The cells are moderately convex, elevated towards the mouth, and regularly punctured round the margin. The peristome is raised, especially in front, where it is hollowed into a rather large loop-like sinus. The avicularium is immersed and inconspicuous; it is occasionally absent. The young cells are perfectly smooth, and with the surface entire.

S. marmorea and S. cheilostoma are kindred forms, having many features in common, but still exhibiting differences of such a kind as entitle them to be accounted distinct. In the former the cell-wall seems never to be punctured, except round the margin, where there is a very conspicuous line of perforations: the surface is coarsely granular ; in S. cheilostoma it is uniformly covered with pores over its entire extent, and thcre is no special row of them round the edge. The cell of $S$. marmorea in its earliest stages is destitute of punctures; so that the difference between the two forms in this respect is not due to mere age and calcification. In the latter the wall of 
the cell rises markedly towards the mouth, and the front of the peristome is thus elevatcd, while the upper margin appears depressed. In S. cheilostoma thc surface is level and uniform, and the margin as much elevated above as in front. That species is always destitutc of avicularia; whilst in $S$. marmorea there is usually one below the orifice, occupying much the samc position as in S. reticulata. There are also differences in the denticle on the lower margin, which in the present species assumes the form of a very broad plate. S. marmorea, so far as I know, is destitute of the deep-red colour which is so characteristic of its ally.

Apart from these divergences, which in the aggregate are not unimportant, there is a difference in general appearance which can hardly be formulated.

I have only seen a few specimens of $S$. marmorea; and possibly a larger series might show an intermingling of characters; but at present I hold the two forms to be distinct.

\section{Smittia bella, Busk.}

Plate XLII. figs. 9, 10.

Leprabia bellaA, Busk, Quart. Journ. Mier. So. viii. (1860), 144, pl. xxvii. fig. 2 (not $L$. bella, Norman, Shetland Polyz., Rep. Brit. Assoc. 1868,306 , which is a var. of Porella concinna).

Zocecia ovate, punctured; aperture orbicular, with a spoutlike sinus below, and within it a large bifid denticle; peristome raised, often thickened. Oøcia subglobose, punctured.

Habitat. On shells.

Locality. Shetland (Barlee). 
I only know this species from Busk's deseription and figures, and ean add nothing to them. It secms to be nearly relatcd to $S$. cheilostoma.

Smittia trispinosa, Johnston.

Plate XIIX. figs. 1-8.

Discopora trispivosa, Johnst. Ed. Phil. Journ. xiii. 322.

Berexicea trispinosa, id. Trans. Newc. Soc. ii. 268.

Lepralia tristivosa, $i d$. B. Z. ed. 2, 324, pl. lvii. fig. 7 : Busk, B.M. Cat. ii. 70 , pl. lexxv. figs. 1, 2, pl. xeviii., pl. cii. fig. 2: Hincks, Greenland Polyz., Ann. N. H. Jan. 1877, 100, pl. xi. fig. 1.

Lepralia yariolosa, var. $a$, Johnst. B. Z. ed. 2, 317, pl. 1v. fig. 8.

Escrarelida Jacotisi, Smitt, forma ramellosa, and forma trpics, loc. cit. Krit. Fört. iv. 11 \& 86, pl. xxiv. figs. 53-57.

? Escharella Jacotini, Smitt, Flor. Bryoz. pt. ii. 59, pl. x. fig. 199.

Lepralia Jefrreysi (=var. a), Norman, Prelim. Rep. 'Valorous' Cruise, Proc. Roy. Soc. no. 173 (1876), 208.

Zocecia ovate or elongate-ovate, sometimes almost reetangular, disposed in linear series or quineuncially, subgranular, separated by raised lines, and punctured round the edge; orifice suborbieular; peristome thin, more or less raised, usually produced in front into a spout-like sinus, a denticle within the lower margin; oral spines 2-4; frequently a large avicularium on one side, a little below the orifice, mandible acute and (usually) direeted upwards; oceasionally a smaller oval avicularium, on one or both sides of the orificc, with rounded mandible, pointing downwards. Oæcia ample, globose, united to the eell above, somewhat flattened in front, usually with two or three large pyriform punctures.

Colonies forming large yellow erusts.

Var. a (Jeffreysi, Norman). Zoccia rectangular, smooth or subgranular, surface much depressed; peristome not raised, dentiele very eonspicuous; oval avicularia irregularly distributed over the surface, sometimes numerous; pointed avicularia often rare, and of small size. 
Range of Variation. Speeimens of this species exhibit very striking diversities ill appearanee; and there is also a considerable amount of variability in eertain eharacters. The zoceia present two very distinet shapes, being in some eases ovate and moderately convex, in others rectangular, with a flat surface. The orifice wears a very different appearance aceording to the degree in which the peristome is developed. In the young cell it is not at all elevated; the mouth is a simple, suborbicular opening, with a flat rim, arehed above, almost straight below, and slightly eompressed laterally. In this eondition, which seems to be permanent in the Aretic varicty $a$, the denticle on the lower lip is a conspicuous feature. Usually the peristome rises in the adult eell and forms a thin wall round the mouth, which is prolonged in front into a kind of spout. In the fertile eells, this raised border is much developed; and in some cases it forms a continuous ring round the mouth, in front of the ovicell. The oral spines vary in number from two to four.

As usual, the avicularium is the most ineonstant member of the colony. It presents itself under two forms : one of these (and the only one which has been noticed by previous writers) is of large size, at times gigantic, clongate, with a triangular mandible; the other is much smaller, oval, with a rounded mandible. In their position and direetion there is no eonstancy; but the larger form seems to be most eommonly plaeed close to the mouth, on one side of the eentral sinus, with the mandible direeted upwards, while the smaller is usually developed near the top of the cell, on one side of the mouth, or on both sides, with the mandible pointing downwards; but the exceptions are numcrous. The large avieularia, which are often wanting altogether, are generally single; but sometimes two oceur on the same cell, in very variable positions. 
The small oval avieularia are equally inconstant, and are often distributed irregularly over the surfaee of the eells. There is sometimes an amazing profusion of them.

When very old, the walls of the eells are much thickened, overlaid with a dense crust, and eoarsely granulated; and in this eondition some of the familiar features of the species are almost obliterated.

Habitax. On stones, shells, \&c., from shallow water to great depths.

Localities. One of the eommonest of our British speeies. Cornwall, 60 fathoms, inerusting Pinne; S. Devon, very eommon; Isle of Man; Guernsey, in large masses on shell (T. H.) : Hastings (Miss Jelly) : Berwick, deep water (Johnst.) : St. Andrews (Dr. M'Intosh) : Hebrides; Shetland, 170 fathoms (Norman): Birterbuy Bay (G. S. Brady): \&c. Var. a. Dogger Bank (T. H.).

Geograpiical Distribution. Norway (Lilljeborg): Bahusia, shells, in great depths (Lovén): Aretic regions, on Rhynchonella (Torell) : Nova Zembla (west), 30-60 fathoms; Kara sea (Stuxberg \& Théel) : Gaspé, Gulf of St. Lawrence, about 30 fathoms (Dawson) : Anticosti and Mingan Islands (Paekard) : Mazatlan (P. P. Carpenter) : Florida (Pourtales) : Cape Horn, 40 fathoms (Darwin) : Aden (W. Oates) : Adriatic (Grube). Var. a. Greenland, lat. $69^{\circ} 31^{\prime} \mathrm{N}$., long. $56^{\circ} \mathrm{l}^{\prime} \mathrm{W}$., 100 fathoms ('Valorous' dredgings) : off Frederiekshaab, Davis Straits, 100 fathoms; Reykjavik Harbour, 15-20 fms. (Wallieh).

Range in Time. Postplioeene, Canada (Dawson).

I do not follow Prof. Smitt in substituting Audouin's specifie designation for Jolnnston's well-known name. Such a course does not seem to be ealled for by a regard to seientifie law, nor would it promote seientifie interests. Savigny's figure may possibly be intended as a represen- 
tation of the present species; but it is so cntirely wanting in character, and fails so completcly to give the striking fcaturcs of $S$. trispinosa, that it is practically useless for the purposc of identification; and as it is unaccompanied by a diagnosis, I am unable to sce that it gives any claim to the name with which it is associated.

\section{Genus PHYLACTELLA, Hincks.}

\section{Der. From $\phi v \lambda a x r \delta s$, fortified.}

Lepralia (part.), auctt. Alrsidota (sp.), Busk.

Generic Character.-Zocecia with the primary orifice more or less semicircular, the lower margin usually dentate; peristome much elevated, not produced or channelled in front. No avicularia. Zoarium (in British species) incrusting.

THIS genus is instituted for two or three species which seem to lie outside the preceding, though nearly related to it. P. labrosa, with its triplet of denticles, its elevated pcristomc, and its porous surface, exhibits much affinity with such forms as S. Landsborovii. P. eximia agrees with it in most points; but the pores are only present round the margin. In $P$. collaris both pores and denticles have disappeared. The chief distinction betwecn this genus and the last lies in the character of its raised peristome, which in Smittia contracts in front into a channelled sinus, whilst in Phylactella it is entire. The primary orifice in the latter is almost semicircular. 
Phylactella labrosa, Busk.

Plate XLIII. figs. 1, 2.

Lepralia labrosa, Busk, B.M. Cat. ii. 82, pl. xcii. figs. 1-3: Hincks, Der. Cat., Ann. N. H. ser. 3, ix. 204 (44 sep.): Norman, Shetland Polyz., Rep. Brit. Assoc. 1868, 308.

alrsidota labrosa, Busk, Crag Polyz. 26, pl, xxii. fig. 7.

Phylactella labrosa, Hincks, Ann. N. H. Feb. 1879, 161.

Zoceia ovatc, distinct, disposed in lines, punctured over the entire surface; orifice almost semicircular, with a square-topped tooth on the lower margin, and on each side of it a minute, sharply-pointed dentiele; peristome much elevated, thickened, expanded, forming a wall round the front and sides of the mouth. Oxcia small, rounded, broader than long, recumbent, punctured.

Primary cell small, ovate, perfectly smooth; aperture orbicular, with a smooth, flat border in front, and surrounded by a few rather tall and slender spines.

Colonies consisting of single or double series of cells, branching irregularly from a eommon centre, where a number are massed together.

Habitat. Usually on old shells, from rather deep water.

Localities. Off the Copeland Islands, Belfast Bay, deep water (W. T.) : Antrim, decp water, rather plentiful (Hyndman): Shetland, scarce, 40 fathoms (A. M. N.) : Oban; South Deron, not common (T. H.) : Hastings (Miss Jelly): Wiek; Cornwall, off Fowey, and 5 miles off the Deadman (C. W. P.).

Distribution in Time. Red Crag, on shell (Searles Wood).

There is little variability in this very pretty specics; the eharacters arc marked and stable. The surface of both the cell and oricell is thickly and regularly punctured. 
The mass of zoceia, from which the lincar scrics are given off, is sometimes of considerable sizc ; in other eases branching eommences at once, and the colony consists of a very small nueleus, surrounded by long, straggling lines of cells.

\section{Pilylactella collaris, Norman.}

Plate XLIII. fig. 3.

Lepralia collaris, Norman; Rep. Brit. Assoc. 1866, 204.

Phylactella collaris, Hincks, Ann. N. H. Feb. 1879, 161.

Zoccia ovate, small, erowded, eonvex, arranged in regular radiating lines, smooth, or subgranular; orifice suborbicular, arehed above, slightly truneate below; peristome elevated into a broad, frill-like border, expanded in front, which surrounds the sides and lower margin. Oøcia somewhat reniform, depressed, punctured.

Colonies small subcireular patches, of a brownish colour.

Haвiтat. On shells, \&e., from shallow to deep water.

Localities. The Minch, Hebrides; Shetland, searee, 80-100 fathoms; Guernsey (A. M. N.) : Torbay; Isle of Man (T. H.): Hastings (Miss Jelly) : off the Maiden Lighthouses, Antrim, 72 fathoms (Swanston).

Nearly related to $P$. labrosa, Busk, from which it differs in the absence of the perforated eell-wall, and the triplet of marginal dentieles. It also shows no tendency to the dendritie habit of growth. The eells are arranged with much regularity in linear scrics, which radiate from a common centre. In eertain states the punetures on the oviccll are almost obliterated. 


\section{Puylactella eximia, Hineks.}

Plate XLIX. fig. 11.

Leprazia zxism, Hincks, Proc. Dubl. Unir. Zool. \& Bot. Assoc. ii. pt. i. 75, pl. iii. figs. 3, $3 a$; Quart. Journ. Micr. Sc., Zooph. viii. 276, pl. xxx. figs. 3, $3 a$ : Peach, Journ. Roy. Inst. Cornwall, no. xriii. (1876), 2 (sep.), fig. 4 .

Puylactella eximia, Hincks, Ann. N. II. Feb. 1879, 161.

Zoccia ovate, distinet, moderately eonvex, punctured, and with an ineonspieuous line round the edge; texture dense, surface minutely granular ; primary orifice almost semieireular, with a rounded tooth on the lower margin, and two small lateral dentieles, surrounded, exeept above, by an elevated peristome, which rises on each side into a broad, somewhat triangular expansion. Oxcia prominent, globose; surface smooth, eovered with raised punctures, silvery when fresh.

Colonies growing in large spreading erusts, with a lobate margin.

Habitat. On shell and stone from deep water.

Localities. Coast of Antrim (Hyndman): off the Deadman (C. W. P.) : Shetland (A. M. N.).

The cells are large and very distinet in the Antrim speeimens; the ovieells are prominent; and the mode of growth is decidedly lobulate. In the single specimen which I have seen from Shetland the granular erust seems to be more fully developed, the ovicells are subimmersed, being partially invested by it, and the sutures between the eells are less marked. The seeondary mouth is somewhat quadrate in shape; and the wall-like peristome, which forms it, slopes outwards in front, and at the sides usually rises into broad expansions, pointed above, and often bending over the aperture. The marginal punetures are frequently wanting. The ovieell is very smooth and silvery, and the walls of the eell are thickly and minutely granulated. 


\section{iii. With a mucronate peristome.}

\section{Genus MUCRONELLA, Hincks.}

Der. From mucro, a point.

Berevicea (part.), Fleming.

Lepralia (part.), Johnston: Busk : \&c.

Escharella, Gray.

Discopora (part.), Smitt.

Generic Cimaracter.-Zocecia with a suborbicular or semicircular orifice; the peristome elevated in front into a more or less prominent mucro. Zoarium (in the British species) incrusting.

Turs genus is equivalent in part to the Discopora of Smitt, but not of Fleming, who originated the name for a speeies belonging to a totally different seetion of the Polyzoa (the Cyclostomata), with which it is still conneeted in the slightly modified form Discoporella. In the British species the lower margin of the orifice is almost universally dentate.

a. Without avicularia.

Mucronella Peachi, Johnston.

Plate L. figs. 1-5, and Plate LI. figs. 1, 2.

Lepralia Peachi, Johnst. B. Z. ed. 2, 315, pl. 1v. figs. 5, 6: Gray, Br.

Radiata, 118: Busk, B.M. Cat. ii. 77, pl. lxxxii. fig. 4, pl.

хci. figs. 5, 6, pl. xcrii.; Crag Pol. 48, pl. v. figs. 6, 7, 8,

pl. vi. fig. 4; (var. labiosa) Quart. Journ. Micr. Sc. iv. 309,

pl. x. figs. 5, 6: Heller, Bryoz. d. Adriat. Meer. 32.

Lepralia immersa, Johnst. B. Z. ed. 2, 325, pl. Ivii. fig. 8.

Berenicea imarersa, Flem. Br. An. 533 : Couch, Corn. Faun. pt. iii. 118.

Escuarella imirersa, Gray, Br. Rad. 125.

Discopora coccines, forma Pescm, Smitt, loc. cit. 26 \& 170, pl.xxvii. figs. $164-166, \& 167$ (referred to $L$. ventricosa).

? Discopora esucronata, id. Krit. Förteckn. Eff. \&c., 1871, 1129, pl. xxi. figs. $27,28$. 
Zocecia rhomboid, not separated by deep sutures, generally arranged quineuncially, granular or smooth, punetured or areolated round the margin; orifice suborbieular, longer than broad, well arehed above, with a slightly raised and thickened peristome, which is produeed in front into a pointed mucro, a small bifid denticle within the lower margin, and six slender oral spines. Oacia small, globose, ereet, with two spines in front, on each side.

Colonies forming large irregular patehes of solid texture, which gencrally present a very flat and uniform surface.

Primary cell with somewhat circular aperture, occupying the upper portion of the front surface, surrounded by about nine spines; covering membranous (woodeut, fig. 16).

Fig. 16.

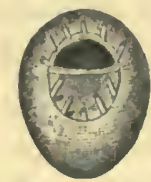

Primary cell.

Var. a (labiosa, Busk). Zocecia ovate, distinet, more decply divided than in the ordinary form, disposed in lines, smooth; orifice mueh raised, the front lip everted and much thickened and produced. (Plate LI. fig. 1.) Var. $\beta$ (octodentata). Zoceia ovate, distinct, convex, smooth, disposed very regularly in linear series; orifice ratler small, with a pointed muero in front and eight marginal spines. Oœcia globose, prominent, set very far back, all the spines in front of it. (Plate IiI. fig. 2.)

Range of Variation. This species presents many diversities of appearanee, due to age and locality; but there seems to be a very moderate amount of variation in the more important eharaeters. In young specimels the eells are smooth and shining, and bristle with their long and slender spines. With age, and in deep-water loealities, the silvery sheen is lost; the eells are thickened, and usually of a dull whitish colour, the surface of the zoarium is flat, the shallow sutures betwien the cells being almost 
obliterated, the arcolation is indistinct, the spines are wanting. In such specimens the conspicuous fcaturc is the slightly everted and projecting lower lip of the aperturc, which shows as a strip of brighter white on the dull uniform surface. The mucro is usually, in such cases, very inconspicuous; but the small bifid dentiele is present, and the stumps of the six spincs may bc traced on the upper margin of the mouth. In this condition M. Peachii is of very frequent occurrence on stones and old shclls from deep watcr. Very grotesque varietics are produced by the growth of the thick granular crust over the primitive cell-wall. Two striking examples are represented in Plate L. figs. 4, 5.

The var. $\beta$ (octodentata) is distinguished by its convex, smooth cclls and by the position of the ovicell behind the numcrous spines. There are commonly eight, oceasionally only six; but, in cither case, the wholc number show in front of the oœcium. This form bears somc resemblance to the Discopora emucronata, described by Smitt from Spitzbergen; but in the Shetland spccimens the mucro is certainly not absent. In other respects the two forms agrcc, and especially in the position of the ovicell behind the numerous spincs. This peculiarity, however, can hardly bc accounted of any great importance; in $M$. ventricosa the oœcium is often sct very far back, so that the whole four spincs are visible in front of it, although commonly only one is to bc scen on each side.

Hавітат. On Laminaria, stones, shells, \&c., from tidemarks to decp water (170 fathoms).

Localities. Universally distributed on our coasts. Var. labiosa. Belfast Bay, deep water (W.T.) : Gucrnsey ('T. H.). Var. octodentata. Shetland (A. M. N.).

Geographical Distribution. Roscoff (Jolict): France, S.W., not common (Fischer): Grecnland (German Pol. 
Exped.): Bahusia, common, on marine plants in the littoral region ehicfly (Smitt): Bergen (A. M. N.) : Marsouin, Gulf of St. Lawrenec (Dawson): Adriatic, rare (Heller).

Range in Trme. Coralline Crag, very abundant (S. Wood): Middle Plioeene beds (Suffolk Crag); Upper Pliocene; Palæolithic (A. Bell) : Seoteh Glacial deposits (Geikie).

\section{Mucronella ventricosa, Hassall.}

Plate L. figs, 6-8.

Lepralia vextricosı, Hass. Ann. N. H. ix. 412 : Johnst. B. Z. ed. 2, 305, pl. liv. fig. 5: Busk, B.M. Cat. ii. 78, pl. $1 \times x \times$ ii. figs. 5, 6, ? pl. Irxiii. fig. 5 (not pl. xci. figs. 5, 6); Crag. Pol. 49, pl. vi. figs. 3 \& 6 : Manzoni, Bryoz. Mediterr. Suppl. Contr. i. 7, pl. iii. fig. 1 .

Discopora coccisea, forma ventricosa (part.), Smitt, 1. c. 26 \& 172, pl. xxvii. fig. 172 (?).

Lepralia arrecta, Reuss, Foss. Bryoz. österreich.-ungarisch. Miocäns, 24, pl. ii. fig. 11.

Zoceia rhomboid or ovate, or subglobose, distinet, convex, divided by deep sutures, eontracted and more or less suberect above, usually disposed very regularly in linear series; surfaee granular, and often traversed by radiating furrows, a single row of punctures round the base ; orifice suborbieular, a large bifid dentiele within the lower margin; peristome raised and thickened, rising in front into a broad, prominent muero, whieh is sometimes bifid; marginal spines four, stout, two on each side. Oxcia globose, elosely united to the cell above, smooth or subgranular, with one or sometimes two spines in front of it, on each side.

Colonies of a greyish-white eolour, often silvery and glistening, forming large crusts, which frequently assume a lobate figure. 
Range of Variation. Like its congener M. Peachii, this species varies much in appearance under different conditions of age and habitat; but the characters are very constant. When old, the cells are of a dead white colour; but in younger states they are bright and glossy. The texture is delicate and somewhat vitreous at first, but becomes coarser and more granulous with age. Except in the earlicst states, the cclls arc almost always more or less granular. The shapc is generally ovate, sometimes rhomboid. The oral extremity is more or less elevated, and the aboral immersed; but this is often by no means a marked eharacter. The number of the spines is very constant; but oecasionally a fifth is interposed between the pairs which oceupy the two sides of the apcrture. The mucro, which is always a striking feature, is at times execcdingly broad and massive, and occasionally bifid. The oøcium is sometimes subimmersed; more commonly it is very prominent; but it is always closely united to the cell above it. Not unfrequently all the spines project in front of the ovicell; but usually only onc on each side is visible.

Навгтат. On stones, shells, \&c., from shallow to deep water.

Localıties. Less eommon perhaps than M. Peachii, but widely distributed. Shetland, 15-170 fathoms; Hebrides (A. M. N.) : Beaufort Dyke, 110-147 fathoms (Capt. Beeehey) : Sana Island (Hyndman): Northumberland and Durham, deep water, rare (Alder): St. Andrews, deep water, not uncommon (Dr. M'Intosh) : Belfast Bay (W. T.) : Dublin Bay ; Burnham, Norfolk (Hassall) : Start Point (Bowerbank): Cornwall, deep water; Guernsey (T. H.) : \&c.

Geographical Distribution. France, S.W., 30-50 fathoms (Fischer) : Mediterranean (Manzoni) : New Zealand (F. W. Hutton): Grcenland, "the most abundant 
Lepralian;" found in all the inshore dredgings (Norman, 'Valorous' dredgings): Nova Zembla, Jugor-seharr, 1014fathoms ; Matotsehkin-seharr, 30-50 fathoms ; Kara sea (Stuxberg \& Théel) : Bergen (A. M. N.) : on the FalmouthLisbon eable, between N. lat. $47^{\circ} 58^{\prime}$ and $47^{\circ} 35^{\prime}$, and in W. long. $7^{\circ} 6^{\prime}$, from 89-205 fathoms (Sir J. Anderson).

RANGE in Time. Coralline Crag (Searles Wood): AustroHungarian Miocene (arrecta) (Reuss): Middle Pliocene; Palrolithie (A. Bell).

The differences between this species and the preeeding are very marked and eonstant; nor have I found that they show auy tendency to run one into the other. In the first place the eells of $M$. ventricosa are always very much larger than those of M. Peachii, and the two, which often oecur side by side on the same shell, may be distinguished at once by the size alone. They are also much more convex, presenting a well rounded anterior surface, and are consequently divided by deep sutures. The flat surface, so eharaeteristic of M. Peachii, is never met with in this form.

The mouth is ereet or subereet, and the eell narrows towards it-a peeuliarity which is wanting in the last-named. Almost the whole of the inferior margin rises, as it were, into the muero, which is broad and massive, whereas that of M. Peachii is a central acuminate process, and a much less prominent feature. The spines are not only fewer in number, but different in eharacter from those of the allied speeies. They are, in the adult, very stout and tusk-like, ranged two on each side, and bend inwards over the aperture. The surface is more or less granular, and with a constant tendeney to striation, which is not met with at all in the other speeies. The oøcium is usually very small in proportion to the size of the eell.

In M. ventricosa the eells are arranged in linear series, 
radiating in all directions from a central point, so that there is a definiteness and regularity of pattern which is usually wanting in M. Peachii.

Mucronella variolosa, Johnston.

\section{Plate LI. figs. 3-7.}

Lepralis variolosa, Johnst. B. Z. 278 , pl. xxxiv. fig. 4 ; ibid. ed. 2, 317 , pl. Iv. fig. 9 (? fig. 8) : Couch, Corn. Faun. iii. 116: Busk, B.M. Cat. ii. 75, pl. lxzv. ; Crag. Pol. 48 , pl. iv. fig. 4 (? fig. 8), \& pl. viii. fig. 8.

Lepralia oyalis, Hass. Ann. N. H. ix. 413.

Escharelin Variolosa, Gray, B.M. Rad. 125.

? Lepralia cheilostora, Boeck, Förh. Vid. Selsk. Christiana, 1861, 50.

Lepralia serrulata, Reuss, Bryoz. osterreich.-ungarisch. Miocäns, 27, pl, ii. figs. $2,3$.

Lepralia tenera, id., ibid. 27 , pl. ii. fig. 4.

Zocecia lozenge-shaped or ovate-elongate, often much produced and narrowed below, flattish, distinet, but not deeply sutured, sometimes subimmersed, granular, quincuncially arranged, punctured or strongly areolated round the base, and bordered by a raised line; orifice suborbicular, slightly elongated transverscly, a hammcrshaped denticle within the lower lip; peristome raised, thin, everted in front, and usually extended into a central mucro; marginal spines 2-4. Ocecia somewhat oval, depressed and immersed, elosely united to the adjacent eell, granular, areolated round the margin, usually with onc spine in front on each side.

Primary cell minute, with an oval aperture oceupying the whole of the front surfaee, bordered by a slight rim, and surrounded by ten or eleven spines.

Colonies forming very large, bright, glistening erusts, white or straw-coloured.

RANGE OF VARIATion: The eells are, in some eases, broader and shorter than in others; but usually they are much 
elongated, lozenge-shaped, or ncarly oval, and mueh narrowed below. The mucro is sometimes bidentatc, and oceasionally almost abortive. The greatest amount of variation oecurs in the marginal areolation, which in some eases almost disappears, whilst in others it exists in such an exaggerated condition as completely to change the appearanec of the speeies. Specimens in which this oecurs arc often of very great beauty, the areolation occupying a large portion of the surface of the cell, and a small ccntral space only being left smooth. In other cases the areolation is very partial, in others extremely obseure; in others it is represented by mere superficial ribs. A variety oeeurs in which the cells are very flat, the peristome is not elerated, and the anterior margin scarcely prominent. In another and very pretty form the cclls are not mucl produced, are bordered by a wlite sinuous line, and speckled with very distinct, minute white granules on a grey ground. With age a thin white crust often forms over the primitive eell-wall, which is of a delicate greyish colour. Very old spceimens present a flat surface, and the walls are thickcned and strongly granulated.

Hавітат. On stones and shells from deep water.

Localities. Common, and generally distributed. It has not oceurred in Shetland, nor on the Scandinavian coast. The Minch, Hebrides (Norman): St. Andrews, decp water (Dr. M'Intosh): Sana Island, 40 fathoms (Hyndman) : Birterbuy Bay (G.S.B.) : off the Deadman, 60 fathoms, on Pinnce (T. H.) : \&e.

Geograpiucal Distribution. Roscoff (Jolict): New Zealand (F. W. Hutton) : Adriatic, rare (Hcller) : mouth of the Jencsci (subfossil) (F. Schmidt).

Ranae in Time. Coralline Crag, on shell (S. Wood) : Middle Pliocene (Coralline Crag and Red Crag, part) (A. Bell) : Austro-Hungar. Miocene (Reuss). 


\title{
Mucronella laqueata, Norman.
}

\author{
Plate LI. fig. 8.
}

Lepralia laqueata, Norman, Ann. N. II. January 1864, 85, pl. x. fig. 5. Drscopora coccrsea, forma ovalis (part.), Smitt, 1. c., pl. xxvii. fig. 175.

Zovecia rhomboid, broad, not produced below, very slightly convex, granular, bordered by raised lines, and with a row of large punctures round the base; orificc semicircular; peristome not raised, lower lip almost straight, pouting, a broad denticle dceply set within it ; marginal spines three. Oocia round, subimmersed, granular, punctured round the margin.

Colonies tinged with red when living, ivory white when dead; the surface dull.

Habitat. On stones from deep water.

Locality. Shetland, 80-100 fathoms; the Minch, Hebrides (A. M. N.) : coast of Antrim (Hyndman).

Geographical Distribotion. Bergen (A.M. N.): Arctic Seas (Smitt).

This species is a critical one, and pcrhaps approaches M. variolosa too nearly. It most markedly differs from it in having the cells much less elongated and much broader in proportion to the length, in bcing always reddish when living, and ivory-white when dead, and destitute of the shining surfacc which characterizcs the last-named species. There is some difference, too, in the form of the mouth, which is wider and less arched (with less spacc betwcen the upper and lower margins) than in $M$. variolosa. The lower margin is turned slightly outwards; though sometimes mueronatc, the mucro is a much less constant and striking featurc than in the allied species. The denticle, which is of great breadth, is very decply planted within the 
eell, whereas that of $M$. variolosa is prominent and eonspienous. The ovieells also seem to be less immersed. The walls of the eells are thick, and the surface is strongly granulated.

In general appearanee the two forms certainly differ considerably ; but, as Norman has remarked, "it is diffieult to point out the distinction in words."

\section{Mucronella abysicola, Norman.}

Plate XXXVIII. figs. $1,2$.

Lepralia Abyssicola, Norman, Shetland Pol., Rep. Brit. Assoc. 1868, 307.

Zoœcia large, distinet, broad in the middle, and tapering off towards each extremity, moderately eonvex, divided by well-marked sutures; surface minutely granular; orifice small, terminal, transversely elongated; the lower margin mueh raised, slightly bent outwards, forming a sereen before the aperture, a wide denticle set deeply within it; upper margin not elevated, bearing two or three rather stout spines. Occia globose, tumid, broader than long, minutely granular, oceasionally a small transverse rib just above the mouth; two spines visible in front.

Colonies forming large, white, glossy crusts, of irregular growth, on which the cells show very distinetly.

Habitat. On stones, \&e., from very deep water.

Locality. Shetland, to the N.N.W. of Unst, in 140-170 fathoms (A. M. N.).

Geographical Distribution. Gulf of St. Lawrence (Dawson).

The eells in this speeies are almost lozenge-shaped. In the eentre they bulge out and attain a eonsiderable breadth, but taper off above and below it, terninating in a point at 
the basc, and becoming much contracted towards the mouth, which is placed at the summit. The primary aperture is a simple opening, narrow between the upper and lower margins, but elongated transverscly. In an early stage of growth the denticle is very apparent; but by the subsequent development of the lower lip, which riscs into a broad and prominent cxpansion, the mouth is partially conccaled, and it is then difficult to detect. The tcxturc of the cells is dense; and so minute is the granulation of the surface that thcy appear almost smooth. They have a polished and glossy appearance. The full number of the marginal spincs appears to be three; but therc arc often only two.

"The form of the ovicells and mouth in the fertilc cclls reminds one forcibly of a helmet with the vizor raiscd" (Norman).

In a fine specimen of the present species from the St. Lawrence, which I owe to Dr. Dawson, the cells are much more convex and distinct and deeply divided than in the Shetland form, and more elevated towards the oral extremity. The ovicell is also more decidedly thrown back off the mouth.

\section{Mucronella microstoma, Norman.}

Plate XXXVIII. figs. 3, 4 .

Leprali microstoma, Norman, Ann. N. H. ser. 3, xiii. 87 , pl. xi. fig. 2 ; Rep. Brit. Aввоc. for 1868, 307.

Zoceia flask-shaped, very distinct, tumid, the oral extremity elevated, frec, contracted into a short neck ; surface smooth or finely granular; orifice small, contracted, much broader than long; peristome thickencd, narrowed, much raised and everted in front, and on the upper margin rising to a central point. Oxcin globosc, tumid, sct far back, minutely granular. 
Colonies often exhibiting an irregular outline, and giving off branching processes, three or four eells wide.

Навітат. On small stones from deep water.

Locality. Shetland sea, 20-25 miles N. and N. by W. of Unst, in 80-140 fathoms (A. M. N.).

Geographical Distribution. On the Falmouth-Lisbou eable, between $\mathrm{N}$. lat. $47^{\circ} 58^{\prime}$ and $47^{\circ} 35^{\prime}$ and in W. long. $7^{\circ} 6^{\prime}$, from 89-205 fathoms (Sir James Anderson).

In this speeies the eclls rise considerably towards the upper extremity, and are produeed into a short neek, which is quite free, and bears the mouth on the top of it. The lower part or body of the eell is ovate. The mouth is small, and as it were drawn out sideways, so as to be transversely elongate. It is surrounded by a simple, thickened peristome, which forms a "pouting lip" in front, and above is more or less pointed. The eclls are without definite arrangement, are divided by well-marked sutures, and, according to Mr. Norman, "rise from a punetured erust, which fills up any interstices between them." In the specimens which I have examined there is very little trace of such a erust; in most eases the eells are contiguous. The ovicell is recumbent and set well back behind the neek, and, like the cells, is almost smooth or very minutely granulated.

This is one of the species which it is very difficult to classify with any thing like certainty. It holds its place in the present genus ehiefly from its apparent affinity to $\boldsymbol{M}$. abyssicola.

\section{b. With two lateral avicularia.}

Mucronella coceinea.

Plate XXXIV. figs. 1-6.

Cellepora coccivra, Abildgaard, Mäll. Zool. Dan. ir. 30, pl. crlvi. Ags. 1, 2: Lamk. An. 8. Vert, ed. 2, ii. 259. 
Berenicea coccisea, Flein. B. An. 533.

Lepralia coccinea, Johnst. B. Z. ed. 2, 322, pl. lvii. figs. 2, 3 : Busk, B.M. Cat. ii. 70, pl. Ixxxviii.

Lepralia tridentata, Couch, Corn. Faun. pt. iii. 115, pl. xxii. fig. 5.

Lepralia appessa, Hassall, Ann. N. H. vii. 367, pl, ix. fig. 3.

Discopora ApPENsA *, Smitt, loc. cit., Krit. Förteckn. iv. 27 \& 175, pl. xxvii. fig. 177.

Lepralia Balli1, Johnst. B. Z. ed. 2, 321, pl. 1vi. fig. 5.

Escilarixa coccinea and Ballit, Gray, B.M. Rad. 124.

Lepralia mamillata, Searles Wood, Ann. N. H. xiii. 19 : Busk, Crag Pol. 46, pl. vi. fig. 5 : Manzoni, loc. eit., Sec. Contr. 6, pl. ii. fig. 8.

Lepralia pteropora, Reuss, Polyp. d. Wien. Tertï̈rbeck. 81, pl. ix. fig. 26 Manzoni, Bryoz. foss. Ital., Terza Contr. 4, pl. i. fig. 3†.

Distansesciarellina pteropora, $D^{\prime}$ Orb. Pal. Fr. ter. crét. v. 451.

Lepralia peregrina, Manzoni, loc. cit. 6, pl. i. fig. 5.

? Lepralia fulgurass, $i d$. loc. cit. 7, pl. i. fig. 6.

? Lepralia Quadricorxuta, Dawson, Canad. Naturalist, 1857.

* Smitt does not identify the present species with the Cellepora coccinea of Abildgaard. He applies this name to $M$. Peachii and kindred forms. Little is to be made of the figures in the 'Zoologia Danica'; and the description is sufficiently vague; but the red colour is characteristic of the present species, and its cells may be properly described as "urceolate;" whereas in neither of these points will the description fit $M$. Peachii. In a case where absolute certainty is unattainable, it seems hardly worth while to disturb the widely accepted nomenclature.

+ I perfectly agree with Manzoni that L. pteropora, Reuss, and L. mamil lata, S. Wood, must be referred to the present species. There can be little doubt that $L$. peregrina of this author (Bryoz. foss. Ital., 3rd Contrib. pl. i. fig. 5) must rank with them. These forms exhibit mere differences of superficial sculpture. L. fulgurans, Manzoni (op. cit. pl. i. fig. 6), also seems to be nothing more than a variety of $M$. coccinea, although, in the absence of specimens, I would not be understood to speak with certainty.

I feel more doubtful about the Lepralia quadricornuta, Dawson, from the Postpliocene deposits of Canada. I am indebted to Dr. Dawson's great kindness for specimens of this form, as well as of many other Canadiau Polyzoa, both recent and fossil ; and, after careful examination, I am inclined to think that it must be regarded as a variety of the present species. So far as the condition of the fossil allows me to judge, it agrees with the latter in all its characters, with perhaps a single exception. The form and sculpture of the cell and ovicell, the shape and position of the avicularia are the same in both. The surface of the cell is adorned with radiating furrows, and it is punctured round the base. The ovicell is small, round, recunbent; and in front of it two spines are distinctly visible, as in $M$. coccinea. The difference between the two seems to lie in the degree in which the peristome is developed. The condition of my specimen does not allow me to determine this portion of the structure with as much precision as I could desire; but 
Zoceia shortly ovate, often enlarged and rounded below, distinet, divided by rather deep sutures, depressed below, rising towards the aperture, bordered by a raised line, and punetured round the margin; surface roughened or granular; orifice terminal, subcircular, with a central tooth on the lower lip and two lateral denticles; the peristome elevated in front into a prominent mucro, by which the central tooth is partially concealed; marginal spines six; on each side of the orifice an avicularium, with a pointed mandible, which is direeted outwards and slightly upwards. Oæcia globular, reeumbent, surface granular, two spines visible on each side, in front of it.

Primary cell rather smaller than the rest, raised, surface smooth; aperture terminal, large, orbicular, with a membranous corering, and about twelve tall marginal spines (woodeut, fig. 17).

Colonies forming subeireular, glistening crusts, of an orange-red colour.

Var. a (mamillata). Zoccia suberect,

Fig. 17.

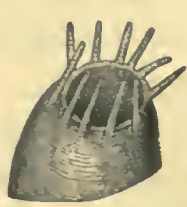

Primary cell.

contracted above, ventricose below; the surface traversed by numerous furrows, which radiate from below the mouth to the sides of the cell, usually a line of perforations round the base; orifice suborbicular; the peristome much produced in front and at the sides; two lateral avicularia, erect, the mandible pointing straight upwards. Oacia globose, suleate, the avicularia standing erect on each side in front.

Raxge of Variation. Apart from the mere superficial layer, the changes to which this species is liable are

it seems to me that the peristome is more elevated and projects more prominently in front than is usual in $M$. coccinea. I can detect no traces of the three denticles; but their absence may be due to the condition of the fossil. Considering the amount of variation to which the peristome is liable, we should hardly bo justifed in treating the difference to which I bore just referred as a dingnostic. 
neither numerous nor important. 'The shape of the cell varies to some extent, especially in crowded colonies; but it commonly exhibits the normal figure, which is slightly contracted towards the aperture, and enlarged and rounded off bclow. In the ordinary form the peristome rises in front into a pointed central process, behind which the median tooth is often completely conccaled. This process, which is a secondary growth, is more or less strongly developed. In the very beautiful variety described by Searles Wood from Crag specimens as Lepralia mamillata, and which I havc recently detected amongst Mr. Hyndman's dredgings on the Antrim coast, the peristome is much produced in front and at the sides, and forms a thickcned and somewhat cxpanded border round these portions of the moutl.

The avicularia, which constitute so striking a feature of the present species, vary considerably in size and, to some extent, in position. Normally there are two of them; but one is frequently wanting; and when both are present they arc very often unequally developed. In the var. mamillata, instead of being turned outwards towards the side, they point straight upwards, and when the ovicell is present they stand erect, one on each side, in front of it.

The superficial changes to which $M$. coccinea is liable are very remarkable. In its earlicst condition the ccllwall is of a greyish colour and very delicate texture, and perfectly smooth. It is soon, however, invested by an opaque crust, roughened on the surface, which after a time takes on a distinctly granular character. In old and dcep-water specimens this granulous condition becomes much more pronounced; and in one very beautiful variety the entire surface of both cell and oviccll is tessellated with smooth white bosses or granules of various sizes and shapes (Plate XXXIV. fig. 3). In var. mamillata there 
is a complete change in the character of the sculpture, and instcad of merc granulation wc have radiating and slightly undulating furrows, which traversc with much regularity the surfacc of the cell, and give it a singularly elegant appcarancc. The oviccll is similarly adorned. This kind of sculpturc is not absolutely confined to this variety; it occurs in the Lepralia pteropora, Rcuss, which is undistinguishable in other respects from the ordinary forms of $M$. coccinea* .

Moxstrosities. The following monstrosities have occurred to me :-

i. A cell, otherwise normal and fully equipped, with an avicularium covering the oral apcrture.

ii. An avicularium with a quadrangular instead of a pointed mandible, of equal width throughout, and squared at the extremity.

Habitat. On weed (chiefly Laminaria), rock, \&c., bctwecn tide-marks and in shallow watcr, and on shells, Ascidians, \&c., from moderately deep watcr (30 fathoms).

Localities. A very common littoral species. South Deron; Ilfracombe; Guernsey; Islc of Man (T. H.) : Cornwall (Couch and Pcach): Tenby (F. Walker): Hastings (Miss Jelly): Isle of Wight (W. T.) : Northumbcrland and Durham (Alder): Ayrshirc (Landsborough): St. Andrcws, rare as compared with southern coasts (Dr. M'Intosh): the Minch; Shctland, between tide-marks and in shallow watcr (A. M. N.) : Belfast Bay (W. T.). Var. mamillata, coast of Autrim (Hyndman).

Geographical Distribution. Roscoff, very common (Jolict) : France, S.W. (Fischer) : Adriatic, on shells and Algae (Heller): Norway (Sars): Spitzbergen, on Ascidians, 16-30 fathoms (Torell and Malmgren): Grecnland

* Iide Manzoni, Bryoz. foss. Ital., Terza Contrib., pl. i. fig. 3. 
(Lütken) : Nova Zembla, 10-50 fathoms ; Kara sea (Stuxbcrg and Thécl).

Range in Time. Pliocene deposits, near Reggio, in Calabria; older Pliocenc, Castrocaro; Middlc Mioccnc (Manzoni) : Austro-Hungarian Mioccne (Reuss). Var. mamillata. Crag (S. Wood) : Quaternary deposit at Livorno (Mallzoni).

\section{Mucronella pavonella, Alder.}

Plate XXXIX. fig. 8-10.

Eschara Payonella, Alder, Quart. Journ. Micr. Sc. n. в. iv. 12.

Eschara cribraria, Busk, Quart. Journ. Mier. Sc. iv. 311, pl, xii. figs. 1-3. Discopora Pavonella, Smitt, CEfv. K. Vet.-Ak. Förh. 1867, Bibang, 28 and 178, pl, xxvii. fig. 181.

Zoarium foliaceous, forming fan-shaped or undulating expansions, which rise from an incrusting or clasping base, or simply adnate, forming large circular patches. Zocecia large, rather broadly ovate, quincuncial, moderately convex, somewhat elevated towards the upper cxtremity, and dcpressed below, strongly areolated round the margin, and with ribs radiating towards the centrc; surface slightly roughened; orifice vcry ample, orbicular, with a small blunt tooth on the lower margin; peristome thin and not raised; on cach side of the orifice, about the middlc, an oval avicularium; mandible rounded and pointing upwards. Oxcia (?).

Height of the ercet form about $1 \frac{1}{2}$ inch; breadth generally excecding the height.

Habitat. On stems of zoophytes, Ascidians, tubcs of annelids, shclls, \&c., from moderate depths to deep water.

Localimes. Cullercoats (Aldcr) : coast of Northumberland, deep water (A. Hancock): Scarborough (Bean): Dogger bank, on mussel (T. H.). 
Geographical Distiribution. Gulf of St. Lawrence (Dawsou): Greenland, off Fredericksliaab, 100 fathoms (Wallieh): Nova Zembla, Jugor-scharr, 10-14 fathoms (Stuxberg and Théel): Spitzbergen, 20-60 fathoms (Torell and Swed. Exped.) : Finmark, 20 fathoms (Goës and Malmgren): west off Jutland, 26 fathoms (Kirchenpaucr). Not yet found in Southcrn Scandinavia (Smitt).

This is a remarkably beautiful specics. In its incrusting state it forms large patches (an inch in diameter) perfectly cireular in shape, slightly depressed in the centre, and wearing the appcarance, even to the naked cye, of most delicate laccwork. When growing erect it assumes, aceording to Mr. Alder, the form Hemeschara or Eschara (of authors), according to the substance on which it is developed.

The zoœcia are large and regularly arranged in quincunx; the surface is ornamented with ribs, which pass off from the margin and radiate towards the centrc of the cell, inclosing rather large loop-like areolar spaces. In the older portions of the colony these are sometimes almost obliterated; but they are generally a conspicuous and characteristic featurc. Smitt states that the mandiblc of the avicularia, though occasionally round, is usually triangular. This is certainly not the case in any of the spceimens which I have examined, whether from this country or from Greenland and North America. In all eases I have found the rounded mandible only.

The mucronate elcvation of the peristome, which is the usual characteristic of the present genus, is wanting in M. pavonella; but its affinitics, on the whole, are with this group. 


\section{Genus PALMICELLARIA, Alder.}

Der. From palma, the palın of the hand, and cella, a cell.

Palmicellaria, Alder, Quart. Journ. Micr. Sc. 1864.

Cellepora (part.), Flem.: Johnston: \&c.

Escinara (part.), Busk: Sars : \&c.

Discopora (part.), Smitt.

Generic Character.-Zoecia with the primary orifice orbicular, or ranging from semicircular to semielliptical; the peristome elevated around it, so as to form a secondary orifice, and carried out in front into a projecting palmate or mucronate process, with an avicularium on its inner aspect. Zoarium (in the British species) erect and ramose, or (?) lamellate.

Distinguished from the preceding genus by the sccondary orifice, with its mucronate and aviculiferous process in front.

\section{Palmicellaria elegans, Alder.}

Plate XXXI. figs. 7-9.

Palmicellaria elggans, Alder, Quart. Journ. Micr. Soc. n. s. iv. (1864), 100, pl. iii. figs. 1-4: Norman, Shetland Pol, Rep. B. A. $1868,309$.

Pustulspora proboscrdea, Johnst. B. Z. ed. 2, 278, pl. xlviii. figs. 4, 4 (fide Norman *).

Zoarium ercet, very slcnder, of ivory whitencss, slightly branched dichotomously, branches ncarly in the same plane, somewhat attenuated towards the top. Zoocia disposed in four longitudinal rows, alternating with each other, oblong-ovatc, smooth, very slightly defined;

* Who has examined the specimens bearing this name in Dr. Jobnston's collection. 
aperture round, somewliat depressed, with a prominent eurved rostrum in front, bearing on its upper surface a cireular avicularinm. Oxcia unknown.

Height $\frac{6}{10}$ inch.

Haвıтат. Deep water.

Localities. Zetland Seas (E. Forbes): Loch Fyne; the Minch, 18 to 25 miles north of Burrafirth lighthouse, the most northern point in Shetland, 80-90 fathoms (A. M. N.).

This is a very elegant species; slender in habit, of a pure whiteness, and remarkable for the neatness and regularity of its dichotomous branching.

It differs from its eongeners in having its cells disposed in four longitudinal series; but the mere number of the rows is not a point of any special importance.

Palmicellaria Skenei, Ellis and Solander.

Plate LII. figs. 1-4.

Millfapora Skevei, Ell. \& Sol. Zooph. 135,

Cellepora palasata, Flem. B. A. 532.

Cell.zpora Skenri, Johnst. B. Z. ed. 2, 297, pl. lii. figs. 6, 7, 8: Busk, B.M. Cat. ii. 88 , pl. crxii.

Eschara Skenei, rar. tridens, Busk, Ann. N. H. ser. 2, xviii. (1856), 33, pl. i. fig. 3: Sars, Beskr. norske Polyz., Vid. Selsk. Christiania, 1862, 147 (9 sep.).

Lepralia bicorsis, Busk, Crag Pol. 47, pl. viii. figs. 6, 7.

1)iscorora Skesei, forma Eschare auctt. (part.), Smitt, l. c. 29 and 179.

Zoarium rising from a spreading erustaccous base, dichotomously branched, of a reddish or yellow colour; branches somewhat palmate, compressed, or flattened, short, dilated and truncate above, rough and hispid. Zoccia elongate, subeylindrieal, distinet, and moderately eonvex, elevated towards the upper extremity, and finely granulated; orifiec arched above, the inferior 
margin slightly curved inwards; peristome clcvated in the adult cell, forming a secondary apcrture, with a eircular avicularium on its lower lip; immediately in front of it a tall muero. Oxcia small, globose, very closely united to the surface of the ccll above, granular. Height $\frac{1}{2}$ to 1 inch.

Var. a (bicornis). With a eylindrical process on each side of the orifice, bearing an avieularium on the summit.

Var. $\beta$ (foliacea). Zoarium forming a broad foliaccous expansion, contracted towards the base, and rising from a spreading crust: entire, contorted, and sinuated on the margin.

Habitat. On zoophytes, stones, and shells, from decp water.

Localities. Abcrdecn (Skene): Wick (C. W. P.) : St. Andrews (var. foliacea), on Cyprina Islandica, from the Coralline ground (Dr. M'Intosh) : 8 miles S.S.W. of Mull of Galloway, 50 fathoms; 5 milcs S.W. of Mull of Galloway, 110-140 fathoms (Capt. Beechey) : the Minch; Shetland, 5-10 miles east of Balta, 40-70 fathoms; Out Skerries Haaf (A. M. N.) : Northumberland and Berwick, not rare (Johnston) : Oban (var. bicornis); Torbay; off Polperro (T. H.) : on stones and Pinne, off the Deadman, rare (Couch) : east coast of Ireland, vcry deep water (Miss Ball) : off the Maiden lighthouses, coast of Antrim, 62-72 fathoms (W. Swanston).

Geographical Distribution. France, S.W., 50-60 fathoms (Fischer) : Roscoff (Joliet) : west coast of Norway to Finmark; Oxfjord and Komagfjord, 20-30 fathoms, on stony ground (Sars): var. tridens (Busk), Norway (M'Andrew) : Grcenland (N. Germ. Pol. Exped.) : Kara sca (Stuxberg and Théel) : St. Gcorgc's Banks, 28-60 fathoms (Smith and Harger).

Range in Time. Var. bicornis, Crag (S. W.). 
In its ordinary condition $P$. Skenei is distinguished by broad, flat, somewhat palmatc and rather short branelies, which expand slightly above, and seldom lie in the same plane; the surface is made rough and hispid by the numerous tall mueronate proeesses which rise from the front of the cells*. It is liable, however, to many changes of habit; and in the remarkable variety $\beta$ (foliacea) it has entircly lost its usual manner of growth. In this form it appears as a continuous lamina, eurved and twisted and folded upon itself, with a deeply sinuated margin. So far as external aspeet goes, the eontrast between this foliated variety and the normal condition is complete and striking; but in the minute characters there is perfect agreement between them. In the young zoœeium there is no elcvation of the peristome, the orifice is on a level with the general surface of the cell, and there is no trace of avieularia; but with advancing growth the peristome rises, and is earried outwards, projecting considerably, and at its extremity in front the avicularium is developed, the muero ascending immediately below it. A secondary orifice is thus formed, which ineloses the primary, and which differs from it widely in size and shape.

The mucro is tall and acuminate, exeept on the eells towards the base of the zoarium, wherc it is sometimes blunt and rudimentary. Oeeasionally a muero is developed on cach side of the orifice, and bears an avieularium on its inner surface at the base, or at times on its summit. The latter variety is the Lepralia bicornis, Busk. Oceasionally the two proeesses are developed in a line with the central mucro; and we have then the rariety tridens of Busk.

In some cases the zoarium glistens as if coated with varnish.

* ". . densis hastilibus horrida." - Vragh. 


\section{Palmicellaria lorea, Alder.}

Plate LII. figs, 5, 6.

Eschara lokes, Alder, Quart. Journ. Mlicr. Sc. n. в. iv. 104, pl. iii. figs. 5-7: Norman, Shetland Pol., Rep. Brit. Assoc. 1868, 309.

Discopora Skexei, forma Escharæ auctt. (part.), Smitt, GEfv, K. Vet.-Ak. Förh. 1867, Bihang, 29 and 179.

Zoarium yellowish white, shining, dichotomously branched; branches slender, compressed, of ncarly cqual width throughout, blunt and generally bifid at the cxtremitics, disposed nearly in the same planc, occasionally anastomosing, given off from a slender comprcssed stem. Zoœcia prominent, distinct, ovate-elongatc, fincly granulated, quincuncially arranged; orifice arched above, slightly curved inwards below; wall of the cell raised and thickened round it; a circular avicularium within the lower lip, and immediately bclow it a short, blunt rostrum; small circular avicularia scattered irregularly over the cells. Oocia small, globose, closely united to the cell above, and inconspicuous, slightly granulated; surface entire.

Height 1 inch to $1 \frac{1}{2}$ inch.

Haвitat. In deep water.

Localities. Shetland (Barlec) : 20-25 miles north of Burrafirth lighthousc, 80-110 fathoms (A. M. N:).

The differences between this species and the preceding are found almost entirely in the habit and mode of growth. The two are united by Smitt; and it is not without hesitation that I have decided to kcep them apart. In general appearance they are distinct enough, though perhaps not more distinct than $P$. Skenei and its variety foliacea.

The habit of $P$. lorea is more crect, and the mode of 
growth morc regular, than those of the last-named species. The slender, flattened stem usually divides dichotomously into two principal branches; and thesc again divide and subdivide, also dichotomously. All the branches are much in the same planc, and occasionally meet and inosculate. The plan of the ramification is regular; and there is a neatness of habit which is wanting in $P$. Skenei.

The branches and stcms are very much of the same width throughout, and there is no tendency to dilatation at the extremities. The surface is comparatively smooth in the absence of the tall spines with which the cells bristle in P. Skenei, and glossy. Mr. Norman tells me (in litt.) that when "it comes up in the dredge the whole zoarium is glistening and bright with prismatic colours."

When we turn to the minute characters we are much morc impressed by the agreement betwcen the two forms than by the points of difference. The latter may be very briefly summed up. The cells of $P$. lorea are somewliat broader and less decidedly subcylindrical than those of $P$. Skenei; the peristomc, though raised, is not carried outwards in front, so as to project promincntly, as in the last; and the rostrum is blunt and short. The small avicularia distributed over the zoarium have not been noticed in $P$. Skenei. In other respects the zoøcia of the two forms agree; the history of the development is the same; the leading features are identical in both.

In $P$. lorea a rostrum is occasionally developed, as in the preceding species, on each side of the orifice, which sometimes bears an avicularium at its base.

There are frequently punctures round the margin of the cells; but they are apt to be obliterated by the progress of calcification. 
Doubtful Species.

Palmiceliaria (?) cribraria, Johnston.

Escitara crtbraria, Johnst. B. Z. ed. 2, 352, pl. 1x. figs. 7-8.

Zoarium rising from a eircular crustaceous base, erect, frondose, expanding into broad undulated and sinuous lobes, eonsisting of a double layer of eells. Zocecia - oval or rhomboidal, quineuneial, punetured; orifice (apparently) suborbicular, with a short mucro projecting in front.

Height $\frac{3}{4}$ inch; breadth about the same.

Locality. Berwick Bay, 45 fathoms (Johnston).

Alder was the first to separate this form from Mucronella pavonella, with which Busk had identified it; and little can be said of it but that it is indubitably distinet from the latter. Johnston's deseription and figures of it are quite inadequate; and until it oeeurs again and can be studied afresh it is impossible to determine with any certainty its affinities and systematic position.

In the older portions of the colony the surface is said to be "punetured like a thimble, with round depressed holes," and the spaee between them to be punetulated. The mature eells are furnished with a muero, which projects over the mouth. The adult orifice, judging from the figure, seems to be suborbicular and somewhat elongated transversely. In young eells it is deseribed as "minute, round, and generally inconspicuous."

This species is referred provisionally to the genus $\mathrm{Pal}$ micellaria. 


\section{Genus RHYNCHOPORA, Hincks.}

Der. From $\rho \dot{u} \gamma \chi 0$, a beak, and $\pi$ ó $\rho$ os.

Lerralis (part.), auctt.

Discopora (part.), Gray.

Generic Character.-Zocecia with the primary orifice transversely elliptical, lower margin slightly sinuated; secondary orifice suborbicular, with a mucro on the lower margin and an uncinate process immediately above it, within the mouth. Zos RIU (in the British species) incrusting.

Tris form is a difficulty in the way of the systematist. Its most strongly marked characters-the mueronate lip and the curious uncinate process within the orifice-conneet it with the present group; but the lower margin of the primary opening is undoubtedly furnished with a sinus -a point in which it agrees with the Myriozoide. It must be regarded as one of those transition forms which are continually reminding us how little the real order of nature ean be represented by a rigorous and unbending system. I had placed it here, the existence of the sinus having eseaped my observation; but I now think that it should rank as a Myriozoidan form having strong affinities with the present family.

RHYNCHOPORA BISPINOSA, Johustoll.

Plate XัL. figs. 1-5.

Lepralia Bispixosa, Johnst. B. Z.ed. 2, 326, pl. Irii. fig. 10 (very indifferent): Busk, B.M. Cat. ii. 77, pl. lrux. figs. I-4: Hincks, Devon \& Cornw. Cat., Ann. N. H. ser. 3, ix. 205 (45 sep.).

Discopora irspinosa, Gray, B.M. Rad. 126.

Zoccia ovate, depressed below, rising towards the mouth, 
granular, glossy, punctured round the edge; orifiee (adult) suborbieular, somewliat elongated transversely, within the lower margin a eurved look-like proeess, and immediately below it a tall sharply pointed muero; peristome elevated, rising on one side, or on botl sides, into a strong spinous proeess, on the upper margin (in young eells) two long and slender spines; frequently below the orifiee a mound-like swelling bearing at the upper end a large avicularium, placed transversely with a strong beak and a pointed mandible; on the lower part of the eell a raised, projeeting avicularium with an aeute mandible. Oxcia more or less immersed, semieireular, smooth or granular, generally with a prominent muero on the front, the opening elosed by a smooth ealcareous opereulum, white or yellowish white.

Colonies forming large erusts, of a delieate lilae colour when fresh.

Range of Variation. The speeifie diagnosis is founded on fully developed eells; but in different stages of growtl the speeies presents a very different appearanee, and, in a large proportion of eases, some of the struetures which I have deseribed are wanting. Colonies frequently oceur in which the large transverse avicularia are either absent altogether or very sparingly developed; in well-developed patehes I have frequently been unable to find one of them. When they are present they eoneeal the eurred proeess on the lower margin, which is so eharaeteristie of the speeies. In the absenee of the mound and avieularium, the muero rises from the lower lip of the seeondary orifice. The spinous proeesses on the side of the mouth vary in number and are sometimes wanting; and the two true spines on the upper margin are rarely to be found, exeept on the edge of the eolony. I know of few speeies, if any, which appear in such varied guise as the present.

In the interior of the colony the eells are erowder, 
reduced in size, and flattish, the sutures disappear, and the punctures mark out the boundarics; under such circumstances the ovicell is completely immersed. The marginal perforations are at times a very conspicuous character; but in many cases they arc hardly distinguishable. The young marginal cells are regularly ovatc, perfectly smooth and horizontal, with a somewhat transverscly clliptical aperturc, very slightly sinuated below, and two slender spincs on the upper lip. At a very early stage a small central prominence appears on the lower margin, which, incrcasing in sizc, bends over to onc side, and forms the uncinatc process to which reference has becn made. A small denticlc projects from the side of the orifice towards which it inclines; and the two processes, meeting, inclose a circular space. Immediatcly behind this process, the foundations of the avicularian swelling (or mound) arc traceable on somc of the cells and in some colonies, while in others the suboral mucro rises in the same position*. In the second or third line from the edge the cclls have gencrally acquircd their granular covering and their polished and glistening appearance. The small avicularia, which arc much elevated, are variable in number; and two or three arc frequently met with on a cell.

In sheltered situations the suboral mucro is much developed, and the surface of the zoarium bristles with long spcar-likc processes.

Habitat. On stones and shclls from shallow to decp water.

Localities. Berwick Bay, on Modiola (Johnstou): South Devon, abundant; Cornwall, off the Deadman, 60 fathoms; Gucruscy (T. H.) : Shetland, 50-170 fathoms (A. M. N.) : Caithness, very $\operatorname{rarc}($ C. W. P.).

* This seems to be the normal position of the mucro; it is, as it were, displaced when the avicularium is present. 
Geographical Distribution. Mazatlan; Adelaide (T. H.).

The appearance of $R$. bispinosa is much altered by the absenee of the large oral avicularia. When present they form a striking eharacter, and add mueh to the picturesqueness of a very remarkable species. The swelling on which they are developed is clearly a modified eell; and in an early stage of growth its foundations are marked out in raised lines, just as the nascent zoœcia are outlined round the edge of the erust. The mode of its formation from the first to the final stage may be studied on the margin of any fresh and growing colony in whieh it is present.

Genus RETEPORA, Imperato.

- Der. From rete, a net, and $\pi$ ó $\rho$ os.

Mulepora (part.), Linnæus: Pallas: Ellis: \&ce.

Retepora, Imperato (Retepora eschara marina) : Johnston: Busk: D'Orbigny: Smitt: \&c.

Reterora (part.), Lamarck: Blainville: \&c.

Escinara (part.), Smitt.

Discopora (part.), Smitt.

Generic Character.-Zowcia disposed on the front surface of an erect and ramose zoarium, the branches of which usually inosculate and form a reticulate expansion; orifice semicircular or semielliptical, with a prominent rostrum on the lower margin, bearing an avicularium. ZoARIUM adherent by means of an incrusting base, composed in great part of aborted cells; avicularia developed on both the back and front of the zoarium.

The present genus, as originally constituted, was founded solely on the retieulated condition of the zoa- 
rium; but it now scems more than doubtfnl whether this eharaeter alone ean supply the basis for a generie group. The reticulation is mercly a peculiar form of ramification, and is probably entitled to no more systematic weight, apart from the characters of the zoceium, than the simple branching, which was the distinction of the old genus Eschara. The retiform zoarium is associated with very different types of eell, whilst, on the other hand, a form in my possession (probably from the Red Sca), which cannot be distinguished generieally, in other respects, from many of the Reteporc, exhibits no trace whatever of reticulation, but has its zoarium as simply branched dichotomously as an Eschara or Hemeschara of authors. Strongly marked as is the facies which its peculiar habit of growth gives to the Retepore, we must not assign too much weight to it as a clue to natural affinity. There are some points, however, connected with the Reteporine group, which may possibly have a greater significance. In all eases, I believe, the zoarium originates in an expanded crust, composed in great part of aborted eells, destitute of an oral aperture, but frequently furnished with an avicularium, occupying its place. The centre of the inerusting base, however, is oceupied by a subcircular group of fully developed zoceia, round the edge of whieh gemmation takes place at intervals in an upward direction, and a number of erect lobes are thus formed, which constitute the rudiments of the (usually) reticulate and eupshaped zoarium. (See page 394 , woodeut, fig. 18.) This mode of growth is very peculiar, and, so far as I know, it is universal amongst the forms which have been hitherto ineluded in the genus Retepora.

Our two British speeies exhibit the same type of zoceium, and this allies them to the Escharida; I have therefore ranked them in this family under the old name, 
leaving the gencral question as to the grouping of the Reteporinc forms to be settled after a morc extended study of their structure and morphology than is possible within the limits of our Fauna.

Smitt has dismembered the genus Retepora, and has placed our R. Beaniana in his genus Eschara as the companion of Porella compressa, Porella lavis, and other species. In this detcrmination I am quite unable to agrec with him, as, besides other differences, $R$. Beaniana secms to me to depart widely from the zoccial type of the genus Porella.

It may be remarked that amongst a considerable proportion of the spccies which have becn litherto ranged under the genus Retepora thcre is a large amount of general agreement, apart from any consideration of the minuter details, or the merc peculiarity in the branching; thcy have many salicnt features in common, and leave on the mind of the student the impression of strong affinity as existing amongst them. The mode of origin and the general character of the zoarium scem to be much the samc in all of them; the existenee of avieularia on the dorsal surface is a very usual character; thesc appendages arc cxceptionally numerous, and their prevalent forms arc similar to a large extent ; the fissured ovicell is commonly (though not universally) present. It is possible that in these and other characteristics we may have the indications of a natural group, under which the various modifications in the strueture of the orifice \&c. which actually occur may be properly ranged. But the materials for a judgment on this point are at present wanting. 
Retepona Beaniana, King.

Plate LIII. figs. 1-5.

Millepora Cellulosa, Jameson, Werner. Mem. i. 560.

Retepora cellulosa, Johnston, Loudou's Mag. N. H. vii. 638, fig. 69.

Reterora Beaviaxa, King, Ann. N. II. xviii. (1816), 237 : Johnst. B. Z. ed. 2, i. 353 , fig. 67 : Busk, B.M. Cat. pt. ii. 9t, pl. cxxiii. figs. 1-5; Crag Pol. 75, pl. xii. figs. 2, 5, 6, \& 7 .

? Retepora cellulosa (part.), Sars, Reiso i Lof. og Finm. 31.

? Lepralia lobata, Busk, Crag Pol. 50, pl. vi. fig. 7, pl. zxii. fig. 4 (the Joung state).

Retepora cellelosa, forma Beasiana, a, var. borealis, Smitt, Oefv. \&c. 1867, Bihang, 34 and 200 , pl. xxviii. figz. 21 $i-221$.

Eschara Beaniasa, Smitt, Bryoz. Nova Zembla, Cefv. \&c. 1878, no. 3, 23.

Zoarium infundibuliform or cup-shaped, wavy, undulated, the recurved edges sometimes uniting and forming more or less cylindrical cavities; or consisting of a broad, spreading expansion, much and irregularly contorted, the margin sinuated and recessed; with a very slort rudimentary stem, which rises from a small, subgranular, inerusting base; fenestre oval, rather large. Zocecia cylindrical, slightly convex, elevated towards the upper extremity; surface smooth; orifice (primary) arehed above, lower margin almost straight, and in the centre of it a short rostrum, supporting an avicularium, with semicircular mandible dirceted downwards *, two or three minute denticles projecting from the inner side of the avieularium; peristome thin, slightly elevated, and rising on each side of the muero into a small point or denticle; oral spines in the young eells six, in the older four, tall and acuminate, of which two are situated a little above the lower margin and are visible in front of the ovicell. Dorsal surface subgranular, vibieate, traversed by raised white lines; at the

* Smitt describes a small, sessile, obliquely plnced avicularium, with a triangular mandible, as ocensionally developed at the base of the rostrum close to its side. This seems to be very marely present. 
top of each fenestra usually a small, raised, subeircular avicularinm. Oøecia somewhat elongated, smooth, frequently subimmersed, with a slit-like fissure in front.

Many small oval avicularia distributed over the zoarium on both surfaces.

Height, of fine speeimens abont 11 inch, morc usual size $\frac{1}{2}-\frac{3}{4}$ ineh. Breadth of the spreading foliaceous form sometimes as much as 2 inehes.

Habitat. On shclls, stones, corals, \&c. from shallow to very deep watcr.

Localities. Northumberland, from the deep-water fishing-boats (King): off the coast of Durham, 60 fathoms (R. Howse): Embleton Bay, deep water, remarkably large and fine specimens from this locality (R. Embleton) : Petcrhead, two speeimens (C. W. P.) : Searborough (Bean): Orkneys (E. Forbes and Barlee) : Shetland and Fulah Island (Jameson): the Minelı; Shetland, oceasionally on the Unst Haaf, to 170 fathoms; abundant on the Out-Skerries Haaf, not so large as on the Nortlumberland coast (A. M. N.) *.

Geographical Distribution. Arctie Sca (Sir E. Belcher): Bohuslän and Norway, pretty eommon, from 20-30 to 200-300 fathoms, in the latter depths on Gorgonia and Oculina (Baron Uggla and Prof. Smitt): Finmark, not rare (Smitt).

Range in Trme. Coralline Crag (S. W.) : Red Crag (A. Bell) + .

* This species is said to have been obtained by Allman at Cape Clear; but as no other southern locality for it is known, I venture to think that there may have been some mistake, and that one of the nearly related forms may have been confounded with it. The Retepora Beaniana of my 'Devon and Cornwall Catalogue 'is the $R$. Conchii of the present work.

t The Italian Pliocene form which Manzoni refers to $R$. Beaniana (Bryoz. Foss. Itnl., Quarta Contrib. p. 19, pl. r. fig. 26) is R. Conchii, milii. 
This lovely form, whilst frequently assuming the shape of a cup, exhibits a very considerable variety of habit. The prettiest speeimens which I liave seen, though small in size, are developed on shells of Ditrupa from Shetland (Plate LV. fig. 2). They are regular in form, resembling a shallow eup, slightly undulated, and sometimes compressed transversely, and of a glossy ivory whiteness. The little Coralline elasps the slender graeefully eurved shell with its spreading base, and rises to a height of about half an inch. In another very eharacteristic form, from Embleton Bay, there is an intrieacy of structure which is altogether wanting in the one which $I$ have just described. The breadth of the specimen is a little less than double the height; the habit is spreading, the growth irregular. Above the eentral eup-like depression, which formed the first stage in the growth of the zoarium, the retieulated lamina is enormously developed on one side (or face) only, attaining a height of about an inch, and a width of nearly two inches; on the opposite side (or face) it is quite rudimentary, so that the eup-like form is lost, and the zoarium has the appearance of a broad foliaceous expansion, variously twisted and curved, with a deeply sinuated margin. In some cases the sinuses are completely inclosed by the union of the opposite edges of the lamina, and a number of funnel-shaped or subeylindrical cavities are formed, which give a singularly involved and labyrinthine character to the whole. In yet another form there is still less trace of a eup, and the zoarium forms a broad, spreading, eontorted expansion.

The minute eliaracters are very constant. The rostrum on the lower margin of the aperture, which supports the avieularium, is never elongated as in $R$. Couchii, but is always rudimentary. The minute dentieles projeeting from the inner side of the avienlarium are also a clistine- 
tive character. There is no trace of the partially closed, loop-like marginal fissure which oceurs in several of the members of the genus. The large avieularium with a looked beak is altogether wanting; but the small oval avicularia are generally distributed in great numbers over the zoarium.

The scmielliptical shape of the aperture is concealed by the rostrum and the growth of the peristome; but it is apparent in the marginal cells. The adherent base is a shining subgranular erust, divided by well-marked lines into somewhat ovate cell-areas; these are destitute of an oral aperture; but its place is usually occupied by a small circular avicularium.

The Lepralia lobata of Busk is founded on the rudimentary stage of a Retepora (possibly of the present species); and the mode of growth is well displayed in one of the figures which he has given in his 'Crag Polyzoa' (plate xxii. fig. $4 a$ ). In the centre of a spreading crust a rather thick subeireular pateh is formed; and round the edge of it rise a number of short erect lobes, which constitute the rudiments of the reticulated eup. As they increase in height they anastomose and form the first meshes of the network.

Fig. 18.

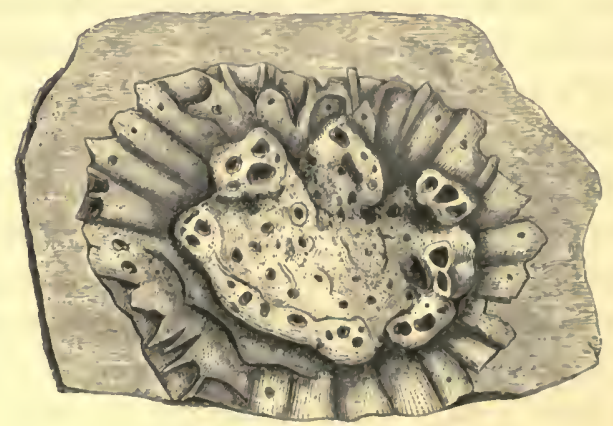

Young state of Retepora. 


\section{Retepora Couchi, Hincks.}

Plate LIII. figs. 6-11.

Retepora Beaxiana, Hincks, Deron Cat., Ann. N. H. ser. 3, ix. 308 (50 sep.). Retepora Covcril, id. Ann. N. H. ser. 5, i. (1878), 355, pl. xriii. figs. 1-6: Waters, Bryoz. Bay of Naples, Ann. N. H. ser. 5, iii. 200 , pl. v. figs. 3-6.

Reterora cellelosa, var. Beaniana, Manzoni, Bryoz. foss. Ital, Quart. Contr. 19, pl. v. fig. 26 (Sitzb. k: Akad. d. Wissensch. Bd. lxi. 1. Abth., März-Heft, 1870).

Zoarium irregularly cup-shaped, undulated and contorted, with a sinuated margin, hispid; fenestree smaller than in the last specics and less regularly oval. Zoccia subcylindrical, depressed, exccpt at the upper extremity, surface smooth; orifice semielliptical, the front margin produced into a tall rostrum, broad below and narrowing towards the apex, much bent outwards, and bearing on its summit a minute avicularium, with rounded mandible; peristomc elcvated on one sidc of the rostrum into a broad, wing-like process, produced at its upper and outer angle into a spine; a narrow, slit-like fissure betwren the rostrum and the process, closed abovc, but forming a loop-likc foramen below; oral spines six; clongate, linguiform avicularia, with a rcry dclicate mandible, distributed orcr the zoarium, frequently one on the front of the ccll at onc side, a little below the rostrum; dorsal surface smooth, dense, with many small subcircular avicularia, and oecasionally one of the linguiform kind, irregularly placed. Oœcia elliptical, smooth, with a narrow longitudinal fissure.

Height (of the largest specimen) a little morc than $\frac{1}{2}$ inch, brcadth about $\frac{3}{4}$ inch.

Haвiтat. On stone, \&c., decp water.

Localities. Off the Land's Find (R. Q. Couch1) : Southwest of Polperio, 40 fathoms, on stone ('T. H.) : Gucinsey (A. M. N. \& 1)r. M'Iutosh h). 
Geograpiical Distribution. Mediterranean, 390 fathoms ('Poreupine' Exped.): Bay of Naples (Waters).

Raxge in Trme. Italian Plioeene beds (Manzoni).

This species is very distinet. from either $R$. Beaniana or R. cellulosa, Smitt. It seems to be a southern form: all my specimens are from Cornwall; and it is not ineluded amongst Smitt's Seandinavian Polyzoa. The very much produeed and reeurved rostrum, with its minute, terminal avieularium, and the wing-like elevation of the peristome on one side of it, are the most salient features. These charaeters distinguish it from both the forms just mentioned; and it is further separated from them by differenees in the avieularia and fenestræ.

The surface of the zoarium in $R$. Couchii is rendered hispid by the immense number of tall, projeeting rostra. The avieularia which they support are very minute, as eompared with the oral avieularium of $\boldsymbol{R}$. Beaniana, and are destitute of the dentieles.

The marginal spines seem to be only present on the youngest eells and eolonies; in fully developed speeimens they are, as far as I have seen, uniformly absent. The small oval or subeireular avieularia are seareely present, if at all, on the front surfaee of the zoarium; they are replaced by the tongue-shaped appendages.

It is impossible to identify $R$. reticulata of the 'Cornish Fauna' by the deseription there given of it; and the synonymy is any thing but a trustworthy guide. At the time of the publieation of the 'Tauna,' its author had not been able to obtain a Cornish speeimen of it; and it holds a plaee in his work beeause it had been found in Seilly by Borlase. Many years after, however, I reeeived from Mr. Coueh himself a speeimen of a Retepora which he had dredged off the Land's End, and whieh proved to 
belong to the present speeies. Subsequently a large stone, dredged off Polperro, and sent me by Mr. Laughrin, yielded a small group of specimens referable to $R$. Couchii, as is also a minute fragment in my possession from some other part of the Cornish eoast. All the south-western examples of Retepora, therefore, which have come under my observation belong to the present species; and it is probable, I think, that Borlase's speeimen belonged to it also. R. Couchii has been taken in Guernsey. I know of no British speeimen of $R$. cellulosa, Smitt, though it oeeurs both in Seandinavia and the Mediterranean.

\section{Family XV.-Celleporidæ.}

Cerleporide, Johnston (part.): Busk : \&c.

Escharid.x (part.), D’Orbigny:

Mrmozoides (part.), Smitt, Flor. Bryoz.

Zocecia cálcareous, more or less vertical to the plane or axis of the colony, irregularly heaped together, with a terminal orifice.

Is his later writings Prof. Smitt has abandoned this family, and plaeed his genus Cellepora amongst the Myriozoida. I venture to think that there are sufficient grounds for its retention. The ereet habit of the eells and the confused way in which they are aggregated are not the only eliaracters whieh differentiate this seetion. The zoceial eharacters, in my judgment, supply a good basis for the family, and, in combination with the rertical habit and the irregular gemmation, indieate a very natural group. 


\section{Genus CELLEPORA, part., Fabricius.}

Der. From cella, a cell, and $\pi$ ópos.

Turipora (part.), Limnæus.

Mílemona (part.), Ell. \& Soland.

Cellepora (part.), Fabricius, 1780 : Linn.: Lamk. (part.): Lamr. (part.), 1816 : Blainv. (part.) : Johnston: Busk: \&c.

Celleporatia, Lamx. 1821 : Reuss: D’Orbigny (for branched species).

Spoxgites, Oken.

Madrepora (part.), Esper.

Flustra (part.), Ell. \& Soland.

Reptocelleporaria (sp.), D'Orb. (for incrusting species).

Generic Cinaracter.-Zocecia urceolate, erect or suberect, heaped together and irregularly disposed; the orifice terminal, with one or more ascending rostra in connexion with it, bearing avicularia. ZомRIUM incmusting, often composed of many layers of cells, or erect and ramose.

The species to which Fabricius applied the name Cellepora werc, with a single exception, members of the old genus Lepralia. But that execption is the well-known C.pumicosa; and it has so happened that it has been taken as the type of his genus, and the name has passed into general use in connexion with the present group. In any ease there would have been little ground for interfering with the common usage; and now that the genus Lepralia is dismembered, all pretext for such interferenee would seem to be removed.

a. Orifice without a sinus; zoarium incrusting.

Cellepora pumicosa, Linneus.

Plate LIV. figs. 1-3.

"Ponovs Escuars," Ellis, Corall. 75, no. 7, pl. xxvii. fig. $f$ F. 
Cellepora pumicosa, Linn. Syst. 1286: Lamk. An. 8. Vert.ed.2, ii. $256:$ Flem. Br. An. 532 : Jolnston, Br. Zooph. ed. 2, 295, pl. lii. fig8. 1-3: Busk, B.M. Cat. ii. 86, pl. cx. figs. 4-6.

Cemlerora venuucosa, Linn. Syst. 1286: Fabricius, Faun. Grœnland. 434 : Olivi, Zool. Adr. 229.

Milletora pumicosa (part.), Pallas, Elench. 254.

Cellepora spixosa, Turton, Brit. Faun. 205.

Madrepora verrecaria, Esper, Madrep. pl. xrii. figg. $c \mathrm{O}$ and $b \mathrm{~B}$.

Zoarium massire, scabrous, often nodulated, composed of many layers, of a pinkish colour when fresh. Zoocia subcylindrical or ovatc, smooth, ercet (cxcept near the margin, wherc they arc decumbent), crowded: orifice orbicular, with a thin raised peristomc; in the ecntre, immcdiately below the inferior margin, a tall pointed rostrum, bearing on its inner aspeet, towards the bottom, a largc avicularium with broad triangular mandible, pointing upwards. Oøcia small, scmicircular, slightly rccumbent, smooth; surfacc entirc, or with a few rather large punctures on the front.

Polypide large and of a delicate orange colour.

Habitat. On stones, shclls, stcms of zoophytes and of Algae, \&c., from beyond low-water mark to deep watcr.

Localities. Generally distributed.

Geograpical Distribution. Meditcrancan (Pallas) : Adriatic (Heller \& Grubc): Roseoff, common (Jolict) : Finmark, 30-50 fathoms at Harösund; Bcrgen (Sars): Hougcsund, North Sca, 5-20 fathoms (Kirchenpauer): Gulf of St. Lawrenee (Dawson): mouth of the Jenesei (subfossil) (F. Schmidt) : California (Dr. Sinelair) : Ncw Zealand, forming small white balls on Sertularia \&e. (F. W. Hutton) : Bass's Straits (Macgillivray).

RaNGe ix Trye. Scotch Glacial deposits (Gcikie) : Manzoni gives this specics a place in the Italian Pliocenc fauna; but his deseription of the apcrture, "antice simuata," raises a doubt as to the accuracy of his identification. He at first referred the Pliocene form to C. scruposa (Busk), but subsequently to the present speeics. 
C. pumicosa varies indefinitely in gencral appearanee. Sometimes it forms small oval masses on the stems of zoopliytes. When devcloped on the surfaee of shells \&e., it takes the shape of a somewhat eireular mound, raised in the eentre, and sloping off towards the edge. Sometimes the surface of the zoarium is distinetly nodulous. Frequently it oecurs in irregularly shaped porous masses of very considerablc size, composed of many layers of erust placed one upon another, and involving more or less the fragment of shell or other body which eonstituted the original site of the eolony. A specimen of this kind from Torbay measures $3 \frac{1}{2}$ inches in length by $2 \frac{1}{2}$ in width.

The cells in the older portions of the eolony are perfeetly erect, the apertures looking straight upwards; they are separated by spaecs, which are occupied at a lower level by the orifiees of other cells. The younger marginal zoceia are decumbent, bright and silvery, and of delicate texture. The large and orbicular mouth, without any traee of sinus, and the strongly developed muero in the centre of the lower margin (which encroaches slightly on the aperture), bearing a pointed avieularium at the bottom of its inner surface, are the most marked distinetive features. The total absenee of the spatulate avicularia, which are so abundant on most of the otler British species, is also a good (negative) character. The mucro varics eonsiderably in size and proportions, but is commonly tall, and rises above the avicularium into a slender and sharply pointed spike. The avieularium itself is generally turned a little sideways.

The surface of the oœeium seems to be generally entire; but in some specimens it is punetured; the punctures are large, eircular, reniform, or wedge-shaped.

A variety oeeurs in whiel the ovieells are not only punctured, but bear, in most eases, a rather large avieularium on eacli side, with a pointed manchible. 
b. Orifice without a sinus; zoarium ramose.

Cellepora ramulosa, Linnaus.

\section{Plate LII. Ags. 7-9.}

Cellebora rayulosa, Linn. Syst. ed. xii. 1285: Flem. B. A. 532 : Lamk. An. s. Vert. ed. 2, ii. 258: Couch, Oorn. Faun. iii. 110, pl. xx. fig. 2: Johnst. B. Z. ed. 2, 296, pl. lii. figs. 4, 5 : Busk, B.M. Cat. ii. 87, pl. cix. figs. 1, 2, 3; Crag Pol. 58, pl. ix. fig. 2: Alder, Quart. Journ. Micr. Sc. (n. s.) iv. 96, pl. ii. fig. 1: Smitt (forma 3), loc. cit. 31 \& 192. (Not C. ramulosa of Manzoni, Bryoz. foss. Ital., Contr. iv. 12, pl. r. figs. $29,29^{\prime}$, and pl. vi. figs. $30,30^{\prime}, 30^{\prime \prime}$ )

Millepora puyicosa (part.), Pall. Elench. 254.

Cellepora pearcosa, rar., M. Sars, Reise i Lof. og Finm. 27.

Zoarium erect, much and irregularly branehed, rising commonly from a spreading base, branches cylindrical, or broad and somewhat eompressed, dichotomous, usually tapcring very slightly towards the extremity. Zocecia orate, smooth and glossy, elongate, slender, and regularly disposed in the younger portions of the eolony; in the older prominent and ventrieose, and irregularly placed; orifiee suborbieular, with a thin raised peristome, a strongly developed rostrum below, generally produeed into a sharp point, with an avicularium on one side of it, the base of which projects, like a spur, over the aperture (Plate LII. fig. 9), mandible aeute, direeted upwards: spatulate avicularia distributed oceasionally amongst the cclls. Oxcia subglobose, broader than high, smooth and silvery, often produeed in front into a penthouse-like projection; surface gencrally entirc, rarely punctured.

Polypide of a faint red or flesh-colour, with numerous tentaeles.

Height 1 to 3 inehes.

Habrat. On the stems of Sertularian hydroids, shells, \&e., ehiefly from rather deep water.

Localities. Cornwall, 30 fathoms; South Devoll; 
Dogger bank (T. H.) : Guernsey; Hastings (Miss Jclly) : St. Audrews, deep water (Dr. M'Intosh) : Shetland, 40170 fathoms; the Mineh (A. M. N.) : between 62 and 72 fathoms off the Maiden Lighthouses, eoast of Antrim (Mr. W. Swanston) : Bclfast Bay (Iyndman) : Donagharlce, 8-10 fathoms (Dr. Drummond) : Youghal (Miss Ball) : 8 miles S.S.W. of the Mull of Galloway, 50 fathoms; 5 miles S.W. of the same, 110-140 fathoms (Capt. Beeelıey) : off Sana Island, 40 fathoms (Hyndman) : \&e.

Geograpiical Distribution. Norway, to the North Cape (Kirehenpaucr) : Bohuslän, 50-60 fathoms (Lovén) : Bergen; Finmark (Sars) : Roseoff (Joliet) : Madcira (J. Y. J.).

Range in Trme. Coralline Crag (S. W.).

There are two marked varietics of this spceics-onc slender and delieate, the other with broad, somewhat flattened branehes, and altogether a stoutcr habit. At its origin, when developed on the various kinds of zoophyte, its favourite sitc, the zoarium surrounds and clasps the stems; and then the creet shoots rise from all parts of the incrusting base. The branching is often luxuriant, and results in the formation of very pretty coral-like masses of eonsiderable size. The surface of the zoarium appears rough and spinous.

The usual differcnecs between the older and younger zoœeia oecur in a very marked degree in this specics; in the latter a row of large punctures may be traced round the very base of the eell. The position of the oral avicularia on the side of the rostrum is onc of the points which distinguishes this form from C.pumicosa; another may be found in the presenee (though rarely) of the large spatulate avicularia, whieh are always wanting in the latter.

Busk represents the ovicell as punctured, whilst Alder, on the other hand, describes it as imperforatc. Both, I 
believe, are, to some extent, right. In a large proportion of cases the surface seems to be entire; but I have met with eases in which it was rather thiekly punetured. This eharaeter can hardly be relied on as a speeific diagnostie. The raised peristome of the eell unites with the areh of the aperture of the ovieell, and gives the latter a hooded appearanee. The projection in front of it is, I believe, generally present when the ovieell is fully dereloped, and gires it a rery peeuliar and pieturesque appearanee.

Celle pora dichotoma, Hineks.

Plate LV. figs, 1-6, \& 7-10 (var, attenuata).

Cerlefpora nichotoma, Hincks, Devon \& Cornw. Cat., Ann N. H. ser. 3, ix. 304 (49 sep.), pl. xii. figs. 7, 8: Alder, Quart. Journ. Micr. Sc. (n. 8.) iv. (1864), 96, pl. ii. figs. 2-4: M'Intosh, Mar. Faun. St. Andrews, 48.

Cenlepora attexuata, Alder, Quart. Journ. Mier. Sc. (n. s.) ir. (1861), $9 \overline{7}$, pl, ii. figs, $5-8$.

Cellepora rayclosa, forma avicularis (part.), Smitt, loc. cit. 32.

Crllepora avicclaris, Smitt, Flor. Bryoz. pt. ii. 53, pl. ix. figs. 193-198.

Zoarium slender, narrowed towards the base and expanding upwards, dichotomously branched with great regularity, or of stouter habit, much and irregularly branched; branches sometimes eylindrieal, slender, tapering, with a somewhat pointed extremity ; sometimes broader, divided above into short blunt segments. Zocecia ovate, ventrieose, smooth, irregularly heaped; orifice suborbieular, with a thin raised peristome; below it a short, broad and blunt rostrum, with an avicularium on one side of it, mandible subtriangular. Oacia globose, prominent, silvery, eovered in front with raised punetures, united to the peristome. Numerous small, raised, circular avicularia, and frequently a considerable number of large spatulate avicularia distributed over the zoarium.

Height not exeeeding $l$ ineh, generally less. 
Var. a (attenuala, Mlder). Zoarium slender and of miform thiekness throughout. Zocecia less ventrieose and erowded, and the surfaee eonsequently smoother and more even; avicularia more sparingly developed.

Haвiтat. On zoophytes, chiefly from deep water.

Localities. Off Polperro, 30 fathoms ('T. H.) : Northumberland, not uneommon (Alder) : St. Andrews, on zoophytes, abundant and fine (Dr. M'Intosh): Wiek and Peterhead (C. W. P.) : Shetland, 40-70 fathoms; the Mineh (A. M. N.) : Oban; Ireland (T. H.). Var. a (attenuata). Shetland (Barlec) : ibid., "local, 80-110 fathoms, 20-25 miles N.N.E. of Unst" (A. M. N.).

Geographical Distribution. Florida, 9-111 fathoms (Pourtales).

In its smaller and more delieate form the habit of this species is very characteristie. It is at onee recognizable by the simplicity of its diehotomous branching and the comparative smoothness of its surfaee. The stem, attenuated below, expands gradually upwards, and divides into two principal branehes, whieh are bifurcate at the top. The ramifieation is eommonly carried no further in this variety. The branches are slender, subeylindrieal, and taper slightly towards the extremity; and the habit is essentially neat and compaet. This is the form which eommonly oceurs on our south-western eoasts.

But in northern examples $C$. dichotoma presents a very different eharaeter. It beeomes irregular and rugged in its mode of growth; the ramification is more eomplex; the branches are often broad and spreading; and the speeies imitates to a large extent the habit of C. ramulosa. Oecasionally the branches are much produced, forming tall, eylindrieal and slender shoots; but in this form, as in the one last described, there is a total absenec 
of the simple regularity which eharacterizes the southern variety*.

In its minute charaeters $C$. dichotoma is very constant. The zoocia are prominent and rentricose; and the rostrum below the aperture is uniformly short and blunt. The ovi eells, with their silvery punctured surfaees, are a eonspieu. ous feature, and are dereloped in great profusion; in some eases they are more or less covered by a dense white erust. They unite witl the elevated peristome in front; and the aperture in the fertile eells is much eontraeted. Perhaps the most remarkable characteristic of this speeies in its ordinary state is the great development of the avicularian appendages, and the variety of form which they exhibit. Some are eireular, of minute size, and placed on the summit of a small rising on the cell-wall, which must be regarded as representing the avieularian eell. Thesc are present in very great numbers, somctimes as many as three oceurring on a single zoœcium. The præoral avieularium has a subtriangular mandible; the rostrum on which it is placed is elearly the equivalent of the rising which bears the smaller form. The spatulate avieularia are often plentifully dereloped, but in some specimens oceur more rarely. They are immersed and rather irregularly distributed; but one is frequently present beside the ovieell.

It can hardly, I think, be considered doubtful that the C. allenuata of Alder is a mere variety of the present speeies. The differenees in habit are of the rery smallest importanee, and are not so great as those which exist between the stout and slender varieties of $C$. dichotoma, whieh I liave just described. Mr. Alder himself mentions a variety of the latter " eonsisting of more slender eylin-

" "It raries a good deal in form, sometimes sprending in a palunate manuer, like an elk's horn, sounctimes consisting of inoro slender cylindrical branehes of nearly equal thickness throughout. The typical form, however, is a little ventricose in the centre and not inuch branchod." - A LDER. 
drical branches of nearly equal thickncss throughout." In the minute characters the two forms cssentially agrce: the only difference at all worth consideration is, that the eells are less ventricosc and crowded in the attenuata varicty, and the surface, as a consequence, smoother. But towards the extremity of the branches this claraeter is less marked, and there is an approach towards the normal eondition. The stcms are in all cases comparatively smooth towards the bottom (i.e. in the older portions); and in the attenuata form a larger proportion of the zoarium seems to be in this statc. I belicve that this variety is more highly calcificd than the normal form, and that the peculiarity in its appcarance is partly due to this circumstancc. I have already referred to the dense white crust which occasionally forms over $C$. dichotoma, and by which the ovicclls are in some cases partially invested; and the varicty scems to have undergone a similar ehange.

The small avieularia are present on C. attenuata, and exhibit exactly the same characters as on the normal dichotoma, but are somewhat less numerous. Mr. Alder seems not to have met with the spatulate avicularia at all; but though extremely rare in the spccimens I have secn, they are not altogether absent. The peeuliaritics of $C$. attenuata, which he has noted with characteristic quickness and accuracy, are certainly those of a variety and not of a species.

c. Orifice with a sinus below; zoarium incrusting.

Cellepora avicularis, Hincks.

Plate LIV. figs, 4-6.

Cellepora avicularis, Minchs, Quart. Journ. Micr. Sc., Zoophytol. viii. 278 ; Proc. Dubl. Un. Zool. \& Bot. Assoc. ii. pt. 1, $7 \tau$; Deron Cat., Ann. N. H. ser. 3, ix. $30+$ ( 48 sep.), pl. xii. fig. 6 : Norman, Shetland Pol., Rep. B. A. 1868, 308. 
Cellepora rantlosa, forma aviculanis (part.), Sinitt, Oefv. $K$. Vet-Akad. Förh. 1867, Bihang, 32 \& 194, pl. xxriii. Ggs. 202 \& $205^{*}$.

Zoarium incrusting, multiform, often nodulated. Zoœcia ovate, smooth, ereet (in the older parts of the eolony), crowded, irregular, the apertures showing at different levels on the surface; orifice orbicular above, with a pointed sinus below; peristome elevated, thin; beneath the aperture, and placed a little on one side of the sinus, a rather massive rostrum, bearing a large avicularium with pointed mandible, whiel is turned a little sideways. Occia prominent, subglobose, rather broader than high, with large punctures, frequently an ascending process on each side or on one side, a little in front, bearing a small avicularium, with a rounded mandible. Very large spatulate avicularia abundant, irregularly distributed.

Habitat. Inerusting the stems and branelies of zoophytes with thick nodulous rolls, on shells \&e. from moderate to great depths.

Localities. South Devon and Cornwall, eommon, on Sertulariaus, Gorgonia, \&e.; Obau (T. H.) : Hastings (Miss Jelly): St. Andrews, occasionally (Dr. M'Intosh) : Shetland, on zoopliytes (A. M. N.) : coast of Antrim (Hyndman).

Geographical Distribution. From Bahusia to Spitzbergen, pretty eommon, in moderate and abyssal depths (Smitt): Naples, 10 fms. (Waters): Le Have bank, lat. $42^{\circ}$ $56^{\prime} \cdot 5$ N., long. $64^{\circ} 5 \mathrm{I}^{\prime} \cdot 3 \mathrm{~W}$., $45 \mathrm{fms}$. (Smith and Harger).

I believe that $C$. avicularis will be found to have a wide distribution; but hitherto it has been recognized in few

* C. avicularis resembles in many points the C. Redoutei of Audouin, figured in Sarigny's 'Eggpte'; but, if the figure uny be trusted, the two must, I think, bo aceounted distinct. A part from other differences, thero are an order and regularity about the latter, which are certainly no characters of the present form. With our present knowledge of Audouin's aperies, we should not be warranted in identifying it with $C$. avicularis. 
loealities, having been passed over probably from its superfieial resemblance to $C$. pumicosa. So far as habit and general appearanee are eoncerned, it affords a striking illustration of the protean eharaeter of its tribe, the erust being moulded on the various substanees which it invests. It ineloses the stem and branches of zoophytes in a stony eylinder, which is often nodulated on the surface. I have in my possession a remarkable specimen, which forms a thick-walled tube about two inches in length, round the ease of an annelid, and is covered with prominent papilla. On shells the erust rises into mound-like masses, often with a mamillated surface; it is sometimes of very great thickness, and eomposed of many strata of cells. The eells are punetured round the edge ; and in eertain conditions of the zoarium this eharacter is a very conspicuous one; they are also crowded and very irregularly plaeed. The sinus on the lower margin of the orifice is broad and pointed. When the ovieell is absent the peristome is very slightly developed; but in fertile eells it rises to a eonsiderable height, and unites with the ovicell, walling in and eoncealing the primary aperture.

The surface of the zoarium offers a bewildering profusion of strueture. Amongst the eells of the uppermost layer those of the one beneatl it are more or less visible; and at all points there are multitudes of the large rostra, avieularia of various form and size, punetured ovicells, now prominent, now deeply immersed, all erowded together, as it were, without plan or order. The small lateral avieularia in front of the ovieell are often wanting; but they must be regarded as a eharacteristic feature of the species. The spatulate avicularia are developed in great quantity; they are met with on all parts of the zoarium, showing no regularity of arrangement, turned now in one direetion, now in another; but in many eases they seem 
to have more or less connexion with the ovicell. Occasionally stout conical rostra occur, apparently unconnected with a zoceium, bearing very large avicularia, with broad triangular mandible.

Cellepora tubigera, Busk.

Plate LIV. figs. 7-9.

Cellepora tubigera, Busk, Crag Pol. 60, pl. ix. figs. 8 \& 10: Manzoni, Bryoz. foss. Ital., Contr. iv. 14, pl. iv. fig. 25 (?).

Zoarium adnate, irregularly convex or subconical. Zoxcia distant, connected by ridges, sparsely punctured; orifice orbicular, with a sinus in front; cylindrical tubular processes supporting avicularia arising from the front or side of a cell, or from the intercellular ridges. [Busk.]

Habitat. On shell, \&e.

Localities. Britain, south and west coasts (Busk): Lamlash Bay, Arran (G. West).

Geographical Distribution. Coast of France (Jeffrcys).

Ravge in Time. Corallinc Crag, on shell (S. W.) : ? Italian Pliocenc (Manzoni).

I am only acquainted with this specics through the description and figures in the 'Crag Polyzoa,' and have sometimes fancied that it might be identical with $C$. avicularis. It is difficult in this genus to form a positive opinion on figures taken from the fossil; the following, lowever, could hardly have been written of the last-named:- "Instead of the strong conical rostrum, with an avicularium on its inner aspect, so characteristic of Cellepora pumicosa, most of the cells are provided with slender subcylindrical aseending processes, having a small avicularium at or near the 
summit" ('Crag Polyzon,' p. 61). Nor could the eells of C. avicularis be eorrectly deseribed as "distant, eonneeted by ridges." I must leave the species to be illustrated by the study of reeent examples.

Cellepora armata, Hineks.

Plate LIV. figs. 10-13.

Cellepora armata; Hincks, Quart. Journ. Micr. Se. (u. s.) viii. 278, pl. iii. fig. 5 ; Proc. Dubl. Uuiv. Zool. \& Bot. Assoc. ii. pt. 1, 77. pl. iii. fig. 5 .

Zoarium adnate, forming a rather thin crust. Zoocia large, distinet, ovate, ventricose, smooth, suberect, except near the margin; orifiee orbieular, more or less produeed and pointed below; peristome thin and raised; a stout subeylindrieal rostrum below it, placed a little on one side, bearing an avicularium immediately under the apex, with a subtriangular mandible; large, raised, spatulate avicularia distributed in great numbers amongst the eells, the mandible generally direeted inwards. Ooecia smooth, walls entire.

Haвiтat. On shell, \&c., probably from deep water.

Localities. Coast of Antrim (Hyndman): Hastings (Miss Jelly) : Dogger bank, on mussel; Cornwall ('I'. H.). Geograpincal Distribution. Algiers, on Lepralic foliacea (J. Y. J.).

This is a large-celled speeies, and in general appearance differs much from $C$. avicularis. Its structure is simple; it has neither the irregular and eonfused appearanee of the latter nor the spinous charaeter of C. pumicosa. The eells are distinet, not erowded together, and very ventrieose. The praoral rostrum is short, subeylindrieal, and blunt above, and immediately below the apex is placed 
the avicularium, turned a little towards one side and looking upwards. The aperture is large, sometimes orbicular, sometimes slightly produced and pointed below, sometimes with a more decided sinus on the lower margin. Many cells occur in which it is simply orbicular. The spatulate avicularia, which are of very large sizc, in kecping with the zoccia, are present in great numbers, and form a striking characteristic.

The discrimination of forms amongst the Cellepora is a very difficult task, and it is necessary to make large allowanee for the variability of the tribe; but the present seems to have the characters of a species.

\section{Cellepora Costazir, Audouin.}

Plate LV. figs. 11-14.

Cellepora Costazil, Audouin, Expl. (1826): Savigny, Egypte, pl. vii. fig. 4 . Cellepora bimucronata, Mass. Ann. N. H. vii. (1841), 367, pl. ix. fig. 1.

Leipralia Hassallit, Johnston, B. Z. ed. 2 (1847), 304, pl. liv. fig. 3.

Cellepora Hassalli, Busk, B.M. Cat. ii. 86, pl. cix. figs. 4-6; var. a, Quart. Journ. Mier. Sc. (n. 8.) ri. 263, pl. xx. fig. 6: Manzoni, Bryoz. foss. Itrl., Contr. iv. 17, pl. iv. fig. 22.

Celleporina IIassalli, Gray, B.M. Rad. 128.

Celezporaria Hassalli, Smitt, OEfv. K. Vet.-Akad. Förh. 1867, Bihang, 33 \& 197, pl. xxriii. fig. 211.

Zocecia ovate, smooth, irregularly disposed, decumbent in tlie younger portions of the eolony, ereet and erowded in the older, sometimes an umbo on the front of the cell, a little below the aperture; orifiec ample, suborbieular, with a rounded sinus on the lower margin; peristome raised, an erect tubular process on each side, bearing on its summit a small oval avicularium facing towards the aperture, lower lip sometimes mucrouate; large, raised, spatulate aviculuria distributed amongst the cells, sometimes wanting. Ocecia recumbent, rounded, rather shallow, much broader than high, with an arelied 
rib on the front inclosing an area which is cither punctured or furrowed, the margin of the apcrture thickened. Polypide largc, of a reddish colour, with abont 14 tentacles. Colonies forming rather thick crusts, composed of several layers of eclls, placed one upon the other.

Var. a (tubulosa). Peristome much raised, forming a subcrect tubular ncek to the cell, with a groove-like depression at the base of it. [Plate LV. fig. 13.]

Habitat. On stones and shclls, and on the stems of Alga, Sertularians, and other zoophytes \&c., from shallow (Laminarian region) to moderately decp water (36 fathoms).

Localities. Lulworth; Coruwall, on stones, 30 fathoms ; Mount's Bay, on tangle; South Devon; Ilfracombe, off the Capstone ; Isle of Man, Ramsay and Point of Ayr ; Gucrnscy (T. H.) : Ayrshire, on Patella carulea (Landsb.): Shetland, rocks and roots of Laminarie; the Minch (A. M. N.) : Dublin Bay? (Hassall) : S.E. by E. from Bamborough, 36 fathoms (Kirchenpauer) : betwecn tide-marks, on Laminaria, \&c., Bamborough (Alder): Peterhead and Wick, plentiful betwcen tide-marks (C. W. P.).

Geographical Distribution. Madeira, without punctures on the ovicell (J.Y. J.) : Bahusia, Nortl Sea, a single colony on an Alga (Lovén): Bergen (A. M. N.) : Hougesund, 5-20 fathoms (Kirchenpauer): France, S.W. (Fischer): Naples; Red Sca (Watcrs).

Range in True. Italian Pliocenc (Manzoni).

The marginal cclls of the primitive layer, which ean be wcll scen in specimens spreading over stone, are completcly decumbent, and of a regularly ovate form. In old colonies, in which scveral layers are superimposed one upon the other, and the zoœcia are crowded together, they become erect or subcrect, the body of the cell is hidden, and only the apcrtures are visible. 'The primary orifice 
is orbienlar, and there is a well-marked sinus below; as growth adranees, however, it is more or less concealed by the elevation of the peristome, which usually forms a thin and shallow rim or border round the front. In the very curious and interesting varicty (tubulosa), the peristome is prolonged into a subereet tubular shaft, within which the orifice is decply sunk. In this form the tubular extension of the peristome rises above the ovicell, which is situated belind it. In old specimens, in which the oøcia are frecly developed, the species takes on a different and very pieturesque appearanec. In some cases the inclosed area on the front of the oceium is perforated with large punctures; in others it is simply furrowed. This is a trifling difference, the furrowed condition being probably due to the confluence of the pores.

The eells are smooth and generally dull and opaque; but in some forms they are of a more delicate texture and almost hyalinc.

Though the list of loealities is eomparatively small, $C$. Costazii is, I believe, a common species. It oceurs abundantly on the stems of various Hydroid zoophytes, over which it spreads in minute colonies.

[The following genus should have been placed amongst the Porinidx, page 226.]

Genus CELLEPORELLA, Gray.

Der. Dim. of Cellepora, a genus of Polyzoa.

Generic Cinaracter.-Zoncia suberect, the anterior extremity tubular and free, with a terminal circular orifice. No special pores. ZOARIUM (in the British species) incrusting. 
This genus includes one or two minute and ineonspieuous specics, which have the Porinidan ecll, but arc destitute of any striking charaeter. They are decp-water forms, and so far have only oecurred in the North.

\section{Celleporella lepralioides, Norman.}

Woodeut, fig. 19.

Celleporella tepalioides, Norman, Quart. Journ. Micr. Sc. (n. 8.) viii. 222 , pl. vii. figs. 4,5 .

Zoxcia irregularly disposed, subeylindrical, elongated, semiereet, upper portion frce, surface rugose, large scattered punctures upon the sides; orifice nearly eircular, terminal, opening upwards; peristome much raiscd.

Colonies forming small lobed patehcs.

Fig. 19.

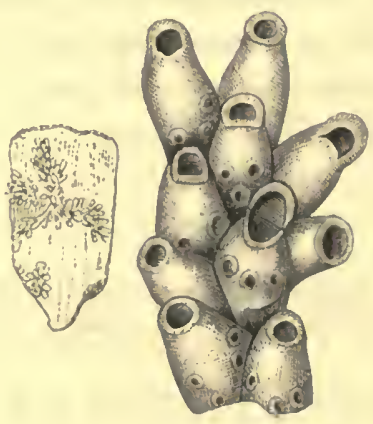

Celleporella lepralioides.

Haвiтat. On small pebbles from deep water.

Locality. Shetland, 90-]10 fathoms (A. M. N.).

Geographical Distribution. Bergen (A. M. N.): Greenland (North-German Polar Expedition). 


\section{Celleponella pygma, Norman.}

Criferornlla pygara, Norman, Shetland Polyzoa, Rep. Brit. Assoc. 1868, 308.

Zoceia very small, short-ovatc, decumbent below, subercet above, irregularly placed; surface smooth; orificc cireular; peristome much raised, tubular, unattached all round. Oxcia rounded, depressed in front, imperforatc.

Colonics forming small round patehes, scldom more than $T_{T}^{2}$ incli in diameter.

Habitat. On stones from very decp water.

Locality. Shetland, 80-170 fathoms, not uneommon (A. M. N.).

Geographical Distribution. Bergen (A. M. N.).

A minute and inconspicuous form, with few salicnt characters. The lower portion of the ecll is short and subrotund; above it is produeed into a ratlier tall cylindrical neck, which is subereet. The primary aperture is almost perfectly circular. The eclls are distinct and somewhat ventricose below; and the surface is smooth and pearly white. The tubular peristome rises in front of the ovicell.

Fig. 20.

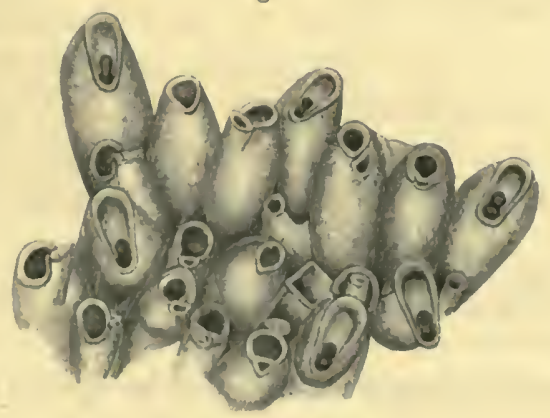

Culomy of Cellepora. 
Fig. 21.

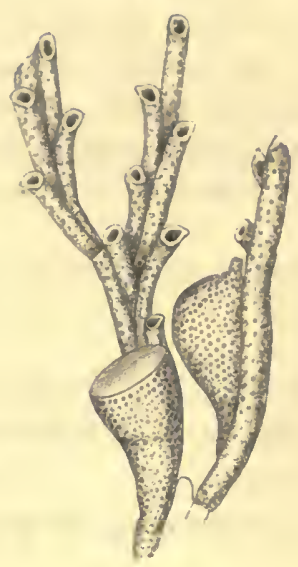

Crisia eburnea.

Suborder II.-CYCLOSTOMATA, Busk.

Crclostomata, Busk: Smitt: \&c.

Tubuliporina, Milne-Edwards: Johnston : \&c.

Aulororina (part.), Ehrenberg.

Mrrioporina (part.), Ehrenberg.

Cerroporisa (part.), Bronn.

Cestrifugrea (part.), D'Orbigny.

Group i. RAdicelitata, D'Orbigny.

Radicellata, D'Orbigny (1850): Smitt.

Articulata 8. Radicata, Busk (1859), Crag Polyzor.

Zos RIU merect, articulated, attached by radical tubes. 
Family I.-Crisiidæ.

Les Cursies, Milne-Ldwards.

Crisiad.E, Jolunston \&c.

Crtside, D'Orbigny.

Crisida, Busk.

Crisire, Smitt.

Crisides, Reuss, Bryoz. d. deutsch. Sept.

ZOARIUM dendroid, calcareous, composed of segments united by corneous joints. Zoccis tubular, disposed in one or two series.

Is this family the polypide is small and of a simple type. When it is expanded, only the erown of tentacles protrudes beyond the opening of the ecll; when retracted, the body is not doubled upon itself, but hangs straight within the eavity. There is no gizzard; the structure of the alimentary canal is perfectly simple. The number of the tentacles is eight ; and they are elothed with extremely minute cilia.

The colony originates in a small disk-like body, with a calcarcous covering, from which the primary cell is developed, jointed at the base. From the sides of the disk radical fibres are given off, which spread in all direetions, attaching themselves to the base on which the eolony is planted; these fibres are also jointed at intervals, and more or less branched. Besides these primitive rootlets other organs of attachment exist, in the shape of long fibrils, which originate at the base of the internodes, and, tending downwards, become adherent by means of lateral offshoots and serve as buttresses to the colony. On the lower portion of the shoot these fibrils are often cxtremely numerous, as many as four or five proceeding from a single internode. They are divided into segments by 
corncous joints (which are frequently jet-black), and are often of very considerable length. In the upper portion of the shoots they are much more sparingly developed, and in this situation may perhaps act as tendrils.

The occia, amongst the Crisice and the Cyclostomata generally, differ widely from those of the Cheilostomata. They secm in the present case to be cells enlarged and modificd for the simple discharge of reproductive functions, and may be regarded as lomologous with the ordinary zoøcium of the Chcilostomata in its reproductive phase, minus the polypide. Smitt has studied their contents $*$, and traced the ovum through some of its changes into the larva. He has found no sign of spermatozoa in the ovarian chamber.

The Crisia are widely distributed, occurring in most parts of the world.

Fig. 22.

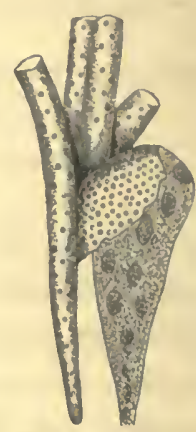

Structure of occium.

\section{Genus CRISIA (part.), Lamouroux.}

Der. From Crisia, a daughter of Oceanus, according to IIesiou.

Sfretularia (part.), Linn. \&c.

Cellularia (part.), Pallas \&c.

Cellarta (part.), Ell. \& Sol. : Lamk. : \&c.

Crisia, Launx. (part.): Flem.: Blainv, : M.-Edwards : Johnston : DOrbigny: Busk: Smitt: \&c.

Falcaria (part.), Oken.

Eucratea (part.), Fleming.

Generic Character.-Zocecra in a single series, or in two alternate series.

* "On Hafsbryozocrnas Utreckling och Fettkroppar," Cefr. Kongl. Tetensk.-Akad. Förh. 1865, no. 1, pl. iv. figs. 1-8. 
a. With the cells in a single series.

Crisia corneta, Linneus.

Plate INT. figs. 1-4.

Goat's-IIors Coraluswe, Ellis, Corall. 42, n. 10. pl. xxi. figs. c C.

Sertularia cornuta, Linn. Syst. 1316: Eaper, Pflanz. Sert. xix. figs. 1-3.

Cellelaita falcata, Pallas, Elench. 76.

Cellularia corveta, Bruguiere, Encycl. Méthod. Vers, i. 442 \& 4 ì3.

Cellaria corveta, Ell. \& Sol. 25: Lamk. An. s. Vert. 2nd ed. ii. 187

Eucratea corvuta, Lamr. Pol. cor. flex. 149 : Flem. B. A. 541.

Eucratea appexdicclats, Lamx. Expos. Méth. 8, pl. lrv. fig. 11.

Falcaria cornuta, Oken, Lehrb. Naturg. Zool. Abth. 2, 91: Gray, B.M. Rad. 137.

Unicellaria corveta, Blainv. Actinol. 461, pl. Ixxvii. figs. $2,2 a$.

Crisia corvuta, Johnst. B. Z. ed. 1, 260, pl. xxx. figs. 1, 2: Hassall: Couch: Smitt: \&c.

Crisidia conscta, Milne-Edwards, Recherches \&c., Mém. sur les Crisies, \&c. 11, pl. viii. figs. $2,2 a, 2 b$ : Johnst. B. Z. ed. 2, 287, woodcut, fig. 63, pl. L. figs. 1, 2: D' Orbigny, Pal. Franç. terr. crét. v. 603: Busk, B.M. Cat. pt. iii. 3, pl. i. figs. 5-10: \&c.

Crisia setaces, Couch, Zoologist, ii. 1096: Johnst. (Crisidia), loc. cit. 283.

Var, $a$ (Gevicelata).

Crisia geniculata, Milne-Edwards, loc. cit. 5, pl. ri. fig. 1 (Ann. d. Sc. N. sér. 2, Zool. ix. 197) : Johnst. B. Z. ed. 2, 286 : Gosse, Dev. Coast, 435: Sars, Nyt Mag. f. Naturv. Bd. vii. 379.

Crrsia corxuta $a$, sine cornibus, Smitt, Effr. K. Vet.-Ak. Förh. 1865, no. 2, $115 \& 126$, pl. xvi. figs. $2,3$.

Filicrisia genicelata, $D$ O Orb. Pal. Franç. loc. cit. 604.

Crisidia corvuta, var. $\beta$, gexiculata, Busk, B.M. Cat. pt. iii. 3, pl. i. figs. 1-4.

Zoarium forming very slender eonfervoid tufts, dichotomously branched. Zocecia in a single line, curved inwards towards the upper extremity, attenuated downwards, free for a great portion of their length, slightly punctate, with a long jointed spinc or bristle, springing from the side at a greater or less distance from the top; orifice circular. Oxcia axillary, oval, thickly speckled, with a tubular orifice at the top.

Height from to $\frac{1}{2}$ inch.

Var. $\alpha$ (geniculata). Without spines.

I Irave followed Busk and Smitt in ranking the Crisiu 2E 2 
geniculata of Milne-Edwards as a variety of the present species; indeed I hare met with what seems to be a form or eondition of $C$. cornuta which agrees with it in most respects. But if the two are ideutical, the distinguished Freuch zoologist must lave overlooked the jointed character of the zoarium, whieh is neither mentioned in his deseription nor shown in his figure. The regularity with whiel the zoceia in $C$. geniculata are bent alternately in opposite direetions, so as to give the stems a zigzagged appearance, has no parallel in the usual form of C. cornuta; but a similar arrangement occurs in the variety setacea of Couch. In the ordinary condition the cells are in a single line and all turned one way.

Hавітат. On Algæ, zoophytes, surface of rocks, shells, \&e., from tide-marks to deep water.

Localities. Widely distributed. Cornwall (Coueh) : Seilly; Mount's Bay; South Devon; Swanage; Ilfracombe ; Llandudno; Isle of Man; Filey ; Oban (T. H.) : Durham, south coast, eommon (J. Hogg): Wick and Peterhead (C. W. P.) : Cullereoats (Alder): Shetland, tide-marks (A. M. N.), \&c.

VAr. With the cells inelined alternately to opposite sides. Ilfracombe, on the underside of rocks (T. H.).

Geographical Distribution. Roseoff, on Alga and various marine bodics at all deptlis (Joliet): Mediterranean (Pallas) : Bahusia (Lovén) : Norway (Sars).

\section{b. With the cells in two series.}

Crisia eburnes, Linnæus.

Plate LVI. figs. 5, 6. Woodent, fig. 21.

"Turtan Ivory Coraline," Ellis, Corall. 39, no. 6, pl. xxi. fig. a A. Sertularia fiburnea, Limn. ed. 12, 1316: Jameson, Mem. Wern. Soc. i. 565 (1809). 
“Sertolario d'avorio," Cavolini, Metn. d. Pol. mar. 240, pl. ix. figs. 5, 6. Celleqaria ebursea, Pallas, Elench. 75.

Cellaria eburnfa, Ellis of Sol. Zooph. 24 : Lamk. An. 8. Vert. ed. 2, ii. 184.

Crisia ebirnea, Lamx. Pol. corall. Alex. 138 : Flem. B. A. 540 : Johnst. Br. Zooph. ed. 2, 283, wooodcut, fig. 62, pl. 1. figs. 3, 4 : Reid, Ann. N. H. xvi. (1845), 385: Van Ben. Recherches, Mrém. Brux. xviii. 28, pl. iii. figs. 12-16: Milne-Edwards, Ann. Se. Nat. ii. Zool. 198, pl. vi. figs. 2, $2 a$ (=var. aculeata): Smitt, GEfv. K. Vet.-Ak. Förb. 186t, 117 \& 132, pl. xvi. figs. 7-19; var. cornuta (=C. aculeata, Hass.), loc. cit. 117 \& 133: \&c. \&c.

Crisia aculeata, Hassall, Ann. N. H. vi. (1841), 170, pl. vii. figs. 3, 4 : Johnst. B. Z. ed. 2, 285.

? Crisia Prodecta, Smitt, loc. cit. 116 \& 131, pl. xvi. figa. 4, 5, 6.

Crisia Haceri, Reuss (fide Manzoni), Foss. Polyp. d. Wiener Tertiärbeck. 54, pl. vii. figs. 22-24; Fauna deutsch. Oberoligocïns, ii. 54 , pl. xr. figs. $6-8$.

Zoarium forming small bushy tufts, of ivory whiteness, much branched, branches usually originating from the lowest eell in the internode, oceasionally higher up, eurled inwards. Zoccia alternate, minutely speckled, more or less eurved, almost entirely adnate, with a circular orifice very slightly bent forwards, frequently a pointed projection on the outer side; $3-9$ cells in an internode; joints horn-coloured or (sometimes) black. Oøcia pyriform, adnate, thickly punetate, irregularly distributed, with a projecting tubular orifiee in the adult state.

Height from to 1 inch.

Var. a (aculeata, Hassall). With a long, slender spine on the outer side of the zoceia, near the top.

Var. $\beta$ (producta, Smitt). Zoøcia more or less straight, elongated, the orifiee direeted upwards.

Habitat. On Algre and zoophytes (ehiefly), stones, \&e., from tide-marks to deep water (170 fathoms in Shetland).

Localities. Generally distributed on our coasts. Var. a (aculeata). Kingstown Harbour; Brighton (Hassall): Antrim, 47 fathous (Swauston) : Ayrshire (W. 'T.) : Shet- 
land (C. W. P.) : \&e. Var. $\beta$. Shetland (A. M. N.). The position of this form $(\beta)$ is doubtful: Busk makes it a variety of $C$. cornuta; Norman refers it to eburnea; Smitt places it between the two.

Geographical Distribution. Roseoff, on Sargassum, frequent (Joliet) : Franee, S.W. (Fiseher): Belgium (Van Ben.) : the Little Belt, 16 fathoms; Hougesund (Kirehenpauer): Bahusia; Norway; Spitzbergen (Smitt): Greenland (Lütken) : Nova Zembla, west, lat. $72^{\circ} 30^{\prime}$, long. $52^{\circ} 45^{\prime}$, in 5-20 fathoms; Möller Bay, 15-20 fathoms ; Besimannaja Bay, 4-6 fathoms, \&e.; Kara sea (Stuxberg \& Théel) : N. shore, St. Lawrenee, 96 fathoms (Whiteaves): Hamilton's Inlet, Labrador, 15 fathoms (Wallich) : St. George's banks, lat. $41^{\circ} 44^{\prime}$ N., long. $64^{\circ}$ $36^{\prime} \mathrm{W}$., in 60 fathoms (Smith \& Harger) : California (W. T.); Mediterranean (Pallas): Adriatic (Heller) : Madeira (Busk): Teneriffe (D’Orbigny): New Zealand (Hutton): Australia (T. H.) : Fiji Islands (Kirehenpauer). Var. $\alpha$. Roseoff (Joliet). Var. $\beta$. Bohuslän, 5-10 fathoms, on Algæ (Smitt): Nova Zembla, 5-10 fathoms, on Algæ (Stuxberg \& Théel).

Range in Trme. Postplioeene, Montreal (Dawson): Palæolithic, British (A. Bell): Seoteh Glacial deposits (Geikie): Austro-Hungarian Miocene (Reuss).

\section{Crisia denticulata, Lamarek.}

Plate LVI. figs. 7-9.

Cellaria denticulata, Lamk. Ann. 8. Vert. ed. 2, ii. 182.

Cusia luxata, Flem. B. A. 540: Blainv. Actinol. 460 : Couch, Corn. Faum. pt. iii. 99, pl. xviii. fig. 3.

Crisia Dexticulata, Milne-Edw. Ann. Sc. Nat. sér. 2, Zool. ix. 201, pl. vii. fig. 1 : Johnst. B. Z. ed. 2, 284, pl. 1. figs. 5, 6: Busk, Crag Pol. 93; B.M. Cat. pt. iii. 4, pl. ii. figs. 3,4 , pl. iii. figs. 1-6, pl. iv, figs. 1-4: Snitt, loc, eit. 117 \& 137: \&c. \&c.

? Crisia Arctica, Sars, Geol. og Zool. Iagttagelser (186i3), 31.

? Crisia attenuata, Hcller, Bryoz. Adr. M. 41, pl. ir. figs. 1, 2. 
Zoarium forming large, dense masses, of a stout and crect liabit, muel branehed, punetate; branehes straight, broad, flattish, attenuated towards the base, originating from the fourth or fifth eell above the joint, sometimes from the second. Zocecia semialternate, elosely aggregated, elongate, nearly straight, almost entirely adnate; orifice elliptieal, usually pointed on the outer side above, slightly bent forward, the internodes variable in length, but generally with numerous eells, sometimes as many as 16 or 17 ; joints usually jet-blaek. Oocia oval, subpedieellate, thiekly speckled, a tubular orifice at tho top.

Height about an ineh.

Var. a. Zoarium more slender; the zoœcia much longer, so that the orifiees are much more distant from each other longitudinally, and appear less erowded; inter.nodes usually of moderate length.

C. DENTICULATA is ehiefly distinguished by its long, straight, broad and flattened internodes, on whieh the eells are elosely packed together. In habit it is deeidedly stout and ercet.

HАвітат. In elefts and roek-pools near low-water mark, and on Alga and zoophytes \&e. from tide-marks to deep water.

Localities. Very generally distributed.

Geographical Distribution. Roseoff, on roeks, and especially on Cystoseira fibrosa (Joliet): Adriatic (Heller): Madeira; South Afriea (Busk): Norway, 30100 fathoms (Sars): Bahusia; Spitzbergen (Smitt): Kara sea (Stuxberg \& Théel): Grand Manan, 10 fathoms (Stimpson).

Range in Trae. Lower Suffolk Crag; Palrolithic (A. Bell) : Scotch Glacial deposits (Geikie). 
Group ii. IncRustata, D’Orbigny.

Centriplenés empatés a cellules nox operculées (part.), D'Orb. Pal. Franç.

INArticulata, Busk, B.M. Cat. pt. iii.

Inarticulate seu adfixa, id. Crag Pol.

Iscrestata, D'Orb. : Smitt.

Zoarius calcareous, continuous, not divided by corneous joints, or furnished with radical tubes; erect and attached by a contracted base, or recumbent and immediately adnate, either wholly or in part.

\section{Family II.-Tubuliporidæ.}

Tobiporada, Fleming.

TUBUhiponide, Jolnnston (part.): M.-Edwards (les Tubulipores): Busk: Smitt (part.): \&c.

Sparside (part.), D’Orbigny.

ZOARIUM entirely adherent, or more or less free and erect, multiform, often linear, or flabellate, or lobate, sometimes cylindrical. Zocecia tubular, disposed in con-

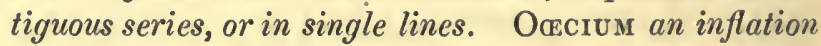
of the surface of the zoarium at certain points, or a modified cell.

\section{Genus STOMATOPORA, Bronn.}

Der. From $\sigma \tau \dot{\rho} \mu a$, the mouth, and $\pi$ ó $\rho \circ$.

Alecro, Lamx. (1821*) : Blainville: Johnston : M.-Edwards : Busk : Se. 'l'ubulipora (part.), Lamk: Smitt.

Stosatopora, Bronn (1825): D’Orbigny (for uniserial species).

Auropora (part.), Goldfuss: Reuss.

Proboscina (part.), Audouin : D'Orbigny : Smitt (subgenus).

Disstopora (part.), Smitt.

Generic Character.-Zoarium repent, wholly adnate,

* Previously (1814) introduced by Leach for a genus of Echinoderms. As the name Alccto is still employed in connexion with the Crinoider and is ordinarily associated with them, I am compelled to abandon it, which I do with much regret. 
or free at the extremities, or yiving off erect processes; simple or branched; branches more or less ligulate. ZoceIs in great part immersed, arranged in a single series or in several, which take a linear direction or are very slightly divergent.

THE distinetion between this genus and Tubulipora is somewhat shadowy. In elassifying the Cyelostomata we lave to base our divisions mainly on habit or mode of growth, on the plan aecording to which the zoceia are aggregated together into colonies; the simplieity and general similarity of the eell throughout the tribe leave no other course open to us. We have to deal with very uniform struetural elements very variously combined; and the modes of eombination ehiefly supply us with the bases of our system. Under these eireumstanees, we may not expeet very strongly marked boundary lines. Stomatopora is distinguished by its linear, adpressed, dichotomously branehed zoarium, in which the eells are generally immersed for a great portion of their length, and are not divergent, exeept in a very slight degree, and then almost exelusively towards the very extremity of the branehes. The most marked variation within the limits of the genus is found in the forms which have the zoarium partially free and ereet. They eonstitute the subgenus Proboscinc of Smitt.

\section{a. Zoarium entirely adherent.}

Stomatopora granulata, M.-Edwards.

Plate LVII. figs. 1, 2.

Alecto guavelata, M.-Eduards, Mrém. 13, pl. xvi. figs. 3, $3 a$ : Johnst. (part.), B. Z. ed. 2, 250 (pl. xlix. figs. 1, 2, are prubably referable to $S$. Johnst(uni): Busk, B.M. Cnt. iii. 24, pl. xxxii. fig. 1 , \&c. 
Stomatopora graxulata, D'Orb. Pul. Fr. terr. crét. v. 836, pl. dexxiii. figs. 5-8 (Alecto un tho plate).

Stomatopora incrassata, id. ib. 837 , pl. dexxviii. figs. 9-11 (Alecto on tho plate).

3 Alecto parasita, Heller, Bryoz. Adr. A. 49, pl. iii. fig. 10: Manzoni, Bry. d. Castrocaro, 41, pl. vii. fig. 69.

Zoarium dichotomously branched; branches linear, sometimes anastomosing. Zoxcia uniserial, minutely granular, the oral extremity more or less ereet and free; orifice cireular. Oæcia (?).

Habitat. On sliells and stones, chicfly from deep water.

Localities. Cornwall (Couch) : Lee, near Ilfracombe, on Laminaria-roots (T. H.) : Hastiugs (Miss Jelly) : Northumberland and Durham, rather rare (Alder): Wiek and Peterhead (C. W. P.) : St. Andrews, not rare (Dr. M'Intosh) : coast of Antrim, abundant (Hyndman) : island of Coll, on Pinna (Landsb.) : Hebrides ; Shetland, Outer Haaf, to 170 fathoms, \&c. (A. M. N.) : \&e.

Geographical Distribution. Roscoff (Joliet) : Bergen (A. M. N.).

Range in Time. Grès vert inféricur, France (MilneEdwards).

In this species the cells are always disposed in a single series; they are of about equal width throughout, or sometimes very slightly cnlarged above, and altogether adnate, with the exception of the oral extremity, which is in a greater or less degree bent upwards, and stands ereet and free. There is, however, much variability in the latter eharacter; and in old specimens, or such as have becn developed in exposed situations, the orifice is often very slightly raised. The walls, in young and fresh colonies, are decidedly vitreous, and the whole surface is prettily frosted; with age the walls become thick and opaque, and are sometimes strongly ribbed transversely. 
The ramifieation, which is often luxuriant, and usually straggling and irregular, is simply dichotomous in plan; occasionally the branches meet and unite, and form a kind of network.

Johnston seems to have based his description of S. granulata on specimens of Milne-Edwards's species, and of the form which Heller has characterized as Criserpia Johnstoni. His figure must be referred to the latter.

Stomatopora Major, Johnston.

Plate LVIII. and Plate LXI. fig. 1.

Alecto yason, Joknston, B. Z. ed. 2, 281, pl. xlix. figs. 3,4 : Busk, B.M. Cat. iii. 24, pl. xvii. figs. 3 (very characteristic) to $5, ? \mathrm{pl}$. lvi. fig. 3: Landsb. Pop. Hist. 279, pl. xvi. fig. 60.

? Tubuhipora tranens, Couch, Corn. Faun. iii. 105, pl. xix. fig. 5.

? Tubulipora repexs, S. V.Wood, Ann. N. H. xiii. 14: Busk (Alecto), Crag Pol. 112, pl. xx. fig. 8 (not fig. 5).

Zoarium usually much branched dichotomously, walls minutely speekled or dense and smooth; branehes rather straggling, stout, often radiating from a central point, widening gradually towards the top. Zoceia disposed in 2-4 series, immersed, the oral extremity more or less erect and free, orifice circular; the free extremitics sometimes arranged in very regular transverse rows, sometimes less regularly disposed. Oocia developed at the end of the branches or immediately below the terminal bifureation, somewhat elongate, broad above and narrowed downward.

Is the present form the branching is often luxuriant, and the most beautiful radiating growtlis are developed in the sheltered hollows of deserted shells (Plate LVIII. fig. 4) ; but, as is universally the ease in this tribe, mueh diversity 
in mere habit prevails. The branelies are decidedly stout and somewhat depressed or flattened, widening gradually, and usually without any abruptuess, towards the top. In a beautiful specimen, however, from Guernsey, which seems to be referable to this species, they terminate above in a triple or double division, and the extremities are rather more expanded than is usual (Plate LVIII. fig. 2). The zoceia are in series ranging from two to three or even four; in some eases they are disposed with extreme regularity, and the orifices are placed side by side and form a line across the ecll (Plate LXI. fig. 1). More commonly there is a certain amount of irregularity; frequently the cells are arranged semialternately, though still preserving their separate grouping. The arrangement of the zoceia in more or less distinct scrics of $2-4$ is one of the points that distinguish the present form from $S$. dilatans.

In the Gucrnsey specimen, before referred to, oøcia are developed immediately under the terminal tri- or bifureations; in other eases they are placed elose to the extremity of the branch. They consist of the usual inflation of the surface of the zoarium, in which a number of the tubes are involved.

In fresh specimens the surface is usually speckled; but states are of frequent occurrence in which the zoarium is dense and smooth.

Habitat. On old shells and stones, ehicfly from deep water.

Localities. Guemsey (A. M. N.) : Cornwall (Couch) : Isle of Man (T. H.) : Northumberland, not common (Alder) : island of Coll (Landsb.) : Sana Island (W. 'T.) : coast of Antrim, common; off the entrance to Belfast Bay, 25-35 fathoms (Hyndman): Shetland, common to 170 fathoms; Hebrides (A. M. N.) : \&e. 
Geograpuical. Distribution. Bergen (A. M. N.) : Roscoff (Jolict).

Ravge in Time. Coralline and Red Crag, on shell (S. V. Wood).

\section{Stomatopora dilatans, Johnston.}

Plate LVII. figs. 3, $3 a$.

A.ecto nilatass, Johnst. B. Z. ed. 2, 281, pl. xlix. figs. 5, 6: Busk, B.M. Cat. iii. 24, pl. xxrii. fig. 2 ; Crag Pol. 112, pl. xx. figs. 6, 7 ; Landsb. Pop. Hist. 2S0: Norman, Shetland Dredging-List, Rep. Brit. Assoc. for 1867 (1868), 310.

? Diastopora kepess (part.), Smitt, loc. cit. 395 and 416, pl. viii. figs. 1-4. ? A recto Repens, Manzoni, Bryoz. d. Castrocaro, pl. ri. fig. 72.

Zoarium entirely adhercnt, slightly ramified, consisting of a short stem, from which two or three long, widcly divergent, serpentine branches originate, which sometimes bifurcatc at the extremity; branches convex, rounded, oftcn constricted at intervals, enlarging towards the end, so as to assume a clavate form. Zoocia rather slender, laid closcly side by side in many scries (7-8 in the cxpanded portions), oceupying the wholc of the front of the branch, commonly alternatc, punetate, vitrcous, and of a delicate whiteness; orifice raised, but usually projecting very slightly. Oœcia at the extrcmity of the branches.

Tnis speeies differs from the preeeding in its mode of branching, which is usually much simpler than that of S. major, in the cliaracter of its branches, which are long and serpentine, not depressed, and decidedly clavate at the extremities, and in the arrangement of the cells, which are slender, horizontal, not disposed in companies of two, three, or four, but packed elosely together and oceupying the whole front surface of the branch, slightly raised towards the orifice, and of singularly delicatc texturc. The branches are usually (so far as $I$ have secu) few in 
number, rather widely divergent, and of eonsiderable length, and gradually dilate towards the top into a rounded expansion.

The basal lamina, by which the zoarium adheres, frequently forms an edging round it.

The largest specimen I have met with measured about $\frac{8}{8}$ inch across.

Habitat. On stones and shells \&c., from deep water.

Localities. Off Sana Island (Hyndman): coast of Antrim, 22 fathoms (Swanston) : coast of Northumberland (W. King): off the Mull of Galloway, 110-140 fathoms (E. Forbes): Scotland, on Pinna (T. H.) : island of Islay (Lady Emma Campbell): Shetland, 80-140 fathoms (A. M. N.).

Geographical Distribution. Roseoff (Jolict) : Scandinavian coasts, from great depths, on Gorgonia, Oculina, \&c. (Smitt).

Range in Time. English Crag (Busk).

\section{Stomatopora Johnstoni, Heller.}

Plate LIX. fig. 1, and Plate LX. figs. 1, $1 a$.

Criserpia Joitnstoni, Heller, Bryoz. Ad. M. 50.

? Alecto qrandulta, Johnst. B. Z. ed. 2, pl, xlix. fig. 2.

Zoarium branched dichotomously, frequently white and vitreous, thickly speckled; branches slender, slightly expanded above. Zocecia almost universally in series of 1-2. Ocecia at the extremities of the branches or at a bifureation, dilated and very ventricose, wedgeshaped.

Var. a. (robusta). Zoarium of somewhat stouter habit; branches broader, and rather more expanded at the extremities. 
Tre main characteristic of this species is the very slender habit, due to the disposition of the cells in series of 1-2 instead of 1-4, as in the preceding. In the lower portions of the branches they are often ranged in single line, the orifice rising alternately on opposite sides; above they form pairs, which are gencrally semialtcrnate, or single cells and pairs follow in regular succession. I have only met with the occia in a single casc; they form somewhat wedge-shaped and very ventricose cnlargements at the extremities of the branches, and also at the bifurcation immediately below the terminal branchlets. A large number of tubes (as many as fiftecn in one instance) are involved in them, and open out on the surface.

It is extremely difficult in this tribe to find valid specific distinctions; but the present form secms to have a fair amount of individuality, and can hardly be ranged under any of our other British Stomatopore. It is probably identical with the Criserpia Johnstoni of Heller; and though, in the absence of a good figure, the determination cannot be made with absolute certainty, I have thought it better to adopt his name *.

Habitat. On shells and stones.

Localities. Guernsey (T. H.) : coast of Antrim (Hyndman).

Geographical Distribution. On Anomia, Adriatic (Heller).

* IIeller's diagnosis is as follows:- "Stock kriechend, rerästelt, die rührenfümigen Zellen zu zweien neben einander liegend, alteruirend; Wan. dungen körnig." 


\section{StoMatopora EXPANSA.}

Plate IXXII. fig. 1.

? Proboscina ramosa, D'Orbigny (=Idmonea cenomana, id.), Pal. Franç. terr. crét. v. 851, pl. dexxxiii. figs. 1-3.

Zoarium adherent, sparingly branehed dichotomously, walls minutely punetulate and transversely rugose; branehes moderately eonvex, generally short, narrow at the base, and rapidly widening out towards the extremity, broadly elavate in figure. Zoceia somewhat irregularly distributed, not erowded together, ereet, and free for a large portion of their length, inereasing in number from one or two at the origin to seven or eight at the top of the branches. Oxcium an irregularly shaped inflation of the zoarium on the enlarged portion of the branches.

I no not venture to identify S. expansa with D'Orbigny's Proboscina ramosa, though it bears a strong general resemblance to it. The form which Smitt has referred to Wood's Tubulipora palmata agrees with it in the eharacter of the ramifieation, but differs from it in having an extended eontinuous crust, from the edge of which the branehes are given off.

The most striking eharacter of this speeies is the form of the branehes-which are short, and terminate above in rather broad elavate expansions. The orifiees of the eells are oecasionally obscurely rowed; but generally they are alternate or semialternate; there is little fixed order in the arrangement. The walls of the zoarium are of a dead white eolour, and thiekly eovered with very minute puneta.

Habitat. On dead shells.

Locality. Isle of Man (T. H.). 
Stomatopora incurvata, Hineks.

Plate LXIV. figs. 6-8.

Tenultpora incurvata, Hincks, Rep. Belfast Dredg. Com., in Rep. Brit. Assoc. 1858.

Alecto ixcunvats, id. Proc. Dublin Univ. Zool. \& Bot. Assoc. ii. pt. 1 (1860), 77; Quart. Journ. Micr. Sc. viii. (1860), 279, pl. zxx. 6g. 6.

Zoarium adherent, linear, unbranelied, eurved, attenuated towards the point of origin, and of equal width above. Zoceia biscrial (exeept towards the base of the zoarium, where they form a single row), alternate, separated by a median line, the walls usually much thiekened, the oral extremity bent abruptly towards the side, the orifices opening out laterally; surface obscurely punctate.

Length of fine speeimens rather more than a $\frac{1}{4}$ ineh.

Tris speeies is at onee reeognized by its simple lincar zoarium, which is always more or less eurved, and is frequently very dceidedly eurled towards the base. The cclls are normally biscrial; but speeimens not uneommonly oceur in which only a single series is dcveloped, and in all eases the basal portion of the zoarium is uniserial. They are disposed with much regularity, bending alternately and abruptly to opposite sides of the zoarium; tlic orifice, which is small, opens out laterally and is not at all visible when the specimen is viewed in front. The bent anterior portion of the ecll is not free, but is adnate to the zoarium; it is often massive and somewhat quadrate in form.

$\Lambda \mathrm{s}$ in others of the tribe, the zoarium originates in a small suborbieular disk or button, from which the first zoceium is developed. 
Habitat. On small stones from deep water.

Localities. Coast of Antrim, abundant (Hyndman) : Guernsey (A. M. N.) : Hebrides; off Caithness, decp water (C. W. P.).

Stomatopora diastoporides, Norman.

Plate LXIII. figs. 3, 4.

Alecto diastoporides, Norman, Shetland Rep. in Rep. Brit. Assoc. for 1867 (1868), 310.

Zoarium lobulate, the branches diverging from a common centre, and rapidly widening into fan-shaped expansions, flat and closely appressed, punctate. Zocecia immersed, rather stout and elongate, irregularly scattered, crowded on the terminal enlargements, the tubes marked out by transparent lines; oral extremity usually very slightly raised. Oœcia (?).

THis is the largest of the British Stomatoporce, and has very much the look of a Diastopora. The zoarium is lobed; and in characteristic specimens branches diverge in all directions from a short and slender stem, and widen out above into broad flabellate extremitics. These fanshaped lobes usually form a very striking feature of the species. The transparent lines marking the boundaries of the eclls are very distinctly traceable on the flat and depressed surface of the zoarium. The zoccial tubes are very large as eompared with those of the following species.

Habitat. On shell and stone from deep water.

Localities. Shetland, 70-110 fathoms (A. M. N.): Wick (C. W.P.) : off the Maiden Lighthouses, co. Antrim, 62-72 fatloms (Swanston). 
Geograpuical Distribution. Gulf of St. Lawrence (Dawsol1): off Hare Island, Waigat Strait, entrance of Baffin's Bay, 175 fathoms ('Valorous' dredgings).

\section{Stomatopora compacta, Norman.}

Plato IXIII. figs. 1, 2.

Auecto cospacta, Noman, Hebridean Polyz, Rep. Brit. Assoc. for 1866 (1867), 204.

Zoarium narrow at the base, rapidly widening above and ramifying irregularly, remarkably flattish and closely appressed, minutely punetate; branches wide and short, their extremitics rounded. Zoceia very small and slender, irregularly scattered and scparated from each other, shortly tubular, the oral extremities scareely raised above the surface, all inclining towards the top of the branches, but slightly bent towards the side. Ooecia (?).

Is this species the primary stem often divides into two or threc short and wide branches, which again divide and terminate in rounded segments. The zoarium is closely adnate and depressed, and always whitc in colour; the cells are small, and the whole habit delicate. This species, like the last, bears some resemblanec to a Diastopora.

Habitat. On stone and shell from deep water.

Localities. Hebrides, the Minch ; Shetland (A. M. N.). 


\title{
b. Zoarium partially erect and free.
}

(Subgenus Proboscina, Smitt.)

\author{
Stomatopora incrassata, Smitt.
}

Plate LIX. figs. 2, 3.

Tubulipora incrassata (subgen. Proboscina), Smitt, loc. cit. $402 \& 458$, pl. v. figs. 1-7; CEfv. K. Vet.-Ak. Förh. 1871, 1119, pl. xx. fig. 8. Alecto Retifonsis, Hincks, Supplem. Devon \& Cornw. Ont., Anu. N. H. ser. 4, iv. 81 (August 1871).

i Filisparsa incrassata, D’ Orb. Pal. Fr. loc. cit. 817.

Zoarium whitc, minutcly punctate, and often grooved transverscly; much branched, the ramification compact; branches depressed, dichotomous, but not widely divergent, often of great brcadth, expanding decidcdly upwards, anastomosing freely, the reticulations generally clongatc and pointed at both extremities. Zocecia usually disposed without much regularity, sometimes two or threc abreast, the anterior extremity crect and frec. The zoarium frequently rises into short cylindrical processes with a ccllular apcx.

Specimens of this finc and very characteristic specics measurc about an inch across, and form somewhat circular patches. In habit it is stout and compact; the branches lic rather close together, and mect and anastomose frecly, so that the zoarium is always more or less retiform. The fenestræ arc pretty uniform in figure; they arc gencrally narrow-elongatc, and produced into a point both above and bclow. The branches cxpand very rapidly upwards, and as they are placed ncar together, the projecting points above come into contact, and unitc so as to form the meshes of the nctwork. There is no regularity in the arrangement of the zoocia, such as we mect with in $S$. major. The zoarium is always white. The tendency to form crect shoots is much morc marked in some specimens than in others. At times the zoarium is studded orer with 
short cylindrical processes, most of them truncate at the top, which arc situated just bclow the bifurcations. In their most fully dereloped state they arc only slightly raiscd, and have a number of tubes projecting from the surface. I have referred the Alecto retiformis, mihi, to this species, though Smitt makes no mention of the anastomosing habit, which is so characteristic of the British form. D'Orbigny's Filisparsa incrassata may be the same thing ; but his bricf description leaves much room for doubt.

Habitat. On shclls from moderate depths to deep water.

Localities. Salcombe Bay, on a valve of Pecten maximus; Cornwall, on Pinna, from deep water; Scotland, also on Pinna (T. H.) : Gucrnsey ; Shetland (A. M. N.).

Geographical Distribution. Bohuslän, in great depths; Spitzbcrgen (Smitt) : Nova Zembla; Kara Sca (Stuxberg \& Théel).

\section{Stomatopora Deflexa, Couch.}

Plate LVII. fig. 4.

Tubulipora deplexi, Couch, Corn. Faun. iii. 107, pl. xix. fig. 4.

Pustulipora deflexa, Johnston, B.Z. ed. 2, 279, ? pl. xlviii. fig. 5 : Hincks, Devon Cat., Ann. N. II. ser. 3, ix. 306 (50 sep.); ? Heller, Bryoz. Ad. M. 49 (Pustulopora): Busk, B.M. Cat. iii. 22: Joliet, Bryoz. d. côtes de France, 94 (not Entalophora deflexa, Smitt, Flor. Bryoz.).

Zourium in great part adhcrent, somewhat flattened, rather sparingly branehed, minutely punetate; branehes lincar, expanding very slightly upwards, the extremities free, crect, subclavatc, with waved tubes projecting from all parts. Zocecia slender, disposed in pairs along the crecping portion of the zoarium, and scmialternate or distributed alternately, the oral extremity free, bent upwards, and projecting considcrably. Occia (?).

Tue form here described, which is common on stones 
and shells from the coast of Cornwall, seems to be the one on which Mr. Couch founded his T. deflexa. But if so, he has omitted all notice of the adnate and repent portions of the zoarium. His description and figure agree so exactly with the erect and somewhat clavate processes in which the creeping branches of the present species terminate, that I eannot but think that the latter may have escaped his notice. This secms the more probable, as this form is abundant on the coast where his researehes were carried on; whilst, on the other hand, nothing more nearly resembling his $T$. deflexa has occurred there, so far as I know, to those who have followed him.

In the present species a number of slender crecping branches radiate from a common stem; and along these the tubular cells are ranged without much regularity, the series never exceeding two in number. Each of these branches terminates in a free portion, somewhat elavate above, at times expanding into an enlarged head, from all sides of which long curved tubes project. The zoarium is white and thickly speckled.

Haвiтat. On shells and stones from deep water.

Localities. Polperro; Mevagissey Bay, and off the Deadman, common (Couch) : Wick and Peterhead; Shetland (C. W. P.).

Geographical Distribution. Roscoff (Joliet).

Stomatopora fungia, Couch.

Plate LVII. figs. 5, 6.

Tubulipora ruxais, Couch, Corn. Faun. iii. 107, pl, xix. fig. 3: Smitt (subgen. Proboscina), loc. cit. 403 \& 462, pl. x. figs. 2-5: Busk, B.M. Cat. iii. 26, pl. xxxii. fig. 3.

Tubulifora fenicillata, Johnst. B. Z. ed. 2, 270, pl. xlviii. figs. 1, 2 (not ş̣tisfactory): Landsb., Alder, Hincks, \&c. (probably not Tubipora penicillata, Fabricius). 
Zourium in great part repent and adnate, irregularly branehed, giving off here and there creet fungiform proeesses, eonsisting of a stem which dilates abovc into a diseoid eapitulum, on the upper surfaee of which a number of tubular cells are disposed; ereeping branches very stout, widening towards the extremities. Zocecia slender, irregularly distributed on the branches, sometimes in clusters of three, the anterior portion free and usually projeeting considcrably ; on the eapitulum seattercd, more thiekly aggregated round the edge; orifice circular and plain.

Height of the ereet fungiform processes rather less than $\frac{1}{4}$ inch.

Is the deseriptions of this form whieh we have from Couch and Johnston the ereet portions of the zoarium only are noticed ; but these are merely the extrcmities of a ereeping linear base, similar to that which we meet with in other members of this genus. The ereet stalks, which bear the expanded head, have usually a few slender tubular cells projecting from the surface, though this is not universally the ease ; they are lineated longitudinally, and also traversed by transverse strix.

The eapitulum is a circular disk, usually somewhat eonvex above, but sometimes depressed in the middle; it is rather thick, and projects on all sides beyond the shaft of the stem. There is in some eases a narrow edging or rim round the head; the walls are minutely punetate. On its upper surfaec the tubes are gencrally ranged without much order (they are sometimes obseurely rowed), most thiekly towards the edge, whcre they are placed almost horizontally, direeted outwards ; in the eentre they are usually few in number and subereet.

The ereeping portion of the zoarium resembles an ordinary Stomatopora : it is stout in habit, and has the cells 
very irregularly and often thickly distributed over its surfaee.

In certain stages of growth, before the development of the diseoid head, the erect stalks terminate above in a number of long, curved, irregularly disposed tubes. Busk's figure (B.M. Cat. iii. pl. xxxii. fig. 3) has the appearance of being drawn from an immature specimen.

The Tubipora penicillata of Fabricius differs from the present specics in having the tubes towards the capitulum aggregated into fascicles, and disposed on its surface in radiating serics. Smitt regards it as distinct, and has figured both forms from northern specimens. It must bc noted, lowever, that his figure of $T$. penicillata bcars a very elose general resemblance to our Wcst-of-England species; and as there is not unfrequently in $T$. fungia a tendeney morc or lcss marked towards a radiate arrangcment of the zoœcia on the capitulum, it may pcrhaps be a question how far the separation of the two is warranted. In the absence of specimens of the penicillata form, the point cannot be determined.

Habitat. On shells and stones generally from decp water.

Localitres. From the Eddystone Lighthouse to the Deadman Point (Couch) : on stone from 40 fathoms off Polperro; Torbay (T. H.) : Wick and Peterhead (C. W. P.) : Banff (Busk).

Geographical Distribution. Finmark, 50 fathoms (Goës and Malmgren) : Grcenland (Lütkcn) : Hamilton's Inlet, Labrador (Wallich, fide Busk). 


\title{
c. Colony clustered.
}

\section{Stomatopora Fasciculata.}

\author{
Plate LIX. figs. 4, 5.
}

Zoarium adherent, composed of a number of clavate cxpansions more or less clongated, unbranched, and usually slightly curved, originating one from the side of another, and forming a cluster. Zoocia immersed, generally only the orifices showing on the surface, and forming groups of 2 to 4 or 5 , which arc disposed along the centrc of the zoarium, the extremities very slightly raised; at the end of each segment a subcircular eellular space, somewhat elevated; rarely the cells are ranged transversely in scries of 3 to 4 .

Length of each clavate portion about $\frac{1}{8}$ inch.

Tue description is founded on a single example; but it is finely developed and leaves no doubt as to the distinctness of the form and its leading characters. It consists of a group of four perfect subcolonies, and a fifth which is only partially formed. Each of them is elavate in figure, with a sinuated outline; but they vary in width and length, one or two being of a shorter and broader type than the rest. The zoarium in the more elongated form is very convex, and the sides slope steeply upwards from the base towards the eentre, along which the zoœcia are ranged; in the broader form the surface is flatter and more depressed. The mode in which these subcolonies are united is peeuliar; each one is given off from the side of another, the point of origin being different in each case. From the primary subcolony two originate, one on each side.

The segments are attenuated towarls the point of 
origin, and widen gradually upward, terminating in a rounded and slightly expanded extremity : they constitute together a composite or elustered colony.

The zoceia show a decided tendeney towards a faseiculate arrangement; in most eases only the orifiees are visible, and these are arranged in clusters of four or five together along the eentral line; groups of two are sometimes interposed; and towards the base of the subcolony there is only a single eell. In all eases the extremity is oceupied by a large cellular area, almost eircular in form, and somewhat raised. In one of the subeolonies the zoccia are not collected in fascicles, but range in series of three to four across the zoarium. They are short and stout, and very slightly bent outwards at the top, and the boundary lines are distinguishable. In this instance there is a reversion to the arrangement which is usual in this genus; and in all eases, at the base of the subcolony the eells are disposed as in an ordinary Stomatopora.

The surface of the zoarium is dense and smooth, and of a dark brown colour.

In the eharacter of the gemmation and the elustered condition of the colony, and in the disposition of the cells, this species stands alone amongst its kindred.

Habitat. On shell, probably from deep water.

Locality. Coast of Antrim (Hyndman).

\section{Genus TUBULIPOR A, Lamarck.}

Der. From tubulus, a little tube, and rópos.

Tunuhirors (part.), Lamk. (1816) : Johnston : Milne-Edwards: D'Orbigny : Smitt : \&c.

Trbulitora, Busk : \&e. 
Certorora (part.), Hagenow.

Pulalaxgelua (sp.), Gray.

Oвelsa (sp.), Lamouroux.

Reptotubigera, D’Orbigny.

Generic Character.-Zonrium adnate or decumbent or suberect, forming a variously shaped expansion, either entire, or lobate, or branched. Zowcia tubular, partially free and ascending, arranged in divergent series.

A COLONY of Tubulipora originates in the small discoid body which constitutes the primary stage of most of the Cyclostomata. From this a single cell is developed, and from this a second, usually bent in the opposite direction; these are followed by an increasing number of series, which diverge more or less on each side. In some cases a simple flabellate crust is thus formed; in others it divides into lobes, which again subdivide. When the division and subdivision are carried to a great extent we have beautifully radiated specimens, in which the lobulate branches spread out circularly round the point of origin (Plate LXI. fig. 4a).

In certain forms the primary flabellate expansion remains unbranched, or is simply bilobate, and as it increases bends backwards on each side, and ultimately ineloses the primary disk, which becomes the centre of a somewhat eircular colony. On this mode of growtl the genus Phalangella of Gray is founded.

The eells in Tubulipora are gencrally (but not universally) free for a very considerable portion of thcir length.

I can see no sufficient ground for placing Tubulipora and Diastopora in separate families; the two genera are nearly rclated and have many common characters. 


\title{
Tubulipora lobulata, Hassall.
}

\author{
Plate LXI. figs. 4,5 .
}

'Tubulipora lobulata, Hassall, Ann. N. H. rii. 367, pl. x. figs. 1, 2: John. ston, B. Z. ed. 2, 272: Hincks, Dev. Cat., Anu. N. II. ser. 3, ix. 307 (51 sep.): Smitt, loc. cit. 400 and 454.

Tubulipora serpexs (part.), Busk, B.M. Cat. iii. 25.

Zoarium closely adnate, lobulate, punetate, and of a dull purplish colour; branches often disposed radiately round a central point, usually short and broad, oceasionally of a narrower and more elongate type, bifureating slightly, and terminating in rounded lobes, which are sometimes dilatcd. Zoocia short, very stout, subearinate in front, widening upwards; the orifice large and elliptical, and very slightly raised; seldom connate, crowded, and irregularly disposed, usually covering uniformly the whole surface of the branch; in the terminal expansions somewhat radiately arranged, or in longitudinal series, with distinct furrows betwcen them; oceasionally an obseure mesial line on the lower portion of the branch. The basal lamina expanded round the edgc of the zoarium.

This form has been treated by some writers as a varicty of Idmonea serpens ; but it wants the distinguishing characters of the genus Idmonea*. The habit is eminently characteristic. Well developed specimens usually assume a radiatc mode of growth-a number of lobes, morc or less branelied, with rounded and often enlarged extremitics, encircling a central point. In younger states the figure is flabellate. Varieties oecur in which the braneling is less regular, and the lobes are elongate, narrow, and

* The description of the present speeies is founded on a large series of specimens, dredged off the Isle of Man, where it is very abundant. 
straggling, but the radiate form is the prevailing one. The eells differ widely from those of $I$. serpens. They are short and stout, and project very slightly from the erust. For the most part they are horizontal, and generally not connate, and they never form the deep, eurved, transverse rows which are so eharacteristic of the last species. The dividing lines are generally absent, and the eclls range in longitudinal series, eovering uniformly the front of the branch. Sometimes, however, they are traccable on the front of the branches, but disappear altogether in the expanded terminations. In all cases the cells preserve their distinctive character. The orifice is large and clliptical.

The branches are thick and usually broad, not much subdivided, and of a dull purplish colour; the texture is much less delicate than that of $I$. serpens, and its bright, vitreous surface is wanting. The zoarium has a decidedly compact appearance, due to the shortness and horizontal position of the cells. The branches flange outwards towards the base, and are edged by an expansion of the basal lamina.

It may be added that the differenees between the two forms are very apparent in the early stages of development. Ha isтат. On shells chicfly, from shallow to deep water.

Localities. Dublin Bay (Hassall) : Isle of Man, off Maughold Head, extremcly abundant; Torbay; Scotland, on Pinna (T. H.) : Hastings (Miss Jelly) : Shetland, on stone, 30-70 fathoms (A. M. N.).

Geograpiical Distribution. Seandinavian consts (Smitt). 
Tubulipora flabellaris, Fabrieius.

Plate LXIV. figs. 1-3.

Temifora flabellaris, Fabricius, Faun. Grœnland. (1780), 430.

Tubulipora Flabelraris, Smitt, Gefv. K. Vet.-Ak. Förh. 1866, 401 and 455, pl. ix. figs. 6-8: Manzoni, Bryoz. foss. d. Miocene d'Austrin ed Ungheria, pt. iii. 14, pl. xii. fig. 50, pl. xiii. fig. 53.

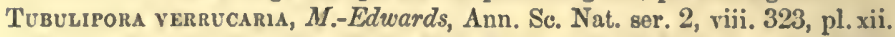
fig. 1 (Recherches, \&o., Mrém. s. les Tubulipores, 3): Heller (? part.), Bryoz. Ad. M. 48.

Tubulipora phalangea, Couch, Corn. Faun. iii. 106, pl. xix. fig. 7 : Johnston, B. Z. ed. 2, 273, pl. xlvi. figs. 1-4: Busk, Crag Pol. 111, pl. sviii. fig. 6: Hincks, Dev. Cat., Ann. N. H. scr. 3, ix. 308 (52 sop.): Busk, B.M. Cat. iii. 25, pl. xxiii. \&c.

Piralajgerla piralaxgea, Gray, B.M. Rad. 139 and 149.

Diastopora plumula, Reuss, Pol. Wien. Tertiärbeck. 51, pl. vii. figs. 11-13 (fide Manzoni).

Zoarium wholly adnate, of a pale purplish colour, suborbieular or obseurely lobed, when young flabellate. Zoocia long, slender, somewhat flexuous, subereet, crowded, irregular, more or less eonnate, sometimes in simple scries radiating from the eentre to the eircumferenee, sometimes (especially in the lobes) disposed in rows on each side of a mesial line, and inclining outwards; walls thin, vitreous, and punctate.

I QUITE agree with Prof. Smitt that this is the species deseribed by Fabricius as Tubipora flabellaris*; and undesirable as it undoubtedly is to interfere with the established nomenelature, it seems only right that the original application of the speeifie name should be restored.

" His words "Tubipora corallio ... tubulis connatis radiato" and "unde in peripheriam ducuntur radii tubulis emincntibus simplici ordine connatis formati" could only apply to the present species. Busk thinks that Fabricius had both forms in view, probably because he applies the term "flabelliformis" to the zoarium. But such it commonly is in this species; it is only in its most perfect condition that it quite loses the fan-shaped figurc. 
$T$. phalangea of Couch and Jolınston must therefore rank as a synonym of the older term.

There are considerable variations in the form of the zoarium in $T$. flabellaris. Generally the outline is more or less lobate, though the lobes are never strongly marked; but in some cases they disappear, and in the adult state the figure is simply orbicular; the lobes are usually five in number.

In fine, well developed specimens of this species the tubes are very long and flexuous, much crowded, and almost crect; they are sometimes disjunct for a considerable portion of their length; but more commonly they are connate, and form series of varying size. The centre of the zoarium is usually destitute of eclls.

In an early stage $T$. flabellaris exhibits a simple bilobed form. In this condition the zoarium is stalked and divided into two rounded lobes, which are bent backwards from the point of division, so as to embrace the stalk, bclow which they finally coalesce. As growth proceeds other lobes are developed until the normal figure is completed. The stalk, with its attached disk, occupics in the adult the eentre of the colony, surrounded and almost entirely conccaled by the lobes.

To this specics should probably be referred a remarkable Tubulipora which I have met with in old bivalve shells from Salcombe Bay. It forms large, somewhat circular, lobate masses, about an inch in diameter. The central portion is round, with sometimes as many as ten lobes, which are broad at the base, then gradually narrow for some way, and at the extremity expand into a clavate head. The heads vary in size, and oecasionally coalesce; and in some eases the lobes are united throughout the greater part of their lengtl, and we have a somewhat circular crust, witl a very irregular and jagged outline. On the 
central disk and the basal portion of the lobes the eclls arc arranged as in the normal $T$. flabellaris; on the enlarged heads they are disposed somewhat radiately. This curious variety, deprived of its terminal expansions, bears a striking resemblance to a Sun-Star (Solaster). In form and general appearance it is quite unlike the ordinary $T$. flabellaris; yct such is the tendency to irrcgularitics of growth and habit in this section of the Cyclostomata that $I$ do not renture to regard it as more than a very singular illustration of this charactcristic.

Habirat. On shells (especially inside old bivalves), Algæ, \&c., in moderate depths.

Localities. Cornwall, 10-20 fathoms, common (Couch): South Devon (Salcombe Bay, in old scallopshclls, \&c.), abundant (T. H.) : off Whitchead, co. Antrim, 20 fathoms (Swanston): Shetland (C. W. P.).

Geographical Distribution. Bahusia (Lovén) : Bcrgen (A. M. N.) : Spitzbergen (Swed. Expcd.) : Greenland (Fabricius, and North-Germ. Pol. Exped.) : ? South Labrador (Packard): Adriatic (Hellcr).

Range in Trme. Coralline Crag (S. Wood): AustroHungarian Miocene (Manzoni) : Scotch. Glacial deposits (Geikie).

Tubulipora Fimbria, Lamarck.

Plate LX. figs, 3, 3a.

Tubipora serpens, Fabr. Faun. Grœnl. 429: D'Orb. 1oc. cit. 847.

Tubulipora fimbria, Lamk. An. 8. Vert. ed. 2, ii. 233 : M.-Edw. loc. cit. 330, pl. xiv. fig. 2: Smitt, loc. cit. 401 and 452 , pl. ix. fig. 5.

Tubultrora flabeldarts, Johnston, B. Z. ed. 2, 274, pl. xlvi. figs. 5, 6:

Landsb. Pop. Hist. 274, pl. xv. fig. 50: Busk, Crag Pol. 111, pl. xviii. fig. 3, pl. xx. fig. 9; B.M. Oat. iii. 25, pls. xxiv., xxv.: Alder, North. Cat. loc. cit. 45 (sep.): Hincks, Ann. N. H. ser. 4, xix. 109.

? Proboscina latifolia, I'Orl. Pal. Fr. terr. crét, r. 847. 
Zoarium adnate, depressed, fan-shaped, sometimes with a lobate margin, minutely punctate, and often transverscly rugose. Zocecia laid horizontally, semialternate, somewhat radiately (but not very regularly) disposed, of comparatively large bore, generally free for only a short distance towards the extremity, the free portion not standing ereet, but taking the horizontal direetion.

In habit, as well as in the minute characters, this species differs very strikingly from the preeeding, and it is diffieult to understand the doubt which has been entertained as to their distinctness. T. fimbria* is distinguished by its flat, fan-shaped zoarium (this form is characteristic of the adult), which is usually opaque, of a dull white colour, and strongly wrinkled transversely. The cells are not arranged in series, or at all connected together $\dagger$; they are disposed somewhat irregularly, are slightly alternate, and spread out radiately over the flabellate expansion. They differ most markedly from those of $T$. flabellaris in being horizontal, and destitute of the very tall, subereet extremities which elaracterize the former. They are stout and transversely wrinkled, and have a plain orifice. The margin of the zoarium is frequently somewhat lobed; but the fan-shaped or plume-like figure is very constant.

T. fimbria seems to be a specially northern form.

Haвıтat. On Algæ ehicfly, shells, \&c., in moderate depths and deep water.

Localities. Wick and Peterhead (C. W. P.) : Northumberland, on Fusus Norvegicus, deep water, rare (Alder): Shetland (Peach, fide Alder): co. Down (W.T.).

- There seems to be room for doubt as to the identification of the present form with T. fimbria, although Milne-Edwards's figure of the latter, which was taken from a specimen labelled by Lamarck himself, certainly bears more resemblance to it. Under the circumstance, however, it is better to accept the decision, which is recommenderl by the authority of Professor Smitt, than to mun the risk of needlessly introducing n uew name.

$\uparrow$ "1'agiua . . superiore tubulis solitariis obsita."-Fanncuvs. 
Geographical Distribution. Grcenland (Fabricius): Davis Straits, 100 fathoms; Hamilton's Inlet, Labrador (Wallieh): Gulf of St. Lawrenee (Dawson): Bahusia (Lovén): Spitzbergen (Swed. Exped.) : west of Nova Zembla, lat. $72^{\circ} 30^{\prime}$, long. $52^{\circ} 45^{\prime}$, 5-20 fathoms (Stuxberg and Théel).

Range in Time. English Crag (S. Wood): Canadian Postplioeene (Dawson).

\section{Genus IDMONEA, Lamouroux.}

Der. From Idmon, one of the Argonauts.

Ioyoxes, Lamx. Expos. Méth.: Blainville: Milne-Edwards: Johnston: Reuss: D’Orbigny (part.) : Busk : \&c.

RETEPorA (part.), Goldfuss: Lamk.

Diastopora (part.), Michelin.

Tubulipora (part.), Lamk.

Crisina (part.), D’Orbigny: Smitt.

Tubulipora, subgenus Idmonea, Smitt.

Generic Ciharacter.-Zoarium erect and ramose, or (rarely) adnate; branches usually triangular. ZoøciA tubular, disposed on the front of the branches, ranging in parallel transverse or oblique rows on each side of a mesial line.

IDMONEA is most elosely allied to Tubulipora, and must rank, I think, in the same family with it. Its ereet habit, and more or less triangular branches, built up of tubes, the free extremities of which form transverse parallel rows, disposed subalternately on each side of a eentral line, give it a very characteristic faeies; but such a form as $I$. serpens, which in its leading character is a true member of the genus, is a eonnecting link between it and Tubulipora. 
In their adult state the Idmonere Fig. 23.

are attaclicd by a somewhat expanded basc, the surface of which is lineated or striated; but their earliest stagc is, I believc, identical with that of Tubulipora. The two conditions may be readily obscrved in $I$. serpens, which may be found in its adnate and rcpent form with the primitive disk and the slender Stomatopora-like

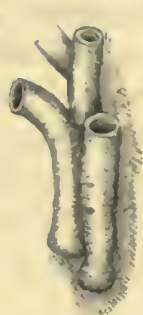

base, whilst in the subcrect and radiate form, described hereafter, it is attached by a sliglitly spreading crustaceous base.

The present genus has almost a world-wide range, and is represented by numerous speeies. Many charming forms occur in the Cretaceous deposits.

Idmonea Atrantica, E. Forbes.

Plate LXV. figs. 1-4.

Idpoxea Arustica, Forbes, MSS. : Johnston, B. Z. ed. 2, 278, pl. xlviii. fig. 3: Gray, B.M. Rad. 141: Gose, Mar. Zool. pt. 2, 8, fig. 3: Busk, Ann. N. H. ser. 2, xriii. 34, pl. i. fig. $6 a-$; Quart. Journ. Micr. Sc. ri. 128, pl. xviii. fig. 5; Rep. Brit. Assoc. (1859), Trans. Sect. 146 (var. tenuis); B.M. Cat. iii. 11, pl. ix. : Smitt (subgen.), loc. cit. 398 and 434, pl. iii. figs. 6, 7, pl. iv. figs. 4-13 ; Flor. Bryoz. 6, pl. ii. figs. 7, 8 (slender form): Manzoni, Bryoz. d. Miocene d'Austria, pt. iii. 4, pl. ii. fig. 6.

Idvosea radiass, I. Beneden, Bryoz. d. la Mer d. Nord, Bull. Brux, Iri. pt. 2, 616, pl. i. figs. 4-6.

? Idronea corosopts, Defrance, Dict. Sc. Nat. srii. 5f(5): M.-Fdwards, Rech., Mém. sur les Crisies \&c. 23, pl. xii. fig. 3.

? Idyonea angutata, D Orbigny, Pal. Fr. terr. crét. v. 731.

Zoarium erect, white, punctulate, irregularly branehed dichotomonsly; branches mucl in the same plane, 
rising from a short stem, triangular, narrow, of great eomparative thiekness, tapering towards the extremities, and bifid; dorsal surface lineated and minutely punetate. Zocecia 1-4 or 5 in each series, the innermost the longest. Oxcium prominent, somewhat pyriform, an inflation of the front surface of the braneh, involving the neighbouring tubes.

Height about $\frac{3}{8}$ inch.

Var. $\boldsymbol{a}$ (tenuis, Busk). Branehes extremely narrow; habit very slender.

THe variations to which this elegant species is liable are ehiefly those of habit. A very slender variety (tenuis) oecurs; and Busk records one from Madeira which is of greater size and more robust in its mode of growth than the northern form. There are also differenees in the number of eells in a row ; but they never seem to execed four or five.

Habitat. On corals, Gorgonia, Sertularian zoopliytes, \&e., chiefly from deep water.

Localities. Zetland scas (E. Forbes): Outer Haaf, 70-140 fathoms; Hebrides (A. M. N.).

Geographical Distribution. Naples, 40 fathoms, a single specimen (Waters): Hammerfæst, 12-20 fathoms (Sars) : Grötsund, 50 fathoms (Goës and Malmgren) : off Norway, 200 fathoms (Baron Uggla): off Frederickshaab, 100 fathoms (Wallich) : entranee of Baffin's Bay ('Valorous' dredgings): Nova Zembla, Beluscha Bay, 30-70 fathoms; Kara Sea (Stuxberg and Théel). Var. tenuis. North Atlantie (Busk): Florida (Pourtales): Madeira (J. Y. J.).

Range in True. Italian Mioeene (Manzoni): Canadian Postplioeene (Dawson). 


\section{IDMONEA SERPENS, Limiaus.}

Plate LXI. figs. 2, 3, and Plate LX. fig. :2.

Sinall purple Eschara, Ellis, Cor. 74, no. 6, pl. xxvii., e, li.

'T'uв pora setrexs, Linn. Syst. Nat. ed. 12, 1271.

Millepola liliacea, Pall. Elcnch. 248.

Millepora tubelosa, Ell. \& Sol. Zooph. 136.

Tubulipori trassversa, Lamk. An. 8. V. ed. 2, ii. 24:2: Lamx. Expos. Métl. 1, pl.1xiv. fig. 1 (after Ellis): Blainv. Actinol. 424: Fischer, Bryoz. du Sud-ouest do la France (1870), 10.

Injonea traxsversi, M.-Edw. Ann. Sc. Nat. sér. 2, ix. 218, pl. ix. fig. 3 : D'Orb. Pal. Fr. terr. crét. v. 731.

? IdNoxea dilatata, id. loc. eit. 731.

Obenia tubulifer., Lamx. Exp. Méth. 81 , pl. Ixxx. figs. 7,8 (young state of the present species) : (REPTOTUBIGERa) D'Orb. loc. cit. $75 \%$.

? Reitotubigera confluens, $i d$. loc. cit.

Tubluipora foramivelata, Blainv. Aetinol. 425, pl. lxii. figs. $3,3 a$.

'Tubulipors serpens, Flem. B. A. 529: Couch, Corn. Faun. iii. 105, pl. xix. fig. 6: Johnst. B. Z. 2nd ed. 275, pl. xlrii. figs. 4-6: Alder, Northumb. Cat., Trans. Tynes. Nat. F. C. 1857, 46 (sep.): Busk, B.M. Cat. iii. 25, pl. xxii. : \&c., \&c.

I druxaA Setrexs, Van Ben. Bull. Ac. Roy. Belg. xvi. no. 12, 647 (5 sep.), pl. i. figs. 7-9: Smitt (subgen.), loc. cit. 399, pl. iii. figs 1-5, and pl. ix. figs. $1,2$.

Zoarium either wholly adnate or attached by the base, the branches growing ereet and free, composed of lobes which are diehotomously divided, slightly expanded and usually bifid at the extremities, of a purplish eolour, vitreous and punetate, the dorsal surfaee striated longitudiually. Zoccia disposed on the branches in promiuent, oblique, semialternate series, more or less eurved outwards above, usually eonnate, sometimes free towards the extremities, the eells in eaeh series inereasing in height from the outer side inwards.

Var. a (radiata). Zoarium regularly radiate in form, attaehed by a eentral disk, the branehes disposed round it, free and subereet, generally bifid at the extremities.

'T'us species varies much in appearanee according to its 
site. On shells it is commonly wholly adnate, and takes on many diverse shapes; but in the very bcautiful varicty radiata it adheres by a ecntral disk only, around which the lobes or branches rise with much regularity. When attached to the stems of zoophytes it is almost entirely free and creet, and forms the prettiest coral-like growtlıs. In its young state it assumes when repent a simple clavate figure, the zoarium, which is much attenuated towards the point of origin, expanding gradually towards the apex, and having the cclls arranged in series on each side of the central line. In this condition it is the Obelia tubulifera of Lamouroux (Plate LX. fig. 2).

The delicate purplish colour and the bright vitreous surface are clraractcristic points. The branches terminate above in thick cellular extremities.

Habitat. On old shells, zoophytes (especially Hydrallmania falcata), and Algæ, from the littoral region to very deep water.

Localities. Generally distributed. Var. $a$, on Cornish Pinnce (T. H.).

Geographical Distribution. France, S.W. (Fischer) : Roscoff, on Algæ, common (Jolict): Mediterranean (Lamx., Heller) : Naples, 2 fathoms and 20-30 fathoms (A. W. Waters): Scandinavian coasts, Bahusia to Finmark, from the littoral region to very great depths (Smitt).

Range in Trme. Scotch Glacial deposits (Geikie) : Pliocene, Castrocaro (Manzoni) : Sicilian Pliocenc (Waters). 


\section{Genus ENTALOPHORA, Lamouroux.}

Der. Named from the supposed resemblance of the zocecium to the shell of Dentalium entale.

Evralopuora, Lamx. (1821): D’Orbigny: Smitt, Flor. Bryoz.

Pustelopora (part.), Blainvillo (1834): MT.-Edwards: Lamk. : Busk: \&c. Pestelipora, Blainville: Johnston: Gray.

Generic Character.-Zoarius erect and ramose, rising from a more or less expanded base, composed of decumbent tubes; branches cylindrical. Zoœcis tubular, opening on all sides of the branches.

ENTALOPIORA is ncarly related to the section of the genus Stomatopora in which the branches have a tendency to grow upwards at certain points. In its young state it consists of an adnate tubular erust.

A question arises as to the name for this genus, though one might think a glance at the dates as given in the synonymy should settle it. Busk scems to admit that in strict propricty Lamouroux's desiguation is entitled to precedence; but he thinks that to restore it under the circumstances would savour of pedantry (Crag Polyzoa, p. 107). I eonfess it seems to mc that the fewer departures from the established rule the better. The accidental prevalence of a much later name does not appcar to be a reason for retaining it. On the contrary, it may be a salutary vindieation of the authority of the law to reject it after such usurpation. The best cure for the disorders of our nomenelature secms to be a rigorous application of the principles which are gencrally accepted for its goverument. Lamouroux's genus is eharacterized in a wcll-known work; and both diagnosis and figure are suffieient for identification : its claim secms to be completc. I shall therefore follow D'Orbigny and Smitt in reinstating his namc. 
Entalophora clavata, Busk.

Plate LXV. figs. 5-8.

P'stulopora clavata, Busk, Crag Polyz. 107, pl. xvii. fig. 1 : Peach, Journ. Roy. Inst. Cornw. iv. (1871-73).

Pestclopora derlexa (part.), Hincks, Dev. Cat., Ann. N. H. ser. 3, ix. 301 (the specimen from Berry Hoad).

Zoarium with a short stem, branched diehotomously, surface minutely and thickly punetate, the puneta white, sometimes a eluster of erect shoots rising from the same base; branches stout, of mueh the same thiekness as the stem, except towards the extrcmities, where they dilate eonsiderably, and present a elavate figure, frequently dividing into a doublet or triplet of branchlets. Zoocia slender, usually projeeting slightly below, above with a mueh larger portion free and flexuous, irregularly disposed; orifiee eireular and plain.

Height about $\frac{3}{8}$ ineh.

'THIs form, which has only oeeurred on our soutl-western shores and off the coast of Antrim, seems to be identical with Busk's Pustulopora clavata from the Crag. Its most marked eharacteristies are the decidedly elavate extremities of the branches, and the tendeney to form triplets of terminal branchlets. In Torbay specimens the branches are thick, and of pretty uniform size up to the terminal division, from whieh they expand into very stout and short branehlets, usually three in number. In Mr. Peach's specimen from Cornwall the elavate expansions are not quite so massive, but are still a very eonspieuous charaeter.

The apex of the branellets is cellular; and the lumina of the tubes on its surfaee sometimes number nearly forty.

In fine specimens as many as four or five ereet and 
branching stems rise from the samc base, forming very beautiful elusters.

The Mcditerranean E. proboscidea, M.-Edwards, is a larger specics, of more slender habit, and wanting the clavate cxpansions, but very nearly akin to the present. It has not occurred in our seas, the spccimens which Johnston referred to it being really Palmicellaria elegans of Alder. (Sec page 378.)

Habitat. On shell, \&c., shallow to decp water.

Localities. Wolf Rock, near Penzance (C. W. P.) : under Berry Head, Torbay (T. H.) : coast of Antrim, off the Maiden Lighthouses, 62-72 fathoms (Swanston).

Range in True. Coralline Crag (S. Wood).

Genus DIASTOPORA (part.), Lamouroux.

Der. From $\delta a \dot{\sigma} \sigma \tau \mu \alpha$, an interval, and $\pi \dot{\rho} \rho o s$, a passage or opening.

Berexices, Lamouroux : D'Orbigny (for one section of the genus).

Diastopora (part.), Lamx.: Smitt.

Disstorora, Johnston : Busk : \&c.

Tubclipora (sp.), Johnston : \&c.

Patixella (sp.), Busk: Hincks.

Mesexteripora, Blainville: Busk: \&c. (for foliaceous bilaninate forms).

Discosransa, D’Orbigny.

Generic Cinaracter.-Zoarium adnate and crustaceous, or foliaceous, usually discoid or fabellate, less commonly irregular in form. Zoecia tubular, with an elliptical or subcircular orifice, crowded, longitudinally arranged, in great part immersed.

There seems to be no sufficient ground for detacling this group from the present family. In its carly state Diastopora rescmbles Tubulipora; and its peculiar habit 
of growth is only a slight variation on that which we have in the section of the latter genus represented by $T$. flabellaris. It agrees with it in being destitute of eancelli; whilst in the eomparatively depressed and immersed eondition of the zoceia it has a parallel in ecrtain forms of Stomatopora.

The genus Diastopora has, however, on the whole, a very distinet facies. The expanded erustaceous mode of growth, the prevalent tendeney to assume a diseoid or flabellate form, the immersed and crowded condition of the (usually) slender zoccia, are characters which combine to give it a very deeided individuality.

The erect and foliaceous forms, which have been ranked under Mesenteripora, Blainville, are ineluded in the present genus as here defined.

\section{Diastopora patina, Lamarek.}

Plate LXVI. figs. 1-6.

Tubulipora patisa, Lamk. An. s. Vert. ed. 2, ii. 244 : Blainville, Actinol. 425: Johnst. B. Z. ed. 2, 266, pl. xlvii. figs. 1-3: Gosse, Mar. Zool. ii. 8, fig. 1 : \&c.

Patinella verrucaria, Gray, Br. Rad. 138.

Patinella patisa, Busk, Rep. Brit. Assoc. 1859, Trans. Sect. 147 : Hincks, Dev. Cat. loc. cit. 468.

Discosparsa marginata (proliferous form), $D^{\prime}$ Orb. Pal. Fr. terr, crét. v. 822, pl. declvii. figs. 5-10.

Discosparsa pativa, Heller, Bryoz. d. Adr. M. 46.

Diastopora pativs, Smitt, loc. cit. 397 \& 426, pl. viii. figs. 13-15: Busk, B.M. Cat. iii. 28, pl. xxix. figs, 1, 2, pl. xxx. fig. 1 .

Zourium diseoid, eircular, or (sometimes) elliptical, more or less eup-shaped, or flat and entirely adherent, surrounded by a rather broad extension of the basal lamina, forming a thin white border, transversely lineated. Zoocia stout, minutely punctate, crowded, in the ecntral portion of the colony immersed and elosed, disposed in 
radiating lines, towards the margin usually ereet, open, sometimes connate, sometimes disjunet; orifice in the central eells subelliptical, plain, in the marginal eells suborbienlar, often produeed at one side, or bifid; the edge of the eclliferous portion of the zoarium sometimes gemmiparous.

Disk in ordinary specimens about $\frac{1}{4}$ inch in diameter.

THe zoarium in this species, which is liable to many variations in sliape, due to the nature of its site, is net with in two very distinet conditions. In one of them it is decidedly ealieulate, the cup being of greater or less depth, and is as a consequenee only partially adherent. It is attached by the eentre of the basal lamina, which is otherwise free, usually rising above the eelliferous centre of the colony, and forming a thin, semitransparent wall around it. In this form the marginal belt of ereet and open zoceia is generally well developed; but there is no uniformity in this respeet, and in many eases almost all the cells in the colony are closed and entirely immersed.

The rule, however, holds good universally that the open eells, when present, oceupy the marginal portions of the zoarium.

The zoceia are thickly punetate, and the puncta are present on the ealcareous lid or opereulum, which eloses the orifiee in a large proportion of them. The edge of the zoarium is somewliat thickened and eellular. In many eases the eup is deep and funnel-sliaped, expanded above, and narrowing off to a fine point below (Plate LXVI. fig. 6) ; but it is very eommonly shallow and depressed, and attached by a larger portion of the basal surface. This eondition makes an approacl to the second of the forms which the zoarium assumes in this species. In the latter the lamina is entirely and elosely adherent, forming a 
thin circular basc, on which is placed the celliferous disk, either flat above, with the zoocia wholly immersed, or depressed in the centre, and with a raised border of ereet cells occupying the margin. In this statc $D$. patina bcars a much closer resemblance to its congeners than in its caliculate form (Plate LXVI. fig. 5).

Occasionally this specics assumes a proliferous habit, and produces gemmie frcely. From Torbay and from deep water off the Cornish coast, I have obtained very beautiful specimens in this condition, bcaring a number of young on the margin of the cup. In one casc as many as five are present, occupying a large portion of the edge of the disk. The buds arc developed just within the basal lamina on the cellular border.

In the fincst proliferous specimens the cup is decp and funnel-shaped and stands crect, being attached by a very small portion of the base. It presents the same character in the Discosparsa maryinata of D'Orbigny, which scems to be merely a proliferous form of the present species.

In some cascs a thin calcarcous crust involves the frec and erect portion of the marginal cells, and forms a continuous inflation round the disk, which represents the oœcium.

It is difficult to determinc what the precise function may be of the closed cells, which occur in such numbers in every colony. Smitt has conjectured that they may bc connected with the production of spermatozon, and notes that in T. patina there is sometimes a small tubular opening in the cap or operculum, analogous to the projecting process in D. Sarniensis*. It may be objected to this vicw that the closed cells are so numcrous as to be out of

* Busk mentions "a minute central perforation" as oceurring in the calcareous lid with which the eells are furnished in Mesenteripora ("Crag Polyzoa,' p. 110). 
all proportion to the function assigned tliem; but it would be diffieult to suggest a better interpretation, and it will do good service by giving direction to inquiry.

In an early stage of growth the zoarium bcars much gencral resemblance to a young Tubulipora, consisting of a short stem, which originates in the usual circular disk, and a scmicircular or somewhat flabcllate lobe or cxpansion, eovered with zoccia, and with a very broad laminar edging (Plate LXV1. fig. 2). Furtlıcr development results in the extension of the lamina and celliferous crust around the primary germ, so as to form a circular diseoid figure, of which it becomes the centre.

Habitat. On shells, stoncs, Algæ, coral, \&c., from almost all deptlis.

Localities. Very eommon. Cornwall, deep water (Couch) : South Devon, abundant; Torbay (prolifcrous form) (T. H.) : Northumberland (Alder) : St. Andrews, deep water, especially on Mytilus modiolus (Dr. M'Intosh) : Hebrides (A. M. .N.) : Shetland, to 170 fatlioms, proliferous form frequeut (Barlee, Norman): Strangford Lough (W. T.) : \&e.

Geographical Distribution. Roscoff (Joliet) : France, S.W. (Fischer) : Adriatic (Heller): Nortl and Aretic seas, 5-10 fms., on Algæ, Flustra, \&e., on slells and coral, 50-100 fms. (Smitt): Bahusia (Lovén): South Norway (Lilljcborg): Finmark (Sars): South Labrador (Packard).

Fig. 24.

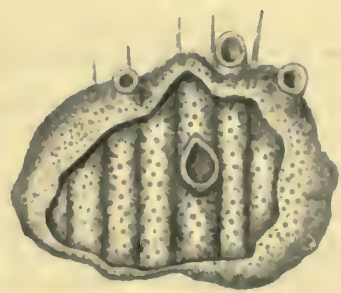

Oureium of $I$. Sitrmiensix. 


\section{Diastopora obelia*, Johnston.}

Plate LIVI. figs. 10, $10 a$.

Tubulipora oвelis, Johnst. B. Z. ed. 1, 269, pl, xxxviii. figs. $7,8$.

Diastopora obelis, id. B. Z. ed. 2, 277, pl. xlvii. figs, 7, 8: Smitt (1865): Busk: Heller : \&c.

Diastopora uyalina, $a$, obelta (Johnst.), Smitt, loc. cit. (1860), 396 \& 421, pl, viii. figs. 9-12.

Zoarium entirely adherent, indefinite in its growth, and of irregular outline, edged by the basal lamina. Zocecia arranged alternately, moderately slender, minutely punetate, surfaee flattened, usually with only a short portion of the anterior extremity free and subereet, separated by distinet, semitransparent lines; orifiee subeireular: small tubules (seeondary eells) interspersed amongst the ordinary zoceia. Oocia transversely elliptieal swellings involving several of the zoœeial tubes.

THE surfaee of the zoarium distinetly lineated by the boundaries of the eells, and the numerous tubules distributed amongst the zoceia, are the features by which this speeies may be at onee distinguished from the following. The eells are also less erowded than in $D$. Sarniensis:

The tubules are present in large numbers; they are very minute, and usually originate immediately behind the ordinary zoœeia, which they resemble elosely in form. Their use is unknown.

The oœeium is very similar to that of the following speeies.

In some eases many of the eells are elosed at the top; but they are never furnished with the tubular proeess which oeeurs in D. Sarniensis.

* This may be the Berenicea hyalina of Fleming; but his description is so little characteristic that the identification cannot be made with any certainty, and I therefore retain Johnston's well-established name. 
Habitat. On shell and stone, and occasionally Alga, shallow to deep water.

Localities. Gencrally distributed on our coasts.

Geograpin ical Distribution. Bahusia (Lovén) : Havösund and Bergen (Sars): Spitzbergen, 6-20 fms., on $L a$ minaria (Swed. Exped.) : Nova Zembla, Jugor-scharr, 1014 fms.; Matotsclıkin-scharr, 2-5 fms.; Kara Sea (Stuxberg \& Thécl): Grecnland (Lütken) : off Bear Island (Dutch Aretic Exped.) : Gulf of St. Lawrence (Dawson) : Roscoff (Joliet) : Algiers (J. Y. J) : Adriatic (Heller) : Naples, 6 fms. and deeper (A. W. Waters).

Range in True. Postpliocene, Canada (Dawson).

\section{Diastopora Sarniensis, Norman.}

Plate LXVI. figs. 7-9.

Diastopora Sarniexsis, Norman, Ann. N. H. ser. 3, xiii. 89, pl. xi. fig8. 4-6 : Hincks, Suppl. Dev. Cat., Ann. N. II. ser. 4, viii. 81.

Diastopora uyalisa (part.), Smitt, loc. cit. 396.

Zoarium forming an irregular crust, usually with a lobed and sinuated outline, milk-white, rather coarsely punctatc, and often transversely striated, with a marginal extension of the basal lamina, and destitute of secondary cells or tubules. Zoccia stout, disposed pretty regularly in lines radiating from the centre, generally free and subereet for a considerable portion of their length ; surface not depressed or flattened, boundary lines inconspicuous, often almost obliterated; orifice elliptical, occasionally elosed by an opereulum, from the upper part of which a small tube projects. Oxecia transwersely clongate, subelliptical inflations of the zoarium, of considerable size.

Zoarium sometimes $\frac{3}{4}$ inch in diameter.

TuE crust is thick in D. Sarniensis, the edge cellu- 
lar, and the basal lamina extends beyond it: it is commonly very distinctly rugose or striated transversely. The points in which it differs most markedly from $D$. obelia are the absence of the interecllular tubules, the indistinctuess of the zoceial outlines, the greater regularity in the disposition of the eells, and (generally) their more ereet habit, and the presence of the elosed cells with the projecting orifice.

The precise significance of the zoœeia (some of which are generally to be met with in each colony), which are operculate and furnished with the small tubular process at the top, is unknown. They have been considered to be subservient to reproduction, and to be equivalent to ovicells; but $D$. Sarniensis is furnished abundantly with oœcia of the usual character-a fact which must throw doubt on this interpretation (woodeut, fig. 24). Smitt's conjecture as to their function has already becn referred to (page 460). Mr. Waters has deseribed similar tubules as occurring on his Reticulipora dorsalis ('Annals' for April 1879, p. 278).

Habitat. On shells, stones, \&c., to deep water.

Localities. Off Guernscy and Jerscy (A. M. N.) : off Polperro, Cornwall, 40 fms. (T. H.) : Lantivet Bay, Cornwall, on Isocardia cor (C. W. P.) : Hastings (Miss Jelly).

Geographical Distribution. ? Red Sea or Mediterranean (R. S. Newall).

Diastopora suborbicularis.

Plate LXVI. figs. 11, $11 a$.

Diastopora simplex, Busk, Crag Pol. 113, pl.xx. fig. 10: Smitt, loc. cit. 396 \& 423, pl. viii. figs. 7, 8. (Not Discosparsa (Diastopora) simplex of D'Orbigny.) 
Distopora onelis (part.), Johnst. B. Z. ed. 2, 270 (probably).

? Diastopora flabeluus, Reuss, Pol. Wien. Tertiärb. 51, pl. vii. fig. 9*.

Zoarium thin, closely adnate, usually forming a suborbicular or elliptical erust. Zoocia quineuneially arranged, very slender, thickly punetate, separated by distinet lines, upper surface flat, immersed, except at the cxtremity, which is rather abruptly bent upwards, the free portion usually short. Occia somcwhat ovate, with a tube projecting at the top, spcckled, disposcd rathcl regularly at intcrvals round the zoarium, in successive series.

Fine specimens are about $\frac{1}{2}$ inch in diameter.

A Leanixg characteristic of this species is the very definite and usually more or less orbicular shape of the zoarium. .The number and regular arrangement of the oøcia, which are generally present, are also points that strike the eye at once. Morphologieally these are modified cells, and form more or less ovate reccptacles, with a tubular orifice. The erust is very thin and closely and entirely adherent, and without any extension of the lamina round it.

The zoccia are elongatc, slender, dotted over with white points, the surface flat, immersed almost throughout, but usually with the extrcmity erect and free. This character is always a very variable one. In the present species the tendency scems to be towards a more complete immersion of the ccll than is usual; but in sheltered situations the free portion is often of considerable lengtl. The boundary lincs are conspieuous.

Busk describes the zoarium as either "orbicular or irregular;" but in all the speeimens I have secn (and the spceies is abundant on the South-Devon coast), the shape

* Manzoni considers that this is probably identical with the present species. Busk, however, regards the identification as too doubtfinl to justify the adoption of Reuss's name. 
is remarkably constant, and there is none of the indefiniteness in the mode of growth which we find in kindred forms. Regularity seems to be the prevalent characteristic.

In the original aceount of this species in the ' $\mathrm{Crag}$ Polyzon,' the tubes are deseribed as " not flattened in front," and this character is insisted upon as important. In the third part of the British-Muscum Catalogue, lowever, they are merely stated to be "decply and entirely immersed," and there is no referenee to their eonvexity. In the form here intended the flatness of the ecll is a marked character.

Mr. Waters has pointed out that the Discosparsa simplex of D'Orbigny belongs to this genus, and that Busk's name eannot be retained. There is too much doubt as to the identification with Reuss's D. flabellum to allow of the. substitution of his name; and the only course therefore scems to be to give it a new one.

Habitat. On shells and stones from shallow to deep water.

Localities. South Devon, abundant; Isle of Man (T. H.) : Beaufort Dyke, 110-145 fms. (Capt. Beechcy) : Macgilligan, Ireland (W. T., fide Busk).

Geograpiical Distribution. Naples, 2-6 fathoms (Waters) : Bahusia; Finmark (Lovén) : Kara Sea (Stuxberg \& Théel) : Greenland (Lütken).

Range in Time. Coralline Crag, on shell (S. Wood). 


\section{Family III.-Horneridæ.}

Horseudd.e, Smitt, Kritisk Fört. 1866.

Crisivide (part.), D'Orbigny.

Les Tedeliponess (part.), Milne-Edwards.

Iososide.e (part.), Busk, Crag Pol., and B.M. Oat.

Io rosead.e (part.), id. Engl. Cyclopaedia.

Zoacra opening on one side only of a ramose zoarium, never adnate and repent.

\section{Genus HORNERA, Lamouroux.}

Der. Named after M. Horner, astronomer to the expedition round the world under Krusenstern.

Millerpora (part.), Linn.: Pallas: Solander: \&c.

Horserı, Lamx. (1821 ): Milne-Edwards(part.): D'Orbigny: Sinitt: Busk: \&c.

ReteporA (part.); Lamk. : Goldfuss.

Sipnodictrun, Lonsdale.

Generic Character.-Zoarium erect, ramose, sometimes reticulate. Zoocia tubular, opening on one side only of the branches, disposed in longitudinal series, the celliferous surface often traversed by wavy anastomosing ridges. Oøcrum $a$ distinct chamber (not a mere irregular inflation of the surface of the zoarium), placed dorsally or in front.

Tue genus Hornera is eonneeted with the Tubuliporide through Idmonea, to which it bears in many points a very close resemblance. It embraees two very charaeteristic groups : in one the zoccia are eorered in front by a ealeareous erust, whieh takes the form of wary longitudinal ridges, often anastomosing, which wind round and inelose the orifices of the eells, and give a fibrous appearance to the surface of the zoarium. Of this section, which may 
be said to inelude the more typieal speeies, we have an example in $H$. lichenoides. In the other group, of which H. violacea is a member, the superfieial fibrous erust is wanting.

Hornera liehenoides, Linnæus.

Plate LXVII. figs. 1-5.

"Corallium," Pontoppidan, Norges Naturl. Hist. i. 258, nos. 7 and 8, pl. xiv. figs. D, E.

Millepora lichenoides, Linn. Syst. ed. xii. 1283: Ström, Act. Hafn, xii. (1799), 309, pl. iii. figs. 1, 2.

Hornera frondiculata, Sars, Reise Lof. Finm., Nyt Mag. f. Nat. Vid. vi. 146: Busk, Ann. N. H. ser. 2, xviii. 34, pl. i. fig. 7.

Hornera borealis, Busk, Crag Polyz. 95 and 103: Alder, Quart. Journ. Micr. Sc. n. ser. iv. (1864), 108, pl. v. figs. $1-6$.

Horners liciexordes, Smitt, loc. cit. 404 and 469, pl. vi. fig. 10, pl. vii. figs. 1-14: Busk, B.M. Cat. iii. 17, pl. xviii. figs. 5, 6.

Zoarium white, rising from an expanded and furrowed base, much and irregularly branehed, spreading, often somewhat flabelliform, the anterior surface fibro-retieulate, with seattered subtubular pores; branelies rising from a very short stem, divided and subdivided diehotomously, so as to form somewhat fan-shaped segments, rather stout, very slightly eompressed, tapering gradually towards the extremities, which are bifid. Zoccia on the front of the branehes, immersed or very slightly prominent, the orifiees quineuneially arranged, eireular, with an even rim-those on the sides produeed, expanded obliquely towards their extremities, the margin sometimes earried out into an aeute point on one side; dorsal surfaee traversed by undulating ridges, with minute pores in the intermediate furrows. Oxcia on the dorsal surface, ovate or suborbicular, sometimes very gibbous, reticulate, or eoarsely punetate, with a tubular orifiee on one side, from whieh a very slender rib stretehes across to the opposite side.

Height from $\frac{1}{2}$ to $\frac{3}{4}$ inch; breadth about the same. 
THE oœeium in this species varies somewliat in position, but seems to be usually situated near the bifureation of the brauches, either immediately below the division, or at a slort distance from it. It is sometimes extremely prominent, almost subconical, the sides being carried abruptly upwards to a central point; in other cases it is more depressed. The raised line or rib takes its origin near the free extremity of the tubular orifice, and passes from this point across the ovicell.

There is some difference in the mode of growth, and specimens oceur which are comparatively tall ( 2 inclies) and exhibit a straggling habit; but so far as I have scen, the compact and somewhat flabellate form is the more usual.

Habitat. From moderate depths to deep water.

Localities. Shetland (Barlee) : ibid., Outer Haaf, 80170 fathoms; Hebrides (A. M. N.).

Geograpuical Distribution. Waderöarne, Bahusia (Lovén) : Norway (Pontoppidan, Ström, Sars (in about 40 fathoms), \&c.) : Nova Zembla (west), 20-30 fatlıoms; Kara sea (Stuxberg and Thécl): Greenland (Lütken) : St. George's Banks, 150 fathoms (Smith and Harger).

\section{Hornera violacea, Sars.}

Plate LXVII. figs. 6-8, and Plate LXII. figs. 2, 3.

Hornera violacea, Sars, Geol. og Zool. Iagtt. Reise Trondhj. St. 1862, N. Mag. f. Nat. Vid. xii. 282 (30 sep.): Smitt (forma violacer), loc. cit. 404 and 467, pl. vi. figs. 6-9: Norman, Shetland Dredg. Rep., Report Brit. Assoc. for 1867 (1868), 310 : Busk, B.JI. Cat. iii. 18, pl. xviii. fig. 1.

Pustulopors Orcadessis, Busk, Quart. Journ. Micr. Sc. viii. (1860), 21t, pl. xxrix. figs. $1,2$.

Zoarium irregularly branched; branclies dichotomous, 
short and truncatc. Zoœcia crowded, distinet, generally a good deal produced, surface punctate; dorsal surface granular, the extremitics of the branches with a rib-like clevation down the centrc. Oxcia clongate, placed in the axils of the branches, partly on the front and partly on the back of the zoarium (chiefly placed on the back, but bent round the side of the branch towards the front), smooth, closcly punctate, witl a slight longitudinal costa; orificc bilabiatc, situated near the top.

Colour, when fresh, white with a violet tingc.

Height from $\frac{1}{2}$ to $\frac{3}{4}$ inch.

II. VTOLACEA differs from the preceding specics in the following points :- The front surface is not fibro-reticulatc as in the last, the cells arc somewhat longer, much morc crowded, and more produced; the dorsal surface is granular, and on this side the branches arc ribbed centrally towards the extremities; the occium is narrow and elongate, with a bilabiate orifice near the top, whereas that of $H$. lichenoides is ovate or suborbicular, much elevated, with a lateral and tubular aperturc. The colour of the zoarium is also distinctivc. The oœcium in the specimen from which the figure was taken (Platc LXII. fig. 3) was invested for some distance above the base by a thick calcarcous crust, apparently continuous with the external layer of the zoarium. This crust extended round the sides of the ovicell, leaving the upper surface frec.

I have not included amongst the synonyms the Hornera violacea, forma proboscina, Smitt, as, judging from the figurc of the oœcium given in the Scandinavian Catalogue, it must be specifically distinct. The ovicell in this form is placed on the front of the branches, is round and flattened, and covered with large pores arranged in radiating rows.

Habitat. On corals \&c., in deep water. 
Localities. Shetland, about 7 miles E.S.E. from Balta, in about 50 fathoms, rare (A. M. N.). Mr. Peach found it less uneommon in Shetland.

Geograpilical Distribution. Esterraat, 70-80 fathoms; Christiansund, \&c., 70-100 fathoms; Mauger, on Oculina, 150-200 fathoms (Sars): off Bergen (Höegh).

\section{Family IV.-Lichenoporidæ.}

Discoporadx, Busk, Brit. Cyclopred.

Caveid.e (part.), D'Orbigny.

Turigendi. $\boldsymbol{x}$ (part.), id.

LiCIIEYOPORIDE, Smitt.

Discororeluid.s, Busk, B.M. Cat.

ZOARIUM discoid, simple or composite, adnate, or partially free and stipitate. Zowcis tubular, erect or suberect, disposed in more or less distinct series, which radiate from a free central area; the intermediate surface cancellated or porous.

\section{Genus LICHENOPORA, Defrance.}

Der. From $\lambda \epsilon \iota \chi \underline{\eta} \nu$, liehen, and $\pi$ ópos.

Madrerora (part.), Fabr. : Esper.

Iicnexorora, Defrance (1823): Blainville: Michelin: Smitt (1878).

Discororella, Gray, B.M. Rad. : Busk: Smitt (1866).

Discopora (part.), Flem.: Busk, Encyclopsed. Brit.

Toвeripora (part.), Jolinston : auott.

Mremobesta, Audouin.

Ransorora, D'Orbigny (for species with confluent disks).

Usicavea (sp.), id.

Discocaves (sp.), id.

Activopora, id. (for adnato species with multiserial rays).

Discotubigera, id.

Hetenoporelea (gp.), Hincks.

Genemic Character.-Zoarium discoid, raised, simple, 
or composed of many confluent disks, entirely adnate, or partially fiee, and sometimes stipitate, developed on a thin lamina, which usually forms a border round it. Zowen distinct or connate, in single radiating lines, or multiserial.

D'OrBIGNy has construeted a large number of genera, which are merely arbitrary groups based on very trivial modifieations of this well-marked type. Some of them are included in the synonymy of the present genus; and others might have been added.

The section in which the zoarium is made up of many confluent disks offers perhaps the most marked variation; but in such a species as $L$. hispida both the simple and complex conditions of the zoarium are of about equally common oceurrenee. The differenee between the species which have the eells in one series and those which have them in two or more is of the very slightest moment; and therefore I have not thought it neessary to relegate $L$. regularis to the genus Actinopora, D'Orb. Still less ground is there for separating the forms which are wholly adnate from those which have the border free and raised and the zoarium somewhat eup-shaped.

The oøeium is represented in Lichenopora by an inflation of the general surface of the disk, furnished with one or more tubular and (usually) somewhat trumpet-shaped orifices.

The genus is widely distributed both in space and time; in the Cretaceous beds it is represented by a large number of very beautiful forms. 
1. Colomy simple; or composed of many confluent disks. (Radiopora, D'Orbigny.)

LicheNopora urspida, Fleming.

Plate LXVIII. figs. 1-8.

Discorora usprid, Flem. B. A. 530: Blainv. Actinol. 446: Couch, Coru. Faun. pt. iii. 109, pl. xix. fig. 1.

Tuвtuipora uispida, Johnst. B. Z. ed. 2, 268, pl. xlvii. figs. 9-11 (bad).

Discoporella irspida, Gray (subgen.), B.M. Rad. 138: Busk, Crag Poljz. 115 , pl. xviii. flg. 5 ; id. B.M. Cat. iii. 30 , pl. xxx. fig. 3 : Smitt, loc. cit. 406 \& 483, pl. xi. figs. 10-12: Sars: Alder: \&c.

Discocavea (Lichenopora) accleata, D'Orbigny, loc. cit. 958, pl. declexvi. figs. 5-8.

? Heteroporelia radiata, Busk, Crag Pol. 127, pl. xix. fig. 2.

Heteroporella inspida, Hincks, Dev. Cat. loc. cit. 469.

Zoarium elosely adherent, or sometimes with the lamina turned up and the border free, subeireular and simple, frequently subeonical; or irregular in shape, often of large size, and eomposed of many confluent disks, the surface mamillated. Zocecia for the most part arranged in radiating series around a eentral space of larger or smaller size; the orifiees somewhat raised, tubular, the upper margin produeed and often trifid, sometimes simply aeuminate; the interspaces between the rows, and the eentral area, eovered with large eircular stellate pores.

Polypide with 10 short tentacles, slightly everted at the extremities.

Var. a (meandrina, Peach). Zoarium eomposite, of large size, with the eentral spaees often elongate and winding or sinuous; the orifiee of the zoceia with a single slender muero; the pores large, forming "liexagonal depressions," and generally not stellate.

Var. ß. Zourium composite, the surface thickly corered with small oval mamilla, somewhat. regularly disposed; 
the ecntral spaees very narrow, linear; zoccia very slightly prominent.

L. IISPIDA Oceurs in two very different conditions. The zoarium is either simple or eomposite, eonsisting of a single disk, whiel is generally suborbieular and often very convex, but oceasionally more or less saucer-shaped; or of many disks united, so as to form rather large masses, witl many papillary prominenees studding the surface. In the sauecr-shaped variety the edge of the basal lamina is free and subereet, and ineloses the eclliferous portion of the zoarium. "In its more usual state the simple form is entircly adnate and a good deal raised, the eells radiate very regularly from the central space at the summit of the eonvex disk towards the margin, the orifiees are but slightly elevated, and the upper margin is usually furnished with three spines, one central and of considerable length, and two lateral and shorter. The latter are often abortive, and the orifice is simply aeuminate*. The pores (or ostioles) are smaller than the zoceial apertures; they eover the eentral area, and are ranged in one or two lines along the interspaees. They are all but universally stellate.

The eomposite form seems to owe its origin to sueessive buddings from the margin (Plate LXVIII. fig. 4), the eluster of distinct disks thus produced gradually eoalescing so as to constitute a massive zoarium, with a mamillated surface. Very beautiful speeimens of this kind oceur : I possess one from the Cornish eoast which measures $1 \frac{1}{2}$ inch in cireumferenee, and is eovered with about thirty of the eharaeteristic eminences. The latter exhibit many diversities: in some eases they are very small, thickly

* In a young and beautifully developed specimen, I haro noticed two mall denticles placed one on each side in front of the usual triplet; in some eases the latter is replaced by two long spines of equal size. 
crowded, oval in form, and with a very diminutive central space; in others the space at the summit is large and subcircular; in others, again, as in the var. $a$, elongate and often winding. Specimens of this composite growth present the most varied appearances. In the meandrina

Fig. 25.

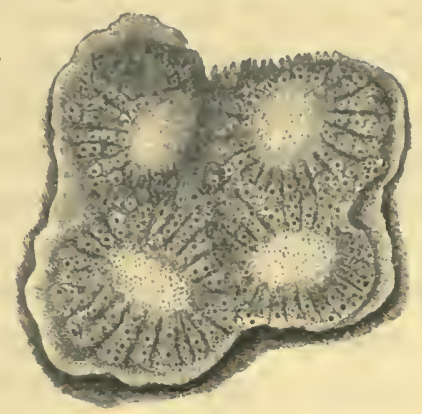

Var. meandrina.

form the zoarium is generally a large, irregularly shaped crust, sinuated and contorted, and often displaying great unerenness of surface. The large straggling systems, in which the lines of eclls are more prominent than is usual, also give it a very characteristic aspect; but I think it has no claim to be regarded as morc than a verý marked varicty. Mr. Peach states that the ostioles want the stellate character which they exhibit in the normal L. hispida; and this is no doubt generally the ease; but this difference is probably duc to a peculiar state of the calcification.

In Mr. Peach's specimens the pores are in most eases partially filled in by a kind of diaphragm, which would coneeal the minute denticles if present; but in rare instances I have detected them.

The varicty $\beta$, with its very uumerous, regularly dis- 
posed, and diminutive systems, offers the most striking contrast to the last-named; but they are both referable to one and the same speeifie type.

Habitat. On corals, Scrtularians, shells, Algæ, \&e., from moderate to great depths.

Localities. Guernsey; South Devon; Cornwall; Ilfracombe; Isle of Man ; Rothesay Bay (T. H.) : Northumberland, not rare (Alder) : St. Andrews, rather rare (Dr. M'Intosh) : Hebrides; Slietland, to 170 fathoms (A. M. N.) : \&c. Var. a. Shetland, 80-100 fathoms (C. W. P.).

Geograpiical Distribution. Bahusia (Lovén) : Norway (Lilljeborg) : Finmark (Sars) : Greenland (Lütken) : South Labrador (Packard) : Roseoff, on Eschara (Lepra. lia) foliacea (Joliet) : France, S.W. (Fischer).

Range in Time. ? Cor. Crag (S. Wood): Scotch Glacial deposits (Geikie) : Postpliocene, Canada (Dawson).

\section{Colony always simple.}

\section{a. Zoøcia uniserial.}

\section{Lichenopora radiata, Audouin.}

Plate LXVIII. fig. 9, 10.

Melobesia radiata, Savigny, Egypte; Audouin, Expl. 235, pl. vi. fig. 3. Tubulipora patina, M.-Edw. Recherches, Sur les Tubulip. 9, pl. xiii. fig. 1. Unicavea radiata, $D^{\prime}$ Orb. loc. cit. 971.

? Discocavea verrtcaria, id. loc. cit. 958.

Discoporella rlosculus, Hincks, Dev. Cat., Ann. N. H. ser. 3, ix. 468, pl. xvi. fig. 3.

Discosparsa patina, Heller, Bryoz. d. Adr. M. 46.

Discoponella radiata, Busk, B.M. Cat. iii. 32 , pl. xxxiv. fig. 3.

Zoarium orbicular, bordered with a thin, adherent lamina, convex, the centre of the disk flat, destitute of cells, caneellated, the openings of various size and shape, not stellate, frequently 1-3 large, trumpet-shaped, tubular 
openings (occial apertures) placed near the margin of the central area. Zoøcia much raised, connate, disposel in uniserial radiating rows, alternatcly longer and shorter; orifice with the upper margin usually mucronate, and sometimes the lower also; one or two rows of ratlier large subcircular pores between the lines of cells.

Disk about $\frac{1}{8}$ inch in diameter.

Turs is a very pretty species, distinguished by the regularity of its radiation and the alternation of long and short rows of cells, which are uniscrial and much clevated above the surface of the zoarium. The innermost tubes are the longest; and there is a gradual diminution in height towards the margin. The orifice is more or less strongly mucronate, and is often bifid.

The central area of the disk, which is of considerable sizc, has the appearance of being irregularly reticulate, and is covered with cancelli of very various shapes and sizes. The pores between the lines of eclls are much larger, and more regularly formed; they are sometimes uniserial and sometimes disposed in a double row.

The zoarium, when attached to Algæ, is often much distorted, clasping and partly enveloping the stem, and loses its characteristic neatness and regularity of appearance.

The occia are formed by a gencral inflation of the upper surface of the disk, the trumpet-shaped processes being the orifices.

Habitat. On shells, sca-weed, \&c., from moderate depths and (?) deep water.

Localities. South Devon, Brixliam, Salcombe, \&c. (T. H.).

Geographical Distribution. Mediterranean ('Poreupine' Exped.): Adriatic (Heller) : Naples, common on 
Laurencia papillosa and other weeds, shallow water (A. W. Waters).

Range in Trme. Pliocene, Brueeoli (A. W. Waters).

Lichenopora veurucaria, Fabricius.

Plate LXIV. figs. 4, 5.

Madrepora verrucaria, Fabr. Faun. Grœnl. 430 : ? Linn. Syst. ed, x. 793. ? TUBULipora IIISPIDA (part.), Johnst. B. Z. ed. 2, 268.

? Discosparsa hispida, Heller, Bryoz. d. Adr. M. 47*.

Discoporella verrucarta, Smitt, loc. cit. $405 \& 479$, pl. x. figg. $6-8$, pl. xi. figs. 1-6: Busk, B.M. Cat. iii. 31, pl. xxriii. figs. 2, 3.

Licirenopora verrucaria, Smitt, Bryoz. Nota Zembla, difv, K. Vetensk. Ak. Förh. 1878, no. 3, 15.

Zoarium subeireular, very eonvex, at times subeonical, with a small central area destitute of eells, the laminar border narrow. Zocecia rather stout, moderately raised, disposed more or less regularly in radiating lines, not connate, frequently traversed by longitudinal ribs; orifice obliquely elliptical, the margin earried up into a tall aeuminate proeess; eells round the border of the disk not elevated, quineuneial, orifice subeireular. Oøcium an inflation of the surface of the disk; orifice trumpetshaped.

Turs is a small species, with the zoarium always simple, and the eells, which are proportionally large, diseonneeted and arranged in short, radiating rows. The orifiee is for the most part elliptieal, and the upper margin is elevated and acuminate; oceasionally the peristome is bifid. The zoœeia are generally buttressed in front by longitudinal ribs, which are sometimes serrate.

* It is a matter of cxtreme difficulty to determine the synonymy with nny certainty in this section of the Oyclostomata. Heller identiffes his specics with the $M$. verrucaria of Frbr.; but his diagnosis is quito insufficient.

As Busk has nlrcady pointed out, Smitt has wrongly referred $D$. flosculus, milhi, to the present species. 
The central part of the disk and the interspaces between the rows of eclls are cancellated or picreed by numerous pores; but this portion of the structure is very often conecaled by the occial inflation (formed of a thin calcarcous crust), which gencrally oecupics the whole of the upper surface and incloses the crect tubes, so as to diminish their apparent height.

The oœcial orifices, according to Smitt, range from 1 to 8 ; very commonly there is only onc.

L. verrucaria is a northern, and specially an Arctic form.

Habitat. On Laminarice, stems of zoophytes, \&c., from moderate depths (15 fathoms) to deep watcr.

Localities. Orkney (Barlec): Arran (Busk): Co. Down (Hyndman).

Geograpiical Distribution. Bahusia (Lovén) : Norway (Lilljcborg): Finmark (Sars): Davis Strait, 100 fathoms; Reykjavik, 15-20 fathoms; Hamilton's Inlet, Labrador (Wallich) : Assistance Bay, Grecnland (Sutherland) : Bay of Fundy (Packard): St. Gcorge's Banks, 150 fathoms (Smith and Harger) : Nova Zcmbla, lat. 70 $30^{\prime}$, long. $52^{\circ} 45^{\prime}$, in 5-20 fathoms; Matotschkin-scharr, 2-5 fathoms, \&c.; Kara sea (Stuxberg and Thécl).

\section{b. Zoœcia multiserial.}

LiCHexopora Regularis, D’Orbigny.

Plate LXVIII. fig. 11 .

Actisopora regularis, $D^{\prime}$ Orb. Pal. Franç. terr. crêt. v. 763, pl. dcclriii. figs. 7-9.

Zoarium entirely adnate, suborbicular, or somewhat elliptical, flat above, with a slight depression in the centre, a rather broad cellular margin sloping up to the rays. 
Zoceia multiserial, not raised above the surface, disposed in regular radiating rows, which taper off towards the centre, consisting of about three cells in the widest part, orifice plain; short rays intercalated at intervals amongst the rest.

The longer diameter $\frac{3}{8}$ inel, the shorter rather less.

There seems to be no essential differenee between the Shetland form, on which this description is founded, and the Cretaccous species described by D'Orbigny as Actinopor'a regularis. The latter, as figured in the 'Paléontologie,' is of rather smaller size than the recent specimen, and seems to be in an earlier stage of development; it has a larger number of the short rays, but in all important characters it agrees with the present.

The zoarium is raised and somewhat mound-like, the upper surface flat, very slightly depressed in the eentre; and from this point the longer lines of cells radiate with much regularity towards the eireumference, widening gradually as they approach it. There is no extension of the lamina round the disk; but a thick and compact cellular border slopes up from the base of the zoarium to the circle of celliferous rays. The latter number about twentyfour in the Shetland specimen. The cells are not free for any portion of their length; but the orifices open out uniformly on the surface of the rays. The shorter series are few in number.

This is a fine addition to our British fauna-one of the many which we owe to the energetic labours of our Shetland dredgers, and doubly interesting as the survivor of so many important ehanges in the condition of our globe.

Habitat. On stone, probably from deep water.

Locality. Shetland (A. M. N.).

Range in Trme. French Cretaceous deposits at SainteCroix, Vaud (D’Orbigny). 


\section{Genus DOMOPORA, D’Orbigny.}

From $\delta \dot{\alpha} \mu o s, a$ dwelling, and $\pi \dot{o} \rho o s$.

Millepora (part.), Jameson.

Túritora (part.), Fleming: Johnston : \&c.

Dosorora, D'Orbigny (1847), Prodrome de Paléontologie: Busk : Poach.

Coronopora, Gray (1848): Smitt.

Deprancia (part.), Reuss: Hagenow: Sars: Manzoni : \&c.

Oeriorora, Goldfuss.

Stelltrora (part.), IIagenow (fide D'Orbigny).

Coryabopora, Smitt (not Michelin).

Semiaclticavea (part.), D’Orbigny.

Generic Character.-Zoarium massive, cylindrical or mammiform, simple or lobed, formed of a number of subcolonies superimposed one upon the other; the whole surface porous. Zoøcis disposed in radiating lines, consisting of one or more series, on the free extremity of the stem or lobes.

\section{Domopora stellata, Goldfuss.}

Plato LXIII. figs. 10-14.

Tubulifora truscata, Flem. B. A. 529: Johnst. (part.), B. Z. ed. 2, 271

(not pl. sxxiii. figa. 8-10).

Coronorora truscata, Gray, B.M. Rad. 140: Sars, Reise Lof. og Finm. 145 : Busk, Rep. Br. Assoo. 1859, Trans. Sect. 146: Smitt, loc. cit. 408 \& 491 .

Defrancia truxcata, Sars, Norsk. Polyz., Vid. Selsk. Förh. 1862, 20 :

Aorman, Brit. Assoc. Rep. 1868, Shetl. Dredg. Rep. 310.

Stellirora stellata, Hagenow, Bryoz. Maast. Kreidebildung, 44 (teste Goldfuss).

Ceriopora atellata, Goldfuss, Petrefact. i. 39, pl. Ixx. fig. 12.

Deprancia stellata, Reuss, Foss. Pol. Wien. Tertï̈rb. 37, pl. vi. fig. 2:

Manzoni, Bryoz. foss. Mioc. d'Austr. ed Ungher. pt. iii. 16,

pl. xvi. fig. 3: Busk, Ann. N. II. ser. 2, xviii. 3i, pl. i.

fig. 9.

? Corymaotora rungrommis, Smitt, loc. cit. $407 \& 490$, pl. xi. figs. 13, 14.

Donopora truxcata, Busk, B.MI. Cat. iii. 35, pl. xxxi. Agg. 1, 2.

Dosupora stellata, Peach, Journ. Linu. Soc., Zool, xiii. 484.

(Not Millepora trucuta, Jameson.) 
Zoarium erect, rising from an irregular, inerusting porous base, more or less stalked and eylindrieal below, simple or lobed, sometimes distinetly branched, sometimes merely proliferous, and bearing elusters of expanded lobes, on whieh the eelliferous rays are disposed. Zoccia bi- or triserial, vertieal, minutely punetate, united so as to form mueh elevated, radiating or lamellate rows on the extremity of the lobe, whieh presents a stellate appearanee; general surfaee of the zoarium eompletely eovered with somewhat hexagonal pores. Oœcia elongate irregular inflations, formed of a minutely granulated ealeareous erust, and situated on or near the border of the stellate eapitula, the "orifiee short and round, and variously plaeed" (Smitt).

Polypide with 8 long tentaeles.

Tніs very beautiful and charaeteristie speeies has long been well known, and has been aeeurately described by various authors, by none more fully or graphieally than by the elder Sars. Mueh confusion, however, has been introduced into the synonymy by Johnston's mistaken identifieation of it with the Tubulipora truncata of Jameson and Forbes. It was first deseribed by Fleming under the latter (specifie) name, whieh.Jameson, however, had previously applied to a totally different form. Johnston, assuming the identity of the species which these authors had in view (he had probably only speeimens of Jameson's speeies before him), ranked the Millepora truncata of the latter and the Tubulipora truncata of Fleming as synonymous; and the error has pervaded our systematie literaturc to this day. The species whieh Jameson originally diseovered, and which Edward Forbes supplied to Dr. John. ston, has been lost sight of ; Fleming's species, in usurping its name, has supplanted it.

We are indebted to Mr. Peach's sagacity for its restoration. He recognized the existence of two distinet forms, 
both ineluded under Johuston's $T$. truncata, and was able to identify the one which Forbes had dredged in Shetland with speeimens of his own from the same loeality. It proves to be, as might have been expected from Johnston's remarks upon it* and figure, very different from Domopora stellata, and will now enjoy, we may hope, undisputed possession of the name originally eonferred upon it.

In $D$. stellata the zoarium adheres by an expanded porous base, from which an ereet subeylindrical stem rises, which is sometimes short and stout, and dilates almost at onee into a eapitulum, on the upper part of which the zoceia are disposed in prominent lamelliform rays. In ecrtain stages a sceond eapitulum is developed by budding from the base or side of the first, and the zoarium becomes bilobate. By repeated gemmation it takes on a elustered form, many short proeesses, each bearing a number of eelliferous eapitula, being united in one composite strueture (Plate LXIII. fig. 10). In proliferous specimens of this kind, the "stars" or eell-bearing eapitula may number from 7 to 13 or even 16 (Sars). In Mr. Peach's finest speeimen there are 15. The stars are mueh erowded together on the separate lobes, one lobe bearing as many as seven. The lamellæ are subtriangular in form and stand out very prominently. The boundaries of the eells, which are ranged in two or three series, are visible on the sides, and give them a lineated appearanee.

'The habit in the proliferous form, which I have just described, is dwarf and stunted; the lobes supporting the eapitula are extremely short and ean hardly be ealled branehes. But the speeies sometimes assumes a very different form: the stem is mueh elongated by sueeessive

* 'British Zoophytes,' p. 271 (afler tho paragraph from Fleming) and p. 272. 
growths, superimposed one upon another, and at length divides diehotomously into distinet eylindrieal branches, which, again, may subdivide into a number of short terminal lobes (Plate IXXIII. fig. 11). The sueessive inerements to the stem and branehes are elearly indicated by transverse grooves on the surface. Not unfrequently the eapitula are rounded and slightly furrowed on the upper part, but show no traees of the eelliferous lamellæ; this is probably an immature condition, and it elosely resembles that which is permanent in D. truncata.

The Corymbopora fungiformis of Smitt is probably founded on a simple specimen of the elongate form in an imperfeetly developed state (Plate LXIII. fig. 13).

I am indebted to Mr. Peach for the opportunity of examining a very fine series of specimens, which fully illustrate the various stages of growth and diversities of habit.

Habitat. On stones, shells, Serpula, \&e., from deep water.

Localimies. Zetland, deep water (Fleming, Peach) : ibid., not uneommon on the Outer Haaf, in 70-170 fathoms (A. M. N.).

Geographical Distribution. Norway (Raseh) : ibid., from Bergen to Bejan, 40-60 fathoms (Sars).

Range IN TIme. "In stratis arenoso-margaceis Westphalice" (Goldfuss): Austro-Hungarian Miocene (Manzoni) : Vienna basin (Reuss). 


\title{
Domopora truncata, Jameson.
}

\author{
Plato LVIII. figs. 5-9.
}

Millepora truxcata, Jameson, Wern. Mem. i. 560.

Tubulipora truxcata, Johnst. (part.), B. Z. ed. 2, 271, pl. xaxiii. figs. 810 (not good).

Domorora trexcata, Peach, Journ. Linu. Soc., Zool. xiii. 483. (Not Tubulipora truncata, Fleming, nor Defrancia truncata, Busk, Annals, ser. 2, rriii.)

Zoarium mammiform, with an adherent, expanded, circular base, white; surface porous, somctimes simple, sometimes proliferous, and consisting of a cluster of the mamillated disks, the top rounded and furrowed. Zoocia disposed in very slightly clevated multiserial rows, varying in number, scparated by very shallow grooves, which originate at the base of the rounded top and radiate towards the summit.

Height not cxcceding $\frac{1}{4}$ inch, usually less.

Tнгs species varics much in different stages and conditions of growth. In its young state it consists of a more or less circular adherent disk, with a ccllular border, sloping a little outwards, very slightly elcvated in the centre, towards which a number of indistinct rays, originating on the inner edge of the border, converge. The wholc surface is porous; but the zoœcia are aggregated on the radiating rows. In this stagc therc is the merest rudiment of the central, somewhat dome-shaped rising which is characteristic of the adult, and the zoarium very closely rescmbles a Lichenopora. The mamillary clevation secms to be formed by successive growths, supcrimposed one upon another. Frequently the expanded base bears a group of sevcral mamillæ, which are sometimes united in pairs; in one case six are joined together in one composite eolony, each of the buds dercloped on the discoid 
erust having its own slightly expanded base. Occasionally fresh disks are produced towards the edge of the original crust, which increase the area of the eolony. Gemmation takes place, to a limited extent, from the surfaee of the mamillary risings, as well as from the erust (Plate LXIII. fig. 5); but there is never any distinet branching as in the preceding speeies. The rows of cells arc chicfly confined to the rounded top of the mamilla, radiating from the base to the summit; but in some cases they extcnd to the very edge of the border of the disk. They are very slightly raised, and separated by mere supcrficial furrows, and never form ereet and prominent lamella, sueh as we find in D. stellata. Of the largest speeimen whieh $I$ have seen, the longer diameter is nearly $\frac{3}{4}$ inch, and the shorter about $\frac{1}{2}$ inch. This form eonneets the present group very elosely with the Lichenopor ${ }^{*}$.

The foregoing aeeount is based on a most interesting series of speeimens, for whieh I am indebted to the kindness of Mr. Peach.

Habitat. On large stones from deep water.

Localities. Shetland (Jameson and Prof. E. Forbes): ibid., brought up by the fishermen's lines from about 80 100 fathoms in the Out Haaf (C. W. P.).

\section{Doubtful Species.}

\section{Tubulipora hyalina, Couch.}

Tubulipora iryalina, Couch, Corn. Faun. iii. 108: Johnst. B. Z. ed. 2, 276.

Zoarium adnate, semitransparent, membrano-ealcareous. Zocecia distinct, tubular, ereet, arranged in one or two eireular rows round a plain eentre; orifice unarmed and frosted.

* D. truncata resembles in many respects the Semimulticavea (Domopora) tuberculata of D'Orbigny, which is evidently a kindred form (Pal. Franç. terr. crét. p. 980, pl. 648. figs. 1-4). 
Colonies forming small patehes of about the diameter of a pea.

\section{Haвitat. On Fucus palmatus.}

Locality. Polperro, rare (Coueh).

Possibly founded on young speeimens of some speeies of Lichenopora.

\section{Note on the Origin of the Cyclostome Colony.}

Accordivg to Barrois*, the larva of Tubulipora, soon after fixation, appcars as a diseoid body (woodeut, fig. 26, $p d$ ), whieh is inelosed by an obscurely eellular endoeyst, around whieh a caleareous ectoeyst is developed, forming an opaque ring round the whole strueture (fig. $26, e c t$ ). The eentre of the diseoid eell is oeeupied by a pyriform body; and between this and the inner wall (endoeyst) lies a soft and transparent mass of fatty globules. The eentral body is gradually moulded into a polypide (fig. 26, pol) : from the endoeyst a round swelling originates over the tentaenlar region of the polypide, which is developed into a ealeareous tube (fig. 26, T). The tentacles are soon partially ineludẹd in this tubc, which ultimately becomcs the true eell and the permanent home of the polypide. The original disk is eonverted into a mere organ of attachment, and is separated by a diaphragm from the tubular eell. In this condition it eommonly oecurs attached to the adult Cyelostomatous eolony.

Fig. 26.

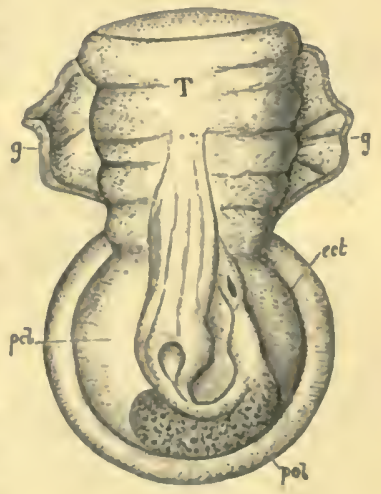

* Rech. sur l’embryologio des Bryozoaires, pp. 70, 71. 
“Dans ces animaux inférieurs, si beaux de simplicité et si riches de formes, on peut faire l'anatomie des organes sans attendre la mort; à travers l'enveloppe transparente on voit fonctionner tous les appareils; la nourriture so transformo sous los yeux do l'observateur, les pertes se réparent en sa présonce; on voit les embryons se former pièce par pièce; ${ }^{*} * * * *$ e'est un atelier en pleine aetivité et dans lequel on peut étudier et los allures et les gestes de chaque ouvrier ou do chaquo organo."VAN BenedeN。 
Fig. 27 .

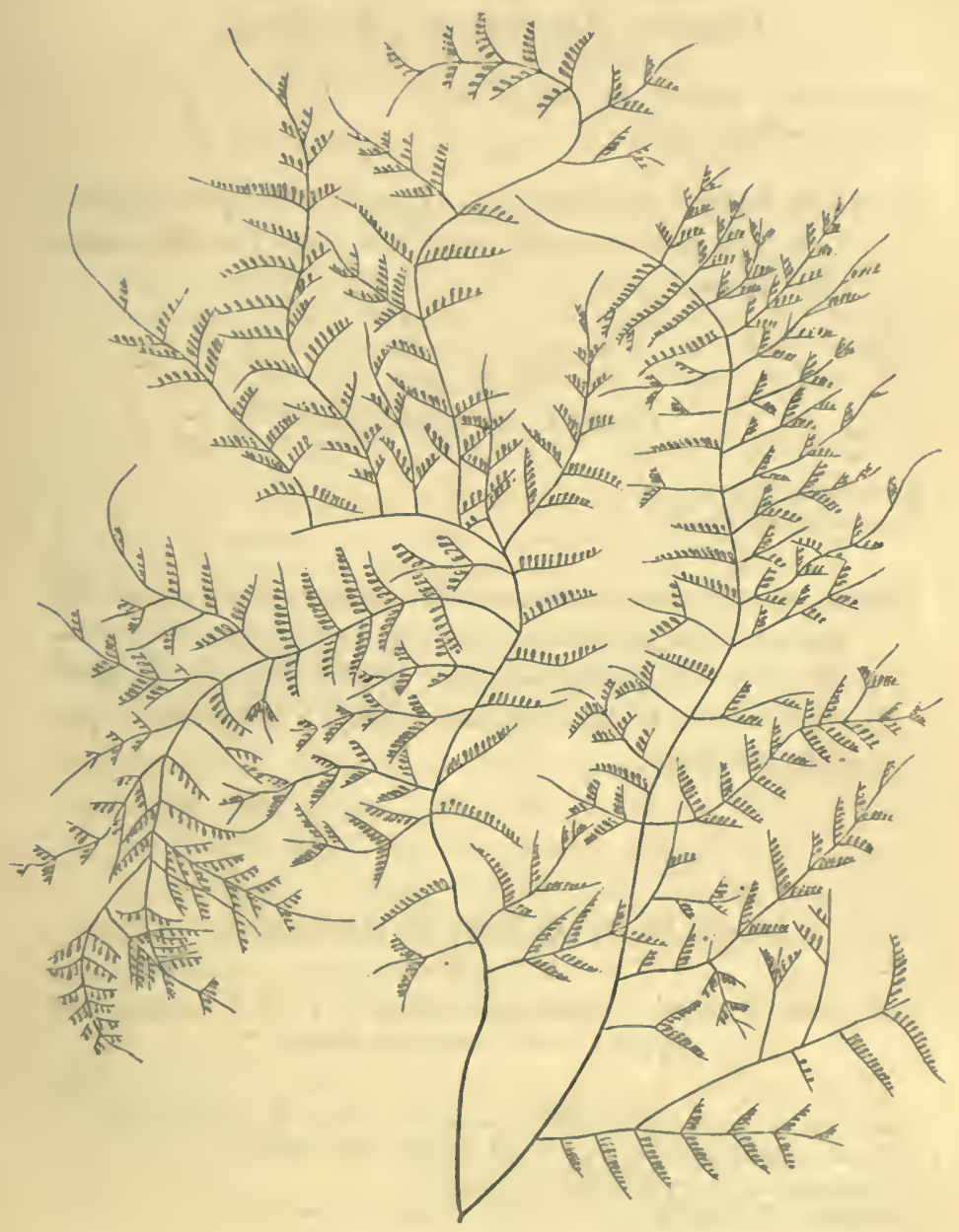

Mimosella gracilis.

Suborder III.-CTENOSTOMATA*, Busk.

Crexostonats, Busk: Alder: Gosso: Smitt: Heller: Carus: Joliet: \&e. HaUcyoNelea and Vegicelarisa, Johnstion.

* The diagnosis of the suborders will be found in the portion of the $\mathrm{I}_{11}$ troduction deroted to Classificntion. 
Group a. Halcroneled, Ehrenberg.

Alcyosidece, Johnston, Brit. Zooph. ed. 1.

Polyzoa carnosa, Gray.

Zosium fleshy or membranous. Zowcis developed by budding from other zoccia, and not from the internodes of a stolon.

Family I.-Alcyonidiidø.

Alcyonidule, Coueh.

HALCYONELLEE, Smitt.

Zoøcis more or less closely united, immersed in an expanded and adherent gelatinous crust, or forming an erect cylindrical or compressed zoarium; orifice closed by the mere invagination of the tentacular sheath; not protected by external labia.

Genus ALCYONIDIUM, Lamouroux.

Der. From Alcyonium, a genus of Actinozoa, to which the prosent was supposed to bear some resemblance.

Alcyosid tur, Lamx. Exposit. Méthod. (1821): Johnston : Couch : \&c. Alcyoniva (part.), Linnæus: Pallas: Müllor: Fleming : \&e. Halodactyuus, Farre (1837): Van Beneden.

Crclous (sp.), Hassall.

Sarcochtтum (sp.), Hassall.

Generic Character.-Zoceia immersed or subimmersed; the orifice simple, papillaform. Zos rum gelatinous or argillaceous, either crustaceous or erect. 


\title{
a. Zoarium gelatinous.
}

\section{Aleyonidium gelatiNosum, Linnæus.}

\author{
Plate LXIX. figs. 1-3.
}

Sea Ragged Staff, Ellis, Corall. 87, pl. xxxii. figs. d, D.

Alcrosiem genativosem, Linn. Syst. ed. 12, 1295: Pallas, Elench. 353 : Miuller, Zool. Dan. iv. 30, pl. exlxii. : Ell. \& Soland. Zooph. 176: Lamx. Pol. cor. flex. 350: Blainv. Actinol. 525, pl. xcii. fig. 1: Dalyell : \&c.

Ulva diapitana. Soucerby, Engl Bot. pl. celriii. : Lamk. \& De Candolle, Flore Franç. ii. 6.

Epipetrey gelativosuy, Oken, Lehrb. Naturgesch. Zool. Abth. 2, 80.

Alcronidiux diapilaver, Lamx. Gen. Thalass. 71, pl. vii. fig. 4.

Halodactruts diariaxus, Farre, Phil. Trans. 1837, 405, pls. xxv. \& exvi.: Van Ben. Rech. 60, pl. riii. fig. 12 (Mém. Bruxelles, xviii. 1845).

Alcronidiva gelativosur, Johnst. B. Z. ed. 2, 358, pl. lxviii. figs. 1-3: Gray: Landsb.: Gosse: Alder: Hincks: Smitt, dc.

Zoarium ereet, gelatinous, subeylindrical or sometimes slightly flattened, yellowish or greenish yellow, simple or variously lobed and branched, assuming the most diverse shapes. Zoceia elosely packed together, their orifices marked by low, blunt papillæ which are erowded together over the entire surface.

Polypide with 15-17 extremely slender and flexible tentacles.

Height usually several inches; sometimes as much as two or three feet.

Habitat. On stones, shells, roeks near low-water mark, erabs \&e. from tide-marks to deep water.

Localities. Common and widely distributed. South Devon; Ilfraeombe; Isle of Man ; Llandudno, tide-marks ; Filey; Oban (T. H.) : Cornwall (Couch) : St. Andrews (Dr. M'Intosh) : Northumberland (Alder) : Isle of Sheppey, abundant (Farre) : Bass Rock, 24 fathoms; S.E. off 
Yarmouth, 16 fathoms (Kirchenpauer): Shetland, 5-8 milcs east of Balta, 40-50 fathoms, sandy bottom; 6 miles north of Whalsey Lighthouse, 40 fathoms (A. M. N.) : of occasional occurrence on the north-cast coast of Ircland; Bclfast Bay (W. T.) : Youghal (Miss Ball) : \&c.

Geographical Distribution. Ostend (Van Ben.): Bahusia, at great depths and in 20 fathoms (Lovén, Smitt) : Spitzbcrgen (Swed. Exped.) : Kattegat; North America (Kirchcnpaucr): Greenland (Lütken): Whitc Sca (Mcrcschkowsky) : Nova Zembla, Matotschkin-scharr, 15 fathoms and 40-50 fathoms: Kara Sea (Stuxberg and Théel) : Natal (W. Oates).

It is difficult to frame a description that can give any idea of the forms assumed by this protean specics. In one of its most charactcristic states it is cylindrical above the contracted base, with an obtusc extremity, and often of very great length. But frequently this finger-likc growth is covered on all sides, and from top to bottom, with short lobate or nodulous processes, giving it a singularly rough and rugged appearance. Nothing can be better than the quaint description of it in this condition which we have from Johnson, the editor of 'Gerarde's Hcrbal,' who was the first to characterize the specics :- "It is of a dark ycllowish colour," he says, "and buncheth forth on cverie side with many uncqual tubcrosities or knots." It is sometimes more decidedly branched in an irregular straggling fashion. In some states it is compressed or flattcned; but the subcylindrical habit is more characteristic.

The polypides are prescnt in enormous numbers, closely packed together in the outcr zone of the semipcllucid cylindrical stem, the centre of it being occupied by a ccllular tissue and fluid. The surface of the zoarium is 
generally described as smooth; but, though destitute of the prominent imperforate papilla which distinguish the following species, the orifices of the zoceia are marked by very small (but distinet) blunt tubereles. Ellis correctly described it as "full of minute papilla which send forth polypes."

Dr. Farre, from whom we have an admirable account of its strueture, has remarked that the arms are sometimes (as in other cases) much longer on one side than the other, so as to give an obliquely truncatc appearance to the tentacular bell. The opereular setæ are short and very stout; Smitt gives the number at 12 to 13. The eiliated intertentacular organ, which oecurs on Membranipora pilosa and other specics, is sometimes met with on $A$. gelatinosum.

\section{Alcyonidium hirsutum, Fleming.}

Plate LXX. figs. 4-7.

Alcronus uresetur, Flem. B. A. 517.

Alcronidium in rsutus, Johnston, B.Z. el. 2, 360, pl. lxix. figs. 1. 2: Couch, Corn. Faun. iii. 133: Van Ben. (Halodactyle relu), Rech., Mém. Bruxelles, xviii. 37 (sep.), pl. v. figs. 3-8: Alder, Northumb. Cat. 63 (sep.): Hincks, Dev. Oat., Ann. N. H. ser. 3, ix. 470 (56, sep.): Gosse, Mar. Zool. pt. 2, 19, fig. 30.

? Alcyonicu raluatem, Dalyell, Rem. Anim. ii. 43, pls. xr., xvii.

Crcloex rapillosu3, Hassall, Ann. N. H. vii. 483: Johnston, B. Z. ed. 2, $364, \mathrm{pl} .1 \mathrm{xx}$.

A Lcrosidues rapillosur, Smitt, loc. cit. 499 \& 516, pl, xii. figs, 20, 21. (Not A. hirsutum, Smitt.)

Zoarium of rather firmer consistency than the last, incrusting or ereet, compressed, cxpanded, palmate, much and variously divided, of a yellowish-brown colour; the surface thickly covered with tall, imperforate, conical papilla, amidst which the slightly prominent zoocial orifices are placed. 
Polypide with 17-18 long and slender tentaeles, which are often spirally eoiled and mueh twisted.

Height 5 or 6 inehes.

Habitat. On Algre between tide-marks and in shallow water.

Localities. South Devon; Ilfracombe, on Corallina; Watehet, Bristol Chaunel; Isle of Man; Filey; Laududno ; Menai Straits ; Oban (T. H.) : Cullereoats, of humble size; North Northumberland, 5 or 6 inehes high and about as much broad, largest beyond. low water (Alder): St. Andrews (Dr. M'Intosh) : Shetland, Balta Sound, and Out-Skerrics, tide-marks (A. M. N.): entranee to the Firth of Forth, 30 fathoms (Kirehenpauer) : Hastings (Miss Jelly); Northern shores of Ireland, not uncommon, especially on Delesseria alata; Connemara (W. T.) : Dublin Bay; Youghal (Miss Ball): Glendore (Allman).

Geographical Distribution. Roscoff (Jolict) : Kattegat (Kirehenpauer) : Bahusia, chiefly on Fucus serratus; Spitzbergen, 12 fathoms, on Fucus (Smitt) : Finmark (Goës and Malmgren) : Greenland (Luitken).

This species oceurs in two very distinet forms-as a rather thick gelatinous erust, overspreading various kinds of Algæ, in which state it is in all probability the Cycloum papillosum of Hassall ; and as an ereet, palmate growtl, which often attains a very eonsiderable size. On the South-Devon eoast it grows luxuriantly, forming large palmate expansions, several inehes in width, variously lobed, and of remarkable beauty. These are given off from a spreading base.

Dr. Johnston mistook the papillæ for the zoœeia; but the orifiees of the latter form low, irregularly-shaped risings, slightly depressed in the eentre, and are distri- 
buted over the surface amongst the larger imperforate promincuces. Smitt, misled by his diagnosis, has sepas rated his $A$. hirsutum from the Cycloum of Hassall ; the former lie identifies with the A. mamillatum of Alder*. Of the identity, however, of Hassall's species with the present there can be little doubt. The arrangement of the ova circularly in clusters seattered over the zoarium, to which he attached so much importance as to make it a generic distinction, is common amongst the Alcyonidia. I lave described it as it occurs in A. mytili, in which the character of the reproductive eclls and disposition of the ova agrec perfectly with Hassall's account.

This author states that on more than onc occasion he has seen specimens of his Cycloum "enveloped in a firm coating of ice ;" when it was dissolved the polypides expanded their tentacles and displayed their usual activity. Such power of enduring cold we might expect in a littoral species whose principal home is in northern latitudes. I have seen the larva of this species liberated in great numbers towards the close of January, in very severe weather.

Alcyonidium mamllatum, Alder.

Plate LXIX. figs. 7, 8.

Azcrosidies uasilutux, Alder, North. Cat. Trans. Tynes. N. F. C. Gt (sep.), pl. v. figs. 3, 4: Smitt (=A. hirsutum, Smitt), Nova Zembla Bryoz., CEfv. K. Vet.-Akad. Förh. 1878, no. 2, 11.

Arcroxidiex unrsurux, 1. Zoceiis hexagonis, $a$. forme inerustantes, $\beta \beta$. forma menbranncea, Smitt, loc. cit. $497 \& 511$, pl. xii. figz. 5,6 .

Zourium a rather thick crust, semitransparent, brownish. Zocecia ovate, the anterior extremities produced into

* Polyzoa of Nora Zemblṇ, Gefr, K. Vet.-Ak. Fürl. 1878, no. 3, 11. 
tall, stout, subconical papilla, wrinkled transversely, from which the polypides issue, and which render the surface hirsute.

Polypide with 16-18 tentacles.

Habitat. On old shclls, Ascidians, stems of zoophytes, from shallow to deep watcr.

Localities. Northumberland, deep water (Alder): Filey (T. H.).

Geographical Distribution. Bahusia, 10-12 fathoms; Spitzbergen, 5-30 fathoms (Smitt) : Nova Zembla, Beluscha Bay, 60-70 fathoms; Kara sea (Stuxberg \& Thécl).

This very marked species is at once recognizable by its roughened surfacc. The zoarium seems to be always adherent; the cells are prolonged above; and the produced portion, supporting thc orifice, turns upward and forms an elongatc, somewhat conical process, which is strongly wrinkled. The roughness of the surface is quite apparent to the naked eye. The crust is thick and somewhat coriaceous.

Alcyonidium lineare, Hincks.

Alcyonidium lineare, Hincks, MS. and Ann. N. H. for September, 1877, 217 : Alder, North. Cat. loc. cit. 21 (sep.).

Alcronidum hrsutum, forma nippthoeides, Smitt, loc. cit. 497.

Zoccia oval, with prominent tubular orifices, immersed in a gclatinous crust, disposed in linear series, which gencrally branch from a central mass.

Haвiтat. On shells from decp water.

Localıties. Dogger bank, on musscls (T. H.) : Culler- 
eoats, deep water, not unfrequent, " rumning over shells in lines" (Alder).

This speeies is included by Mr. Alder under the above name in his 'Catalogue.' I had previously eorresponded with him about it, and had so named it in my letters, but had published no deseription of it. My speeimens of it have unfortunately perished; and I ean add but little from my notes or from memory to the brief aceount which has been given of it.

The tubular aperture is very prominent and direeted upwards, projecting at the extremity of the cells, instead of standing ereet as in other species. To the best of my recollection, the orifiees are turned slightly outwards; and I find, from a note made at the time of its first oceurrence, that it resembles a Stomatopora in habit.

Alcronidium disjunctum, Hincks.

Plate LXX. fig. 1.

Alcroxidius disuexctus, Hincks, Ann. N. H. ser. 4, xx. 217.

Zoarium inerusting. Zoccia elongate-ovate, disposed in linear series, which bifureate at intervals and oceasionally anastomose; the lines of cells bordered by a gelatinous erust; orifice small, not raised, placed near the anterior extremity; eells often massed together.

Habitat. On pieces of broken pottery.

Locality. Unknown; probably Nortliumberland. My specimens were reeeived from Mr. Alder.

The eells are elongate and sometimes subtruneate at the two extremitics, and are linked together in single $2 \mathrm{~K}$ 
series; on each side runs a margin of the gelatinous (?) erust. The series bifureate frequently, two lines originating from the summit of a cell. At the bifurcation the crust forms a web-like expansion between the two series. Every here and there collections of eells oceur, from which the single series are given off.

I have only had the opportunity of examining dried specimens of this form; and there is therefore a possibility that in some points the eharacters may not be adequately represented.

\section{Alcyonidium mytili, Dalyell.}

Plate LXX. figs. 2, 3.

Alcronidum мyтhi, Daly. Rem. An. ii. 36, pl. xi.: Smitt, loc. cit. 496 \& 507, pl. xii. figs. $1,2$.

Aucyonidium uexagonum, Hincks, Quart. Journ. Micr. Sc. v. 176; Ann. N. II. ser. 3, ix. 470: Alder, North. Cat., Trans. Tynes. F. C. 1857,65 (sep.).

Alcyonidius parasiticum, Smitt, CEfv. Vet.-Ak. Förh. 1865, 27, pl. v. figs. 8-19.

? Sarcochitum polyoun, Gosse, Mar. Zool.

Zoarium inerusting, fleshy, dingy white or yellowish, sometimes of a darker eolour; thiekly eovered, when the polypides are retraeted, with very small obtuse prominenees. Zoøcia hexagonal, the septa showing distinetly on the surface.

Ovarian cells seattered over the zoarium, the ova opaquewhite, disposed eircularly within them.

Polypide with about 15-18 tentacles.

Habitat. On shells, stones, and Fucus from tide-marks to deep water.

Localitins. Probably very eommon and generally distributed, though few localities have been recorded. Seot- 
land (Dalycll): South Devon, Saleombe Bay, Torbay, inerusting shells of Trochus, \&e.; Mount's Bay, Coruwall; Ilfracombe; Llandudno; Isle of Man, eommon; Menai Straits; Herm, on Trochus (T. H.) : Northumberland, eommon (Alder).

Geographical Distribution. Baliusia, on Alga, 5-20 fathoms (Smitt): Baltic Sea, eastern basin, very abundant (K. Möbius).

The cells in this specics are normally hexagonal; but they are subject to many irregularities, and in older eolonies, whcre they are closcly paeked together, they vary greatly in figure. The septa are usually distinetly visible on the surface. The erust is sometimes very thin; in other states it is much thicker, loses much of its transpareney, and becomes eharged (aceording to Smitt) with argillaecous partieles. There are also varieties in the colour. The speeies, however, is readily recognizable by its eomparatively smooth surfaee, mapped out into distinet areas by the zoœcial septa.

The ovaries are distributed irregularly, and often in great numbers, over the zoarium, and oeeur as somewhat eireular papilla, within which the opaque-white ova arc visible, ranged so as to form a ring. The ovarian ehamber is merely a zoceium destitute of polypide, and set apart for the diseharge of reproduetive functions.

The mature embryos may be seen moving about freely within the eavity; when about to eseape, a tubular orifice is gradually pushed forth at a point near the top of the eell, marked by a slight depression, through which they sueeessively work their way by means of their eilia. I have scen seven pass from a single ehamber in the eourse of a few seconds; and very interesting it was to wateh them struggling through the narrow passage and launehing 
themsclves into their new sphere of being. As the sunlight fell upon the cilia, they were tinted with a most lovely violet colour. As soon as they have effected their escape, the larva begin to move with great aetivity through the water*.

\section{Alcyonidium albidum, Alder.}

Plate LXX. figs. 8-12.

Alcrosidius albidus, Alder, North. \& Durh. Cat., Trans. Tynes. Nat. F. C. 64 (sep.), pl. v. figs. 5,6 .

Alcroninius nirsutur, 2. $\gamma$, forma inorustans, Smitt, loc. cit. 497 and 511.

Zourium incrustıng, semitransparent, yellowish whitc. Zoœcia distinct, ventricose, not closely united, flaskshaped, rccumbent below, subercet towards the oral extremity.

Polypide with 18 tentacles.

Habitat. On Algæ, zoophyte-stems \&c., shallow to decp water.

Localities. Northumberland, on Hydrallmania falcata from the deep-water fishing-boats (Alder): Ilfracombc, not uncommon (Leipner) : Shetland (T. H.).

Geograpilical Distribution. Spitzbergen, 30 fathoms (Malmgren, teste Smitt).

The most striking feature of this species is the more or less disconnected condition of the cclls. In the younger portions of the colony they are often completely separated, and present the appearanee of distinct flaskshaped bodics united by a common crust (Plate LXX. fig. 8). In this state they are rcadily detached from

* See a paper by the author in the Quart. Journ. Mier. Sc. rol. v. p. 176. 
the mass; figure 10 is taken from two zoceia which had fallen from a speeimen preserved in fluid. In the inner and older parts of the erust they lie more elosely together, but are still very distinet and retain much the same form. The lower part of the cell is ovate and recumbent; the anterior extremity is bent upwards and subereet, and forms the neek of the flask-shaped figure. As Alder has remarked, this speeies in eertain states "looks somewhat like a eluster of separate animals."

\section{Alcyonidium polyoum, Hassall.}

Plate LXIX. fig. 9.

Sarcocirtur polrour, Hassall, Ann. N. H. vii. 484: Johnst. 13. Z. ed. 2, 365 , pl. Ixxi.

Zoarium forming a thin fleshy erust, eovered with numerous large papilla of irregular form and unequal size, from which the polypides issue. Ova seattered singly through the zoarium.

Polypide with 20 tentacles.

Habitat. On Fucus serratus \&c., and on shells and stones.

Localities. Dublin Bay (Hassall): Northumberland, on the underside of stones, tide-pools (Alder) *.

Geograpincal Distribution. Roseoff, especially on Rhodlymenia palmata and Fucus serratus, very fine (Joliet).

A. polyoum is chiefly distinguished from $A$. mytili by

* Mr. Alder was rathet doubtful as to his identification of the Northumberland form with the present species. A. polyoum is included in my Devon Catalogue; but I am uow inclined to think that the specimens which I referred to it really belongel to $A$. mytili. 
having no septa visible on the surface, and by its large papilla, marking the cntranee of the cells. The ova also appear to be distributed singly throughout the zoarium, instead of being produecd in elusters. Jolict* states that it oeeurs under two very different forms: in its young state it eonsists of a very delieate transparent crust ; but with age it inereases in thickness, and forms at last a fleshy mass whieh covers the Fuci so as eompletely to distort them, and even throws out oecasional lobes. In this eondition it has a spongy appearanee, and is of a dull grey colour. In the months of May and June, he adds, the ova are developed in immense numbers, and appear as white, or oeeasionally rose-eoloured, points seattered over the surface of the eolony.

The speeies requires further investigation.

\section{b. Zoarium argillaceous.}

Alcyonidium parasiticum, Fleming.

Plate LXIX. figs. 4-6.

Alcyoniun parasiticuas, Flem. B. A. 518: Blainv. Aetinol. 525.

Alcyonidium Parasiticum, Johnst. B. Z. ed. 2, 362, pl. lxviii. figs. 4, 5 : Hassall, Ann. N. II. vii. 370 : Reid, Ann. N. H. xvi. 393, pl. xii. fig. 11: Van Ben. (Halodactylus) Rech. (Mém. Bruxelles, xviii.), 62, pl. viii. figs. 9-12: Dalyell, Rem. An. ii. 33, pl.x. : Smitt, loc. cit. 498 and 514, pl. xii. figs. 14-19, \&c.

Zoarium inerusting, argillaeeous. Zoocia very small, with minute papilla disposed round an oval or eircular area, which is eovered by a smooth hyaline nembrane. Polypide with 15-16 tentaeles. 
Habitat. On the stems and branelics of Sertularian $\mathrm{Hy}$ droids (especially Hydrallmania falcata), which it invests with an earthy coating.

Localimies. St. Andrews, abundant (Rcid \& M'Intosh): Northumberland, common (Alder) : Filey; Menai Straits; South Deron, not common (T. H.) : Coruwall (Couch) : Ireland, north and east shores (W. T.) : Dublin Bay, common (Hassall).

Geographical Distribution. Bahusia, not rare (Lovén).

Descriptions of this species have commonly been founded on dried specimens, and have thercforc failed to represent its true character. In this condition it appears as an carthy incrustation, with a porous surface (Platc LXIX. fig. 5). Smitt has given us an account of it, founded on Lovén's detailed obscrvations, which leaves little to be desired*.

The younger marginal cclls are somewhat elongatc in shape, with distinct septa and a fincly granulated surface. In the older portions of the colony they are shorter, with a circle of minutc papillæ, a little within the margin, forming an opaque border, in the midst of which there is a rounded area, covered by a hyalinc membranc. In the oldest cells the scpta are 1 o longer visible, the papillæe are irregularly placed, or form several rows round the ecntral area, which still retains the transparent membranous covering. In all cases the zoœcia arc cxceedingly small.

* It should be noted that Hrasall's brief description of this species (the true nature of which he seems to have been the first to determine), published in 1811, agrees substantially with Lorén's. 
Doubtful Species.

\section{Alcyonidium radiatum, Alder, MS.}

IN his Report on Shetland Polyzoa, Norman mentions a species of Alcyonidium which he had found between tidemarks in the Out Skerries, and to which Mr. Alder had given the above (manuscript) namc. No description of it has becn published.

Family II.-Flustrellidæ.

HALCYONELLE: (part.), Smitt.

Zoøcia immersed in a gelatinous crust; orifice bilabiate. LARVe furnished with a bivalve shell.

\section{Genus FLUSTRELLA, Gray.}

Der. Dim. of Flustra, the sea-mat.

Flustrella, Gray, B.M. Cat. Radiata: Redfern: Alder : \&c.

Fustra (part.), Fleming: Blainville: Johnston: Couch : Hincks : \&c. Alcronidium (part.), Smitt.

(Not Flustrella of D'Orbigny.)

Generic Cinaracter.-Zocela immersed, the orifice bilabiate, with a movahle lip, which acts as an operculum. ZoARIUM a gelatinous crust.

THIs genus is distinguished from Alcyonidium, with which it agrees in most points, by an important difference in the structure of the orifice. It is furnished with a 
kind of external opereulum, which, though not so highly organized as that of the Cheilostomata, bears some analogy to it, and is very different from the ordinary Ctenostomatous structure. The orifice in Flustrella, which is placed at the very top of the cell, resembles exactly the opening of a common clasp-purse. It is bounded above and below by narrow horny ribs, which correspond with the metal clasps of the purse, and which are connected at the sides much in the same way as the latter, and so as to allow of their opening and elosing. When the polypide is about to issue from its cell the mouth opens, just as the purse docs, by the separation of the two ribs (or lips), which come together again on its retreat. The upper lip seems to be fixed, and is very slightly arehed; the movable portion appears to be the lower lip, which, though not furnished with a hinge, like the opereulum of the Cheilostomata, bends outwards to allow of the passage of the polypide. In this respect, of course, the analogy with the purse fails. When the orifice is fully open, it is somewhat quadrangular in form. This arrangement is replaced in Alcyonidium by the simple inversion of the oral apparatus, giving rise, during retraction, to the formation of a papillary eminence, puckered in the centre, on the surface of the zoarium. As the polypide of Flustrella issues, a stout cylinder is first protruded, which often remains exserted in spirit specimens.

In another point the genus exhibits some divergenee from the rest of the present suborder. The setose opcreulum is much less conspicuous than it usually is, and, indeed, is often difficult to detect; but it exists, and is composed of numerous small and slender bristles. The embryology of the genus presents some interesting points. It has been reeently investigated by Barrois and Jolict, who have demonstrated the somewhat complex organization of the 
larva (Cyphonautes), which is furnished with two transparent valves, resembling in shape those of a Cypris, within which the soft portions of the body are lodged. As in other eases, this highly organized larva, on becoming fixed, is redueed, so far as the soft portions of its structure are concerned, to an amorphous mass of protoplasm, from which the primary polypide is developed *.

The Alcyonidium corniculatum of Smitt, from Spitzbergen, is a sccond species of the present genus.

\section{Flustrej.la hispida, Fabricius.}

Plate LXXII. figs. 1-5.

Futstra urspida, Fabricius, Faun. Grœnl. 438: Flem. B. A. 537 : Johnston, Trans. Newc. Soc. ii. 266, pl. ix. fig. 7 : Blainv. Actinol. 450: Hincks, Ann. N. H. ser. 2, viii. 357, pl. xiv. figs. 1-4. Alcycxidium uispidum, Johnst. B. Z. ed. 2, 363, pl. Ixvi. fig. 5: Smitt, loc. cit. 499 and 517, pl. xii. figs. 22-27.

Fuestra spongiosa, Templeton, Loud. Mag. N. H. ix. 469.

Membianipora spongrosa, Johnst. B. Z. ed. 1, 282.

Flustra carvosi, Johnst. B. Z. ed. 1, 288, pl. xxxvii. fig. 5: Couch, Corn.

Faun. iii. 125: Hassall, Ann. N. H. vii. 369.

Crcloum urspidis, W. Thompson, Nat. Hist. Ireland, iv, 476.

Flustrella nispida, Gray, B.M. Rad. 108: Redfern, Quart. Journ. Micr. Sc. vi. 96, pl. iv. : Alder, Cat. loc. cit. 57 : Smitt, Ups. Univ. Arsskrift, 1863, 12 (sep.).

Zoarium a rather thick brown erust, the surface rendered hispid by numerous reddish-brown corncous spincs. Zoceia elongate-ovate or subquadrangular, or six-sided,

* In a paper published so long ago as 1851, I have described and figured the transparent case by which the larva of $F$. hispida is protected, showing clearly (in the figure), its bivalve character, and also the mass into which the larva is resolved after fixation. In the same paper an account is given of the development of the polypide out of this (protoplasmic) mass. I believe that this is the earlicst notice of the occurrence of a bivalve protective case amongst the Polyzoan larve. (See Ain. N. I. for November 1851. (ser. 2, vol. viii.) pl. xiv. figs. 1, 2.) 
quineuncially arranged, the front surface flat, smooth and dense ; orifice somewhat raised, bilabiate, bordered above and below by a thin horny rib, the lower one connected with a movable or cxtensible lip, which acts as an operculum; a variable number of tall spines surrounding the orifice, and, in many cases, a row of similar appendages along the margins of the cells.

Polypide with 30-35 tentacles.

Habitat. On various Fuei (Fucus serratus, Gigartina mamillosa, \&c.) between tide-marks.

Localities. Very common and widely diffused.

Geographical Distribution. Bahusia, 5-10 fathoms (Smitt) ; Finmark (Goës \& Malmgren) : Grecnland (Lütken) : Heligoland (Kirchenpauer) : Roscoff (Joliet) : France, S.W. (Fischer).

This is in many ways a remarkable form. Its chicf structural peculiaritics have already been noticed; but more remains to be said of it. In the size and beauty of its polypides it is unequalled amongst the Polyzoa. Its rather coarsc-looking gelatinous crust, bristling with spines, is to be found on almost every coast where the Fucus serratus grows, and spreads over many other kinds of wced between tide-marks and in the neighbouring shallow water. The multitudes of the large tentacular bells, when expanded, give rise to the appcarance which Sir John G. Dalyell has happily likened to a "thin palebluc eloud," interposed between the dark surface and the spectator's cye. Through the clear still water of the rockpool on a summer day the blue mist may readily be secn, hovering, as it were, over the masses of Flustrella on the weed. The size of the polypide is remarkable: it has often as many as between 30 and 40 tentacles, and is three or four times as large as that of Alcyonidium mytili, 
which is furnished with eighteen arms, and is by no means a pygmy. The tentacular wreath presents a most clegant campanulate figure, with an everted margin.

In the young cells the form is hexagonal and very regular, the outlines are distinetly defined, and the walls are almost hyaline. At this stage few spines are developed; only an occasional one is to be met with. In many eases these appendages are confined to the neighbourhood of the orifice, around which as many as five to seven are often ranged; but in others they surround the eell, and are placed along the margin in a row, bending inward over the front surface. Apart from this important variation, they differ considerably in number. Each spine rises from a swollen basc.

In the older parts of the colony the eells are crowded together, and lose their regularity of form.

Family III.-Arachnidiidæ.

ALCronidia DE (part.), Hincks (1862): Alder.

Zodeis usually more or less distant, membranous.

Genus ARACHNIDIUM, Hincks.

Der. Dim. of ú $\rho$ á $\chi \nu เ o \nu$, a spider's web.

Alacisidia, Hincks, Cat. Deron and Cornw. Zooph: Alder. Arucinidiur, Hincks, Ann. N. H. for Sept. 1877.

Generic Character.-Zoarium membranaceous. ZoECIA usually separate, distant, adnate, united by a more or less filiform prolongation of the cell-wall, so as to form a delicate network. 
Is this genus the massive gelatinous crust, which characterizes the Alcyonidiida, is replaeed by a membranous zoarium. Arachnidium may be regarded as an Alcyonidium with its cells detached from one another and held together by a slender thrcad, instcad of being immersed in a fleshy crust. Oceasionally the cells are massed together; but in general they are separated by considerable intervals, and eonneeted by a filiform extension of the lowcr extremity, branches being given off from the sides. The habit of the Cheilostomatous genus Hippothoa is curiously imitated by this form.

Arachnidium hippothooides, Hincks.

Plate LXXI. figs. 1, 2.

Arachisin mippothooides, Hincks, Dev. Cat., Ann. N. H. ser. 3, ix. 471, pl. xvi. fig. 2.

Aracisidiey mippotuooides (part.), Alder, North. Cat., Trans. Tynes. F. C. v. pt. 3, 21 (sep.).

Zoccia usually rather distant, ovate or lozenge-shaped, of a light horn colour, conneeted by a slender fibre; orifice marked by a small papilla near the top; branches given off from each side of the cell. Zoarium composed of lines of cells, which anastomose and form a very delicate network.

In this species the connecting fibre is generally well-developed, and the cells are separated by considerable intervals; their form is regular and definite. The branch lines originate at different points on the sides of the zoocia ; most commonly they occur in opposite pairs; but occasionally two are giren off on each side; sometimes they originate from the crecping fibrc. The orifice is 
marked by a small papillary rising; but there is 110 prominent tube, as in $A$. fibrosum.

In the original description of this form the cells are said to be furnished with marginal processes; and $\mathrm{Mr}$. Alder, in his account of it, states that they occur occasionally. On recxamination, however, I cannot satisfy imyself of their existence.

Habitat. On shells.

Localities. On a Cyprina, dredged off the Isle of Man ; on shell, Torbay ('T. H).

Arachinium clavatum, Hincks.

Plate LXXI. figs. 3-5.

Aracinidius cisvatum, Hincks, Ann. N. II. for September 1877, ser. 4, xx. 216.

Aracinidia nippotiooides, Norman, Shetland Pol., Rep. Brit. Assoc. for $1867,3 \mathrm{i} 1$.

Zoarium forming an irregular network. Zoccia clavate, elongate, enlarged and rounded at the top, and tapering off below; orifice small, placed near the upper cxtremity.

Distinguishe from $A$. hippothooides by its larger size and its elongated, tapering, club-shaped cclls. They are frequently connected directly by the peduncular lower extremity; in other cases this is prolonged into a fibre. Occasionally two or three zoceia are laid side by side and apparently united. The lateral branches are given off from the upper part of the eell, a little below the orifiec.

Habitat. On the tests of Aseidians, in deep water.

Localities. Shetland (J. G. Jeffreys): ibid. 5-8 miles off Balta, on the test of Ascidia sordida (A. M. N.). 


\section{Arachididum fibrosum.}

Plato LXXI. figs. 6, 7.

:Aracusidius nippotiooides (part.), Alder, Suppl. Northumb. Cat., Trans. Tynes. F. C. v. pt. 3, 21 (sep.).

Zoccia irregularly shaped, generally more or less ovate, connected by short anastomosing fibres, which are given off with much irregularity; the margin of the cells set round with very numerous fibrils or filiform processes; orifice long, tubular, projeeting.

TuE most marked characteristics of this species are the irregular form of the cells, and their numerous marginal processes, and the long and prominent orifice. The connecting threads are generally short, and vary both in number and position; frequently several originate from a ecll. The margin of the zoœcia commonly gives off a number of very delicate fibrils, often of considerable length, which spread out in all directions, and constitute a kind of fringe. Sometimes the cells are united at the cxtremities and form a continuous line; occasionally they are massed together ; but in its usual condition the zoarium is a rude and irregular network. The tubular orifice is of very considerable length, subereet, and prominent.

Habitat. On the tests of Ascidians and on shell.

Localities. Lulworth Cove; ? Northumberland (Alder). 
Group b. Stolonifera, Ehlers.

Vesicularisa, Johnston.

Les Centrifugines radicelles (part.), D’Orbigny.

Vesicularies, Smitt.

Zosisum horny or membranous. Zoceris developed by budding from the internodes of a distinct stolon or stem.

i. ORTH ONEMida, Hincks.

Polypines with all the tentacles erect and forming a perfect circle.

Family IV.-Vesiculariidæ.

Zorecia contracted below, not closely united to the stem at the base, deciduous, destitute of a membranous area. ZOARIUM repent or erect.

a. Polypides furnished with a gizzard.

Genus VESICULARIA (part.), J. V. Thompson.

Der. From vesicula, dim. of vesica, a bladder.

Vesicularia, J. V. Thompson (part.), Zool. Illust. 1830: Farre: Johnston : \&c.

Serturaria (part.), Linnæus : Pallas : \&c.

LAojedea (part.), Lamouroux : Blainville.

VAlKeria (part.), Fleming: Dalyell.

Generic Character.-Zocein ovate, distant, disposed regularly in a single series on one aspect of the stem. Zoarium phytoid, rooted by a fibrous base. Polypine with a small number of tentacles and a gizzard. 
Vesiculakia spinosa, Linnæus.

Plate LXXIII. figs. 3-7.

Silk Coraluise, Ellis, Corall. 20, no. 17, pl. xi. figs. b, B, C, D.

Sertularia spinosa, Linn. Syst. ed. 12, 1312: Ellis \& Sol. Zooph. 48 :

Lamk. An. s. V. ed. 2, ii. 148.

Sertclaria serices, Pall. Flench. 114.

L.soxedeA srixosA, Lamx. Pol. cor. flex. 208: Blainv. Actinol. 474.

Valkeria spixosa, Flem. B. A. 551 : Dalyell, Rem. An. i. 251, pl. li. figs. 3, $3 a$.

Vesicularia spisosa, J. V. Thomps. Zool. Illust. Mem. v. 98, pl. iii. figs. 1-8: Farre, Phil. Trans. 1837, 401, pl. xxii.: Van Ben. 'Recherches,' Mém. Acad. Roy. Brux. xviii. 30, pl. iv. fig. 0: Couch, Corn. Faun. iii. 94, pl. xrii. fig. 1: Johnst. B. Z. ed. 2, 370, pl. lxxii, figs. 1-4.

Zoarium confervoid, slcnder, of very delicate texture, the principal and secondary shoots regularly branched, rooted by a fibrous basc; main stems overlaid with many capillary tubes, zigzagged, tapcring; branchlets given off from each bend in pairs, which are placed alternatcly on differcut aspects of the stem, short, much divided dichotomously, the divisions terminating in spinc-likc points, jointed above cach bifurcation. Zocecia oval, transparent, rather distant, rising from a circular orifiec, with raised rim, threc to each internodc. Polypide with 8 tentacles.

Height from about 4 inches to a foot.

Ha вiтst. On stones, oystcr-shells, Corallines, wecd, \&c., from tidc-marks to deep water.

Localities. The Nore (Ellis): Gucrnsey, Fermain Bay; South Devon; Ilfracombe, on weed in roek-pools, and off the Capstone, 8-10 fathoms; Menai Straits; Llandudno; Lytham, Laneashire; Islc of Man; Yorkshire ('T. H.) : Liverpool (Landsb.): off the Deadman, on Corallines, rarc (Coueh): S.E. of Yarmouth (Kirchenpaucr) : ncar Hartlepool, rarc (J. Hogg): Cullercoats, 
Northumberland, a single specimen (Alder): St. Andrews, on rocks near low-water mark (Prof. John Reid) : Leith shore (D. Landsb., jun.) : Wiek, rare (C. W. P.) : Shetland (Barlee, fide Alder) : Ireland, north, east, and west eoasts; very fine near Dublin (W. T.).

Geograpuical Distribution. Ostend (Van Ben.) : Roseoff, abundant (Joliet): Mediterranean (Pallas): Italy (Kirehenpauer).

$V$. spinosa grows in tall and graecful shoots, tapering towards the top, and thickly elotlied with dichotomously divided and somewhat flabellate branehlets. These are arranged in pairs at eaeh flexure; and the pairs arise alternately from opposite aspeets of the stem, so as to give a full and rounded and almost subverticillate appearance to the whole. From the main stems branches are frequently given off, which are eopies of the original shoot; in large specimens the ramifieation is luxuriant. The spinous terminations of the branchlets, to which the species owes its name, are not met with on those portions of the zoarium where growth is proceeding: here the tips are rounded and blunt, and the eharacteristic habit of the speeies is wanting (Plate LXXIII. fig. 5).

The tubular fibres, which loosely invest the stems for a considerable portion of their length, take their origin on the internodes a little above each bend, and tend downwards, becoming free at the base of the shoot, where they act as rootlets.

The zoarium is singularly delicate in texture and transparent, and the internal strueture may be thoroughly investigated with the greatest ease. The endosare consists of a slender thread, running through tlie tubular stem from cell to cell, and.communicating with each through an orifiee at the base; at each division of the 
stem it bifurcates. The zoœcia, which are pretty regularly orate in form, and so transparent as to kcep no secrets, are unilateral, and ranged in single file, diminishing gradually in size towards the end of the branchlets. The polypide is furnished with short stiff tentacles, destitutc of the tactile setæ which occur in Bowerbankia imbricata and other forms.

\section{Genus AMATHIA, Lamouroux.}

Der. From Amathia, one of the Nereids, according to Homer.

Avatira, Lamouroux (1812): D'Orbigny (for species with the cells in continuous series).

Sertelaria (part.), Linnæus: \&c.

Serialaris, Lamarck (1816): Fleming: Johnst. : D'Orbigny (for specics with the cells in distinet groups): \&c.

Vazkeria (part.), Dalyell.

Ayatiella (sp.), Cruradella (\$p.), \&c., Gray.

Generic Character.-Zoarium consisting of a creeping tubular stem and erect filiform shoots, dichotomously branched. Zocera subtubular, in two parallel rows, disposed in distinct groups, which are placed on one or both sides of the stem, or wind spirally round it ; or forming a continuous series.

D'OrbignY has placed the species with the eclls in groups and those with the eclls in continuous series in two separate genera, applying Lamouroux's name to one and Lamarek's to the other. But the distinction is purely artificial; the struetural difference between the two sections is quitc unimportant, and they are united by intermediate forms. The species like our own $A$. lendigera, with the cells in distinet unilateral groups, are connected through such forms as $A$. allernata, Lamx., in which the groups are placed alternately on opposite sides, with 
those which have them spirally disposed (the latter arrangement being a slight modification of the altcrnatc); and they again (as represented, for instance, by $A$. semiconvoluta, Lamk.) are but a step removed from the species with a continuous spiral winding round the entire stem.

The known species arc not numcrous; but the genus is widely distributed, ranging from our own shores and the Mediterranean to Japan, the American scas, and Australia.

\section{Amatila lendigera, Linnæus.}

Plate LXXIV, figs. 7-10.

Nit Coraluine, Ellis, Corall. 27, pl. xv. no. 24, fig. $b$, B.

Sertularia lexplgera, Linn. Syst. 1311 : Pall. Elench. 124: Ellis \& Sol. Zooph. 52: Lister, Phil. Trans. 1834, 384.

La Sertolara lendinosa, Cavolini, Polip. Mar. 229, pl. ix. figs. 1, 2.

Amatuin lesdigera, Lamouroux, Bull. Soc. Philom. 1812; Pol. cor. flex. 159 ; Expos. Méth. 10: Heller, Bryoz. Ad. Meer. 51.

Serialaria lexdigera, Lamk. Ann. s. Vert. ed. 2, ii. 169: Flem. B. A. 547 : Blainv. Actinol. 476, pl, xxxviii. fig. 2 : Couch, Corn. Faun. iii. 94, pl. xvi. fig. 4: Johnst. B. Z. ed. 2, 368, woodeut, fig. 68: D'Orb. Pal. Franç. terr. crét.: Landsb. Pop. Hist. 367, pl. xix. fig. 76: Alder, Northumb. Cat. 66 (sep.) : \&c.

Valkeria lendicera, Dalyell, Rem. An. i. 249, pl, lii.

Zoarium much branched, forming dense tangled masses; branches dichotomous, pellucid, obscurely jointed above each division. Zoøcia subcylindrical (ovatc, compressed laterally), disposed in distinct unilateral groups, placed immediately bclow a fork, and containing, usually from 4-8 cclls in each row, which decreasc in size towards the upper extremity.

Polypide with 8 tentacles.

Habitat. On Fuci (espccially Halidrys siliquosa) and zoophytes, from low-water mark to decp watcr. 
Localities. Very generally distributed, but seems to be less abundant in the nortl than in the south and west. It is not recorded from Shetland; nor does it occur in the Scandinavian and Aretic lists. Northumberland and Durham, not rare (Alder) : Firth of Forth (D. Landsb., jun.) : Filey, Yorkshire; Llandudno; Menai Straits; Isle of Man, common; Swanage Bay, in profusion; Ilfracombe, tide-marks and 8-10 fathoms; South Devon, in great luxurianee, ehiefly on Halidrys ('I. H.): Isle of Wiglit (W. T) : Hastings, somewhat rare (Miss Jelly) : Sussex, frequent (Pallas) : Tenby (F. Walker) : Cornwall (C. W. P.) : north, east, and west coasts of Ircland (W. T.) : Youghal (Miss Ball).

Geographical Distribution. Roscoff, at all deptlis, especially on fibrous Algæ in the Zostera-beds (Jolict): France, S.W. (Fischer) : coast of Belgium (Pallas) : Posilipo, St. John's Grotto (Cavolini) : Adriatic, on Alga and zoophytes (Heller): Soutl Africa, the present species or onc closely resembling it (Busk).

This pretty species is diffuse and luxuriant in its habit of growth, and overspreads the Algæ and corallines, in which it delights, with a perfect tangle of its delicate, flexile stems. As Ellis has remarked, "it elimbs up and runs over other Corallines and Fucuses as Dodder does over other plants." It is truly scandent in its liabits, and not only attaches itself by means of its slender intertwining branches, but also gives off here and there at times, as the ivy does, delieate fibrils, which seize the nearest support, and secure, as it werc, a new startingpoint for its vigorous growth.

The zoceia, which form the isolated groups, are ranged in two contiguous parallel rows, those in each row being closely united to one another. 'They become gradually 
shorter towards the upper extremity of the group, and imitate in their arrangement "the antique figure of Pan's pipe." The surface, both of the stem and eells, is speekled.

\section{Genus BOWERBANKIA, Farre.}

Der. Named in honour of Dr. Bowerbank.

Bowerbankia, Farre, Phil. Trans. (1837): Johnston: Van Benedell : dic. Sertularia (part.), Adams : \&c.

VAlí ERIA (part.), Johnston, B. Z. ed. 1: Hassall: Couch.

Serialaria (part.), Templeton.

Generic Character.-Zocecia ovate, disjunct, clustered, often subspirally arranged. ZоARIUM repent or erect. Polypide with a small number of tentacles (8-10) and a gizzard.

The genus Bowerbankia, as founded by Dr. Farre, was distinguished from Valkeria auctt. by the possession of a gizzard, and embraced a single species. We now know that there is a wider range of difference between these two forms; and it has been necessary to remove the latter to a distinct group (Campylonemida), of which it constitutes the type.

In his genus Valkeria, Dr. Johnston has included the Sertularia pustulosa of Ellis and Solander; but this form is furnished with a gizzard, and agrees with Bowerbankia in the arrangement of the tentacles and in gencral strueture, and should undoubtedly be united with it. The slight difference between them in the number of arms (the one has 10 and the other 8 ) is a point of no special importance. One or two other species have oceurred sinee Jolnston's time, which bear a general resemblanec to B. pustulosa, and will rank with it in the 
same genus. They all possess eight tentaeles; they are of slighter build and more delieate habit than $B$. imbricata, and the struetural features are less strongly pronouneed than in the latter, but there are no differenees between them of gencric value. They are all furnished with the mandueatory organ, and have the arms arranged in a perfeet circle.

Little is known as yet of the distribution of the Ctenostomata generally. The forms have been so imperfectly diseriminated that some doubt necessarily attaches to the identifieation of the species, and at the same time the comparative difficulty of preserving them has greatly limited our knowledge of the foreign members of the group.

The genus Bowerbantia has one representative at least on the northern coasts of Ameriea (B. gracilis, Leidy); it las occurred in the Caspian Sea; and I have detected specimens of B. imbricata form densa on an Alcyonidium from the White Sea, for which I am indebted to M. Meresehkowsky. Smitt records it from Norway and Spitzbergen.

Valkeria Vidovici of Heller, from the Adriatic, is also probably referable to this genus*.

Bowerbankia imbricata, Adams.

Plate LXXIII. figs. 1, 2.

Sertularia imbricata, Adams, Linn. Trans. $\nabla .11$, pl. ii. figs. 5-11: J. $V$. Thomps. Zool. Illust. 94, pl. i. figs. 1-4.

Falkeria olosizata, Coldstream, Edinb. N. P. Journ. ix. 235 , pl. ii. Ins. 1, 2.

Serialara indricata et verticillata, Templeton, Mag. Nat. Hist. ir, 46i, fig. 66.

Vaukeria imbricata, Johnst. B. Z. ed. i. 254 : ? Couch, Corn. Faun. iii. 05, pl. xvii. fig. 2.

- Kirchenpauer mentions a Vesicularian, apparently allied to $B$. pustulosa, which had been brought by Dr. v. Martens from Yokohnma. 
Bowerbankil imbricata, Johnst. B. Z. ed. 2, 377, pl. Irxii. figs. 5, 6 : Alder, Northumb. Cat. loc. eit. 67 (sep.): W. Thompson, N. H. Irel. iv. 466: Hincks, Dev. Cat., Ann. N. H. ser. 3, ix. $473(59$, sep.) : Joliet, Bryoz. d. côtes do France, 102, \&c. (Not B. imbricata, Gosso, Mar. Zool. ii. fig. 39.)

Bowerbankia densa, Farre, Phil. Truns. 1837, 391, pls. xx. \& xxi. : Johlest. B. Z. ed. 1, 255: $\operatorname{Van} B$ en. Rech. 29, pl. iv. fig. A (Mem. Brux. xviii.).

Stem tubular, crecping (B. densa auett.) or ereet, and irregularly branched (B.imbricata)*. Zoceia large, ovatocylindrical, transparent, broad and squarish at the top, somewhat narrowed below, disposed in groups along the creeping stolon, or in irregular clusters (sometimes almost continuously) on the erect stems and branches.

Polypide with 10 tentacles, furnished with a row of about 12 tactile setæ on the back: gizzard large and powerful.

Height of the ereet form 1-3 inehas.

IN its erect form this species grows in "bushy, flaceid tufts," mueh and irregularly branched, and attains a very considerable size. The eclls are arranged in large, dense clusters along the stem, either on one aspect of it only, or (not unfrequently) on all sides of it. Oecasionally the groups blend, and the zoceia range almost continuously along the branches. The stem is stout and smooth, and of a decided horn-colour. In its humbler form B. imbricata spreads on the surface of Algre, stones, \&c., the cells being grouped at intervals on the crecping stolon. The common Corallina is a favourite habitat; and on this it forms compaet suborbieular tufts, which completely surround the stem.

* "Au printemps * * * on trouve abondamment la forme densa do la Bowerbankia composée d'une quantité de loges dressées sur la surface del'Algue et pressées l'une contre l'autro de manière d ne former qu'un tapis. Plus tard se détachent de ee groupe des stolons, puis des rameaux libres qui poussent des branches et, se garnissant de paquets do loges, reproduisent la forme imbricata."-Jouter, Bryozoaires des cótes de France. 
The eells are large and stout, and somewhat squared at the top, during retraction. Through the transparent walls the polypide, which exhibits the most highly specialized form of the Ctenostomatous structure, can be readily examined*. It has ten tentacles, which are not everted at the extremities, and form a rather slightly cxpanded bell. They are furnished with numerous bristles, ranged in a single line along the back. Joliet states that in the case of the ereet form he has frequently met with only eight tentacles; ten, however, seems to be the prevalent and normal number.

In summer, when reproduction is proceeding, the colonics are tinted red by the larvæ which oceupy the cells.

Habitat. On various Fuci, Corallina officinalis, other Polyzoa (Flustra, Vesicularia, \&c.), on the underside of stones, \&c., from between tide-marks (chiefly) to deep water (?).

Localities. Very common and generally distributed.

Geograpincal Distribution. White Sea, on Alcyonidium (Mcreschkowsky) : Caspian Sca (O. Grimm): Ostend (Van Ben.) : Roscoff, on Fucus serratus and Fucodium nodosum (chicfly), also on Cystoseira, in the Laminarian zone; especially fine and abundant in brackish water (Jolict).

Bowerbankla caudata, Hincks.

Plato LXXV. figs. 7, 8.

Valkemia caudata, Hincks, Ann. N. H. ser. 4, xx. 215 (1877).

Stem ereeping. Zoccia elongate, subcylindrical, biserial, opposite, truncate at the top, slightly narrowed below,

* It is the subject of one of Dr. Farre's claseical memoirs, which hare contributed so largely to our knowledge of the anatomy and physiology of the Polyzon. 
and produced at the base into a short, pointed, caudate process, which bends outwards; disposed in eompanies along the ereeping stem.

Polypide with 8 tentacles.

In the original account of this species I have stated that I had been unable to detect a gizzard. But I have sinec had the opportunity of examining a eonsiderable number of well-preserved specimens; and I find that this organ is present and well-developed, and that the structure generally agrees with that of Bowerbankia.

The cclls are much smaller and slenderer than those of B. imbricata, and are not so broad and squarish at the top as the latter. Below they terminate in a pointed, somewhat spur-like extremity, which is very conspicuous in the youngest eclls, but is often less apparent in the adult. The cell is attached at a point a little above the base ; and the extremity commonly bends outwards. Normally the zoccia are disposed in separate groups or companies along the stem, and are placed opposite to one another with much regularity; but in certain states they are more crowded together, and the elusters almost blend.

I have little doubt that $B$. caudata will prove to be far from uncommon; it has probably been confounded witl B. imbricata.

Habitat. On Algæ, from moderatc depths.

Locality. Ilfracombc (Leipner).

Bowerbankia pustulosa, Ellis \& Sol.

Plate LXXVI. figs. 1-5.

Dichotomous Tobular Coralline, Ell. Corall. 54, pl, xxvii. fig. $e, \mathbf{B}$. Sertularia pustulosa, Ell. \& Sol. Zooph. 54: Flem. Br. An. 551. Vesicularia fusturosa, J. V. Thompson, Zool. Illust. 99, pl. i. figs. 5-11. Valkenia Pustulos.1, Johnst. B. Z. ed. 2, 376, pl. lxvii. figs. 7-9 : \&e. 
Zoarium erect, phytoid, much branched dicliotomously, jointed, branches given off just below a joint, blunt at the extremities; stem flexuous, rather stout, of a light horn-colour. Zoccia ovate, disposed at intervals in groups along the stem and branclies, a group on each internode, subspirally arranged in two series; the clusters dense, elongated, oceupying gencrally about two thirds of the internode, narrowed below and widening upwards.

Polypide with 8 tentacles.

Height 2 or 3 inches.

From the large size of the elusters of eclls, this species has a comparatively stout habit. It grows in tall and dense arborescent tufts, sometimes attaining a height of four inches. The zoœcia, during the retraction of the polypides, are contracted above, and, for a short distance below the extremity, transversely striated. Their subspiral arrangement is very apparent in the young terminal clusters.

The polypide is furnished with a gizzard, which is small as eompared with that of $B$. imbricata; indeed there is a delicacy in the entire strueture which is wanting in the latter. The œsophagus is very long; whilst the stomach is short and slender, and pointed below. The setose operculum is a remarkably beautiful object, and is composed of about twenty tall and extremely delicate bristles, united by a membranous sheath of extreme tenuity.

Habitat. On Fuei \&c., in shallow water.

Localities. Isle of Wight (Ellis) : Cork Harbour (J. V. Tliompson): Youghal (Miss Ball): Dublin Bay (Hassall) : Belfast Bay (W. T.) : Menai Straits; Llandudno; Ilfracombe, extremely abundant off the Capstone; Saleombe Bay, plentiful (T. H.) : Fowey Harbour, and off Goran, Cornwall, very rare (C. W. P.): Leith slıore, rare (D. Landsb., juu.). 
Bowerbankia citrina, Hineks.

Plate LXXVI. figs. 6-8.

Valkeria citrina, Hincks, Ann. N. H. ser. 4, xx. 215 (1877).

? Valkemia inbricata, Dalyell, Rem. $\Delta$ n. i. $246, \mathrm{pl}$. 1.

Stem ereet, slender, dichotomously branehed. Zovecia elustered, somewhat spirally disposed, oval, small and delieate, not densely erowded; the elusters short, plaeed immediately below each bifureation, and oeeupying about the upper half of the internode or less.

Polypide of a eitron colour, with 8 tentacles: very tall when expanded.

Shoots elustered, of slender habit, forming bushy tufts.

From the preceding speeies $B$. citrina is distinguished by its smaller size and more delieate habit, by its short and not very dense eompanies of eells, which do not extend far below the joint, whilst those of the kindred speeies are elongated and eompact and oeeupy a large proportion of the internode, and by the exquisite colour of the tentaeles and other portions of the polypide.

This might perhaps be regarded as a variety of $B$. pustulosa, were it not that the differenees in habit (whieh are so striking that the two forms are distinguished at a glanee) are always assoeiated with the remarkable peculiarity in the eolour of the polypides. The eoloured portions are the tentacles and a line running down the body and probably marking the eourse of the œsophagus. Each of the arms is traversed by a eentral line of bright eitroncoloured granules.

The polypides of this speeies are most beautiful objeets, both when stowed away in their transparent eells and when expanding their tinted wreaths of tentaeles. 
Haniтat. On rocks near low-water mark, and in shallow water.

Localities. Ilfraeombe, the Tunnels, and dredged off the Capstone (T. H.).

Bowerbankia gracillima, Hincks.

Plate LXXV. fig. 6.

Palkeria gracillima, Hincks, Ann. N. H. Sept. 1877, 216.

Stem ereeping, rather stout, and sinuous. Zoœcia disposed in groups of varying size at intcrvals, slender, elongate-oval when contraeted, flask-shaped when the polypide is extended, rounded off below, of a light horncolour.

Polypide with 8 tentacles.

Tris species is not characterized by any very marked feature, but is very distinct notwithstanding from any form with which I am acquainted. The eells originate on the sides of the ereeping stem, but are not regularly biserial; they are very slender and graceful in form, and are eonsiderably larger than those of $B$. pustulosa and citrina. The gizzard is rery conspicuous. Along the back of ench tentacle runs a line of very delicate setæ; and two or three stand out very prominently at the extremity. A very long bristle also projeets at the base, and is visible standing out on each side at the bottom of the tentacular bell.

Habitat. On Corallina and stones between tidc-marks.

Localities. Ilfracombe, probably (Leipner): Salcombe, in rock-pools; Torquay, tide-marks (T. H.). 


\section{Genus AVENELLA, Dalyell.}

Der. Dim. of avena, onts.

Aveseru, Dalyell, Rom. An. Scotland: Wyville Thomson.

Generic Character.-Zocecia solitary, irregularly scattered, subunilateral, curved, and slightly contracted above. Stem repent, nearly simple. Polypides with numerous tentacles and a small gizzard.

THERE has been some strange misapprehension amongst authors respecting this well-marked form. Notwithstanding the figures and execllent descriptions of it which we have from Sir J. G. Dalyell and Sir Wyville Thomson, it has been perseveringly identified by scveral of our recent writers on the Polyzoa with the Cylindrocium dilatatum of the present work, a species with which it has little in common. Indced the two forms belong to different families. Avenella is furnished with distinct, dceiduous cells ; whilst the species with which it has been eonfounded has its cylindrical zoœcia closely and permanently unitcd to the crecping stem.

It is somewhat remarkable that a form which Sir Wyville Thomson deseribes as "one of the largest and most conspicuous of our Vesicularian Polyzoa," and which seems to be abundant on eertain parts of the coast, should have attracted hitherto -so little attention and been so generally misunderstood.

Avenella is separated from the other members of the family by the peeuliarities of its cell and its large number of tentacles. 
Avenelia fusca, Dalyell.

Plate LXIVII. figs. 6, 7 .

Aves flu fusca, Dalyell, Rem. An. ii. 65 ; i. pl. xii. fig. 11 . (Not Farrella fusca, Busk, Q. J. Micr. Sc., nor Avenella fusca, Alder, Northumb. Cat, nor Valkeria fusca, Smitt, loc. eit. 502 , pl. xiii. fig. 38.)

Avenella Dalvelli, Wyville Thomson, Ann. N. H. ser. 2, ix. (1852), 403, pl. $x$ ri. $B$.

Stem very much attenuated, " much matted and interwoven." Zocecia large (about $\frac{1}{16}$ ineh long), set at irregular intervals, and not in the same line, more or less curred, roughened with seattered horny bristles, of a brown colour.

Polypide with 20-24 tentacles.

A. FUSCA is remarkable for luxuriant growth, and forms "dense tangled masses." Its cells, according to Sir W. Thomson, are not unlike the ergot of rye.

Habitat. On Sertularian hydroids, chiefly from rather deep water.

Locslities. Scotland, on zoophytes, "or on sluggish animals," c. g. Hyas araneus (Dalyell): Newharen, amongst rejeetamenta of the oyster-dredges, on various species of Halecium and other corallines; off Port Appin, Argyllshire, on Diphasia pinaster; Dogger bank (Sir Wyville Thomson). 
b. Polypides destitute of a gizzard.

\section{Genus FARRELLA, Ehrenberg.}

Der. Named in honour of Dr. Farre.

Farrella, Ehrenberg, Abhand. König. Akad. d. Wissenseh. zu Berlin, 1838: Johnston: Hincks.

Lagenelda *, Farre, Phil. Trans. (1837): W. Thompson : Hassall. Laguxcula, Van Beneden (1845).

Generic Character.-Zogcia with a bilabiate orifice, elliptical, scattered. Zoarium repent. Polypides without a gizzard.

THE most important distinetion between the present form and Bowerbankia is to be found in the absenee of the gizzard, which is so striking a feature of the latter genus. Farrella is also distinguished by the bilabiate orifice of its eell. But there are also differenees in the general east of its strueture; and we have in this genus, on the whole, a less highly specialized form than Bowerbankia. In the latter the œesophagus is of great length, the gizzard is a highly organized and powerful strueture, and the tentacles are furnished witl an apparatus of taetile setæe, which is wanting in the present genus.

Dr. Farre has also notieed a differenee between the two forms in the position of the stomach during retraction. In Farrella it is never brought down to the bottom of the cell, but remains suspended from the upper part of it by the intestine. Altogether the differences between the polypides of the two genera are of mueh signifieanee.

Smitt is inelined not to attach so much importanee as Farre to the presenee or absenee of the gizzard. He has

\footnotetext{
* This name had been previously applicd (1832) to a Protozoon.
} 
notieed that within the limits of one eolony this organ is in some eases very conspicuous and fully devcloped, that in otleers it is destitutc of its dark colour, less completely developed, and much less apparent, while in others, again, it seems to be absent. He appears to think that this character is hardly to be trusted as a diagnostic. My own experienee certainly does not support this view. I eannot remember that I have ever met with a cell of Bowerbankia imbricata (for instanee) in which the gizzard was not well developed and a conspicuous feature.

If it be oeeasionally absent in species which are usually furnished with it, this exceptional fact would hardly affeet its importanee as an clement of structure.

The ova are liberated in this genus, according to Van Beneden, through an orifiee at the base of the tentacular wreath.

\section{Farrella repens, Farre.}

\section{Plate LXXVIII. figs. 5, 6 .}

Lagexela repess, Farre, Phil. Trans. 1837, 403, pl, xxir.: W. Thompson, N. H. Ireland, iv. $4(i+1$ (not L. repens of Hassall).

BoWeribaxkia rzpens, Johnst. B. Z. ed. 1, 256.

Laguncula repens, Van Ben. Recherches \&c., "Sur l'organisation des Laguncula," Mém. Acad. Roy. Bruxelles, xriii. 25, pl. i. and pl. ii. A.

laguicula elongata, id. loc. eit. 26 , pl. ii. B.

Farrella prodvcta, Hincks, Ann. N. II. ser. 2, viii. 361, pl. xiv. fig. 10.

Farrelua repess, Johnst. B. Z. ed. 2, 380, woodcut, fig. 58 (after Farre).

Stem repent. Zoccia oblong, transparent, springing irregularly from the sides and upper surfaee of the stem, peduneulate, the pedunele mueli shorter than the eell.

Polypide usually with 12 tentacles, which are destitute of seta; occasionally with 10 or 11 . 
Form elongata. With the peduncle as long as the cell, or longer.

Polypide with 10-16 tentacles; 12 I have found to be the usual complement.

WE can hardly, I think, regard the difference in the length of the peduncular portion of the cell in the two forms (repens and elongata) as more than varictal, as they secm to agree in all other respects. The usual number of the tentacles in both is twelve; but there are slight irregularitics.

As to the distribution of the species, it is somewhat peculiar that the elongata form, which is too remarkable readily to cscape obscrvation, has only been noticed on certain portions of the Lancashire eoast, where it occurs in amazing profusion, investing all kinds of marine substances. For the form repens we have only onc or two British localitics; but it may be more casily overlooked or confounded, on slight cxamination, with Bowerbankia.

From the cxtreme tenuity and transparcncy of the cetocyst, the internal structure can be studied to the greatcst possible advantage in this spccies. It forms the subject of an admirable memoir by Van Beneden.

Habitat. Carapacc of crabs, shells, Algæ, Hydroids, \&c.

Locaxities. Isle of Sheppey, not very common (Farre) : Strangford Lough, on Algæ (W. T.).

Form elongata. Flectwood, on a buoy; Lytham, cxtremcly abundant (T. H.).

Geograpuical Distribution. Ostend, very common, especially on Sertularia, Tubularia, and Flustra (Van Bcneden) : Caspian Sca (Grimm).

Form elongata. Ostend, on the carapace of the common crab (Van Beneden). 
Family V.-Buskiidæ.

Vesiculariade (part.), Alder.

Zowcis contracted below, not continuous with the creeping stolon, with an aperture on the ventral surface.

Genus BUSKIA, Alder.

Der. Named in honour of Prof. Busk.

Buski , Alder, Trans. Tyues. Nat. F. O. (1857).

Generic Character.-Zowcia corneous, flask-shaped, decumbent, adherent for a great part of their length, developed at intervals from a creeping tubular stem; a membranous area on the ventral (or under) side immediately below the orifice. PoLYPIDE with a small number of tentacles. Gizzard?

Several genera contend for the honour of bearing Mr. Busk's name; but there seems to be no doubt that Mr. Alder's Buskia was the first in the field. The welldeserved tribute is enhanced in value, eoming, as it does, from so accurate and accomplished a student of the Invertebrata.

In this genus there is an "aperture" on the under or ventral side of the zoceium, which is covered by a thinner material than that of which the upper portion of the ecll is composed. This aperture corresponds with the similar strueture which we find in Triticella and Mimosella, and represents the inembranous area of the Cheilostomata, on which the oral opereulum is placed. It oceupies the whole space between the terminal orifiee and the point at 
which the cell becomes adherent. This portion of the cell bears a somewhat close rescmblance to the end of a quill prepared for pen-making. I am inclined to think that the membranous area extends also over the adherent part of the zoceia; for, when detached, the lower wall is generally found to have disappeared, as if it might have been formed of more delicate material than the rest. This structural peculiarity must separate the present genus from the Vesiculariida.

Buskin nitens, Alder.

Plate LXII. figs. 6, 7 ; and Woodcut, fig. 28.

Buskia niters, Alder, North. Cat. loc. cit. 66, pl. v. figs. 1, 2 ; Quart. Journ. Micr. Sc. v. (1857) 24, pl, xiii. figs. 1, 2.

Stem slcnder, branching or anastomosing, with occasional short spinous offshoots. Zoxcia minute, glossy, flaskshaped, rather ventricosc, the antcrior portion frec and slightly turned upwards, tapering towards the orifice, which is terminal and placed at the top of a membranous arca, occupying the under surface of the frec neck-like portion of the ecll; irregular, flattened, and adherent spines given off from the sides of the ecll. Polypide with 8 shortish and rather stout tentacles.

BuskIA NITENS, though abundant, is so minute and inconspicuous that it readily cscapes observation, and very few localities for it have hitherto been recorded. It ranges to extreme northern latitudes, where it occurs in a profusion which shows the conditions of life to be congenial. The stems and calycles of the various species of Lafoëa are a favourite habitat, and are often overspread with its bright insect-like cells. I liave also found it creeping over 
Crisia cornuta, and even running up its long slender setæ, which were literally elasped by the spinous base of the cell.

There is very great irregularity in the development of the processes round the base of the zoceium. They seem to be oceasionally wanting altogether; in other cases they arc short and very numerous, in others again, fewer in number and more produced.

The neck-like prolongation of the zoccia in front is variable in length; it is quite free and slightly turned upwards, and its underside is oecupied by the aperturc, which is closed in by a membranous eovering. The cells are laid alongside the stem, to which they are attached by the lower extremity. They arc remarkable for their smooth and shining surface; and the species well deserves its name.

Habitat. On various kinds of Hydroida and Polyzoa, \&c., and occasionally on stone, from tide-marks to decp water.

Localities. Northumberland, on Hydrallmania, Lafoëa, \&c., deep water, rather rarc (Alder): Whitley, on stone at low-water mark (J. Coppin) : Guernsey; Salcombe Bay, on Lafoëa dumosa ; off Lulworth Cove ; Llandudno; Filey; Whitby (T. H.) : Wick, on Sert. abietina (C. W. P.) : Shetland, on Halecium labrosum (Barlee).

Geograpircal Distribution. Davis Straits, on Hydroids, 100 fathoms (Wallich): White Sea, on Lafoëa (Mereschkowsky).

Fig. 28.
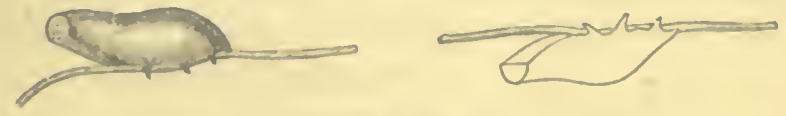
Family VI._Cylindrœciidæ.

Vesiculariad (part.), Busk, Quart. Journ. Micr. Sc. :-Alder : IHincks. Vesicularie.e (part.), Smitt, Krit. Förteckn.

Zoceria not contracted below, closely united to the stem at the base, not deciduous; destitute of a membranous area.

In this family the zoccium is not an isolated chamber contracted below and only communicating with the common stem through a small orifice at the base, as amongst the Vesiculariida, but is elosely and permanently united to the stem and preserves its cylindrical form pretty uniformly to the point of junetion with it. In some species it rises from an expansion in the course of the creeping stolon, with which its walls are continuous, and which must be regarded as a decumbent portion of the ecll itself. During retraction the polypide is sometimes partially withdrawn into it. This expansion of the stem, now constituting the basal portion of the zoœcium, may be compared with the similar struetures in Aetea and Eucratea, and must probably be regarded as represcnting the primitive condition of the cell.

Throughout the family the ectoeyst, or wall of the zoœcium, is more or less charged with earthy particles, which render it opaque. 


\section{Genus CYLINDRGCIUM.}

Der. From $\kappa \dot{\lambda} \lambda(v j \rho o s$, a cylinder, and oixiov', a house.

Farrella (part.), Busk: Gosse: Hincls.

Averelua, Alder: Hineks : Gosse (not Dalyell).

VALKERI (part.), Smitt.

Generic Cinaracter.-Zoeera elongate, cylindrical, crowded together or scattered, rising from a creepiny stolon. Polyprde without a gizzard.

Cylindrecium giganteum, Busk.

Plate LXXVII. figs. 3, 4 .

Farrella gigantea, Busk, Quart. Journ. Micr. Sc. iv. 93, pl. v. figs. 1, 2: Gosse, Mar. Zool. pt. ii. 22, fig. 40.

Avenelas gionstea, Hincks, Dev. Cat., Ann. N. H. ser. 3, ix. 473 (59, sep.).

Zoceia tubulous, thiekly crowded together, the walls rendered dark and opaque by imbedded earthy matter, of great length (oceasionally more than $\frac{1}{8}$ inch), not deeumbent at the base.

Polypide with 18-20 tentacles.

Is a specimen of this species from Tenby, which I owe to Mr. Busk, the eells are densely erowded together on the stolon; and he deseribes it as "growing in a elose and thick pile" on the walls of the eave where it was diseovered. The length of the eell is remarkable, and also the opacity of the eetoeyst, due to the very large quantity of earthy matter with which it is eharged. I have never been able to detect any dilatation of the stem at the base of the zoœcia in $C$. giganteum.

Habitat. On rocks near low-water mark.

Locality. 'T'enby (13usk). 
Cyundnecium dilatatum, Hincks.

Plate LXXVII. figs. 1, 2; Plate LXXIX, figs. 1-3.

Farrella Dilatata, Hincks, Proc. Dubl. Un. Zool. \& Botan. Agsoc, ii. pt. 1 (1860), 78; Q. J. Micr. Sc. viii. 279, pl. xxx. fig. 7.

Avenella dilatata, $i d$. Dev. Cat., Ann. N. H. ser. 3, ix. 473 (60, scp.).

Farrflla fusca, Busk, Q. J. Micr. Sc. iv. 94, pl. iii. fig. 6.

Avenella FuscA, Alder, North. Cat. 69 (sep.): Norman, Shetl. Polyz., Rep.

Brit. Assoc. 1867, 311.

V'esicularia fusca, forma simplex, Smitt, loc. cit. 503 and 524, pl. xii. fig. 38.

Stem slender, anastomosing, dilating at intervals into an cxpansion, which forms the basal part of the ccll, and from which the erect tubular portion rises; this cxpansion is frequently set round with spinous processes. Zoøcia rather distant, tubulous, of moderate length, decumbent towards the base, the walls opaque, having the appearance of being sanded over with very minute particles.

Polypide with about 18-20 tentacles.

THIs form has becn identified by most recent writers on the Polyzoa with the Avenella fusca of Dalycll, with which (as I have pointed out in the account of that species) it has no close affinity whatever.

It is distinguished from C. giganteum not mcrely by the size of its cells (which, though very variable, are always much smaller than those of the latter species), but more markedly by the expansion of the creeping stolon, constituting the basal portion of the zoccium. The cetocyst is also less laden with carthy matter, and thereforc much less opaque and coarse in appearance than that of $C$. giganteum. The ecll is of about equal size throughout, and is continuous below with the expansion of the creeping stem, which is a striking characteristic of the species. This varies, to some cxtent, in sizc and figure. When 
C. dilatatum grows on the frond of a Flustra or the stem of some otlier Polyzoon, it is inconspicuous and often difficult to deteet. But when it spreads over the surface of a shell, it frequently attains a comparatively large. size, and is furnished round the edge with a number of spinous projections, which give it very much the appearance of the cell of Buskia nitens. Under such circumstanees the species presents a very altered appearanee (Plate IXXXIX. figs. 1-3). From each side of the dilatation a branch is generally giren off a little below the termination of the erect portion of the zoccium; and frequently onc or two more are present. This branching may remind us of that of Aetea amongst the Cheilostomata.

Habrtat. On various Polyzoa and Hydroida, tests of Ascidians, and shells, from shallow to deep water.

Localities. Antrim (Hyndman): South Devoll ; Ilfracombe ; Llandudno; Isle of Man; Oban (T. H.) : Cullereoats, Coralline zone (Alder): Shetland, deep water (A. M. N.) : Wick (C. W. P.).

Geograpinical Distribution. Bahusia (Smitt) : Roscoff, on Cellaria and Lepralia foliacea, abundant (Jolict).

\section{Cylindracium pusillè.}

Plate LXXX. fig. 8*; and Woodeut, fig. 29.

Zoocia minute, seattered, tubular, slightly bent, rendered more than semi-opaque by the presenec of minute eartliy (? sandy) particles in the walls, the lower portion decumbent and continuous with the crecping stem.

Polypides small, with about 10 slort tentacles.

- This figure is defectire in not showing the decumbent portion of the cells (eec woorlcut, fig. 2?) $)$. 
Tuts is a very small species, with a slender eell, which declines very markedly to one side on the retreat of the polypide. The walls of the zooeium have the appearanec, under a high power, of being coated with minute granulcs.

The creeping stem dilates slightly and gradually at the base of each of the erect tubes; the expansion thus formed constitutes the lower extremity of the cell; and into the decumbent portion of its dwelling the polypide, during completc retraction, is partially withdrawn.

Fig. 29 .

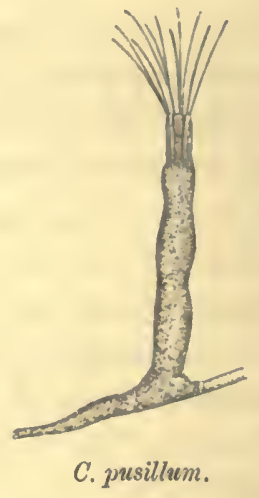

This is an inconspicuous form, which is to be found creeping over the roots of Laminaria ncar low-water mark. It has all the characters of a typical member of the genus, but differs from its congeners in its minute size and delicate habit and the small number of its tentacles. I have met with a still minuter form (Plate LXXX. fig. 9), bearing a elose gencral resemblance to the present, of which it may perhaps be a dwarf varicty. It is often extremely difficult to examine the minuter Ctenostomatous spccies, not mercly on account of their sizc, but from the nature of their habitats; and I have little doubt that many exist on our shores which have, so far, escaped detcetion.

Habitat. On tanglc-roots \&e. within tide-marks.

Localities. The Castle roeks, Salcombe; the Capstonc, Ilfracombe (T. H.) 


\section{Genus ANGUINELLA, Van Beneden.}

Der. from anguis, a smake; named from its supposed aflinity with tho genus Anguinaria.

Ascusalu, Van Beneden, Rech. sur les Bryoz. (18H): Busk.

Genemic Cuaracter.-Zonnum consisting of an erect common stem, giving off branches at intervals, on which the cells are borne; the ectocyst incrusted by earthy matter, opaque. Zoocia cylindrical. PoLYPIDEs without a gizzard.

Anguinella palmata, Van Beneden.

Plate LXXVII. figs. 5, $5 a$; and Woodcut, fig. 30.

Anguinelu palsita, Van Beneden, Recherches, \&c. (Mém. Bruxellos, xriii.), 58, pl. vii. figs. 18-24: Busk, Q. J. Micr. Sc. iv. (1856), 95, pl. vi. figs. 1, 2.

Zoarium attached by the base, dendroid, thickly branched; the branches elothing the stem from the base to the summit, more or less palmate, of an earthy-brown colour. Zoccia eylindrical, irregularly distributed on the branches, with which they are continuous below, slightly bent inwards.

Polypides with 10 short tentacles, clothed with remarkably long cilia.

Height from 3 or 4 to 6 or 8 inches.

Vas Beneden likens this curious speeies to a fir-tree elothed with branches to its very base. Mr. Busk gives a better idea of it in saying that it "rescmbles a small Fucus covered with mud." 
It requires a keen and practised eye to detect it in the muddy situations in which it chiefly delights; and, indeed, without a previous knowledge of its peculiarities it is pretty sure to eseape observation or to be passed by as a weed. The cells are rendered very dark-coloured and opaque by the large quantity of earthy matter imbedded in their walls. They are

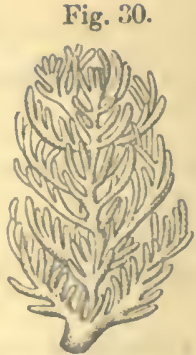
gencrally curved slightly inwards towards the stem; they are not contracted at the base, and have rather the appearance of processes of the branch than of distinct cells.

Habitat. On shells, dead or living, stones, \&e., between tide-marks, especially in muddy situations and in shallow water.

Localities. River Deben, Suffolk, abundant on oystershells; Tenby, eaves in St. Catherine's Isle, sparingly (Busk) : Filey, between tide-marks (T. H.) : Ilfracombe (Allman).

Geographical Distribution. Ostend, very abundant, especially in autumn (Van Ben.): Charleston, South Carolina (Dr. Harvey).

Doubtful Species.

Nolella stipata, Gosse.

Nolella stipata, Gosse, Mar. Zool. ii. 21, fig. 38.

Zoccia ereet, subeylindrieal, erowded on tubes which form an undefined inerusting mat. Polypide with 18 tentacles.

Probably referable to Cylindrœcium. 
Family VII.-Triticellidx.

Tratticellidid, G. O. Sars.

Vesiculariade (part.), Alder.

II ippuraru de, Busk (for the genus Hippuratia).

Zocecis horny, with an aperture and membranous area on the ventral aspect; borne on a rigid peduncle, to which they are attached by a movable joint, deciduous.

ONE of the characteristics of this remarkable group is the presenee of an aperture or area, with a membranaccous eovering, on the ventral aspect of the eell. This is the representative (as before remarked) of the aperture which exists in many of the Cheilostomata, and may remind us especially of the form of it which we find in the genus Aetea. Through this genus, on the one hand, and Triticella and Cylindrcecium on the other, as Smitt and G. O. Sars have already pointed out, the two great divisions of the Ctenostomata and Cheilostomata are very elosely and firmly linked together.

Sars goes so far as to place Triticella amongst the latter; but the Ctenostomatous eharacter seems to me to preponderate in this form, and the Cheilostomatous in Aetea.

The presenee of a setose opereulum and a corneous eetocyst, and the absence of an oral lid or valve, are eminently eharacteristic of the present suborder; and in all these points Triticella is Ctenostomatous. The aperture is a prevalent Cheilostomatous character; but Triticella is not the only Ctenostome which possesses it. It exists also in Buskia and Mimosella, and may probably be deteeted in other forms.

The members of the present family live in most eases as commensals on various species of Crustacen. 


\section{Genus TRITICELLA, Dalyell.}

Der. Dim. of triticum, wheat; named from its resemblance to a grain of wheat.

Triticella, Dalyell (1848), Rem. An. Scotl.: G. O. Sirs. Fartelia (part), Alder.

Generic Character. Stem repent. Zocecia with a membranous area on one side (the ventral), flat or slightly depressed; more or less gibbous on the other (the dorsal*); compressed laterally, attached by a movable joint to a rigid peduncle. PoLyPIDE without a gizzard.

Tris is the only British Polyzoon in which the zoceia are movable, with the exeeption of Mimosella, the sessile eells of which sway baekwards and forwards as the polypide issues or retreats. In Triticella the eell is attached by an elastie joint to the summit of the stalk, and is eapable of being moved about to a eertain extent at the will of the animal. Aceording to an observation of Sir Philip Egerton's, in Hippuraria it can be bent, so as to form a right angle with the pedunele.

In a speeies belonging to the present family (Lagenella nutans), and probably referable to Hippuraria, Joliet has observed two groups of museles, attached on the one hand to the walls of the zoceium, and on the other to

- "Instead of the regular cylindrical or orate shape (of cell) which distinguishes all known Vesiculariide (including Cylindrœciide), we moet here universally in fully developed zoceia with a very characteristic bilateral formation, so that we can distinguish, as amongst the Cheilostomata, a brek and front side, or, more correctly, a rentral and dorsal sidc, which in form and structure are essentially different from one another. . . . . The ventral side is that immediately within which, when the polypide is retracted, the tentacular wreath with the lophophore is placed; the dorsal side is that near which the alimentary canal with the anal opening lies, and immodiately within which the sexual elements are devoloped."-G. O. SArs. 
the peduncle, which by their contractions produce very remarkable nodding movements in the eell*.

Some of the species are furnished with a semicireular chitinous band or rib, which passes upward from the dorsal surface on each side towards the aperture, and may scrve to strengthen the wall of the eell. Sars has named it frenaculum. I have not included the character in the generic diagnosis, as it does not seem to have any special significance, and is wanting in a form which in all the most important points agrees with Triticella.

Dalycll was the first (1858) to deseribe a member of the present genus; but his brief account of Triticella flava gives no true idea of its structure. The peculiarities of the gencric type were really unknown until the publication (in 1873) of a most able paper by G. O. Sars, on certain Scandinavian species of Triticella, in which he has fully demonstrated its structure and discressed its affinities and systematic position $\dagger$.

'T'ziticelea flava, Dalyell.

Plate LXXX. fig. 7 .

Triticella Flava, Daly. Rem. An. ii. 66, pl. xix. fig. 1: G. O. Sars, Christian. Vidensk. Selsk. Fürhand. 1873, 398.

Zocecia of a faint yellowish colour, short ovate (viewed latcrally), the dorsal surface curved outwards; peduncle very short, about half the length of the cell.

Polypide with 20 tentacles.

* 'Bryozonires des côtes de Franee,' p. 101.

† "Om en hidtil lidet kjendt moerkelig Slagstype af Polyzoer," af G. O. Sars. 
Dalyell's description of $T$. flava is not sufficiently minute, nor his figure sufficicntly trustwortly in details, to cnable us to form a satisfactory judgment as to the form which he had in view. Mr. Norman, who has obtained the T. Korenii of G. O. Sars in Seotland, is of opinion that it is identieal with the present speeics. He eonsiders the length of the peduncle comparatively unimportant as a speeifie character; whilst the fact that all the Scottish speeimens wcre attached to the same kind of Cirriped affords a presumption that they are referable to the same specics. On the other hand, it may be said that the habitat cannot ecrtainly be accountcd conclusive evidenee of identity, and that (though there may be considerable diversities in the length of the peduncle within the same colony) the faet that in a large "group of $T$. flava (containing thirty or forty cells), as stated by Sir J. Dalyell, the peduncle was always only about half as long as the eell, and the maximum length thereforc much less than in $T$. Korenii, may possibly indieate a difference of speeies.

I would not be understood as giving any decided opinion on the point; but under all the eircumstances it secms better to keep the forms apart and retain the two names, if only to challenge further investigation.

Dalycll says that "the cell is apparently somewliat of membranaceous texturc; it becomes distorted, and it stands awry on its pedicle. . . . The form of the cell bears some rescmblance to a grain of wheat."

Habitat. On Sacculina carcini (a Cirriped parasitic on the common shore-crab, Carcinus mcenas).

Locality. Scotland (Dalyell). 


\section{Triticella Korenit, G. O. Sars.}

Plate XLV. figs. 8-10 (omitted in the description of the Plates. Fig. 10, a young cell); Plate LXXX. fig. 6 ; and Woodcut, fig. 31.

Terticella Konexn, G. O. Sars, Christian. Vidensk.-Selsk. Förh. 1873, 393, pl, ir.

Triticella flaya, Norman, Ann. N. H. February 1879, 138.

Fig. 31.

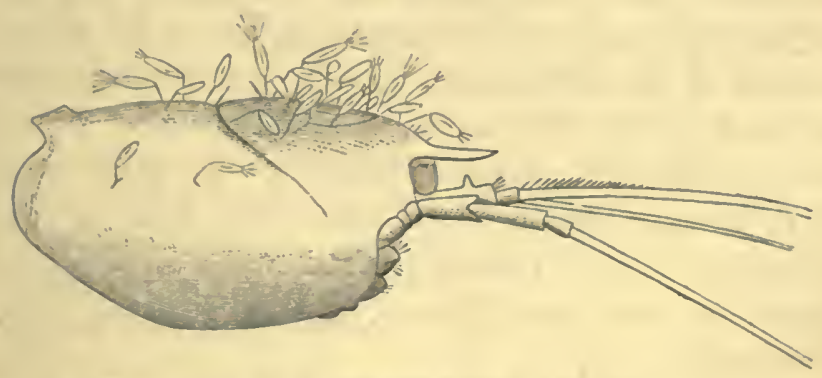

Colony of Triticella Korenii, nat. size.

Zoœcia hyaline, scattered on a delicatc crecping stem, slender, clongate-ovate, slightly curved outwards on the dorsal side, except at the very basc, where the outline is somewhat incurved, the chief convexity being below the ecntre of the cell; the ventral or front side occupicd in great part by a produced clliptical area, which is slightly depressed and covered in by a very delicate membrane. Frenaculum (or horny band) very much attenuated, placed at a short distanec (about one fifth the length of the ecll) above the base. Peduncle of very variable length, usually as long as the cell or longer.

Polypide with about 18 tentacles, which nearly equal the cell in height.

'THIs species is characterized by its tall and very slender 
eell, the dorsal outline of which (when viewed sideways) is very slightly eurved outwards, and presents no abrupt eonvexity at any part. The opposite or front side, from the lower extremity of the area (where there is usually more or less of an angular projeetion) upwards, is somewhat flattened. When viewed in front, the eell presents a very regular figure, attenuated below, slightly enlarged towards the eentre, and above it narrowing off very gradually towards the truneate top. From T. Boeckii, Sars, the present speeies differs in the more regular shape and slenderer proportions of the zoceium, and in the size and position of the frenaculum, which is plaeed muel nearer the base of the cell than in the first named. On the average, too, the pedunele seems to be much longer in T. Boeckii than in T. Korenii; 'but there is muel variability in this eharacter. The frenaculum in this speeies is very ineonspieuous, and may readily eseape observation.

As T. Boeckii may probably oeeur on our Fig. 32. eoasts, an outline of its eell is given, taken from one of Sars's excellent figures (woodeut, fig. 32).

Навітат. On various Crustacea, from tide-marks to very deep water.

Locality. Shore of Kerrera Sound, near Oban, on Sacculina carcini (A. M. N.).

Geographical Distribution. Near Bergen, in 120 fathoms, on the earapace of Calocaris Macandrei, Bell; Bohuslän, on the same (G. O. Sars).

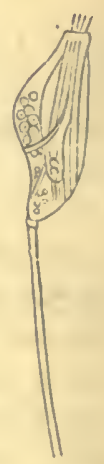

Triticella Boeckii, Sars. 
Triticella pedicellata, Alder.

\author{
Plate LXXX. figs. 3-5.
}

Farrelua Pedicellata, Alder, N. Cat. loc. cit. 68, pl. vi. figs. 1-3; Quart. Journ. Micr. Sc. v. 24, pl. xiv. figs. 1-3.

Zoccia ovate-oblong, transparent, scattered along a delieate ereeping stolon; the dorsal side (viewed laterally) very slightly eurved outwards, the front side oceupied almost entirely by the membranous area, which extends nearly to the bottom of the cell. The zocecium (viewed in front) slightly contracted at the base, but of about equal width for a great proportion of its length, scareely narrowed towards the top; no angular projection at the lower extremity of the area. Frenaculum wanting. Peduncle very slender, usually two or three times the length of the cell.

Polypide with 12 tentacles.

Length of cell $\frac{1}{30}$ inch.

Turs is a much smaller species than the preeeding, witl a very regularly shaped cell; though destitute of the frenaculum, it exhibits all the more important struetural peculiarities of the genus Triticella.

"The animal, as seen through the transparent cellwalls, is of a pale ycllow colour, with a brownish-red patch indicating the position of the stomach. The ovaries are white. The base of the eell is finely wrinkled, and at its junetion with the pediele it forms a kind of joint, which ean be more or less twisted at the will of the animal." -Alder.

Haвitat. On old shells from deep water.

Locality. Nortlumberland, on Buccinum undatum and Fusus antiquus (Alder). 


\section{Genus HIPPURARIA, Busk.}

Der. From i $\pi \pi 0$, a horse, and ovipi, a tail.

Hippuraria, Busk, Proe. Zool. Soe. Lond. 1874.

Lagenelua (part.), Joliet.

Generic Character.-Stem repent or erect, tubular, jointed, nodular. Zodera with a membranous area on the front or ventral side, attached to a peduncle by a movable joint, and disposed in whorls or yroups at the nodes.

The generie eharaeter is framed to include tlie furm deseribed by Joliet under the name of Lagenella nutans*, which has a erecping nodular stcm, on which the zoccia are placed in groups at the nodes, instead of being disposed round an ereet stem in whorls, as in the specics eharacterized by Busk. The reeent observations of G. O. Sars on Triticella enable us to interpret this remarkable form, and throw light on several points in its structure, which Mr. Busk, having only a single, imperfectly preserved speeimen before him, was unable to determine.

Hippuraria appears to be a clustered Triticella. Its cell secms in most respects to resemble so exaetly that of the latter genus, that we are perhaps warranted in supposing that the appearanees which led Mr. Busk to describe it as composed of two distinet eompartments may have been due to the condition of his specimen. If the zoccium of Hippuraria is indeed two-ehambered, this eharaeter will make it the type of a separate family.

- This species occurs on Vesicularia spinosa and the leaves of Nitophyllum. 
Hippuraria Egertoni, Busk.

Plate IsXVIII. figs. 1-4.

IIrpuraria Egrutoni, Busk, Proc. Zool. Soc. Lond. for Jan. 6, 1874, 29, pl. $\mathbf{\gamma}$.

Stem ereet, obseurely jointed, with nodular enlargements at nearly equal distanees apart. Zoccia attached by a movable joint to long, slender, transpareut peduneles, which are elustered at the nodes, springing from all sides of the stem, pyriform, attenuated at the base and widening upwards to the top, where they are about three times as broad as below, the dorsal side somewhat gibbous, on the front (or ventral) side a broadly elliptical area, occupying about two thirds of its whole extent, with a membranous covering. ? Frenaculum.

Height of ecll and peduncle about $\frac{1}{8}$ inch.

WE must wait for a more satisfactory account of this interesting speeies until its rediseovery may give the opportunity of making a thorough study of its structure. The fragment on which Busk's deseription is founded was about a quarter of an inch in length; it had been dried and reexpanded, and was, of course, in a very unfavourable state for examination. The sketeh of the Polyzoon when alive, by Sir P. Egerton (Plate LXXVIII. fig. 3), shows the extent to which the ecll ean be berit upon its peduncle.

Habitat. On the earapace of Crustacea.

Locality. Berehaven, Ireland, on Gonoplax angulatus (Sir Philip Egertou1). 
Fig. 33.

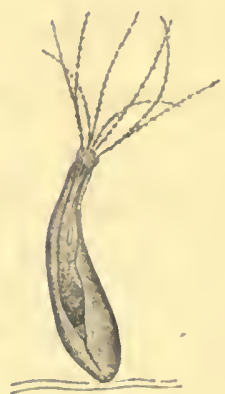

Valkeria uva.

ii. CAM PYLONEM IDA, Hincks.

Tentacles not forming a perfect circle, two of the number being always everted.

Throughout this group the polypide is of the simplest structure and of very delicate habit, and in all cases it exhibits the curious arrangement of the tentacles which has suggested the name. Two of the number are universally bent outwards towards the side, so that the tentacular wreath does not form a perfect circle; the remaining six stand crect, in the usual way. I bclicve that the two everted tentacles are always placed on the samc side as the anal opening. The number of tentacles is constantly cight; a gizzard is always wanting.

The remarkable modification of the tentacular wreath must be regarded as an important character, and as affording a very sure indication of natural affinity. 


\section{Family VIII.-Valkeriidæ.}

Vesiculariad.e (part.), Johnston: Alder.

Vesicularisa (part.), Landsborough.

'Loccis contracted below, deciduous, destitute of a membranous area.

\section{Genus VALKERIA (part.), Fleming.}

Der. Named in lionour of Dr. Walker, Professor of Natural History in the University of Edinburgh.

Valkeria (part.), Fleming, Mem. Werner. Soc. (1823); Br. An. : Farre: Van Beneden: Johnston : \&c.

Sertularia (part.), Linnæus : Pallas, \&e.

Clytia (part.), Lamouroux.

Vesicclaria (part.), J. V. Thompson: Sinitt.

Cuscutaria, Blainville.

Cayprlonema, Hincks, Ann. N. II. 1872 (for $V$. tremula).

Generic Character.-Zoariom erect or repent. Zoecia orate, clustered. PoLyPIDE destitute of a gizzard.

\section{Valkeria UVA, Limnaus.}

Plate LXXV. figs, 1-5, and Woodeut, fig. 33 .

Repent form. Grapz Coralline, Ellis, Corall. 27, no. 25, pl. xv. fig. c, C, D. Sertularia uya, Linneus, Syst. ed. 12, 1311 : Ellis of Sol. Zooph. 53.

Curtia uva, Lamx. Pol. cor. flex. 203.

Valkeria uva, Flem. B. A. 551 : Johnst. B. Z. ed. 2, 375: Couch, Corn. Faun. iii. 95, pl. xvi. flg. 5 : Alder, North. Cat. 67 (sep.), \&c. (not Vesicularia uta, Snitt, Krit. Fürt. pl. xiii. figs. 2y-333). Caypastlaria ovipera, Blainv. Actinol, 473.

Erect form. Chimbing Dodugithise Conalise, Ellis, Corall. 28, no. :2t, pl. xir. fig. $c, \mathbf{C}$.

Sehtularia cescura, Lim. Syst. ed. 12, 1311 : Pall. Elench. 125: Ellis \& Sol. Zooph. 53: Alildgaard, Zool. Dan. iii. (52, pl. exvii. figs. 1-3: Lamx. Pol, cor. Hex. 198: Flem. Men. Wern. Soe. iv. 4 S5, pl. Ir. fig. 1 
Valkeria cuscuta, Flem. B. A. 550 : Farre, Phil. Trans. 1837, 402, pl. xxiii. : Van Ben. 'Recherches' (1815), 27, pl. iv. fig. B (Jém. Brux. xviii. 3, pl. i.): Johnst. B. Z. ed. 2, 374: Dalyell, Rem. An. i. 248, pl. li. figs. 1, 2: Landsb. Pop. Hist. 370, pl. xx. fig. 78: Smitt, Qifv. \&ic. 1866, 501 \& 523, pl. iii. figs. 28, 34, 35 : Joliet (including both forms), Bryoz. d. côtes d. France, 101.

Nigellastrom cuscutus, Oken, Lehrb. Naturg. Zonl. pt. ii. 93.

Vestcularsa cuscuta, J. V. Thomps. Zool. Illustr. 97, pl. ii. figs. 1-4.

Cuscutaria cuscuta, Blainv. Actinol. 497, pl. 1xxxii. fig. 2.

Stem repent and adnate, jointed at intervals, giving off branches in opposite pairs, also adnate (form $u v a$ ); or sending up free, slender, flcxile shoots of varying length, much attenuated towards the extremitics, and bearing oppositc branches (form cuscuta). Zocecia small, slender-ovatc, transparent, clustered about the joints, ehiefly on the lateral branches.

Polypide with 8 tentacles.

Height of the ercet form (cuscuta) about 2 inches; occasionally 4 .

The only difference between the Linnæan species Sertularia uva and S. cuscuta seems to lic in the habit of growth. The latter is an creet and luxuriant variety of the former.

In its repent condition $V . u v a$ is a very minute and inconspicuous specics (though a singularly beautiful object when living) ; the variety cuscuta, on the contrary, is free and vigorous in its growth, and forms clustcring masses of tall wavy shoots. The groups of eells placed at the origin of the branclies, and scattcred at intervals along them, give it a very pretty and characteristic appearance.

The branches are always given off immediately below a joint, where the stem is somewhat dilated; the eells are borne principally on the branches; and in some cases a large number of very short internodes occur above the point of origin, on which they are thickly clustcred (Plate LXXV. fig. 2). 
The polypide affords a good illustration of the Campyloncmidan structurc (woolcut, fig. 33). It is intercsting to watch it issuing from its cell; at suclı a time the peculiarity in the tentacular wreatl is very apparent. When the peneil of tentacles is rising, as soon as it has reached a ccrtain point the two bcnt arms spring out, one at each side, the rest continuing straight and folded together until the wholc bcll expands. $V$. uva, especially in its humbler form, is one of the commonest of our littoral species, and may be rcadily obtained on the Corallina in rock-pools, over which it crecps in great abundance.

Habitat. On various Fuci, Corallina, Sertularia pumila, \&c., and occasionally on shells, betwecn tide-marks and in shallow water; rarely in decp water (form cuscuta).

Localities. Form uva. Widely distributed. Cornwall (Couch): Guernsey and Jcrscy; South Devon; Ilfracombe; Menai Straits, on the larger Fuci, in immense quantity (T. H.) : Northumberland (Alder) : Lcith (Jameson) : coasts of Antrim and Down (W. T.) : Dublin Bay (llassall): Belfast Bay, 20 fathoms, on Flustra foliacea (Hyndman), \&c.

Form cuscuta. Isle of Shcppcy (Farre) : Firth of Tay, in braekish water (Fleming): Leith (Jameson): Ayrshirc (Landsb.) : Petcrhcad, very rare; Wick, deep water; Norfolk; Cornwall (C. W. P.) : Isle of Wight (W. T.) : Gucrusey (R. S. Cooper) : Moúnt's Bay ; Exmoutlı ; Torquay, in rock-pools on Corallina; Plymouth, of remarkable size; Llandudıo; Menai Straits, on the larger Fuci; Filey; Oban (T. H.) : Tenby (F. Walker) : Shetland ( $A$. M. N.) : Dublin Bay (Miss Ball) : co. Sligo (Mrs. Haneoek): Magilligan (Hyudman): Belfast and Strangford Loughs (W. 'I'). 
Geograpuical Disturbution. Baltie (Müller): Belgium (Van Ben.) : Bahusia, 5-10 fathoms (Smitt) : Kattegat (Kirchenpauer) : Roscoff (Joliet)*.

Valkeria themula, Hineks.

Plate LXXX. figs. 1, 2.

Valikeri tremula, Hincks, Dev. Cat., Ann. N. II. ser. 3, ix. (1862), 472, pl. xii. fig. 9 .

Campylonema tremulum, $i d$. Ann. N. H. ser. 4, x. (1872), 396, pl. xx. fig. 5.

Stem filiform, ereeping. Zoccia distributed upon it at intervals in groups, very small and slender, elongate, slightly narrowed above, and below tapering off to a point.

Polypide with 8 tentacles.

THIs speeies is distinguished by its extreme minuteness and its tapering eells, which are attenuated downwards from the middle and terminate in a point. They are very slightly attached: when the polypide is retraeted they droop a little to one side, and rise into an ereet position when it expands.

The polypides are extremely minute and very nimble in their habits; those of Valkeria uva appear coarse and elumsy beside them.

This is the first speeies in which I observed the peeuliar arrangement of the tentaeles, and the genus Campylonema was founded for its reeption. But as it now appears that $V$. cuscuta, the type of Fleming's genus Valkeria,

* Joliet records both the creeping form and the erect-" dont les filaments flottant librement dans l'cau attcignaient jusqu'à 6 et 8 centimètres de longueur," - and remarks that it is impossible to distinguish the two specifically: 
exhibits the same strueture, his name, of eourse, has preeerlence.

Habitat. On stones and stems of Alga between tidemarks, and on shell from moderately deep water.

Localities. Saleombe Bay, on Flustra papyracea; Ilfracombe, on the Capstone, not uneommon; dredged off the Isle of Man (T. H.)

\section{Family IX.-Mimosellidæ.}

Zoders contracted below, movable, deciduous, with an aperture on the ventral side.

\section{Genus MIMOSELLA, Hincks.}

Der. Dim. of Mimosa, the Sensitive Plant.

MısoseluA, Hincks, Ann. N. H. 1851 : Landsborough : Heller : \&c.

Generic Cinaracter.-Zoarium phytoid, regularly jointed, consisting of a creeping tubular base and erect shoots, much and irregularly branched, branches opposite. Zowcia ovate, biserial, opposite, attached to the sides of the stem by a basal joint, by means of which they can be moved to and fro and folded together. PoLYPIDEs with a small number of tentacles; without a gizzard.

Mrsosella is separated from the Valkeriide by its movable cells, and more especially by the large aperture on the ventral aspect of the zoccium. The latter oecupies almost the whole of the front side, extending from the top nearly to the base of the eell. It is elosed by a thin membranous eovering, and, when the polypide is retracted, is very ineonspicuous and may most readily eseape obser- 
vation. When the polypide, however, issues from its dwelling, the membranous wall is drawn inwards, a depression or eleft is distinetly visible, and the eell appears distorted; the solid part is somewhat boat-shaped, forming a kind of shicld.

I have not been able to deteet any speeial arrangement of museles eonneeted with the remarkable movements of the zoceia; and from their eharaeter, and the faet that they are eoineident with the expansion and retraction of the polypide, I should eertainly regard them as dependent on these ehanges, were it not that I have, on more than one oeeasion, seen eells from which the polypide had disappeared move baekwards and forwards.

The folded cells open slowly; and there is an oceasional pause before they are thrown fully baek. They begin to elose (as it seems) not when the polypide merely retreats, but when it draws itself down to the very bottom of its eell. Then they instantly begin to fold up, moving slowly at first, but, when they have fairly swung round to the front side of the stem, elosing rapidly with a kind of jerk. A hollow at the base of the eells fits over a tubular projeetion on the stem; and upon this they sway baekwards and forwards.

The polypide is small, with a short and slender stomaeh, and is destitute of a gizzard.

Mimosella gracilis, Hineks.

Plate LXXIV. figs. 1-6, and Woodeuts, figs. 27 \& 34.

Misosella Gracilis, Hincks, Ann. N. H. ser. 2, viii. 359, pl. xiv. figs. 5-8; xi. 184 ; Dev. Cat., Ann. N. I. ser. 3 , ix. 472 (58, sep.), pl. xvi. fig. 1 : Heller, Bryoz. Ad. M. 52, pl. vi. figs. 1, 2. Valkeria cusceta, Cquch, Corn. Faun. iii. 96 , pl. xvii. fig. 3.

Zoarium ereet, eonfervoid, of a light horn-eolour, eonsisting of slender, jointed, tapering stems, mueh and ir- 
regularly branched, which risc from a mass of ramified and interlacing tubes; the branehes opposite, either short and simple pinnæ, or elongate tapering shoots pinnate or bipinnate, the pinnæ divided by joints into very short internodes, cach of which supports a pair of eells. Zoœcia ovate, biserial, opposite, borne chicfly on the pinne and rarcly on the principal stems, folded together when the polypides are retraeted, but thrown back and standing out from the side of the pinna when thcy cxpand.

Polypide with 8 tentaeles.

Tirs beautiful spceics is a very frec grower, and forms large intricate masses, whieh hang in festoons about the stems of the Halidrys, on which it is always found. The ramification is irregular and luxuriant; the tall flexile stems, which arc much attenuated towards the extremity and run out into filamentary, tendril-like prolongations, are thickly sct, now with short pinnæ, now with long, slcnder, tapering branehes either pinnate or bi- and tripinnate. Not unfrequently these are replaced by longcr shoots, mueh and variously branched, which are copies of the prineipal stems. The pinnx or branches originatc immediately below a joint and tend upwards, so as to form with the stem an aeutc angle; the pairs very frequently spring from different aspects of the shoot.

Towards the base of the pinna the zoceia are tall and oval; as they approael the apex they beeome short

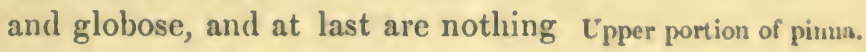
more than littlc round exereseences.

Fig. 34.

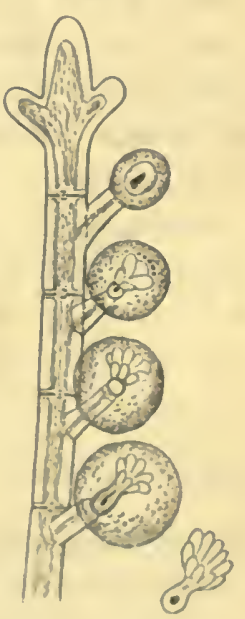


When the cells are all folded together, just as the leaflets close on the leaf of the Sensitive Plant, they appear (on slight inspection) as if they were unilateral in their arrangement. Generally, however, in the living specimen, one or two eells at least on a pinna are thrown back; and when the polyzoon is healthy and vigorous, there is a constant folding and unfolding of the pinnules, as the polypides issue and retreat.

I first dredged Mimosella gracilis under the rocky shores of Salcombe Bay ; it appears to be common whereever Halidrys siliquosa abounds along our south-western coasts. Devonshire specimens are preserved in Dr. Johnston's collection, ranked under Valkeria cuscuta, with which it was also confounded by Couch, who had obtained it in Cornwall.

Habitat. In the Laminarian zone, on Halidrys siliquosa.

Localitres. Saleombe Bay, abundant; Torbay, in shallow water, under Berry Head, and east in plentifully in autumn on Meadfoot beach, after strong south-casterly winds (T. H.) : Plymouth Sound (Templar) : Polperro and Goran (Couch): Penzanee (C. W. P.): Guernsey (R. S. Cooper).

Geographical Distribution. Adriatic (Heller): La Spezzia (Reichert).

\section{Family X.-Victorellidæ.}

Homodiatide, W. Saville Kent, Quart. Journ. Micr. Sc.

Zocels originating in an enlargement of the creeping tubular stem, with which they are continuous at the base; above free and cylindrical; not deciduous.

TuE present fumily was first defined by Mr. Saville Kent, 
who elearly pointed out the important differenee in the structure of the zoceium, which separates it from the Vesiculariide. I have not adopted his name for it (Homodicetida), beeause thronghout this work the family designations have been derived from typieal genera, and it seems desirable to preserve uniformity of practice.

\section{Genus VICTORELLA, Saville Kent.}

Der. Named after the Victoria Dock, London, in which it was first discovered.

VictoreluA, W. Saville Kent, Quart. Journ. Micr. Sc. 1870.

Generic Character.-Zonrium consisting of a creeping ramified stem, which swells out at intervals into somewhat fusiform or clavate enlaryements, in which the cells originate. Zoøcla decumbent at the base, which is continuous with the stem, above free and cylindrical; branches given off from the sides of the expansions in the course of the stem. PoLrpides with few tentacles; no gizzard.

Is the character of the zoccium Victorella agrees with the Cylindraciide; but from this group it is separated by the structure of the polypide, which is of the Campylonemidan type. It is a simple and primitive form, as shown by the imperfeet differentiation of the eell; and, from the extreme transparency of the eetocyst, whieh interposes no difficulty in the way of observation, it would afford the best opportunities for the study of the strueture and funetions of the endosare, and of many other interesting problems.

In an early stage of development the cell eousists wholly of the stolonic expansion, within which the formation of the polypide proeeds up to a eertain point. The ereet tube is an after-growth (Plate LXXIX. fig. $\tilde{\tau}$ ). I have 
only seen a few mounted cells (which I owe to Mr. Kent's kindness), and have therefore liad no opportunity of making a minute study of the structure. But a few points it has been possible to determine.

The endosarcal cord which pervades the stolon dilates as it enters the ccll-like expansion, and takes the form of a plexus-like tissue, which partially fills the eavity, and within which the polypide is developed. The cxpanded and more or less ovate portion of the stolon is elosed above by a diaphragm, beyond which the stem is eolltinued. At its upper end, and immediately below the diaphragm, a tubular projection rises in front, which is the rudiment of the erect portion of the adult ccll. At this stage (as represented in Plate LXXIX. fig. 7) the forming polypide eonsists of an ovate body, prolonged and attenuated below, where it seems to be doubled upon itself, and above continued into a kind of neek, which reaches to the top of the tubular projection. The later course of the development I have not been able to follow; but the polypide must inerease greatly in size to fill, as it does, the ereet tube into which it is ultimatcly withdrawn.

These fragments of the devclopmental history of $\mathrm{Vic}$ torella give the following results :-

1. They confirm Joliet's views respecting the formation of the polypide out of the endosare.

2. They suggest very foreibly the homology between the zoceium and the stolonie internodes amongst the Ctenostomata.

3. They indicate the primitive eondition of the zoœcium, and give us a elue to the meaning of the stolonic expansions in such a form as Aetea, and to the mode in which the tube may have been gradually superadded in the latter to a simple hippothooid cell. 


\section{Victorella PaVida, Saville Kent.}

Plate LXXIX. figs。 4-7.

Victorella Payida, Kent, Quart. Journ. Mier. Sc. (n. 8.), x. 34, pl. iv.

Stem repent, very slender and transparent, the elavate enlargements usually wide apart. Zoceia with the upper portion ereet, eylindrieal, tall, slender, perfeetly transparent, below adherent and dilated; branelies given off at each side of the expanded base, near the origin of the ereet tubular portion of the eell.

Polypide with 8 long and remarkably flexible tentacles, two of which are everted.

Turs is an extremely minute speeies, and has hitherto only been taken in braekish water amongst a prevailingly fluviatile fauna. Bowerbankia imbricata was obtained in the same loeality.

The zoceial tubes vary in height, but are usually tall, and very slender; they are generally plaeed at very eonsiderable distances from each other. The stolon widens out at intervals into eell-like expansions, of whieh the ereet tubes are a direet eontinuation, rising immediately out of them, so that they eonstitute an integral part of the zoceium. Just above the eell there is a joint; and in most eases (but not, I think, universally) there is also one at the point.where the expansion narrows into the stem. The ramifieation is simple and uniform; on each side of the enlargement, near the base of the ereet tube, a single branch is given off, a joint always oceurring at the point of origin; and after a longer or shorter interval the branch, like the main line of the stolon, dilates into a cell.

The zoœcium terminates above in a remarkably tall peneil of setre. 
Навітат. On Cordylophora lacustris in brackish water, chiefly at a depth of some 5 or 6 fect below the surface. Locality. Victoria Dock, London (W. S. Kent).

Fig. 35.

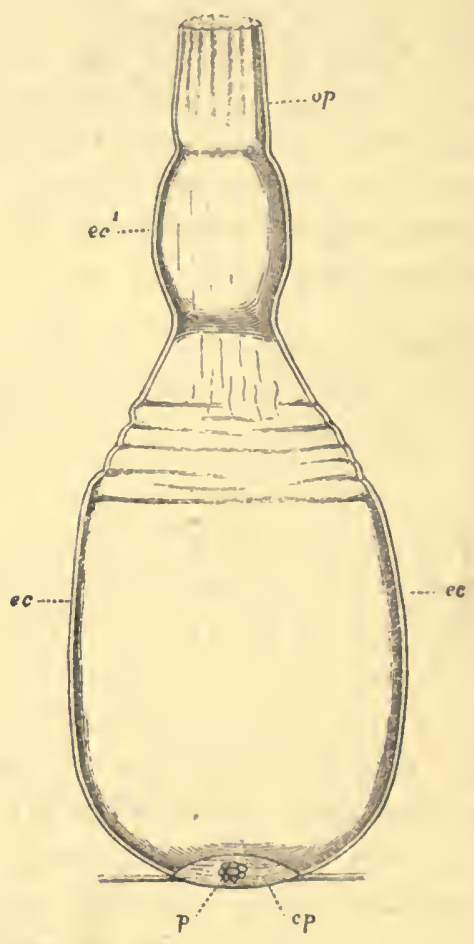

The Ctenostome cell (after Reichert).

ec. Ectocyst, forming the solid portion of the cell-wall. ecl. The flexible portion of the ectocyst. op. The setose operculum. cp. The communication-plate or septum. $p$. Pores, for the passage of the endosarc. 
Subclass Holobraxchia, E. Ray Lankester.

Group $b$. ENTOPROCTA, Nitsche.

PoLrzos having both the orifices of the alimentary canal within the lophophore; tentacular sheath wanting; tentacles bilaterally disposed, not retractile; no perivisceral cavity*.

Order PEDICELLINEA.

The only order.

Family I.-Pedicellinidø.

Polypiaria pedicellixea, P. Gervais (1837).

Pedicellise, Jobnston.

PoLYPIDEs borne on a retractile peduncle, united in colonies by a creeping stolon.

WE owe the separation of the Entoprocta from the rest of the Polyzoa as a distinct group to the able German biologist, Nitsche (Zeitsch. wiss. Zool. xx. 1 Heft).

The chief structural peculiarity which distinguishes them is the position of both the orifices of the alimentary canal within the tentacular wreath; amongst the ordinary Polyzoa (Ectoprocta) the mouth only is surrounded by the tentacles. But associated with this important

- Amongst the Entoprocta there is no true body-cavity containing a perigastric Auid, as in most other Polyzos. Such small spaco as there is between the inner wall of the zoccium and the alimentary canal is occupied by a more or less solid parenchymatous tissue. 
and cardinal character are others which, though secondary, arc of great interest and systcmatic valuc. The tentacles are not attached to a retractile portion of the cell; there is no invagination of the anterior region, and conscquently no tentacular shcath. The arms originatc from the upper margin of the cup-likc body, and are bilaterally disposed; thcy are not withdrawn into the cavity of the cell, but merely rolled up, when at rest, and in this condition are partially within the vestibule which occupies the upper portion of the body. The integument of the body (equivalent to the zoocium) is comparatively soft, and is nercr strengthened by calcareous matcrial; it immediatcly incloses the alimentary canal; and there is therefore no perivisceral space, like that by which the polypide is surrounded in the ordinary Polyzoa. The polypide of the Entoprocta is incapablc of the lively movements which are so characteristic of the latter: it is fixed in its ccll; and the system of musclcs concerned in the acts of protrusion and retraction, which attains so high a development in other sections of the class, is wanting. The Pedicellinida are all furnished with a contractile stcm, on the free extremity of which the body is placed; and this peculiarity distinguishes them in a very marked way from the rest of the Polyzoa.

\section{Genus PEDICELLINA, Sars.}

Der. From pes, a foot.

Pedicelliwa, Sars, Beskrivelser \&c. (1835): Johnston: Van Beneden : Nitsche: Smitt: \&o.

Hrora (part.), Bosc: Blainville : \&c.

Оuтомоврі1, Van Beneden (1844).

Generic Character.- Polypides pedunculate, distri- 
buted along a creeping, ramified stolon; the body separated by a diaphragm from the stem, and deciduous; tentacular crown terminal.

Pedicellina cernua, Pallas.

Plate LXXXI. figs. 1-3; and Woodeut figs. 36, 39.

? "Flesur polypes of a red colour aNd a particular kisd," Elliv, Corall. pl. xxxriii. figs. $5,6, \mathrm{E}, \mathrm{F}$.

Bracuonts cerveus, Pallas, Naturges. merkwïrd. Thiere (1771), Samml. 10,57 , pl. iv. fig. 10.

? Hroka lutra, Bosc*, Hist. Nat. des Vers (1802) ii. 236, pl. xxii. fig. 2 : Lamk. An. s. V. ed. 2, ii. 71 : Blainv. Dict. Sc. Nat. Ix. 459.

Hrdra coronata, Flem. B. A. 554 .

Proicelisi eciunata, Sars, Beskr. og Iakttag. \&c. (1835), 5, pl. i. figs. 1, $a-f$ : Hassall, Ann. N. H. ser. 1, vii. 365 : Reid, Ann. $\mathbf{~}$. H. xvi. 390 , pl. xii. figs. 8, 9 : Johnst. B. Z. ed. 2, 382, pl. lxx. fig. 5: Smitt, CEfv. Vet.-Ak. Fürh. 186ī, 458: Nitsche, Zeitsch. f. wiss. Zool. xx. 13, pl. ii.: Barrois, Embryol. d. Bryoz. 27, pl. ii.: Joliet (forma typica and var. glabra), Bryoz. \&c. 103, sc.

Penicelliva cerver, Smitt (forma cernuce and forma mutans), CEfv. sc. $1871,1132$.

Pedicellisa вflgica, Gosse, Dev. Coast, 210, pl. xii. figs. 2-4 (var. without spines): Hincks, Ann. N. H. ser. 2, viii. 360 (the same).

Polypides borne on a flexuous, transparent stolon, more or lcss branched; often denscly clustered. Body whitish, cup-shaped, somewhat compressed latcrally, usually very ventricose on one side (the dorsal or anal), and subtruncate on the opposite; tentacles 14-24. Peduncle stout, tapering slightly towards the top, and corcred with short obtuse spines.

Var. $a$ (glabra). With the peduncle smootl.

- It must be held doubtful whether Bosc's species is identical with the prewent. His figure is of no value; he makes no mention of spines on the stem, and describes the whole zoarium as being of a sulphur colour. His specimens were attached to Fucus nutans. 
TuE form of the body is liable to some variation, apart from the ehanges which are due to the different degrees of eontraction. It is oceasionally mueh elongated (Plate LXXXI. fig. 2) ; but eommonly it is rather short, very gibbous on one side, and almost straight on the other. In one marked variety the pedunele is quite destitute of spines; but normally they are present in great numbers, and sometimes are also seattered sparsely over the body*.

The movements of the pedunele are vigorous and lively: the polypides, when exeited, dash themselves vehemently from side to side; and one striking against another, the eommotion spreads throughout the eolony until " the effeet is that of a field of eorn swept by a strong breeze " $\dagger$.

The body, whieh is separated from the stem by a distinet diaphragm, is deeiduous; it falls, and after a time is renewed by a proeess of gemmation, the headless stalk retaining its museular aetivity.

The larvæ, aeeording to Joliet, are produeed throughout the summer, from May to September, but espeeially in May and Fig. 36.

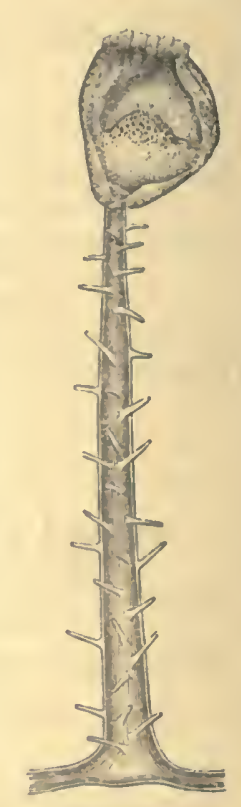
June.

It is with extreme reluetanee that $I$ have abandoned Sars's familiar name for this speeies; but, aeeording to the ordinary laws of nomenelature, there ean be no doubt

* Joliet states that he has often found amongst a group of polypides with smooth peduncles an individual furnished with spines, and that in some cases these appendages occur only on a section of the length of the stem or on one of its sides.

+ Van Beneden. 
that Pallas, who deseribed and figured it nearly sixty years before the Norwegian zoologist wrote, is entitled to precedence. His deseription of the external form is very aceurate and quite sufficient for identification. He mentions the soft, cup-shaped body with its tentaeles, the hairy or spinous stem, and the common, branched stolon. His figure is a very fair one of its elass. He regarded it as one of the "Sceaster-polypen," referable to Brachionus or Vorticella. It is curious that Sars eonsidered that there was considerable affinity between Pedicellina and the last-named form, and that it was a link between this tribe of Infusoria and the Polypes (' $\mathrm{Be}$ skrivelser' \&c. p. 4).

Pallas's work in which the deseription of Brachionus cernuus appeared was published at Berlin in 1771 .

НавітAт. On zoophytes, Algæ, shells, \&c., between tide-marks and in shallow water.

Localities. Common and widely distributed.

Geographical Distribution. Roscoff, dredged on Vesicularia, and on Antennularia and other Hydroids, common; also on Bugula at extreme low-water; (var. glabra) in the littoral zone on Corallina \&c. (Joliet) : Naples (Waters) : Norway (Sars) : Spitzbergen, smooth var. (Smitt) : Heligoland (Nitsche): White Sea, smooth var. (Mereschkowsky).

Pedicellina nutans, Dalyell.

Woodcut figs. $37,38,40$.

Pedicellixa xutaxs, Dalyell, Rem. An. ii. pl. xx. figs. 1-12.

? Pedicellixa axericasa, Leidy, Invert. Rhodo Isl. and New Jersey, Journ. Ac. N. Sc. Philadelph. ser. 2, iii. 135, pl. x. fig. 25.

Body small, vase-shaped, regular, not gibbous on the 
dorsal side; tentacles 12-16 (?). Peduncle usually of a yellowish-red eolour, tapering very deeidedly towards the top, where it is much attenuated, always destitute of spines. Stolon distinctly jointed at intervals*.

Tins form must not be confounded with the smootlstemmed variety of $\boldsymbol{P}$. cernua. It is distinguished by the small size and regular shape of the body, whieh has none of the distorted appearance so claracteristic of the last specics, as well as by its very tapering peduncle, which is usually of an elongate-conieal form. The latter charaeter seems to be very eonstant: the stcm tapers rapidly upwards from about the middle of its length to the point of junction with the body, terminating in a subacuminate extrcmity.

The ordinary lieiglit of $P$. nutans equals that of $P$. cernua; but it never reaehes (in the speeimens which I have examined) the somewhat gigantic proportions Fig. 37.

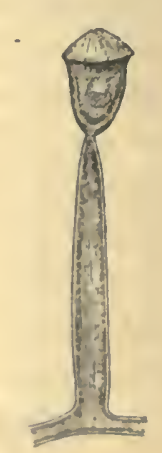
whieh the latter not unfrequently attains.

\section{Pedicellina} nutans. The body is almost perfectly symmetrical, and is not unlike a graeeful vase mounted on a pedestal; in its diminutive size it resembles that of $P$. gracilis.

This seems to be the form which Dalycll has described under the name of $P$. nutans. His figures very accurately represent its chief characteristics, and eould not have been suggested by $P$. cernua, as no trace is shown of the distortion of the body. It is true that he represents his $P$. nutans as frequently crect and branehed, a condition which $I$ have not observed in the present form; but, assuming the polypides to be identieal, this would not be a speeific distinction; and it seems right therefore to retain his name.

* The stolon is much stouter than that of $P$. cernua, which is not jointed. 
I have met with no British form agrecing with the $P$. Belgica of Vau Beneden, which is characterized by the smoothness of the stem and the eurious knots or enlargements at its base and in its course, and which seems to have a more regularly shaped body than $P$. cermua. The figure is accompanied by a very brief and insufficient diagnosis.

Habitat. On Algze.

Localities. Seotland (Dalyell) : Tenby (Leipner).

Fig. 38.

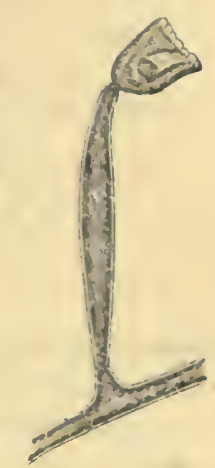

Pediellina mutans.

Fig. 39.

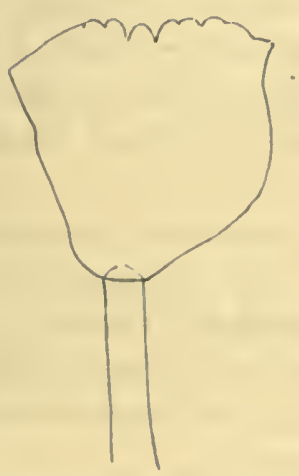

Pedicellina cernua*.

* 'These two figures aro drawn to the pane scale.
Fig. 40.

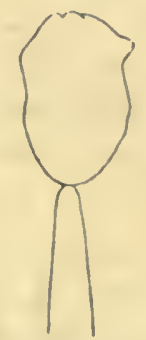

Pedicellina nutans*. 


\section{Pedicellina gracilis, Sars.}

Plate LXXXI. figs. 4-6.

Pediceluisa gracilis, Sars, Beskr. og Iagttag. 6, pl. i. fig. 2, $a, b$ : Johnst. B. Z. ed. 2, 385 : Goodsir (Forbesia), Ann. N. H. xv. (1845) 380 , pl. xx. fig. 4 : Gosse, Dev. Coast. 217 , pl. xii. fig. 5 : Hincks, Ann. N. H. ser. 2, viii. 360, pl. xiv. fig. 9 : Smitt (part.), Efv. \&c. 1871, 1133: Joliet, Bryoz. \&c. $104, \& c$.

Polypides scattered on a dclieate creeping stolon. Body somewhat ovate, usually a little gibbous on one side ; tentacles about 20. Peduncle cxpanded below into a short thick eylinder, above which it is extremely slender, widening slightly upwards to the point of junction with the body, destitute of spines.

THis is a much smaller speeies than $P$. cernua, and may be at once reeognized by the enlarged base of the peduncle. It is in this portion that the muscular power resides, to which the remarkably energetie movements of the Pedicellina are due, the part above it being a mere rigid rod supporting the body. The basal cylinder varies in length, and in the proportion it bears to the rest of the stem. Oceasionally the latter is very mueh elongated, and consists of several seetions separated by knots or swellings, which are also muscular in character.

Haвitat. On Corallina and Laminaria, Hydroida, Polyzoa (espeeially Vesicularia), \&c., and under stones, between tide-marks and in shallow water.

Localities. Jerscy; South Devon, common; Ilfracombe; Swanage and off Lulworth Cove; Llandudno; Aberystwith; Isle of Man; Fleetwood, on a buoy; Filey; Lamlash; Oban ('T. H.): Guernscy, on Hermione hystrix, with Loxosoma (Dr. M'Intosh): Cullereoats 
and Tynemouth, common (Alder): Shetland, rare (A. M. N.)

Geograpiucal Distribution. Norway (Sars): Spitzbergen, 30 fathoms (Malmgren, fide Smitt): Whitc Sea, on Lafoea dumosa (Mereschkowsky): Roscoff (Joliet).

Family II.-Loxosomidæ.

PolyPides borne on a contractile peduncle, solitary, always furnished in the young state with a pedal gland; gemme produced on the body of the polypide.

Tне Loxosomida agree in all essential points with the Pedicellinide; but they are solitary animals, and this character is accompanied by ccrtain variations in the common plan of structure. Their leading family peculiarities are all determined by this point in their history. The foot-gland for attachment, which is always prescnt in the young, though frequently aborted in the adult, is rendcred nccessary by the absence of any adherent stolon. The mode of gemmation is dependent on the same circumstance*.

Curious tactile organs, placed one on each side of the body, and consisting of contractile papillæ supporting a number of delicate setre, have been noticed in some species, and are probably always present.

* Alder records two cases in which he had observed the production of buds in Pedicellina from the polypide. "In one the young arose from the body of the animal, and at right angles to it; in the other from the stem a little below the body" (Suppl. to Northumb. Cat. p. 22, sep.). Barrois (in his 'Embryologie des Bryozoaires,' pl. ii. fig. 15) represents a discoid mass at the base of the peduncle in the primary polypide of Pedicellina, which, he conjectures, may be the rudiment of a pedal gland. We may hove here memorials of the solitary ancestry of the present colonial forms. 
The larva has been described, and its strueture demonstrated, by Vogt and Barrois : it is essentially identical with that of the Pedicellinida, and constitutes a strongly marked type.

\section{Genus LOXOSOMA, Keferstein.}

Der. From $\lambda_{0} o_{\delta}$, oblique, and $\sigma \bar{\omega} \mu a$, body.

Loxosors, Keferstein, 1863.

Cyclopelsa, Busch, 1851 (founded on the larra).

Orcratella, Van Beneden, 1864 (referred to the Tristomidea).

Generic Character.-Polypides pedunculate, solitary, the body closely united to the stem, and not deciduous; tentacular crown placed obliquely, on the ventral side of the body.

THE unsymmetrieal conformation of the body in the present genus, which shows itself in the displacement of the tentacular wreath from the summit to one side, also exists, though in a muel slighter degree, in Pedicellina, as Vogt has remarked. There are eonsiderable differences in the extent to whieh this displacement is earried amongst the speeies of Loxosoma.

The absence of the diaphragm in Loxosoma, which in Pedicellina divides the body from the stem, and which involves the frequent fall of the former, is a very marked distinetion between that genus and the present. In some forms of Loxosoma, however, there is much more appearanee of a separation between the two regions than in others, though in no case is the body deeiduous.

Several speeies of the present genus have been diseovered, ranging from the Bay of Naples to the Arctic Seas and the Nortl-Ameriean coast. They live ehiefiy, 
but not exelusively, as " commensals" with various species of Annelida. They have also oceurred on Sponge, and on other Polyzoa (c. g. Bugula and Zoobotryon).

Loxosoma sivgulare, Keferstein.

Plate LXXXI. figs. 7, 8.

Loxnsoma stwgthare, Keferstein, Zeitschrift f. wiss. Zool. xii. (1862) 13, pl. xi. fig. 29: Claparède, Beob. ïb. An. u. entw. wirbell. Thiere an d. Küste v. Normandie, 135, pl. ii. figs. 6-10: Barrois, Embryol. d. Bryoz. 9 \& 10, pl. i. \& pl, xri. fig. 6.

Body oval; tentacles 10 ; peduncle short (about half the length of the body) and stout, wrinkled transversely, terminating below in a diseoid expansion, by which the polypide is attached; no pedal gland in the adult ; $1-3$ buds on each side.

Is the specimens examined by Keferstein only a single bud seems to have been dereloped on each side; but in Shetland examples, which I owe to Dr. M'Intosh, as many as three are sometimes present on a side.

The short pedunele, narrowing sliglitly downwards, with its disk-like foot, is a eharacter which separates this speeies from all its eongeners.

Habitat. On Annelids.

Localitr. Slietland, on Latmonice filicornis (Dr. M'Intosh).

Geograpuical Distribution. St. Vaast-la-Hougue, abundant, on Capitella rubicurda (Keferstein): ibid. on the ventral surface of Aphrodite, in eompany with Pedicellina gracilis \&e. (Barrois). 


\title{
Loxosoma phascolosomatum, Carl Vogt.
}

\author{
Woodcut figs. 41,42 .
}

Loxosoma phascolosomatus, Vogt, Arch. de Zool. expérimentale, v. (1877) 305, "Sur le Loxosome des Phascolosomes;" translnted. (by Hincks), Quart. Journ. M. Sc. (n. s.), xvii. (1877) 353, pl. xxii. : Barrois, Rech. sur l'embryologie d. Bryoz. (1877), 8, pl. xvi. figs. 3, 4 : Norman, Ann. N. H. for February $1879,133$.

Strephesterus clavigrr (tentacular appendages of), Norman, Ann. N. H. ser. 3, vii. (1861) pl. ix. figs. 1-3.

Body elongatc-ovate; tentacles 12-18; peduncle of great length, the lower extremity "pointed like the nib of a pen;" no pedal gland or other special organ of attachment; buds never exceeding two.

The long peduncle of this species is highly contractile, and its movements are very energetic; besides bending to one side and then straightcning itself, it is occasionally twistcd into a spiral. In the buds the pedal gland is very distinctly visible; but it subscquently disappears altogether. According to Vogt, it is absorbed after furnishing the secretion by which the animal is permanently fixed.

In both this and the preceding specics, the oblique position of the tentacular crown on the ventral side Fig. 41.

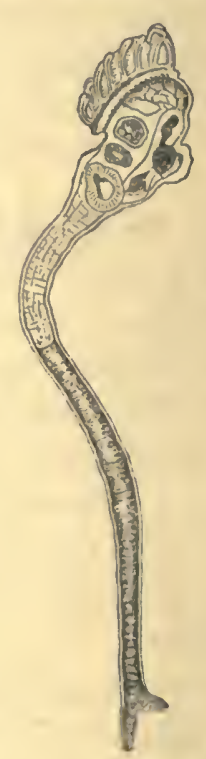
of the body is a very marked characteristic. 
Fig. 42.

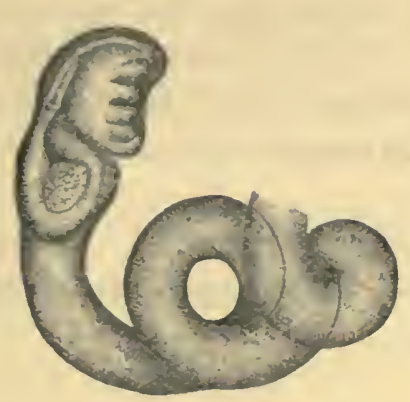

Loxosoma phascolosomatum.

Habitat. On the caudal extremity of certain Annelids (Sipunculidea).

Locality. Bantry Bay, forming a tuft on the posterior extremity of Phascolosoma Harveii, Forbes (A. M. N.).

Geographical Distribution. Roseoff, abundant, on Phascolosoma elongatum and P. margaritaceum (C. Vogt; Barrois).

\section{LOXOSOMA CLAVIFORME.}

Plate LXXXI. figs. 9-12.

Body ovate; tentacles (probably) 10 or 12 ; peduncle somewhat longer than the body, tapering off gradually downwards, and terminating below in a short, foot-like expansion,- the whole figure very regularly clavate when the tentacles are withdrawn; ? pedal gland; only a single bud observed, placed about halfway down the body.

TuE foregoing is a very imperfect diagnosis, as the specimens examined had been long preserved in spirit, and 
I was quite unable to determine with certainty either the number of the tentacles or the strueture of the base of the peduncle. The form seems, however, to be distinct from the various species that have been described, so far as the somewhat meagre descriptions given of them allow us to judge.

Habitat. On Annelids.

Locality. Guernsey, abundant on Hermione hystrix (Dr. M'Intosh). 
Subclass Pterobranchia, E. Ray Lankester.

Aspidopiora, Allman, Journ. Linn. Soo. Zool. xiv. 1879.

Order PODOSTOMATA, Lankester.

Foot large, discoid, overhanging the mouth.

\author{
Family Rhabdopleuridæ.
}

ZOARIOM a chitinous, adherent tube, divided by septa into compartments, from which erect tubular cells rise, in which the polypides are lodged; the whole of the adherent portions traversed by a chitinous cylindrical rod, to which the polypides are attached by means of a flexible cord; endocyst not differentiated, and the polypide consequently unattached to its cell; retractor and other muscles absent; a large, shield-like organ (foot) placed near the mouth; the young (bud) furnished with two valve-like fleshy plates.

\title{
Genus RHABDOPLEURA, Allman.
}

Der. From $\dot{\rho} a \dot{\beta} \delta o s$, rod, and $\pi \lambda \epsilon u \rho \dot{\alpha}$, side.

Ritabdoplevra, Allman (1867).

Halilopies, MI. Sars (1868)*.

The only genus.

OF this remarkable form, which constitutes the type of

* 'Forsatto Bemserkninger om det dyriske Lirs Udbredning i Harets Dybuler,' p. 12. 
a distinct Subclass, we have an account from Allman and from G. O. Sars : the formcr has studicd our British $R$. Normani; whilst the latter has given us an cxhaustive memoir on a Scandinavian specics, $R$. mirabilis, founded on a carcful cxamination of living specimens. The most significant peculiarities of Rhabdopleura are the strueture of the lophophore and the disposition of the tentacles upon it. Instcad of a circular or crescentic stage round which the arms are ranged in a continuous scries, we have here two long and narrow and more or less divergent lobes, extending out from the anterior region of the body in a dorsal direction, and each bearing a double row of tentacles. The tentacular wreath has disappeared; and in its place we have two independent tentaculiferous processes, which are highly flexible and mobile, reminding us more of the "gill-tentacles" of Terebratula than of the lophophore of the ordinary Polyzoa.

Another striking fcature of the present form is the large shicld-like organ (" buecal shield") situated between the two orifices of the alimentary canal, which is probably the homologue of the Molluscan foot*. According to Sars's observations, it is by means of this organ (in the abscnce of all protrusor museles) that the polypide slowly draws itself up to the mouth of the cell.

* Allman, indeed, takes a different view of this organ, based chiefly on observations made on the early development of the polypide, and is inclined to compare it with the mantle of a Lamellibranchiate mollusk. His account of the evolution of the bud I am unable to follow so as fully to appreciate its bearing on the point in question; but there seem to me to be serious objections to the proposed interpretation. Sars regards the shield as the equivalent of the epistome of the Freshwater Polyzoa; and Prof. Ray Lankester identifies it with the Molluscan foot,-conclusions in which (with our present knowledge) I fully concur. 
The relation of the polypide to its dwelling in Rhabdopleura is totally unlike that to which we are aceustomed in the ordinary, typical polyzoon. There is no endocyst, or at most only the remains of onc, and consequently no tentacular sheath; and the polypide is thereforc wholly unconnected with its cell. With the endocyst or cnveloping sae go the perigastric cavity and the system of muscles by which the polypide is moved up and down within it. Its only connexion is with a cylindrical chitinous rod, inclosing a soft, cellular corc, and traversing the whole of the adherent portion of the zoarium, to which it is attached by means of a contractile cord. This cord is united to the body of the polypide, not at the bottom of the stomach, but some way up on one side; it possesses a high degree of contractility; and it is by means of it that the retraction of the polypide is effected. It is probably homologous with the "funiculus" of the ordinary polyzoon, whilst in the soft cor'c of the axial rod (which, according to Sars, resembles in structure the contractile cord) we may recognize the equivalent of the endosare as it appears (for instance) in the stems of the Ctenostomata. The septate condition of the adhercnt portion of the cœnœeium has also its parallel in the latter.

The polypide, as we might expect, is sluggish in its movements, both in issuing from its cell and retreating, and has none of the activity of its tribe.

The annulated condition of the chitinous cœnœcium is also a peculiarity which docs not oceur in the other known Polyzoa. In the general cliaracter of the zoarium, as well as in several other important points, the present form makes an approach to the freshwater group of the Phylactolamata. 
Rhabdopleura ranges from about 100 to 300 fathoms, and, aceording to Sars, is most plentiful at the greatest depths*.

\section{Rhabdopleura Normani, Allman.}

Plate LXXXII. figs. 1, 2, and 4-7.

Ruabdopleura Normani, Allman, in Rep. on Shetl. Dredgings, Rep. Brit. Assoc. for 1867 (1868), 311 ; Quart. Journ. Micr. Sc. n. 8. ir. (1869) 57 , pl. viii.

Zoarium subalternately branehed, delieate, transparent and eolourless; the tubular eells rising at the extremity of the branehes, of the same diameter as the adherent portion, closed below by a thin transverse septum, distinctly and regularly annulated.

In this species the eells are adherent at their eommencement, like the other portions of the eœnœeium, but soon beeome free and ereet. They are beautifully annulated, whilst the adherent portions of the tube are crossed by faint ridges, which pass obliquely from eaeh side towards the eentre, intereepting each other in thcir eourse. The axial eord is opaque and dark-eoloured, and shows very conspicuously through the hyalinc walls of the tubc. Aeeording to Allman, certain bodics, elothed in a darkbrown chitinous capsule, are developed on the funieulus, which he regards as probably equivalent to the "statoblasts" of the freshwatcr Polyzoa.

Haвiтat. On dead shells from deep water.

Locality. Shetland, Outer Haaf, off Unst, 93 fathoms (A. M. N.).

* See a paper, "On Rhabdopleura mirabilis (M. Sars)," by George Ossian Sars, 'University Programme' for the first half-year, 1869: Christiania, 1872. Reprinted in the Quart. Journ. Micr. Sc. vol. xiv. n. 8. Also Allman, "On Rhubdopleura Normani," Quart. Journ. Mier. Sc. January 1869 ; and "On the Relations of Rhabdopleura," Journ. Linu. Soc., Zool. vol. xiv. p. 581. 


\section{RHABDopleura COMPACTA.}

Plate LXXII. figs. 8, 8a, 9.

Zoarium composed of delicate ehitinous tubes laid closely side by side, and forming small, erust-like colonies; ereet, annulated cells, of very moderate height, rising at intervals from the adherent portions; many dark-coloured somewhat oval bodies, with a ehitinous eovering, in the course of the axial rod, developed on its upper surface.

$R$. COMPACTA differs remarkably from the preeeding, and also from the Seandinavian $R$. mirabilis, in its habit of growth. Instead of a creeping, more or less ramified zoarium, it forms minute, compact crusts, composed of tubes placed side by side, and elosely appressed one to the other. The ereet cells seem to be short as compared with those of $\boldsymbol{R}$. Normani; they are given off, I believe, at intervals, in the course of the adherent tube, as in R. mirabilis, and not merely at the extremity of the branches, and probably rise one from each compartment of the stem. The preeise mode in which the adherent tubes are disposed and the eells originate I am unable to determine, as my specimens, which are mere specks on the surface of old shells dredged years ago, are much shrivelled up, and do not show many of the structural details. They leave no doubt, however, as to their true nature; and the habit of growtl is so marked as to separate them from both the known species. The axial cord, which is of a very dark colour, is admirably preserved, as are also eertain oval bodies in its eourse, which are probably the so-ealled statoblasts of Allman (Plate LXXII. fig. 9). They oceur usually just below the expansions of the rod, to which the funiculus was attached. 
$R$. compacta is one of the many interesting forms for a knowledge of whieh we are indebted to Mr. Hyndman's enthusiasm and praetical skill as a dredger.

Habitat. On shells from deep water.

Locality. Coast of Antrim (Hyndman).

"Multum adhuc restat operis, multumque restabit, nec ulli nato post mille sæcula præcludetur occasio aliquid adjiciendi." - SENECA. 


\section{LIST OF WORKS}

\section{AND \\ PAPERS ON THE POLYZOA.}

"Oo n'est que par les travaux successifs de plusieurs hommes sur le même objet, qu'on parvient d̀ le connaitre parfaitement. Un seul architecte no peut tracer le plan, rassembler les matériaux et élever l'édifice."Layourotx.

Alder, J. "A Catalogue of tho Zoophytes of Northumberland and Durham," Trans. 'Tyneside Nat. F. Club, 1857.

- Supplement to the abore, ibid. vol. v.

- Descriptions of new British Polyzoa, \&c., Quart. Journ. Micr. Sc. (n. s.) iv.

Alusax, J. G. Monograph on Brit. Freshwater Polyzoa. Ray Soc. 1856 .

- "On Rhabdopleura," Quart. Journ. Micr. Sc. 1869, pp. 57-63, pl. viii.

-. "On tho Structure of Cyphonautes," ibid. Oct. 1872.

-. "On the Relations of Rhabdopleura," Linn. Soc. Journ., Zool. xiv. p. 395.

Barrols, J. Rech. sur l'embryologie des Bryozonires. 1877. See Comptes Rendus, vol. lxxxi. (1875).

Blarnville, De. Janual d'Actinologio. 1834.

Besк, G. "On Aetea anguina," Trans. Micr. Soc. 1847.

-. "On Notamia bursaria," Trans. Micr. Soc. 1847.

- "On the Priority of the term Polyzoa," Ann. N. H. x. 1852.

- "On Avicularia and Vibracula," Trans. Micr. Soc. vol. ii.

- Cataloguo of tho Marino Polyzo in tho Brit. Mus. Parts i. \& ii. (Cheilostomata), part iii. (Cyclostomata).

- Monograph of tho Crag Polyzoa. Palnontographical Soc.

—. "Zoophytolog5." Papers on Polyzo (chiefly) in the Quart. Journ. Micr. Sc. 
Cavolist. Memorie per servire alla storia dei Polipi marini. 1785 .

Clapark̀de, E. "Beitrïge zur Anat. u. Entwicklungsgesch. d. Seebryozoen," Siebold \& Kölliker's 'Zeitsch.' xxi. (1871), Heft 1, pp. 138-174.

—. "Loxosoma Kefersteini," Ann. Sci. Nat. sér. 5, Zool. viii. p. 28.

Covcr, R. Q. Cornish Fauna. 1844.

Datyeli, Sir J. G. Remarkable Animals of Seotland. 1847.

D'Orbigny, A. Paléontologie Française, Terr. Cretacés, จ. $1850-51$.

- Voyage dans l'Amérique méridionale, $\nabla .4$ th part, Zoophytes, 1839.

EHLers. "Hypophorella expansa," Abhandl. königl. Gesellsch. d. Wissensch. Göttingen, xxi. (1876).

Elurs, J. Essay towards a Nat. Hist. of Corallines. 1755.

Fabkicios, Oтпо. Fauna Gronlandica. 1780.

Farre, A. "On the Minute Structure of some Polypi" \&c., Phil. Trans. 1837.

Fischer, P. "Sur les Bryozoaires perforants," Comptes Rendus, 1866 , no. 18 , p. 985 .

—. "Bryozoaires d. côtes du Sud-ouest de la France," 1870, Aetes Soc. Linn. Bordeaux, xxvii.

Gosse, P. H. Marine Zoology, vol. ii.

_. Devonshire Coast (passim).

Grant, R. E. "On the Strueture and Nature of Flustroe," Ed. N. Phil. Journ. iii. pp. 107-137.

GraY, J. E. Catalogue of Radiata in Brit. Mus. 1848.

Haxcock, A. "Anatomy of Freshwater Polyzoa," Ann. N. H. 1850.

Hassall, A. H. "Catalogue of Irish Zoophytes," Ann. N. H. vii. (1841).

Hatschex, B. "Embryonalentwicklung u. Knospung d. Pedicellina echinata," Zeitsch. \&c. xxix. (1877), pp. 502-548.

Heller. Die Bryozoen d. adriatisches Meeres. 1867.

Hrxcrs, T. "Notes on British Zoophytes (Mimosella, Intertentacular Organ, Development of Flustrella, \&c.)," Ann. N. H. Nov. 1851.

-. "Note on Ovieells of Cheilostomata," Quart. Journ. Mier. Se. 1861 , p. 278 . 
Hrxck8, T. "New Polyzoa from Ireland," Quart. Journ. Micr. Sc. viii.

-. "Now British Polyzoa," ibid. v.

- "Catalogue of the Zoophytes of South Deron and Cornwall," Ann. N. H. 1861-62.

- Supplement to ditto, Ann. N. H. Aug. 1871.

- "Contributions to History of Polyzoa" (Germ-capsule, Oœcium, Larra of Pedicellina, \&c.), Quart. Journ. Micr. Sc. xiii. (n. s.) p. 17.

-. "On Campylonema, a new Genus of Polyzoa," Ann. X. H. Nor. 1572.

—. "Polyzoa from Greenland and Labrador," Ann. N. H. Jan. 1877 .

—. "On British Polyzoa," part i., Ann. N. H. Sept. 1877.

—. Ditto, part ii. (Classification), ibid. Dec. 1877.

- "On the Classification of the Polyzoa," Ann. N. H. ser. 5 , iii.

- "On the Morements of the Vibracula in Caberea Boryi," Quart. Journ. Micr. Sc. xriii. (n. s.).

Hexuer, T. H. "On the Reproductivo Organs of the Cheilostome Polyzoa," Q. J. M. Sc. iv. (1856) p. 191.

-. English Cỵelopxdia, 1855, article "Mollusca."

- The Classification of Animals. Polyzoa.

Hyatr, A. "Observations on Polyzoa, suborder Phylactolæmata," Proc. Essex Inst. ir. (1866-68) p. 197.

Jonssros, G. History of British Zoophytes, 2nd ed. 1849.

Joliet, L. “Bryozoaires d. côtes de France," Arch. de Zool. expérimentale \&c. vi. (187i).

Kferensterv. " Lo.xosoma singulare," Zeitsch. \&c. xii.

Kircnirpacer. “East-Greenland Polyzoa" in "Die zweito deutsche Nordpolarfahrt.'

Konotriep. "Budding in Puluelicella" (in Russian). Abstraet in German, J.13. Anat. Physiol. iii. p. 369.

Kowalewgry. "Beiträge zur Anat. u. Entwicklungsgesch.d. Loxosoma Neapolitanum," Mrém. Acad. Imp. d. Sc. do St. Pétersbourg, sér. 7, x. Nr. 2, 1866.

Laxarck, J. B. dc. Système d. Animanx sans Vertèbres, 2nd edit. 1835-38.

L LیNOROEx, J. V. "Extrait d'un mémoire sur la classification des polypiers coralligènes," \&c., Bullet. Soc. Philomatique, 1812. 
Lısoorodx, J. V. Hist. Nat. des polypiers eoralligines flexibles \&c. 1816

- Exposition méthodiquo des genres de l'ordre des Polypiers. 1821.

Landsorougri. Popular History of British Zoophytes. 1852.

IAANKester, E. Ray. "Remarks on the Affinities of Rhubdopleurce," Quart. Journ. Mier. Se. xiv. (n. s.) 1). 77.

-. "Notes on Embryology and Classifieation," Quart. Journ. Mier. Se. xvii. (n. s.) 1877.

Leuckart. Ueb. die Morphologie \&c. d. wirbellosen Thiere. 1848. Lister, J. J. "Obserrations on the Strueture and Funetions of tubular and eellular Polypi," \&e. Phil. Trans. 1834.

MrIrtosi, W. C. Marine Fauna of St. Andrews. 1877.

Maxzoni, A. "Bryozoi plioceniei italiani," 4 parts, Sitzb. der k. Akad. d. Wissenseh. 1869-70.

-. "Supplem. alla Fauna dei Bryozoi mediterranei," itid. 1871.

—. I Bryozoi del Plioeene antieo di Castroearo. Bologna, 1875.

Menegmimt. "I polipi Tubuliporiani dell' Adriatieo," Nuovi Annali dell' Istituto di Bologna, ser. 2, iii. p. 115.

Mrтschniкorf. “On Cyphonautes," \&e., Bull. Aead. St. Pétersbourg, $\mathrm{x} \nabla .(1871)$.

—. Nachriehten d. Universtät Göttingen, 1869, no. 12.

Mulve-Edwards. Recherehes anatomiques, physiologiques et zoologiques sur les Polypes. 1838.

MoLr, J. P. C. Esehara, ex zoophytozoorum ordine puleherrima ae notatu dignissima. 1803.

MUUller, Fritz. "On the eommon Nervous System of the Bryozoa," Wiegmann's Arehiv, 1860, p. 31. Translated in Quart. Journ. Mier. Se. i. (11. s.) p. 300.

NIтscIIE, H. " Beiträge z. Anat. u. Entwieklungsgeseh. d. phylaetolæmen Süsswasserbryozoen," Arch. f. A nat. 1868.

—. "B. z. Kenntniss d. Bryozoen," Heft 1. i. Ueb. die Entwieklungsgeseh. einiger eheilostomen Bryoz. ii. Ueb. d. Anat. von Pedicellina echinata. Zeitseh. xx. Hefte 1 and 2. 1869.

- "B. z. Kenntniss" \&e. iii. Ueb. Flustra membranacea. iv. Ueb. die Morphologie d. Bryozoen. Zeitsch. wiss. Zool. xxi. Heft 4. 1871. 
Nirscue, H. " "On some interesting Points concerning the Reproduction of tho Bryozoa," Q. J. M. Se. April 1871.

—. "On Cyphonautes," Zeitseh. \&e. xxii. p. 471.

-. "Uob. dio Knospung der Süsswasserbryozocn, insbesondero der Alcyonella," Sitzb. d. naturforsch. Gesellsch. zu Leipzig, 1874.

—. "Ccb. die Knospung d. Bryozocn" (Phylactolamata and Lo.rosoma), Zoitsch. Sc. xxr. Suppl. Bd. Hcft 3, 1876.

Nordarasx. In Démidoff's 'Voyage dans la Russie méridionalo' \&c. 1861-62, rol. iii. (Tendra zostericole, \&c.); Ann. Sc. Nat. sér. 2, xi.

Normas, A. M. "On undoseribed British Hydrozoa, Actinozoa, and Polyzoa," Ann. N. H. Jan. 1864.

—. "Notes on rare British Polyzoa, with Descriptions of new Specios," Q. J. M. Se. viii. (n. s.).

-_. "Report on Hebridean Polyzoa," Rep. Brit. Assoc. for 1866.

- "Last Report on Shetland Dredgings," Part ii. Rep. Brit. Assoc. for 1868, p. 303.

_. "On Loxosoma and Triticella," Ann. N. H. Feb. 1879.

PACKARD, A.S. " "List of Animals dredged near Caribou Island,

South Labrador," Canad. Nat. \& Geol. viii. no. 6, Dec. 1863.

Pallss. Elenchus Zoophytorum. 1766.

PARfitr. Fauna of Deron-Zoophytes. 1866.

Peacir, C. W. "On Eschara verrucosa," Journ. Roy. Inst. Cornw. iii.

- " "On Pustulipora clavata," ibid. iv.

—. "On Radical Fibres of Polyzoa," \&c., Linn. Soc. Journ. Zool. xiii.

REDFERx. "Flustrellu hispila and its derelopment," Q. J. M. Sc. ri. $(1858)$ p. 96.

REICIERT. "Vergleich. anat. Untersuchungen üb. Zoolotryon pelluciılus," Abhandl. königl. Akad. d. Wissensch. zu Berlin, 1869.

Reid. "Anatom. and Physiol. Obscrvations on some Zoophytes," Aun. N. H. xvi. p. 385.

Repraciof, W. "'Mur Entwicklungsgesch. der Tendra zostericole," \%eitseh. \&c. xxr. (1875) p. 129.

- "Zur Naturgesehichte d. cheilostomen See-Bryozocn," Zeitsch. \&c. xxvi. pp. 139-160. 
Reuss. Pol. d. Wien. Tertiärbeck.; Foss. Bry. österr.-ungar. Miocäns \&ic.

SaLexskr. "Études sur les Bryozoaires Éntoproctes," Ann. Sc. Nat. sér. 6, Zool. v. (1871), article no. 3.

—. "Untersuch: an See-Bryozoen," Zeitsch. \&c. xxii. (Gemmation).

—. "Untersuch." \&c., Zeitsch. \&e. xxiv. (1874).

SARs, M. Beskrivelser og Iagttagelser, \&e. 1835.

- Beskrivelser over nogle norske Polyzoer. 1863.

- "Zool. Reise i Lofoten og Finmarken," N. Mag. Naturv. vol. vi.

- Geol. og Zool. Iagttagelser anstillede paa en Reise i en Deel af Trondhjem's Stift. 1863.

SARs, G. O. "On some remarkable Forms of Animal Life from the great Depths off the Norwegian Coast," University programme for the first half year 1869. (Rhabdopleura mirabilis.) Reprinted Q. J. M. Sc. Jan. 1874.

- " "On the Genus Triticella," Christ. Vidensk.-Selsk. Förh. 1873.

Sarigxy, J. C. 'Ieonographie des Zoophytes de l'Egypte,' from the 'Deseription de l'Egypte.'

Schurdr, Oscar. "Die Gattung Loxosoma," Arch. f. mikroscop. Anat. xii. (1876).

Scunfider, A. "On the Developmental History and Systematie Position of the Bryozoa and Gephyræa," Sehultze's Archiv, v. pt. 2.

-_. "On Cyphonautes and its Development into Membranipora pilosa," ibid. v. p. 260.

Scrwalbe. "On the Histology of the Muscles of Bryozoa," Arch. f. mikroseop. Anat. v.

Syitr, F. A. Om Hafs-Bryozoornas Utreckling. Upsala, 1863.

-. Om Hafs-Bryozoernas Utreekling och Fettkroppar. 1865.

- Bryozoa marina in regionibus arctieis et borealibus viventia. 1867.

—. Kritisk Förteckning öfver Skandinariens Hafs-Bryozoen. i. Cyclostomata; ii. ditto (eontinued), Ctenostomata; iii. Cheilostomata; iv. ditto (continued). 1864-68.

- "Remarks on Dr. Nitsche's Rescarches on Bryozoa," Q. J. M. Sc. July 1872. 
Sмiтt, F. A. "Floridan Bryozoa," Kongl. Srenska VetenskapsAkad. Handl. 1872-73.

Trompsox, J. V. Zoologieal Rescarches. Mem. v. On Polyzoa, a new animal, an inhabitant of some zoophytes, \&c. 1830.

Uluaxis. "On the Structure of Pedicellina," Bullet. Soe. Imp. Mose. 1869 , p. 425.

Vax Bexedex, P. J. " Rech. sur les Polypes Bryozoaires de la mer du Nord," Bull. Acad. Roy. Belg. 1849.

- . "Rech. sur les Bryozoaires qui habitent la côte d'Ostende," 3 parts, Mróm. Ae. Roy. Belg. 1844-45.

- - "Rech. sur les Bryozoaires fluviatiles de Bclgique," ibid. 1847 .

Vogt, C. "Sur le Loxosome des Phascolosomes," Areh. de Zool. expérimentalc, 1877. Translated, Q. J. M. Sc. xvii. (n. s.) p. 353.

Waters, A. W. "Bryozoa of Bay of Naples," Ann. Feb. 1879, and following numbers.

"The Use of the Opercula in the Determinations of the Cheilostomatous Bryozoa," Proc. Manehester Lit. and Phil. Soc. vol. xriii. no. 2, 1878. 


\section{EXPLANATION OF INITIALS.}
A. H. H.
Arthur Hill Hassall.
A. M. N.
Alfred Merle Norman.
C. W. P.
Charles William Peach.
D. I.
David Landsborough.
G. S. B.
George Stewardson Brady.
J. Y. J
J. Yate Johnson.
S. W
Searles Wood.
T. $\mathrm{H}$
Thomas Hincks.
W. T
William Thompson.

\section{CORRIGENDA.}

Pages 90, 91. For B. fastigiata read B. purpurotincta.

Page 379, seventh line from the top. After "Minch" read a semicolon instead of a comma.

Page 449, footnote, fifth line from the bottom. For more read much.

Page 532, eleventh line from the top. For Plate LXII. read Plate LXXII. 


\section{INDEX TO THE WOODCU'TS.}

\section{INTRODUCTIUN.}

No.

viii. Alimentary canal of Celleprora. . T. H

xxviii. Avicularium of Bugula ......

xxxii. Ditto of Cellaria temuirostris .. After SMitT .... Ixxi

xxxiii. Ditto of Scrupocellaria scruposa After Besk..... Lxii

xxxiv. Ditto, pedunculate, of Bicellaria tuba .............

xxxr. Ditto, fixed "Bird's head," of Membranipora princeps ...

After Besh ..... I Ixxii

After Surrt $\ldots$. Ixxiii

xxxvi. Ditto of Diachoris Magellanica. After Busk ...... Ixxiii

xxxvii. Ditto of Notamia........... After Busk..... Ixxiii

xxxviii. Ditto and zoocium of the same. T. Hl. ....... Ixxiii

xxx. Ditto, rudimentary, of Membranipura longricornis ....

xxix. Ditto, primary .............

xxxi. Ditto, fixed pedunculate and mamillated......... .

xxxix. Ditto, rudimentary polypide of. After Nrrscire .. I IxxV

xl. Ditto, surmounted by ovicell .. T. II. ........ l.xxvii

xx. Bud in young cell of Beania .. T. H. ........ li

xxi. "Brown body" in situ ...... After Ehlens.... Ivi

xxii. Ditto with bud .......... After Smit ... Ivii

xxiii.

xxiv. Ditto, supposed budding of .. T. H. ....... Iviii $\mathrm{xxv}$.

xxri. Ditto, with polypide developed on surface ........

After Jolrit ... lis

xxvii. Ditto in stomach of polypide.. After Jolikt .... Lxi

r. Ciliary cell .............. After Hyatt ... xv

x. Crecal appendage of Bicellaria. . T. II. ........ xxv

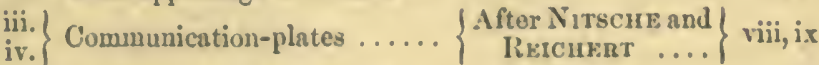

xvii. Endasarc-cord and plexus .. After Jolubt .... xlii

xri. Endoearcal (fusiform) cells .. Ifter Jolate ... xxxviii 
No.

xi. Ganglion, nervous

After Nitscue . .

Page.

viii. Ditto, supposed, in stem ......

xlv. Homologies of Phylactolemata, Rhabdopleura, and Lamellibranch .........

T. H.

rliv

After RAY I $\operatorname{IAN}^{-}$cxi

xliiı. Larva, ideal primitive form of. . xiii. Muscular fibre, striated ...... xii. Muscles-great retractors .... xix. Ora in young zocecium of Farrella..............

i. Polypide, plan of (exserted) ..

ii. Ditto, ditto (retracted) ......

ix. Ditto of Bowerbankia ........ kistir .....? cxi

After Barrols .. ci

After Nitsche .. $\quad x x x i$

T. H. ....... $\mathrm{xxx}$

After Jolikt .... xlviii

T. H. ...... iv

T. H. ...... vi

T. H. $\ldots \ldots \ldots$ xxiii

T. H. ...... $\quad x$ xix

vi. Ditto of Bugula plumosa......

vii. Ditto of Beania mirabilis ....

xlvi. Ditto of Farrella, retracted

xiv. Stem of Bowerbankia.-Septum.

xv. Ditto, Ctenostomatous, with endosarc ............

xli. Vibraculum.-Scrupocellaria scruposa..............

xliv. Zoœcium, young, of Mucronella

T. H. $\ldots \ldots \ldots \ldots \quad x x i$

$\left.\begin{array}{c}\text { After VaN } \\ \text { Beneden }\end{array}\right\}$ opposite p.i After Joliet .... xxxvi After ReIChent. . xxxvii After Smit $\ldots . \quad \operatorname{lxxx}$ T. H. ....... cv xlii. Ditto, shortly after the fixation of the larva ........

After BARrors .. xcviii

\section{GENERAL TEXT.}

30. Anguinella palmata........... After VAN Benedes.. 540

4. Beania mirabilis. Single zoøcium.. T. II. ......... 66

1. Bicellaria (Australian) ........ T. H. .......... 64

5. " ciliata. Primary cell.... T. H. .........68 68

2. Bugula Murrayana. Single zoœcium T. H. ........ 65

28. Buskia nitens ............. T. H. ......... 533

20. Cellepora. Colony of ........ T. H. ........4 415

19. Celleporella lepralioides ........ After Alder .....414

21. Crisia eburnea ............. T. H. ......... 416

22. " " Structure of oœcium

35. Ctenostome cell ....... 48

29. Cylindrocium pusillum ........ T. I. ......... 538

3. Diachoris spinigera ........... T. H. ......... 65

24. Diastopora Sarniensis. Gonocyst.. T. Il. .......... 461 
No.

6. Flustra securifrons. Oœcium ....

After SuIt Page

23. Idmonea. Early stage .........

25. Lichenopora hispida, var. meandrina.

41. Loxosoma phascolosomatum

T. H. ......... 451

42.

stem spirally "oiled $\ldots . . .$. .

After Peacr .......4 475

After Vogr ...... 574

After Barrols ...... 575

9. Microporella ciliata. Median pore. .

T. H. . . . . . . . 210

8. " Malusii. Median pore

10. " " Primary cell

T. H. .........205

11. " " Centre of colony

T. II. .......... 212

12. $"$ violacea. Young cell. .

T. H. .......... 212

27. Mimosella gracilis ...........

T. H. ......... 219

34. of pinna "..................

T. H. .......... 489

T. H. ........ 557

17. Mucronella coccinea. Primary cell. T. H. ......... 373

16. " Peachii. " " Т. H............ 361

36. Pedicellina cernua ........... T. H. .......... 566

37.,$\quad$ nutans $\ldots \ldots \ldots \ldots \ldots$ T. H. ......... 568

38. $\quad " \quad, \quad \ldots \ldots \ldots \ldots \ldots$. T. H. .......... 569

40. 3 outline for comparison ..... In $\}$ T. H. .......... 569

14. Porella compressa. Nut. size..... T. H. .......... 322

18. Reteprora. Young state......... After Busk ....... 394

13. Schizoporella spinifera. Primary cell T. H. ......... 242

15. Simittia Landsborovii. Erect form.. After ALDER ...... 343

7. Steganoporella. Sections of zocecia. T. H. .......... 177

31. Triticella Korenii. Nat. size...... After G. O. SARs ... 545

32. " Boeckii ........... After G. O. SAns ... 546

26. Tubulipora. Early state ....... After BArrors ..... 487

33. Valkeria uva............... T. H. .......... 550 



\title{
GENERAL INDEX.
}

\author{
[Synonyms are printed in Italics.]
}

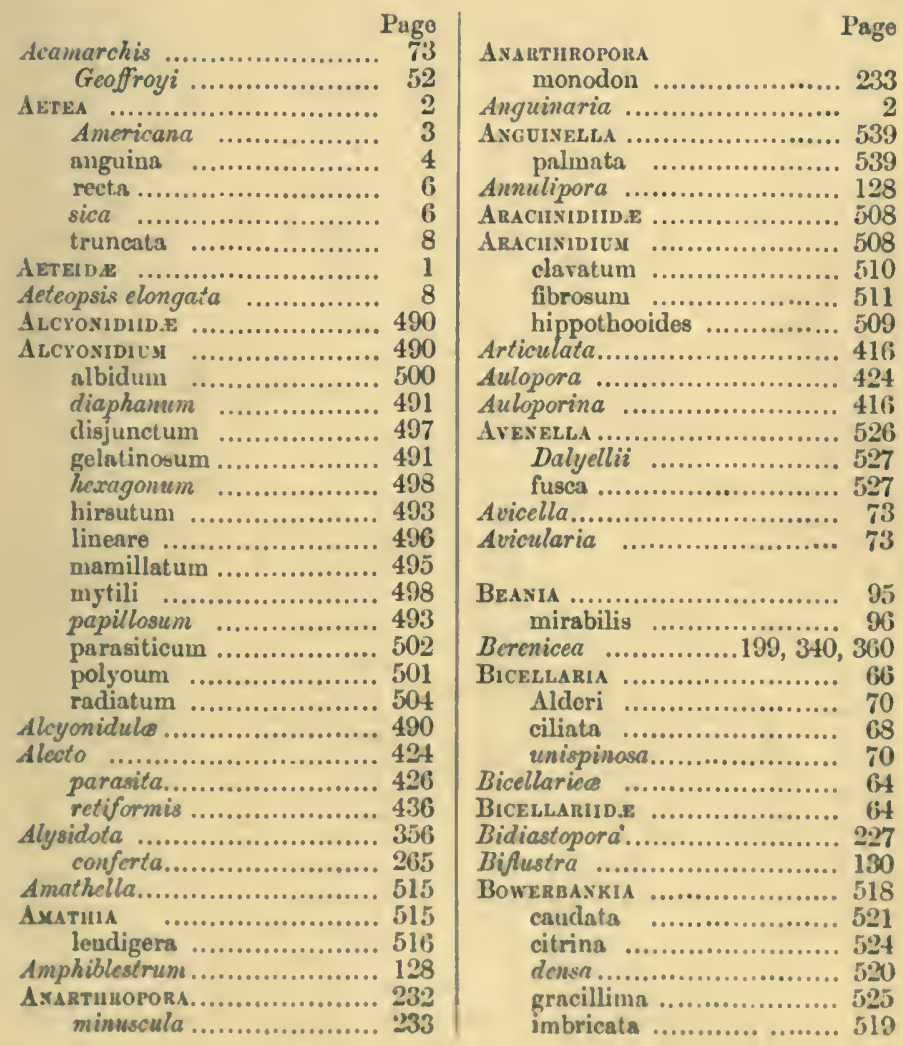




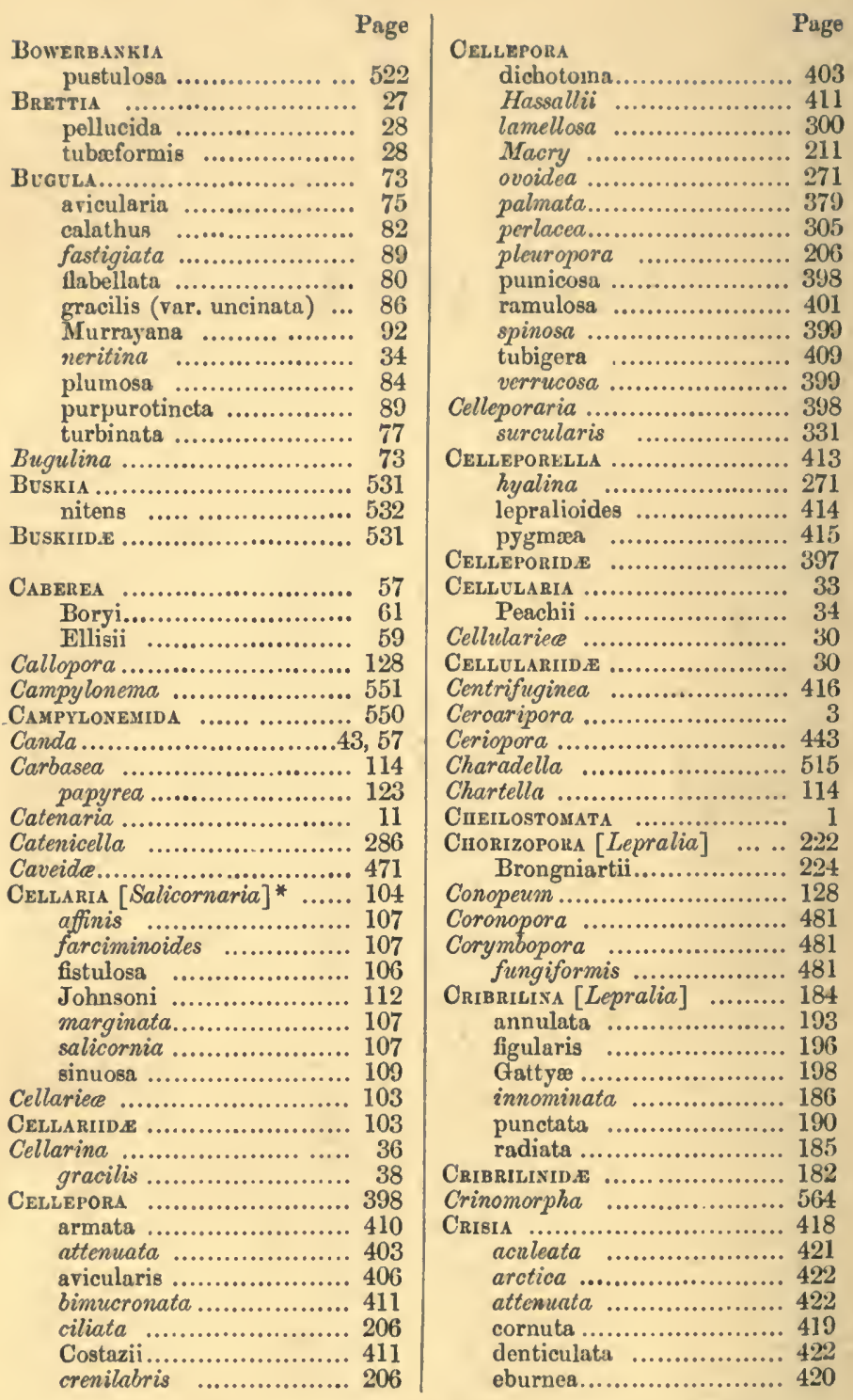

* The corresponding generic terms in the works of Johnston and Busk are given in brackets. 


\begin{tabular}{|c|c|}
\hline USIA & Epipetrum gelatinostin \\
\hline geniculc & Epistomia.................. \\
\hline & Eschara....... \\
\hline & ... 300 \\
\hline & nis \\
\hline $\begin{array}{l}\text { risidia } \\
\text { risiee }\end{array}$ & alis... \\
\hline iee ................ & \\
\hline D.E & retiformis ....... \\
\hline & stellata ............ \\
\hline laria..... & \\
\hline A ................ & Escharella ..............23 \\
\hline n................. & ini...... \\
\hline & 2 \\
\hline (.............. & \\
\hline$a \ldots \ldots \ldots$ & Escha \\
\hline ........ & e.... \\
\hline ................. $4^{4}$ & Woin \\
\hline$\ldots . .$. & (............. \\
\hline 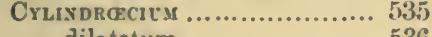 & ............. \\
\hline . ............. & $a$ \\
\hline ................. & . 346 \\
\hline ylindroporella pus................. & .. 238 \\
\hline & \\
\hline & \\
\hline ............... & Eschara] \\
\hline ............. & $\dddot{\ldots} \cdot \cdot \cdot$ \\
\hline -..... & lis \\
\hline …............ & (n................ \\
\hline (n................. & iculata ................. 419 \\
\hline & ........... \\
\hline (n........... & Evcratid.E... \\
\hline & \\
\hline ris . & 0 \\
\hline , .................. & . \\
\hline$\ldots \ldots \ldots \ldots \ldots \ldots, 2$ & ta \\
\hline ........................ 478 & (................... \\
\hline 127 & ulata \\
\hline & issata \\
\hline ................. & tria ................... \\
\hline & W \\
\hline Dis & laba... \\
\hline 4 & I \\
\hline & $c$ \\
\hline scoti & a. \\
\hline No & \\
\hline & 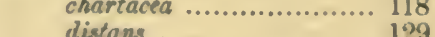 \\
\hline & ......... \\
\hline 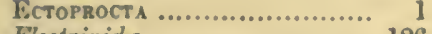 & \\
\hline ... 12 & .29 \\
\hline & ( \\
\hline A [Restulipora] ... & . \\
\hline TOP: & ons ......... \\
\hline
\end{tabular}




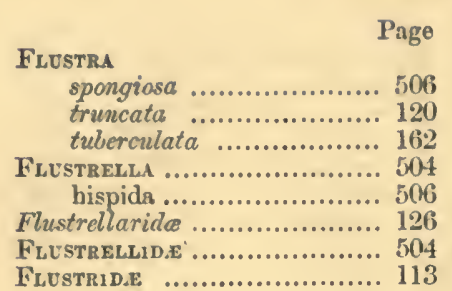

Genflolaria ..................... 17

loricata..................... 18

lorivulata ................. 18

Willisii...................... 18

Gemellariade .................... 98

Gemellipora glabra ............... 276

Gemicellaria....................... 17

Glauconome ....................... 107

Grunolemata .................. 1

HALCYONELLEA .................. 490

Halilophus ....................... 577

Halodactylus .................... 490

Hemeschara ..................... 320

Herentia .................. 204, 278

Heteroporella ................... 471

Hippotios ..................... 286

cassiterides ................. 294

catenularia ................... 134

divaricata.................... 288

divergens $. . . \ldots \ldots \ldots \ldots \ldots \ldots . . . . .255$

Ellioto ........................ 134

expansa.................... 291

flagellum ................... 293

lanceolata .................... 288

longicauda ................. 288

Patagonica ................. 288

porosa ....................... 281

rugosa ...................... 134

sica .............. 6

Hipperaria ....................... 548

Egertoni ..................... 549

Hippurariadce ................... 541

Holobraxchila ................, 563

Homodictide ................... 558

Hornera ........................ 467

borealis ....................... 468

frondiculata ..................448

lichenoides ............... 468

violacea.................... 469

HoRNERid . ...................... 467

Horn-wrack, broad-leaved...... 115

," narrow-leaved ... 120

IIUXI.EYA ......................... 21

fragilis ................... 22

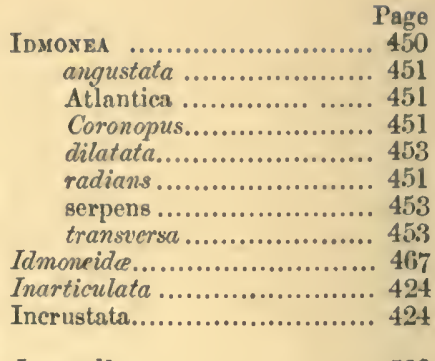

Lagenella ........................ 528

LAGENIPORA ...................... 235

socialis ...................... 235

Lagnncula ....................... 528

elongata .................. 52y

Lepralia ........................ 297

adpressa .................... 327

alba ......................... 244

ansata ...................... 238

aperta ...................... 323

appensa..................... 372

arrecta ..................... 363

assimilis .................. 224

aurita ...................... 279

Ballii .................... 372

Barleei ........................ 243

Belli ........................ 323

bicomis ...................... 379

biforis ...................... 211

calomorpha .................. 185

canthariformis............... 299

capitata ................... 224

chilopora ..................... 326

cognata ....................... 244

cribrillina.................. 186

cribrosa...................... 190

cylindrica .................... 271

diversipora ................ 216

edax ......................... 311

Endlicheri................... 186

foliacea ...................... 300

fulqurans ................... 372

glairra ........................ 206

granifora .................... 214

hastata ..................... 247

hippopus ..................... 309

immersa ..................... 360

innominata ............... 185

insignis..................... 200

intermedia ................ 245

Jacotini..................... 22t

Jeffreysi ..................... 353

lata ........................... 307

lobata .................... 391

lunata ....................... 206 


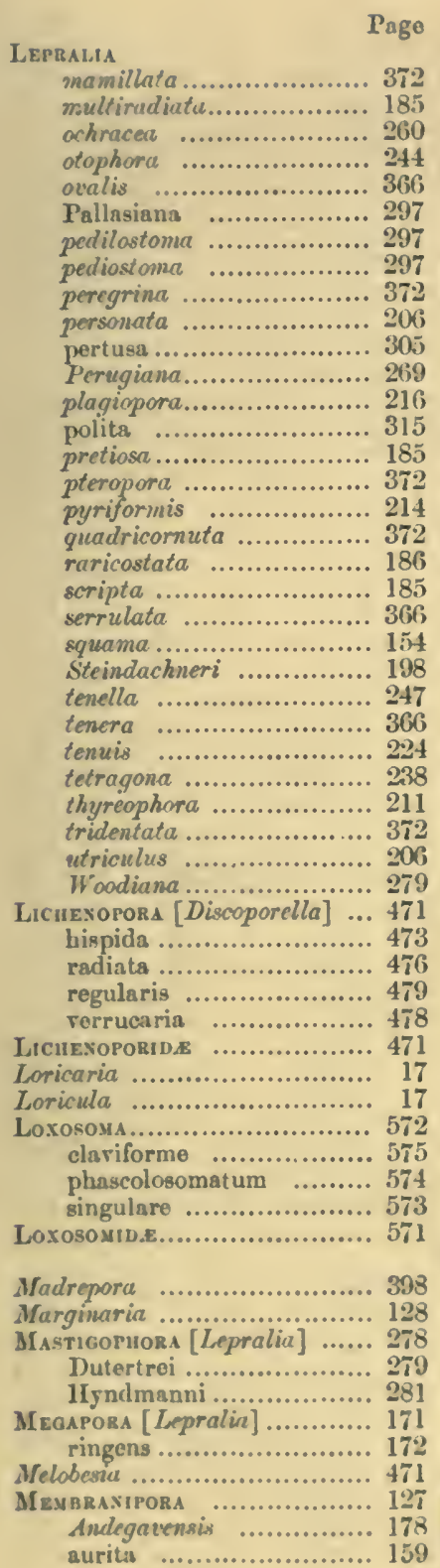

Membranipota

Pago

catenularia ................ 134

cornigers ................. 164

craticula .................. 147

curvirostris ................ 153

dentata ...................... 13i

discreta.................... 152

Dumerilii ................... 156

Fleıningii ................... 162

flustroides.................... 151

hexagona ................... 143

imbellis...................... 160

Lacroixii ................... 129

linenta ...................... 143

membranacea .............. 140

$\operatorname{minax} \ldots \ldots \ldots \ldots \ldots \ldots \ldots . . . . . .6169$

monostachys................ 131

nobilis ...................... 131

nodulosa .................. 170

Peachii..................... 130

pilosa ..................... 137

Pouilletii ..................... 156

reticulum .................. 130

Rosselii................... 166

sacculata .................... 167

Smittii ..................... 175

solida...................... 167

solidula...................... 158

spinifera .................. 149

stellata .................... 137

trifolium ................... 167

unicornis ..................... 154

vulnerata (Setosella) ...... 181

Membraniporelda [Lepralia].. 199

melolontha ................. 202

nitida ....................... 200

Membraniporida................. 126

MeNipea ........................ 36

fruticosa ................... 92

Jeffreysii .................. 92

Smittii ...................... 43

ternata ...................... 38

Mesenteripora .................. 457

Micropora [Membranipora] ... 173 coniplanata ................ 175

coriacen ................... 174

Mickororelba [Lepralia] ...... 204 ciliata ...................... 206

impressa ................... 214

Malusii....................... 211

riolsera....................... 216;

Microtorellid.e................ 34

MIICROPORID. ...................... 172

Millepora ............................. 388

compressa .................... 330

liliucea ....................... 453

tenialis...................... 300 


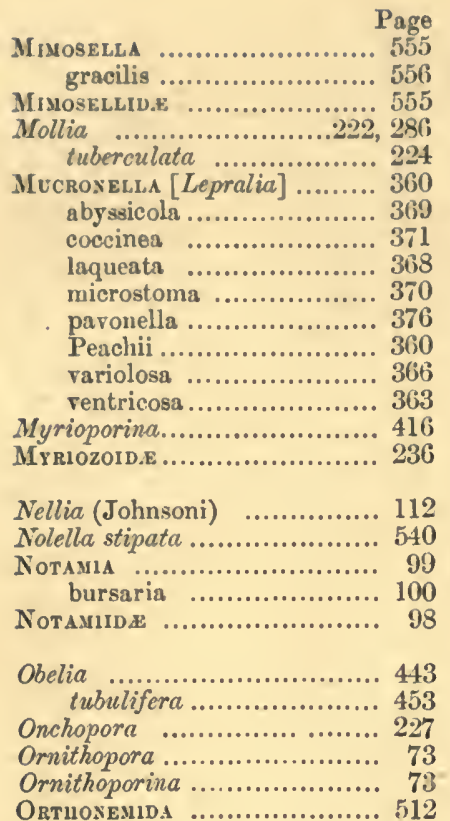

Palmicellaria [Eschura \&c.]... 378 cribraria ................... 384 elegans ..................... 378

lorea ...................... 382

Skenei ....................... 379

Patinella ......................... 457

Pedicellixa $\ldots \ldots \ldots \ldots \ldots \ldots \ldots . . .565$ Americana ............... 567 Belgica ....................... 565 cernua ...................... 565 echinata ................. 565 gracilis .................... 570 nutans .................... 567

Pedicellivea .................... 563

Pediceldivide. .................. 563

Phalangella ..................... 443

Puylactella [Lepralia]......... 356 collaris ....................... 358 eximia ...................... 359 labrosa ...................... 357

Ponostomata ................... 577 Porella [Lepralia, Eschara, Hemeschara]............. 321 cervicornis................... 331 compressa .................... $\$ 330$ concinna .................. 323 lavis ...................... 334
Porella
$\quad \operatorname{minuta} \ldots \ldots \ldots \ldots \ldots \ldots \ldots \ldots$
struma $\ldots \ldots \ldots \ldots \ldots \ldots \ldots \ldots$

Porellina ....................... 204

Porina [Lepralia, Tessaradoma] 227 borealis...................... 229 tubulosa .................... 230

Porinid. ........................ 226

Proboscina............................ 424 latifolia...................... 448 ramosa ...................... 432

Pterobranchia ................. 577

Pustulipora ........................ 455 gracilis ....................... 227 proboscidea ................. 378

Pustulopora .......................... 455 Orcadensis ................. 469

Pyripora ........................ 134

Quadricellaria ................... 227 gracilis ..................... 229

RADICELLATA ................... 416

Radiopora....................... 471

Reptelectrina .................. 137

Reptescharella ..................... 184

Heermanni ................. 193

Reptescharellina ............ 173, 176

Reptescharinella rhomboidalis... 224

Reptocelleporaria .................. 399

Reptoflustra ..................... 140

Reptoporellina subvulgaris ...... 206

Rcptoporina ................. 204, 237 hexagona .................. 211

Reptotubigera... .................... 443 confluens .................... 453

RETEPORA....................... 388 Beaniana .....................391

cellulosa ..................... 391

Couchii ....................... 395

RIABDorleURA................. 577 compacta ..................... 581

Normani ................... 580

RHynchopora [Lepralia] ...... 38.5 bispinosa .................. 385

Salicornia....................... 104

Salicornaria ........................ 104

Salpingia ......................... 8

Hassallii ................... 8

Sarcochitum..................... 490

Schizoporelda [Lepralia] ...... 237

Alderi ..................... 243

armata ...................... 258

guriculata................... 260

biaperta.................... 255

Cecilii ....................... 269 


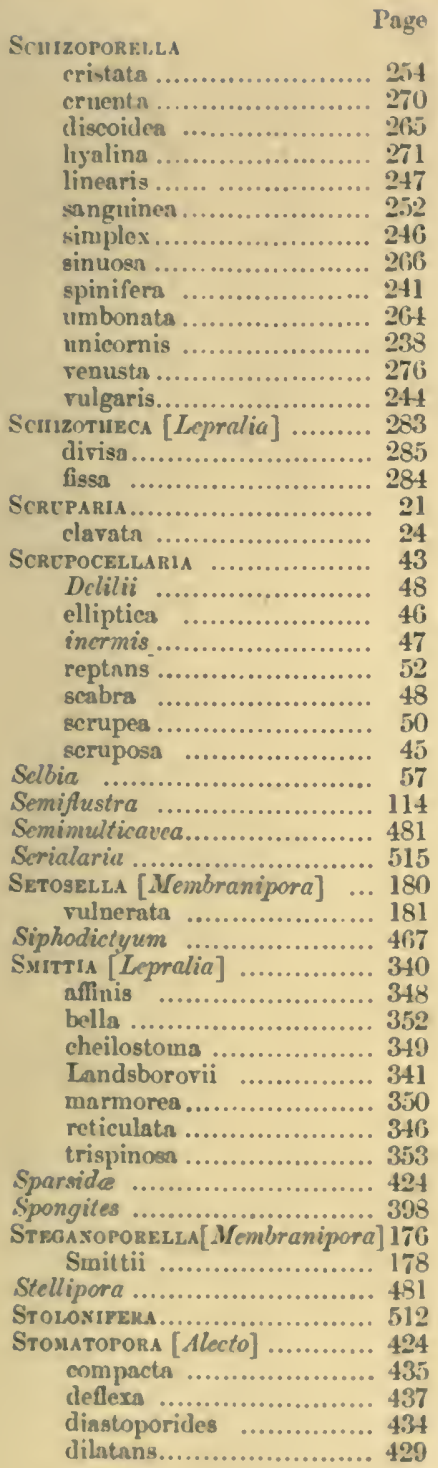

Stomator'on.

Page

expansa................... 432

fasciculata ................. 4 41

fungia .................... 4 48

granulata ................ 42.5

incrassata ................... 43f

incurvata .................. 433

Jolınstoni .................... 430)

major ......................4 427

Tata rugosa ...................... 14t

Tercbripora ....................... 286

Tessaradoma...................... 227

Tricellaria

Triticella

flava ........................ 543

Korenii .................... 545

pedicellata ................. 547

Triticellid $\boldsymbol{E}$................... 541

TÚnULIPORA .................... 442

fimbria ..................448

flabellaris .................... 446

foraminulata ............ 453

hyalina ..................... 486

lobulata.....................444

penicillata ................. 438

phalangea ................... 446

verrucaria..............440 44

TUBULIPORID E ................... 424

Tubuliporina .................. 410

Ul'a diaphana .................. 491

UMBONTLA (UMBONELLA in the text $) *[$ Lepralia $]$......... 310

verrucosa .................... 317

Unicavea ....................... 471

Unicellaria ...................... 11

FALKeria ....................... 551

etrscuta

glomerata .................... 519

trentula...................... 55.

uva $\ldots \ldots \ldots \ldots \ldots \ldots \ldots \ldots . . . . .551$

VALKERHDA.................... 551

Vesictiania .................... 512

spinosa ..................... 513

Trsicularidis..................... 512

Vesicularina................... 512

Victorella ....................... 559

parida ..................... 5f

Fictorelato. ................... 555

I"inculariade ..................... 103

- See Introduction, Srsteuntic Table. 


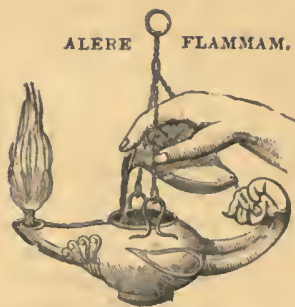

PRINTED BY TAYLOR AND FRANCIS, RED LION COURT, FLEET STREET. 




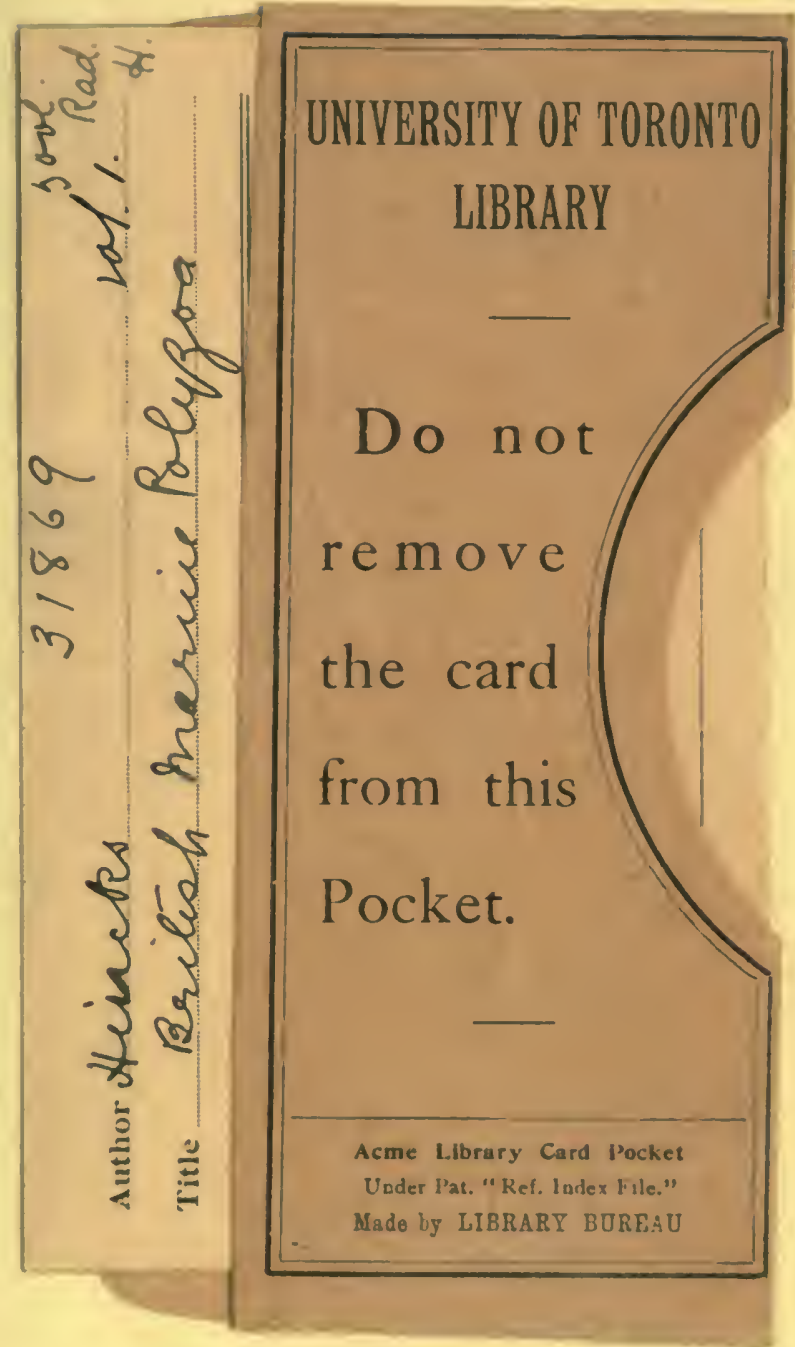




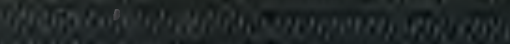

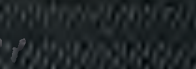

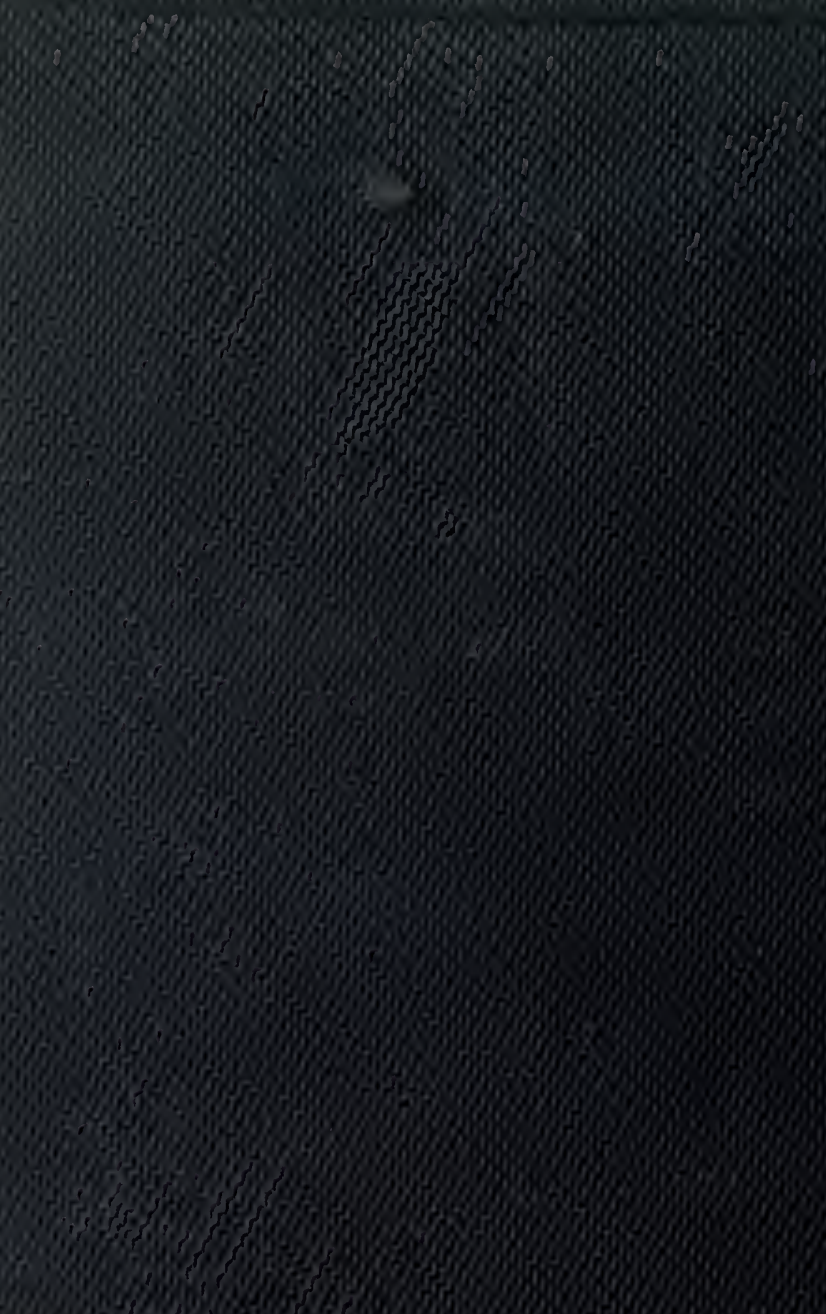

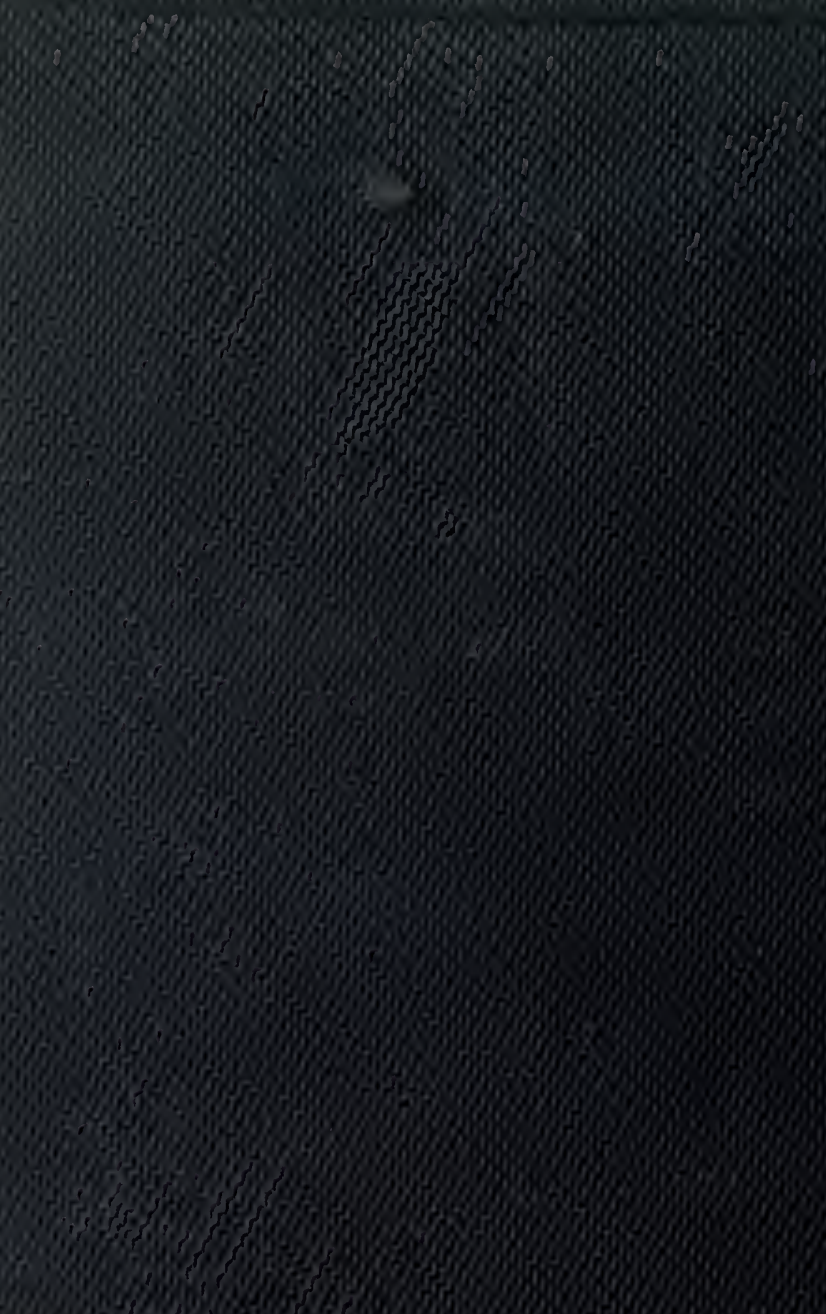

1 (6)

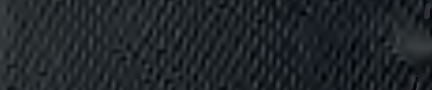

20030

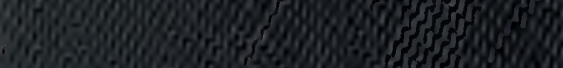

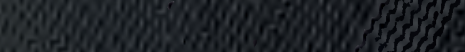

3.

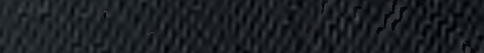

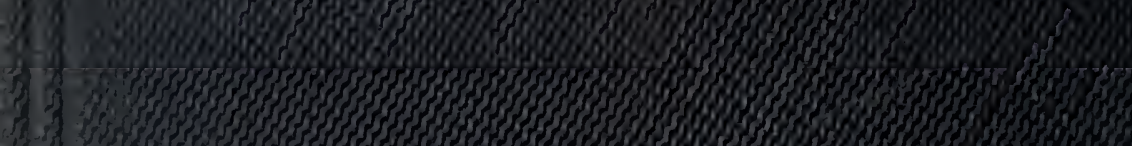

